

\title{
THEORY, PRACTICE AND SCIENCE
}

Abstracts of XXIII International Scientific and Practical Conference

\author{
Tokyo, Japan
}

April 27 - 30, 2021 


\section{Library of Congress Cataloging-in-Publication Data}

\section{UDC 01.1}

The XXIII International Science Conference «Theory, practice and science», April 27 - 30, 2021, Tokyo, Japan. 493 p.

ISBN - 978-1-63848-669-5

DOI - 10.46299/ISG.2021.I.XXIII

\section{EDITORIAL BOARD}

\begin{tabular}{ll} 
Pluzhnik Elena & $\begin{array}{l}\text { Professor of the Department of Criminal Law and Criminology } \\
\text { Odessa State University of Internal Affairs Candidate of Law, } \\
\text { Associate Professor }\end{array}$ \\
\hline Liubchych Anna & $\begin{array}{l}\text { Scientific and Research Institute of Providing Legal Framework for } \\
\text { the Innovative Development National Academy of Law Sciences of } \\
\text { Ukraine, Kharkiv, Ukraine, Scientific secretary of Institute }\end{array}$ \\
\hline$\underline{\text { Liudmyla Polyvana }}$ & $\begin{array}{l}\text { Department of Accounting and Auditing Kharkiv } \\
\text { National Technical University of Agriculture named after Petr } \\
\text { Vasilenko, Ukraine }\end{array}$ \\
\hline$\underline{\text { Mushenyk Iryna }}$ & $\begin{array}{l}\text { Candidate of Economic Sciences, Associate Professor of } \\
\text { Mathematical Disciplines , Informatics and Modeling. Podolsk State } \\
\text { Agrarian Technical University }\end{array}$ \\
\hline$\underline{\text { Oleksandra Kovalevska }}$ & $\begin{array}{l}\text { Dnipropetrovsk State University of Internal Affairs } \\
\text { Dnipro, Ukraine }\end{array}$ \\
\hline$\underline{\text { Prudka Liudmyla }}$ & $\begin{array}{l}\text { Odessa State University of Internal Affairs, } \\
\text { Associate Professor of Criminology and Psychology Department }\end{array}$ \\
\hline$\underline{\text { Slabkyi Hennadii }}$ & $\begin{array}{l}\text { Doctor of Medical Sciences, Head of the Department of Health } \\
\text { Sciences, Uzhhorod National University. }\end{array}$ \\
\hline$\underline{\text { Marchenko Dmytro }}$ & $\begin{array}{l}\text { Ph.D. in Machine Friction and Wear (Tribology), Associate } \\
\text { Professor of Department of Tractors and Agricultural Machines, } \\
\text { Maintenance and Servicing, Lecturer, Deputy dean on academic } \\
\text { affairs of Engineering and Energy Faculty of Mykolayiv National } \\
\text { Agrarian University (MNAU), Mykolayiv, Ukraine }\end{array}$ \\
\hline Belei Svitlana & $\begin{array}{l}\text { Candidate of Technical Sciences, specialty 05.22.20 - operation and } \\
\text { repair of vehicles. }\end{array}$ \\
\hline $\begin{array}{l}\text { Ph.D. (Economics), specialty: 08.00.04 "Economics and } \\
\text { management of enterprises (by type of economic activity)" }\end{array}$
\end{tabular}


TABLE OF CONTENTS

\begin{tabular}{|c|c|c|}
\hline \multicolumn{3}{|c|}{ ADVERTISING } \\
\hline 1. & $\begin{array}{l}\text { Азарова А.О., Остапчук Я.Ю. } \\
\text { ДОСЛІДЖЕННЯ ВПЛИВУ COVID-19 НА IHTЕРНЕТ- } \\
\text { МАРКЕТИНГ }\end{array}$ & 15 \\
\hline \multicolumn{3}{|c|}{ AGRICULTURAL SCIENCES } \\
\hline 2. & $\begin{array}{l}\text { Воропай Г.В., Молеща Н.Б. } \\
\text { ОПТИМАЛЬНІ ПАРАМЕТРИ ВОДОРЕГУЛЮВАННЯ ПРИ } \\
\text { ВИРОЩУВАННІ КОРМОВИХ КУЛЬТУР НА ОСУШУВАНИХ } \\
\text { ЗЕМЛЯХ ПІВНІЧНОГО ЛІСОСТЕПУ УКРАЇНИ }\end{array}$ & 21 \\
\hline 3. & $\begin{array}{l}\text { Цехмістренко С.І., Бітюцький В.С., Цехмістренко О.С. } \\
\text { ВИКОРИСТАННЯ СПОЛУК ЦЕРІЮ У СІЛЬСЬКОМУ } \\
\text { ГОСПОДАРСТВІ }\end{array}$ & 26 \\
\hline \multicolumn{3}{|c|}{ ARCHITECTURE, CONSTRUCTION } \\
\hline 4. & $\begin{array}{l}\text { Vozniuk L., Rymar Y., Lisnykh L. } \\
\text { REVIEW OF METHODS FOR RESEARCHING LIGHTWEIGHT } \\
\text { COVERING PLATES }\end{array}$ & 32 \\
\hline 5. & $\begin{array}{l}\text { Савенко В.И., Окружкин А.А., Ежов С.В., Дубинка А.В., } \\
\text { БлагодЫрев В.А. } \\
\text { ЭФФЕКТИВНАЯ ИННОВАЦИОННАЯ ТЕХНОЛОГИЯ } \\
\text { СТРОИТЕЛЬСТВА ОБЬЕКТОВ НА БАЗЕ УНИВЕРСАЛЬНОЙ } \\
\text { СИСТЕИЫ СБОРНО-МОНОЛИТНОГО БЕЗРИГЕЛЬНОГО } \\
\text { КАРКАСА }\end{array}$ & 35 \\
\hline \multicolumn{3}{|c|}{ ART HISTORY } \\
\hline 6. & $\begin{array}{l}\text { Datsiuk N., Netrybiak М. } \\
\text { НОВІТНІ ТЕХНІКИ ВИКОРИСТАННЯ НЕТРАДИЦІЙНИХ } \\
\text { МАТЕРІАЛІВ У САКРАЛЬНОМУ МИСТЕЦТВІ ХХІ СТОЛІТТЯ }\end{array}$ & 39 \\
\hline 7. & $\begin{array}{l}\text { ЛисенКо Л.О. } \\
\text { СТЕНДАЛЬ У РОЛІ ХУДОЖНЬОГО КРИТИКА } \\
\text { ФРАНУЦЗЬКОГО САЛОНУ } 1824 \text { РОКУ }\end{array}$ & 42 \\
\hline
\end{tabular}


BIOLOGICAL SCIENCES

\begin{tabular}{|c|c|c|}
\hline 8. & $\begin{array}{l}\text { Kazimli L., Heybatova N. } \\
\text { STUDY OF SOME BIOLOGICAL FEATURES OF PELVİC } \\
\text { GRAPE SNAİLS (HELIX POMATIA LINNAEUS) }\end{array}$ & 49 \\
\hline 9. & $\begin{array}{l}\text { Гнатюк Н.О., Підан Л.Ф. } \\
\text { МОЖЛИВІ ШЛЯХИ ВИКОРИСТАННЯ ХІМІЧНОЇ ВЗАЄМОДІЇ } \\
\text { МІЖ ОРГАНІЗМАМИ У БОРОТЬБІ } 3 \text { КОМАХАМИ } \\
\text { ШКІДНИКАМИ }\end{array}$ & 52 \\
\hline 10. & $\begin{array}{l}\text { ТроїцьКа О.О., БакарДЖИєВ Р.О. } \\
\text { ЕКОЛОГІЧНИЙ КОНТРОЛЬ ЯКОСТІ ПОВЕРХНЕВИХ ВОД Р. } \\
\text { ДНІПРО З РАЙОНІВ ВОДОЗАБОРІВ М. ЗАПОРІЖЖЯ ЗА } \\
\text { ОКРЕМИМИ ПОКАЗНИКАМИ БЛОКУ СОЛЬОВОГО СКЛАДУ }\end{array}$ & 56 \\
\hline 11. & $\begin{array}{l}\text { Трускавецька І.Я., Костюкевич В. } \\
\text { ВИДОВЕ РІЗНОМАНІТТЯ ЕНТОМОФАУНИ РІЧКИ СЛУЧ У } \\
\text { МЕЖАХ М. БЕРЕЗНЕ РІВНЕНСЬКОЇ ОБЛАСТІ }\end{array}$ & 63 \\
\hline \multicolumn{3}{|c|}{ CHEMICAL SCIENCES } \\
\hline 12. & $\begin{array}{l}\text { Дарменбаева А.С., Даутова Н.А., Нұрзатхан И., Қалдаман Д. } \\
\text { ҚОС БАЙЛАНЫСТЫ КӨМІРСУТЕКТЕРДІ АЛУҒА } \\
\text { АРНАЛҒАН КАТАЛИЗАТОРЛАР }\end{array}$ & 66 \\
\hline \multicolumn{3}{|c|}{ CULTUROLOGY } \\
\hline 13. & $\begin{array}{l}\text { Зайцева В.І. } \\
\text { ВПЛИВ РОЗВИТКУ ДИЗАЙНУ В СУЧАСНІЙ УКРАЇНІ НА } \\
\text { СОЦІОКУЛЬТУРНІ ТРАНСФОРМАЦЇ СУСПІЛЬСТВА }\end{array}$ & 70 \\
\hline 14. & $\begin{array}{l}\text { Олійник О.М. } \\
\text { МІСТО ЯК ЦЕНТР СОЦІОКУЛЬТУРНОГО РОЗВИТКУ: } \\
\text { ЦИВІЛІЗАЦІЙНИЙ ПІДХІД }\end{array}$ & 73 \\
\hline 15. & $\begin{array}{l}\text { Павленко В. } \\
\text { ПЕРЕДУМОВИ ВИНИКНЕННЯ КОМУНАЛЬНИХ КВАРТИР У } \\
\text { КИСВІ }\end{array}$ & 75 \\
\hline 16. & $\begin{array}{l}\text { Щербій С.О. } \\
\text { ЗНАЧЕННЯ ДІЯЛЬНОСТІ МЕТОДИЧНОГО ОБ’ЄДНАННЯ } \\
\text { ХОРМЕЙТЕРІВ ДИТЯЧИХ І ЮНАЦЬКИХ КОЛЕКТИВІВ } \\
\text { «ТНІКА» }\end{array}$ & 78 \\
\hline
\end{tabular}


ECONOMIC SCIENCES

\begin{tabular}{|c|c|c|}
\hline 17. & $\begin{array}{l}\text { Hobela V. } \\
\text { MODERN METHODS OF RECRUITMENT AS AN ELEMENT OF } \\
\text { ENSURING THE ECONOMIC SECURITY OF THE ENTERPRISE }\end{array}$ & 81 \\
\hline 18. & $\begin{array}{l}\text { Iukhno A. } \\
\text { FORMATION OF INDICATORS OF NORMATIVE MONETARY } \\
\text { VALUATION OF INDUSTRIAL LANDS }\end{array}$ & 83 \\
\hline 19. & $\begin{array}{l}\text { Malinoshevska K. } \\
\text { STRATEGY OF SUPPORT OF AGRICULTURAL ENTERPRISES } \\
\text { BY THE STATE }\end{array}$ & 89 \\
\hline 20. & $\begin{array}{l}\text { Базалійська Н., Пархомець Ю. } \\
\text { КРАУДРЕКРУТИНГ ЯК ЕФЕКТИВНИЙ ІНСТРУМЕНТ HR- } \\
\text { ІНЖИНІРИНГУ НА ПІДПРИСМСТВІ }\end{array}$ & 92 \\
\hline 21. & $\begin{array}{l}\text { БУДЬКо О.В. } \\
\text { НОРМАТИВНО-ПРАВОВЕ ЗАБЕЗПЕЧЕННЯ СТАЛОГО } \\
\text { РОЗВИТКУ ОБ’СДНАНИХ ТЕРИТОРІАЛЬНИХ ГРОМАД }\end{array}$ & 99 \\
\hline 22. & $\begin{array}{l}\text { Денисенко М.П., Бреус С.В. } \\
\text { ПІДВИЩЕННЯ РІВНЯ ЕКОНОМІЧНОЇ БЕЗПЕКИ ДЕРЖАВИ } \\
\text { НА ІННОВАЦИЙНИХ ЗАСАДАХ }\end{array}$ & 103 \\
\hline 23. & $\begin{array}{l}\text { Драчук Ю.З., Сав’юк Л.О., Чейлях Д.Д. } \\
\text { ПРОБЛЕМИ РОЗВИТКУ СТАРОПРОМИСЛОВИХ } \\
\text { ШАХТАРСЬКИХ РЕГЮНІВ: ЄВРОПЕЙСЬКИЙ ДОСВІД } \\
\text { ІНСТИТУЦЙННГО ВПОРЯДКУВАННЯ }\end{array}$ & 109 \\
\hline 24. & $\begin{array}{l}\text { Кірсанова В.В., Янковська О.А. } \\
\text { ЗВ’ЯЗОК СТАЛОГО РОЗВИТКУ ТА ЕКОНОМІЧНОЇ БЕЗПЕКИ }\end{array}$ & 117 \\
\hline 25. & $\begin{array}{l}\text { Мустафаев А.А., Захариев Р.Л. } \\
\text { НЕКОТОРЫЕ ОСОБЕННОСТИ ПРОГНОЗИРОВАНИЯ } \\
\text { ЭФФЕКТИВНОСТИ ИНВЕСТИЦИОННЫХ ПРОЕКТОВ АПК } \\
\text { СЕВЕРНОГО РЕГИОНА }\end{array}$ & 119 \\
\hline 26. & $\begin{array}{l}\text { Тєшева Л., Алексєєва В., Пустовалова О. } \\
\text { ФІНАНСОВИЙ КОНТРОЛЬ В УКРАЇНІ }\end{array}$ & 125 \\
\hline
\end{tabular}




\begin{tabular}{|c|c|c|}
\hline \multicolumn{3}{|c|}{ GEOGRAPHICAL SCIENCE } \\
\hline 27. & $\begin{array}{l}\text { Rybalova O., Stupka T. } \\
\text { THE INFLUENCE OF CLIMATE CHANGE ON THE } \\
\text { ECOLOGICAL CONDITION OF THE OSKIL RIVER BASIN }\end{array}$ & 132 \\
\hline 28. & $\begin{array}{l}\text { ІЛікчієв О.Г. } \\
\text { ПЕВЕРХНЕВИЙ СТІК У М. ОДЕСА ЗА ПЕРІОД 2000-2019 } \\
\text { РОКИ У ПЕРІОД ЗЛИВОВИХ ОПАДІВ }\end{array}$ & 139 \\
\hline 29. & $\begin{array}{l}\text { Дєрябіна І.О., Уманська О.В. } \\
\text { АНАЛІЗ РЕЖИМУ ЛІТНІХ ОПАДІВ В МІСТІ ПОЛТАВА ЗА } \\
\text { ДВАДЦЯТИРІЧЧЯ } 2001 \text { - } 2020 \text { РР. }\end{array}$ & 142 \\
\hline \multicolumn{3}{|c|}{ HISTORICAL SCIENCES } \\
\hline 30. & $\begin{array}{l}\text { Бачинська О., ПолТорак В. } \\
\text { ПАМ'ЯТЬ ПРО УКРАЇНСЬКЕ КОЗАЦТВО: НАУКА ТА } \\
\text { ПРАКТИКА (НА МАТЕРІАЛАХ КУЛЬТУРНОЇ СПАДЩИНИ } \\
\text { ОДЕСЬКОЇ ОБЛАСТІ УКРАЇНИ) }\end{array}$ & 146 \\
\hline 31. & $\begin{array}{l}\text { Рацлав В.В. } \\
\text { ЕКЛОЛІЧНИЙ СТАН ТА ІСТОРІЯ ВИКОРИСТАННЯ ВОД } \\
\text { СІВЕРСЬКОГО ДІНЦЯ }\end{array}$ & 149 \\
\hline 32. & $\begin{array}{l}\text { Чернуха О.В., Тесля Д.С. } \\
\text { ДЕНЬ КОСМОНАВТИКИ: ПЕРША КОСМІЧНА ЛЮДИНА }\end{array}$ & 158 \\
\hline 33. & $\begin{array}{l}\text { Чернуха О.В., Манаєнкова К.А. } \\
\text { АРХІТЕКТОР ОЛЕКСІЙ БЕКЕТОВ ТА ЙОГО СПАДОК }\end{array}$ & 161 \\
\hline \multicolumn{3}{|c|}{ LEGAL SCIENCES } \\
\hline 34. & $\begin{array}{l}\text { Guyvan P. } \\
\text { TEMPORAL LIMITS OF EXERCISE OF SUBJECTIVE LAW }\end{array}$ & 164 \\
\hline 35. & $\begin{array}{l}\text { Гусак А.П., Веремчук С.В. } \\
\text { МІЖНАРОДНЕ СПІВРОБІТНИЦТВО КРАЇН В ГАЛУЗІ } \\
\text { БОРОТЬБІ З ОРГАНІЗОВАНОЮ ЗЛОЧИННІСТЮ }\end{array}$ & 169 \\
\hline 36. & $\begin{array}{l}\text { Гусар О.А., Устинова І.П., Толкачова І.А. } \\
\text { ПЕРСПЕКТИВИ РОЗВИТКУ ВІДНОСИН МІЖНАРОДНИХ } \\
\text { ФІНАНСОВИХ ОРГАНІЗАЦІЙ З УКРАЇНОЮ }\end{array}$ & 172 \\
\hline
\end{tabular}




\begin{tabular}{|c|c|c|}
\hline 37. & $\begin{array}{l}\text { Левчук В.О. } \\
\text { ДИЛЕМА АДМІНІСТРАТИВНОЇ ВІДПОВІДАЛЬНОСТІ ЗА } \\
\text { ВИГОТОВЛЕННЯ ТА ЗБЕРІГАННЯ САМОГОНУ }\end{array}$ & 176 \\
\hline 38. & $\begin{array}{l}\text { МозоЛєв О.є. } \\
\text { ПРОБЛЕМИ ПРАВОВОГО РЕГУЛЮВАННЯ ВЕКСЕЛЬНОГО } \\
\text { ОБІГУ В УКРАЇНІ }\end{array}$ & 180 \\
\hline 39. & $\begin{array}{l}\text { Мілімко Л.В., Ткаченко В.В. } \\
\text { ОСОБЛИВОСТІ ПРАВОВОГО РЕГУЛЮВАННЯ } \\
\text { ЛІСОКОРИСТУВАННЯ У СІЛЬСЬКОГОСПОДАРСЬКОМУ } \\
\text { ВИРОБНИЦТВІ }\end{array}$ & 185 \\
\hline 40. & $\begin{array}{l}\text { Мілімко Л.В., Стукало В.І. } \\
\text { СТАНДАРТИЗАЦІЯ І НОРМУВАННЯ У ГАЛУЗІ ЕКОЛОГІЇ }\end{array}$ & 188 \\
\hline 41. & $\begin{array}{l}\text { Обловацька Н.О. } \\
\text { СУТНІСТЬ ПРОФЕСІЙНӦ̈ ПРАВНИЧОЇ ДОПОМОГИ В } \\
\text { ДІЯЛЬНОСТІ АДВОКАТУРИ }\end{array}$ & 192 \\
\hline 42. & $\begin{array}{l}\text { Сіда С.С. } \\
\text { ПРАВА ЛЮДИНИ: ІСТОРИЧНІ ПЕРЕДУМОВИ Й ВПЛИВ НА } \\
\text { СУЧАСНІСЬ }\end{array}$ & 197 \\
\hline 43. & $\begin{array}{l}\text { ХатнюК Н.С., Саган Д.О. } \\
\text { ПРЕТЕНЗЙНИЙ ПОРЯДОК ВРЕГУЛЮВАННЯ } \\
\text { ГОСПОДАРСЬКИХ СПОРІВ: ПЕРЕВАГИ І НЕДОЛІКИ }\end{array}$ & 200 \\
\hline 44. & $\begin{array}{l}\text { Шкляр І.В. } \\
\text { СУЧАСНИЙ ПОГЛЯД НА ПРИНЦИПИ НАДАННЯ МЕДИЧНОЇ } \\
\text { ДОПОМОГИ ІЗ ЗАСТОСУВАННЯМ ТРАНСПЛАНТАЦЇ̈ }\end{array}$ & 205 \\
\hline \multicolumn{3}{|c|}{ MANAGEMENT, MARKETING } \\
\hline 45 . & $\begin{array}{l}\text { Brodovska I., Smereka S., Schuchmann V. } \\
\text { BLOCKCHAIN AS AN ESTABLISHED TREND IN THE } \\
\text { DEVELOPMENT OF INFORMATION TECHNOLOGIES: CASES } \\
\text { OF DEFI AND NFT CRYPTOCURRENCIES }\end{array}$ & 209 \\
\hline 46. & $\begin{array}{l}\text { Voronina A., Andreieva N. } \\
\text { SIMULATION OF THE TRAINING PROCESS OF THE } \\
\text { MANAGEMENT STAFF OF THE METALLURGICAL } \\
\text { ENTERPRISE }\end{array}$ & 213 \\
\hline
\end{tabular}




\begin{tabular}{|c|c|c|}
\hline 47. & $\begin{array}{l}\text { Камашев А.В. } \\
\text { СПІВРОБІТНИЦТВО ГРОМАД ЯК ІНСТРУМЕНТ } \\
\text { ІНФРАСТРУКТУРНОГО РОЗВИТКУ ТЕРИТОРІЙ }\end{array}$ & 218 \\
\hline 48. & $\begin{array}{l}\text { КотлУбай В.О., Редіна С.В. } \\
\text { ІННОВАЦІЙНИЙ МЕНЕДЖМЕНТ ЯК ОДИН ІЗ НАПРЯМКІВ } \\
\text { РОЗВИТКУ СУЧАСНОГО БІЗНЕСУ }\end{array}$ & 220 \\
\hline 49. & $\begin{array}{l}\text { Нікітенко К.В. } \\
\text { ОСОБЛИВОСТІ МЕТОДИКИ ВИКЛАДАННЯ } \\
\text { СПЕЦДИСЦИПЛІНИ «МЕНЕДЖМЕНТ МИСТЕЦТВА» }\end{array}$ & 223 \\
\hline \multicolumn{3}{|c|}{ MEDICAL SCIENCES } \\
\hline 50. & $\begin{array}{l}\text { Marynchyna I., Rykhlo I., Ratushna I. } \\
\text { PLACENTAL MORPHOMETRIC INDICES IN WOMAN WITH } \\
\text { PLACENTAL DYSFUNCTION }\end{array}$ & 228 \\
\hline 51. & $\begin{array}{l}\text { Pasiieshvili T., Pasiyeshvili L., Zhelezniakova N., Kovalyova O. } \\
\text { KERDO INDEX AS AN INDICATOR OF THE STATE OF THE } \\
\text { VEGETATIVE NERVOUS SYSTEM IN STUDENTS WITH } \\
\text { GASTROESOPHAGEAL REFLUX DISEASE AND } \\
\text { AUTOIMMUNE THYROIDITIS }\end{array}$ & 230 \\
\hline 52. & $\begin{array}{l}\text { Slonetskyi B., Kotsiubenko V., Yaroshuk D., Verbytskyi I. } \\
\text { OPTIMIZATION OF HERNIOPLASTY METHOD FOR } \\
\text { PATIENTS WITH INCARCERATED INGUINAL HERNIA }\end{array}$ & 232 \\
\hline 53. & $\begin{array}{l}\text { Горбанёва Е.П., Рябчук Ю.В. } \\
\text { ДИАГНОСТИКА НАРУШЕНИЙ ВЕГЕТАТИВНОГО БАЛАНСА } \\
\text { У ШКОЛЬНИКОВ СТАРШИХ КЛАССОВ ПО ДАННЫМ } \\
\text { ОПРОСНИКА ВЕЙНА А.М. }\end{array}$ & 234 \\
\hline 54. & $\begin{array}{l}\text { Міхєєв А.О. } \\
\text { РОСЛИННІ ЕФІРНІ ОЛІЇ - АЛЬТЕРНАТИВНІ КОНСЕРВАНТИ } \\
\text { ТА СТАБІЛІЗАТОРИ ЇЖІ (ОГЛЯД ЛІТЕРАТУРИ) }\end{array}$ & 239 \\
\hline 55. & $\begin{array}{l}\text { Петров В., ЯремКевич Р. } \\
\text { ДІАГНОСТИКА І ЛІКУВАННЯ ТРАВМ АРТЕРІЙ ДІТЕЙ ТА } \\
\text { ДОРОСЛИХ }\end{array}$ & 245 \\
\hline
\end{tabular}




\begin{tabular}{|c|c|c|}
\hline 56. & $\begin{array}{l}\text { Сальнікова Т.В. } \\
\text { ФОРМУВАННЯ ВНУТРІШНІХ ТА ЗОВНІШНІХ «Я- } \\
\text { КОНЦЕПЦІЙНИХ» ОРІЕНТИРІВ ОСОБИСТОСТІ УЧАСНИКІВ } \\
\text { АТО/ООС }\end{array}$ & 249 \\
\hline 57. & $\begin{array}{l}\text { ЩеПанський С.О. } \\
\text { ВІРТОПСІЯ - СУЧАСНИЙ МЕТОД ДОСЛІДЖЕННЯ ТРУПІВ } \\
\text { ПРИ СУДОВО-МЕДИЧНІЙ ЕКСПЕРТИЗІ }\end{array}$ & 252 \\
\hline \multicolumn{3}{|c|}{ PEDAGOGICAL SCIENCES } \\
\hline 58. & $\begin{array}{l}\text { Gusak L., Hedz S., Smalko L., Gusak O. } \\
\text { ASSOCIATIVE METHODS IN TEACHING ENGLISH }\end{array}$ & 255 \\
\hline 59. & $\begin{array}{l}\text { Veligura O. } \\
\text { THE REALIZATION OG THE PRINCIPLE OF THE CONTINUITY } \\
\text { IN THE INSTITUTIONS OF PRESCHOOL AND GENERAL } \\
\text { SECONDARY EDUCATION IN CONTEMPORARY UKRAINE }\end{array}$ & 258 \\
\hline 60. & $\begin{array}{l}\text { Zelenska O. } \\
\text { THE COMMUNICATIVE APPROACH TO TEACHING THE } \\
\text { FOREIGN LANGUAGES AT THE ESTABLISHMENTS OF } \\
\text { HIGHER EDUCATION OF THE MINISTRY OF INTERNAL } \\
\text { AFFAIRS OF UKRAINE }\end{array}$ & 263 \\
\hline 61. & $\begin{array}{l}\text { Айтуарова А.Т. } \\
\text { ЭКОЛОГИЧНАЯ МУЗЫКА ИЛИ МУЗЫКАЛЬНАЯ ЭКОЛОГИЯ } \\
\text { (ПЕДАГОГИЧЕСКИЙ АСПЕКТ) }\end{array}$ & 268 \\
\hline 62. & $\begin{array}{l}\text { БаКай С.Ю. } \\
\text { МУЗИЧНО-ПЕДАГОГІЧНА ДІЯЛЬНІСТЬ Г.СКОВОРОДИ У } \\
\text { ХАРКІВСЬКОМУ КОЛЕГІУМІ (ДО 300-РІЧЧЯ ВІД ДНЯ } \\
\text { НАРОДЖЕННЯ) }\end{array}$ & 272 \\
\hline 63. & $\begin{array}{l}\text { ДУдик Р.В. } \\
\text { ПРОЦЕС ВИКОРИСТАННЯ ІНФОРМАЦІЙНИХ ТЕХНОЛОГІЙ } \\
\text { НА УРОКАХ МУЗИКИ В ЗАГАЛЬНООСВІТНІЙ ШКОЛІ }\end{array}$ & 280 \\
\hline 64. & $\begin{array}{l}\text { Дудина Б.В., Строганова Г.М. } \\
\text { РОБОТА НАД ПОМИЛКАМИ НА УРОКАХ УКРАЇНСЬКОЇ } \\
\text { МОВИ }\end{array}$ & 286 \\
\hline
\end{tabular}




\begin{tabular}{|c|c|c|}
\hline 65. & $\begin{array}{l}\text { Завітренко Д.Ж., Бабенко Д.Я.А. } \\
\text { ЗАСТОСУВАННЯ ХОЛДИНГ-ТЕРАПІЇ В РОБОТІ З ДІТЬМИ, } \\
\text { ЩО МАЮТЬ РОЗЛАДИ АУТИЧНОГО СПЕКТРУ }\end{array}$ & 289 \\
\hline 66. & $\begin{array}{l}\text { Кос О.І. } \\
\text { ВИДИ ЛІКАРНЯНОЇ АНІМАЦІЇ ЯК ЕЛЕМЕНТ } \\
\text { РЕКРЕАЦЙНОЇ ПРОГРАМИ }\end{array}$ & 292 \\
\hline 67. & $\begin{array}{l}\text { ОЛефір Н.В. } \\
\text { ПСИХОЛОГО-ПЕДАГОГІЧНИЙ СУПРОВІД ДІТЕЙ } 3 \\
\text { ОСОБЛИВИМИ ОСВІТНІМИ ПОТРЕБАМИ В УМОВАХ } \\
\text { ІНКЛЮЗИВНОГО НАВЧАННЯ }\end{array}$ & 295 \\
\hline 68. & $\begin{array}{l}\text { ПодОЛяКа Н.С., КолОМОєць Т.Г. } \\
\text { САМООЦІНКА ДІТЕЙ ПЕРЕДШКІЛЬНОГО ВІКУ ЯК } \\
\text { ПСИХОЛОГО-ПЕДАГОГІЧНИЙ ФЕНОМЕН }\end{array}$ & 298 \\
\hline 69. & $\begin{array}{l}\text { РазУменко Д.О. } \\
\text { СОЦІАЛЬНО ЗНАЧИМІ НАВИЧКИ В ОСВІТНЬО- } \\
\text { ПРОФЕСІЙНИХ ПРОГРАМАХ ПІДГОТОВКИ ФАХІВЦІВ } 051 \\
\text { ЕКОНОМІКА }\end{array}$ & 302 \\
\hline 70 . & $\begin{array}{l}\text { Скрипник М.І. } \\
\text { УКРАЇНСЬКИЙ ПЕДАГОГ ЯК СУБ’ ЄКТ МОДЕРНІЗАЦІЇ: } \\
\text { РЕЗОНИ ДЛЯ ЗМІН У ПІДВИЩЕННІ КВАЛІФІКАЦІЇ }\end{array}$ & 304 \\
\hline 71. & $\begin{array}{l}\text { Сухіна Т.С., КоЛОМоєць Т.Г. } \\
\text { ГРА ЯК ЗАСІБ ФОРМУВАННЯ ЛІДЕРСЬКИХ ЯКОСТЕЙ У } \\
\text { ДІТЕЙ ПЕРЕДШКІЛЬНОГО ВІКУ }\end{array}$ & 314 \\
\hline 72. & $\begin{array}{l}\text { Сєрих Л.В. } \\
\text { ПСИХОЛОГІЧНІ МЕХАНІЗМИ-МЕТОДИКИ ВЗАЄМОДІЇ } \\
\text { ЗАКЛАДІВ ЗАГАЛЬНӦ̈ СЕРЕДНЬОЇ ТА ПОЗАШКІЛЬНОЇ } \\
\text { ОСВІТИ В ЕСТЕТИЧНОМУ ВИХОВАННІ ПІДЛІТКІВ }\end{array}$ & 317 \\
\hline 73. & $\begin{array}{l}\text { ТУПаЛьська Г.О. } \\
\text { ДО ПРОБЛЕМИ ТЕХНОЛОГІЇ РОЗВИТКУ КРИТИЧНОГО } \\
\text { МИСЛЕННЯ У ПРОЦЕСІ НАВЧАННЯ УЧНІВ ПОЧАТКОВИХ } \\
\text { КЛАСІВ }\end{array}$ & 319 \\
\hline
\end{tabular}




\begin{tabular}{|c|c|c|}
\hline 74. & $\begin{array}{l}\text { Хлєбнікова Т., Тищенко Т., Гречаник О. } \\
\text { ВИКОРИСТАННЯ ІНТЕРАКТИВНИХ МЕТОДІВ НАВЧАННЯ } \\
\text { МЕНЕДЖЕРІВ ОСВІТИ ЯК УМОВА ВДОСКОНАЛЕННЯ ЇХ } \\
\text { ІННОВАЦЙНӦ̈ ДІЯЛЬНОСТІ }\end{array}$ & 324 \\
\hline 75 . & $\begin{array}{l}\text { Хом Я.О.А., Баланович Ж. } \\
\text { МЕТОДИКА ФОРМУВАННЯ ПАТРІОТИЧНИХ ПОЧУТТІВ } \\
\text { МОЛОДШИХ ШКОЛЯРІВ НА УРОКАХ «Я ДОСЛІДЖУЮ } \\
\text { СВІТ» В НОВІЙ УКРАЇНСЬКІЙ ШКОЛІ }\end{array}$ & 329 \\
\hline 76. & 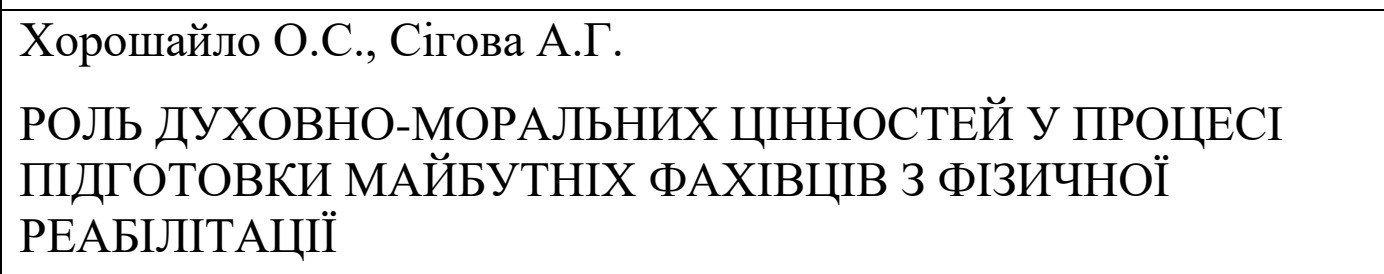 & 337 \\
\hline \multicolumn{3}{|c|}{ PHARMACEUTICAL SCIENCES } \\
\hline 77. & $\begin{array}{l}\text { Нестеренко М.А., Ярних Т.Г., Олійник С.В. } \\
\text { ЗАСТОСУВАННЯ ARNICA MONTANA В ГОМЕОПАТIÏ TA } \\
\text { ФІТОТЕРАПIÏ }\end{array}$ & 339 \\
\hline 78. & $\begin{array}{l}\text { Трутаева Л.Н., Цубанова Н.А. } \\
\text { О НЕОБХОДИМОСТИ ПОЛИМОДАЛЬНОГО ДЕЙСТВИЯ } \\
\text { ГЕПАТОПРОТЕКТОРОВ ДЛЯ КОМОРБИДНЫХ ПАЦИЕНТОВ }\end{array}$ & 343 \\
\hline \multicolumn{3}{|c|}{ PHILOLOGICAL SCIENCES } \\
\hline 79. & $\begin{array}{l}\text { Arkushenko A. } \\
\text { EMOTIVE-EXPRESSIVE UNITS IN THE BRITISH COMEDY } \\
\text { "LOVE ACTUALLY" AND PECULIARITIES OF THEIR } \\
\text { REPRODUCTION INTO UKRAINIAN }\end{array}$ & 346 \\
\hline 80. & $\begin{array}{l}\text { БУЛЬбачИнсьКа О.І. } \\
\text { КІНЕМАТОГРАФІЧНА КАТЕГОРІЯ ПЛАНУ ЯК ЗАСІБ } \\
\text { ПІДСИЛЕННЯ ПСИХОЛОГІЗМУ В ПРИГОДНИЦЬКОМУ } \\
\text { РОМАНІ Є. ГУЦАЛА «УЛЮМДЖІ» }\end{array}$ & 350 \\
\hline 81. & $\begin{array}{l}\text { Данилюк Л.В., Рябокінь Н.О., Січова Д.Ю. } \\
\text { ОСОБЛИВОСТІ ПЕРЕКЛАДУ АНГЛІЙСЬКИХ АБРЕВІАТУР У } \\
\text { ДИСКУРСІ ЦИФРОВОЇ СТОМАТОЛОГІЇ }\end{array}$ & 353 \\
\hline 82. & $\begin{array}{l}\text { Поліщук А.В., Берко М.О. } \\
\text { ВЖИВАННЯ ГЕРУНДІЯ В НАУКОВО-ТЕХНІЧНОМУ } \\
\text { ДИСКУРСІ }\end{array}$ & 356 \\
\hline
\end{tabular}




\begin{tabular}{|c|c|c|}
\hline \multicolumn{3}{|c|}{ PHILOSOPHICAL SCIENCES } \\
\hline 83. & $\begin{array}{l}\text { Galuyko R., Галуйко Р. } \\
\text { ХУДОЖНИКИ ІКОН: КРИТЕРІЇ ТА ВИМОГИ }\end{array}$ & 359 \\
\hline 84. & $\begin{array}{l}\text { Адилбаев А.Ш., Адилбаева Ш.А. } \\
\text { ИСЛАМ ҚҰҚЫҒЫНДАҒЫ ИСТИСХАБ ДӘЛЕЛІ }\end{array}$ & 363 \\
\hline 85. & $\begin{array}{l}\text { Сманова Н.Ә. } \\
\text { ДІНИ ЭКСТРЕМИЗМНІҢ ЖАСТАР САНАСЫНА ӘСЕРІ }\end{array}$ & 371 \\
\hline \multicolumn{3}{|c|}{ PHYSICAL AND MATHEMATICAL SCIENCES } \\
\hline 86. & $\begin{array}{l}\text { Muminov I.A., Qo'chqorov M.X., Sultanov R.R., Tashkhodjayev T.T. } \\
\text { TWO QUANTUM ABSORPTION OF POLARIZED RADIATION } \\
\text { IN N-GAP }\end{array}$ & 374 \\
\hline \multicolumn{3}{|c|}{ PSYCHOLOGICAL SCIENCES } \\
\hline 87. & $\begin{array}{l}\text { Khlon O. } \\
\text { LEGAL CULTURE OF YOUTH }\end{array}$ & 379 \\
\hline 88. & $\begin{array}{l}\text { Polishchuk D. } \\
\text { THE INFLUENCE OF THE SOCIAL ENVIRONMENT ON THE } \\
\text { FORMATION OF ADOLESCENT INDEPENDENCE }\end{array}$ & 381 \\
\hline 89. & $\begin{array}{l}\text { Бередіна О.В. } \\
\text { ВПЛИВ ЕМОЦІЙНО-ВОЛЬОВОЇ СФЕРИ ОСОБИСТОСТІ } \\
\text { СПЕЦІАЛІСТА НА ВИКОНАННЯ ТРУДОВИХ ОБОВ'ЯЗКІВ }\end{array}$ & 385 \\
\hline \multicolumn{3}{|c|}{ SOCIOLOGICAL SCIENCES } \\
\hline 90. & $\begin{array}{l}\text { Kulichenko T. } \\
\text { MOTHERHOOD IN ADOLESCENCE AS A SOCIO- } \\
\text { PEDAGOGICAL PROBLEM }\end{array}$ & 388 \\
\hline \multicolumn{3}{|c|}{ TECHNICAL SCIENCES } \\
\hline 91. & $\begin{array}{l}\text { Elizarov A., Gulak N., Dubchak H. } \\
\text { EXPERIENCE IN USING OF CISCO NETWORKING ACADEMY } \\
\text { MATERIALS IN CYBER SECURITY BACHELOR TRAINING }\end{array}$ & 391 \\
\hline
\end{tabular}




\begin{tabular}{|c|c|c|}
\hline 92. & $\begin{array}{l}\text { Havaliukh O., Vovk О. } \\
\text { СИНТЕЗ ТА АНАЛІЗ СКЛАДНИХ СИГНАЛІВ КУТОВОЇ } \\
\text { МОДУЛЯЦІЇ В РЛС }\end{array}$ & 396 \\
\hline 93. & $\begin{array}{l}\text { Kisietov J., Kuklina O. } \\
\text { FEATURES OF THE INFORMATION-MANAGEMENT SYSTEM } \\
\text { FOR THE PREPARATION OF BACHELORS IN MARINE } \\
\text { EDUCATION }\end{array}$ & 400 \\
\hline 94. & $\begin{array}{l}\text { Melnyk O., Kozarevych V. } \\
\text { PRACTICE OF DESIGN MODERN NANOCIRCUITS }\end{array}$ & 406 \\
\hline 95. & $\begin{array}{l}\text { Polishchuk V. } \\
\text { INNOVATIVE TECHNOLOGY OF FLOOD ALARM AND } \\
\text { FORECASTING }\end{array}$ & 409 \\
\hline 96. & $\begin{array}{l}\text { Voskoboinick V. } \\
\text { HYDRODYNAMIC NOISE AND VIBRATIONS OF TOWED } \\
\text { MARINE ANTENNA }\end{array}$ & 412 \\
\hline 97. & $\begin{array}{l}\text { Власов А.В., Пономарева М.В. } \\
\text { МОДЕЛИРОВАНИЕ ТЯГОВОЙ ХАРАКТЕРИСТИКИ } \\
\text { ЭЛЕКТРОМАГНИТА КВМ } 45 \text { СВЯУ (2D ОСЕСИМЕТРИЧНЫЙ } \\
\text { АУДИТ) }\end{array}$ & 419 \\
\hline 98. & $\begin{array}{l}\text { Власова В.К., Власов В.В. } \\
\text { МОДЕЛИРОВАНИЕ ТЯГОВОЙ ХАРАКТЕРИСТИКИ } \\
\text { ЭЛЕКТРОМАГНИТА КВМ } 45 \text { СВПР (2D ОСЕСИМЕТРИЧНЫЙ } \\
\text { АУДИТ) }\end{array}$ & 423 \\
\hline 99. & $\begin{array}{l}\text { Дьяченко Є.В., Пасічний В.М. } \\
\text { НАПІВФАБРИКАТИ ЗАБАГАЧЕНІ ЙОДОМ }\end{array}$ & 429 \\
\hline 100. & $\begin{array}{l}\text { Козуб Ю.Г., КЛИмУхіна А.М. } \\
\text { МЕТОДИ І ЗАСОБИ ПРОЦЕДУРНОЇ ГЕНЕРАЦІЇ КОНТЕНТУ } \\
\text { В ІГРОВИХ ДОДАТКАХ }\end{array}$ & 432 \\
\hline 101. & $\begin{array}{l}\text { Марчевський В.М., Войтюк В.О. } \\
\text { ОХОЛОДЖЕННЯ ПЕРЛІТУ }\end{array}$ & 435 \\
\hline
\end{tabular}




\begin{tabular}{|c|c|c|}
\hline 102. & $\begin{array}{l}\text { Мікосянчик О.О., Якобчук О.Є., Мнацаканов Р.Г., Хімко А.М. } \\
\text { ОЦІНКА ЯКОСТІ АВІАЦІЙНОЇ ОЛИВИ }\end{array}$ & 438 \\
\hline 103. & $\begin{array}{l}\text { Сергеев А. } \\
\text { ВЫСОКОЭФФЕКТИВНАЯ ТЕХНОЛОГИЯ ФИНИШНОЙ } \\
\text { ОБРАБОТКИ ОТВЕРСТИЙ ЦИЛИНДРОВ }\end{array}$ & 443 \\
\hline 104. & $\begin{array}{l}\text { Скобло Т.С., Нанка А.В., КЛочко О.Ю., Сайчук А.В., } \\
\text { Рыбалко И.Н. } \\
\text { АНАЛИЗ ПРОЦЕССОВ ДЕСТАБИЛИЗАЦИИ КАРБИДНОЙ } \\
\text { ФАЗЫ В ЧУГУНЕ ПРИ НАГРЕВЕ И ДЕФОРМАЦИИ }\end{array}$ & 448 \\
\hline 105. & $\begin{array}{l}\text { СЛОНОВ М.Ю. } \\
\text { КВАЗИНЕПРЕРЫВНОЕ ИЗОБРАЖЕНИЕ В ВИДОВЫХ } \\
\text { СРЕДСТВАХ С ДИСКРЕТНЫМИ ПРИЕМНИКАМИ: } \\
\text { СНИЖЕНИЕ ТРЕБОВАНИЙ К ПИКСЕЛЬНОМУ РАЗМЕРУ } \\
\text { СВЕТОЧУВСТВИТЕЛЬНОЙ МАТРИЦЫ }\end{array}$ & 456 \\
\hline 106. & $\begin{array}{l}\text { Тулашвілі Ю.Й., Лук’янчук Ю.А. } \\
\text { ВИКОРИСТАННЯ СУЧАСНИХ SLA ЗАСОБІВ В АДИТИВНИХ } \\
\text { IT-ТЕХНОЛОГІЯХ }\end{array}$ & 462 \\
\hline 107. & $\begin{array}{l}\text { ЧовнюК Ю.В., Москвітіна А.С., Пефтєва І.О. } \\
\text { РОЛЬ ГЕОМЕТРІЇ ТІЛА, ЩО НАГРІВАСТЬСЯ, ГРАНИЧНИХ } \\
\text { УМОВ ТА ФІЗИЧНИХ ВЛАСТИВОСТЕЙ МАТЕРІАЛУ, ЯКИЙ } \\
\text { ПРИЙМАЄ УЧАСТЬ У ПРОЦЕСАХ ТЕПЛООБМІНУ }\end{array}$ & 468 \\
\hline 108. & $\begin{array}{l}\text { ШаповаЛ В.Г., СКобенко А.В., ПономаренКо И.А. } \\
\text { К ОПРЕДЕЛЕНИЮ АКТИВНОГО ДАСЛЕНИЯ НА } \\
\text { ОГРАЖДАЮЩИЕ КОНСТРУКЦИИ УЧЕТОМ ФИЗИЧЕСКОЙ } \\
\text { НЕЛИНЕЙНОСТИ ПРОЧНОСТНЫХ СВОЙСТВ ГРУНТА }\end{array}$ & 476 \\
\hline \multicolumn{3}{|c|}{ VETERINARY SCIENCES } \\
\hline 109. & $\begin{array}{l}\text { Антіпов А.А., Гончаренко В.П., Соловйова Л.М., Авраменко } \\
\text { Н.В., Козій Н.В. } \\
\text { ПОРІВНЯЛЬНА ЕФЕКТИВНІСТЬ ПРЕПАРАТІВ ЗА } \\
\text { АСКАРОЗНО-ТРИХУРОЗНОЇ ІНВАЗІІ }\end{array}$ & 480 \\
\hline 110. & $\begin{array}{l}\text { Токарчук Т.С., Антонецька Л.В., Колащук Л.Г. } \\
\text { ВПЛИВ ВІТАМІНУ Е ТА ЦИТРАТІВ МІКРОЕЛЕМЕНТІВ НА } \\
\text { ПЕРОКСИДНЕ ОКИСНЕННЯ ЛІПІДІВ У КРОВІ ПОРОСЯТ }\end{array}$ & 486 \\
\hline
\end{tabular}




\title{
ДОСЛІДЖЕННЯ ВПЛИВУ COVID-19 НА IНTЕРНЕТ- МАРКЕТИНГ
}

\author{
Азарова Анжеліка Олексіївна \\ к.т.н., проф. каф. МБІС \\ Вінницький національний технічний університет \\ Остапчук Ярослав Юрійович \\ студент 3 курсу \\ Вінницький національний технічний університет
}

\begin{abstract}
Анотація
У дослідженні вивчено вплив COVID-19 на поведінку споживачів та детально проаналізовано його наслідки для формування продуктивної маркетингової стратегії та маркетингової політики. Виявлено, щзо кризовий стан економіки, який спричинений впливом коронавіруса, має у поведіниі споживачів та способах здійснення маркетингу схожі зміни до тих, щзо виникають під час економічного спаду. Разом із тим, криза, яка виникла внаслідок пандемії, набула характеристик, які відрізняються від попереднього ичкклу, зокрема, зміна споживання між категоріями та прискорений перехід від режиму офлайн до поведінки в Інтернеті. Це змушує кінцевих споживачів переоцінити життєві пріоритети.
\end{abstract}

Ключові слова: маркетинг, пандемія, Covid-19

Світова економіка переживає одну 3 найбільших проблем після Другої світової війни. Криза COVID-19 впливає на всі аспекти життєдіяльності людства. Наразі, вона значно гальмує усі економічні процеси, суттєво сповільнює динаміку розвитку країн світу, кожна з яких фактично знаходиться у стадії рецесії. Цей процес чітко спостерігається шляхом аналізу відповідних статистичних даних щодо впливу COVID-19 на реальний світовий ВВП, як зображено на рис.1. 

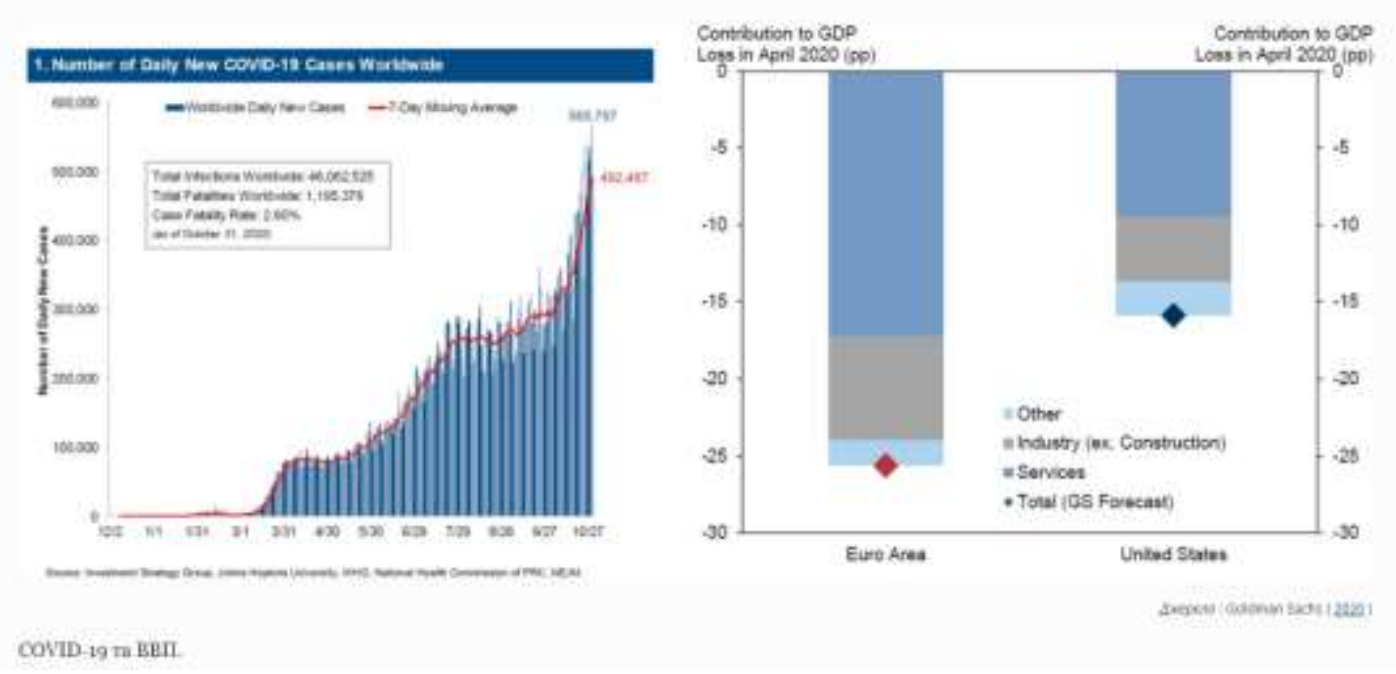

Рис. 1 - Впливу COVID-19 на реальний ВВП країн світу в 2020 p.

Лівий бік рис. 1 демонструє неухильне зростання у всьому світі випадків захворювання на COVID-19. Рис. 1, зображений праворуч, свідчить про суттєве падіння ВВП у світі, що може мати довгострокові наслідки.

Результати проведеного авторами дослідження свідчать про високу ймовірність того, що криза COVID-19 матиме суттєві наслідки впливу на поведінку споживачів, що стосуватиметься майже всіх підприємств. Щоб мати змогу продовжувати задовольняти основні потреби споживачів та підтримувати рівень зайнятості, компанії повинні максимально обмежити негативні наслідки впливу кризи. Одним із доступних інструментів для досягнення цього $\epsilon$ маркетинг.

Дослідження, проведені авторами, дозволяють окреслити шляхи, якими компанії можуть адаптувати свою маркетингову політику в кризові часи.

Спочатку виявімо наслідки безпрецедентного зриву, спричиненого COVID19, на негайну та довгострокову поведінку споживачів. Після цього визначимо наслідки впливу коронавіруса на формування маркетингових стратегій та маркетингової політики.

Використання маркетингу під час (i після) кризи COVID-19 демонструє (i надалі буде демонструвати) схожість зі способом здійснення маркетингу під час економічних спадів.

Dekimpe i Deleersnyder (2018) узагальнили найбільш відповідні дослідження щодо ефективності маркетингових зусиль під час спадів та підйомів. Однак, ця специфічна криза, яка супроводжуватиметься спадом, має характеристики, які відрізняються від тих, що пов'язані з рецесією. Наприклад, падіння споживання через нижчу довіру споживачів, нижчі доходи, неплатежі споживачів за кредитами та зменшення фінансових можливостей у результаті падіння цін на акції; зрушення у споживанні між категоріями товарів. Крім того, соціальне дистанціювання також негативно впливає на поведінку споживачів.

Споживачів чекають переоцінки своїх життєвих пріоритетів, що може породити нову парадигму цінностей та критеріїв витрат. У цьому відношенні 
Euromonitor International (2020) спостерігав за акцентом уваги на сім'ї, спільноті, особистості, здоров'ї та цифрових рішеннях, і очікує, що це триватиме в довгостроковій перспективі. Зокрема, Euromonitor визначив різні мегатренди, зокрема:

1. Пов'язані споживачі: як споживачі, так і бізнес демонструють сильніші емоційні зв'язки з надійними постачальниками у пошуках стабільності та цінності. У цьому відношенні цифровізація набуває особливого значення i демонструє шлях для споживачів, роботодавців та працівників, яким вони можуть продовжувати працювати в майбутньому. Такі послуги, як Zoom та Google Meet, виявляються необхідними у багатьох ситуаціях. Морально-етичним цінностям (ї називають етичним життям) також приділяється більша увага. У зв'язку з цим Euromonitor згадав про тенденцію споживачів більше залучатися до продуктів та послуг та надавати більшу цінність зв'язкам із надійними, часто важливими та відомими брендами.

2. Здоровий спосіб життя: здоровий спосіб життя та здорові звички всередині та поза домом стають все більш важливими, а також застосовується більш цілісний підхід до оздоровлення.

3. Середній та нижчий економічні класи намагаються зберегти своє економічне становище та спосіб життя під впливом пандемії. При цьому, безробіття в світі різко зростає.

4. Перехід придбань до онлайн режиму соціального дистанціювання призводить до переходу до Інтернет-покупок серед багатьох споживачів. Сюди входять як продовольчі товари, так і товари тривалого користування. Як результат, Інтернет-магазини відчувають колосальне зростання обороту. Спостерігається, що споживачі, які раніше не були знайомі з онлайн-покупками, зараз їх активно використовують. Очікується, що принаймні частина людей, яка перейшла до покупок засобами Інтернет, буде постійною. Криза COVID-19 також привела до купівлі переважно продуктів місцевого виробництва. Наприклад, платформа електронної комерції Streetify об'єднує покупців та місцеві магазини.

Спостерігається, що компанії адаптують свої цілі та ініціюють ініціативи, спрямовані на вирішення проблеми COVID-19. Такі заходи називаються «маркетингом цілей» або «маркетингом, пов'язаним із причинами», i демонструють корпоративну соціальну відповідальність (КСВ). Багато існує закликів до цільового маркетингу, щоб допомогти людям похилого та вразливого віку в суспільстві, а також підтримати та заохотити тих, хто потребує емоційної підтримки.

Наприклад, Coca-Cola пожертвувала 120 мільйонів доларів на боротьбу з COVID-19 і тимчасово припинила свою комерційну діяльність. Nivea (Beiersdorf) пожертвувала 50 мільйонів, а Facebook - 100 мільйонів. Toyota Netherlands використовує свою дилерську мережу для збору та розподілу медичних та інших матеріалів. Інший приклад - мережа супермаркетів, яка жертвує Червоному Хресту десять євроцентів за кожну продану коробку молока, каші та заварного крему. У мета-аналізі Fan et al (2020) виявляють, що ефект маркетингу, 
пов'язаного з причинами, більший, коли це здійснюється знайомою торговою маркою утилітарного товару, коли жертвується відносно велика сума грошей і причина є менш відомою.

Важливо також, щоб така діяльність пов'язувалася з автентичністю брендів, які ініціюють такі компанії. Таким чином, ці заходи також зміцнять прихильність споживачів до бренду та покращать усне передавання інформації.

Під час кризи COVID-19 маркетинг стикається з основною проблемою: як дістати продукцією до покупців? Поширення обмежене, i багато торгових мереж (IKEA, мережі одягу) навіть змушені (тимчасово) закрити свої двері. Компанії, що мають власний Інтернет-канал, мають переваги порівняно з магазинами, які працюють лише в режимі офлайн. Дослідження показують, що компанії, які застосовують багатоканальну стратегію, в якій вони поєднують офлайн-та онлайн-канали, працюють ефективніше з точки зору частки гаманця (Melis et al, 2016 ) та з точки зору доходів (Pauwells та Neslin, 2015).

Такі компанії краще функціонували під час пандемії, оскільки вони вже були готові пропонувати свої продукти та послуги в Інтернеті - там, де інших не було, i, отже, більш чутливо реагували на зміни у пересуванні клієнтів (Lemon and Verhoef 2016). Водночас, підвищений попит на їх продукцію також потребує креативних рішень. Наприклад, популярний універмаг у Нідерландах (HEMA, де продажі в Інтернеті зросли втричі) використовує близько двадцяти магазинів як розподільчі центри, щоб уникнути тривалого часу очікування в центральному розподільчому центрі. Косметична мережа Rituals обрала подібну стратегію (збільшення обсягу продажів в Інтернеті на 300\%).

Компанії без власного Інтернет-каналу можуть пропонувати товари в Інтернеті, використовуючи існуючі платформи.

Криза COVID-19 також чітко дала зрозуміти, наскільки компанії залежні від зовнішніх ринків як з боку попиту, так і з боку пропозиції. Що стосується попиту, спостерігається багато онлайн-та офлайн-ініціатив на кшталт «купуйте місцеве», які дозволяють виробникам генерувати продажі там, де це було б неможливо. Наприклад, місцеві роздрібні торговці можуть (тимчасово чи постійно) використовувати різні платформи, щоб пропонувати свої товари шляхом самовивезення або доставкою додому. Загалом, спостерігається тенденція до скорочення ланцюгів поставок.

Частка приватних брендів зростає під час спаду за рахунок національних брендів і скорочується, коли економіка процвітає. Навіть після спаду частка брендових товарів, як правило, нижча, ніж була до спаду. Таким чином, необхідно інвестувати у фірмову продукцію.

Особливо актуально для національних та міжнародних брендів бути посправжньому прозорими та безпечними. Стійкість бренду також відіграє важливу роль, оскільки криза COVID-19 збігається з постійними дискусіями щодо зміни клімату та його наслідків для нашої планети та їі мешканців.

Під час цієї кризи ціну (як інструмент маркетингу) слід використовувати 3 великою обережністю. 
Чутливість споживачів до ціни зростає під час скорочення. Ступінь підвищення чутливості до ціни залежить від різних чинників, зокрема: унікальність продукту, важливість для споживачів, зосередження на масовому ринку чи «ніші». Бренди, орієнтовані на масовий ринок і менш унікальні, більш чутливі до ціни, ніж інші унікальні бренди, які орієнтуються на ніші.

Зараз особливо актуальним $є$ створення продуктів, що пропонують споживачеві «співвідношення ціни та якості». Споживачі будуть незадоволені, якщо їм доведеться платити більше без одночасного підвищення якості продукції та / або послуг.

Тимчасові пропозиції зі знижками можуть бути використані для реагування на підвищену чутливість до ціни. У той же час, підвищення ціни може призвести до цінової війни та зниження базової ціни (ціни, яку споживачі очікують заплатити за товар). Постачальники, які хочуть зменшити ризики таких наслідків, можуть використовувати інші види просування, крім ціни, наприклад, пропонуючи подарунки та (можливо, додаткові) послуги. Крім того, знижки $\epsilon$ неприпустимими, оскільки поточна криза призвела до небажаного накопичення продукції.

На жаль, виявилося, що багато компаній сьогодні мають обмежене бачення того, що таке ефективність. Вони головним чином зосереджуються на короткостроковому скороченні витрат на мікрорівні і приділяють мало уваги або зовсім іiі не приділяють часу та енергії виробничих факторів, що використовуються в їхніх операційних процесах. Цей обмежений підхід був застосований до надмірного ступеня у деяких компаніях, що призвело до масштабного аутсорсингу замість власного виробництва, низького рівня запасів, високого ступеня залежності від іноземних виробників (наприклад, китайських) та низьких цін (що стосується продовольчих товарів).

Прогноз. Надалі нам доведеться платити більше за щоденні продукти та за багато послуг, включаючи охорону здоров'я. Якщо це призведе до зменшення попиту на товари, які загрожують майбутньому нашої планети (транспорт, наприклад, подорожі), це само по собі буде мати позитивний ефект. Можна сподіватися, що нинішні події приведуть до творчих інновацій, які сприятимуть більш стійкій та етичній економіці і суспільству в епоху після COVID-19.

Отже, в результаті проведеного дослідження виявлено багато можливостей маркетологам продемонструвати свою цінність для компаній, які або постраждали від COVID-19. Крім того, задачею науковців-маркетологів $\epsilon$ вивчення тимчасових та постійних наслідків впливу COVID-19 на поведінку споживачів, а також того, як організації можуть адаптувати маркетингові стратегії та маркетингову політику.

\section{Список використаної літератури}

1. COVID-19: вплив на маркетинг. URL: https://vrk.org.ua/newsevents/2020/covid-and-marketing.html (режим доступу: 29.03.2021 p.).

2. Вплив ковіда на рекламу URL: https://livepage.pro/blog/coronavirusimpact-on-marketing.html (режим доступу: 29.03.2021 p.). 
3. Стратегія маркетингового розвитку під час карантину URL : https:// amdg.ru/research/strategii-marketinga-i-pr-vo-vremya-covid-19/ (режим доступу: 29.03.2021 p.).

4. Виживання вимагає змін. Маркетинг під час карантину. URL : https://zmist.pl.ua/blogs/marketing-u-krizu-vizhivannya-vimagaje-zmin (режим доступу: 29.03.2021 р.).

5. Антикризовий маркетинг URL: https://stud.com.ua/62970/marketing/ antikrizoviy_marketing (режим доступу: 29.03.2021 p.).

6. Марущак О.Я., Косар Н.С., Кузьо Н.С Вплив кризи на маркетингову діяльність

підприсмств та поведінку споживачів С. 75 - 95. 120с.

7. Маркетингові стратегії під час кризи. Концепція «Криза - Відновлення Зростання». URL : https : //business.diia.gov.ua/cases/antikrizovi-risenna/ marketingovi-strategii-pid-cas-krizi-koncepcia-kriza-vidnovlenna-zrostanna (режим доступу: 29.03.2021 p.).

8. Маркетинг в умовах кризи URL: https://smartpeople.ua/praktychniporady/marketing-v-umovah-krizi (режим доступу: 29.03.2021р.).

9. Застосування маркетингових комунікацій у період пандемії COVID-19. C. $10-20$.

10. Вплив пандемії на економіку URL: https://www.ukrinform.ua/rubriceconomy/3154276-ak-karantin-vplinuv-na-ekonomiku-ukraini.html (режим доступу : 29.03.2021 p.). 


\title{
ОПТИМАЛЬНІ ПАРАМЕТРИ ВОДОРЕГУЛЮВАННЯ ПРИ ВИРОЩУВАННІ КОРМОВИХ КУЛЬТУР НА ОСУШУВАНИХ ЗЕМЛЯХ ПІВНІЧНОГО ЛІСОСТЕПУ УКРАЇНИ
}

\author{
Воропай Галина Василівна \\ к.т. н., завідуюча відділу дренажу \\ Інститут водних проблем і меліорації НААН України \\ Молеща Неля Богданівна \\ к.т. н., старший науковий співробітник \\ Інститут водних проблем і меліорації НААН України
}

В процесі масштабних змін клімату стрімко змінюються умови сприятливості вирощування основних сільськогосподарських культур стосовно різних грунтово-кліматичних зон України [1]. Меліоровані землі північного Лісостепу України $є$ важливими для ведення сталого та ефективного сільськогосподарського виробництва .

Вітчизняний i світовий досвід свідчить про те, що впровадження у виробництво пайзи, амаранту та кормових бобів дає змогу не тільки забезпечити тваринництво високоякісними кормами, а й задовольнити потреби харчової i фармацевтичної промисловості цінною сировиною [2].

Для отримання сталих урожаїв пайзи, амаранту та кормових бобів у польовому кормовиробництві на меліорованих землях гумідної зони потрібно розроблення оптимальних параметрів водорегулювання, які забезпечать необхідні меліоративні режими осушуваних грунтів при їх вирощуванні.

Пайза, амарант і кормові боби мають значний адаптивний та продуктивний потенціал, ряд біологічних переваг та особливостей, які зумовлюють перспективність і доцільність їх вирощування у складних грунтово-кліматичних умовах осушуваних земель Вони $є$ і цінними кормовими, продовольчими та лікарськими культурами; високоенергетичними; 3 високим вмістом білку, унікально збалансованого за вмістом незамінних амінокислот; 3 високим вмістом вітамінів, макро- та мікроелементів та інших біологічно активних речовин [3].

Актуальними будуть дослідження, спрямовані на вдосконалення водорегулювання меліоративних об’єктів при дотриманні оптимального водноповітряного i поживного режимів осушуваних грунтів, економічних та екологічних вимог згідно 3 положеннями «Стратегії...» [4]. Основою для розроблення технологічних параметрів водорегулювання при вирощуванні пайзи, амаранту та кормових бобів $є$ результати натурних досліджень із визначення метеорологічних параметрів (опадів, температури повітря), динаміки рівня грунтових вод (РГВ) та вологості в кореневому шарі грунту, які проведено 
на меліорованих землях впродовж 2016-2020 рр. осушувально-зволожувальної системи «Ромен» (Сумська область). Вибраний пілотний об’єкт досліджень 3 урахуванням природно-кліматичних умов та конструктивно-технологічних особливостей меліоративної системи є репрезентативним для території гумідної зони північного Лісостепу.

Дослідження технологічних параметрів водорегулювання високопродуктивних кормових культур основані на проведених метеорологічних спостереженнях, визначенні РГВ, вологості грунту, біометричних характеристик, урожайності впродовж вегетаційних періодів 2016-2020 pp. Аналіз кліматичних умов на пілотному об'єкті осушувально-зволожувальної системи «Ромен» (ОЗС «Ромен») отримано за даними спостережень по метеорологічному посту пілотного об'єкту (рис 1).

Особливості погодних умов у період 2016-2020 рр. проявляються у тому, що у зазначений 5-річний період значно менше норми випало опадів у серпні та вересні, а також суттєве зменшення за останніх два роки осінніх та зимових опадів. Протягом 2016-2020 pp. середньомісячна температура повітря за вегетаційний період в усі роки була на $0,7^{\circ} \mathrm{C}$ меншою до середньо багаторічних значень. Хоча середньорічна температура за цих п'ять років на $2,0{ }^{\circ} \mathrm{C}$ збільшилася у порівнянні з кліматичною нормою Середньомісячна кількість опадів та динаміка середньомісячних температур повітря у вегетаційний період 2016-2020 рр. на ОЗС «Ромен» представлені на рис. 1.

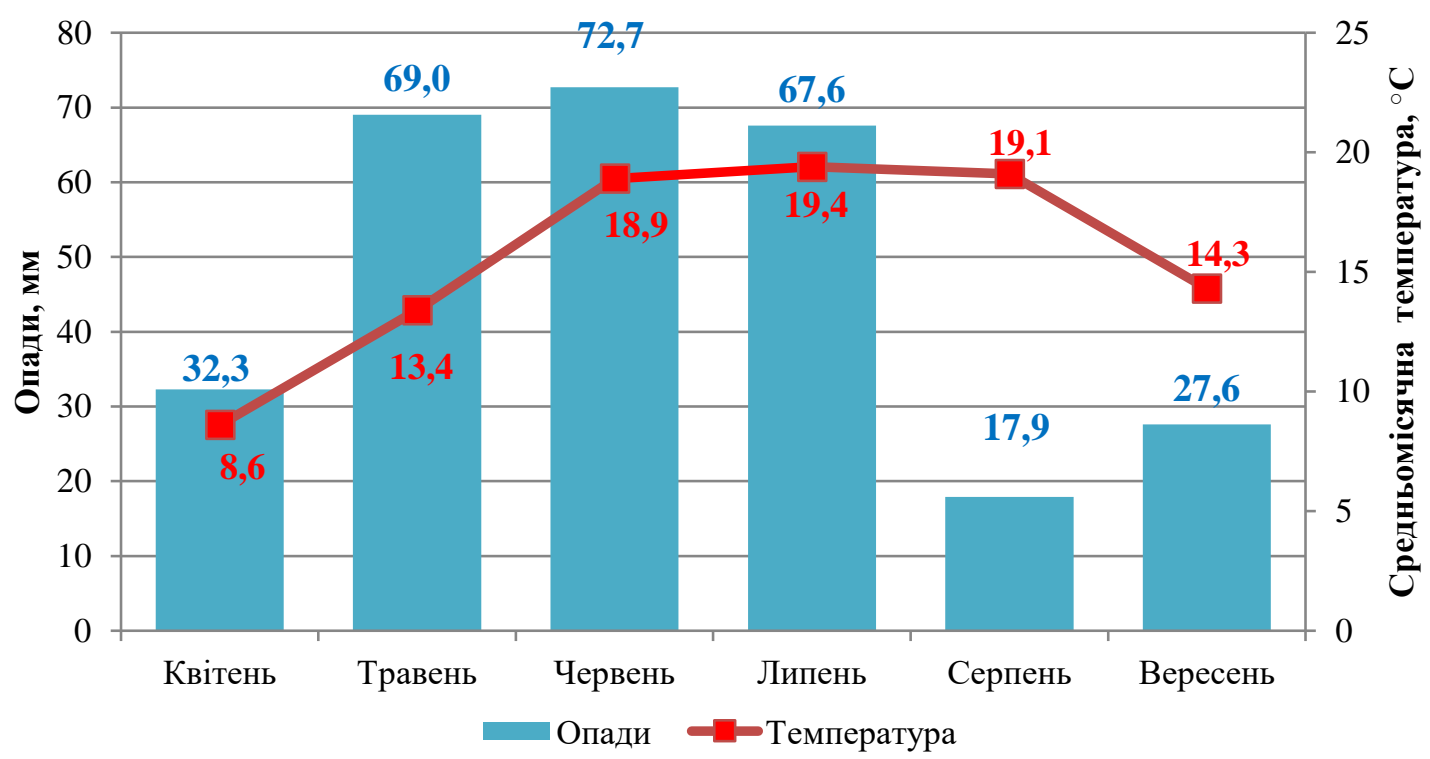

Рисунок 1. Середньомісячна кількість опадів та динаміка середньомісячних температур повітря у вегетаційний за період 2016-2020 рр., ОЗС «Ромен»

Таким чином, за останні п'ять років відзначається зміна кліматичних умов зволоження північного Лісостепу, що приводить до зниження зволоженості території. Наведені показники вказують, що досліджуваний об'єкт в середньому не дуже посушливий, хоча $є$ кожного року посушливі (бездощові) періоди, в яких протягом десяти і більше днів не спостерігаються опади, або їх добова кількість не перевищує 1 мм, що вимагає додаткового зволоження в посушливі вегетаційні періоди. 
Середній гідротермічний коефіцієнт протягом вегетаційного періоду 20162020 рр. досліджуваної території північного Лісостепу становить 1,0 - зона не дуже посушлива, хоча 40 \% випадків, 35 років спостерігаються посушливі і дуже посушливі періоди.

Оптимальні меліоративні режими та технологічні параметри водорегулювання враховують особливості водоспоживання кормових культур, їхні біологічні та господарські характеристики, а також особливості їх вирощування в залежності від типу грунту [2].

На об'єкті ОЗС «Ромен» у вегетаційний період 2016-2020 p. РГВ у весняний період були у межах 60-95 см, літній період - 100-155 см, наприкінці вегетаційного періоду - 190- 200 см від поверхні грунту.

Експериментальними дослідженнями встановлені рекомендовані норми РГВ та вологості грунту для вирощування пайзи, амаранту та кормових бобів на осушуваних землях (табл. 1, 2).

Таблиця 1.

Рекомендовані РГВ при вирощуванні кормових культур на осушуваних землях

\begin{tabular}{|c|c|c|c|c|c|c|c|}
\hline \multirow{2}{*}{$\begin{array}{c}\text { Фаза } \\
\text { вегетації }\end{array}$} & \multicolumn{7}{|c|}{$\begin{array}{c}\text { Рівень грунтових вод, м } \\
\text { (у чисельнику - оптимальний; у знаменнику - найменший допустимий) }\end{array}$} \\
\hline & $\begin{array}{l}\text { передпосівний } \\
\text { період }\end{array}$ & $\begin{array}{c}\text { сходи- } \\
\text { кущення }\end{array}$ & $\begin{array}{l}\text { вихід у } \\
\text { трубку }\end{array}$ & $\begin{array}{r}\text { викид } \\
\text { воль }\end{array}$ & & цвітіння & $\begin{array}{c}\text { достигання } \\
\text { насіння }\end{array}$ \\
\hline \multicolumn{8}{|c|}{ Пайза } \\
\hline $\begin{array}{l}\text { Торфові } \\
\text { грунти }\end{array}$ & $0,50-0,55$ & $\frac{0,60-0,65}{0,65-0,70}$ & $\frac{0,60-0,75}{0,75-0,85}$ & $\frac{0,60-(}{0,75-(}$ & & $\frac{0,75-0,85}{0,90-0,95}$ & $\frac{0,75-0,90}{0,9-1,0}$ \\
\hline $\begin{array}{l}\text { Мінеральні } \\
\text { грунти }\end{array}$ & $0,50-0,60$ & $\frac{0,60-0,70}{0,70-0,75}$ & $\frac{0,65-0,75}{0,80-0,85}$ & $\frac{0,65-(}{0,80-(}$ & & $\frac{0,80-0,90}{0,90-1,0}$ & $\frac{0,85-0,90}{1,0-1,1}$ \\
\hline \multicolumn{8}{|c|}{ Амарант } \\
\hline $\begin{array}{c}\text { Фаза } \\
\text { вегетації }\end{array}$ & $\begin{array}{c}\text { передпосівний } \\
\text { період }\end{array}$ & $\begin{array}{c}\text { сходи-поява } \\
\text { справжнього } \\
\text { листка }\end{array}$ & \multicolumn{2}{|c|}{ викидання волоті } & \multicolumn{2}{|c|}{ цвітіння } & $\begin{array}{c}\text { достигання } \\
\text { насіння }\end{array}$ \\
\hline $\begin{array}{c}\text { Торфові } \\
\text { грунти }\end{array}$ & $0,60-0,65$ & $\frac{0,60-0,65}{0,65-0,75}$ & \multicolumn{2}{|c|}{$\frac{0,60-0,70}{0,70-0,80}$} & \multicolumn{2}{|c|}{$\frac{0,65-0,80}{0,80-0,90}$} & $\frac{0,80-1,0}{1,0-1,1}$ \\
\hline $\begin{array}{c}\text { Мінеральні } \\
\text { грунти }\end{array}$ & $0,50-0,60$ & $\frac{0,60-0,70}{0,70-0,75}$ & \multicolumn{2}{|c|}{$\frac{0,65-0,75}{0,75-0,80}$} & \multicolumn{2}{|c|}{$\frac{0,70-0,85}{0,90-1,0}$} & $\begin{array}{c}0,85-1,0 \\
1,0-1,1\end{array}$ \\
\hline \multicolumn{8}{|c|}{ Кормові боби } \\
\hline $\begin{array}{c}\text { Фаза } \\
\text { вегетації }\end{array}$ & $\begin{array}{c}\text { передпосівний } \\
\text { період }\end{array}$ & $\begin{array}{c}\text { сходи-поява } \\
\text { справжнього } \\
\text { листка }\end{array}$ & бутонізація & цвіті & & $\begin{array}{c}\text { утворення } \\
\text { бобів }\end{array}$ & $\begin{array}{c}\text { достигання } \\
\text { насіння }\end{array}$ \\
\hline $\begin{array}{c}\text { Торфові } \\
\text { грунти }\end{array}$ & $0,55-0,65$ & $\frac{0,55-0,65}{0,70-0,75}$ & $\frac{0,60-0,65}{0,70-0,75}$ & $\underline{0,65-1}$ & & $\frac{0,75-0,90}{0,90-1,0}$ & $\frac{0,90-1,0}{1,1-1,2}$ \\
\hline $\begin{array}{c}\text { Мінеральні } \\
\text { грунти }\end{array}$ & $0,55-0,65$ & $\frac{0,60-0,70}{0,70-0,75}$ & $\frac{0,60-0,70}{0,70-0,75}$ & $\underline{0,65-1}$ & & $\frac{0,80-0,90}{0,90-1,0}$ & $\frac{1,0-1,1}{1,1-1,2}$ \\
\hline
\end{tabular}


Таблиця 2.

Рекомендовані норми вологості грунту при вирощуванні високопродуктивних кормових культур на осушуваних землях

\begin{tabular}{|l|c|c|c|c|}
\hline \multirow{2}{*}{ Культура } & \multicolumn{3}{|c|}{ Вологість грунту у шарі 0-0,5 м, \% від повної вологоємкості } \\
\cline { 2 - 5 } & \multicolumn{2}{|c|}{ торфового } & \multicolumn{2}{c|}{ мінерального } \\
\cline { 2 - 5 } & оптимальна & $\begin{array}{c}\text { найменша } \\
\text { допустима } \\
\text { (у літній період) }\end{array}$ & оптимальна & $\begin{array}{c}\text { допустима } \\
\text { (у літній період) }\end{array}$ \\
\hline Пайза & $70-75$ & 60 & $65-80$ & 60 \\
\hline Амарант & $65-75$ & 55 & $65-75$ & 55 \\
\hline Кормові боби & $70-75$ & 60 & $65-75$ & 60 \\
\hline
\end{tabular}

На основі експериментальних досліджень, проведених на ОЗС «Ромен» розроблено науково-методологічні засади управління водним режимом при вирощуванні перспективних кормових культур на осушуваних землях враховуючи: вплив агрокліматичних умов на вирощування пайзи, амаранту та кормових бобів; вимоги культур до регулювання водно-повітряного режиму грунту (допустимі терміни, у які меліоративна система має забезпечити відведення надлишкових вод; рекомендовані РГВ та норми вологості в кореневому шарі грунту протягом вегетаційного періоду); вимог культур до регулювання поживного режиму грунту (вапнування кислих грунтів, внесення органічних та мінеральних добрив та мікродобрив); основних технологічних параметрів вирощування пайзи, амаранту та кормових бобів, в т.ч. за фазами розвитку зазначених культур та 3 врахуванням критичних періодів їх оптимального вологозабезпечення, оптимальні режими зволоження (осушення), агротехнічні заходи та оптимальні норми удобрення при вирощуванні на органогенних та мінеральних грунтах.

Дотримання оптимальних технологічних параметрів водорегулювання на початку вегетації та на період сходи-поява справжнього листка, який припадає на критичний період їх вирощування забезпечило урожайність цих культур на рівні середніх показників. За результатами досліджень, встановлено, що впродовж вегетаційного періоду потреби пайзи, амаранту та кормових бобів у вологості в кореневому шарі грунту змінюються залежно від їхніх біологічних особливостей і поточних метеорологічних умов та зволоження. Середня урожайність вегетативної маси пайзи, амаранту та кормових бобів в залежності від удобрення на пілотному об'єкті зволожувальна система «Ромен» за 20162020 рр. наведена на рис. 2. 


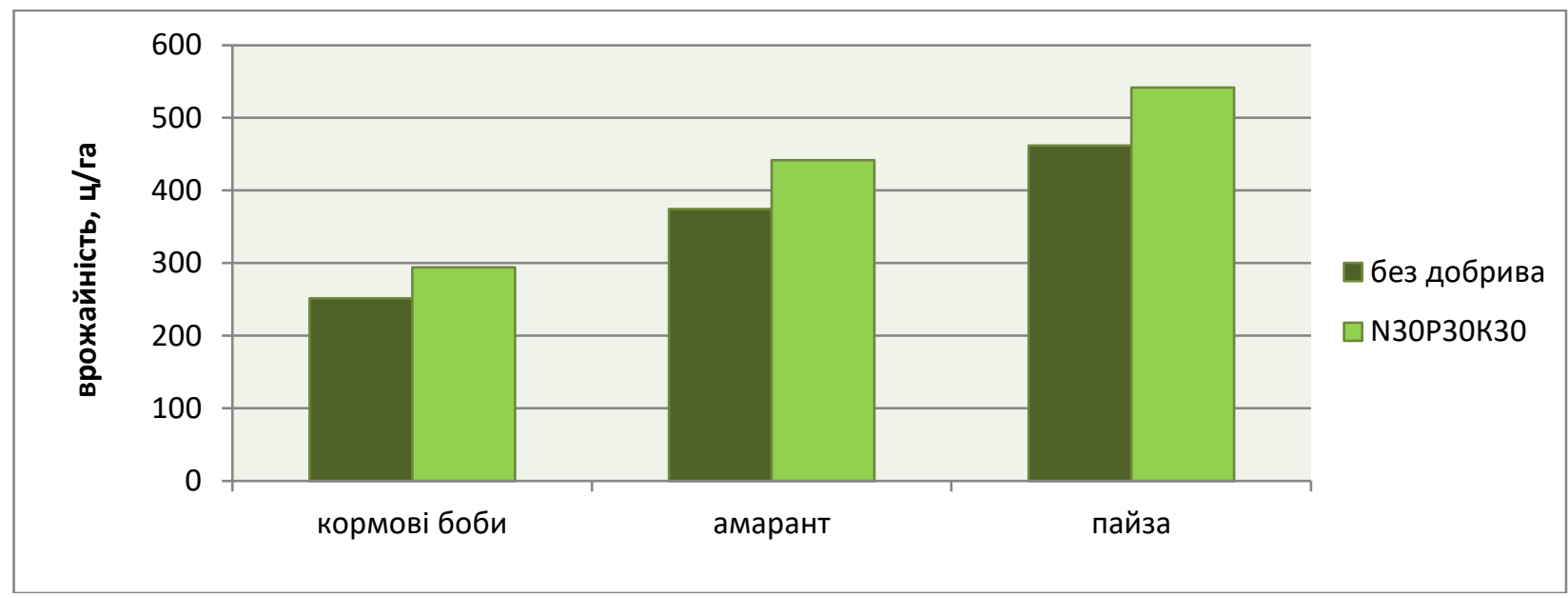

Рисунок 2. Середня врожайність вегетативної маси кормових культур на фоні удобрення (ОЗС «Ромен»)

Встановлено, що при внесенні добрив у нормі $\mathrm{N}_{30} \mathrm{P}_{30} \mathrm{~K}_{30}$ урожайність вегетативної маси пайзи становила 541,7 ц/га, що на 14,6 \% більше, ніж на контролі; амаранту - 442,5 ц/га, що 15,3 \% більше, ніж на контролі; кормових бобів - 294,0 ц/га, що 14,4 \% більше, ніж на контролі. (рис.2).

Визначено технологічні параметри водорегулювання (норми рівня грунтових вод і вологості в кореневому шарі грунту) упродовж періоду вегетації для вирощування високопродуктивних кормових культур на меліорованих торфових i мінеральних грунтах Отже пайза, амарант та кормові боби мають значний адаптивний i продуктивний потенціал при вирощуванні в екстремальних агрокліматичних умовах, ряд біологічних переваг та особливостей, які вказують на їх перспективність та доцільність вирощування в складних грунтовокліматичних умовах осушуваних земель північного Лісостепу України.

\section{Список літератури}

1. Ромащенко М.І.,Тараріко Ю.О. Меліоровані агроекосистеми. Ніжин: видавництво ПП Лисенко М.М., 2017. 696с.

2. Яцик М.В., Воропай Г.В., Кіка С.М. Обгрунтування режимів водорегулювання при вирощуванні високопродуктивних кормових культур на осушуваних землях .// Вісник аграрної науки. 2019. № 5 С. $60-67$.

3. Коваль С.І., Зосимчук О.А. Продуктивність ланок кормових сівозмін 3 малопоширених кормових культур на осушуваних торфових грунтах Західного Полісся. // Вісник Національного університету водного господарства i природокористування. 2014. № 65 (1). С. 64 - 72.

4. Стратегія зрошення та дренажу в Україні на період до 2030 року. Схвалено Кабінетом Міністрів України., 2019. № 688-р. 


\section{ВИКОРИСТАННЯ СПОЛУК ЦЕРІЮ У СІЛЬСЬКОМУ ГОСПОДАРСТВІ}

\section{Цехмістренко Світлана Іванівна,}

доктор с.-Г. наук, професор, завідувач кафедри хімії

Білоцерківський національний аграрний університет

Бітюцький Володимир Семенович, доктор с.-г. наук, професор, завідувач кафедри екології та біотехнології Білоцерківський національний аграрний університет

\section{Цехмістренко Оксана Сергіївна,}

кандидат с.-г. наук, доцент, доцент кафедри екології та біотехнології Білоцерківський національний аграрний університет

У перелік десяти пріоритетних наноматеріалів експерти міжвідомчої програми 3 коректного управління хімічними препаратами (IOMC) і організації економічної кооперації та розвитку (OECD) включений нанодисперсний діоксид церію [1]. Церій $\epsilon$ найпоширенішим рідкоземельним металом (близько $0,0046 \%$ маси Земної кори), i, безумовно, $є$ елементом промислового значення. Діоксид церію $\left(\mathrm{CeO}_{2}\right)$, який також називають церієм, $\epsilon$ найвідомішою сполукою церію, завдяки його неперевершеним окисно-відновним властивостям і здатності гарантувати чудову рухливість кисню. Це потужний окиснювач, який використовується в каталізі та медицині. Нанодисперсний діоксид церію $є$ перспективним матеріалом, що знаходить широке застосування в сучасних високотехнологічних галузях промисловості [2].

Значний інтерес, який виявляють в останні роки до вивчення діоксиду церію, в першу чергу обумовлений фактом, що при переході в нанокристалічний стан дана сполука значно змінює свої фізико-хімічні властивості, причому характер цих змін досить незвичайний. Зокрема, на відміну від цілого ряду речовин (наприклад, елементарного золота), зі зменшенням розмірів частинок параметр елементарної комірки $\mathrm{CeO}_{2}$ збільшується. Одночасно з цим спостерігається зміна кисневої нестехіометрії діоксиду церію, обумовлене збільшенням частки атомів, що знаходяться на поверхні частинок, що обумовлює зміну його електронних і електрофізичних властивостей [3].

Яскраво виражений вплив розмірного фактору на фізико-хімічні властивості нанодисперсного діоксиду церію обумовлює унікальну біологічну активність матеріалу $[1,3]$. Перспективи та особливості його застосування визначаються низькою токсичністю і високою кисневою нестехіометрією. Перший фактор забезпечує порівняльну безпеку застосування наночастинок діоксиду церію in vivo. Другий обумовлює активність нанодисперсного $\mathrm{CeO}_{2}$ в окисно-відновних 
процесах у живій клітині, особливо у разі інактивації активних форм кисню [4]. До специфічних властивостей $\mathrm{CeO}_{2}$ слід віднести і здатність до регенерації кисневої нестехіометрії, яка виражається у здатності наночастинок діоксиду церію після участі в окисно-відновному процесі за порівняно невеликий проміжок часу повертатися до вихідного стану, що забезпечує можливість їх багаторазового використання $[1,5]$.

Наночастинки, завдяки маленьким розмірам, легко проникають у організм через органи дихання, травлення, шкіру та проявляють більш виражену біологічну активність внаслідок великої площі поверхні на одиницю маси. Зміна фізико-хімічних механізмів дії наночастинок зумовлена тим, що більшість атомів знаходиться на поверхні. Таке розташування змінює фізичні, хімічні, біологічні, токсикологічні властивості речовини та сприяє полегшенню взаємодії наночастинок $з$ живим організмом.

Нині значна кількість рослинної продукції вирощується із застосуванням нанотехнологій. Очікується, що у найближчий час понад 15 \% всіх продуктів на світовому ринку буде мати певні включення нанотехнологій у їх виробничий процес. Сконструйовані наночастинки (від 1 до 100 нм) можуть мати інакші фізичні та хімічні властивості, аніж ті, що зустрічаються в природі, їх вплив на здоров'я людини має бути оцінений залежно від їх розміру і форми [1].

Нанотехнологічні прийоми можуть застосовуватися для контрольованого вивільнення лікарських засобів, пестицидів, агрохімікатів, для ефективного використання мікроелементів, не порушуючи життедіяльність корисних комах. При цьому забезпечується перетворення органічних відходів у товарну продукцію. Наночастинки здатні виявляти абсолютно нові або поліпшені властивості, у порівнянні з більшими частками дисперсного матеріалу, з якого вони виготовлені. Біорозкладані органічні відходи рослин можуть бути використані для синтезу наночастинок, оскільки всі вони містять феноли, флавоноїди і відновлюючі агенти. Сучасна стратегія одержання наночастинок, зокрема діоксиду церію, передбачає використання принципів та підходів «зеленої хімії» [6].

Незважаючи на ризики, нанотехнології широко впроваджуються у всіх галузях промисловості та сільського господарства. Наразі ведеться інтенсивна дискусія щодо впливу наночастинок на навколишнє середовище і здоров'я людини. Потрапивши у біологічну систему, наночастинки стикаються з низкою фізичних і хімічних особливостей організму, які впливають на їх властивості та здатні змінити відповідь [7]. Ці особливості значною мірою обумовлені здатністю до проходження у окисно-відновному циклі між двома природними станами окиснення $\left(\mathrm{Ce}^{3+} \mathrm{i} \mathrm{Ce}{ }^{4+}\right)$. Проте раніше вважали, що наночастинки $\mathrm{CeO}_{2}$ стабільні та малорозчинні або нерозчинні в умовах навколишнього середовища, що залежить від носія, $\mathrm{pH}$ і розміру часток. Розчинення наночастинок залежить від співвідношення між $\mathrm{Ce}^{3+}$ i Ce ${ }^{4+}$ на їх поверхневому шарі. 3i зменшенням розміру наночастинки все більше звільняються від вакансій кисню в решітці, що призводить до місцевого зниження кількості $\mathrm{Ce}^{4+}$.

Виявлено, що токсичність наночастинок $\mathrm{CeO}_{2}$ до кишкової палички пов'язана 3 поверхнею наночастинки, що змінюється за присутності бактерії. Додавання 
фосфату до поверхні наночастинки може зупинити цей редокс-цикл шляхом

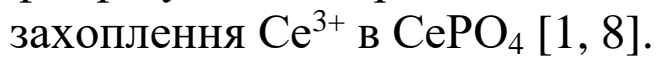

В останні роки у літературі зустрічаються повідомлення щодо застосування наночастинок металів, зокрема церію у тваринництві, оскільки використання антибіотиків в якості стимуляторів росту заборонено в Свропейському Союзі. Тому вчені та виробники продукції тваринництва розпочали інтенсивні пошуки альтернативи кормовим антибіотикам. Ефірні олії, отримані зі спецій і трав, преі пробіотики, органічні кислоти і ферменти нині успішно застосовуються в якості заміни для антибіотичних кормових добавок. Повідомляється, що низка рідкоземельних елементів (РЗЕ), до яких належить церій, можуть успішно застосовуватися в якості нових природних добавок до корму з метою підвищення продуктивності тварин [9].

Існують повідомлення, що РЗЕ можуть активізувати обмін білків та інших поживних речовин шляхом стимулювання діяльності гормонів, зокрема гормону росту і $\mathrm{T}_{3}$, індукувати синтез металотіонеїнів та підвищувати вміст глутатіону в печінці. Окрім того, встановлена антимікробна та антиоксидантна дія РЗЕ для тварин. У разі їх застосування у раціоні свиней (100 мг/кг) виявляли позитивний вплив на коефіцієнт конверсії корму та показники росту.

Встановлені зміни прооксидантно-оксидантного статусу крові корів 3 гіпогонадизмом та після їх лікування при використанні препарату каплаестрол, який містить наночастинки $\mathrm{CeO}_{2}$ (діоксиду церію). Також визначено ефективність репарації яєчників і відновлення репродуктивної здатності корів. Проведено дослідження змін показників гомеостазу і морфо-функціонального стану молочної залози корів сухостійного періоду у разі дефіциту каротину, вітаміну А, порушення у прооксидантно-антиоксидантній системі та за застосування препаратів каплаестрол $+\mathrm{CeO}_{2}+$ прозон $\mathrm{i}$ овакс-1+прозон. Використання наночастинок церію в комплексі 3 препаратами дає змогу нормалізувати структуру та функцію молочної залози й підвищити рівень колостральних імуноглобулінів.

Застосування РЗЕ мали позитивні результати для домашньої птиці. Додавання різних рівнів РЗЕ (200, 400, 600 і 800 мг/кг) сприяло значному збільшенню виробництва яєць, ваги яєць і швидкості запліднення інкубаційних яєць 6-місячних курей-несучок. Було встановлено що додавання різних рівнів РЗЕ-нітрату до раціону курей-несучок (300, 400 і 500 мг/кг) значно поліпшило швидкість утворення яєць та їх масу.

Додавання до раціону цитрату РЗЕ сприяє підвищенню продуктивності бройлерів [10]. Одним із механізмів впливу є підвищена секреція соків травних залоз. Додавання РЗЕ до раціону сприяло значному підвищенню СОД-активності у крові риб і курей.

Додавання курям-несучкам різної кількості діоксиду церію $(0,100,200,300$ або 400 мг/кг) не мало істотного впливу на споживання корму і масу яйця, однак при цьому поліпшується коефіцієнт конверсії корму і збільшується $(\mathrm{p}<0,05)$ виробництво яєць. Критерії якості яйця за винятком міцності на розрив шкаралупи не змінювалися. Зокрема, добавка 200 і 300 мг/кг діоксиду церію до корму несучок призвели до суттєвого $(p<0,01)$ підвищення міцності яєчної 
шкаралупи на розрив. Концентрація Кальцію і Фосфору у сироватці крові значно збільшилася $(\mathrm{p}<0,05)$ за введення 100 мг/кг оксиду церію. Було також відзначено, що в сироватці крові супероксиддисмутазна активність і концентрація малонового діальдегіду (МДА) значно зменшилася за додавання діоксиду церію. Різні дози додавання діоксиду церію не мали достовірного впливу на активність амінотрансфераз, вміст глюкози, тригліцеролів, загального холестеролу, ліпопротеїдів високої та низької щільності сироватки крові. У разі включення до раціону курей діоксиду церію спостерігали значне зменшення вмісту ТБК-АП у жовтку яєць. Водночас внаслідок добавок діоксиду церію поліпшується окисна стабільність яйця, і це, можливо, сприятливо вплине на термін їх зберігання. У застосовуваній дозі нанокристалічний діоксид церію не акумулюється в яйцях і паренхіматозних органах птиці [11].

Рідкоземельні елементи мають схожі характеристики до Са, що може призвести до підвищеної міцності оболонки яйця птиці. Вважають, що діоксид церію також може збільшити вміст Са у сироватці. Так концентрація кальцію в сироватці крові японських перепелів значно збільшилася за введення добавок 3 низькими концентраціями РЗЕ (50 і 100 мг/кг). Пероральне введення РЗЕ бройлерам не впливає на концентрацію Кальцію в сироватці крові. Зі збільшенням вмісту РЗЕ у раціоні бройлерів концентрація глюкози в крові зменшується. При цьому встановлений зворотній ефект: вміст Кальцію і Фосфору в сироватці крові підвищується низькими концентраціями добавок діоксиду церію (100 мг/кг), але високі концентрації оксиду церію не мають впливу.

Випоювання перепелам нанокристалічного діоксиду церію позитивно впливає на яєчну продуктивність. При використанні наноцерію в дозі $1 \mathrm{mM} /$ л питної води підвищилась несучість перепелів на 7,8 \%, маса яєць - на 16,9\%, інтенсивність несучості - на 6,7 \%. У дозах 0,1-10 мМ/л питної води наноцерій не акумулюється в яйцях і паренхіматозних органах птиці. Виявлений вплив на інтенсивність росту та споживання кормів молодняком перепелів.

Досліджено вплив нанокристалічного діоксиду церію та встановлені летальна та напівлетальна дози препарату. $\operatorname{Ld}_{50}$ нанокристалічного діоксиду церію є більшою за 2000 мг/кг, що підтверджує належність даної сполуки до V класу токсичності та свідчить про дуже низьку токсичність [12]. Виявлений позитивний антибактеріальний потенціал наночастинок $\mathrm{CeO}_{2}$ проти патогенів птиці, а саме Klebsiella sp., E. coli, Staphylococcus sp. та Salmonella sp.

Висока ступінь біосумісності, низька токсичність і каталітична активність нанодисперсного діоксиду церію дає змогу його розглядати як перспективний нанобіоматеріал для застосування у біології, медицині та сільському господарстві. Проте нині всі можливі механізми його біологічної активності $\epsilon$ мало вивчені та потребують подальших досліджень $[13,14]$.

Органи-мішені й механізми розвитку реакції-відповіді відрізняються для різних наночастинок металів. Вони здатні індукувати активні форми кисню, порушувати мембранні структури, проникати через тканинні бар'єри, надходити в клітини і взаємодіяти з внутрішньоклітинними компонентами [15]. Питання дослідження позитивного ефекту та токсичності наночастинок металів неоднозначне й багатогранне, потребує комплексного підходу. Особливо це 
відноситься до наночастинок, які застосовуються в фармакології, медицині та сільському господарстві, що сприяє їхньому безпосередньому надходженню в організм людини [16-19].

\section{Список літератури}

1. Козик В. В., Щербаков А. Б., Иванова О. С., Спивак Н. Я., \& Иванов В. К. (2016). Синтез и биомедицинские применения нанодисперсного діоксида церия. Томск: Издательский Дом Томского государственного университета, 476.

2. Aneggi E., de Leitenburg C., Boaro M., Fornasiero P., \& Trovarelli A. (2020). Catalytic applications of cerium dioxide. In Cerium Oxide $\left(\mathrm{CeO}_{2}\right)$ : Synthesis, Properties and Applications (pp. 45-108). Elsevier.

3. Цехмістренко О.С., Цехмістренко С.I., Бітюцький В.С., Мельниченко О.М., Олешко О.А. Біоміметична та антиоксидантна активність наносполук діоксиду церію. Світ медицини та біології, 2018, 1(63), 196-201.

4. Shcherbakov, A. B., Zholobak, N. M., \& Ivanov, V. K. (2020). Biological, biomedical and pharmaceutical applications of cerium oxide. In Cerium Oxide $\left(\mathrm{CeO}_{2}\right)$ : Synthesis, Properties and Applications (pp. 279-358). Elsevier.

5. Ц Цехмістренко О.С., Бітюцький В.С., Цехмістренко С.I. Нанотехнології і навколишне середовище. Аграрна освіта та наука: досягнення, роль, фактори росту. Екологія, охорона навколишнього середовища та збалансоване природокористування: освіта - наука - виробництво: матеріали Міжнар. наук.практ. конф., Біла Церква, 30 жовт. 2020 р., 26-29.

6. Tsekhmistrenko, S.I., Bityutskyy, V.S., Tsekhmistrenko, O.S., Horalskyi, L.P., Tymoshok, N.O. Bacterial synthesis of nanoparticles: A green approach. Biosystems Diversity, 2020, 28(1), 9-17.

7. Бітюцький В.С., Цехмістренко О.С. Шляхи взаємодії наночасточок діоксиду церію із живими клітинами та біологічними мембранами. Іхтіологія та морфологія - наукова та практична основа рибництва: матеріали Міжнар. наук.практ. конф., Біла Церква, 24 жовт. 2017 р., 32-33.

8. Бітюцький В.С., Цехмістренко О.С. Методи одержання нанокристалічного діоксиду церію та використання його сполук. Новітні технології виробництва та переробки продукції тваринництва: матеріали держ. наук.-практ. конф. молодих учених, аспірантів і докторантів, Біла Церква, 18 трав. 2017 р., 14-15.

9. Бітюцький В.С., Співак М.Я., Цехмістренко О.С., Шадура Ю.М. Використання сполук церію у тваринництві. Аграрна наука - виробництву: матеріали держ. наук.-практ. конф., Біла Церква, 17 листоп. 2016 р., 84-85.
10. Цехмістренко
O.C.,
Бітюцький
B.C.,
Цехмістренко
C.I., Мельниченко О.М., Тимошок Н.О., Співак М.Я. Використання наночастинок металів та неметалів у птахівництві. Технологія виробництва і переробки продукції тваринництва. Зб. наук. праць, 2019, 2, 113-130.

11. Шадура, Ю. М., Співак, М. Я., Бітюцький, В. С., Мельниченко, О. М., Сотніченко, І. І., Щербаков, О. Б., ... \& Жолобак, Н. М. (2015). Біохімічні показники та продуктивні якості курей-несучок за використання наночастинок діоксиду церію. Технологія виробництва і переробки продукції тваринництва, (2), 174-177. 
12. Шадура, Ю. М., Бітюцький, В. С., Співак, М. Я., Мельниченко, О.М., Щербаков, О. Б., Демченко, О. А., \& Жолобак, Н. М. (2015). Доклінічні дослідження гострої токсичності нанокристалічного діоксиду церію. Вісник Житомирського національного агроекологічного університету, 2 (1), 358-363.

13. Bityutsky V.S., Tsekhmistrenko S.I., Tsekhmistrenko O.S., Tymoshok N.O., Spivak M.Ya. Regulation of redox processes in biological systems with the participation of the Keap1/Nrf2/ARE signaling pathway, biogenic selenium nanoparticles as Nrf2 activators. Regulatory Mechanisms in Biosystems, 2020, 11(4), 483-493.

14. Tsekhmistrenko, S.I., Bityutskyy, V.S., Tsekhmistrenko, O.S., Polishchuk, V.M., Polishchuk, S.A., Ponomarenko, N.V., Melnychenko, Y.O., \& Spivak, M.Y. Enzyme-like activity of nanomaterials. Regulatory Mechanisms in Biosystems, 2018, 9(3), 469-476.

15. Bityutsky V.S., Tsekhmistrenko O.S., Spyvac M.Y., Tsekhmistrenko S.I., Shadura U.M. Perspectives of cerium nanoparticles use in agriculture. The Animal Biology, 2017, 19(3), 9-18.

16. Бітюцький В.С. Цехмістренко О.С., Цехмістренко С.I., Харчишин В.М. Використання різних форм церію в аграрному секторі. Аграрна освіта і наука: досягнення, роль, фактори росту: сучасний розвиток ветеринарної медицини та технологій тваринництва. Інноваційні технології в харчових технологіях: матеріали Міжнар. наук.-практ. конф., Біла Церква, 27-28 верес. 2018 р., 38-40. 17. Tsekhmistrenko O. S., Bityutskyy V. S., Tsekhmistrenko S. I., Spivak M. Y. Influence of cerium dioxide nanoparticles on biochemical indicators in the organism of broiler chicken. Veterinary science,technologies of animal husbandryand nature management, 2020. 6, 112-117.

18. Tsekhmistrenko O., Tsekhmistrenko S., Bityutskyy V. Nanoscale cerium dioxide as a mimetic of antioxidant protection enzymes. Multidisciplinary conference For young researchers, 22 November 2019, 68-71.

19. Tsekhmistrenko O.S., Bityutskyy V.S., Tsekhmistrenko S.I., Kharchishin V.M., Melnichenko O.M., Rozputnyy O.I., Malina V.V., Prysiazhniuk N.M., Melnichenko Y.O., Vered P.I., Shulko O.P., L.S. Onyshchenko L.S. Nanotechnologies and environment: A review of pros and cons. Ukrainian Journal of Ecology, 2020, 10(3), 162-172. 


\section{REVIEW OF METHODS FOR RESEARCHING LIGHTWEIGHT COVERING PLATES}

Vozniuk Leonid, Ph.D., Assistant Lviv Polytechnic National University

Rymar Yaroslav, Ph.D., Associate Professor Lviv Polytechnic National University

\section{Lisnykh Larysa,}

Assistant

Lviv Polytechnic National University

At the National University "Lviv Polytechnic" the study of multilayer plates was engaged in Demchina BG [1,2], Melnyk IV [3], Litvinyak O.Ya. [4] and others.

Demchyna BG and Litvinyak O.Ya. studies of prefabricated monolithic reinforced concrete floor slabs with the use of foam concrete for bending under the action of installation and operating loads were carried out. Experimental formwork slabs were tested for mounting loads according to the standard method for testing the reinforced concrete beam for bending, with its hinged support on two supports. The authors of the study propose to use in complex construction long complex slabs up to $4.2 \mathrm{~m}$ long using autoclaveless foam concrete design brand D800 and with appropriate reinforcement with polypropylene fiber, when designing floors for buildings with a characteristic payload up to $2 \mathrm{kN} / \mathrm{m} 2$, and short slabs with a length of $2,1 \mathrm{~m}$ with a payload of up to $10 \mathrm{kN} / \mathrm{m} 2$.

In Kharkov under the leadership of Dr., Prof. Shmuklera VS [5] a complex of field tests of reinforced concrete slabs of heavy concrete with hollow-forming inserts was carried out, which were supported along the contour and developed for the systems "Rampa", "Ikar" and "Dobol". The tests were performed on samples of two panels measuring $3.42 \times 3.42 \mathrm{~m}$, for which a special stand was developed, which consisted of 4 frames of the "Rampa" system, mounted on support parts to which the strands were attached.

The upper traverse, which rested on a string and was fixed with nuts, was used as a jack support. To transfer the load from the jacks to the experimental floor slab, a system of cross-distribution traverses made of rolled steel was mounted on top of it. The support of the traverse on the plate was performed in such a way that the load was transmitted at no more than two points.

As a result of the experiments, the bearing capacity and deformability were investigated and it was found that the maximum deflections of the plate in the center 
of the span, at a load of $120 \mathrm{kN}$, was $4.1 \mathrm{~mm}$, after reaching $160 \mathrm{kN}$ increased to 18.6 $\mathrm{mm}$, and at $180 \mathrm{kN}$ recorded deflection $21 \mathrm{~mm}$. The destruction of the prototype occurred due to loss of load-bearing capacity at a load of $205 \mathrm{kN}$.

The pattern of crack formation on the lower surface of the reinforced concrete slab with hollow-forming inserts approached the nature of the cracks supported along the contour (by type of envelope). According to the results of the study, the pattern of crack development practically did not repeat the contour of the inner ribs, which confirms the integrity of the structure when bending from the action of the load.

Also in Kharkiv under the leadership of Dr., Prof. Shmuklera VS a test of a reinforced concrete spherical shell of the coating, which was a complex internal and external geometry, with dimensions in terms of $2200 \times 2200 \mathrm{~mm}$ [6]. The total thickness of the shell is $260 \mathrm{~mm}$; in particular: hollow formers from extruded expanded polystyrene $160 \mathrm{~mm}$ thick, upper and lower concrete shells $50 \mathrm{~mm}$ thick. Both shells are reinforced with sieve, with a step of 200x200 mm, diameter of reinforcement - $6 \mathrm{~mm}$. Diagonal ribs and longitudinal walls are reinforced with rods with a diameter of $10 \mathrm{~mm}$. In this study, the concreting of the structure was carried out by the method of wet shotcreting. The general view of the structure is shown in Fig.2.
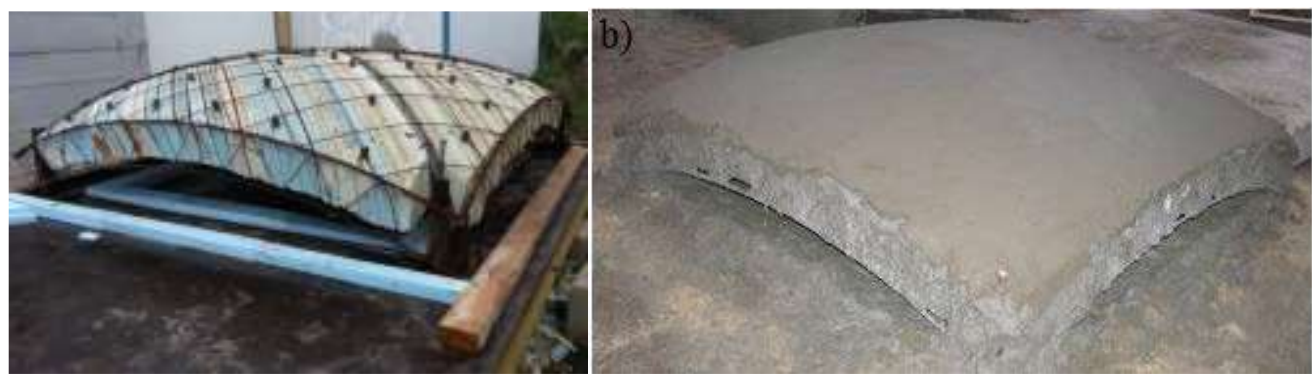

Рис. 2 Сферична оболонка даху:

At the CSIR Structural Engineering Research Center (Chennai, India), a team of authors [7] tested multilayer insulated sandwich panels for bending. The floor panels were $1220 \times 1220 \mathrm{~mm}$ and $3000 \times 1220 \mathrm{~mm}$ in size and $150 \mathrm{~mm}$ thick. The middle layer was made of $100 \mathrm{~mm}$ thick polystyrene foam, the outer layers of heavy concrete were $25 \mathrm{~mm}$ thick, and $100 \mathrm{~mm}$ wide ribs were arranged around the perimeter, connecting the upper layer with the lower one. As a result of the research, experimental data were obtained, which allowed to understand the influence of different loading conditions on the stress-strain state of the experimental sandwich panels. The authors also compared the experimental values of bearing capacity and deformability with theoretical calculations, which showed good convergence.

Comparing the own weight of slabs with their load-bearing capacity and establishing the economic efficiency of different types of structures of multilayer floor slabs and expanded clay concrete slabs with hollow inserts will confirm their effectiveness compared to existing single-layer reinforced concrete precast and monolithic floor structures.

\section{References}

1. Demchyna B.H. Vohnestiikist odno- i bahatosharovykh prostorovykh budivel // Avtoref. dys. d-ra tekhn. nauk. - Kharkiv, 2003. 
2. Demchyna B.H. Osoblyvosti rozrakhunku bahatosharovykh plyt perekryttia na PK "LYRA" / B.H. Demchyna, L.I.Vozniuk, I.Z.Rutkovska // Zhurnal "Suchasne promyslove ta tsyvilne budivnytstvo". - 2009/ -- Tom 5, №4. - S. 179-184.

3. Melnyk I. V. Monolitni ploski zalizobetonni perekryttia z pinopolistyrolnymy vstavkamy / I. V. Melnyk, V. M. Sorokhtei, O.O. Kuzyk // Visn. Lviv. teryt. vidnia Akad. bud-va Ukrainy. — 2010. — № 5/10. — S. 146-153.

4. Lytvyniak O. Ya. Mitsnist i deformatyvnist zbirno-monolitnykh zalizobetonnykh plyt perekryttia z vykorystanniam pinobetonu : avtoref. dys. ... kand. tekhn. nauk : 05.23.01 / O. Ya. Lytvyniak // Nats. un-t "Lviv. Politekhnika". - Lviv, 2015. - 20.

5. Shmukler V.S. Karkasnыe systemы oblehchennoho typa / V.S. Shmukler, Yu.A. Klymov, N.P. Burak. // - Kharkov: Zolotbe stranytsы, 2008. - 336 s.

6. Babaev V. Analysis of Stress-Strain State of Spherical Roof Shell / V. Babaev, V. Shmukler, S. Feiruscha, S. Grebenchuk, L. Gaponova, O. Kalmykov // ZANCO Journal of Pure and Applied Sciences - \#28 (2), 2016; S. 42-49.

7. Daniel Ronald Joseph J., Prabakar J., P. Alagusundaramoorthy, Experimental and numerical study on flexural behavior of precast light-weight concrete sandwich panels, Int. J. Res. Eng. Technol. 4 (13) (2015) 463-467. 


\title{
ЭФФЕКТИВНАЯ ИННОВАЦИОННАЯ ТЕХНОЛОГИЯ СТРОИТЕЛЬСТВА ОБЬЕКТОВ НА БАЗЕ УНИВЕРСАЛЬНОЙ СИСТЕИЫ СБОРНО- МОНОЛИТНОГО БЕЗРИГЕЛЬНОГО КАРКАСА
}

\author{
Савенко Владимир Иванович \\ доктор техн..наук, профессор Киевский национальный университет \\ строительства и архитектуры Украина
}

\section{Окружкин Анатолий Андреевич} член-корреспондент Академии строительства Украины,директор ООО компания СК Градострой г.Обухов Киевская обл.

\section{Ежов Сергей Валентинович} академик Академии архитектуры Украины, профессор Киевский национальный университет строительства и архитектуры

\section{Дубинка Александр Владимирович} член=корреспондент Академии строительства Украины, ассистент кафедры организации и управления строительством Киевский национальный университет строительства и архитектуры Украина

\section{Благодырев Владимир Александрович член=корреспондент Академии строительства Украины,директор ООО компания ПСК Монолит г. Мелитополь Запорожская обл.}

В практике строительства известно и освоено множество систем, серий проектов и методов возведения строительных объектов. Однако нет пределов совершенству и человечество идет по этому нелегкому пути постоянного совершенствования. Технология на базе КУБ-2,5 (каркас универсальный безригельный) [1], освоена и внедрена в практику строительства в Украине ООО производственно-строительным комбинатом «Монолит» в полном цикле: проектирование, производство, транспортировка и монтаж каркасов зданий.

Объекты по данной технологии построены в городах Обухов, Киевской области, Севастополь, Бердянск и Мелитополь, Запорожской области. В настоящее время ведутся проектные работы по другим объектам. Эффективность представленной технологии домостроения определяет оригинальные конструктивные и технические решения несущего каркаса здания.[2]

КУБ-2,5 (рис. 1) представляет собой пространственную конструкцию, образованную колоннами, дисками перекрытия, которые одновременно выполняют роль ригелей и диафрагм жесткости, обеспечивающие устойчивость каркаса здания. 


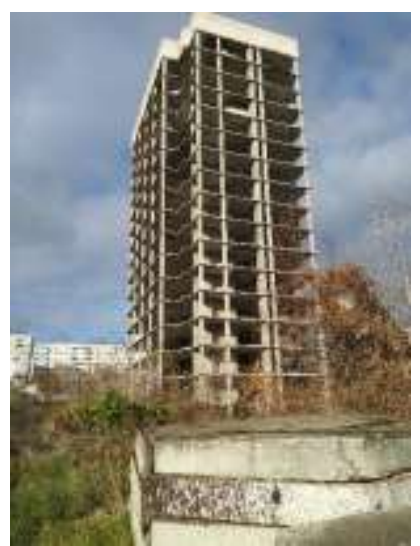

Рис. 1. Каркас здания на основе КУБ-2,5

Преимущества применения системы:

1. Универсальность (жилищное, гражданское, промышленное строительство);

2. Надежность и сейсмостойкость конструкции (несущая способность диска перекрытия от 1300 до 2500 кг/м²; несущая способность узла соединения плиты с колонной - 140тн, сейсмостойкость системы - 9 балов);

3. Возможности разнообразных решений фасадов;

4. Свободная планировка помещений внутренних пространств (нет несущих стен);

5. Минимальное количество элементов каркаса (6 элементов);

6. Высокая скорость монтажа каркаса (за 12 часов работы монтаж конструкций в количестве $150 \mathrm{M}^{2}$ площади диска перекрытия под одним монтажным механизмом);

7. Возможность изготовления элементов каркаса здания до начала его монтажа;

8. Экономичность строительства: расход бетона и металла зависит от этажности здания, шага колонн, высоты этажа, удельные показатели системы для диска перекрытия составляют- бетон - от 0,18 до $0,24 \mathrm{~m}^{3} / \mathrm{M}^{2}$; арматура от -18 до $25 \kappa \Gamma / \mathrm{m}^{2}$. Расход арматуры на $1 \mathrm{~m}^{3}$ каркаса от 94 до $100 \mathrm{\kappa} / \mathrm{m}^{3}$. Количество монолитного бетона на строительной площадке составляет от 5 до $6 \%$ от объема каркаса здания.

Основные изделия заводского изготовления:

1) колонны сечением 400 х 400мм, длиной до $15 \mathrm{M}$ из высокомарочных бетонов В30 -:- В60, что позволяет производить монтаж каркаса 24-х этажных зданий;

2) плиты перекрытий толщиной 160мм двух основных типоразмеров 2980 х 2980 мм и 2980 х 5980мм из бетона В25;

3 ) диафрагмы жесткости, состоящие из колонн толщиной $160 \mathrm{Mм}$, шириной от 600 до $1000 \mathrm{Mм}$ и длиной до $6,6 \mathrm{M}$ и дисков жесткости толщиной $160 \mathrm{Mм}$ изготовляемых необходимых конструктивных размеров из бетона В30;

4) система также комплектуется лестничными маршами, вентиляционными блоками, связями, балками. 
Производство сборных конструкций организовано на производственностроительном комбинате «Монолит» в г. Мелитополь, Запорожской области. Проектная производственная мощность - 500000м ${ }^{2}$ дисков перекрытия в год.

На базе известной и успешно применяемой системы КУБ-2,5 возникла инновационная технология строительства сборно-монолитного каркаса универсально безригельного: (СМКУБ). Ее достоинства при строительстве объектов недвижимости:[1,3]

1) полезная нагрузка на перекрытия от $900 \kappa г с / \mathrm{m}^{2}$ до 2100 кгс/ $\mathrm{M}^{2}$;

2) ведение строительство в районах с сейсмической активностью в 9 балов по шкале Рихтера;

3) строительство 24-х этажных зданий;

4) технология изготовления конструкций полностью соответствует требованиям пожарной безопасности ДБН В.1 1-7-2002 (защитный слой бетона $4,5 \mathrm{~cm})$;

5) сборно-монолитный каркас имеет 1 степень по огнестойкости;

6) сборный железобетон является негорючим материалом класса НГ;

7) индустриальное (заводское) изготовление конструкций обеспечивает экологическую и радиационную безопасность применяемых исходных материалов, путем обязательного входного лабораторного контроля;[2,3]

8) значительная несущая способность перекрытия каркаса позволяет обеспечить применение эффективных строительных шумозащитных материалов в ненесущих наружных и внутренних стенах, а также в конструкциях пола помещений;

9) данная технология позволяет строить здания в любых климатических районах;

10) несущая способность перекрытия каркаса позволяет обеспечить применение в наружных стенах зданий современных эффективных теплоизоляционных материалов, обеспечивающих эффективность расходования потребляемых энергоресурсов, в том числе из-за возможности использования энергии солнца или применения автономных систем энергоснабжения; $[4,5]$

11) обеспечивает экономию применения основных природных ресурсов (щебень, песок) при строительстве каркаса, оснований и фундаментов, потому что вес сборно-монолитного каркаса легче аналогичного, выполненного по технологии монолитного домостроения в 1,5 раза;

12) удельный максимальный расход сборного железобетона в системе составляет $0,21 \mathrm{~m}^{3} / \mathrm{M}^{2}$, (в технологии монолитного строительства не менее 0,35

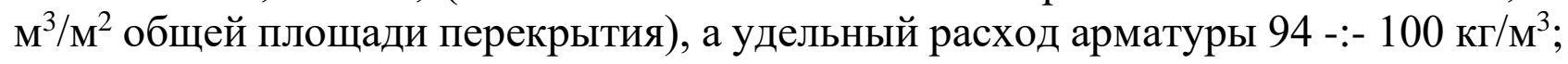

13) данная технология позволяет использовать для строительства наружных и внутренних стен применения местных стеновых строительных материалов (в районе строительства объекта);

14) данный способ строительства применяется в промышленном, гражданском или жилищном строительстве;

15) ряд архитектурных достоинств (“гладкий” потолок, “гибкий” фасад, изменяемая высота этажа и другие) дополняет эффективность применения 
системы, возможность применения наружного утепленного фасада, в т.ч. вентилированного, солнечных батарей и т.д.;[3]

16) высокая скорость монтажа $\left(200 \mathrm{M}^{2}\right.$ плит перекрытия в сутки под одним монтажным механизмом - бригадой в 7 человек) сокращает вдвое время и построечные затраты на объекте;

17) использование системы позволяет выполнять проектирование и изготовление индивидуальных конструкций параллельно до получения разрешительных документов на строительство, 9 из 10 объектов недвижимости можно проектировать и строить в системе СМКУБ.

На все выпускаемые изделия системы СМКУБ имеются сертификаты качества (UA1/032/0086467-06 № 28 -:- 34). Конструкция системы прошла испытания на огнестойкость (протоколы ИЦ «Вест» № 1/БК-07 лт. 22.03.2007г.).

Полный жизненный цикл строительных объектов - это время: от идеи, сбора исходных данных, проектирования, прохождения экспертизы проекта, строительство, сдача объекта в эксплуатацию, эксплуатация, модернизация производства и до ликвидации (утилизации) объекта недвижимости.

Выводы: 1. Высокие технико-экономические показатели технологической системы СМКУБ и ее модификаций дает ей преимущества перед известными, освоенными сериями индустриального домостроения и должна по праву пользоваться поддержкой профессионалов, строителей, а также на местном и государственном уровне, особенно в случаях бюджетного финансирования строительства.

2. Для обеспечения людей, нуждающихся в жилье, качественным и доступным жильем (рис. 2), необходима при строительстве предлагаемая прогрессивная, инновационная технология.

\section{Литература}

1. Патент України №54694 Індустріальна конструктивна технологія

Система збірно-монолітний каркас універсальний бетонний (Система 3МКУБ) автори Благодирьов В.О.,Брусан А.А.Данилець В.М.Куцепко Є.М.2014 р.Україна

2. В.I. Савенко, С.I. Доценко, В.Г. Васильков та ін. Менеджмент якості в будівництві та виробничі організаційні системи [Текст] монографія В.І.Савенко під ред. Лівінського О.М. та ін. - Київ Центр учб.літер.2018 -230с.

3. В.I. Савенко С.I. Доценко, П.М. Куліков, І.С. Нестеренко та ін. Дослідження i математичне моделювання організаційних структур та виробничих процесів будівельних організацій комбінатного типу УАН, - Київ Центр учб. літ. 2018 -124c.

4. В.I. Савенко, С.С. Савенко, С.I. Доценко та ін. Конкурентоспроможність будівельної організації - основа виживання економіки УАН - Київ Центр учб.літ. $2017-128 \mathrm{c}$.

5. C.I. Доценко. Розвиток принципу бінарних відносин в теорії управління економічними процесами [Текст]: монографія / С. І. Доценко; під ред. В. О. Тімофеєва, І. В. Чумаченко. - Х.: ХНУРЭ, 2015. - 245 с. 


\title{
НОВІТНІ ТЕХНІКИ ВИКОРИСТАННЯ НЕТРАДИЦЙНИХ МАТЕРІАЛІВ У САКРАЛЬНОМУ МИСТЕЦТВІ ХХІ СТОЛІТТЯ
}

\author{
Datsiuk Nataliia \\ graduate student of the Carpathian National \\ Vasyl Stefanyk University; \\ assistant of the department of fine arts, \\ design and methods of their training \\ Ternopil National Pedagogical \\ Volodymyr Hnatyuk University \\ Netrybiak Mykhailo \\ Professor of the department of fine arts, \\ design and methods of their training \\ Ternopil National Pedagogical \\ Volodymyr Hnatyuk University
}

На сучасному етапі творення Української церкви питання власної духовної та культурної ідентичності постало надзвичайно важливим. Сакральне мистецтво у всі періоди існування впливало на духовний розвиток вірян, відповідно великого значення надавалося оздобленню храму. Потреби сучасного суспільства вимагають пошуку тих ланцюжків, які б пов'язували традицію 3 актуальними духовними та естетичними орієнтирами. Таке питання виникало після спорудження нових храмів і велись пошуки митців, які б могли задовільнити сучасні потреби належного оздоблення храму.

Сучасний підхід до організації сакрального простору - це єдність архітектури та мистецтва, вони повинні гармонійно доповнювати один одного. Візуальна організація храмового простору часто $є$ канонічною. Живописцю, що знаходиться під впливом сучасного культурного процесу, властиво використовувати новації у своїй творчості, для отримання оригінального результату. Під новаторством варто розуміти відступ під традиційного підходу, введення нових, таких, що майже не використовувалися раніше, стильових та художньо-виражальних засобів.

Використання новаторських прийомів і технік в поєднанні 3 традиційними матеріалами в організації сакрального простору простежується у храмі Святої Хатини Марії Діви з Назарету, збудованого і освяченого у 2017 році в Марійському духовному центрі села Зарваниця, за проектом архітектора Михайла Нетриб'яка. Автор мозаїчних панно - Теодозій Будуйкевич, учень о. Марка Івана Рупніка, при оздобленні храму керувався усталеними канонами, визначеними Церквою. У монументальних мозаїках Теодозія Будуйкевича 
присутня колоритна цілісність, статичність та врівноваженість композицій. Такий результат досягнутий за рахунок своєрідної манери послідовно викладених кубиків смальти, яка підкреслює одухотвореність та динамічність зображуваних святих в іконографічних сценах храму.

Підтримуючи стилістику мозаїчного оформлення сакрального простору, в самій хатині Матері Божої знаходиться копія ікони Зарваницької Божої Матері, виконана в оригінальному, авторському, нетрадиційному для ікони матеріалі фарфорі. Автор ікони - художник-кераміст Свген Овчарик.

Творчість Свгена Овчарика характеризується створенням нестандартних форм у порцеляні, постійним пошуком нефігуративного художнього зображення, а його унікальні ікони вирізняються особливим авторським стилевим рішенням. У них майстерно поєднані традиційні та канонічні іконографічні зображення із власним авторським баченням. Художник відтворив ікону Зарваницької Божої Матері, з інтерпретацією у певному колористичному та фактурному вирішенні та унікальною технологією вкраплення кольорових пігментів у фарфорову масу.

Сьогодні цифрові технології все глибше проникають у наше життя і побут. Художники використовують різні комп'ютерні програми, технології, які полегшують та урізноманітнюють їх творчі задуми. В оздобленні храмів художники все частіше користуються 3D моделями для розписів, наприклад, складного куполу, який має великі розміри, виготовлення іконостасів. Існують сучасні програми для створення схем для вишивки. На Тернопільщині, у селі Тютьків, Теребовлянськоого району у церкві Положення ризи Пресвятої Богородиці знаходиться унікальний триярусний іконостас вишитий бісером. Церква хрестово-купольна, п'ятибанна, збудована у 2000 році, за проектом архітектора Михайла Нетриб'яка. Ідея створення оригінального іконостасу 3 бісеру прийшла настоятелю храму отцю Степану Суканцю та громаді села. Схеми для вишивання бісером розробив Олег Стечкевич зі Львова.

Вперше до оздоблення сакрального простору вишитими іконами звернувся отець доктор Дмитро Блажейовський. Знаючи, що первісні іконостаси починалися в ранні віки християнства саме 3 вишитих і гаптованих ікон, поставив собі за мету відродити старовинну традицію, наблизити іiі до українських мотивів і технік народної вишивки.

Церква розвивається, в оздобленні сучасного храму повинні бути використані нові технічні елементи. Отець доктор Дмитро Блажейовський зумів відродити прекрасне мистецтво вишиваної ікони, за ним пішли численні продовжувачі цієї галузі церковного мистецтва, зокрема: Микола Симчич із села Нижній Березів, Івано-Франківської області, його ікони не канонічні - це зображення святих в авторському художньому виконанні, де майстер застосовує багато технік вишивки; Марта Кулинич-Новицька зі Львова вишиває технікою художньої гладі; Надія Соломко 3 міста Івано-Франківськ, захопившись вишитими іконами о. Дмитра Блажейовського почала в'язати ікони за схемами отця.

До сучасних тенденцій оздоблення храмового простору слід також віднести використання кованого каркасу в зведенні конструкцій іконостасу. Вперше таку 
техніку художньої ковки було використано у 2013 році майстрами з міста Шпола на Черкащині.

У 2015 році таку ж ідею кованого каркасу для іконостасу використав священник Віталій Вовк, адміністратор парафії собору Преображення Господа i Спаса нашого Ісуса Христа міста Зборів, Тернопільської області. Проект виконав Віталій Городецький зі Львова, художню ковку виконали Володимир та Ольга Загребельні з смт. Козлів, Тернопільської області. Для іконостасу замовили різьблені вручну ікони у майстра 3 Івано-Франківщини - Володимира Кіндрачука.

До новітніх технологій використання нетрадиційних матеріалів у сакральному мистецтві XXI століття можемо віднести іконоаплікацію з соломки. Викладачка Прикарпатського національного університету імені Василя Стефаника, професійний художник і член Національної спілки майстрів народного мистецтва України Ольга Мельник-Солудчик заснувала школу іконоаплікації з соломки в Івано-Франківську на початку 1990-х років. У іконах художниці збережений іконографічний канон, який надає сакральним творам внутрішньої гармонії та авторська стилізація, як творча інтерпретація використання архаїчного матеріалу з метою надання іконі сучасного звучання.

Розглянувши сучасні тенденції в оздобленні сакрального простору бачимо, що вплив нових технологій на мистецтво незаперечно. Технології та мистецтво все більше взаємодіють між собою, у результаті цього феномену виникають нові, нетрадиційні техніки в храмовому середовищі.

На нашу думку експерименти з новими матеріалами та формами не завжди $\epsilon$ виправданими, проте мають право на існування та вказують на новий етап культурної еволюції.

\section{References:}

1. Ковальчук I. Досвід іконотворчості отця-доктора Дмитра Блажейовського. Українське релігієзнавство. 2013. №68. С. 244-258

2. Степовик Д. Українська ікона. Іконотворчий досвід діаспори. Київ: Балтія друк, 2003. С. 97-105

3. С. Вольська. Художня кераміка Західного Поділля. Мистецтвознавство України: Зб. Наук. Пр./Редкол.: А. Бокотей та ін.; ІПСМ НАМ України. Львів: Афіша,2011. - Спецвип. - 424 с.; с.162

4. Кравченко Я. Святослав Владика: нове трактування іконопису / Я. Кравченко // Образотворче мистецтво. - 2012. - № 1/2. - С. 72-73

5. На Тернопільщині - єдиний в Україні іконостас повністю вишитий бісером. 07.02.2019 18:43 Опубліковано : Анастасія Гарасим'як. Джерело: Тернопільська нова

Режим доступу: https://uanews.org.ua/post/view/1549554231-na-ternopilschiniediniy-v-ukraini-ikonostas-povnistyu-vishitiy-biserom-foto 


\title{
СТЕНДАЛЬ У РОЛІ ХУДОЖНЬОГО КРИТИКА ФРАНУЦЗЬКОГО САЛОНУ 1824 РОКУ
}

\author{
Лисенко Людмила Олександрівна, \\ кандидат мистецтвознавства, \\ доцент кафедри теорії та історії мистецтва \\ Національна академія образотворчого мистецтва і архітектури \\ м. Київ. Україна
}

Майбутній письменник Анрі Бейль, відомий під псевдонімом Стендаль (1783-1842), став новобранцем культури 19 ст. За твердженням російського мистецтвознавця В.Турчина (1941-2015) він один 3 перших серед французів використав у 1819 році термін «романтизм» стосовно до образотворчого мистецтва [1, с. 81$]$, хоча його ім'я разом з О. де Бальзаком у виданні «Історія естетики» знаходиться у розділі «Естетика французького класичного реалізму» [2, с. 625-639]. На ці позиції письменник остаточно перейде пізніше, в романах «Червоне і чорне», «Пармський монастир». Цікаво, що Стендаль розпочав свою літературну діяльність як оригінальний тлумач образотворчого мистецтва. У нього був достойний попередник з улюбленої ним епохи Просвітництва, автор відомих «Салонів» Дені Дідро. Але спочатку юнак приїхав з Гренобля до Парижа поступати до Політехнічної школи в 1799 році. Він з дитинства цікавився мистецтвом. Тому відразу почав відвідувати Лувр, де була відкрита експозиція «Музею Наполеона», виставки Салонів, почав збирати гравюри [1, с. 87]. Розпочиналася епоха Наполеона. Талановитий провінціал палко розділяв ідеали Великої французької буржуазної революції, на деякий час став учасником наполеонівських походів, дійшов 3 французькою армією до Росії. Своїм демократичним ідеалам він ніколи не зраджував. Багатющий життєвий досвід, глибоке знання культури привели майбутнього письменника до думки про можливість вираження свого уявлення про сучасність через літературу i мистецтво. Ці нові тексти мають суттєво відрізнятися від холодної, зваженої ритміки вчених трактатів. Сучасний авторський текст має бути насичений відчуттями, реальними спостереженнями. Свої романтичні переконання він вперше реалізував спочатку у написанні «Історії живопису в Італії», що народилася 3 безпосереднього досвіду спілкування 3 мистецтвом Рима, Флоренції, Болоньї, Неаполя, ознайомлення 3 численними історичними текстами, трактатами італійських, німецьких, англійських авторів. Заслугою молодого автора стала абсолютно нова версія трактування і розуміння важливих для сучасності тенденцій в мистецтві доби Відродження. 3 семи книг - друга, третя і сьома присвячені відповідно Джотто та його школі, Леонардо да Вінчі та Мікеланджело. Рафаель, як незаперечний спадкоємець античної краси і еталон усіх європейських академій, свідомо вилучений автором з дослідницького поля. Очевидне бажання ближче роздивитися те, що існує поза його мистецької території, дуже нагадує позицію німецьких назарейців, англійських прерафаелітів. Молодий літератор стає своєрідним провісником тих ідей, якими 
буде захоплена творча молодь, формулює своє розуміння нового ідеалу краси. I це займає ще три - четверту, п’яту, шосту книги «Історії». Його характерними якостями повинні стати надзвичайно живий ум, багато грації у рисах обличчя, сяючий погляд, багато веселості, великий запас сприйнятливості, по-юнацьки живий вираз обличчя [3, с. 271]. I $€$ ще одна якість краси, яку стверджує Стендаль, - це прагнення щастя, як прояв енергії у боротьбі за нього, напруження талантів і сили [2, с. 625-627]. До того, як звернутися до розгляду творів французьких Салонів, переконаний романтик написав брошуру «Расін і Шекспір» (1823) [4, с. 271], в якій на прикладі творів представників двох поетичних традицій довів абсолютну перевагу драматичного задоволення від англійця Шекспіра над епічним задоволенням від француза Расіна.

Таким чином, у 1824 році, коли Стендаль виступив у ролі критика сучасного французького мистецтва, він вже сформулював ті критерії, за якими він буде оцінювати будь-яке явище сучасної культури. Салон 1824 року став однією 3 найгучніших арен «романтичної битви» між класиками та представниками нового напряму в образотворчому мистецтві. Стендаль присвятив йому вісімнадцять статей, нумеруючи кожну римськими цифрами. Вони були опубліковані в газеті «Journal de Paris» i стали своєрідним маніфестом художників-романтиків. Загальний текст займає у шостому томі видання 1959 року 81 сторінку [3, с. 429-510]. Важко уявити, з якої кількістю мистецьких творів довелося працювати його автору, який у V статті називає цифру 2,5 тис. картин! [3, с. 449]. Завдяки матеріалам Стендаля можна зрозуміти, що експозиція Салону в Луврі протягом року часто змінювалася, доповнювалася новими роботами. Більшість 3 них висіла у незручних для огляду місцях, як це можна уявити і по картині Гюбера Робера «Гранд-Galerie в Луврі» (1796. П., о. 112x143. Лувр). І з цієї безкінечної кількості робіт автор відзначає (інколи навіть не згадуючи автора, інколи просто перелічує) за нашими підрахунками, близько 127 картин і скульптур. Навряд чи має сенс зберігати порядок фіксації окремих спостережень, аналізів, думок автора згідно з послідовністю виданих статей. Оскільки творчість навіть вже відомих майстрів представлена в різних частинах грандіозної експозиції, критик кілька разів в різних статтях повертається до одного і того ж імені і твору, додаючи якісь нові, інколи прямо протилежні спостереження і судження. Але вже у I статті Стендаль відразу активно висловлює своє розуміння сучасної ситуації у мистецтві, де вже розпочалася війна між класиками - послідовниками великого Давида - і новаторами, які намагаються рухатися вперед [3, с. 429]. У II статті Стендаль з викликом заявляє: «Мета моя - домогтися, щоб кожний глядач заглянув у свою душу... Відвертати разом 3 тим молодих художників від школи Давида і від наслідування Орасу Верне - така друга моя задача» [3, с. 435]. До речі, робіт самого Давида (17481825) у Салоні представлено не було. Він вже давно жив вигнанцем у Брюсселі і в рік відкриття Салону написав останню картину «Марс, якого обеззброюють Венера і німфи», продемонструвавши свою нелюбов до війни і непохитну любов до античності. Головне звинувачення школі Давида у V статті складає один рядок - вона, на думку Стендаля, спроможна зображувати тільки тіла і нездатна зображувати душі [3, с. 448]. Але неможливо без захвату читати у VIII статті 
чеканний абзац, присвячений самому Давиду: «Давид перетворив теперішню французьку школу у першу школу Свропи; цей великий художник, у якому вражає сила характеру, що дала йому сміливість нехтувати жанром різних Лагрене і Ванлоо, був новатором і в якості такого збереже свою слава назавжди» $[3$, c. 462$]$.

Батальні картини Ораса Верне (1789-1863), улюбленця публіки, згадуються і в I, і в VII статтях з побажанням розміщувати на передньому плані батальних сцен 3 маленькими фігурками портрети красивих молодих людей, наприклад генералів Гоша, Дебеля, Кольбера, які в свій час викликали захоплення армії $[4$, c. 458-459].

Протягом всього тексту Стендаль, безумовний прихильник мистецтва правди, щирості, душевних рухів, страждає від відсутності краси, замість якої часто в картинах переважає потворність. Але інколи вона може стати доречною для виразу сили, експресії характеру. Яскравий приклад цього подає оригінальна картина К. Сигалона (1787-1837) «Нарцис» (сучасна назва - «Локуста, яка передає Нарцису отруту, призначену для Британника, випробує його дію на молодому рабі» [5, с. 92-93] ). Дещо гротескна образність і манера письма викликали незадоволення публіки. Але Стендаль дуже переконливо пише про достоїнства і недоліки цього живописного твору. Напівоголене, огидне тіло отруйниці є зображенням іiі душі. Це підкреслює і різка манера письма, що нагадала критику італійця Сальватора Розу (1615-1673). Але не можливо залишити глядача 3 цим негативним відчуттям. На думку Стендаля, потрібно було зобразити помираючого раба не жалюгідним потворою, але юнаком вражаючої краси. Адже саме краса переборює жах. «...залишається лише благородна i злегка упокорена скорбота, єдино допустима у витончених мистецтвах» [3, с. 457-458]. Ми свідомо навели повну цитату з VII статті Стендаля для розуміння його особистого підходу до мистецтва, яке повинно зберігати відчуття краси. Починаючий літератор реагує на неї миттєво. Його погляд тішить єдине обличчя рідкісної краси без пихатості [3, с. 463] у маленькій картині брюссельця Навеза «Свята родина». Серед численних похмурих портретів Салону такі несподівані зустрічі викликають бажання автора уважно, 3 насолодою роздивлятися гарне обличчя, як це відбулося і $з$ чарівним жіночим портретом Ораса Верне, в якому поєднуються північна чуттєвість і живий південний ум [4, с. 456].

Відображення реальних переживань, правди характеру Стендаль часто знаходить не тільки в жанрі портрету, але й у пейзажу. Наприклад, в картині Лепренса «Катання на човні Сен-Пре і Жюлі на Женевському озері» (герої роману Ж.Ж. Руссо «Юлія, або Нова Елоїза») автор звертає увагу на бездоганну правдоподібність туману над озером і води на веслі човняра [3, с. 461]. В оцінці маленької картини Т. Гюдена (1802-1880) «Розбурхане море» Стендаль дозволяє собі гучне визначення «страшенна правдивість», яке він закріплює гаслом «хай живе правда!» [3, с. 431]. Саме правдивість вираження привернула увагу критика до чудових пейзажів англійця Дж. Констебла (1776-1837), у яких немає нічого ідеального, і які як дзеркало передають природу [3, с. 468]. Але пізніше він зробить наступне уточнення: «...тільки хотілося б, щоб дзеркало це поставлене 
було перед розкішним видом, /.../ а не перед візком для сіна, котрий перебирається убрід через канал зі стоячою водою» [3, с. 475]. (Додамо для уточнення, що візок їде через річку Стур, на якій працювало багато млинів!).

Стендаль був не завжди готовий швидко сприйняти i оцінити правду вираження і колористичні якості. На знакову багатофігурну картину «Різанина на Хіосі» представника нового напряму Е. Делакруа (1798-1863), він відгукнеться кількома рядками про неприродну перевагу скорботи і мороку. Виразно представлені фігури постраждалих греків залишили враження наполовину написаних посинілих трупів [3, с. 433]. Пізніше, у VIII статті, Стендаль додає до першого негативного враження ще кілька абзаців. На цей раз він пише про оголену фігуру молодого грека, що нагадує зачумленого, який спробував вирвати у себе чумний бубон; і дитину, яка намагається смоктати груди мертвої матері [3, с. 460-461]. Досить стримано відзначає у живописця чуття колориту і передачу руху в фігурах, що дає підстави сприйняти його учнем Тинторетто (1518-1594) [3, с. 461]. В устах Стендаля - це висока оцінка. Він часто радить учасникам Салону хоча б півроку прожити у Венеції, щоб повчитися передачі колориту, світлотіні. У якості потенційних вчителів для молодих французьких художників в різних статтях називає Корреджо (14891534), Гвідо Рені (1575-1642), Доменікіно (1581-1641), фра Бартоломео (14721517), Веронезе (1528-1588), Каналетто (1697-1768). I навіть пропонує закрити французьку Школу в Римі і направляти учнів безпосередньо до Венеції (на один рік), Риму (на один рік), Флоренції (шість місяців), Неаполю (шість місяців) зберігаючи звіт картинами, що будуть надсилатися в Париж [3, с. 460].

В оцінці невеликого ескізу А. Шеффера «Смерть Гастона де Фуа після битви при Равенні 11 квітня 1512 року» Стендаль цілком співпадає з оцінкою мистецтвознавців 20 ст. [5, с. 96; 6, іл. 111в]. Героїчний епізод з французької історії початку 16 ст. вирішений художником у романтичному дусі. Цей несподіваний досвід у творчості налаштованого на сентиментальні образи майстра викликає співчуття критика 19 ст. Його не задовольняє неохайність, незавершеність, поспішність виконання, деяка театральність у зображенні головних героїв. Стендаль жалкує, що автор не здогадався оголити торс смертельно пораненого Гастона де Фуа. На думку критика, це б дало можливість відпочити оку від великої кількості заліза (зброї, лицарських обладунків). Але неприкрашена правда картини піднімає iї над загальним рівнем салонних творів [3, c. 454-455].

Стендаль не обходить увагою й інші картини на сюжети давньої історії, яку він добре знає не тільки з боку подій і фактів, але і біографій і графічних зображень провідних діячів. Буквально на початку I статті він відзначає картину «Кардинал, що допитує Жанну д’Арк у в’язниці», звертаючи увагу на переконливий контраст щирості і запалу героїчної душі французької дівчини i підступності і нечутливості кардинала у червоному одязі (ім'я відомого художника Поля Делароша (1797-1856) критик не називає) [3, с. 430].

У X, XIV i XVII статтях автор приділяє значну увагу картинам Ж.-О.-Д. Енгра i починає 3 його невеликої «Смерті Леонардо». Він звертає увагу на анекдотичність представленої сцени прощання короля Франції з помираючим 
художником. Але високо оцінює достовірність образу Франциска I, який, за переконанням Стендаля, належить до самих красивих історичних портретів в Салоні 1824 року [3, с. 470]. Друга картина - «Людовик XIII, що ввіряє Францію покровительству пресвятої діви» (сучасна назва - «Обітниця Людовика ХІІІ») користувалася великою повагою у публіки. Вона стала уособленням класичних цінностей і протиставлялася роботі Делакруа «Різанина в Хіосі». Обрані критерії в оцінці сучасного мистецтва привели критика до розуміння певних недоліків урочистої композиції з фігурою короля, що стоїть на колінах перед троном 3 величною фігурою діви Марії з немовлям. Він миттєво відчув сухість та еклектичність твору, в якому відсутні почуття. Святі персонажі не викликають уявлення про божественне і замилування. Колорит відзначається жорсткістю. Образ короля залишає доволі безпорадне враження. Картина викликає сумні роздуми про охолодження души сучасної людини. В численних картинах на виставці немає вогню, що відчувається в опері Россіні (музичні, а також театральні асоціації - улюблений прийом у критичному аналізі мистецьких творів Стендаля). Але незважаючи на численні зауваження критик називає «Обітницю» однією з найкращих картин релігійного змісту. Він хоче бачити її в церкві і дивитися на неї довгий час. Енгр працює сумлінно, вивчає предмет глибоко і пильно. Йому можна довірити розробку історичних сюжетів, які не потребують глибокої експресії [3, с. 488-490]. Не можливо не погодитися і 3 іншою оцінкою невеликої картини Енгра «Папа, що служить месу у Сикстинській капелі». Вона дійсно надає живу насолоду дуже точним зображенням капели і фрагменту фрески «Страшний суд» Мікеланджело. Папа Пій VII здійснює богослужіння за участю знаменитого кардинала Консальві. Зліва від глядачів видно край лави кардиналів 3 шлейфоносцями, які сидять перед ними. Картина сповнена величі і з правдивістю зображає рідкісну i вражаючу церемонію. Стендаль хотів би побачити ії у більшому форматі [3, с. 504-505].

I все ж таки жодному з майстрів критик не приділив стільки уваги, скільки портретним творам представника школи Давида Франсуа Жерара (1770-1837), яким повністю присвячена III стаття. Дуже влучну характеристику його майстерності дала О. Кожина. Її варто навести: «Вся його творчість - блискуча ілюстрація того, з якою легкістю класицизм, що позбавився своєї первісної змістовності і революційного духу, пристосовується до будь-яких віянь, спрямовується у будь-яку колію 3 повною байдужістю до ії направлення» [5, c. 9]. В. Турчин пояснює симпатію Стендаля до Герена і Жерара бажанням навести приклади «сучасного ідеалу краси». Саме тому картинам цих майстрів приписуються якості, яких вони не мали. Це був шлях компромісу. Адже Стендаль був проти усіх крайнощів, як класицистичних, так і романтичних [1, с. 85-86]. Спробуємо захистити Жерара і Стендаля 3 позицій сьогоднішнього дослідника. Французький Салон поступово перетворювався на ринок мистецтва, що віддалено нагадує сучасні світові арт-ярмарки, на яких є свої імена, покупці, цінності. Кожний майстер мріяв зробити ім'я, блискучу кар'єру, знайти свого шанувальника. Це стосувалося творчості і таких видатних майстрів, картинами яких сьогодні захоплюються відвідувачі Лувру, як А. Гро, Е. Делакруа, П. 
Деларош, А.-Л. Жироде-Триозон, П.-П. Прюдон, Ж.-О.-Д. Енгр та багатьох інших. Серед робіт, представлених Жераром в Салоні 1824 року, варто зупинитися на картині «Коринна на Мізенському мисі», яка так само як і роман Жермени де Сталь «Коринна або Італія» (1807) викликали активний попит у сучасної публіки. Слава роману, безумовно, переносилася і на обидва варіанти картини Жерара. Перша була створена у 1819 року. Німецький літературний критик В. Шлегель написав про неї статтю-панегірик [3, с. 437]. Картина 1824 року була меншою за розміром 3 додаванням нових персонажів. Стендаль не жаліє жодної фарби своєї літературної палітри для переконання читачів i глядачів в тому, що картина задовольняє абсолютно усім його вимогам до сучасного твору мистецтва. Коринна має прекрасне тіло, вправно одягнене в убрання, що спадає гармонійними складками. Це викликає у пам'яті пропорції найпрекрасніших грецьких статуй. В очах героїні літератор бачить відлуння тих ніжних пристрастей, які стали доступними тільки сучасним народам. Тут $є$ щось спільне 3 хмурою завзятістю Вертера. Ї̈і фігура чудово виділяється на фоні неаполітанського неба, що зображене у момент бурі. В картині - вся душа Коринни [3, с. 437, 439]. 3 ніжною симпатією зупиняється автор і на фігурі молодого грека, який слухає імпровізацію Коринни, опустивши очі. Він відзначає дуже точно передану пристрасну манеру слухати, що властиве південним народам [3, с. 438]. Одним з найменш вдалих персонажів Стендаль вважає улюбленого Коринни Освальда [3, с. 437-438]. Сумний, стражденний вигляд цього холодного мешканця Півночі, якому не вистачило мужності і сили подолати забобони суспільства і стати справжньою опорою для своєї щиро наділеною талантами подруги, не може викликати симпатії. Наша сьогоднішня оптика, переобтяжена колосальним вантажем візуальної культури, навряд чи допоможе підтримати високу оцінку картини у сприйнятті Стендаля. Нам заважає мелодраматизм і театральність ідеалізованої сцени. Але критик, в першу чергу, відгукується на натхнення, душевне поривання героїні, які $є$ найвищими ознаками романтичної натури.

3 часів так званої романтичної битви, яка в своїй активній фазі проходила в паризьких Салонах 1822, 1824 i 1827 рр., минуло майже два століття. Але уважне читання текстів Стендаля під час семінарів, які ми щороку проводимо зі студентами мистецтвознавцями, і по сьогодні викликає глибоке враження від ерудиції, ретельності аналізу художніх творів, широкого погляду на сучасність, де мистецтво має відбивати саме ті образи і теми, що хвилюють суспільство і вимагають його йти шляхом удосконалення і правди. Стендаль писав, що його зрозуміють у 20 ст. Можемо запевнити, що і 21 ст. не обходить увагою його палкі і натхненні статті, книги, присвячені долі мистецтва у зв'язку з долею людства у пошуках щастя. Цей пошук Стендаль довіряє виключно чутливим, тонким i сильним натурам.

\section{СПИСОК ЛІТЕРАТУРИ}

1. Турчин В.С.Из истории западно-европейской художественной критики XVIII-XIX векав. - М.: Издательство Московского университета, 1987. - 368 с.

2. История эстетики. Памятники мировой эстетической мысли. - М.: Искусство, 1967. - Т. III. - 1007 с. 
3. Стендаль. Собрание сочинений в пятнадцати томах. - М.: библиотека «Огонек», издательство «Правда», 1959. - Том шестой. - 560 с.: ил.

4. Стендаль. Собрание сочинений в пятнадцати томах. - М.: библиотека «Огонек», издательство «Правда», 1959. - Том седьмой. - 392 с.

5. Кожина Е.Ф. Романтическая битва. Очерки французской романтической живописи 1820-х годов. - Ленинградское отделение: Искусство, 1969. - 271 с.: ил.

6. Европейское искусство XIX века 1789-1871 / Авторы текста Л.С. Алешина, Ю.Д. Колпинский, Е.И. Марченко, В.В. Стародубова. - М.: Искусство, 1975. 188 с.: 325 ил. (Памятники мирового искусства. Выпуск VI, серия первая) 


\title{
STUDY OF SOME BIOLOGICAL FEATURES OF PELVIC GRAPE SNAILS (HELIX POMATIA LINNAEUS)
}

\author{
Kazimli Leyla \\ Doctoral student \\ Azerbaijan National Academy of Sciences, Institute of Radiation Problems, \\ Baku, Azerbaijan \\ Heybatova Naringul \\ Master student \\ Baku State University, Department of Biophysics and Biochemistry, \\ Baku, Azerbaijan
}

Snails are invertebrates which found in freshwater, seas and land. They are often seen in the humid places, in the autumn months, when there is plenty of rain and the weather is not completely cool. They freeze in very cold weather because they have plenty of water in their bodies. In very hot weather, they can lose water and dry out. They produce a sticky liquid with a bright color, that is why, when they move, they leave a mark on their backs. The dry sticky liquid between the pelvis and the body allows them to retain moisture in their bodies. In winter, snails continue their activities by taking refuge in the ground or in tree trunks. They can live three years without food. Survival rates are very high. They are very resistant to stress $[1,2,3]$.

In the study of pelvic grape snails by the method of Electronic Paramagnetic Resonance (EPR), it was found that the influence of radiation factors plays a stimulating role in the formation of new paramagnetic centers in them. This allows the use of EPR spectra of pelvic grape snails as a bioindication parameter in environmental assessment [4,5]. Similar studies have been also conducted with plants [6-9].

Due to these interesting features, we chose pelvic grape snails (Helix pomatia Linnaeus) as the object of study. The snails we studied were collected from the territory of the garden of ANAS and they were kept in special containers in the laboratory with 22 individuals each (fig. 1). In preliminary studies, we studied the effect of some factors (food, temperature, etc.) on the activity and development of snails. 

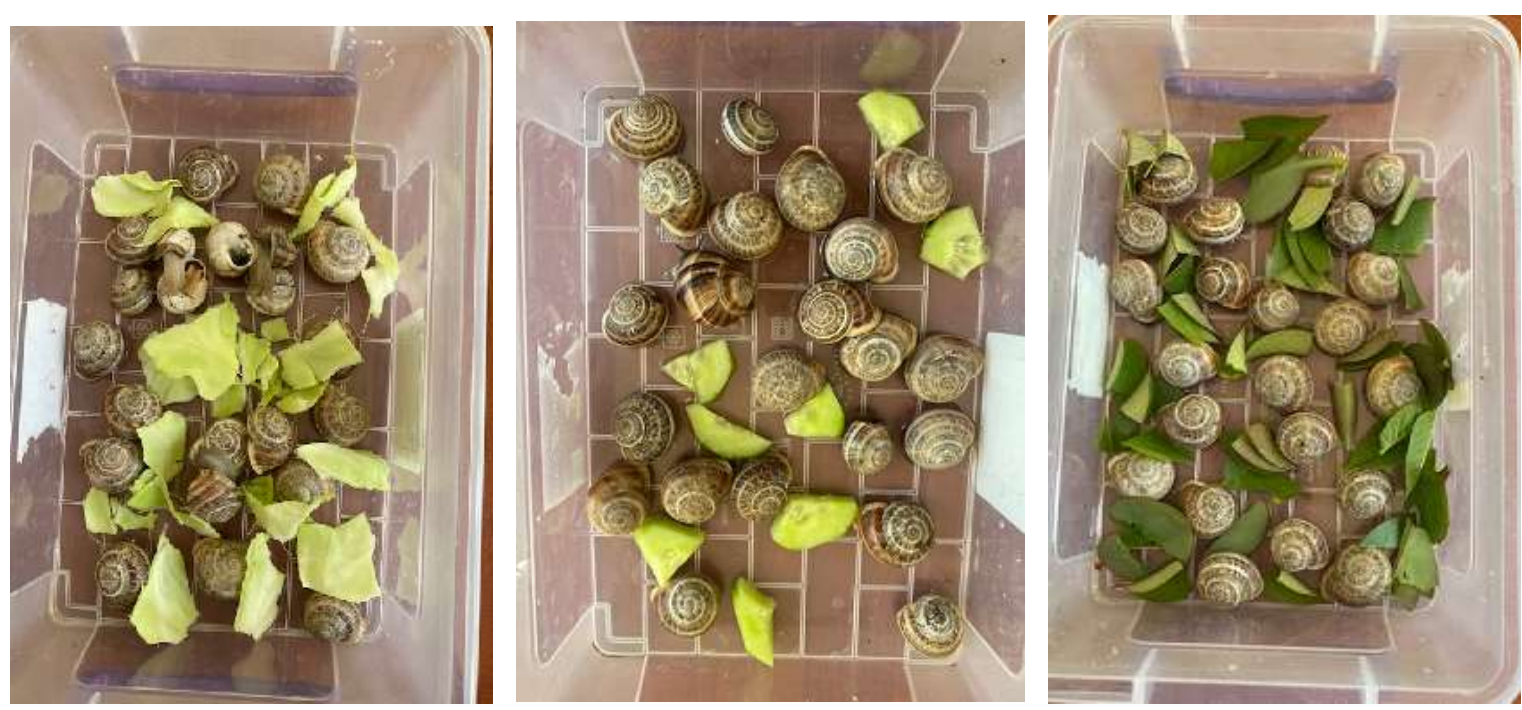

Figure 1. Snails fed on vegetables and leaves

Cucumbers, cabbage and tree leaves were chosen as food. The snails were fed daily with cucumbers, cabbage, leaves (weighing about $15 \mathrm{~g}$ ) and kept in the same conditions for 30 days. Experiments have shown that grape snails, which fed on vegetables, especially cucumbers, are more active and also gain more weight.

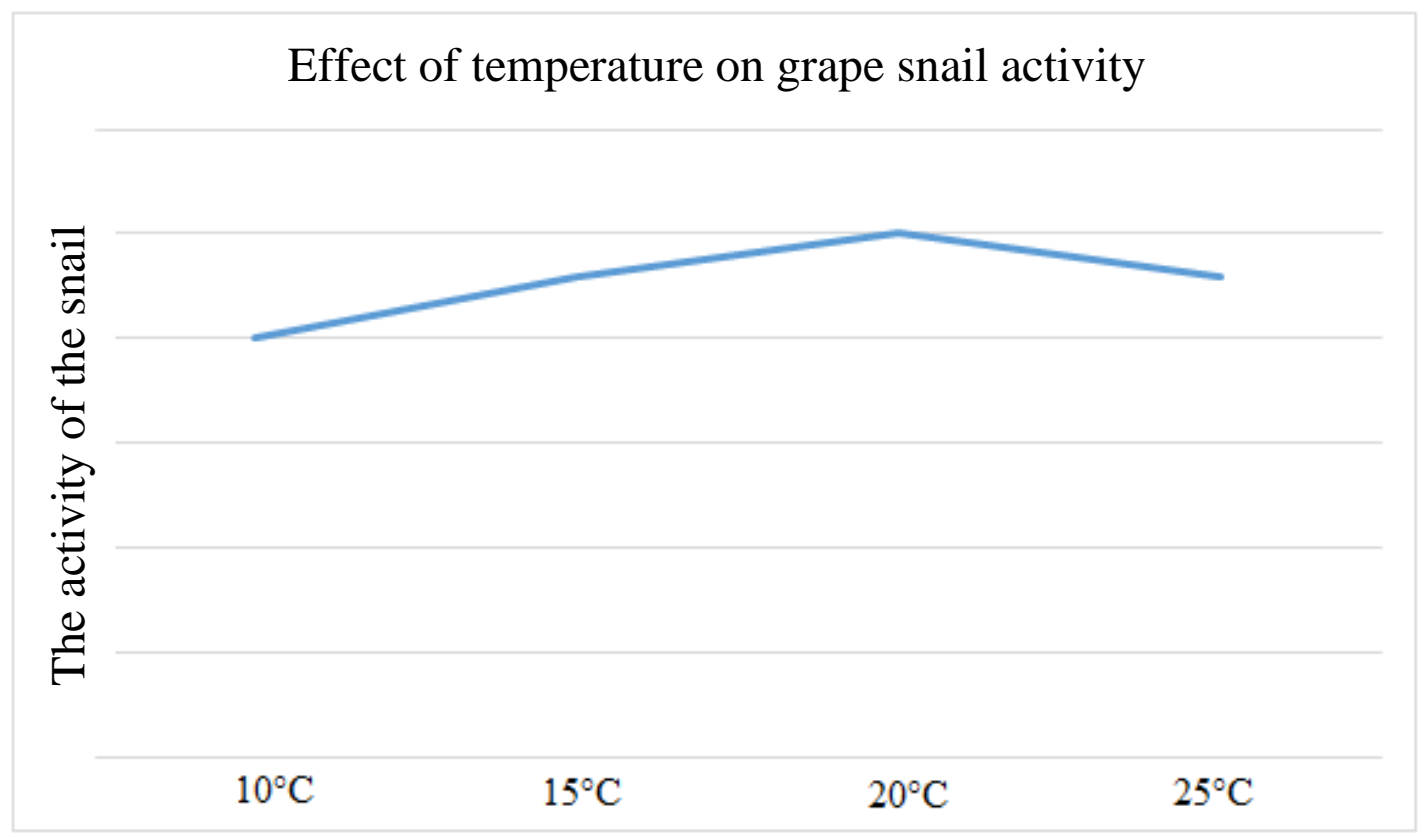

Figure 2. The effect of temperature on the activity of grape snails

In addition, the activity (fig. 2) and development of snails that kept in different temperature conditions $\left(10-12^{\circ} \mathrm{C}, 18-20^{\circ} \mathrm{C}\right.$ and $\left.25-26^{\circ} \mathrm{C}\right)$ were studied. At the end of the experiment, it was found that snails stored at a temperature of $18-20^{\circ} \mathrm{C}$ have more activity. During the initial studies, effect of temperature was not observed on their developmental dynamics.

We are currently conducting research with grape snails in the laboratory. 


\section{References:}

1. Kowalczyk-Pecka D, Kowalczuk-Vasilev E. Peroxidation and unsaturation indices as potential biomarkers of multifarious zinc and copper microsupplementation in Helix pomatia L. February 2018, Pages 713-720

2. WłostowskiT,KozłowskiP,Łaszkiewicz-Tiszczenko. Accumulation of cadmium in and its effect on the midgut gland of terrestrial snail Helix pomatia L. from urban areas in Poland. 2014 November.Page 526-531

3. Nowakowska A, Michal Caputa Antioxidants and oxidative stress in Helix pomatia snails during estivation November 2009, Pages 481-486.

4. A.N. Nasibova. The use of EPR signails of snails as bioindicative parameters in the study of environmental pollution. V.4, I.3, P.196-205. 2019.

5. A.N. Nasibova, L.T. Kazimli, M.F. Gurbanova, R.I. Khalilov. Determination of environmental quality using EPR spectra of grape snails. 27th International Conference "Mathematics. Computing. Education". 2020

6. R.I. Khalilov, A.N. Nasibova. Endogenous EPR-detected ferriferous nanoparticles in vegetative objects. News of Baku University. V.3, P.35-40. 2010.

7. Aygun Nasibova, Rovshan Khalilov, Uzeyir Qasumov, Boris Trubitsin, Alexander Tikhonov. EPR signals in plant systems and their informational content for environmental studies. European Journal of Biotechnology and Bioscience. V.4, İ.2, P. 43-47, 2016.

8. T.S. Kavetskyy, R.I. Khalilov, O.O. Voloshanska, L.M. Kropyvnytska, T.M. Beyba, V.A. Serezhenkov, A.N. Nasibova, A. Akbarzadeh, S.Ya. Voloshanska. SelfOrganized Magnetic Nanoparticles in Plant Systems: ESR Detection and Perspectives for Biomedical Applications. Advanced Nanotechnologies for Detection and Defence against CBRN Agents. P.487-492. 2018.

9. A.N. Nasibova, R.I. Khalilov. Impact of radioactive pollution on endogenous paramagnetic centers in the leaves and seeds of the plant. News of Baku University. V.3, P.65-71. 2013. 


\section{МОЖЛИВІ ШЛЯХИ ВИКОРИСТАННЯ ХІМІЧНОї ВЗАСМОДІЇ МІЖ ОРГАНІЗМАМИ У БОРОТЬБІ 3 КОМАХАМИ ШКІДНИКАМИ}

\section{Гнатюк Наталія Олександрівна,}

Кандидат біологічних наук, доцент кафедри екології та безпеки життєдіяльності Уманського національного університету садівництва

м. Умань, Україна

\section{Підан Любов Федорівна,} Кандидат біологічних наук,

Уманський навчально-виховний комплекс "Загальноосвітня школа I-III ступенів №10 - медична гімназія" Уманської міської ради Черкаської області м. Умань, Україна

Вступ. Основні проблеми, які виникають при використанні відомих до цього часу інсектицидів, полягали в тому, що:

$\checkmark$ Інсектициди мають токсичні речовини не тільки по відношенню до шкідників, але також до багатьох інших комах і тварин;

$\checkmark$ Комахи проти яких використовують інсектициди, досить швидко виробляють пристосування до них.

Деякі препарати не розкладаються в оточуючому середовищі i накопичуються в харчових ланцюгах. Зрозуміло, що людині хочеться мати в своєму розпорядженні такі засоби вибіркової дії, які могли б досить довго залишатися ефективними за рахунок нездатності комах набувати стійкості до них. Вибірковість дії інсектицидів особливо важлива, оскільки як з'ясувалося, лише близько 0,1% всіх видів комах несуть небезпеку як шкідники сільського господарства або як переносники хвороби людини і тварин.

Природні інсектициди в рослинах. З'являється велика кількість літературних даних, що своїм виживанням рослини завдячують перш за все власним засобам захисту, які виробляються в процесі еволюції у відповідь на напади фітопатогенних організмів.

Фітофаги - (в даному випадку) шкідники рослин.

Патогенні - хвороботворні або паразитичні організми, які викликають хвороби рослин.

Речовини, які продукують рослинні організми, можуть відлякувати шкідників, перешкоджають їхньому харчуванню i відкладанню яєць на рослинах, гальмують їх ріст і розмноження. Результати, які отримали вчені, свідчать про можливості практичного використання подібних речовин проти речовин шкідників. Рослини в природніх екосистемах повністю залежать від власних засобів захисту проти комах і травоїдних тварин - зайві докази того, наскільки ефективними можуть бути природні захисні засоби. Багато із 
учасників цієї хімічної взаємодії належать до груп танінів і алкалоїдів, є гіркими на смак і $є$ токсичними для ссавців і інших тварин.

Селекція культурних рослин, як правило проводиться 3 метою отримання певних структурних ознак, і такі зміни можуть послабити захисні механізми рослин проти комах. Крім того, великі групи подібних рослин комахам знайти легше ніж відокремлені особини, які зазвичай зустрічаються в природніх екосистемах. Всі ці чинники, принаймні частково зумовили посилення залежності від промислових інсектицидів в сільському господарстві.

Все таки в своїй більшості культурні рослини володіють тим або іншим ступенем стійкості до деяких комах-шкідників. Дуже часто зустрічаються сорти або споріднені види із значною стійкістю до конкретних шкідників. Іноді їх можна використовувати в програмах селекціонерів, щоб надати сортам поряд 3 іншими бажаними властивостями, стійкість до деяких шкідників.

Використання стійких сортів часто підвищують як урожай культури, так $\mathrm{i}$ його якість. Більше того стійкі рослини дуже часто скорочують популяцію шкідників і в сусідніх посівах чутливих культур. Всі інші міри боротьби 3 шкідниками потребують постійної участі людини протягом усього періоду вирощування рослин, тоді як стійкість дає можливість рослинам самим захищати себе від шкідників або зменшити втрати, який завданий ними рослинам. Успіх інших мір боротьби дуже часто залежить від того, наскільки суворо дотримуються правила їх застосування; стійкість практично не залежить від змін умов середовища. Ще одна явна перевага стійких рослин полягає в тому, що комахи, які живляться ними, часто мають нижчу життєздатність і швидше гинуть при несприятливих зовнішніх умовах. 3 ними можна боротися, якщо це необхідно, меншими дозами інсектицидів. Як виявилося, шкідники, які живляться на стійких сортах в великих кількостях з'їдаються іншими комахами, що забезпечує кращий біологічний контроль. Таким чином, стійкі рослини більш сумісні $з$ додатковими мірами боротьби. Важливо пам'ятати, що речовина, яка $є$ токсичною для одного виду комах або інших тварин. Багато із ймовірно отруйних рослин жадібно поїдаються щонайменше кількома видами комах без шкоди для них, хоча, звичайно, деякі з цих рослин $є$ токсичними для багатьох інших комах. Навпаки, ротенон, $\epsilon$ надзвичайно токсичний для комах, i малотоксичний для ссавців. С комахи, які здатні знешкоджувати певні речовини, які вбивають інших комах. Велика кількість продуктів вторинного метаболізму рослин в достатніх концентраціях можуть діяти як інсектициди проти деяких комах.

Таким чином, за якою б ознакою ми не намагалися класифікувати токсини рослинного походження, ця класифікація завжди буде мати ті чи інші недоліки. В даний час запропоновано вісім основних категорій токсинів, що містяться в насінні: 1). фітогемагглютініни; 2). інгібітори ферментів; 3). полісахариди; 4). ціаногени; 5). сапоніни; 6). алкалоїди; 7). небілкові амінокислоти; 8). інші токсини.

Фітогемагглютініни. Більшість фітогемагглютініни є вуглецевмісні білки, деякі - ліпідовмісні білки. Ці сполуки широко поширені в царстві рослин і зустрічаються навіть в деяких мікроорганізмів, але найбільш відомі із них слід 
шукати в родинах молочайних і бобових. Рицин виявлений в рицині звичайній. Встановлено, що фітогемагглютініниіз чорних бобівв певних концентраціях здійснюють пагубний вплив на личинок зернівки Callosobruchus maculatus.

Інгібітори ферментів. В насінні земляного горіха, сої, нуту та інших бобових рослин було виявлено інгібітор протеази личинок борошнистого хруща.

Селекція бобових на більш високий вміст цього інгібітору могла б сприяти зменшенню втрат насіння при збереженні. Інгібітори амілаз (ферментів, які здійснюють розщеплення крохмалю) були виявлені в насінні принаймні двадцяти видів бобових, а також в насінні пшениці і жита. Інгібітор, який міститься в рослинах пшениці, являє собою специфічний ингибитор альфаамилази, який утворюють личинки жука Tenebrio molitor, який харчується насінням.

Полісахариди. Стійкості квасолі (Phaseolus vulgaris) до личинок зернівки Callosobruchus chinensis служить складний полісахарид(його молекула складається із залишків молекул багатьох простих сахаридів). Зазвичай на частку цієї сполуки припадає близько $1 \%$ сухої маси насіння. За такої концентрації вказаний полісахарид нешкідливий для іншої зернівки, Acanthoscelides obtectus, основного шкідника квасолі при зберіганні, але в більш високих концентраціях він забезпечує стійкість і до цієї комахи.

Ціаногени. Відомо понад тисячу видів рослин, які синтезують синільну кислоту $(\mathrm{HCN})$; зазвичай це відбувається в результаті пошкодження тканин, при якому вміст в рослині ціаногенних речовин контролюється ферментом, здатним вивільняти 3 нього НCN. Відомі ціаногени являють собою або ціаногенні глікозиди, або ціаногенні ліпіди. Один із таких глікозидів - амігдалін.

Амігдалін присутній в гіркому мигдалі і кісточках інших розоцвітих, зокрема вишні і персика. Він міститься також в коренях, листі і стеблах деяких із цих видів. При розпаді амігдаліну утворюється цукор (гентіобіоза), бензальдегід і синильна кислота. Ціаногенні глікоиди виявлені і в багатьох інших рослинах. Цукри і аглікони (нецукрові частини молекул) досить різноманітні, але всі ціаногенні глікозиди утворюють синильну кислоту, яка $є$ сильно отруйною для багатьох тварин, зокрема і для багатьох комах.

Сапоніни. Це глікозиди у яких нецукрова частина молекули утворена стеролом або тритерпеном. Ці сполуки містяться в насінні і інших частинах рослин багатьох видів.

Вміст сапонінів, як правило змінюється в різних частинах рослини, на різних стадіях їх росту і в різних сезонах. В вегетативних частинах посівного куколю (Agrostema githago L.) представників роду тунгових (Aleurites), букових (Fagus), плющових (Hedera), льону вузьколистого (Linumangastifolium Т.), люцерни (Medicago), видів роду мильнянки (Saponaria) і видів роду Sesbania сапоніни виявлені у відносно великих кількостях. Деякі із сапонінів, що містяться у насінні більшості культивованих рослин бобових, токсини для личинок зернівки Callosobruchus і личинок борошнистого хруща Tribolium.

Алкалоїди відповідно до своєї назви володіють основними властивостями i містять одне або декілька кілець з атомами азоту. Добре відомі такі алкалоїди, як нікотин, атропін, хінін, морфін, стріхнін, резерпін і колхіцін. Широке поширення 
алкалоїдів в рослинному царстві було переконливо описано в роботах багатьох дослідників одинадцять алкалоїдів проти личинок зернівки і досліджено, що при додаванні в корм в концентраціях $0,1-1,0$ \% всі вони мали летальну дію. Всі алкалоїди, були токсичними за малих концентрацій.

Небілкові амінокислоти. В рослинах було знайдено більше двухсот амінокислот, які не входять до складу білків і не є проміжними продуктами метаболізму.

Багато із них можуть діяти як антиметаболіти а, також як токсини по відношенню до деяких організмів. Таким чином, було встановлено, що серед амінокислот цієї групи $є$ такі, які отруйні для більшості тварин, а також для мікроорганізмів і деяких вищих рослин.

\section{Список літератури}

1. Берестецький О.А. Биологические основы плодородия почв / О.А. Берестецький, Ю.М. Возняковская, Л.М. Доросинский и др. -М.: Колос, 1984. $-287 \mathrm{c}$.

2. Биляновская Т.М. Аллопатическое взаимодействие овощных культур витаминного комплекса через среду крорнеобитания. -Минск, $1992-16$ с.

3. Возняковская О.М. Некоторые аспекты взаимодействия здоровых растений с микроорганизмами // Алелопатия и продуктивность растений. - Киев: Наукова думка, 1990. - 119.

4. Головко Э.А. Микроорганизмы в алелопатии высших растений. - Киев: Наукова думка, 1984. - 200 с.

5. Головко Э.А. Алелопатия культурных растений // Физиология и биохимия культурных растений / Э.А. Головко, Т.М. Биляновская, И.И. Воробей и др. 1999. - Т.31. - №2. - С.103-110

6. Гродзинский А.М. Алелопатия в жизни растений и их сообществ. - Киев: Наукова думка, 1965. - 198 с.

7. Гродзинский А.М. Алелопатия растений и почвоутомление: избр.тр. Киев: Наукова думка, 1991. - 432 с.

8. Гродзинский А.М. Взаимодействие летучих выделений в замкнутой экосистеме / А.М. Гродзинский, Э.А. Головко, А.Я. Безмелов. - Киев: Наукова думка, 1992. - 125 с.

9. Гродзинський А.М. Основи хімічної взаємодії рослин. - Київ: Наукова думка, 19973. - 205 с.

10. Работнов Т.А. Фитоценология. М. Изд-во Моск.ун-та, 1978. - 382 с.

11. Райс Э. Алелопатия. М.: Мир, 1978. - 392 с. 


\title{
ЕКОЛОГІЧНИЙ КОНТРОЛЬ ЯКОСТІ ПОВЕРХНЕВИХ ВОД Р. ДНІПРО 3 РАЙОНІВ ВОДОЗАБОРІВ М. ЗАПОРІЖЖЯ ЗА ОКРЕМИМИ ПОКАЗНИКАМИ БЛОКУ СОЛЬОВОГО СКЛАДУ
}

\begin{abstract}
Троїцька Олена Олександрівна, канд. біолог. наук, старший науковий співробітник, доцент каф. ПЕОП Запорізький національний університет

\section{Бакарджисв Роман Олександрович}

канд. техн. наук, доцент, доцент каф. ТКМ

Таврійський державний агротехнологічний університет ім. Д. Моторного
\end{abstract}

До основних цілей співпраці України та ЄС слід віднести розвиток всеосяжної стратегії у сфері навколишнього середовища. Двостороння співпраця з СС у цій сфері переважно охоплює питання ефективного моніторингу забруднення, контроль та оцінку стану навколишнього середовища. У країнах Європейського Союзу регламентовані достатньо жорсткі вимоги до вмісту небезпечних та токсичних сполук у об'єктах довкілля. Обов'язки України щодо вимог СОТ, вимагають налагодження системи контролю за якістю навколишнього середовища [1].

Найнебезпечнішим різновидом антропогенного навантаження на поверхневі води $\epsilon$ їх забруднення екологічно небезпечними хімічними речовинами, які здатні порушувати самоочисні і біопродукційні процеси, призводити до глибоких змін у структурно-функціональній організації біотичної складової водних екосистем. Основними джерелами забруднення водних об'єктів є скиди стічних вод підприємств різних галузей економіки, а також побутові та сільськогосподарські стоки, компонентний склад яких дуже різноманітний. До водних об'єктів потрапляють сотні тисяч хімічних речовин, багатьом з яких притаманні токсичні властивості [2].

Більшість неорганічних забруднювачів не піддаються будь-яким перетворенням у довкіллі. Тому їх надходження до водойми викликає надзвичайно стійке забруднення. Найбільш важливими неорганічними забруднювачами $є$ важкі метали, деякі неметали, сульфати, хлориди, ціаніди, тощо. Численні дослідження пов'язують 3 хімічним (мінеральним) складом води можливість розвитку серед населення масових захворювань. Особливе значення набула оцінка сольового складу питної води $[2,3]$.

Річка Дніпро є одним із життєво важливих компонентів екологічного середовища та необхідною частиною соціально-економічного розвитку в цілому, задоволення основних потреб людей, діяльності у галузі виробництва продовольства, збереження екосистем. Певна обмеженість у водних ресурсах в Україні вимагає втілення таких засад управління, комплексного використання 
та охорони вод, які б відповідали сучасним вимогам, що постають перед країнами Європи. Особливу увагу необхідно приділяти питанням управління якістю водних ресурсів річкових басейнів на основі комплексних екологічних оцінок складу вод [3].

Екологічна оцінка стану поверхневих вод побудована за екосистемним принципом. Комплекс показників екологічної класифікації якості поверхневих вод включає загальні та специфічні показники. Загальні показники, до яких належать показники сольового складу, характеризують звичайні властиві водним екосистемам інгредієнти, концентрація яких може змінюватись під впливом господарської діяльності людини [3].

Мета дослідження - аналіз та оцінка екологічного стану поверхневих вод p. Дніпро з районів водозаборів Дніпровських водопровідних станцій № 1 та № 2 (ДВС-1 і ДВС-2) (м. Запоріжжя) за показниками блоку сольового складу (сумою іонів, сульфатів і хлоридів) на протязі п’ятирічного періоду (2015-2019рр.), шляхом оцінки якості дослідних поверхневих вод за відповідними класами i категоріями, а також ступенем антропогенного забруднення.

Запорізьке комунальне підприємство «Водоканал» готує воду питної якості на Дніпровських водопровідних станціях № 1 та № 2 (ДВС-1 і ДВС-2). Водозабірні і очисні споруди ДВС-1 розташовуються на лівому березі, ДВС-2 - на правому березі р. Дніпро. Джерелом водопостачання служить Дніпро вище греблі. Забір води здійснюється з різних глибин.

У табл. 1 наведені значення середньорічних та максимальних (найгірших) показників вмісту суми іонів, хлоридів і сульфатів в поверхневих водах р. Дніпро з районів водозаборів ДВС-1 та ДВС-2 (м. Запоріжжя) за 2015-2019 pp.

На основі групування та аналізу середньорічних та максимальних (найгірших) значень для досліджуваних показників блоку сольового складу вмісту суми іонів, хлоридів і сульфатів, визначили клас та категорії якості поверхневих вод р. Дніпро 3 районів водозаборів ДВС-1 та ДВС-2 за середньорічними (табл. 2) та максимальними (найгіршими) (табл. 3) значеннями.

На рис. 1 проілюстровані результати визначення класу та категорій якості поверхневих вод р. Дніпро з району водозабору ДВС-1 за середньорічними і за максимальними (найгіршими) значеннями вмісту суми іонів за п'ятирічний період досліджень (2015-2019 рр.).

На рис. 2 проілюстровано результати визначення класу та категорій якості поверхневих вод р. Дніпро з району водозабору ДВС-2 за середньорічними і за максимальними (найгіршими) значеннями вмісту суми іонів за п'ятирічний період досліджень (2015-2019 рр.). 
Таблиця 1. Значення середньорічних та максимальних (найгірших) показників вмісту суми іонів, хлоридів і сульфатів в поверхневих водах р. Дніпро з районів водозаборів ДВС-1 і ДВС-2 (м. Запоріжжя) за 2015-2019 рр.

\begin{tabular}{|c|c|c|c|c|c|c|c|c|c|c|c|}
\hline \multirow[b]{3}{*}{ Блок } & \multirow[b]{3}{*}{$\begin{array}{l}\text { Показ- } \\
\text { ники }\end{array}$} & \multicolumn{10}{|c|}{ Значення показників по роках } \\
\hline & & \multicolumn{2}{|c|}{$2015 \mathrm{p}}$. & \multicolumn{2}{|c|}{$2016 \mathrm{p}}$. & \multicolumn{2}{|c|}{$2017 \mathrm{p}}$. & \multicolumn{2}{|c|}{$2018 \mathrm{p}}$. & \multicolumn{2}{|c|}{$2019 \mathrm{p}}$. \\
\hline & & $\begin{array}{c}\text { серед } \\
\text { ньо- } \\
\text { річні }\end{array}$ & $\begin{array}{l}\text { макси } \\
\text { мальні } \\
\text { (найгі } \\
\text { рші) }\end{array}$ & $\begin{array}{c}\text { серед } \\
\text { ньо- } \\
\text { річні }\end{array}$ & $\begin{array}{c}\text { макси } \\
\text { мальні } \\
\text { (найгір } \\
\text { ші) }\end{array}$ & $\begin{array}{l}\text { серед } \\
\text { ньо- } \\
\text { річні }\end{array}$ & $\begin{array}{l}\text { макси- } \\
\text { мальні } \\
(\text { найгір } \\
\text { ші) }\end{array}$ & $\begin{array}{l}\text { серед } \\
\text { ньо- } \\
\text { річні }\end{array}$ & $\begin{array}{l}\text { макси } \\
\text { мальні } \\
\text { (найгі } \\
\text { рші) }\end{array}$ & $\begin{array}{c}\text { серед } \\
\text { ньо- } \\
\text { річні }\end{array}$ & $\begin{array}{c}\text { макси } \\
\text { мальн } \\
\text { i } \\
\text { (найгі } \\
\text { рші) }\end{array}$ \\
\hline 1 & 2 & 3 & 4 & 5 & 6 & 7 & 8 & 9 & 10 & 11 & 12 \\
\hline \multicolumn{12}{|c|}{ Район водозабору Дніпровської водопровідної станції № 1 (ДВС-1) } \\
\hline \multirow{3}{*}{$\begin{array}{c}\text { Блок } \\
\text { сольо- } \\
\text { вого } \\
\text { складу }\end{array}$} & $\begin{array}{l}\text { Сума } \\
\text { іонів, } \\
\text { мг/дм }\end{array}$ & 833 & 953 & 769 & 855 & 787 & 941 & 725 & 858 & 883 & 907 \\
\hline & $\begin{array}{l}\text { Хлориди } \\
\text {, мг/дм }{ }^{3}\end{array}$ & 37,2 & 46,1 & 40,9 & 49,63 & 29,38 & 34,39 & 25,1 & 39,0 & 34,6 & 37,58 \\
\hline & $\begin{array}{l}\text { Сульфати, } \\
\text { мг/дм }{ }^{3}\end{array}$ & 64,1 & 87,2 & 81,1 & 91,97 & 66,73 & 75,1 & 51,7 & 67,9 & 48,9 & 61,11 \\
\hline \multicolumn{12}{|c|}{ Район водозабору Дніпровської водопровідної станції № 2 (ДВС-2) } \\
\hline \multirow{3}{*}{$\begin{array}{c}\text { Блок } \\
\text { сольо- } \\
\text { вого } \\
\text { складу }\end{array}$} & $\begin{array}{l}\text { Сума } \\
\text { іонів, } \\
\text { мг/дм }\end{array}$ & 835 & 925 & 711 & 885 & 792 & 903 & 691 & 799 & 805 & 873 \\
\hline & $\begin{array}{l}\text { Хлориди } \\
\text {, мг/дм }{ }^{3}\end{array}$ & 40,2 & 50,0 & 36,3 & 45,38 & 30,9 & 35,5 & 27,7 & 31,9 & 32,2 & 37,6 \\
\hline & $\begin{array}{l}\text { Сульфати, } \\
\text { мг/дм }{ }^{3}\end{array}$ & 55,3 & 71,93 & 57,0 & 66,3 & 51,9 & 61,9 & 63,44 & 78,9 & 49,7 & 49,9 \\
\hline
\end{tabular}




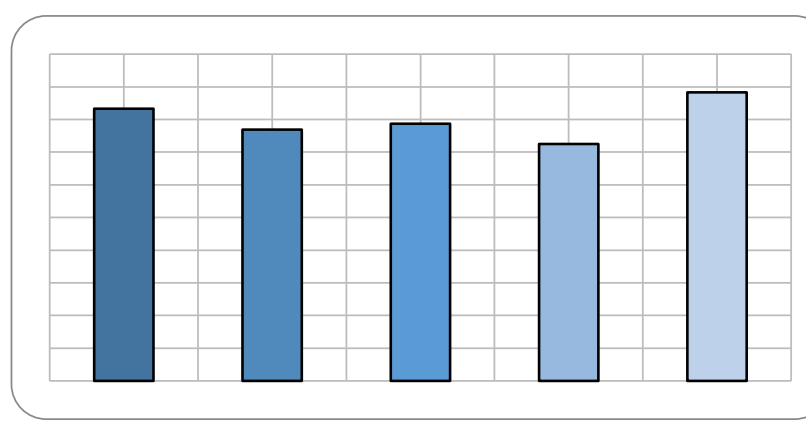

a)

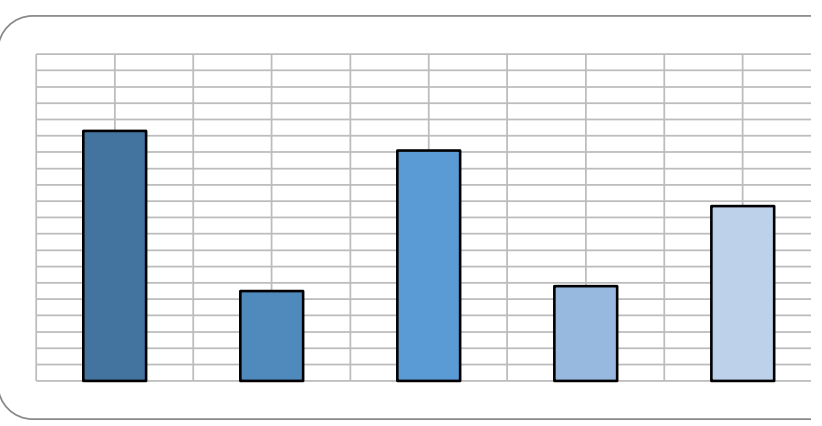

б)

Рисунок 1. Клас і категорії якості поверхневих вод p. Дніпро з району водозабору ДВС-1 за середньорічними (а) і за максимальними (найгіршими) (б) значеннями вмісту суми іонів за 2015-2019 pp.

Таблиця 2.

Оцінка якості поверхневих вод р. Дніпро з районів водозаборів ДВС-1 та ДВС-2 за середньорічними значеннями вмісту суми іонів, хлоридів і сульфатів (2015-2019рp.)

\begin{tabular}{|c|c|c|c|c|c|c|c|c|c|c|c|}
\hline \multirow[b]{3}{*}{ Блок } & \multirow{3}{*}{$\begin{array}{c}\text { Показ- } \\
\text { ники }\end{array}$} & \multicolumn{10}{|c|}{ Значення по роках } \\
\hline & & \multicolumn{2}{|c|}{$2015 \mathrm{p}$} & \multicolumn{2}{|c|}{2016 p. } & \multicolumn{2}{|c|}{2017 p. } & \multicolumn{2}{|c|}{2018 p. } & \multicolumn{2}{|c|}{2019 p. } \\
\hline & & $\begin{array}{c}\text { серед } \\
\text { ньорі } \\
\text { чні }\end{array}$ & $\begin{array}{l}\text { клас i } \\
\text { кате- } \\
\text { горія } \\
\text { якості }\end{array}$ & $\begin{array}{c}\text { серед } \\
\text { ньорі } \\
\text { чні }\end{array}$ & $\begin{array}{l}\text { клас i } \\
\text { кате- } \\
\text { горія } \\
\text { якості }\end{array}$ & $\begin{array}{c}\text { серед } \\
\text { ньорі } \\
\text { чні }\end{array}$ & $\begin{array}{l}\text { клас } \\
\text { i кате- } \\
\text { горія } \\
\text { якості }\end{array}$ & $\begin{array}{c}\text { серед } \\
\text { ньорі } \\
\text { чні }\end{array}$ & $\begin{array}{r}\text { клас } \\
\text { i кате- } \\
\text { горія } \\
\text { якості }\end{array}$ & $\begin{array}{c}\text { серед } \\
\text { ньорі } \\
\text { чні }\end{array}$ & $\begin{array}{c}\text { клас i } \\
\text { кате- } \\
\text { горія } \\
\text { якості }\end{array}$ \\
\hline
\end{tabular}

Район водозабору Дніпровської водопровідної станції № 1 (ДВС-1)

\begin{tabular}{|l|l|l|l|l|l|l|l|l|l|l|l|}
\hline \multirow{2}{*}{$\begin{array}{l}\text { Блок } \\
\text { сольо- } \\
\begin{array}{l}\text { вого } \\
\text { складу }\end{array}\end{array}$} & $\begin{array}{l}\text { Сума } \\
\text { онів, } \\
\text { мг/дм }\end{array}$ \\
\cline { 2 - 10 } & $\begin{array}{l}\text { Хлориди } \\
\text { мг/дм }\end{array}$ & 37,2 & II (3) & 40,9 & II (3) & 29,4 & II (3) & 25,1 & II (2) & 34,6 & III (3) \\
\cline { 2 - 9 } \\
$\begin{array}{l}\text { Сульфати, } \\
\text { мг/дм }\end{array}$
\end{tabular}

Район водозабору Дніпровської водопровідної станції № 2 (ДВС-2)

\begin{tabular}{|c|c|c|c|c|c|c|c|c|c|c|c|}
\hline \multirow{3}{*}{$\begin{array}{l}\text { Блок } \\
\text { сольо- } \\
\text { вого } \\
\text { складу }\end{array}$} & $\begin{array}{l}\text { Сума } \\
\text { іонів, } \\
\text { мг/дм }\end{array}$ & 835 & III (5) & 711 & III (4) & 792 & III (5) & 691 & III (4) & 805 & III (5) \\
\hline & $\begin{array}{l}\text { Хлориди } \\
\text {, мг/дм }\end{array}$ & 40,2 & II (3) & 36,3 & II (3) & 30,9 & II (3) & 27,7 & II (3) & 32,2 & II (3) \\
\hline & $\begin{array}{l}\text { Сульфати, } \\
\text { мг/дм³ }\end{array}$ & 55,3 & II (3) & 57,0 & II (3) & 51,9 & II (3) & 63,44 & III (4) & 49,7 & II (3) \\
\hline
\end{tabular}




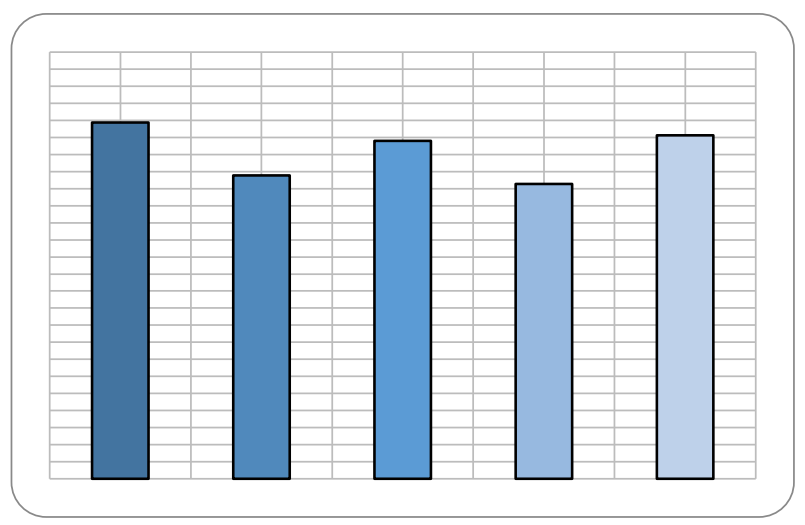

a)

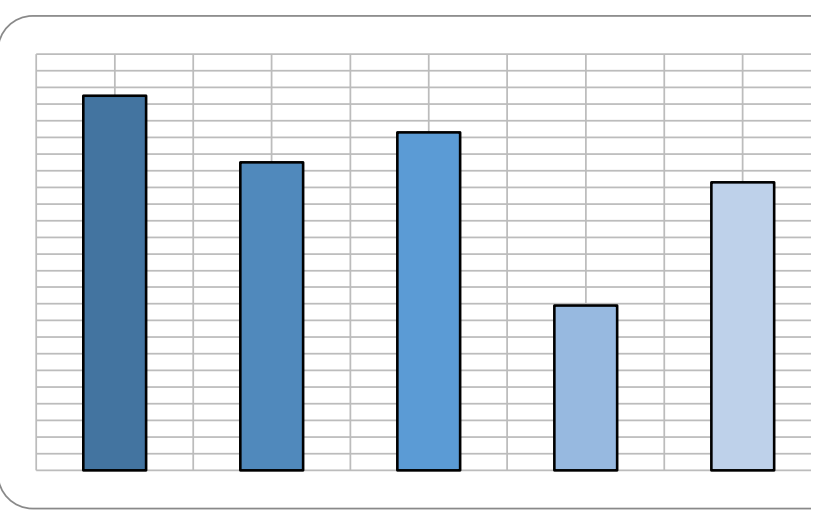

б)

Рисунок 2. Клас і категорії якості поверхневих вод p. Дніпро з району водозабору ДВС-2 за середньорічними (а) і за максимальними (найгіршими) (б) значеннями вмісту суми іонів за 2015-2019 pp.

Таблиця 3.

Оцінка якості поверхневих вод р. Дніпро з районів водозаборів ДВС-1 та ДВС-2 за максимальними (найгіршими) значеннями вмісту суми іонів, хлоридів і сульфатів (2015-2019 pp.)

\begin{tabular}{|c|c|c|c|c|c|c|c|c|c|c|c|}
\hline \multirow[b]{3}{*}{ Блок } & \multirow[b]{3}{*}{$\begin{array}{c}\text { Показни } \\
\text { ки }\end{array}$} & \multicolumn{10}{|c|}{ Значення по роках } \\
\hline & & \multicolumn{2}{|c|}{2015 p. } & \multicolumn{2}{|c|}{$2016 \mathrm{p}$. } & \multicolumn{2}{|c|}{2017 p. } & \multicolumn{2}{|c|}{2018 p. } & \multicolumn{2}{|c|}{2019 p. } \\
\hline & & $\begin{array}{c}\text { макси } \\
\text { маль } \\
\text { ні } \\
\text { (найг } \\
\text { ірші) }\end{array}$ & $\begin{array}{c}\text { клас i } \\
\text { катего } \\
\text { рія } \\
\text { якості }\end{array}$ & $\begin{array}{c}\text { макс } \\
\text { имал } \\
\text { ьні } \\
\text { (найг } \\
\text { ірші) }\end{array}$ & $\begin{array}{c}\text { клас i } \\
\text { катего } \\
\text { рія } \\
\text { якості }\end{array}$ & $\begin{array}{c}\text { макс } \\
\text { имал } \\
\text { ьні } \\
\text { (найг } \\
\text { ірші) }\end{array}$ & $\begin{array}{c}\text { клас } \\
\text { i } \\
\text { катег } \\
\text { орія } \\
\text { якост } \\
\text { i }\end{array}$ & $\begin{array}{c}\text { макс } \\
\text { имал } \\
\text { ьні } \\
\text { (найг } \\
\text { ірші) }\end{array}$ & $\begin{array}{c}\text { клас } \\
\text { i } \\
\text { катег } \\
\text { орія } \\
\text { якост } \\
\text { i }\end{array}$ & $\begin{array}{c}\text { макс } \\
\text { имал } \\
\text { ьні } \\
\text { (найг } \\
\text { ірші) }\end{array}$ & $\begin{array}{c}\text { клас i } \\
\text { катего } \\
\text { рія } \\
\text { якості }\end{array}$ \\
\hline
\end{tabular}

Район водозабору Дніпровської водопровідної станції № 1 (ДВС-1)

\begin{tabular}{|c|c|c|c|c|c|c|c|c|c|c|c|}
\hline \multirow{3}{*}{$\begin{array}{l}\text { Блок } \\
\text { сольо- } \\
\text { вого } \\
\text { складу }\end{array}$} & $\begin{array}{l}\text { Сума } \\
\text { іонів, } \\
\text { мг/дм }\end{array}$ & 953 & III (5) & 855 & III (5) & 941 & III (5) & 858 & III (5) & 907 & III (5) \\
\hline & $\begin{array}{l}\text { Хлориди } \\
\text {, мг/дм }\end{array}$ & 46,1 & II (3) & 49,6 & II (3) & 34,39 & II (3) & 39,0 & II (3) & 37,6 & II (3) \\
\hline & $\begin{array}{l}\text { Сульфати, } \\
\text { мг/дм }\end{array}$ & 87,2 & III (4) & 91,9 & III (4) & 75,1 & III (4) & 67,9 & III (4) & 61,1 & III (4) \\
\hline
\end{tabular}

Район водозабору Дніпровської водопровідної станції № 2 (ДВС-2)

\begin{tabular}{|c|c|c|c|c|c|c|c|c|c|c|c|}
\hline \multirow{3}{*}{$\begin{array}{l}\text { Блок } \\
\text { сольов } \\
\text { ого } \\
\text { складу }\end{array}$} & $\begin{array}{l}\text { Сума } \\
\text { іонів, } \\
\text { мг/дм }\end{array}$ & 925 & III (5) & 885 & III (5) & 903 & III (5) & 799 & III (5) & 873 & III (5) \\
\hline & $\begin{array}{l}\text { Хлориди } \\
\text {, мг/дм }\end{array}$ & 50,0 & II (3) & 45,4 & II (3) & 35,4 & II (3) & 31,9 & II (3) & 37,6 & II (3) \\
\hline & $\begin{array}{l}\text { Сульфати, } \\
\text { мг/дм³ }\end{array}$ & 71,9 & III (4) & 66,3 & III (4) & 61,9 & III (4) & 78,9 & III (4) & 49,9 & II (3) \\
\hline
\end{tabular}

Визначено, що за середньорічними і максимальними (найгіршими) значеннями вмісту суми іонів, в поверхневих водах р. Дніпро з районів водозаборів ДВС-1 і ДВС2, якість дослідних вод, на протязі всього п'ятирічного періоду досліджень, 
відповідала III класу та 5 категорії якості. Таким чином, екологічний стан дослідних поверхневих вод визначений як «посередній», а за рівнем забрудненості стабільно характеризується, як «помірно забруднений».

Встановлено, що якість поверхневих вод р. Дніпро з районів водозаборів ДВС1 і ДВС-2, за середньорічними значеннями вмісту хлоридів, у 2015, 2016, 2017 і 2019 рр., відповідала II класу і 3 категорії якості (за станом «добра», за ступенем чистоти - «досить чиста»). За максимальними (найгіршими) значеннями вмісту хлоридів, якість дослідних вод, в межах екологічної класифікації, всі п'ять років відповідала II класу і 3 категорії якості (за станом «добра», за ступенем чистоти - «досить чиста»).

Виявлено, що за середньорічними значеннями вмісту сульфатів в поверхневих водах р. Дніпро з району водозабору ДВС-1, якість дослідних вод, у 2015, 2016 і 2017 pp. відповідала III класу та 4 категорії якості (за станом «задовільна», за ступенем чистоти - «слабко забруднена»). У 2018 р. і 2019 р. якість дослідних вод, покращилася і відповідала II класу і 3 категорії якості (за станом «добра», за ступенем чистоти - «досить чиста»). За максимальними (найгіршими) величинами, весь п'ятирічний дослідний період, відповідала III класу і 4 категорії якості води («задовільна» вода прийнятної якості; за ступенем чистоти - «слабко забруднена»). Встановлено, що якість поверхневих вод р. Дніпро $з$ району водозабору ДВС-2, за середньорічними значеннями вмісту сульфатів, у 2015, 2016 і 2017 рр. відповідала II класу і 3 категорії якості (за станом «добра», за ступенем чистоти - «досить чиста»). У 2018 р. зафіксоване погіршення якості дослідних вод до III класу та 4 категорії якості (за станом «задовільна», за ступенем чистоти - «слабко забруднена»). Але у 2019 році якість дослідних вод знову покращилися і відповідала II класу і 3 категорії якості. Максимальні (найгірші) показники дослідних вод у 2018 р. і 2019 р. знаходилися в межах вищенаведених класів і категорій якості.

Результати екологічного оцінювання якості поверхневих вод р. Дніпро 3 районів водозаборів ДВС-1 і ДВС-2 (м. Запоріжжя) за п'ятирічний період досліджень (2015-2019 рр.), дозволяють констатувати досить стабільний екологічний стан дослідних поверхневих вод за окремими показниками блоку сольового складу (сумою іонів, хлоридів та сульфатів). Однак, враховуючі отримані результати оцінки екологічного стану дослідних вод за сумою іонів, $\epsilon$ підстави стверджувати, що ця стабільність вказує на постійний антропогенний пресинг на екосистему р. Дніпро в межах м. Запоріжжя. Можна констатувати, що значне антропогенне навантаження, вже, порушило природну рівновагу та знизило якість дослідних вод. Встановлена тенденція, вказує на те, що хоча у природному водному середовищі постійно проходять різноманітні процеси самоочищення, їх ефективності, у зв'язку із постійним ростом антропогенного навантаження, недостатньо для того, щоб уникнути негативного антропогенного пресингу на динаміку водно-сольового режиму дослідних водних екосистем в сучасний період.

\section{Список літератури:}

1. Про Основні засади (стратегію) державної екологічної політики України на період до 2030 року. № 2697-VIII § ст. 70, 2019. 
2. Раціональне використання та відновлення водних ресурсів. Монографія / За заг. ред. Фещенка В.П. Житомир : Вид-во ЖДУ ім. І. Франка, 2016. 250 с.

3. Троїцька О.О. Екологічний стан поверхневих вод р. Дніпро в межах м. Запоріжжя в контексті сталого розвитку Запорізького регіону. Матеріали XXI Міжнародної науково-практичної конференції «Екологія. Людина. Суспільство» (21-22 травня 2020 р., м. Київ). Київ : НТУУ «КПІ ім. Ігоря Сікорського», 2020. 275 c., C. $268-271$. 


\section{ВИДОВЕ РІЗНОМАНІТТЯ ЕНТОМОФАУНИ РІЧКИ СЛУЧ У МЕЖАХ М. БЕРЕЗНЕ РІВНЕНСЬКОЇ ОБЛАСТІ}

\section{Трускавецька Ірина Ярославівна}

кандидат історичних наук доцент кафедри біології і методики навчання

Університет Григорія Сковороди в Переяславі, м. Переяслав Україна

\section{Владислав Костюкевич} здобувач бакалаврського ступеня, спеціальності 014 Середня освіта

(Біологія та здоров'я людини) Університет Григорія Сковороди в Переяславі, м. Переяслав

Тваринний світ досить різноманітний. Тварини, а особливо безхребетні, зустрічаються майже у всіх біосферних оболонках.

Досить цікавими об'єктами безхребетної фауни є представники водного середовища існування. Актуальність теми дослідження зумовлена недостатнім рівнем відомостей про фауністичний склад, біологічні особливості видового складу тварин - гідробіонтів річки Случ [1].

Значну увагу вивченню комах водойм, які найпоширеніші на території України, приділили В. М. Срмоленко та 3. Ф. Ключко. Відомості про методику дослідження екосистем малих річок, про річкову долину та пї утвори, водні рослини та тварини викладено ученим-біологом Р. Хімкою у методичних вказівках «Досліджуємо малі річки» [4].

Водну ентомофауну Рівненської області вивчали Коротун I. М., Геренчук К. I., про результати їхніх досліджень свідчить монографія «Природа Ровенськой области», у якому автори окреслили природоохоронні об'єкти, рослинність та тваринний світ Березнівщини. Про природоохоронні об'єкти Рівненської області та Березнівського району розповідає Т. Л. Андрієнко в книзі «Край лісів та імлистих боліт», описує райони, які потребують охорони, та тварин, занесених до Червоної книги України, що зустрічаються на даній території [3].

Березнівський район розташований у східній частині Рівненщини і межує на заході з Житомирською областю, на півночі - із Сарненським та Рокитнівським районами, на сході - із Костопільським районом та на півдні - із Гощанським та Корецьким районами Рівненської області. Місто Березне розміщене на плоскій рівнині, на лівому березі річки Случ.

У річці Случ виділяють три частини, які можна розглядати як окремі екосистеми:

- прибережна частина - літораль; 
- глибоководна частина - профундаль;

- основна товща води - пелагіаль.

Рослинний та тваринний світ р. Случ у багатьох випадках визначається наявністю у воді поживних речовин. У прибережній частині річки ростуть звичайні для цих місць очерети, комиші, лепешняки та стрілолист. У товщі води плавають елодея, латаття. При зростанні швидкості течії до 0,3-0,6 м/сек. та більше товща води вже не зростає. Для річки планктон не характерний, оскільки зноситься течією [5].

Ентомофауна річки Случ досить різноманітна. Тут чимало водяних комах та їхніх личинок. Часто зустрічаються рачки-бокоплави. У прибережній зоні добре прогріваються численні найпростіші, коловертки, гілчастовусі і веслоногі ракоподібні.

Таблиця 1

Видове різноманіття водної ентомофауни р. Случ у межах м. Березне Рівненської області

\begin{tabular}{|c|c|c|}
\hline Ряд & Родина & Вид \\
\hline \multirow[t]{4}{*}{ Бабки (Odonata) } & Красунєві (Calopterygidae) & $\begin{array}{c}\text { Красуня блискуча } \\
\text { (Calopteryx splendens) }\end{array}$ \\
\hline & Люткові (Lestidae) & Лютка зелена (Lestes viridis) \\
\hline & Стрілки (Coenagrionidae) & $\begin{array}{c}\text { Стрілка чудова } \\
\text { (Coenagrion puchellum) }\end{array}$ \\
\hline & Коромисла (Aeschnidae) & $\begin{array}{l}\text { Коромисло велике } \\
\text { (Aeschna grandis) }\end{array}$ \\
\hline \multirow[t]{2}{*}{ Одноденки (Ephemeroptera) } & \multirow[t]{2}{*}{$\begin{array}{c}\text { Справжні одноденки ( } \\
\text { Ephemeridae) }\end{array}$} & $\begin{array}{c}\text { Одноденка звичайна } \\
\text { (Ephemera vulgata) }\end{array}$ \\
\hline & & $\begin{array}{l}\text { Одноденка двокрила } \\
\text { (Ephemera dipterum) }\end{array}$ \\
\hline \multirow[t]{5}{*}{ Жуки (Caleoptera) } & \multirow[t]{2}{*}{$\begin{array}{c}\text { Водолюби } \\
\text { (Hydrophilidae) }\end{array}$} & $\begin{array}{c}\text { Водолюб великий (Hydrous } \\
\text { piceus) }\end{array}$ \\
\hline & & $\begin{array}{l}\text { Водолюб малий (Hydrous } \\
\text { caraboides) }\end{array}$ \\
\hline & \multirow[t]{2}{*}{$\begin{array}{c}\text { Плавунці } \\
\text { (Dyctiscidae) }\end{array}$} & $\begin{array}{c}\text { Полоскун борозенчастий } \\
\text { (Acilius sulcatus) }\end{array}$ \\
\hline & & $\begin{array}{c}\text { Плавунець облямований } \\
\text { (Ditiscus marginalis) }\end{array}$ \\
\hline & Вертячки (Gyrinidae) & $\begin{array}{c}\text { Вертячка денна (Gyrinus } \\
\text { marinus) }\end{array}$ \\
\hline \multirow[t]{3}{*}{$\begin{array}{l}\text { Напівтвердокрилі } \\
\text { (Hemiptera) }\end{array}$} & $\begin{array}{l}\text { Хребтоплави } \\
\text { (Notonectidae) }\end{array}$ & $\begin{array}{l}\text { Хребтоплав звичайний } \\
\text { (Notonecta glauca) }\end{array}$ \\
\hline & $\begin{array}{l}\text { Водяні скорпіони } \\
\text { (Nepidae) }\end{array}$ & $\begin{array}{l}\text { Скорпіон водяний (Nepa } \\
\text { cinerea) }\end{array}$ \\
\hline & Водомірки (Gerridae) & $\begin{array}{c}\text { Водомірка озерна (Gerris } \\
\text { lacustris) }\end{array}$ \\
\hline Двокрилі (Diptera) & Комарі (Culicidae) & $\begin{array}{l}\text { Комар звичайний (Culex } \\
\text { pipiens) }\end{array}$ \\
\hline
\end{tabular}


Отже, як бачимо із результатів спостереження на досліджуваній території зафіксовано 15 видів комах водної фауни, що належать до 5 рядів та 12 родин. Найбільш чисельними виявились представники ряду Бабки (4 види), Жуки, Напівтвердокрилі (по 3 види) і Одноденки та Двокрилі (по 1 виду).

\section{ЛIТЕРАТУРА}

1. Географічна енциклопедія України: В 3-х т./ Редкол.: О. М. Маринич (відп. ред.).К.: Українська енциклопедія ім.. М. П. Бажана, 1989-1993. Т.1. 480 с.

2. Геренчук. К. І. Природа Ровенської області. Л.: Вища школа, 1976. 192 с.

3. Гузій А.І. Фауна і населення хребетних Західного регіону України. Т.1. Розточчя. Київ. 1997.148 с.

4. Коротун І. М., Коротун Л. К. Географія Рівненської області. Природа. Населення. Господарство. Екологія./ Рівн. відділ укр. гоегр. тв-ва. Укр. екобезпеки в Рівн. обл. Рівне: Рівненський ін-т пед. кадрів, 1996. 274c.

5. Романенко В.Д. Гідробіологічні дослідження континентальних водойм України. Київ: Наук. думка. 2008. 324 с. 


\title{
ҚОС БАЙЛАНЫСТЫ КӨМІРСУТЕКТЕРДІ АЛУҒА АРНАЛҒАН КАТАЛИЗАТОРЛАР
}

\author{
Дарменбаева Ақмарал Сабетбекқызы \\ $\mathrm{PhD}$, «Химия және химиялық \\ технология» кафедрасы доцент м.а., \\ М.Х.Дулати атындағы Тараз өңірлік \\ университеті, Тараз, Қазақстан
}

\section{Даутова Нурзада Адыхамовна}

«Химия және химиялық технология» кафедрасы I курс магистранты,

М.Х.Дулати атындағы Тараз өңірлік университеті, Тараз, Қазақстан

Нұрзатхан Инабат «Химия және химиялық технология» кафедрасы IV курс студенті,

М.Х.Дулати атындағы Тараз өңірлік университеті, Тараз, Қазақстан

Қалдаман Дінмұхамед «Химия және химиялык технология» кафедрасы IV курс студенті, М.Х.Дулати атындағы Тараз өңірлік университеті, Тараз, Қазақстан

Көптеген авторлардың зерттеулері көрсеткендей, жоғары қанықпаған қосылыстарды гидрогенизациялау процестері отырғызылған металл катализаторларында азды-көпті сәтті жүзеге асырылуы мүмкін, ал d-металдары белсенді компонент ретінде қолданылады [1-2].

Қанықпаған қосылыстарды гидрогенизациялау үшін тірек никель катализаторларын құруға бағытталған бірқатар зерттеулер әртүрлі елдердің зерттеушілерінің үлкен тобымен жасалды [3-4]. Бұл катализаторлар, мысалы, Euro-Ni-1 $\left(25 \% \mathrm{Ni} / \mathrm{SiO}_{2}\right.$ құрамы) қаңқа катализаторларының белсенділігі мен басқа параметрлерінен кем болған жоқ. Бұл катализатор біртекті тұндыру әдісімен дайындалады, мұнда никельдің бір бөлігі тасымалдағышта гидросиликат түзеді. Процесс сулы ортада тоқтатылған микросфералық силикагельдегі мочевинаның қатысуымен жүреді [4]. Катализаторды дайындау кезінде $\mathrm{Ni}$ мен $\mathrm{SiO}_{2}$ арасындағы өзара күшті әрекеттесуге никель гидроксидімен салыстырғанда силикаттың қиын тотықсыздануымен байланысты. 
Катализатордың толық тотықсыздандыру үшін $400^{\circ} \mathrm{C}$-ден $600^{\circ} \mathrm{C}$-ге дейін жоғары температура қажет.

$[2,3]$ жұмыстардың авторлары никельдің меншікті бетін ұлғайту үшін оның құрамын 25\% -дан 4-10\%-ға дейін азайтты. Бұл үшін сіңіру әдісі және органикалық еріткіштердегі $\mathrm{SiO}_{2}$ және $\mathrm{Al}_{2} \mathrm{O}_{3}$ тасымалдағыштарының бетін өзгертетін металлорганикалық кешендері де қолданылды. Авторлардың пікірі бойынша кремний диоксидінің бетіне $\mathrm{NiCl}_{2}$ химиялық бекітілуі және оны кейіннен литий алюминогидридімен тотықсыздандыру жұмсақ жағдайда қанықпаған көмірсутектерді гидрлеудің тиімді катализаторын алуға мүмкіндік береді. Сіңірілетін аналогтан оның басты айрықша ерекшелігі - белсенді фазаның тасымалдаушының бетімен берік байланысуы. Жұмыстарда $\mathrm{NiCl}_{2} / \mathrm{SiO}_{2}$ $+\mathrm{LiAlH}_{4}$ катализаторының белсенді фазасының пайда болу процесі зерттеліп, оның құрамы мен құрылымының каталитикалық қасиеттерге әсері зерттелді. Al: $\mathrm{Ni}=1-3$ қатынасы аралығында $\mathrm{Ni}^{2+}$ азаяды және $\mathrm{Ni}$ атомдары мен никель гидрид топтарының диффузиясы нәтижесінде белсенді фазаның микрокристалиттері түзіледі. Белсенді фазада алюминий гидриді болуы мүмкін.

Түзілген микрокристалиттердің тасымалдағыш бетінде тұрақтануы өзіндік «якорь» рөлін атқаратын иондық топтардың қатысуымен жүреді. Олар сондайақ ұсақ кеуектерде тұрақтана алады. Al:Ni арақатынасының одан әрі өсуі $\mathrm{Ni}$ қалпына келтіру дәрежесінің жоғарылауына және микрокристалиттер құрамындағы алюминий гидридті топтары бар қосылыстар концентрациясының артуына әкеледі. Al: Ni = 5-8 коэффициенті аралығында қалпына келтірудің шекті дәрежесіне қол жеткізіледі. Тотықсызданбаған $\mathrm{Ni}^{2+}$ не белсенді фазаның микрокристалиттерімен блокталады немесе тотықсыздану молекулалары жетпейтін жерлерде орналасады.

Осылайша, белсенді комплексті тасымалдағышқа отырғызу немесе оны белсенділігі төмен гетерогенді катализаторлар бетінде синтездеу арқылы органометаллдық жүйелерді жобалау тәжірибе үшін маңызды гидрогенизация процестерінде металлорганикалық катализаторларды қолдануға мүмкіндік берді. Алайда селективті гидрлеу реакцияларында ауыспалы металдарға негізделген дәстүрлі катализаторлар қолданылады, дегенмен олар қажетті селективтілікті қамтамасыз етеді, бірақ олардағы белсенді металдардың мөлшері едәуір жоғары. Сонымен қатар, мұндай катализаторлар көбінесе мақсатты өнімнің сапасын төмендететін біртекті модификаторларды қолдануды талап етеді. Мұндай жүйелерде процесті жүргізу одан да ауыр жағдайларды қажет етеді (жоғары қысым мен температура).

Бұл жұмыста полиэтиленгликоль түрлендірілген бейорганикалық тасымалдағышқа отырғызылған металл нанобөлшектері адсорбция әдісімен дайындалды [5].

Ұнтақтардың морфологиясын және беттің микроқұрылымын зерттеу үшін сканерлеу электронды микроскопиясы (СЭМ) және рентгендік спектрлік микроанализ қолданылды. Микроқұрылым JSM-7500F сканерлейтін электронды микроскопы мен INCA Оксфорд рентгендік микроанализаторы көмегімен зерттелді. Үлгілердің жалпы (орташа) құрамын анықтау және олардың бетіне 
элементтердің концентрациясының таралуын зерттеу, сондай-ақ біртектіліктің құрамын анықтау үшін рентгендік спектрлік микроанализ жүргізілді.

Металл құрамдас нанобөлшектердің мөлшерін, морфологиясын және кристалдық құрылымын зерттеу үшін өзара толықтыратын әдістерді қолданатын кешенді тәсіл, оларды қолдану синтезделген үлгілерді жан-жақты сипаттауға мүмкіндік берді. СЭМ микрофотографияларына сәйкес, кешендер ірі кеуекті материал болып табылады. Алынған кешендердің кеуектілігі жоғары (1-сурет, а, б) және субмикронды тесіктер түзіледі, бұл октаэдрлік никель кешенінің ПЭГмен құрылымдық ерекшеліктерімен байланысты.

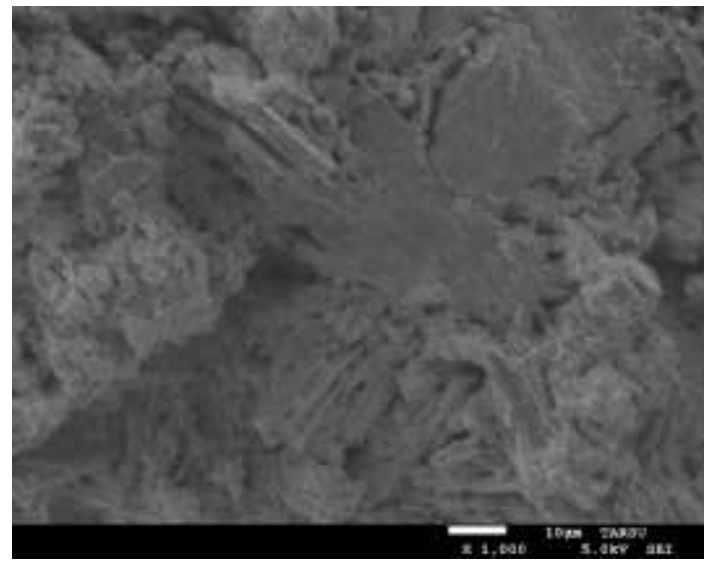

a)

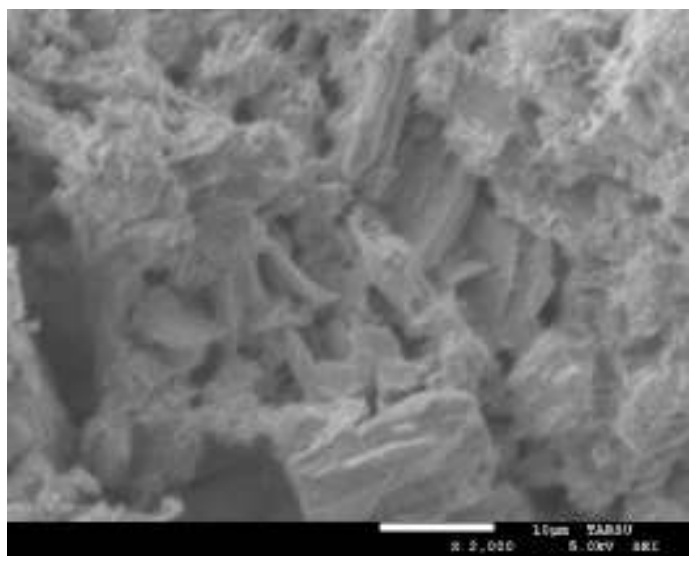

б)

1-сурет - Әр түрлі рұқсаттағы Ni-Mo-PEG / Al $(\mathrm{OH})_{3}$ микрофотографиялары: $\mathrm{a}-1000 ; \sigma-2000$

Рентгендік микроанализатор мен сканерлі электронды микроскоптың көмегімен алюминий гидроксидіне отырғызылған полимер-метал катализаторларының құрылымы зерттелді.

Әр түрлі тотығу дәрежесіндегі молибденнің болуы рентгендік спектрлерде көрсетілген (2-сурет).

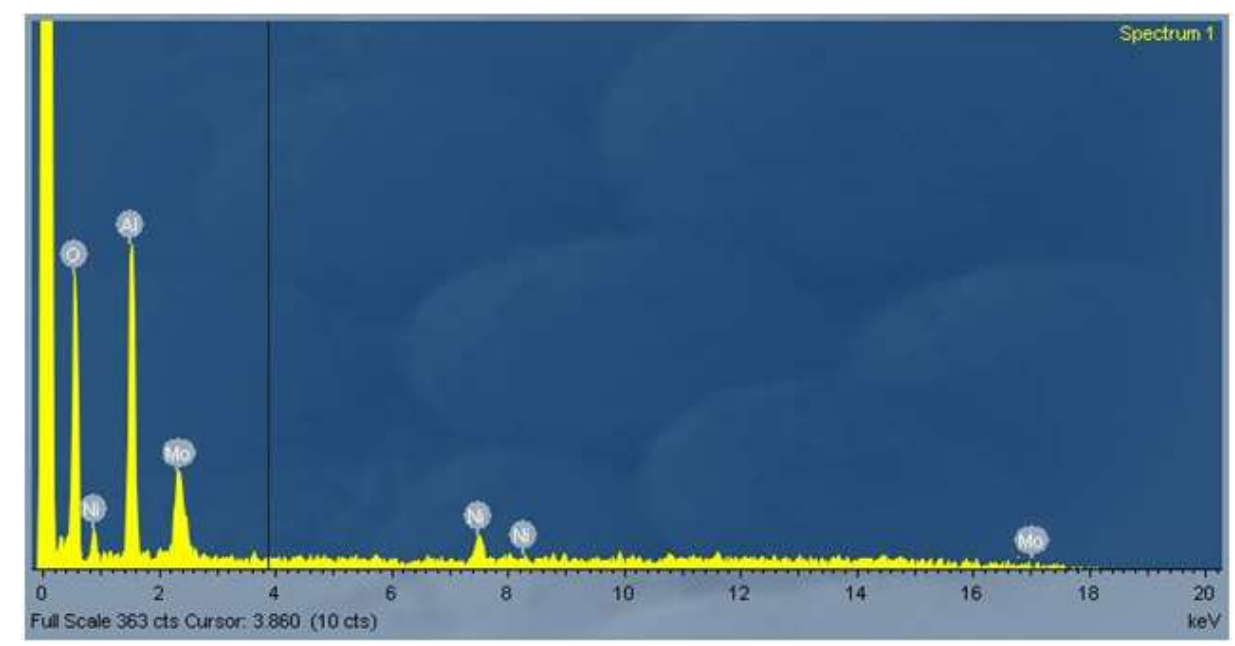

2-сурет - Ni-Mo-PEG / Al $(\mathrm{OH})_{3}$ рентгендік спектрі 
Осылайша, полимер тұрақтанған металл нанобөлшектері алынды және оның қасиеттері зерттелді. Бұл жерде полимердің қызметі тасымалдаушының бетіне отырғызылған металл нанобөлшектерін қалыптастыру және бекіту болып табылады.

\section{Қолданылған әдебиеттер}

1. Xu Q., Smith C.M., Blackson J., Salaita G., Dunmore G., Crozier P.A. TEM study on catalyst deactivation during selective acetylene hydrogenation // Microsc. Microanal. 2005. - V.11 (Suppl.2). - P.1576-1580.

2. Кочубей Д. И., Старцев А. Н. Структура активного компонента сульфидных катализаторов гидрообессеривания // Катализ и катализаторы: Фундаментальные исследования Института катализа им. Г. К. Борескова. Новосибирск: Изд-во Ин-та катал. СО РАН. 1998, с. 137-138.

3. Hamilton C.A., Jackson S. D., Kelly G. J., Spence R., Bruin D. Competitive reactions in alkyne hydrogenation // Appl. Catal. A: General. 2002. - Vol.237. - № 2. - P.201-209.

4. Bergbreiter D.E., Kimmel T., Caraway J.W. Modification of Substrate Reactivity Using Soluble Polymeric Supports // Tetrah. Let. 1995. - Vol. 36, -№ 27. P.4757-4760.

5. Жармагамбетова А.К., Заманбекова А.Т., Мухамеджанова С.Г., Тумабаев Н.Ж. Гидрогенизация 3,7,11,15-тетраметилгексадецин-1-ола-3 на нанесенных полимер-палладиевых катализаторах // Известия НАН РК, Серия химическая. 2009. - №4. - C.61-65. 


\title{
ВПЛИВ РОЗВИТКУ ДИЗАЙНУ В СУЧАСНІЙ УКРАЇНІ НА СОЦІОКУЛЬТУРНІ ТРАНСФОРМАЦЇ̈ СУСПІЛЬСТВА
}

\author{
Зайцева Вероніка Іванівна \\ к. н., доцент кафедри \\ Образотворчого мистецтва \\ Інституту мистецтв \\ Київського університету \\ ім. Бориса Грінченка \\ м. Київ, Україна
}

Дослідження в галузі розвитку дизайну в сучасній Україні є актуальним в умовах інтеграції нашої країни у світове культурне поле. Слід зауважити, що сучасний дизайн охоплює широку сферу культурного та громадського життя українців і може сприяти розвитку прогресивних явищ у суспільстві. Адже дизайн буквально можна визначити як переосмислення, повернення до сенсів, пошук нових значень. Саме дизайн $\epsilon$ універсальним засобом спілкування на рівні почуттів і смислів, одна 3 головних цілей якого - гармонізація, і навіть формування сприйняття світу, створення нових образів або переосмислення сутності звичних речей.

Ідеологія сучасного дизайну відповідає глибинним соціокультурним трансформаціям, що відбуваються у суспільстві. А також - сутнісним змінам сприйняття цінності знання як безперервного самовдосконалення протягом життя. Внаслідок цього неабиякого значення набуває вироблення стратегії $\mathrm{i}$ тактики брендингової політики. Серед викликів найбільш відчутними є: жорстка конкуренція на споживацькому ринку, постійна модернізація технологій, вимога відповідності європейським стандартам розвитку. Вагомим фактором реалізації будь-якої продукції та відповіді на можливі виклики є брендинг - сукупність інструментів просування іміджу у сфері суспільних комунікацій у конкурентному середовищі та на ринку споживачів.

Характер, історія, неповторність, привабливість настрій - це і $є$ цінність бренду для споживачів. Важливою $\epsilon$ інформація, яка стоїть за брендом, наповнюючи його змістом. «Ідея повинна бути незвичайною і унікальною, але, в той же час, простою та зрозумілою - в цьому і полягає складність її розробки» зазначає в навчальному посібнику з маркетингу О. Азарян [2].

«Для аналізу ситуації та визначення стратегії використовуються різні види маркетингових досліджень, спрямовані на те, щоб визначити переваги, побажання, потреби та сприйняття цільової аудиторії, оцінити сильні і слабкі сторони конкурентів, визначити нішу продукту на ринку тощо. Цей дуже 
важливий етап розробки бренду створює основу для всієї подальшої роботи над образом продукту» - досліджує нову концепцію брендингу Д. Аакер [1].

Вагомим для споживацького ринку $\epsilon$ розробка послання бренду, адресованого споживачеві. Саме завдяки цьому покупці вибирають той чи інший товар з ряду продуктів-конкурентів. Вдале позиціонування - це лаконічне i зрозуміле, але в той же час максимально розкриваюче переваги бренду послання.

Дизайн доносить інформацію і має своє емоційне забарвлення. Це допомагає переосмисленню суті звичних речей, за допомогою носіїв зовнішньої реклами і комунікацій, що сприймаються на емоційному рівні.

«Найчастіше саме дизайн додає бренду емоційних переваг. Робить продукт або послугу більш привабливою і затребуваною... Дизайн дозволяє не тільки ідентифікувати продукт, а й диференціювати його по відношенню до конкурентів. Він стає помітним, навіть не володіючи раціональною перевагою» - наголошує Дж. Барлоу [4].

Важливо зазначити, що в епоху глобалізації, коли глобальні корпорації та бренди стирають національні та культурні границі між державами, як ніколи виникає потреба в тому, щоб мати свій власний, неповторний образ. I для країн ця задача $є$ не менш важливою ніж для компаній. Репутації країн, регіонів і міст, як правило, створюються значно складніше ніж імідж корпорацій, маючи глибокий вплив на долі людей, вони можуть мати більш серйозні наслідки.

Державний брендинг - це один з напрямків маркетингових технологій «PR». Для створення бренду країни необхідно розуміти ऑii національну ідею, інтелектуальну власність, комплекс уявлень та асоціацій, які виникають, коли ми чуємо назву тої, чи іншої країни. Національний брендинг країни, це процес узгодженних дій: інновацій і комунікацій, необхідних для реалізації стратегії конкурентної ідентичності.

Сприйняття культурної спадщини, національні традиції, рівень освіти та люди $-\epsilon$ також важливим виміром іміджу країни. Позиціонування держави на світовій арені, створення бренду держави та вміле управління ним, або так званий брендинг країни, в сьогоднішніх реаліях набуває все більшої ваги.

В цілому варто зазначити, що брендинг - це вагомий інструмент для сприяння збільшенню кількості «контактів» i, як наслідок, прихильність покупців до певної торгової марки та просуванню української продукції на світовому ринку. Оцінка успішності комерційного дизайну, в першу чергу, повинна виходити із поставленого перед ним завдання, охоплюючи широку сферу культурного та громадського життя, сучасний брендинг може сприяти розвитку прогресивних явищ у суспільстві.

\section{Список літератури:}

1. Аакер Д. Бренд-лидерство: новая концепция брендинга. М. : Издательский дом Гребенникова, 2003. 380 с.

2. Азарян О. М., Баширов I. Х., Воробйов Б. 3. [та ін.] за ред. О. М. Азаряна. Маркетинг: принципи і функції: навч. посібник для вищих навч. Закладів - 3-те вид. перероб. і доп. Х. : Студцентр, 2002. 320 с.

3. Бажеріна К. В. Управління формуванням та використанням торгових марок підприємств: автореф. дис. канд. екон. наук. Київ, 2004. 
4. Барлоу Дж. Якщо за брендом не доглядати, він просто загине... [Електронний ресурс] - Режим доступу: http://www.management.com.ua/ events/ barlow.html

5. Белешев С. Д. Математико-статистические методы экспертных оценок. [2 изд.]. М. : Статистика, 1980. 263 с.

6. Бельских И. Е. Корпоративные коммуникации промышленного предприятия: в поисках эффективной национальной стратегии // Маркетинг в России и за рубежом. 2006. №5. С. 24-31. 


\title{
МІСТО ЯК ЦЕНТР СОЦІОКУЛЬТУРНОГО РОЗВИТКУ: ЦИВІЛІЗАЦІЙНИЙ ПІДХІД
}

\author{
Олійник Оксана Миколаївна \\ кандидат культурології, \\ старший викладач кафедри готельно-ресторанного бізнесу, \\ ПВНЗ «Київський університет культури»
}

У XVII ст. англійський дослідник Т. Херберт для характеристики столиць держав запропонував використовувати термін «мегаполіс» (суперагломерація) (3 грецьк. megas - великий та polis - місто).

На початку XX століття англійський соціолог і містобудівник П. Геддес у праці «Еволюція міст» (1915 р.), зважаючи на багатолюдність і масовість людських контактів у великих містах, запропонував використовувати поняття «світове місто» та вивів його характерні ознаки. Дослідник включив до відповідного переліку такі відомі мегаполіси, як Лондон, Париж, Берлін, Відень, Нью-Йорк, Бостон, Чикаго і Філадельфія [5].

Досліджуючи найбільш яскраві міста Нью-Йорк, Лондон, Токіо, американський соціолог С. Сассен ввів поняття «глобальне місто», підкресливши їх інтернаціоналізовану економіку та соціальну структуру [3, с. $15]$.

Термін «мегаполіс» у сучасному розумінні закріпив у гуманітарних науках у 30-х роках XX ст. американський історик, соціолог, теоретик містобудування та урбанізму Л. Мамфорд. Він наголошує на масштабності мегаполіса, в якому вбачає зародження окремого соціокультурного феномена. Також Л. Мамфорд у першій половині XX століття (зокрема, у працях «Культура міст» [1] та «Місто в історії» [2]) вводить поняття «палеотехнічні міста», зважуючи на трансформацію міст під впливом цивілізаційних процесів. Останнє фактично призводить до об'єднання техніко-технологічних можливостей і соціокультурних норм часто за рахунок нівелювання значення останніх. Це перетворює міста, на думку дослідника, на стратегічні центри, оборонні укріплення, комунікаційні вузли, в яких етично-моральні норми і правила поведінки почасти відходять на другий план. Л. Мамфорд наголошує на відмінностях між епохою найперших міст i сучасним періодом: «Технічний прогрес вже не керований, а в своєму гуманістичному розвитку ми відстаємо на значно більшу відстань, ніж просуваємося вперед. Ми живемо практично у Всесвіті, що вибухає, породженому нашими механічними уявленнями про його життя. Химери нашого раціоналізму жахливі, ми втрачаємо мету нашого існування» [2].

Підтримують зазначені вище візії і дослідження американського економіста Дж. Фрідмана, зокрема у праці «Гіпотеза виникнення глобальних міст» [4]. Вчений обгрунтовує об'єктивність становлення системи світових міст, пов'язуючи процес стрімкої світової урбанізації 3 розвитком глобальної економіки. Гіпотеза виникнення світових міст Дж. Фрідмана, на думку дослідників, має чіткий політекономічний характер та стосується просторової 
організації нового міжнародного поділу праці, який актуалізувався наприкінці 70-х років XX століття.

Британський дослідник, урбаніст-футуролог П. Холл у праці «Світові міста» однойменним терміном позначає простір міст, які посідають вагоме місце у світовій політиці, виробництві, культурі та мистецтвах. Він називає світові міста місцями, в яких відбувається досить непропорційна частина найбільш важливих світових справ. Тобто такі міста є центрами концентрації: політичної влади національного і світового рівня, урядових і різних громадських організацій, торгових спілок, підприємницьких федерацій тощо; міжнародної торгівлі й систем зв'язку; банківських, фінансових та ін. послуг; транспортних потоків i комунікацій, включаючи дороги, міжнародні повітряні та морські шляхи; інформацію та ЗМК; культури та мистецтв. До таких міст П. Холл відносить Лондон, Париж, Москву, Нью-Йорк, Токіо, урбанізовані ареали Рандстад і РейнPyp [6].

Отже, як зрозуміло з такого переліку, світове місто може виникнути на будьякому континенті та у будь-якій країні. Водночас саме такі міста задають напрями не лише майбутнього розвитку міст, а й слугують маркером майбутнього «вигляду» цивілізації.

Загалом теоретики обгрунтовують об’ єктивність і незворотність становлення системи глобальних міст та пов'язують їх виникнення із глобалізацією та становленням глобальної економіки, зокрема процесами транснаціоналізації та інтернаціоналізації капіталу, бурхливим розвитком інформаційних технологій та значними потоками постійного переміщення людей.

Нині без співвіднесеності з найважливішими світовими містами сучасному місту важко розвивати свою інфраструктуру, яка повинна відповідати дедалі зростаючим потребам та мінливим інтересам людини. Адже світові міста стали центрами соціокультурного розвитку за рахунок концентрації фахівців найбільш високої професійної кваліфікації у галузі економіки, бізнесу, юриспруденції, медицини, вищої освіти, науки тощо, а також осередками мистецтв, культури, дозвілля, туризму, комунікаційними центрами накопичення і поширення різної інформації.
1. Мамфорд
Л. Город
B
истории.

URL: http://www.ukrainica.org.ua/ukr/projects/misto_i_chas/993-993.html
2. Мамфорд
Л. Культура
городов.
Нью-Йорк,
1938.

URL: http://bookscience.ru/social/territory/l-memford-o-kul-ture-gorodov.html

3. Сассен С. Глобальный город: введение понятия. Глобальный город:

теория и реальность / под ред. Н. А. Слуки. Москва, 2007. С. 14-16.

4. Friedmann J. The World City Hypothesis. Development and Change. 1986. № 4. P. $12-50$.

5. Geddes P. Cities in evolution. London, 1915. 409 p.

6. Hall P. The World Cities. London, 1966. 271 p. 


\section{ПЕРЕДУМОВИ ВИНИКНЕННЯ КОМУНАЛЬНИХ КВАРТИР У КИЕВІ}

\section{Павленко Вікторія \\ магістр}

Київський національний університет імені Тараса Шевченка

Комунальна квартира - тип житлового приміщення квартирного типу, у якому проживають одразу декілька сімей. Зазвичай одна сім'я у комунальній квартирі займала одну, набагато рідше дві або більше кімнат. У комунальних квартирах виділялися приватні приміщення - особисті житлові кімнати. Окрім цього, було виокремлено приміщення «загального користування» - як правило, такими приміщеннями були кухня, ванна кімната, туалет, передпокій, коридор.

Масова поява комунальних квартир у великих містах Російської імперії, до складу якої входили українські землі до 1917-го, а пізніше республік Радянського Союзу, розпочалася під час революції 1917 року. Підкреслимо, що на території тогочасної України та зокрема й у Києві, такий тип житла почав поширюватися після 1921 року (після україно-більшовицької війни) та входження території України до складу СРСР як однієї з республік.

За словами історика I. Утьохіна, поява комунальних квартир стала результатом житлової політики більшовиків, реалізація якої передбачала перерозподіл житлової площі [4].

У свою чергу, історик-науковець М. Борисенко слушно зауважує, що квартирне питання для більшовицької (радянської) влади мало ще й ідеологічний характер. Надання житла працівникам пролетаріату, які приїжджали до міста 3 сіл - було реальною демонстрацією змін, які буцімто міг «подарувати» новий режим. Таким чином, комунальна квартира ставала інструментом заохочення пролетаріїв до виконання плану по «підкоренню» і «довірі» до нової влади [1].

Окрім цього, об'єктивні процеси у суспільстві поч.. XX ст, зокрема розвиток промисловості, вимагали збільшення кількості робочих рук, а відтак і населення міст.

Окреслимо детальніше урбаністичні процеси, що відбулися в Україні у 20-х роках, що призвели до збільшення кількості міського населення. Після революції 1917 року та війни міста спорожніли. Однак, на початку 20-х років урбаністичні процеси знову посилюються. Історик М. Борисенко пояснює збільшення населення в містах у цей період стрімким розвитком промислового виробництва [1].

Студіювання наукової літератури засвідчило, що урбаністичні процеси стимулювали притік необхідної робочої сили в міста 3-поміж сільського населення. Зокрема питома вага сільськогосподарської групи населення в Києві на той час складала 42,9 \% [1]. Безумовно, селяни, що переїздили до міста на роботу, потребували житла. Вирішенням житлового питання, яке гостро постало в той період, стало перепрофілювання приватних прибуткових будинків на комунальне житло. Слід зауважити, що такі зміни докорінно змінили портрет 
мешканців окресленого житла. За словами історика та дослідника історії Києва Д. Малакова, у прибуткових будинках Києва проживала, в основному, родини представників інтелігенції - юристів, лікарів, чиновників, викладачів, учителів, інженерів, журналістів тощо [3]. Виникнення комунальних квартир на підвалинах прибуткових будинків докорінно змінило прошаркову градацію мешканців цього житла, що значно вплинуло на організацію подальшого співжиття та вибудову сусідський відносин у комунальних квартирах.

Окрім урбаністичних процесів, що впливали на виникнення комунальних квартир, важливе місце відіграли й політичні процеси у тогочасному суспільстві. Дослідник М. Борисенко слушно зауважує, що в період появи комунальних квартир у суспільстві існувала диктатура пролетаріату. Відповідно до такої політики, представники пролетаріату займали панівне становище в суспільстві. Відповідно їм надавалися й неабиякі житлові преференції - для працівників заводу або фабрики вартість комунальних послуг була втричі меншою, ніж для працівників культури, освітньої галузі тощо.

Дослідники 20-х років XX століття зазначають, що процес перерозподілу житла у місті, зокрема Києві, був дещо хаотичним. Відповідальними за так званий квартирний переділ приміщень були групи людей, які складалися переважно з представників пануючого на той час пролетаріату, які очевидно не мали ані знань, ані досвіду для здійснення якісного менеджменту в житловокомунальному господарстві міста. Щодо процесу перерозподілу житлової площі науковець М. Борисенко зауважує, що створені групи реквізували не лише житлові приміщення, а й предмети побуту: меблі, столові прибори, коштовності, постільну білизну тощо. Проте, процес розподілу не знімав питання управління житловим фондом міста. Функції, які раніше виконували власники квартир, по догляду, ремонту, оплаті житлових приміщень мав хтось виконувати. Так, для забезпечення функціонування комунальних квартир, наприкінці 20-х років 3'являються спеціально створені житло-орендні кооперації, які займалися збором орендної плати, доглядом за станом будівлі тощо.

Створення комунальних квартир певною мірою сприяло вирішенню житлової кризи в містах. Так, начальник Секретаріату відділу обліку праці Г. Полляк зазначав, що до 1922 року практично кожна робітнича родина СРСР мала хоча б одну кімнату для проживання в місті.

Додамо, що «окремі» квартири в житловому фонді таки будувалися, однак передбачалися вони для окремого прошарку населення СРСР - партійної верхівки, чиновників вищого рангу, держслужбовців, певних представників культурної сфери (кіноактори, режисери, співаки); отримати таку квартиру можна було за лояльність чи за визначні заслуги перед країною (перевиконання робочого плану тощо).

Окреслимо історію комунальних квартир у 50-ті роки XX століття післявоєнний період. За дослідженнями І. Утьохіна, під час Другої Світової війни та в перші роки після ії закінчення населення комунальних квартир змінювалося буквально раз у два-три місяці. Кількість жителів у післявоєнний період, за словами історика, збільшилась у комуналках практично в два рази. 
Така статистика пояснюється, звичайно, не збільшенням кількості населення чи масовими міграціями, а зменшенням кількості житлових приміщень у містах як наслідок воєнних дій на їх територіях. Друга Світова війна стала причиною повторного «ущільнення» житла.

Якщо у період 20-х років XX століття комунальні квартири були інструментом створення нового типу суспільства - соціалістичного й демонструвало перерозподіл житла як наділення рівними правами усіх жителів цього суспільства, то у 50-х роках збільшення кількості комунальних квартир, як наслідок чергового «ущільнення», стали вимушеним заходом. У перші роки післявоєнного періоду перед керівництвом СРСР, у першу чергу, постала проблема відновлення та відбудови промислово важливих об'єктів, серед яких: великі заводи, фабрики, залізні дороги тощо. Проблему житла почали вирішувати лише в другій половині 50 -х років XX століття. Отже, в історії комунальних квартир післявоєнний період став новим етапом житлового перерозподілу, коли пліч-о-пліч проживали ветерани війни, працівники культури, письменники, водії та інші.

Відбудова підприємств, інфраструктури міст потребувала рук, якої так бракувало, відтак у післявоєнний час спостерігається нова хвиля міграції сільського населення в міста. За свідченнями М. Борисенка, комунальні квартири ставали для багатьох емігрантів з сіл та невеликих містечок першим досвідом міського життя. Зокрема, можна говорити про підвищення культури гігієни, догляду за одягом тощо [2].

Отже, комунальні квартири почали з'являтися в Києві у 20-х роках XX століття як наслідок політики «ущільнення», яка розпочалася після приходу до влади більшовиків. Цей процес носив як ідеологічний, так і економічний характер і певною мірою вирішив житлову кризу, що існувала у той період у містах.

\section{Лiтература:}

1. Борисенко М. Урбаністичні процеси в українській літературі 20-х років. Етнічна історія народів Європи. 1999. Вип. 1. С. 3-5. URL: http://nbuv.gov.ua/UJRN/eine_1999_1_3 (дата звернення: 25.04.2021)

2. Комуналки i квартирний переділ у радянській Україні URL: https://www.youtube.com/watch? $\mathrm{v}=\mathrm{u} 49 \mathrm{i} 59 \mathrm{HBMwo} \& \mathrm{t}=556 \mathrm{~s} \& \mathrm{ab}$ (дата звернення: 25.04.2021)

3. Малаков Д. Прибуткові будинки Києва. Київ : «Кий», 2009, 384 с.

4. Утехин И. В. Быт больших коммунальных квартир г. Ленинграда (СанктПетербурга) в 1970-1990-е гг.: Стереотипы повседневного поведения : диссертация ... кандидата исторических наук : 07.00.07. Санкт-Петербург, 2001. 309 c. 


\title{
ЗНАЧЕННЯ ДІЯЛЬНОСТІ МЕТОДИЧНОГО ОБ'ЄДНАННЯ ХОРМЕЙТЕРІВ ДИТЯЧИХ І ЮНАЦЬКИХ КОЛЕКТИВІВ «ТОНІКА»
}

\author{
Щербій Світлана Олександрівна \\ аспірант Навчально-наукового інституту мистецтв \\ ДВНЗ «Прикарпатський національний університет \\ імені Василя Стефаника» (Івано-Франківськ)
}

Проблема функціонування хорового мистецтва в Україні хвилювала всіх поціновувачів цього виду діяльності. А дитяче хорове виконавство, як один із важливих віх, чи $\epsilon$ не найголовнішим способом, для забезпечення майбутнього співочої культури. У 50-роках минулого століття стався перелом у хоровій творчості, коли масова пісня, виконуючи завдання більше для гуртування людей, ніж для виховання художнього смаку. В наслідок естетичної кризи зазвичай виникає переосмислення та пошук рішень шляхом різних методичних об'єднань. Всесоюзний клуб хормейстерів дитячих та юнацьких колективів «Тоніка» виник в наслідок потреб удосконалення хорового виконавства та дав поштовх для розвитку класичних традицій дитячого хорового співу.

Очолила це об'єднання в 1978 році при Київському відділенні Національної Всеукраїнської музичної спілки талановита особистість, видатний дитячий хормейстер, педагог, музично - громадська діячка, заслужений діяч мистецтв України, професор Елеонора Виноградова. Вона засновник та художній керівник дитячих хорів «Дзвіночок», «Любисток», «Київський Кантус». Керувала хором хлопчиків та юнаків Київської середньої спеціалізованої музичної школи-інтернат імені М. В. Лисенка. Елеонора Олексіївна мала вагомий вплив на становлення українського дитячого хорового співу. Ї̈і активна музично-громадська діяльність яскраво проявилася після десятирічної успішної творчої діяльності та численних перемог на конкурсах та фестивалях 3 капелою хлопчиків та юнаків «Дзвіночок». Елеонора Олексіївна прагнула ділитися досвідом та активізувала відродження дитячого хорового виконання, відстоюючи високий професіоналізм. Вона була головою художньої ради по естетичному вихованню дітей і юнацтва при музичній спілці, членом спілки видавництва «Музична Україна», а також членом ради дискусійного клубу хормейстерів і композиторів «Камертон» при Всесоюзнім домі композиторів і Московській обласній хоровій спілці при головуванні відомого композитора та хорового диригента Г. Струве. Про українську «Тоніку» він відгукувався, що «народилась рідна сестра «Камертона».

При методичному об'єднанні «Тоніка» проводилися семінари, майстеркласи, проходили дискусії на різноманітні теми - від особливостей репертуарної політики до проблем музичного виховання школярів. Головними аспектами творчої діяльності клубу хормейстерів були питання розвитку хорів хлопчиків, вивчення музичної грамоти і робота над інтонацією, організаційна та виховна робота в колективі, проводилися відкриті уроки видатних педагогів, відбувалась 
активна співпраця з композиторами щодо написання відповідного репертуару для дитячих хорів. Велика роль надавалась розвитку насамперед слухових навичок дітей, що сприяло б збагаченню художніх смаків підростаючого покоління. Кожне засідання було присвячене конкретному питанню, до обговорення якого запрошувалися провідні фахівці. Здійснювалася концертновиконавська діяльність для збереження та розвитку співочих традицій України дитячих та хорових колективів. Розроблялась стратегія розвитку хорового мистецтва пов’язаних з підготовкою кадрів, де було важливо зацікавити співаків та керівників хорового виконавства залучаючи до участі у різних фестивалях та конкурсах. Але найцікавішим був практичний показ роботи 3 дитячими хорами. Діапазон тут вельми широкий: від перших кроків в світ музики до створення великих концертних програм. I так виник цикл філармонійних концертів «Співають дитячі хори». Активними учасниками концертних заходів були такі дитячі хорові колективи, як хор хлопчиків та юнаків «Дзвіночок» (Е. Виноградова), Великий дитячий хор Українського телебачення та радіо (Т. Копилова), «Зірниця» (П. Мережин), «Сяйво» (С.Голуб), «Веснівка» (Ж.Сосновська), хор хлопчиків та юнаків Державної академічної чоловічої хорової капели України ім. Л. Ревуцького (А. Зайцева), «Елегія» (А. Васильєва), «Унісон» (Н. Нікітіна), «Вогник» (С. Степаненко), «Благовіст» (О. Маєва), хор хлопчиків та юнаків Мукачівської хорової школи (В. Волонтир) та інші учасники. Особливою подією була участь гостей зарубіжжя таких, як хор хлопчиків середньої спеціальної музичної школи імені Е. Дарзіня міста Риги (Я. Еренштрейс) та ін.

На засіданнях «Тоніки» звучало багато цікавої музики, деякі з них звучали вперше. Щоб долучити до досвіду роботи клубу найбільш широке коло художніх керівників хорових колективів, було вирішено найкраще 3 прослуханого періодично видавати. Е. Виноградовою було упорядковано п’ять випусків репертуарних збірників під назвою «Свято хору».

В 1991-му це мистецьке об'єднання припинило свою роботу і відновило концерти й відкриті уроки лише через десятиліття.

У 2001 році «Тоніка» відродилася новими мистецькими заходами. Від 2004 - головою клубу хормейстерів дитячих хор. колективів і композиторів «Тоніка» стала Тетяна Копилова, хоровий диригент, педагог, музичногромадська діячка. художній керівник і головний диригент Великого дитячого хору Радіомовної компанії України, з яким здійснила багато фондових записів (часто вперше) як великих вокально-симфонічних форм української та світової музичної класики, так і хорових обробок українських народних пісень.

Новий етап творчості «Тоніки» розпочався 32017 року. Хорове товариство імені Миколи Леонтовича Національної музичної спілки на чолі 3 О. Тарасенком сприяло відновленню діяльності клубу. Тоді засідання відвідали 85 хормейстерів-керівників колективів музичних шкіл, студентських хорів позашкільної освіти. Новообраним керівником став заслужений артист України, художній керівник народної хорової капели «Дзвіночок» Київського Палацу дітей та юнацтва Р. Толмачов. Він окреслив нові шляхи розвитку дитячих та юнацьких колективів у сучасних соціально-економічних умовах, запропонував 
принципи репертуарної політики, підкреслив значущість патріотичного виховання на базі уважного вивчення музично-культурних традицій. Рубен Владиславович висунув пропозицію сформувати на базі «Тоніки» всеукраїнську платформу для міжнародної промоції української хорової культури.

Однією з останніх значущих культурних подій була дитяча літня хорова асамблея у 2020 році. Це був вісімнадцятиденний хоровий табір, під час якого 250 учасників хорових колективів працювали під керівництвом найкращих спеціалістів у галузі хорового та сольного співу, хореографії, соціальних дисциплін. Готували спільну програму 3 творів вітчизняних та зарубіжних композиторів та провели великий фінальний концерт із запрошенням відомих українських виконавців. Цей громадський проект надав можливість вдосконалити свої виконавські та соціальні навички. Діти та їх керівники набули новий досвід у професійній галузі та соціалізації особистості.

Отже, діяльність клубу хормейстерів дитячих та юнацьких хорових колективів «Тоніка» володіючи історією, очолюваної видатними хормейстерами Елеонорою Виноградовою і Тетяною Копиловою, налічує багато славетних сторінок у галузі хорової творчості. Його творчість відіграла значну роль у розвитку дитячого хорового виконавства в Україні. Нова віха цього творчого об'єднання 3 основними напрямками продовжує активізувати розвиток величного мистецтва дитячого хорового співу.
1. Берденникова
К. Тоніка
означає центр. https://zn.ua/ukr/ART/tonika_oznachae_tsentr.html [дата доступу 21.04.2021]
2. Національна
Всеукраїнська
Музична
Спілка.
Сайт https://muzunion.com/?page_id=299 [дата доступу 21.04.2021]

3. Виткалов В. УКРӒ̈НСЬКИЙ МИТЕЦЬ У ПРОСТОР СУЧАСНОЇ КУЛЬТУРИ Часопис Національної музичної академії України імені П. І. Чайковського. 2020. № 4 (49) ст. 46-65. 


\section{MODERN METHODS OF RECRUITMENT AS AN ELEMENT OF ENSURING THE ECONOMIC SECURITY OF THE ENTERPRISE}

\section{Hobela Volodymyr}

Ph.D. in Economics

Senior lecturer, Management department, Lviv State University of Internal Affairs

An important place for each manager is occupied by the recruitment of employees - the process of finding and attracting people from whom candidates will be selected for a particular vacancy. While recruiting employees, it is necessary to take into account the size of the enterprise. Therefore, the manager must solve current problems, making the following decisions:

$>$ the total number of employees required for the operation of the enterprise;

$>$ place and methods of selection and selection of potential employees; what professional skills potential employees should have;

$>$ choose the method of disseminating information on the implementation of recruitment for vacant positions;

$>$ to form a system of indicators for assessing the effectiveness of work on the selection of employees.

Applicants for vacant positions can not only be hired but also hired temporarily. The experience of developed countries suggests that temporary employment has long been used in practice. To solve urgent tasks, organizations invite not only technical staff but also highly paid employees, such as accountants or lawyers.

Candidates for the vacant position can be selected on their own with the help of the media. Namely: press, radio, television. One of the most promising channels for finding specialists is the Internet search. After all, currently, there are specialized and personal sites of various companies. Recruitment of candidates through employment exchanges is free, but this selection can be done in a very narrow circle. Enterprises specializing in recruitment have an extensive database containing a large number of specialists of a certain profile, which is necessary for the customer. In most cases, the number of vacancies is ten times bigger than the existing needs of the enterprise. It should also be borne in mind that the relevant base is formed only by relevant specialists who have passed a rigorous professional selection (interviews, professional psychological tests). Nowadays, there is a tendency to involve recruitment agencies in the recruitment and selection of employees. The advantages of specialized recruitment companies are obvious. For one or two vacancies in the company, you can consider several times more applicants with almost equivalent professional skills. There is another way to select employees - recruitment in educational institutions. Its essence is that the organization sends a representative to a certain educational institution, who tells students about his 
company, the benefits of employment, and vacancies. At the same time, certain promotion materials, brochures, and other means of informing about the company's activities are being prepared. After the event, a representative of the company invites potential candidates to visit the company. Additional information is provided to the persons invited for an interview at the enterprise, meetings with the management are organized, measures are taken to check the professional skills.

Particular attention should be paid to the method of shock interview, which is used in the selection of employees for positions that require a significant level of stress [1].

The brain teaser interview method is gaining popularity. Its essence is that the candidate for the vacant position is asked several questions that require highly intelligent and non-standard solutions. The main goal is to analyze the candidate's ability to think outside the box, logically and creatively to solve problems [2].

An important place in the selection process is the verification of the data provided by the candidate, which is the information that is written in the resume, questionnaire, or personal file. It is better to have an honest employee, not a very smart one, than the other way around. After analyzing the information obtained from the documents, it is advisable to interview the candidate. Thus, there are many ways to select and recruit staff, but the management of the organization must choose the one that will most effectively meet the needs of the company is highly qualified personnel.

\section{References}

1. Skasko I. M. Vyznachennia efektyvnykh metodiv vidboru personalu. Upravlinnia rozvytkom (Identification of effective methods of personnel selection). Development management. 2014. № 3(166). P. 11-19.

2. Hlukhodid H. Yu. Vdoskonalennia metodyky doboru personalu $\mathrm{z}$ urakhuvanniam psykholohichnykh osoblyvostei pretendenta na posadu. (Improving the methodology of personnel selection taking into account the psychological characteristics of the candidate for the position). Bulletin of Sumy National Agrarian University. 2016. № 1 (67). P. 15-18. 


\title{
FORMATION OF INDICATORS OF NORMATIVE MONETARY VALUATION OF INDUSTRIAL LANDS
}

\author{
Iukhno Alona \\ $\mathrm{PhD}$ of economics, Assistant \\ Kharkiv National Agrarian University named after V.V. Dokuchaiev
}

Industrial lands occupy minor area in the structure of the land fund of Ukraine (less than $1 \%$ ), but perform a very important function - act as a basis for the placement of the production means.

The normative monetary valuation of industrial lands is carried out in accordance with the Methodology of normative monetary valuation of non-agricultural lands (except for settlements) [1] and the Procedure for normative monetary valuation of non-agricultural lands (except for settlements) [2] and takes into account the metric characteristics of the land plots: (its area), rental income per unit area of the relevant category of land, capitalization period, coefficients that take into account the location, type of use and coefficient that takes into account the land belonging to the lands of environmental, health, recreational, historical and cultural purposes.

The economic meaning of the use of the land resources, which are the basis to place the production means, is their ability to make a profit. The indicators of normative monetary valuation of the industrial land plots, which are formed under the influence of the rent-forming factors, local and regional coefficients responsible for the location of the land plot, create the conditions for receiving the revenues to the local budgets in the form of land fees from land tax and rent. The regulation of land valuation for tax purposes is carried out in the context of the procedure of their normative monetary valuation. Some provisions of the normative monetary land valuation, despite the long period of their application, have points that need to be clarified and improved.

The practical application of the scientific provisions for industrial land valuation in real conditions on the specific spatial objects indicates certain miscalculations and inaccuracies, which confirms the need to improve the scientific and methodological provisions and principles of regulatory monetary valuation of the land plot with maximum consideration of its geospatial characteristics.

The object of the researchis industrial lands (code 11 according to the Classification of the types of land purpose), which belong to the category of lands - industrial lands, transport, communications, energy, defense and other purposes.

In accordance with the provisions of Art. 66 of the Land Code of Ukraine [3] industrial lands include lands provided for the location and operation of the main, subsidiary and auxiliary buildings and structures of industrial, mining, transport and other enterprises, their access roads, utilities, administrative and domestic buildings, other buildings.

Industrial lands can be of state, communal and private forms of ownership.

There is a certain dynamics during 2012 - 2018 regarding a slight increase in the area of industrial land in the overall structure of the land fund of Ukraine and directly in the structure of built-up land (table 1). 
Table 1

Structure of land fund of Ukraine by lands during $2012-2018, \%{ }^{*}$

\begin{tabular}{|c|c|c|c|c|c|c|c|}
\hline \multirow{2}{*}{$№$} & Main types of land & \multicolumn{2}{|c|}{ As of 01.01.2012 } & \multicolumn{2}{c|}{ As of 01.01.2015 } & \multicolumn{2}{c|}{ As of 01.01.2018 } \\
\cline { 3 - 7 } & $\begin{array}{c}\text { area, } \\
\text { thousand } \\
\text { hectares }\end{array}$ & $\begin{array}{c}\text { specific } \\
\text { weight, } \\
\%\end{array}$ & $\begin{array}{c}\text { area, } \\
\text { thousand } \\
\text { hectares }\end{array}$ & $\begin{array}{c}\text { specific } \\
\text { weight, } \\
\%\end{array}$ & $\begin{array}{c}\text { area, } \\
\text { thousand } \\
\text { hectares }\end{array}$ & $\begin{array}{c}\text { specific } \\
\text { weight, } \\
\%\end{array}$ \\
\hline 1 & Agricultural lands & 42776,9 & 70,9 & 42731,5 & 70,8 & 41489,3 & 68,8 \\
\hline 2 & $\begin{array}{c}\text { Forests and other } \\
\text { wooded areas }\end{array}$ & 10611,3 & 17,6 & 10630,3 & 17,6 & 9365,5 & 15,5 \\
\hline 3 & Built-up lands & 2523,2 & 4,2 & 2550,4 & 4,2 & 3602,1 & 6,0 \\
\hline 4 & $\begin{array}{c}\text { Oncluding industrial lands } \\
\text { Open water-logged } \\
\text { lands }\end{array}$ & 223,2 & 0,4 & 224,1 & 0,4 & 224,2 & 0,4 \\
\hline 5 & $\begin{array}{c}\text { Dry open lands with } \\
\text { peculiar vegetation }\end{array}$ & 17,7 & 0,0 & 17,9 & 0,0 & & 5,7 \\
\hline & $\begin{array}{c}\text { Open lands without } \\
\text { vegetation or with little } \\
\text { vegetation }\end{array}$ & 1022,9 & 1,7 & 1015,8 & 1,7 & & \\
\hline 6 & Water & 2422,8 & 4,0 & 2426,4 & 4,0 & 2401,4 & 4,0 \\
\hline & Total & 60354,9 & 100 & 60354,9 & 100 & 60354,9 & 100 \\
\hline
\end{tabular}

"Source: formed by the authors according to the data of the State Geocadastre of Ukraine [4]

According to the State Geocadastre of Ukraine for the period from 2012 to 2018, there is a tendency to reduce the area of agricultural lands (by 1287,6 thousand hectares), at the same time, when there is an increase in the area under built-up lands from 2523,2 thousand ha in 2012 to 3602,1 thousand ha in 2018. The area of industrial lands in the overall structure of the land fund of Ukraine increased by 1,0 thousand ha and as of 01.01.2018 amounted to 224,2 thousand ha or $0,4 \%$.

Since industrial lands are the basis for the placement of production means, the basis for determining their normative monetary value is the capitalization of rental income from the use of land.

Rent income (Ri) is defined as the income that can be obtained as a result of land use depending on its quality and location. The rental income standards for each category of land are determined in accordance with the Order.

The term of capitalization of rental income is set for industrial lands at the level of 33 years.

The coefficient that takes into account the location of land (C) is determined for the cadastral quarter, the boundaries of which are displayed on the index cadastral map and is calculated as the product of the coefficient $\mathrm{Cr}$, which takes into account the regional factors of the cadastral quarter location (distance from the administrative center of the district and the nearest settlement, which has highways, entering the suburban area of large cities, etc.) and $\mathrm{Cl}$ (coefficient that takes into account local factors of the location of the cadastral quarter by territorial and planning, engineering and geological, historical and cultural, natural and landscape, sanitary and hygienic and other conditions). 
Here is an example of calculating the normative monetary valuation of industrial land on a particular land plot (table 2).

Table 2

Calculation of normative monetary valuation of industrial land plot (cadastral number 6323581700:04:001:0501), located on territory of Kachalivka village council of Krasnokutsk region of Kharkiv oblast, as of 01.01.2021, UAH ${ }^{*}$

\begin{tabular}{|c|c|c|c|}
\hline № & Indicators & $\begin{array}{l}\text { Order of receipt or } \\
\text { calculation of indicator }\end{array}$ & $\begin{array}{l}\text { Value of } \\
\text { indicator }\end{array}$ \\
\hline 1 & 2 & 3 & 4 \\
\hline 1 & Total area of land plot $(\mathrm{P})$, ha & $\begin{array}{l}\text { Extract from State Land } \\
\text { Cadastre of land plot }\end{array}$ & 0,0004 \\
\hline 2 & $\begin{array}{l}\text { Rent income per } 1 \mathrm{~m}^{2} \text { of the area for the } \\
\text { corresponding category of lands }(\mathrm{Ri}), \mathrm{UAH} / \text { year }\end{array}$ & Annex 1 of Order & 0,6637 \\
\hline 3 & The term of capitalization (Tc), years & Annex 2.2 of Order & 33 \\
\hline 4 & $\begin{array}{l}\text { Coefficient that takes into account the location of } \\
\text { land (C) }\end{array}$ & $\mathrm{C}=\mathrm{Cr} \times \mathrm{Cl}$ & 1,711 \\
\hline 4.1 & $\begin{array}{l}\text { Coefficient that takes into account regional factors } \\
\text { of the location of cadastral quarter }(\mathrm{Cr})\end{array}$ & $\mathrm{Cr}=\mathrm{Cr} 1 \times \mathrm{Cr} 2 \times \mathrm{Cr} 3$ & 1,599 \\
\hline & $\begin{array}{l}\text { Coefficient that takes into account distance of } \\
\text { cadastral quarter from settlements }(\mathrm{Cr} 1)\end{array}$ & Annex 2.5 of Order & 1,23 \\
\hline & $\begin{array}{l}\text { Coefficient that takes into account distance of } \\
\text { cadastral quarter from roads of state } \\
\text { importance }(\mathrm{Cr} 2)\end{array}$ & Annex 2 of Order & 1,30 \\
\hline & $\begin{array}{l}\text { Coefficient that takes into account location of } \\
\text { cadastral quarter in areas of radioactive } \\
\text { contamination due to Chernobyl disaster }(\mathrm{Cr} 3)\end{array}$ & Annex 1 of Order & 1,0 \\
\hline 4.2 & $\begin{array}{l}\text { Coefficient that takes into account local factors of } \\
\text { location of cadastral quarter by territorial and } \\
\text { planning, engineering and geological, historical and } \\
\text { cultural, natural and landscape, sanitary and } \\
\text { hygienic and other conditions }(\mathrm{Cl})\end{array}$ & \multirow[t]{2}{*}{ Annex 6 of Order } & 1,07 \\
\hline & $\begin{array}{l}\text { - Location of cadastral quarter in area of pedestrian } \\
\text { accessibility (not more than } 600 \mathrm{~m} \text { ) to settlements } \\
\text { and community centers }\end{array}$ & & 1,07 \\
\hline \multirow[t]{3}{*}{5} & $\begin{array}{l}\text { Coefficient that takes into account type of land plot } \\
\text { use }(\mathrm{Cu})\end{array}$ & $\begin{array}{c}\mathrm{Cu}= \\
\mathrm{Cu} 1 \times \mathrm{Cu} 2 \times \mathrm{Cu} 3 \times \mathrm{Cu} 4\end{array}$ & 1,428 \\
\hline & $\begin{array}{l}\text { Coefficient that takes into account composition of } \\
\text { land }(\mathrm{Cu} 1)\end{array}$ & $\begin{array}{c}\text { Annex } 7 \text { of Order, } \\
\text { according to Extract from } \\
\text { State Land Cadastre about } \\
\text { land plot }\end{array}$ & 1,2 \\
\hline & $\begin{array}{l}\text { Coefficient that takes into account regional } \\
\text { differences in formation of rental income and is } \\
\text { determined for land for industry, transport, } \\
\text { communications, energy, defense and other } \\
\text { purposes }(\mathrm{Cu} 2)\end{array}$ & Annex 8 of Order & 1,19 \\
\hline
\end{tabular}


Continuation of table 2

\begin{tabular}{|c|c|c|c|}
\hline 1 & 2 & 3 & 4 \\
\hline & $\begin{array}{l}\text { Coefficient that takes into account the productivity } \\
\text { of forest plantations and is determined for lands } \\
\text { covered with forest (wood and shrub) vegetation } \\
(\mathrm{Cu} 3)\end{array}$ & paragraph 2.7 of Order & 1,0 \\
\hline & $\begin{array}{l}\text { Coefficient that takes into account the productivity } \\
\text { of water bodies and is determined for lands with } \\
\text { these objects }(\mathrm{Cu} 4)\end{array}$ & paragraph 2.7 of Order & 1,0 \\
\hline 6 & $\begin{array}{l}\text { Coefficient that takes into account the affiliation of } \\
\text { the land plot to the lands of environmental, health, } \\
\text { recreational, historical and cultural purposes (Ce) }\end{array}$ & paragraph 2.12 of Order & 1,0 \\
\hline 7 & $\begin{array}{l}\text { Normative monetary valuation of land in } \\
\text { accordance with Order as of } 01.01 .2013(\mathrm{~V}), \mathrm{UAH}\end{array}$ & $\begin{array}{c}\mathrm{V}=\Pi д \times \mathrm{P} \times \mathrm{Tc} \times \mathrm{C} \times \mathrm{Cu} \\
\times \mathrm{Ce}\end{array}$ & 214,05 \\
\hline 8 & Indexation coefficient & $\begin{array}{c}\text { Letter of State } \\
\text { Geocadastre } \\
\text { of } 06.01 .2021 \mathrm{p} \text {. } \\
\text { №22-28-0.222-171/2-21 }\end{array}$ & 1,897 \\
\hline 9 & $\begin{array}{l}\text { Normative monetary valuation of land plot tak } \\
\text { coefficient as of } 01.01 .2021 \text {, UAH }\end{array}$ & into account indexation & 406,05 \\
\hline
\end{tabular}

* Source: calculated by the authors

The geometrically smallest distance from the boundary of the cadastral quarter, where the valued land plot is located, to the boundary of the settlement, which is the settlement with the status of the district center (Krasnokutsk village) is less than the zone of influence of the settlement (D) $5 \mathrm{~km}$ and makes up respectively 4,5 km (Df), so the coefficient that takes into account the distance of the cadastral quarter from the settlements ( $\mathrm{Cr} 1)$ is determined by calculation.

The basic land value ( $\mathrm{Vb})$ of Krasnokutsk village as of 01.01.2021 is $126,71 \mathrm{UAH} / \mathrm{m}^{2}$.

The coefficient, which takes into account the degree of urban value of the territories in the area of influence of settlements (Cs), is determined in accordance with Annex 4 of the Order and is for the valued land 0,75 (population of Krasnokutsk village according to the Handbook of normative monetary valuation of settlements) official website of the State Geocadastre of Ukraine) is 7928 people).

The capitalization period in accordance with paragraph 2.2 of the Order is 33 years.

The rent income per $1 \mathrm{~m}^{2}$ of industrial land, transport, communications, energy, defense and other purposes in accordance with Annex 1 of the Order is 0,6637 UAH / year.

The coefficient that takes into account the distance of the cadastral quarter from the roads of state importance $(\mathrm{Cr} 2)$ is determined in accordance with Annex 2 of the Order. The highway of state importance T2106 Krasnokutsk - Stary Merchyk passes through the lands of the cadastral quarter, within which the valued land plot is located, therefore the coefficient $\mathrm{Cr} 2$ is 1,30 .

For the cadastral quarters that do not belong to the areas of radioactive contamination due to the Chornobyl disaster, the coefficient ( $\mathrm{Cr} 3)$ is taken to be equal to one. 
The coefficient, which takes into account the local factors of the location of the cadastral quarter by territorial and planning, engineering and geological, historical and cultural, natural and landscape, sanitary and hygienic and other conditions $(\mathrm{Cl})$, is determined in accordance with Annex 6 of the Order as the result of the coefficient values which correspond to the local factors that are manifested within this cadastral quarter. $\mathrm{Cl}$ is determined in accordance with the Cartogram of the local factors of the location of the cadastral quarter, within which the valued land plot is located, according to territorial and planning, engineering and geological, historical and cultural, natural and landscape, sanitary and hygienic and other conditions.

The cadastral quarter, where the valued land plot is located, is directly adjacent to the border of the settlement - Kachalivka village $(1,07)$.

The Merchyk River flows within the cadastral quarter (Fig. 1). A small part of the cadastral quarter is located in the water protection zone.

But the given local factor is manifested in a smaller area than the area of half of this cadastral quarter, so this local factor in accordance with the Order is considered to have no manifestation.

The cadastral quarter is located in the zone of exceeding the permissible noise level from the state road T2106 Krasnokutsk - Stary Merchyk. But this local factor of location is manifested in a smaller area than the area of half of this cadastral quarter, so this local factor in accordance with the Procedure is considered to have no manifestation.

The total coefficient, which takes into account the local factors of the location of the cadastral quarter $(\mathrm{Cl})$, is 1,07 .

Since the valued land plot contains land under industrial development, $\mathrm{Cu} 1$ in accordance with Annex 7 of the Order is taken to be 1,2.

The value of the coefficient $\mathrm{Cu} 2$ in accordance with Annex 8 of the Order for Kharkiv region, where the valued land plot is located, is 1,19 .

The $\mathrm{Cu} 3$ coefficient takes into account the productivity of forest plantations and is determined for lands covered with forest (wood and shrub) vegetation. For the valued land plot of industrial land is equal to 1,0 .

The coefficient $\mathrm{Cu} 4$ takes into account the productivity of water bodies and is determined for lands with these objects: natural watercourses (rivers and streams), artificial watercourses (canals), lakes, ponds, reservoirs and other water bodies. For the valued land plot of industrial land is 1,0 .

The coefficient, which takes into account the affiliation of the land plot to the lands of nature reserve and other nature protection, health, recreational, historical and cultural purpose $(\mathrm{Ce})$ for the valued land plot of industrial lands is 1,0 .

The normative monetary valuation of the land plot as of 01.01 .2021 is UAH 406,05, per $1 \mathrm{~m}^{2}$ - UAH 101,51.

But it should be noted that on the territory of the cadastral quarter there are other land plots of industry (cadastral numbers: 6323581700:04:001:0499, 6323581700:04:001:0500, 6323581700:04:001:0502, 6323581700:04:001:0503, 6323581700:04:001:0504, 6323581700:04:001:0505, 6323581700:04:001:0506, 6323581700:04:001:0507, 6323581700:04:001:0508, 6323581700:04:001:0509), normative monetary valuation of which as of 01.01 .2021 is also UAH $101,51 / \mathrm{m}^{2}$. 
Accordingly, the value of the coefficient, which takes into account the regional factors of the location of the cadastral quarter $(\mathrm{Cr})$ is 1,599 . The coefficient, which takes into account the local factors of the location of the cadastral quarter in terms of territorial and planning, engineering and geological, historical and cultural, natural and landscape, sanitary and hygienic and other conditions $(\mathrm{Cl})$, for the researched land plots is 1,07 .

The same indicators of the normative monetary valuation of the land plots per $1 \mathrm{~m}^{2}$ indicate the disregard of the particular local factors for each individual land plot, and the adoption of the generalized regional and local factors in the form of the appropriate coefficients for a specific cadastral quarter, within which the valued land plots are located.

Conclusions. The normative monetary valuation of industrial lands is based on the capitalization of rental income. The indicators of monetary valuation of industrial lands are significantly influenced by the coefficients of the location of the land plot, which take into account regional and local factors of the location of the land plot within the cadastral quarter.

During the calculations it was found out that the normative monetary valuation of other industrial land plots located on the territory of one cadastral quarter depends only on the area of the land plot and does not take into account local features of a specific land plot, which, of course, has advantages in terms of automation objects and allows to avoid as much as possible the subjective interpretation of the valuator of the manifestation of the local factors on a particular land plot. But at the same time, this approach to the valuation of objects has the character of averaging the indicators of their valuation and makes it impossible to take into account the unique characteristics of each land plot.

\section{References:}

1. Resolution of the Cabinet of Ministers of Ukraine "Methodology of normative monetary valuation of non-agricultural lands (except for settlements)" №1278 (2011). Available at: http:// rada.gov.ua.

2. Resolution of the Cabinet of Ministers of Ukraine "Procedure for normative monetary valuation of non-agricultural lands (except for settlements)" №508 (2013). Available at: http:// rada.gov.ua.

3. Land Code of Ukraine: Adopted 25.10.2001 № 2768-III // Bulletin of the Verkhovna Rada of Ukraine. - 2002. - № 3-4. - Art. 27.

4. The structure of the land fund of Ukraine and the dynamics of its changes. Available at: https://land.gov.ua/info/struktura-zemelnoho-fondu-ukrainy-tadynamika-ioho-zmin/. 


\section{STRATEGY OF SUPPORT OF AGRICULTURAL ENTERPRISES BY THE STATE}

\section{Malinoshevska Kateryna}

$\mathrm{PhD}$.,

Financial Director of «Highline Media» Ltd., Ukraine

The agro-industrial complex has changed over the years, and our country has become the center of food security in the world, a global supplier of cereals and oilseeds, organic products and poultry and eggs. Export positions of corn, wheat and barley to the markets of Africa, India and China are changing. We have the opportunity to obtain our own cheap raw materials for flour production and to become the main supplier of certain types of fresh vegetables and other crops in the EU.

Ukraine has become a major partner for countries in the Middle East and North Africa that have the money but the opportunity to grow their own quality food. Ukraine's role in supplying food to Sub-Equatorial Africa has grown significantly. Ukraine supplies environmentally friendly products to Europe. New forms of cooperation and collaboration are a clear example of business models, where ecosystems, joint programs, procurement and delivery systems, new jobs, irrigation strategy is implemented, which promotes the development of fruit and vegetable crops. Technologies and innovations change business processes in agro-industrial complex, production management is carried out by means of virtual service.

The development of the agro-industrial complex is influenced by the negative consequences of coronavirus infection, which reduces the export of agricultural products. It should be noted that the development of agro-industrial complex is related to the quality of life of the rural population and requires the improvement of transport, engineering and social infrastructure. The developed structure of the agro-industrial complex is important for the welfare of the economy as a whole. Reliable food is provided by agricultural holdings and farms, support the growth of jobs in rural areas, the competitiveness of agriculture. Highly productive animals and plants will increase the efficiency of the agro-industrial complex on a practical level, provide high positions in the growth of the agricultural market: ensure effective financial security, support for viable agriculture, production and support of jobs and economic growth. Understanding customer needs is essential for quality service. Assessing the experience of farms and their interaction with customers will provide a better understanding of consumer expectations, identify projects that have the greatest impact on customers and develop performance indicators. The analysis of such indicators will allow to determine investment priorities, to improve clients' access to risk management programs through highly qualified employees.

A competitive agricultural system is not possible without increasing agricultural opportunities, supporting economic growth and creating new markets. Departments and services of the agro-industrial complex provide sectoral services to help agriculture, food producers and enterprises that create and improve the agricultural system. Evaluation, design, planning of food producers is associated with improving 
the efficiency of permanent food market facilities and stakeholders. These facilities include wholesale markets, farmers' markets, government markets and food centers, all of which are important parts of the national food distribution network and provide important agricultural opportunities for producers.

Government programs aim to support domestic producers, local and regional food systems, innovative methodologies and marketing strategies, including expanded access to fruits and vegetables, transport, food security and sustainability. It is necessary to expand new markets for agricultural products because the demand for agricultural products is growing, so the programs have tools to meet the current and future needs of consumers and producers. The creation and expansion of markets is impossible without training, creating a service project, evaluating the activities of agricultural enterprises and improving the efficiency of food systems and the food market. Developing and maintaining markets for domestic producers is a very important step, using innovative methods to gather information, the state should modernize and restructure agricultural services programs that meet customer needs and take advantage of opportunities to achieve greater efficiency through simplified processes in the agricultural market. Market transparency and free access to food develop market opportunities, forming communication links between consumers and agricultural enterprises. Through industry specifications, domestic agricultural producers have the opportunity to create and improve the quality of production, trying to comply with quality standards, market analysis and product integrity. Research, food security, market access for agro-industrial products, improving the efficiency of distribution systems are important areas for stakeholders and the food supply chain as a whole.

The expansion of international marketing and export of products is of crucial importance for domestic agro-industrial enterprises. Promotion of agricultural products on world markets through promotional activities, development of international standards, compliance with trade agreements that will promote cooperation with developing countries and developed countries. Long-term international relations are the basis for building future markets and will contribute to the further development of the country's agro-industrial complex. By removing barriers to agricultural exports and building the potential to increase export demand.

\section{References:}

1. United Nations (2013). Trade and development report 2013. United nations conference on trade and development. New York, Geneva : United Nations.

2. Laczko, F., \& Gozdziak, E. M. (2006). Migration for Development: Within and Beyond Frontiers.

3. Mazzucato, V., Van Den Boom, B., \& Nsowah-Nuamah, N. N. (2008). Remittances in Ghana: Origin, destination and issues of measurement. International Migration, 46(1), 103-122.

4. Hlushkova T.V. Innovation Components of the Modern Advertisement [Online]. Available at: http://nbuv.gov.ua/UJRN/apmk_2013_14_31. Accessed on: February 15, 2021.

5. Vovk I. P. (2012) Osoblyvosti vprovadzhennia zakhodiv resursozberezhennia ta metodyka vyznachennia yikh efektyvnosti na mashynobudivnykh pidpryiemstvakh 
$\mathrm{v}$ konteksti resursonomiky [Features of resource conservation measures and methods of their effectiveness in engineering enterprises in the context of resourcenomy]. Visnyk of Sumy State University. Economics Series, no. 4, pp. 107-117.

6. Official Website of the Analytical Agency Business Views [Online]. Available at: http://businessviews.com.ua/ Accessed on: February 10, 2021.

7. Mazaraki A.A, Melnyk T.M., Chaiun T.I. 2000. International Marketing: Textbook for Students of HEI. Kyiv, KNTEU, 306 p. 


\title{
КРАУДРЕКРУТИНГ ЯК ЕФЕКТИВНИЙ ІНСТРУМЕНТ HR-IНЖИНІРИНГУ НА ПІДПРИЕМСТВІ
}

\author{
Базалійська Наталія, \\ к.е.н., доцент \\ Хмельницький національний університет \\ Пархомець Юрій, \\ студент \\ Хмельницький національний університет
}

У останні роки інтерес до HR-технологій зростає з боку не тільки фахівців 3 кадрів, але й з боку менеджерського корпусу, інвесторів, самого персоналу компанії та інших. Всі ці процеси продиктовані одним глобальним фактором посиленням ролі людських ресурсів у бізнесі. І цей фактор дійсно охоплює різні види діяльності, галузі, території без будь-яких винятків. Управлінська практика в сучасному столітті цифрових технологій націлена на ключове завдання реальне інтегрування раніше самостійної функціональної області управління персоналом в системно організовану площину управління, вибудувану на принципово нових засадах.

Впровадження системи HR-інжинірингу дозволяє адаптувати внутрішнє середовище і структуру компанії до нових завдань. HR-інжиніринг розглядається як методологія системно-структурної організації управління людськими ресурсами, що інтегрує персонал 3 організаційною структурою, бізнеспроцесами, інформаційною системою і іншими підсистемами корпоративної архітектури організації.

Інжиніринг та реінжиніринг бізнес-процесів орієнтовані на фундаментальну побудову та кардинальну перебудову всієї діяльності підприємства, а не на часткові зміни в тій чи іншій сфері управління, інжиніринг може розглядатися та використовуватися як процесна частина методології реінжинірингу. При цьому у якості основних показників оцінки ефективності бізнес-процесів розглядаються такі, як кількість виробленої продукції (наданих послуг) заданої якості, кількість споживачів продукції (послуг), кількість типових операцій, які необхідно виконати при за визначений проміжок часу, тривалість та вартість виконання цих операцій, капіталовкладення.

Сьогодні кожна сучасна людина, яка вважає себе технологічно освідченою, так чи інакше стикалась 3 поняттям краудтехнологій. Краудтехнології - це набір ефективних інструментів, що працюють за принципом внесенням великою кількістю людей добровільного вкладу в загальну справу. Загалом краудтехнології - це використання особистих ресурсів громадян для виробництва будь-якого продукту, розробки i впровадження послуги або рішення різних соціальних завдань. 
Найпопулярніші краудтехнології в світі - це краудфандінг, краудінвестинг, краудрекрутинг [1]:

1. Краудфандинг (Rewards crowdfunding) - донор отримує винагороду за вкладення в кінці проекту. Так як такий вид краудфандингу розвиває креативні проекти, то і винагорода найчастіше не грошова. Наприклад, якщо режисер збирає гроші, щоб зняти власний фільм, то шанувальники-донори отримають право перед прем'єрного перегляду фільму. Також це може різна сувенірна продукція з фірмовими логотипами (футболки, брелки, календарики тощо).

2. Краудінвестинг (Equity crowdfunding) - має багато спільного зі стандартним інвестуванням укомпанії. Донор в обмін на вкладення отримує частку в компанії. Це ризикований вид інвестування, так як гарантії отримання прибутку немає, а сам донор, стаючи партнером компанії, бере на себе всі ризики, які пов'язаноз їі діяльністю.

3. Краудрекрутинг (від англ, crowd - «натовп», recruiting - «наймання робочої сили») - це технологія пошуку, підбору та оцінки нового персоналу за допомогою проведення спеціально розробленого краудсорсінгового проекту, $\mathrm{i}$ що здійснюється за допомогою мережі Інтернет на спеціалізованій платформі.

В умовах сучасної конкуренції на ринку робочої сили для будь-якої організації найважливішим завданням $\epsilon$ своєчасне залучення кращих працівників, професіоналів своєї справи, так як ефективність роботи будь-якої компанії безпосередньо залежить від персоналу, який в ній працює.

Пошук «кращого з кращих» кандидатів для роботи у вашій компанії - складне завдання. Складність полягає не в тому, що немає з кого вибрати, чи існують якісь технічні (організаційні) обмеження для пошуку, а в тому, що навіть на саму рядову позицію важливо знайти того самого «кращого кандидата»: компетентного, відповідального, ініціативного, йде працювати надовго в компанію, що підходить для вашого колективу.

Сучасний світ змінюється щодня, і часто традиційні технології пошуку, підбору та оцінки персоналу застарівають і стають неефективними. Тому в нових умовах, що змінюються по роботі 3 персоналом доцільно застосовувати інноваційні технології, однією з яких є краудрекрутинг.

Іншими словами, краудрекрутинг розуміє під собою організацію $\mathrm{i}$ проведення фірмою роботодавцем краудсорсингового проекту, в якому полягають важливі для цього підприємства конкретні завдання. Для реалізації проекту необхідна спеціальна інтернет-платформа (наприклад, Witology), завдяки якій $є$ можливість залучити потенціал сотень і тисяч людей шляхом надання їм спільної online роботи. Завдяки такій платформі у організаторів проекту є можливість поспостерігати за роботою кожного учасника, зробити висновки і підвести підсумок: хто стане штатним співробітником організації.

Краудрекрутинг - спосіб оцінки і набору нових співробітників (формування кадрового резерву в компанії), заснований на застосуванні технології краудсорсингу [1].

Краудрекрутинг розуміє під собою організацію i проведення краудсорсингового проекту, під час якого в учасників (кандидатів або співробітників компанії) $є$ можливість показати себе, вирішуючи різні бізнес- 
завдання, а в організаторів проекту є можливість оцінити учасників та зробити відповідний вибір. $1)$.

Впровадження краудрекрутингу можна розділити на кілька етапів (рисунок
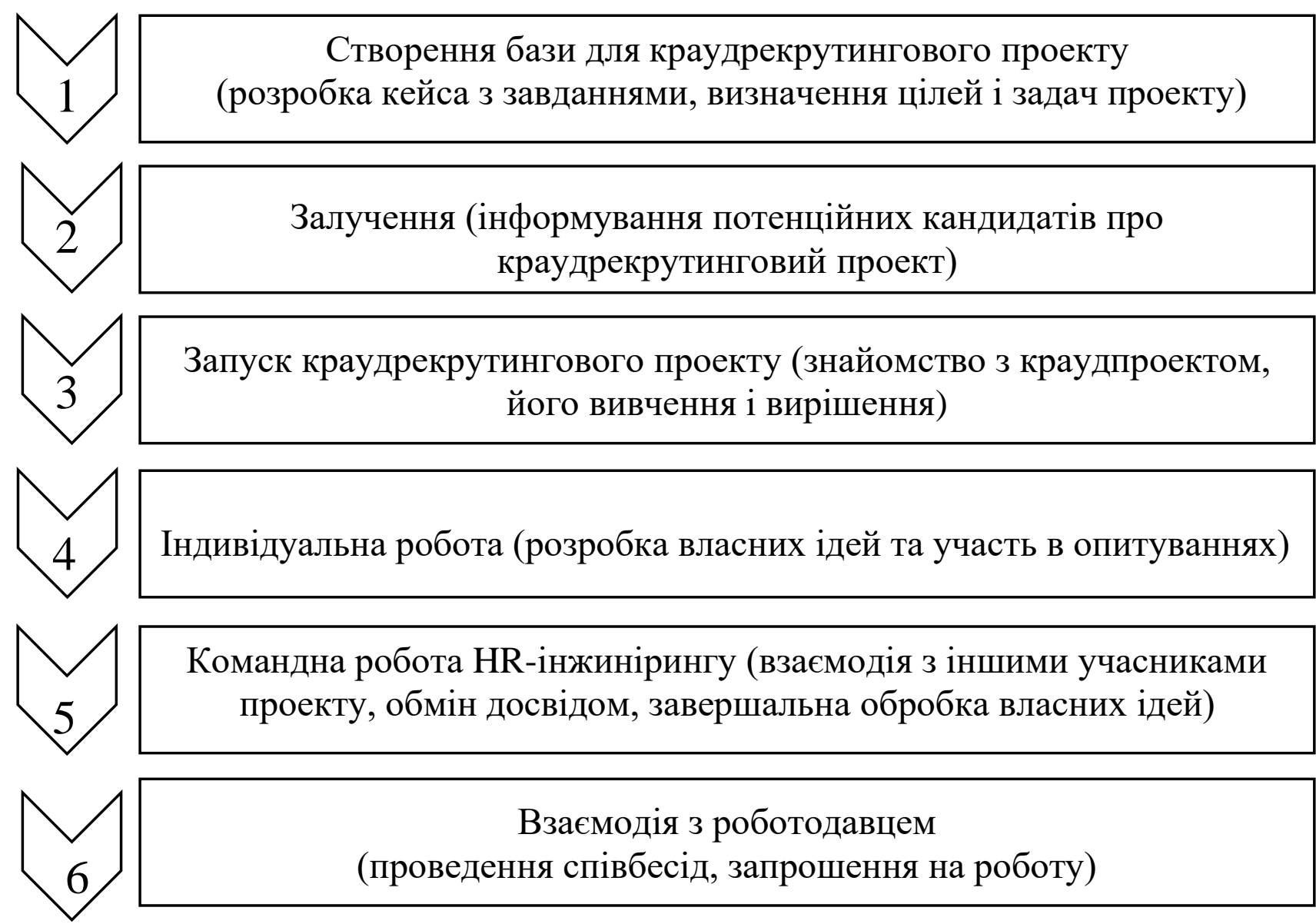

Рисунок 1. Етапи проведення краудрекрутингового проекту як ефективного інструмену HR-інжинірингу на підприємстві

3 огляду на той факт, що, як правило, краудсорсингове проектування тривають близько 3-5 тижнів, а участь в них можуть брати від декількох сотень до кількох тисяч учасників, то до кінця проекту у роботодавця (організатора) $\epsilon$ докладний звіт про кожного з активних учасників, що дозволяє йому зробити більш зважений і правильний вибір тих, з ким він буде продовжувати роботу далі. Все, що залишається зробити організатору проекту після його завершення, - запросити всіх цікавих для нього учасників на фінальне інтерв'ю або відразу ж надіслати пропозицію про роботу.

Краудрекрутинг як самостійний і профільний продукт з'явився відносно недавно на ринку РФ і зараз активно просувається двома провідними в цьому напрямку компаніями (Witology i IBS, см. Прес-реліз).

Краудрекрутинг утворився на стику двох напрямків: краудсорсингові проекти і рекрутинг. Правильно організовані краудсорсингові проекти самі по собі також дозволяють виявляти цікавих учасників проекту, але цього недостатньо для повноцінної оцінки учасника як співробітник 3 боку роботодавця. Саме тому i виникла необхідність об'єднання зусиль 3 
професіоналами в області рекрутингу, які володіють усіма необхідними інструментами для всебічної оцінки учасників проекту як майбутніх співробітників.

Другою передумовою для виникнення «нового продукту на ринку HR» стала необхідність швидкого відбору серед великої кількості кандидатів на роботу.

При цьому важливо було виконання декількох особливих умов:

- зменшення тривалості процесу відбору кандидатів;

- зниження вартості відбору і завантаження співробітників HR-служби;

- відбір кращих кандидатів з перевіркою «в справі»;

- відповідна зацікавленість працювати в компанії з боку кандидатів, познайомившись 3 колективом і компанією «в справі»;

- можливість реалізації процесу відбору кандидатів своїми силами без необхідності залучення рекрутингових агентств.

Не будемо також забувати і про те, що сьогодні масштаб присутності в соціальних мережах та інтернет досяг максимальних за останнім часом значень. Ігнорувати тенденції не має ніякого сенсу. Краудрекрутинг не тільки ефективний і вигідний для роботодавців, але зрозумілий і зручний для учасників, тому що проекти проходять в інтернет і в форматі «живого» спілкування, що можливість учасникам зберегти свій звичний стиль життя (бути в on-line) і при цьому наприклад, отримати пропозицію про роботу від успішної компанії.

I все ж головним в технології краудрекрутинга, як вже було написано вище, залишається можливість перевірити учасників проекту «в справі», фактично працюючи з ними вже як з повноцінними співробітниками компанії (актуально для проектів 3 відбору нових співробітників). Після такої перевірки роботодавець не просто набирає вподобаних йому учасників, але і точно знає, на що вони здатні, якими якостями володіють, як діють в різних ситуаціях $\mathrm{i}$ наскільки саме ці учасники підходять для подальшої роботи. Не будемо забувати і про те, що учасники проекту також переймаються духом спільної роботи (залученість в проект), що також мотивує їх ще більше на роботу у організатора проекту. Відмінним бонусом $\epsilon$ i той факт, що і роботодавець і кандидати зацікавлені в спільній роботі, вони готові чути один одного, домовлятися про найбільш прийнятних для всіх умовах праці та іï оплати. А відсутність третіх осіб в процесі відбору значно знижує вартість відбору кожного з кандидатів.

Важливим моментом $\epsilon$ те, що метою краудрекрутингового проекту $\epsilon$ не отримання прибутку від вирішення поставленого завдання і навіть не саме рішення задачі, а пошук співробітників. Тобто мета може бути повністю не вирішена, але організатори проекту, поспостерігавши за роботою учасників, можуть запросити на кінцеву співбесіду найбільш, на їх погляд, підходящих на вакантну посаду кандидатів. Саме через повне залучення учасників проекту в рішення поставлених завдань, завдяки якому учасники отримують шанс в найкоротші терміни показати себе 3 абсолютно різних сторін і максимально розкрити свій потенціал, краудрекрутинг відрізняється від інших методів підбору персоналу. Тому краудрекрутинговий проект повинен включати в себе завдання, які допоможуть учасникам показати такі знання і навички, як [3]: 
- професійні знання: знання i розуміння предмета, над яким працює організація;

- загальні знання: вміння вирішувати поставлені завдання, застосовуючи знання в суміжних областях;

- робота з інформацією: iї аналіз, синтез, пошук;

- робота в команді: здатність бути як лідером, так і цінним « рядовим »учасником команди в спільній роботі;

- індивідуальна робота: особистісні якості, необхідні для успішної роботи (наприклад, пунктуальність, ініціативність і т.д.).

Краудрекрутинговий проект триває в середньому 2-4 тижні (в окремих випадках - 5), участь в ньому беруть сотні і тисячі людей, тому в кінці проекту у роботодавця є докладний звіт практично про кожного учасника, що допомагає оцінити і зробити правильний вибір, не витративши при цьому великої кількості часу і грошових коштів.

Виходячи їх цього, можна виділити наступні переваги i недоліки краудрекрутингу (таблиця 1).

Таблиця 1.

Переваги і недоліки технологій краудрекрутингу

\begin{tabular}{|c|c|}
\hline Переваги & Недоліки \\
\hline $\begin{array}{c}\text { Одночасне виконання трьох функцій } \\
\text { системи управління персоналом: } \\
\text { пошук, підбір і оцінка кадрів; }\end{array}$ & \multirow{2}{*}{$\begin{array}{c}\text { У краудрекрутингових проектах частіше } \\
\text { беруть участь молоді спеціалісти та } \\
\text { випускники вузів, в той час як } \\
\text { висококваліфіковані фахівці віддають } \\
\text { перевагу більш традиційні } \\
\text { методи пошуку роботи; }\end{array}$} \\
\hline $\begin{array}{l}\text { Величезний охоплення кандидатів на } \\
\text { посаду (від декількох сотень } \\
\text { до декількох тисяч чоловік); }\end{array}$ & \\
\hline $\begin{array}{c}\text { Скорочення витрат часу } \\
\text { на підбір персоналу; }\end{array}$ & \multirow{2}{*}{$\begin{array}{c}\text { У той час як технологія краудрекрутинг } \\
\text { активно розвивається в зарубіжних країнах, } \\
\text { українські підприємці ще насторожено } \\
\text { ставляться до таких інновацій, що гальмує } \\
\text { процес розвитку краудрекрутингу в Україні; }\end{array}$} \\
\hline $\begin{array}{l}\text { Зменшення вартості підбору } \\
\text { персоналу; }\end{array}$ & \\
\hline $\begin{array}{l}\text { Унікальна можливість оцінки роботи } \\
\text { учасників проекту в режимі реального } \\
\text { часу; }\end{array}$ & \multirow{4}{*}{$\begin{array}{c}\text { Хоча технологія краудрекрутингу } \\
\text { теоретично може бути застосована для будь- } \\
\text { яких організацій, вона буде економічно } \\
\text { неефективна для підприємств малого бізнесу, } \\
\text { з невеликим штатом або відсутністю служби } \\
\text { з управління персоналом. }\end{array}$} \\
\hline $\begin{array}{c}\text { Можливість роботодавця побачити } \\
\text { потенціал кандидата на посаду в реальній } \\
\text { ситуації , оцінити його з різних сторін, } \\
\text { перевірити «в справі»; }\end{array}$ & \\
\hline Свобода дій учасників проекту; & \\
\hline $\begin{array}{l}\text { Можливість підібрати персонал з } \\
\text { різних сфер, віку, статі. }\end{array}$ & \\
\hline
\end{tabular}

Краудрекрутинг в якості однієї з моделей пошуку персоналу досить вигідний компанії за кількома показниками.

1. Термін підбору кандидатів на вакансію. Істотно скорочуються терміни, протягом яких можна вибрати найбільш підходящих кандидатів. Як правило, 
краудсорсинговий проект триває 3-5 тижнів, і за цей час рекрутер отримує можливість оцінити і виявити найбільш успішних претендентів.

2. Зниження завантаженості HR-служб. За рахунок того, що відпадає необхідність в проведенні великої кількості співбесід, рекрутер зосереджується безпосередньо на оцінці діяльності здобувача.

3. Перевірка на практиці. Найбільш істотним бонусом $є$ безпосередня можливість побачити кандидата в справі. Якщо на співбесіді він може показати себе з кращого боку, не завжди відповідає дійсності, то в ході виконання завдання демонструє реальні знання і навички.

4. Ознайомлення майбутніх співробітників з корпоративними цінностями. В ході виконання кандидатами завдань на основі краудсорсингу відбувається їх неминуче ознайомлення 3 цінностями компанії. Таким чином, здійснюється природний відсів тих, кому ці норми чужі.

Важлива перевага краудрекрутинга полягає в тому, що кількість потенційних претендентів на порядок більше, ніж при традиційних методах підбору персоналу.

Реалізуючи краудрекрутинговий проект, HR-служба може сформувати велику резервну базу. При цьому в ній нескладно позначити найбільш бажаних кандидатів. В результаті зменшується кількість співробітників, які не пройшли випробувальний термін, так як багато спірних питань вирішуються ще до формального укладення трудового договору. За цей час у роботодавця з'являється шанс оцінити не тільки професіоналізм людини, але i його психологічну сумісність 3 іншими членами колективу, його майбутніми колегами.

Переважна більшість крауд-проектів припускають командну роботу, обговорення ідей один одного, а нерідко і критику. Так роботодавець отримує можливість вибрати 3 найбільш активних кандидатів тих, хто спочатку «заточений» під командну роботу, здатний відстоювати свої ідеї і адекватно реагувати на критичні зауваження інших.

Ще одна важлива перевага краудрекрутинга полягає в тому, що кількість потенційних претендентів на порядок більше, ніж при традиційних методах підбору персоналу. Якщо компанії необхідно закрити відразу кілька десятків вакансій, то без подібної масовості просто не обійтися.

Одним з безперечних плюсів краудрекрутинга $є$ його незалежність від часу i географічних кордонів: процес роботи над проектом за рахунок різниці часових поясів може відбуватися практично цілодобово, істотно скорочуючи терміни вирішення бізнес-завдання і виявлення найбільш талановитих кандидатів.

Краудрекрутинговие технології знаходять успішне застосування не тільки в процесі відбору персоналу на наявні вакансії, а й у використанні творчого потенціалу діючих співробітників. Це особливо актуально для великих корпорацій, де діяльність службовців відрізняється досить жорсткою регламентацією і обмежена посадовими обов'язками. Нерідко це призводить до того, що багатий творчий потенціал фахівців залишається незатребуваним. Це також $є$ однією з причин звільнення найбільш талановитих і перспективних працівників. 
Внутрішній краудрекрутинг знижує собівартість розробки креативної ідеї, так як відпадає необхідність залучати дорогих топ-менеджерів. Нестандартне рішення бізнес-завдання цілком під силу штатним співробітникам самих компаній, що переконливо доводить практика. Пошук творчих рішень до того ж підвищує їх залученість і відчуття повної самореалізації, що в свою чергу робить позитивний вплив на рівень лояльності.

Крім того, HR-служба отримує фактичну картину про можливості співробітників, а також про найбільш бажаних кандидатів на підвищення або переведення на інші посади.

Сьогоднішній масштаб використання соціальних мереж сприяє тому, що краудсорсингові проекти стають одним із способів підвищення впізнавальності бренду. Залучення великої кількості людей до участі в них веде до підвищення привабливості іміджу компанії як роботодавця.

Проведення краудрекрутингової діяльності $\epsilon$ хорошим інформаційним приводом, що дозволяє оптимізувати витрати на рекламні публікації в ЗМІ та проведення PR-акцій. Якщо роботодавець спочатку відкрито говорить про свої корпоративні цінності, то це підвищує його репутацію в очах потенційного здобувача, тобто відбувається певна демократизація.

Модель рекрутингу, заснована на крауд-технологіях, дозволяє HR-службі оптимізувати час пошуку та оцінки, а також відбирати не тільки творчих, але i активних кандидатів, націлених на результат. Роботодавець отримує можливість оптимізувати управління персоналом і більш раціонально використовувати творчий потенціал штатних співробітників.

Можна зробити висновок, що краудрекрутинг - сучасна технологія, що дозволяє швидко і ефективно підібрати і оцінити персонал, але, на жаль, слабо розвинена в Україні.

\section{Література:}

1. Аккерман К. Краудфандінг як фінансовий інструмент. // «Україна фінансова». - Інформаційно-аналітичний портал Українського агентства фінансового розвитку. - [Електронний ресурс]. - Режим доступу: http://www.ufin.com.ua/analit_mat/sdu/139.htm.

2. Краудрекрутинг - новая технология массового поиска талантов // Компаньон. - 2012. - 31 авг. [Электронный ресурс]. - Режим доступа: http://www.companion. ua/articles/content?id=208489.

3. Polyakova Yu.M. Human Resource Management Based on Modern Crowd Technologies: Crowd Staffing, Crowd Recruiting and Crowd Training. Scientific Research of Faculty of Economics. Electronic Journal. 2020;12(3):16-30. (In Russ.) https://doi.org/10.38050/2078-3809-2020-12-3-16-30 


\title{
НОРМАТИВНО-ПРАВОВЕ ЗАБЕЗПЕЧЕННЯ СТАЛОГО РОЗВИТКУ ОБ'ЄДНАНИХ ТЕРИТОРІАЛЬНИХ ГРОМАД
}

\author{
Будько Оксана Володимирівна \\ доктор економічних наук, доцент, \\ завідувач кафедри фінансів та обліку \\ Дніпровський державний технічний університет
}

В умовах децентралізації та реформування місцевого самоврядування важливе значення має процес об'єднання територіальних громад, який здійснюється відповідно до «Концепції реформування місцевого самоврядування та територіальної організації влади в Україні» [1] та Закону України «Про добровільне об'єднання територіальних громад» [2].

Відповідно до Закону України «Про добровільне об’єднання територіальних громад» умовами добровільного об'єднання територіальних громад визначено такі (рис. 1):

\begin{tabular}{|c|}
\hline Умови добровільного об’єднання територіальних громад \\
\hline $\begin{array}{c}\text { 1. У складі об’єднаної територіальної громади (ОТГ) не може існувати іншої } \\
\text { територіальної громади, яка має свій представницький орган місцевого } \\
\text { самоврядування }\end{array}$ \\
\hline $\begin{array}{l}\text { 2. Територія ОТГ має бути нерозривною, межі ОТГ визначаються по зовнішніх } \\
\text { межах юрисдикції рад територіальних громад, що об'єдналися }\end{array}$ \\
\hline $\begin{array}{l}\text { 3. ОТГ має бути розташована в межах території Автономної Республіки Крим, } \\
\text { однієї області }\end{array}$ \\
\hline $\begin{array}{l}\text { 4. При прийнятті рішень щодо добровільного об’єднання територіальних громад } \\
\text { беруться до уваги історичні, природні, етнічні, культурні та інші чинники, що } \\
\text { впливають на соціально-економічний розвиток ОТГ }\end{array}$ \\
\hline $\begin{array}{l}\text { 5. Якість та публічність послуг, що надаються в ОТГ, не можуть бути нижчими, } \\
\text { ніж до об’єднання }\end{array}$ \\
\hline
\end{tabular}

Рис. 1. Умови добровільного об'єднання територіальних громад Джерело: складено за [1]

Порядок об'єднання територіальних громад здійснюється відповідно до Методики формування спроможних територіальних громад за такими етапами:

1) ініціювання добровільного об'єднання;

2) громадське обговорення пропозиції добровільного об'єднання; 
3) прийняття радою рішення про надання згоди на добровільне об'єднання та делегування представника для розробки проекту рішення про добровільне об'єднання;

4) прийняття радою рішення про схвалення проекту рішення про добровільне об'єднання;

5) подання рішення до обласної державної адміністрації для надання висновку щодо відповідності цього проекту Конституції та Законам України;

6) розпорядження голови обласної державної адміністрації щодо відповідності цього проекту Конституції та законам України;

7) прийняття радами рішення про добровільне об'єднання територіальних громад [3].

Відповідно до Методики формування спроможних територіальних громад, спроможна територіальна громада - це територіальні громади сіл (селищ, міст), які в результаті добровільного об'єднання здатні самостійно або через відповідні органи місцевого самоврядування забезпечити належний рівень надання послуг, зокрема у сфері освіти, культури, охорони здоров'я, соціального захисту, житлово-комунального господарства, 3 урахуванням кадрових ресурсів, фінансового забезпечення та розвитку інфраструктури відповідної адміністративно-територіальної одиниці [3].

Розвиток ОТГ має здійснюватися 3 урахуванням цілей і завдань сталого розвитку. Під сталим розвитком слід розуміти безперервний розвиток, який задовольняє потреби нинішнього покоління і не ставить під загрозу можливості майбутніх поколінь задовольняти свої власні потреби. Це визначення було надано у доповіді міжнародної комісії по навколишньому середовищі та розвитку і далі закріплено в Декларації, прийнятій на Конференції ООН в Ріо-деЖанейро у 1992 році. У зв'язку з тим, що значна частина природних ресурсів планети вичерпана, а самій планеті загрожує перенаселення і загострення екологічної ситуації, рішенням конференції була визначена програма дій. У 2015 році на Саміті ООН зі сталого розвитку на період до 2030 року були ухвалені «Цілі сталого розвитку», які включають 17 Глобальних цілей та 169 завдань. Підсумковим документом Саміту стала резолюція «Перетворення нашого світу: порядок денний у сфері сталого розвитку до 2030 року». Це знайшло відгук і в Україні у Національній доповіді «Цілі сталого розвитку: Україна», в якій відображено 17 цілей та 86 завдань, реалізація та виконання яких регулюється 145 нормативно-правовими актами [4].

Перші завдання щодо сталого розвитку територіальних громад визначені ще у 1999 році Концепцією сталого розвитку населених пунктів, якою визначено, що сталий розвиток населених пунктів - це соціально, економічно і екологічно збалансований розвиток міських і сільських поселень, спрямований на створення ïх економічного потенціалу, повноцінного життєвого середовища для сучасного та наступних поколінь на основі раціонального використання ресурсів (природних, трудових, виробничих, науково-технічних, інтелектуальних тощо), технологічного переоснащення і реструктуризації підприємств, удосконалення соціальної, виробничої, транспортної, комунікаційно-інформаційної, інженерної, екологічної інфраструктури, поліпшення умов проживання, 
відпочинку та оздоровлення, збереження та збагачення біологічного різноманіття та культурної спадщини [5]. Сталий розвиток ОТГ характеризується взаємозв'язком трьох складових її діяльності:

- економічна складова - економічний розвиток ОТГ має бути спрямований на створення робочих місць для місцевого населення, активізацію підприємництва, в тому числі малого та середнього, впровадження інноваційних технологій, збільшення надходжень до бюджету, забезпечення привабливих умов для інвесторів. Економічний розвиток ОТГ є більш ефективним за умови, що він відбувається екологічно збалансованим шляхом;

- екологічна складова - населення ОТГ має погодитися, що збереження екологічної рівноваги $\epsilon$ важливим завданням розвитку місцевого самоуправління. Будь-яка активність, яка загрожує збереженню біорізноманіття та екологічній рівновазі як території, так і регіону має бути небажаною та неприйнятною для країни та суспільства;

- соціальна складова - соціальний розвиток ОТГ має базуватися на створенні гідних умов для особистого розвитку та соціального забезпечення мешканців громади (підвищення якості надання послуг у сфері освіти, культури, відпочинку, соціального захисту та охорони здоров'я).

Отже, під сталим розвитком ОТГ слід розуміти ії розвиток як системи, яка орієнтована на гармонізацію соціальних аспектів іiі функціонування, впливу на навколишнє середовище та економічної діяльності з метою підвищення рівня і якості життя населення.

Кожна ОТГ має розробити власну Стратегію сталого розвитку, яка визначатиме напрями реалізації принципів і завдань сталого розвитку. Для визначення напрямів сталого розвитку ОТГ слід використовувати метод SWOTаналізу, який є класичним інструментом співставлення сильних і слабких сторін громади, iї можливостей і загроз за такими напрямами, як органи місцевого самоврядування, інфраструктура i використання території, економіка, навколишнє середовище і туризм, суспільство і людський капітал тощо. Так, за напрямом «економіка» за методом SWOT-аналізу можуть встановлені такі сильні сторони ОТГ, як значні доходи бюджету ОТГ від податків сільськогосподарських підприємств, невисокий рівень безробіття, відкритість до співпраці з інвесторами та ін. До слабких сторін слід віднести залежність економіки від доходів сільського господарства, відсутні можливості на території громади для переробки сільськогосподарської продукції, слабкий розвиток інфраструктури, відсутність інформації для інвесторів. Можливостями для ОТГ можуть бути можливості розвитку сільськогосподарського виробництва, створення робочих місць новими підприємствами, покращання стану інфраструктури, земельні й екологічні ресурси, до загроз можна віднести неврегульовану податкову політику, високі відсотки за кредит, несприятливий інвестиційний клімат, нестабільну ситуацію в країні, законодавство, яке часто змінюється тощо.

Врахування всіх сторін за визначеним аспектом дозволить сформулювати чіткі завдання у сфері реалізації Стратегії сталого розвитку ОТГ та визначити потенційні джерела iï фінансування. Такий аналіз також доцільно зробити і за 
іншими напрямами, які будуть складати зміст екологічної і соціальної складової сталого розвитку ОТГ.

Сталий розвиток ОТГ потребує певного ресурсного забезпечення, яке дозволить підтримувати соціальну, екологічну і економічну сфери діяльності громади. Відповідно до законодавства джерелами фінансування є різного роду надходження (близько 25 видів податків, акцизів, мита та інших надходжень), які повністю або частково зараховуються до бюджету ОТГ [6], базові та реверсні дотації, субвенції та дотації на виконання, передбачених законодавством функцій, державні субвенції на формування відповідної інфраструктури об'єднаної територіальної громади [2, 6].

Отже, розвиток територіальних громад має здійснюватися у напрямі гармонійного поєднання економічних, екологічних та соціальних аспектів іiі діяльності. Кожний член ОТГ має усвідомлювати завдання, які стоять перед нею. Удосконалення нормативно-правового регулювання, яке буде спрямовано на створення сприятливих умов для розвитку ОТГ, забезпечить економічне зростання, покращання рівня життя, соціальної інфраструктури та екологічну безпеку. Відповідно, об’єднані територіальні громади стануть повноцінними суб' єктами, функціонування яких сприятиме досягненню цілей сталого розвитку державою на макрорівні.

\section{Список літератури:}

1. Концепція реформування місцевого самоврядування та територіальної організації влади в Україні, затв. Постановою КМУ від 01.04.2014 р. №333-р. URL: https://zakon.rada.gov.ua/laws/show/333-2014-\%D1\%80\#Text

2. Закон України «Про добровільне об'єднання територіальних громад» від 05.02.2015 p. №157-VIII . URL: https://zakon.rada.gov.ua/laws/show/157-19\#Text

3. Методика формування спроможних територіальних громад, затв. Постановою КМУ від 08.01.2015 p. №214. URL: https://zakon.rada.gov.ua/laws/show/ 214-2015-\%D0\%BF\#Text

4. Цілі сталого розвитку та Україна. Урядовий портал. URL: https://www.kmu.gov.ua/diyalnist/cili-stalogo-rozvitku-ta-ukrayina

5. Концепція сталого розвитку населених пунктів, затв. Постановою ВРУ від 24.12.1999 p. №1359-XIV. URL: https://zakon.rada.gov.ua/laws/show/1359-14\#Text

6. Бюджетний кодекс України від 08.07.2010 p. №2456-VI. URL: https://zakon.rada.gov.ua/laws/show/2456-17\#Text 


\section{ПІДВИЩЕННЯ РІВНЯ ЕКОНОМІЧНОЇ БЕЗПЕКИ ДЕРЖАВИ НА ІННОВАЦІЙНИХ ЗАСАДАХ}

\section{Денисенко Микола Павлович,}

д.е.н., професор, професор кафедри економіки та сфери обслуговування Київський національний університет технологій та дизайну

\section{Бреус Світлана Василівна,}

д.е.н., доцент, професор кафедри менеджменту та публічного адміністрування Київський національний університет технологій та дизайну

У світовій теорії та практиці існує достатньо механізмів, що сприяють активізації участі держави у створенні сприятливого інноваційного середовища та комерціалізації результатів досліджень. Найбільшого досвіду у цій сфері набули США, Великобританія, Франція, Канада, Німеччина, Гонконг, Японія, Індія, Китай, ПАР [1].

В Україні існує біля 200 документів [2], за допомогою яких здійснюється регулювання науково-технічної та інноваційної діяльності, однак поки що на державному рівні не створені необхідні умови для ії активізації. Як результат, відбувається зниження рівня інноваційної вітчизняної економіки, що справляє негативний вплив на економічний розвиток держави в цілому та рівень іiі економічної безпеки як складової національної безпеки України й становить загрози їй. Відповідно до Закону України «Про національну безпеку України» «загрози національній безпеці України - явища, тенденції і чинники, що унеможливлюють чи ускладнюють або можуть унеможливити чи ускладнити реалізацію національних інтересів та збереження національних цінностей України» [3].

Зростання ВВП провідних країн світу на 60-80 \% пов'язане з наукою [4]. В Україні ж частка витрат на виконання наукових досліджень і розробок у ВВП зменшилась з 0,75 \% у 2010 році до 0,43 \% у 2019 році (табл. 1) [5]. При цьому, відбулось збільшення витрат на виконання наукових досліджень і розробок у 2019 році порівняно з 2010 роком у 2,13 рази, у тому числі на виконання фундаментальних наукових у 1,72 рази, прикладних наукових досліджень - у 2,29 рази, науково-технічних (експериментальних) розробок - у 2,27 рази. Для порівняння, зростання витрат на виконання наукових досліджень і розробок 3 2014 року уповільнилось в цілому та за видами робіт. 
Таблиця 1

Витрати на виконання наукових досліджень і розробок за видами робіт

\begin{tabular}{|c|c|c|c|c|c|c|c|c|}
\hline \multirow[b]{3}{*}{ Роки } & \multirow{3}{*}{ 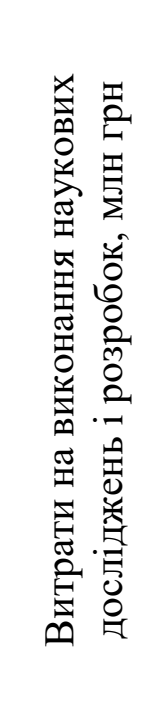 } & \multicolumn{6}{|c|}{ У тому числі на виконання } & \multirow{3}{*}{ 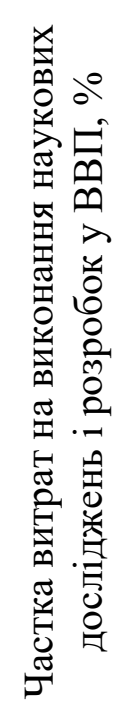 } \\
\hline & & \multicolumn{2}{|c|}{$\begin{array}{c}\text { фундаментальних } \\
\text { наукових } \\
\text { досліджень } \\
\end{array}$} & \multicolumn{2}{|c|}{$\begin{array}{c}\text { прикладних } \\
\text { наукових } \\
\text { досліджень } \\
\end{array}$} & \multicolumn{2}{|c|}{$\begin{array}{c}\text { науково-технічних } \\
\text { (експериментальних } \\
\text { ) розробок }\end{array}$} & \\
\hline & & $\begin{array}{l}\text { 莒 } \\
\text { 悬 }\end{array}$ & 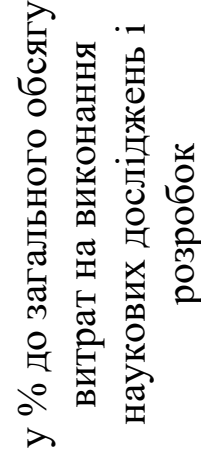 & 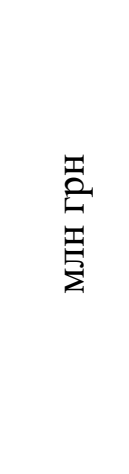 & 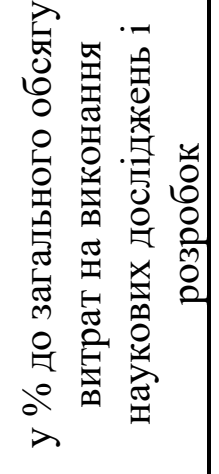 & 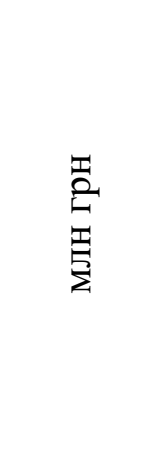 & 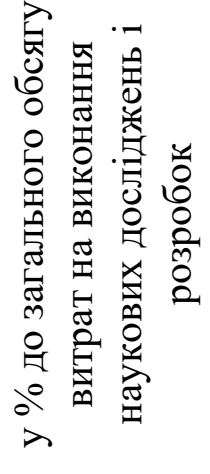 & \\
\hline $2010^{1}$ & 8107,1 & 2175 & 26,8 & 1589,4 & 19,6 & 4342,7 & 53,6 & 75 \\
\hline $2011^{1}$ & 8513,4 & 2200,8 & 25,9 & 1813,9 & 21,3 & 4498,7 & 52,8 &, 65 \\
\hline $2012^{1}$ & 9419,9 & 2615,3 & 27,8 & 2023,2 & 21,5 & 4781,4 & 50,7 & ,, 67 \\
\hline $2013^{1}$ & 10248,5 & 2698,2 & 26,3 & 2061,4 & 20,1 & 5488,9 & 53,6 & 0,7 \\
\hline $2014^{1,2}$ & 9487,5 & 2452 & 25,9 & 1882,7 & 19,8 & 5152,8 & 54,3 & 0,6 \\
\hline $2015^{1,2}$ & 11003,6 & 2460,2 & 22,4 & 1960,6 & 17,8 & 6582,8 & 59,8 & 0,55 \\
\hline $2016^{2}$ & 11530,7 & 2225,7 & 19,3 & 2561,2 & 22,2 & 6743,8 & 58,5 & 0,48 \\
\hline $2017^{2}$ & 13379,3 & 2924,5 & 21,9 & 3163,2 & 23,6 & 7291,6 & 54,5 &, 45 \\
\hline $2018^{2}$ & 16773,7 & 3756,5 & 22,4 & 3568,3 & 21,3 & 9448,9 & 56,3 & 0,47 \\
\hline $2019^{2}$ & 17254,6 & 3740,4 & 21,7 & 3635,7 & 21,1 & 9878,5 & 57,2 & 0,43 \\
\hline
\end{tabular}

${ }^{1}$ Дані за 2010-2015 роки перераховано без урахування витрат на виконання науковотехнічних послуг.

2 Дані за 2014-2019 роки наведені без урахування тимчасово окупованої території Автономної Республіки Крим, м. Севастополя та частини тимчасово окупованих територій у Донецькій та Луганській областях.

Джерело *. [5].

Аналізування даних табл. 2 свідчить про те, що найменше фінансувались фундаментальні дослідження, незважаючи на збільшення витрат на їх виконання в абсолютному вимірі з 2175 млн грн у 2010 році до 3740,4 млн грн у 2019 році (1,72 рази). Для порівняння, фінансування прикладних наукових досліджень збільшилось з 1589,4 млн грн у 2010 році до 3635,7 млн грн у 2019 році та склало 2,29 рази, науково-технічних (експериментальних) розробок - 34342,7 млн грн до 9878,5 млн грн (2,27 рази).

Причиною чого $\epsilon$ негативний вплив низки чинників зовнішнього та внутрішнього середовища. До зовнішніх чинників в сучасних умовах господарювання доцільно віднести такі: анексія АР Крим Російською Федерацією, нарощування обсягів зовнішньої агресії з боку Росії у результаті військових дій на сході України, що призводять до ескалації конфлікту в цій 
частині України та загострення ситуації Росією на Азовському узбережжі моря та, як результат, збільшення міграційних процесів усередині країни з Криму та зони проведення ООС (Операція об'єднаних сил) [6, с. 57]; нарощування обсягів пандемії, викликаних коронавірусною інфекцією COVID-19, що охопила практично усі країни світу та справила негативний вплив на економічний розвиток як окремих секторів їх економік, так і держав в цілому. Зовнішні чинники опосередковано, а почасти й безпосередньо сприяють дестабілізації економічної ситуації в країні та підсилюють негативну дію внутрішніх чинників, що знаходить прояв у зниженні рівня інноваційної активності суб'єктів господарювання, обсягів виробництва та реалізації продукції, погіршенні їх фінансово-економічних результатів, а також, як результат.

Для поглиблення дослідження його доповнено аналізуванням темпів приросту витрат на виконання наукових досліджень і розробок за видами робіт, результати якого наведено у табл. 2.

Таблиця 2

Темпи приросту витрат на виконання наукових досліджень і розробок за видами робіт

\begin{tabular}{|c|c|c|c|c|}
\hline \multirow{2}{*}{ Роки } & Темпи приросту витрат & \multicolumn{3}{|c|}{ У тому числі на виконання } \\
\cline { 3 - 5 } & $\begin{array}{c}\text { дослідження наукових } \\
\text { \% до попереднобок, }\end{array}$ & $\begin{array}{c}\text { фундаментальних } \\
\text { наукових } \\
\text { досліджень }\end{array}$ & $\begin{array}{c}\text { прикладних } \\
\text { наукових } \\
\text { досліджень }\end{array}$ & $\begin{array}{c}\text { науково-технічних } \\
\text { (експериментальних) } \\
\text { розробок }\end{array}$ \\
\hline $2010^{1}$ & $\mathrm{X}$ & $\mathrm{X}$ & $\mathrm{X}$ & $\mathrm{X}$ \\
\hline $2011^{1}$ & 5,01 & 1,19 & 14,12 & 3,59 \\
\hline $2012^{1}$ & 10,65 & 3,83 & 11,54 & 6,28 \\
\hline $2013^{1}$ & 8,80 & $-9,17$ & 1,89 & 14,80 \\
\hline $2014^{1,2}$ & $-7,43$ & 0,33 & $-8,67$ & $-6,12$ \\
\hline $2015^{1,2}$ & 15,98 & $-9,53$ & 4,14 & 27,75 \\
\hline $2016^{2}$ & 4,79 & 31,40 & 23,63 & 2,45 \\
\hline $2017^{2}$ & 16,03 & 28,45 & 12,81 & 8,12 \\
\hline $2018^{2}$ & 25,37 & $-0,43$ & 1,89 & 29,59 \\
\hline $2019^{2}$ & 2,87 & & & 4,55 \\
\hline
\end{tabular}

${ }^{1}$ Дані за 2010-2015 роки перераховано без урахування витрат на виконання науковотехнічних послуг.

2 Дані за 2014-2019 роки наведені без урахування тимчасово окупованої території Автономної Республіки Крим, м. Севастополя та частини тимчасово окупованих територій у Донецькій та Луганській областях.

Джерело *. Сформовано та розраховано за даними [5].

За даними табл. 2, є нестабільною динаміка зменшення темпів приросту витрат як в цілому на виконання наукових досліджень і розробок, так і за видами робіт. Так, темпи приросту витрат на виконання наукових досліджень і розробок у 2019 році порівняно 32014 роком становили 81,87 \%, у тому числі фундаментальних наукових досліджень - 52,54 \%, прикладних наукових досліджень - 93,11 \%, науково-технічних (експериментальних) розробок - 91,97 $\%$.

Складна ситуація у сфері фінансування науково-дослідної роботи на рівні країни негативно впливає на стан економічної безпеки держави в цілому та сприяє 
породженню загроз їй та національній безпеці, до основних з яких можна віднести такі [7, с. 249-250]:

- неефективність державної інноваційної політики, механізмів стимулювання інноваційної діяльності;

- недосконалість механізмів захисту прав інтелектуальної власності;

- низька конкурентоспроможність продукції;

- зниження внутрішнього попиту на підготовку науково-технічних кадрів для наукових, конструкторських, технологічних установ тощо.

Високі темпи економічного зростання у світі сьогодні забезпечуються за рахунок впровадження нових технологій та інновацій, розробки і виробництва нових видів продукції і послуг. В Україні, за даними [5] спостерігається негативна динаміка в освоєнні досягнень науки i, як результат, відбувається зменшення питомої ваги промислових підприємств, що здійснюють розробку й використання інновацій (табл. 3).

Таблиця 3

Впровадження інновацій на промислових підприємствах ${ }^{1,2,3}$ [5]

\begin{tabular}{|c|c|c|c|c|c|c|}
\hline $\begin{array}{l}\frac{5}{0} \\
\stackrel{0}{0}\end{array}$ & 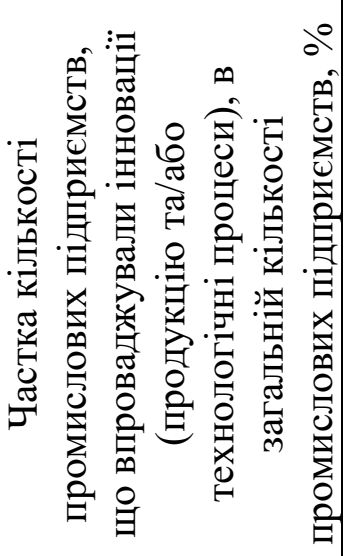 & 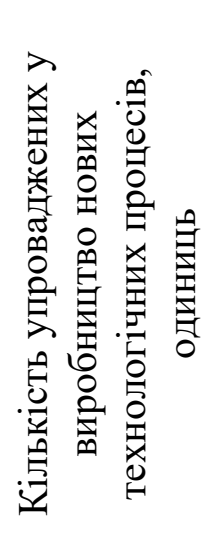 & 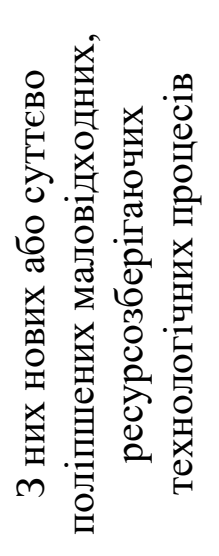 & 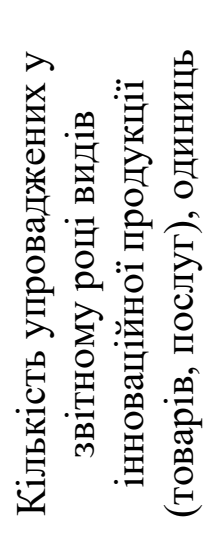 & 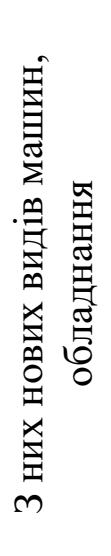 & 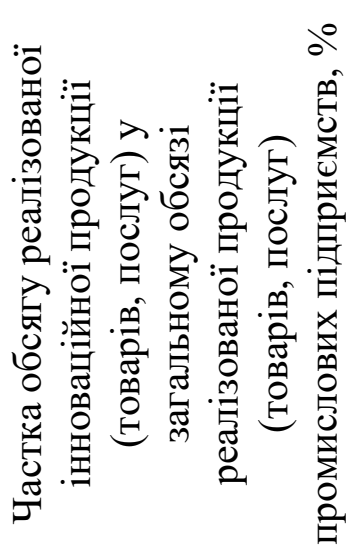 \\
\hline 2010 & 11,5 & 2043 & 479 & 2408 & 663 & 3,8 \\
\hline 2011 & 12,8 & 2510 & 517 & 3238 & 897 & 3,8 \\
\hline 2012 & 13,6 & 2188 & 554 & 3403 & 942 & 3,3 \\
\hline 2013 & 13,6 & 1576 & 502 & 3138 & 809 & 3,3 \\
\hline 2014 & 12,1 & 1743 & 447 & 3661 & 1314 & 2,5 \\
\hline 2015 & 15,2 & 1217 & 458 & 3136 & 966 & 1,4 \\
\hline 2016 & 16,6 & 3489 & 748 & 4139 & 1305 & 4 \\
\hline 2017 & 14,3 & 1831 & 611 & 2387 & 751 & 0,7 \\
\hline 2018 & 15,6 & 2002 & 926 & 3843 & 920 & 0,8 \\
\hline 2019 & 13,8 & 2318 & 857 & 2148 & 760 & 1,3 \\
\hline
\end{tabular}
які здійснювали промислову діяльність.

2 Дані за 2014-2019 роки наведені без урахування тимчасово окупованої території Автономної Республіки Крим, м. Севастополя та частини тимчасово окупованих територій у Донецькій та Луганській областях.

${ }^{3}$ Дані за 2015-2019 роки наведені по юридичних особах, які здійснювали промислову діяльність, із середньою кількістю працівників 50 осіб і більше.

Джерело *. [5]. 
Аналізування даних табл. 3 свідчить про те, що наявність негативних тенденцій впродовж 2010-2019 років, формування та нарощування яких свідчить про погіршення рівня інноваційного розвитку:

- низька частка кількості промислових підприємств, що впроваджували інновації (продукцію та/або технологічні процеси), в загальній кількості промислових підприємств (для порівняння: 13,8 \% у 2019 році проти 11,5 \% у 2010 році);

- незначне зростання кількості упроваджених у виробництво нових технологічних процесів, одиниць (13,46 \% у 2019 році порівняно з 2010 роком). При цьому, на 10,8 \% у 2019 році порівняно з 2010 роком зменшилась кількість упроваджених у звітному році видів інноваційної продукції (товарів, послуг), незважаючи на певне збільшення, яке становить 14,63 \%, кількості нових видів машин, обладнання;

- зменшення частки реалізованої інноваційної продукції (товарів, послуг) у загальному обсязі реалізованої продукції (товарів, послуг) промислових підприємств майже у 3 рази з 3,8 \% до 1,3\%.

Така ситуація справ в інноваційній сфері свідчить про доцільність розроблення та використання заходів за рахунок нівелювання чи принаймні зменшення впливу загроз економічній безпеці держави. Цього можна досягти, зокрема, шляхом стимулювання комерційної реалізації науково-технічних розробок з використанням досвіду розвинених країн світу у результаті консолідації збережених елементів інноваційної інфраструктури та активізації участі держави у цій сфері задля здійснення ефективного державно-приватного партнерства, об'єднання всіх регіональних ресурсів (державного й регіонального бюджетів, банків та підприємств) задля підвищення рівня економічної безпеки держави на інноваційних засадах [8-11].

\section{Список літератури:}

1. Комерціалізація результатів наукових досліджень: проблеми, підходи, інструменти, напрями розвитку.

URL: http://www.uintei.kiev.ua/viewpage.php?page_id=387 (дата звернення: 23.04.2021).

2. Кучерява 3. Правове забезпечення інноваційного розвитку в Україні. URL: http://www.minjust.gov.ua/0/13958 (дата звернення: 23.04.2021).

3. Закон України «Про національну безпеку України». Документ 2469-VIII, редакція від 24.10.2020, підстава - 912-IX. URL: https://zakon.rada.gov.ua/laws/show/2469-19\#Техt (дата звернення: 23.04.2021).

4. Семиноженко В. Комерціалізація винаходів - спільна справа бізнесу і держави. URL: http://seminozhenko.net/documents/2387/ (дата звернення: 24.04.2021).

5. Державна служба статистики України. http://www.ukrstat.gov.ua/ (дата звернення: 23.04.2021). 
6. Бреус С. В. Управління економічною безпекою системи закладів вищої освіти: проблематика використання ієрархічно-фасетного методу. Науковий вісник Ужгородського національного університету. Серія. Міжнародні економічні відносини та світове господарство. 2019. Вип. 24 (1). С. 55-63.

7. Ревак І. О. Інформаційна база оцінювання науково-технологічної безпеки України. Актуальні проблеми економіки. № 10 (112). 2010. С. 247-254.

8. Прантенко Г. Комерціалізація технологій у сучасних умовах в URL: http://www.experts.in.ua/baza/analitic/index.php?ELEMENT_ID=31888 (дата звернення: 23.04.2021).

9. Денисенко М. П., Бреус С. В. Науково-технологічна безпека: сучасні проблеми та перспективи ії забезпечення. Збірник тез доповідей міжнародної науково-практичної конферениії "Фінансова безпека та стратегічний розвиток держави", Київ - Полтава, 20-21 грудня 2012 року. Полтава: Верстка, 2012. 236 c. C. $130-132$.

10. Денисенко М. П., Бреус С. В. Заходи щодо стимулювання комерціалізації науково-технічних розробок. Тези доповідей IV Міжнародної науково-практичної відеоконференції "Управління інновачійним процесом $в$ Україні: проблеми комерціалізації науково-технологічних розробок" 23-24 травня 2012 р. Львів: Видавництво Львівської політехніки, 2012. 252 с. С. 17-18.

11. Денисенко М. П., Бреус С. В. Взаємозв'язок інноваційної політики та економічної безпеки держави. Ефективність управління в процесі реформування: макро-та мікроекономічний аспекти : колективна монографія / За наук. ред. проф. Радіонової І.Ф. К.: ВНЗ "Університет економіки та права "КРОК", 2012. 364 c. C. $191-201$. 


\section{ПРОБЛЕМИ РОЗВИТКУ СТАРОПРОМИСЛОВИХ ШАХТАРСЬКИХ РЕГІОНІВ: СВРОПЕЙСЬКИЙ ДОСВІД ІНСТИТУЩЙНОГО ВПОРЯДКУВАННЯ}

Драчук Юрій Захарович., д.е.н., професор

Сав’юк Лариса Олександівна, к.т.н., доцент, докторант

\section{Чейлях Дмитро Дмитрович, гол.економіст, Київ Інститут економіки промисловості НАН України}

Вступ. В даний час у Європейському Союзі набуває розвитку концепція необхідності розробки регіональних інноваційних стратегій смарт-спеціалізації, що визначається як практичний інструмент політики забезпечення орієнтованого на інновації сталого розвитку та згуртованості $\mathrm{CC}$, політики, що поєднує регіональну, інноваційну та промислову складові, як зазначається в роботі [1]. Старопромислові регіони (СПР) є територією з економікою, в якій домінують промислові комплекси, що розвивалися протягом певного часу, але на даний момент зазнають занепаду, мають відносно низький рівень технологічного розвитку, що призводить до втрати регіональних конкурентних переваг та мають погіршення якісних і кількісних характеристик ресурсної бази регіону [1;2;3]. «Проблема структурної модернізації СПР постала перед промислово розвиненими країнами ще наприкінці $70-\mathrm{x}$ - на початку 80 -х років минулого століття. У країнах СС проблему до початку XXI ст. було вирішено.. Але 3 початком глобальної економічної кризи у 2008 р. питання подолання соціальноекономічних наслідків залежності деяких регіонів від сфер економічної діяльності, що зазнали стагнації, знову постали серед актуальних та пріоритетних завдань перед політичними силами. Вимоги до промисловості щодо загострення екологічної ситуації, зокрема перехід до так званого безвуглецевого виробництва, ще більше актуалізували проблеми трансформації $\mathrm{C} \Pi \mathrm{\gg}[1]$.

Мета роботи. Розглянути інституційні та практичні засади виживання старопромислових шахтарських регіонів на основі інноваційних технологій, креативних підходів до управління ринками матеріальних та нематеріальних ресурсів в умовах наявності процесів стійкого занепаду вугільної промисловості, особливо за останні два десятиліття, що притаманно країнам в усьому світі.

Матеріали і методи. Свропейські країни та країни інших континентів знаходять та активно реалізовують проблеми виживання старопромислових шахтарських регіонів. Слід відзначити, що стагнація старопромилових 
шахтарських регіонів Донбасу має особливо тяжкий і тривалий характер, що пов'язано із пануванням в українській економіці перехідного укладу інверсійного типу, глибокою політичною кризою та військовими діями на сході нашої країни. Повернення тимчасово захоплених територій Донбасу у склад нашої держави, інтегрування старопромислових регіонів у економічну систему країни потребує негайних та ефективних заходів підтримки їхнього виживання та подальшого сталого розвитку. Як зазначається в роботі дослідників, в економічному відродженні «Донбас має стати територією для комплексного впровадження найсучасніших методів управління та організації економічних й виробничих процесів, де важливу роль відіграватимуть впровадження передових інноваційних технологій, застосування нових методів управління, інструментів та форм публічно-приватного партнерства, соціальної відповідальності бізнесу; механізмів цифрової економіки та смарт-індустрії, впровадження у виробничі процеси технологій індустріального Інтернету речей (ІІоТ), систем штучного інтелекту (для економії витрат, забезпечення умов безпеки, зміцнення ефективності всієї виробничої системи. На сьогодні перспективи інноваційного розвитку промисловості в Україні на базі IT технологій мають такі види діяльності як виробництво основних фармацевтичних продуктів, харчова промисловість, машинобудування, хімія та нафтохімія, металургія. Значна частина цих видів діяльності зосереджена саме на території Донбасу. Модернізація має забезпечити кардинальні зміни технологічного профілю Донбасу і виробничої системи України в цілому. Потрібна розробка та реалізація такого Національного проекту модернізації економіки України, в межах якого передбачатиметься реалізація Стратегії комплексного відродження та розвитку Донбасу. Ця Стратегія буде сприяти збереженню та розвитку інтелектуального, наукового, виробничого і кадрового потенціалу регіону, досягненню високих якісних стандартів виробництва, перетворенню Донбасу із всеукраїнської кузні в «Національний інноваційний технопарк»» [4, С. 236].

Результати і обговорення. Старопромислові шахтарські регіони, в тому числі й України, в умовах глобального господарювання, не можуть орієнтуватися на вугільно-видобувну галузь та повинні обрати власний шлях економічного відродження та розвитку на платформі відповідного світового досвіду. А світовий досвід свідчить про необхідність організаційних заходів на рівні держави, які б забезпечили професійну перепідготовку колишніх працівників вугільно-видобувної галузі старопромислових шахтарських регіонів.

Так, у США Аппалачський кам'яновугільний басейн (штати Пенсильванія, Огайо, Західна Вірджинія, Теннессі, Алабама, східна частина Кентуккі) - один 3 найбільших вугільних басейнів світу. Однак вугільна видобувна промисловість США протягом багатьох років веде боротьбу за своє виживання. Керівництво країни, починаючи із каденції адміністрації президента Б.Обами, реалізує політику щодо скорочення викидів вуглекислого палива "Чиста енергетика". Більшість економістів та енергетичних аналітиків погоджуються 3 тим, що 
згортання та падіння обсягів виробництва вугільної видобувної галузі пов'язані 3 потрійною суперечкою [5]:

- конкуренцією із набагато дешевшим і чистішим енергетичним носієм природним газом, що поширюється за допомогою технології крекінгу;

- зростанням виробництва сонячної та вітрової енергії;

- більш жорсткими національними та світовими екологічними нормами. Упродовж 2005 та 2015 років видобування вугілля в Аппалачському кам'яновугільному басейні зменшилося майже на 45\%. В результаті з 2011 року весь регіон втратив близько 33500 робочих місць у даній видобувній галузі промисловості. У 2016 році, згідно із повідомленням Кабміну з енергетики та навколишнього середовища штату Кентуккі рівень розвитку вугільної видобувної галузі промисловості американської держави опустився до найнижчої точки за останні 118 років. Кількість робочих місць по всій країні скоротився на 17,9\%, що склало 6900 працівників у цій галузі. При цьому штат Кентуккі втратив 21,6\% своїх робочих місць галузі, сьогоднішній рівень безробіття у штаті Кентуккі становить від 9 до 12\%, а при врахуванні неповної робочої зайнятості - 44\%. У той же час штат Кентуккі прагне до розвитку програм забезпечення альтернативної зайнятості та професійної перепідготовки шахтарів, які працюють за допомогою поєднання місцевих, державних, федеральних, приватних та громадських програм. Ускладнення реалізації реабілітаційних програм для шахтарів полягає у тому, що багатьом шахтарям, особливо старшим, не вистачає ступеня коледжу, що $є$ наслідком добре оплачуваних гірничих робіт, які були доступними починаючи із середньої школи. Тому курси спеціалістів для автомобільної, зварювальної та електротехнічної спеціалізації є найбільш популярними серед гірників, особливо старшого покоління. Структурна зміна видобувних районів - це складний процес, який кидає виклик містам, регіонам та уряду у всьому світі. Він включає економічні, соціальні, екологічні та культурні зміни. Країни європейської союзу також прикладають значні зусилля до вирішення проблем виживання та трансформації старопромислових шахтарських регіонів. Навіть, якщо видобуток корисних копалин триває 3 довгостроковими перспективами. в цих регіонах важливість видобутку зменшується, а економіка перебуває в перехідному періоді і є ряд потенціалів для їх відродження та сталого розвитку [6]. У Західній Свропі ця тема знаходиться у колі політичних дискусій та наукових роздумів протягом останніх 50 років. Дебати в основному зосереджені на великих вугільних i сталевих регіонах, таких як Північно-Східна Англія та Уельс (Великобританія), Валлонія та Лімбург (Бельгія), Нор-Па-де-Кале і Лотарингія (Франція), Рур і Caар (Німеччина), та Астурія (Іспанія). У зазначених районах закінчення видобутку спровокувало загальний спад промисловості. Вплив був далекосяжним, приносячи економічний, соціальний та екологічний збиток старопромиловим регіонам. 3 урахуванням економічної та політичної важливості згаданих регіонів, їх відродження ставиться завдання "національної важливості" та виклик урядам, профспілкам та великим підприємствам.

Досвід успішного трансформування старопромислових шахтарських регіонів доводить, що основна увага повинна приділятися так званим 
"потенціалам" гірничих регіонів. Ці потенціали можна визначити як спадщину видобутку сировини, яку можна експлуатувати та оцінити навіть після припинення видобутку корисних копалин. С дві категорії потенціалу: природні; культурні. Природні потениіали - це гірські ландшафти, відновлювані джерела енергії та термальні води. Культурні потенціали - це штучні релікти, такі як технічні споруди, будівлі та інфраструктура, а також традиції шахтарів. Існує сенс розрізняти їх, оскільки обидві категорії мають різні можливості та шляхи використання. Концепція потенціалів відрізняється від категорії «спадщини», що розглядається в основному в контексті "збереження". Розвиток потенціалів після гірничих робіт включає, наприклад, такі аспекти спадщини, як використання старопромислових гірничих споруд в якості музеїв. Такі приклади мають позитивний соціальний вплив на старопромислові регіони - нейтралізацію історичного та культурного занепаду, протекціонізм ремесел, нейтралізацію безробіття та інша [7]. Це також може бути пов'язано з такими поняттями, як "інновація" та "модернізація". Концепція потенціалу дає стратегічний штрих економічній перебудові регіонів. Більше того, "потенційний підхід" легко поєднується з міськими та регіональними питаннями відродження. Це відповідає таким тенденціям розвитку, як економіка ресурсів, адаптація до клімату, перетворення енергії та сталий розвиток. Концепція також може поширюватися на регіональну ідентичність та традиції. У цьому сенсі вона може відігравати прогресивну роль у системі спілкування політичних зацікавлених сторін. На відміну від більшості наукових починань на сьогоднішній день, в цьому ракурсі вирішуються проблеми гірничих регіонів з малими та середніми містами, переважно розташованими на зовнішній та внутрішній периферії країн. Ця просторова категорія часто обмежена загальними функціями. Такі райони наділені малоефективною інфраструктурою. Особливо бракує високоякісних навчальних закладів, таких як університети та дослідницькі центри. Малі та середні міста стають все менш важливими для бізнесу та промисловості у багатьох країнах. I місцева влада, як правило, не має широких можливостей для практичних дій. Малі та середні міста мають невелику адміністративну спроможність для планування, розробки стратегій та контролю за їх виконанням. Загалом, політика мало приділяє уваги цьому типу гірничого регіону.

Слід відзначити, що Європейський досвід вказує не необхідність проведення всебічного аналізу демографічної, економічної ситуації та зайнятості населення у кожному регіоні. Основна увага повинна приділяється фактичним та інституційним аспектам змін при одночасній розробці ефективних управлінських рішень, довготривалої стратегії розвитку із залученням всіх учасників процесу - держави, промислових та бізнес структур, соціального підприємництва, представників громадськості [8]. Аналіз кожного регіону повинен ззавершуватися обгрунтуванням системи потенціалів та стратегічними заходами їх втілення. На основі заздалегідь розроблених та заповнених статистичних форм встановлено відмінність між ефективними, довготривалими проектами з використання культурних потенціалів (наприклад, музеїв гірничих робіт, туристичних шляхів, пов'язаних із гірничо-видобувними роботами) та новими, фінансово витратними (переважно пілотними) проектами використання 
природних потенціалів, наприклад як виробництво біомаси на деградованій землі або геотермальної енергії для централізованого опалення (Табл.1).

Можна зауважити, що українські вчені проводили та проводять власні аналітичні дослідження для реалізації можливостей використання куотурного потенціалі стааропроислових шахтарських регіонів. Так, ними запропоновані активізація рекреаційно-туристичної діяльності в промисловому Донбаському регіоні та соціальне підприємництво в розвитку зеленого туризму у даному промисловому регіоні $[9,10]$.

Таблиця 1. Європейський досвід використання природних i культурних потенціалів (розроблено авторами згідно джерела [6]

\begin{tabular}{|c|c|c|}
\hline $\begin{array}{c}\text { Природні } \\
\text { потенціали }\end{array}$ & Ландшафт & Відновлювана енергія \\
\hline \multirow[t]{4}{*}{$\begin{array}{l}\text { Досвід та } \\
\text { регіон } \\
\text { реалізації }\end{array}$} & $\begin{array}{l}\text { Встановлення } \\
\text { гірськолижних трас } \\
\text { (Боттропі, Німеччина) }\end{array}$ & $\begin{array}{l}\text { Інноваційна технологія шахтної } \\
\text { води для обігріву та охолодження } \\
\text { будівель (Херлен - Нідерланди; } \\
\text { Німеччина) }\end{array}$ \\
\hline & $\begin{array}{l}\text { Геологічні музеї } \\
\text { відкритим небом } \\
\text { під } \\
\text { (Ганті та } \\
\text { Уготі }\end{array}$ & $\begin{array}{lcr}\text { Виробництво } \quad \text { біомаси } \\
\text { біологічного } \\
\text { гірських землях } \\
\text { сатеріалу } \\
\text { сад" у мнергетичний } \\
\text { мелзов, Німеччина) }\end{array}$ \\
\hline & $\begin{array}{l}\text { Створення місцевості для } \\
\text { пішого туризму, їзди на } \\
\text { велосипеді } і \text { т.д. } \\
\text { («Ерцберг Родео» в } \\
\text { Айзенерці в Австрії, } \\
\text { бігова траса в Мості) }\end{array}$ & $\begin{array}{l}\text { Використання термальної води зі } \\
\text { старої свинцевої шахти в } \\
\text { лікувальних цілях, тунельна } \\
\text { терапія (Блейберг (Австрія) }\end{array}$ \\
\hline & $\begin{array}{lr}\text { Створення } & \text { озерних } \\
\text { районів } & \text { затопленням } \\
\text { відкритих литих вугільних } \\
\text { шахт, забезпеченням } \\
\text { об'єктів для купання, } \\
\text { водних видів спорту та } \\
\text { судноплавства (Чеська } \\
\begin{array}{l}\text { Республіка, Польща та } \\
\text { Німеччині) }\end{array}\end{array}$ & $\begin{array}{l}\text { Природний } \\
\text { потенціал для } \\
\text { відновлення міст та регіонів, для } \\
\text { покращення якості життя, простір } \\
\text { для зелених зон відпочинку, } \\
\text { спорту та іншого дозвілля } \\
\text { (Лужицьке озеро в Східній } \\
\text { Німеччині, Валбжич, Польща) }\end{array}$ \\
\hline
\end{tabular}




\begin{tabular}{|c|c|c|}
\hline $\begin{array}{l}\text { Культурні } \\
\text { потенціали }\end{array}$ & Традиція & $\begin{array}{l}\text { Гірничі будівлі } \\
\text { інфраструктура }\end{array}$ \\
\hline \multirow[t]{2}{*}{$\begin{array}{ll}\text { Досвід } & \text { та } \\
\text { регіон } & \\
\text { реалізації } & \end{array}$} & $\begin{array}{l}\text { Фольклорні товариства, } \\
\text { місцеві духові оркестри, } \\
\text { святкування дня шахтаря } \\
\text { як стратегії розвитку } \\
\text { туризму }\end{array}$ & $\begin{array}{l}\text { Музеї на основі сучасних та } \\
\text { iнноваційних } 1 \text { презентаційних } \\
\text { концепцій } 33 \text { активними } \\
\text { елементами («Друзі Радверка IV } \\
\text { у Ворденбергу», Штирійський } \\
\text { залізний шлях Австрія) }\end{array}$ \\
\hline & & $\begin{array}{l}\text { Видобувні шахти у якості музеїв } \\
\text { iз звуковими та світловими } \\
\text { ефектами } \\
\text { (Terra Mysticax Bad Bad } \\
\text { Bleibergs (Kapiнтія, Австрія) }\end{array}$ \\
\hline $\begin{array}{l}\text { Потенціали } \\
\text { росту }\end{array}$ & $\begin{array}{l}\text { Людський } \\
\text { освіта }\end{array}$ & Економічні стимули \\
\hline
\end{tabular}

При реалізації Європейського досвіду інституційного впорядкування розвитку старопромислових шахтарських регіонів може бути розглянуто наступні проблеми [6, С. 26-27]:

1. Трансформація системи та потенціали старопромислових шахтарських регіонів. Як доводить досвід, на етапах структурних змін важко залучати зовнішні інвестиції. Поганий інвестиційний клімат може бути спричинений низкою факторів, таких як екологічні збитки, неінноваційне середовище та фактори представлення проблеми. У таких ситуаціях важливими стають потенціали росту, такі як людський капітал, освіта та економічні стимули. Дослідження можуть допомогти уточнити процедури об'єднання людського капіталу та потенціалів старопромислових шахтарських регіонів.

2. Розробка стратегії та потенціали старопромислових шахтарських регіонів. Генерування стратегій розвитку стало невід'ємною частиною міського та регіонального розвитку в останні десятиліття. Такі стратегії повинні охоплювати багато окремих факторів: - навколишнє середовище; економіку; культуру. Вони необхідні для забезпечення орієнтації, мотивації у визначенні та реалізації цілей. Потенціали для старопромислових шахтарських регіонів $\epsilon$ сполучною ланкою між екологічною та культурною реабілітацією, з одного боку, та економічним розвитком з іншого.

3. Традиції, туризм та потенціали для видобутку альтернативних корисних копалин. В останні десятиліття багато місць, що займаються гірничодобувною справою, були модернізовані як об'єкти природної та культурної спадщини. Але місця культурної спадщини в основному розглядаються як окремі приклади збереження та розвитку природних та культурних благ. Не часто зустрічається сума потенціалів. Виняток становлять «Монтанрегіон Ерцгебірге» в Німеччині та «Штирейський залізний шлях» в Австрії. 3 наукової точки зору необхідно дослідити вплив ініціатив спадщини в 
масштабних ландшафтах старопромислових шахтарських регіонів на економіку регіону, ринок праці, ідентичність такої стратегії та її сприйняття громадськістю.

3. Потенціали участі громадськості. Реабілітація часто $є$ ексклюзивним процесом, що об'єднує місцеві та регіональні еліти, але нехтує потребами людей, які живуть та працюють у даних умовах. Це може призвести до ігнорування із боку громадськості неоптимальних рішень, конфліктів і, нарешті, - посилення негативних наслідків. Дані потенціали можуть стати силою для залучення людей до процесів, натхнення нових і кращих рішень та цікавих молодих людей для участі у проектах по відновленню та відродженню старопромислових шахтарських регіонів. Такі дослідження можуть сприяти визначенню ступеня сприйняття та мотивації місцевого населення до відповідних трансформаційних процесів.

4. Модернізація. Міста та регіони старопромислових шахтарських регіонів пов'язують із такими негативними явищами як екологічна шкода та економічний занепад. На цьому тлі використання потенціалів старопромислових шахтарських регіонів може стати частиною інноваційних концепцій їхнього розвитку. Якщо інновації розглядаються як регіональне завдання, в якому беруть участь учасники різних галузей та рівнів, творче використання гірничих потенціалів може сприяти модернізації гірських міст та регіонів. Оскільки в невеликих містах та віддалених регіонах можна знайти багато перешкод, дослідження повинні проводитися з метою аналізу ініціатив 3 передової світової практики.

Висновки. Реалізація інституційного впорядкування розвитку старопромислових шахтарських регіонів у повному обсязі та у стислі терміни можлива при використанні та поєднанні всіх їх потенційних можливостей та ініціатив 3 передової світової практики. Деградація старопромислових шахтарських регіонів відбувається на тлі нестачі кваліфікованих працівників у багатьох галузях промисловості. Проблему можна вирішити шляхом формування у працівників необхідних якісних характеристик та компетенцій, що потребує часу i загальної освіти, профорієнтаційної роботи, професійної теоретичної та практичної підготовки, адаптації працівників до сучасних вимог трудової діяльності.

\section{Список літератури:}

1.Циркулярна смарт-спеціалізація старопромислових шахтарських регіонів України: монографія / Д.Ю. Череватський, М.О. Солдак, О.В. Лях, Ю.С. Залознова та ін.; за заг. ред. О.І. Амоші / НАН України, Ін-т економіки пром-сті. Київ, 2020. 196 с.

2. Жаліло Я.А., Снігова О.Ю. Послаблення залежності економіки старопромислових регіонів України від зовнішньоекономічних чинників як стратегічний орієнтир структурної політики. Стратегічні пріоритети. 2012. № 1 (22). С. 85. 
3.Хаджинов І.В. Старопромислові регіони України: тенденції розвитку. Теоретичні і практичні аспекти економіки та інтелектуальної власності. 2012. Вип. 1. т. 3. С. 72.

4. Амоша О. І., Новікова О. Ф., Залознова Ю. С., Панькова О. В., Касперович О. Ю. Формування моделі стратегічного розвитку Донбасу: від сучасних реалій до візії майбутнього. Економічний Вісник Донбасу, 2020, №3. C. 234-245.

5. This Kentucky coal town is fighting for survival long after the war on coal is over [Електронний pecypc] // CNBC. - 2018. - Режим доступу до ресурсу: https://www.cnbc.com/2018/03/29/the-kentucky-coal-town-fighting-to-survive-aftercoal-mining-closings.html.

6. Peter Wirth, Barbara Černič Mali, Wolfgang Fischer (Editors). Post-Mining Regions in Central Europe - Problems, Potentials, Possibilities [Електронний pecypc] / Peter Wirth, Barbara Černič Mali, Wolfgang Fischer (Editors) // oekom, München. 2012. - Режим доступу до ресурсу: https://www.ioer.de/fileadmin/internet/IOER_Projekte/PDF/FB_L/Book_Publication _Post-Mining_Regions_in_Central_Europe.pdf.

7. Yuriy Drachuk, Irina Dultseva World experience to create competitive a adventages in tourism on the principles of social intepreneurship // International Journal of Economics and Society April 2015, Issue 1.- C. 227-230.

8. Драчук Ю.З., Дульцева I.І. Чинники розвитку туристичних підприємств на засадах соціального підприємництва // Інноваційна стратегія і тактика фінансово-економічного розвитку суб'єктів національного господарства. Матеріали міжнар. наук.практ. конф.: Буковинський державний фінансовоекономічний університет.- Ч. II.- 19-20 грудня 2014 р.-Чернівці, 2014.- С.171-174.

9. Драчук Ю.З. Мотиви і активізація рекреаційно-туристичної діяльності в промисловому РЕГІОНІ «ДОНБАС» // Матеріали Всеукр. наук.-практ. конф. Можливості та розвиток сучасного туризму: світовий та національний досвід.16-17 жовт. 2014 р., Запоріжжя. - С. 165-170

10. Дудьцева I.I., Драчук Ю.З. Соціальне підприємництво в розвитку зеленого туризму промислового регіону // Електронна версія наукового журналу "Молодий вчений. - №2 (17). - лютий , 2015. - Частина 6. - С.1057-1061. 


\title{
ЗВ'ЯЗОК СТАЛОГО РОЗВИТКУ ТА ЕКОНОМІЧНӦ̈ БЕЗПЕКИ
}

\begin{abstract}
Кірсанова Вікторія Василівна
кандидат економічних наук, доцент, доцент кафедри обліку, аналізу і аудиту, Державний університет «Одеська політехніка»
\end{abstract}

\section{Янковська Ольга Андріївна аспірантка, Державний університет «Одеська політехніка»}

В сучасних турбулентних умовах одним з найважливіших завдань будь-якої країни $€$ забезпечення сталого розвитку на усіх рівнях господарювання. 3 огляду на це, важливість ролі економічної безпеки організації підкреслюється під час іiі визначення як чинника сталого розвитку.

Науковці зазначають, що сталий розвиток є стабільним, узгодженим, розрахованим на тривалу перспективу економічним і соціальним розвитком на основі підтримуваного використання природних ресурсів для забезпечення потреб теперішнього і майбутнього поколінь інформаційного суспільства $[1, \mathrm{c}$. 48].

Вважають, що економічну безпеку треба розглядати як фінансовоекономічний стан підприємства, який сприяє забезпеченню захищеності його фінансово-економічних інтересів від негативних факторів зовнішнього та внутрішнього середовища і створенню необхідних фінансово-економічних умов для безперервної успішної діяльності та сталого розвитку підприємства [2].

Зв'язок сталого розвитку та економічної безпеки зображено на рис. 1.

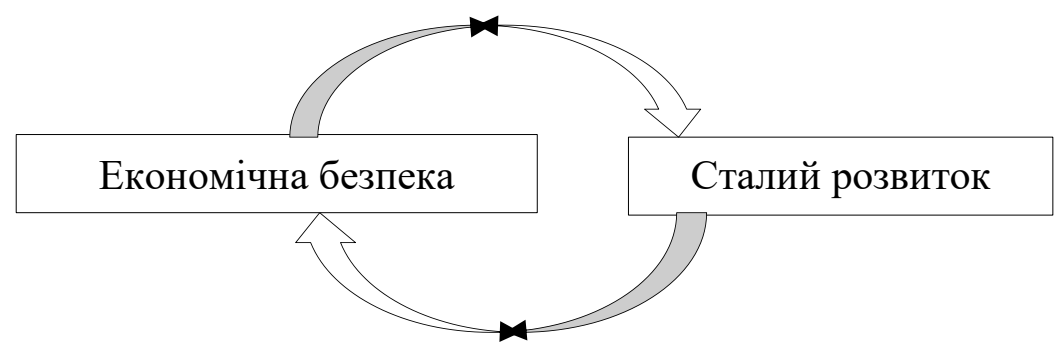

Рисунок 1. Модель зв'язку економічної безпеки та сталого розвитку підприємства

Простежується залежність між економічною безпекою суб'єкта господарювання та можливостями задовольнити різноманітні запити стейкхолдерів. Зв'язок розкривається у наступній взаємодії: умова - економічна безпека, мета - сталий розвиток. Зростання рівня розвитку обумовлює його більшу стійкість до негативних впливів.

У цьому випадку під безпечним розвитком організації розуміється найбільш оптимальний стан ії економіки, що орієнтується на неспинний сталий розвиток, умовою досяжності якого є захищеність від дестабілізаторів. 
Н. В. Васюткіна [3, с. 80] виокремлює наступні види розвитку організації: прогресивний, що характеризується зростанням показників діяльності, адаптивний, що відображає пристосування суб'єкту господарювання до змін, трансформаційний, що передбачає перетворення наявного стану за рахунок використання потенціалу підприємства, та сталий, який розглядається, як комбінація особливостей та характеристик прогресивного, адаптивного та трансформаційного.

Основою модернізації та реформування збалансованого економічного розвитку підприємства $\epsilon$ удосконалення складових безпеки, a саме: інституційної, соціальної, економічної та екологічної. Доцільно виявити альтернативи та напрями переходу до бажаного стану згідно визначених менеджерами цілей [4, с. 41].

Можна зазначити, що сталий розвиток та економічна безпека суб'єкта господарювання є взаємозалежними, взаємопов'язаними і взаємообумовленими. Вони не можуть існувати окремо та забезпечуються за рахунок один одного.

Впровадження концептуальних засад сталого розвитку на підприємствах, особливо інноваційно активних, сприятиме підвищенню рівня економічної безпеки, ефективності та оптимізації ризик-менеджменту, довіри з боку зацікавлених осіб, ділової репутації, конкурентоспроможності та потенціалу у перспективі.

\section{Список літератури:}

1. Кириченко М. О. Інформатизація як фактор оптимізації ідеології інформаційного суспільства та забезпечення його сталого розвитку. ScienceRise: pedagogical education. 2017. № 1 (9). C. 46-50.

2. Бондарчук Н. В., Гуменчук М. С. Сутність фінансово-економічної безпеки підприємства та необхідність її забезпечення. Ефективна економіка. 2016. № 11. URL: http://www.economy.nayka.com.ua/?op=1\&z=5409.

3. Васюткіна Н. В. Методологічні засади управління сталим розвитком авіапідприємств: дис. ... д-ра екон. наук: 08.00.04 / Нац. авіац. ун-т. Київ, 2015. $541 \mathrm{c}$.

4. Харазішвілі Ю. М. Системна безпека сталого розвитку: інструментарій оцінки, резерви та стратегічні сценарії реалізації: монографія. Київ: НАН України, Ін-т економіки пром-сті, 2019. 304 с. 


\title{
НЕКОТОРЫЕ ОСОБЕННОСТИ ПРОГНОЗИРОВАНИЯ ЭФФЕКТИВНОСТИ ИНВЕСТИЦИОННЫХ ПРОЕКТОВ АПК СЕВЕРНОГО РЕГИОНА
}

\begin{abstract}
Мустафаев Азиз Агасалимович,
Кандидат экономических наук, старший научный сотрудник, Институт социально - экономических и энергетических проблем

Севера ФИЦ Коми научный центр Уральского отделения Российской академии наук, г. Сыктывкар, Российская Федерация AuthorID: 500448

Захариев Радослав Любомиров

Магистр, старший инженер, Институт социально - экономических и энергетических проблем Севера ФИЦ Коми научный центр Уральского отделения Российской академии наук, г. Сыктывкар, Российская Федерация
\end{abstract}

Первостепенными задачами обеспечения эффективности АПК Республики Коми являются периодическое прогнозирование ее инвестиционных проектов, разработка новых моделей и прогнозов перспективного инвестирования его сфер и предприятий. Среди ключевых проблем АПК доминирующая роль принадлежит взаимообусловленным категориям «инвестиционное развитие» и «роста производства», постоянному обновлению производственных мощностей и улучшение основных (количественных и качественных) параметров выпускаемых товарных продукций. Увеличение объема и улучшение качества эксплуатируемых материальных и нематериальных ценностей АПК - это надежный гарант роста производства его сфер и предприятий.

Актуальность данного исследования, с одной стороны, связана с улучшением теоретико-практических положений обеспечения эффективности инвестиционного проекта АПК, активизации процессов обновления производственных сфер, то с другой, необходимостью преодоления сложившихся трудностей из-за специфических природно-климатических, экономических, экологических, инфраструктурных, демографических и иных условий развития АПК региона. Так как объективная природа ведения сельского хозяйства в Северном регионе обусловлена с колоссальными природноэкономическими, инфраструктурными, социальными, экологическими, и иными трудностями - повышенными затратами труда и средствами.

Ocобое внимание заслуживает регулярная оценка эффективности инвестиционного проекта сельского хозяйства АПК региона, представляющей собой целесообразность развития региональной перерабатывающей промышленности на основе современной техники и технологии. Исторический 
опыт показывает, что общее состояние дел в АПК региона можно судить не только по характеру процессов, по степени происходящих изменений, но и по оценкам прогнозных расчетов, состоянием инвестиционной среды.

Отсюда вывод, что процессы прогнозирования эффективности инвестиционных проектов АПК создают своеобразный «механизм», которой обеспечивает принципами равноправного финансирования и функционирование всех его сфер на длительный период времени. Сохранение эффективности инвестиционного проекта за вес период его осуществления приводит к существенным структурным трансформациям рыночных и институциональных отношений АПК, укреплению кооперационных и интеграционных основ его развития [1, с. 158$]$.

Нельзя забывать о том, что при неоднородности характера объектов очень сложно определить функциональные признаки и свойства действующих хозяйственных субъектов АПК. Так как последнее создает неблагоприятные ситуации в межотраслевом ареале АПК, разрушает принципы равноправного финансирования и функционирование его отдельных сфер и предприятий. Следовательно, в зависимости от межотраслевой специфики и степеней неопределенности хозяйственной деятельности, эффективность инвестиционных проектов АПК может иметь различные результаты.

С учетом всесторонней сложности функционирования АПК северного региона, проблемы прогнозирования эффективности его инвестиционного проекта должно стать приоритетной задачей. Именно прогнозирование эффективности инвестиционного проекта АПК содержит решение ключевых задач в долгосрочной стратегии его развития. Особое значение при этом имеет обеспечение эффективного управления инвестиционным проектом АПК. Так как «управление проектами - это набор инструментов, применяемых для достижения в проекте поставленных целей с учетом специфики работ, установленного бюджета и сроком выполнения» [2, с. 78]

Научно обоснованное инвестиционное развитие АПК региона определяет объемы и времени требуемых вложений и обеспечение его эффективности в долгосрочном функционировании. Исходя из этого, основными затратами инвестиционного проекта следует отнести следующих: затраты на научноисследовательские и опытно конструкторские (НИОКР) разработки; затраты на организационно-управленческие меры осуществление производства; затраты для формирования оптимальной структуры основного и оборотного капиталов; затраты на повышение квалификации работников и их эффективной расстановки; затраты на улучшение характеристики обрабатываемых земель; затраты для формирования производственных и социальных инфраструктур; затраты на рекреационные работы, обеспечение защиты окружающей среды; затраты на формирование рыночных инфраструктур, улучшение маркетинговой деятельности.

Следует особо отметить, что обеспечение рациональной структуры производственного и потребительского потенциалов сфер и предприятий АПК региона предопределяют будущее положение их на товарном рынке. Это говорит о разработке прогрессивных принципов и созданию необходимых условий, 
способствующих обеспечению целостности и целесообразности вложения по конкретным хозяйственным направлениям, сохранению устойчивого темпа роста производства. Полноценный и эффективный проект инвестирования АПК региона должен остановить процессы разрушения его экономического потенциала, противостоять дезинвестиционной тенденции функционирования, замедлить темпы оттока сельскохозяйственных работников в другие сферы, активизировать заказы на высокотехнологичную продукцию, повысить уровень конкурентоспособности собственной продукции [3, с. 225].

Эффективность инвестиционного проекта в большей степени зависит от своевременного обнаружения и устранения различных негативных явлений и последствий в основном технологическом цикле АПК. Так как в рамках технологической цепочке «финансы-наука-производство-рынок» данные последствия могут присутствовать в их каждом элементе. Все вопросы, тесно связанные с эффективной реализацией инвестиционного проекта АПК региона, требуют не только сбалансированности ресурсов (материальных, трудовых, земельных, финансовых и др.), но и обеспечению коммерческих интересов участников данного проекта.

С этой точки зрения, инвестиционный прогноз воплощает в себя совокупные научно-методические предпосылки для проведения детального анализа об эффективности АПК. Иными словами, прогнозирование эффективности инвестиционного проекта АПК является своеобразным индикатором, определяющим не только общее состояние и движение агропромышленных сфер и предприятий на перспективу, но и предварительную величину выпускаемого товарного продукта и ожидаемого дохода и иных эффектов.

Учитывая специфические особенности отраслей и предприятий АПК региона необходимо констатировать, что теоретические подходы не всегда соответствует практическим задачам прогнозирования эффективности его инвестиционных проектов. Иными словами, разрабатываемые на основе прогнозных расчетах, капитальные и текущие затраты не всегда совпадают с ожидаемыми результатами - объемами производства, реализацией товарной продукции и получением необходимого дохода.

Причиной этого является множество негативно воздействующих факторов и явлений: природно-климатические, финансово-экономические, рыночные, административные, правовые и т.д. Неправильный учет происходящих изменений в хозяйственных координатах АПК региона приводит не только к некорректности агропромышленных прогнозов, но и нерациональному использованию различных видов вложений - деструктуризацию размещаемых производительных сил.

Необходимо учитывать, что любая неблагоприятная ситуация, создавая своеобразный барьер, не дает возможность более реально оценить долгосрочные потребности АПК на необходимые капитальные ресурсы. Последствиями этого является сужение потребительского спроса агропромышленных предприятий, замедление темпов обновления сфер производства АПК по многочисленным объектам. С замедлением темпов инвестирования появляется дезинвестиционная тенденция обновления производственных сфер АПК, что тормозит процессы и 
масштабы проводимой модернизации, реконструкции и техническое перевооружение хозяйствующих субъектов в различных координатах и видах деятельности.

Отсюда вывод, что исходя из совокупности воздействующих факторов, существующих специфических условий и особенностей функционирования, а также быстроменяющийся производственно-рыночных обстоятельств, разработка эффективности инвестиционного проекта АПК и обеспечения роста производства требует особого подхода. Следовательно, в силу неблагоприятных природных явлений, происходящих различных административно-правовых изменений и сложившейся неблагоприятной финансово-экономической обстановке, значительная часть инвестиционных задач АПК региона остается не решенным. В большинстве случаев это завершается провалом или срывом в реализации инвестиционных проектов, потерей большей части производимой товарной продукции и ожидаемого дохода.

Нельзя забывать о том, что любые изменении в системе АПК вместе с положительными результатами создают и своеобразную питательную среду для проявления множество негативных факторов, которые способствуют росту ошибок и вероятностей снижения эффективности. Поэтому для прогнозирования эффективности инвестиционного проекта АПК региона необходимо иметь как системно-комплексный, так и частный подход. Частный подход в свою очередь тоже имеет собственные задачи, методы и результаты, делит прогнозы на этапы, что в большей степени связано со спецификой прогнозирования конкретных видов деятельности агропромышленных сфер.

В целом все варианты прогнозирования инвестиционного проекта подлежат к периодической научно обоснованной разработке с использованием современной информационной технологии. Отметим, что анализ состояния основных технико-экономических показателей не дает обнадеживающих успехов устойчивого развития АПК региона, наблюдается мало возможностей его долгосрочного инвестиционного развития. При всем разнообразии поставленных задач, важное место принадлежит формированию надежной интеграционной цепочке АПК, начиная от научных разработок до создания и реализации новой агропродовольственной продукции. Для достижения данной цели необходимо периодическая разработка крупных инвестиционных проектов, которые смогут обеспечить перевод региональных агропромышленных предприятий на исключительно интенсивно-инвестиционный путь развития [4, c. 86].

Надо отметить, что, несмотря на стремление обеспечить прозрачность прогнозных расчетов эффективности инвестиционного проекта АПК, есть определенные трудности достижение цели. К числу их основных следуют отнести: некорректность измерения инвестиционных потребностей в различных отраслях, подотраслях и видах деятельности; недостаточность учета технологически взаимосвязанных процессов в сельском хозяйстве; несвоевременное обнаружение допущенных ошибок и происходящих изменений; неспособность оперативного обнаружения природно-климатических изменений; малого опыта определение уровня инфляции, хозяйственной 
неопределенности и инвестиционного риска; невозможность определение уровня диспаритета цен между сельским хозяйством и промышленностью; отсутствие навыков организационно-управленческой деятельности, применение устаревших методов производственно-рыночного функционирования.

Большую сложность представляют проблемы прогнозирования величины затрат на следующие основные цели: на проведении научных исследований, приобретение и внедрение инновационных результатов; на приобретение основного и оборотного капитала; на осуществление реконструкции действующих объектов и модернизации технологически взаимосвязанных процессов; на развитии интеллектуального капитала: инновационного, человеческого, организационного, управленческого, клиентского, отношенческого; на улучшение качественной характеристики земельных угодий.

Исследование показывает, что эффективность любого проекта АПК обусловлена состоянием его отраслей и предприятий: уровнем технической оснащенности и технологии производства; урожайностью сельскохозяйственных культур и продуктивностью животных; уровнем специализации и концентрации производства, степенью межотраслевой и межхозяйственной интеграции; уровнем производительности труда, себестоимостью продукции и рентабельности производимой и реализуемой продукции; степенью достоверной разработки прогнозов: краткосрочной, среднесрочной, долгосрочной, дальнесрочной.

Подчеркнем, что стремление повысить долгосрочную эффективность инвестиционного проекта АПК сопряжено не только с изменением внешней среды, но и субъективных и объективных факторов: ужесточением требований, стандартов, законодательства и т.д. [5, с. 313]. Учитывая, что факторы субъективного характера полностью зависят от практической деятельности самого человека, от его знаний, подготовленности, опыта работы, а также ориентации в условиях рынка, то допущенные ошибки или нарушения в технологии производства продукции приводят, как правило, к непредсказуемым последствиям. Любая ошибка или недостаток опыта работников негативно сказываются в конечных результатах хозяйственной деятельности. При этом есть и объективные факторы, которые не зависят от человека, такие как природно-климатические условия (морозы, наводнение, оползни, грады и т.д.); сезонный характер производства; диспаритет цен; проценты на кредит; налоговые ставки на прибыль; колебание мировых цен и их влияние на основные виды агропромышленной продукции; инфляционные процессы и т.д.

Вывод. Резюмируя, отметим, что в рыночных условиях хозяйствования, наращивание темпов производства и обеспечение высокого качества и низкой себестоимости выпускаемой продукции невозможно без долгосрочного прогнозирования эффективности инвестиционных проектов. Как правила, результаты хозяйственной деятельности АПК во многом определяются объемами капитальных вложений и применением новой техники и технологии. Это требует соблюдению следующих обязательств: научное обоснование вложений с учетом долгосрочной потребности производства на необходимые 
капитальные и иные ресурсы; обоснование спроса и предложения агропродовольственной продукции на перспективу; определение конкурентоспособности действующих сфер, предприятий и товарной продукции; выявление состояний производственных, потребительских, инновационных и иных потенциалов АПК; оценка состояний трудовых ресурсов и земельных угодий в сельском хозяйстве.

Учитывая, что сельское хозяйство АПК региона из-за сложных природноэкономических условий хозяйствования подвергается к большому количеству рисков, то его инвестиционная привлекательность в большей степени будет находиться на низком уровне. В таких случаях особое значение имеет государственная финансово-экономическая поддержка сельского хозяйства. Дело в том, что новые потребности населения выдвигают более сложные требования к производителям агропродовольственной продукции. Такое требование в большей степени связано с выпуском более широких ассортиментов и качественных товаров, имевших наименьшие производственные затраты и низкие цены. Это говорит о том, что в условиях острой рыночной конкуренции, производителю необходимо более детально изучить потребности покупателей, улучшить количественные и качественные параметры выпускаемой товарной продукции в соответствии с мировым стандартом.

\section{Список литературы}

1. Суворова Л.А. / Институциональные и региональные аспекты управления развитием интеграционных образований / Материалы XI Всероссийской научнопрактической конференции с международным участием /. Уфа, 2019, С.158.

2. Биглова А.А.,, Едренкина Т.А./Особенности применения проектного менеджмента в сфере HR/Материалы XII Международной научно-практической конференции internet-конференции/. Уфа, 2018, С.78.

3. Татаркин А.И., Львов Д.С., Куклин А.А./монография «Моделирование устойчивого развития как условие повышения экономической безопасности»/. Екатеринбург, 1999, С.225

4. Мустафаев А.А./Экономический потенциал - основа устойчивого развития АПК/монография «Факторы и условия устойчивого развития агропродовольственного комплекса и сельских территорий Севера/. Сыктывкар, 2011, C.86

5. Бурима Л.Я., Литвинчук А.А./Использование критериев оценки состояния предприятия для совершенсвования системы экологического управления в условиях происходящих социально-экономических изменений/Материалы IV Международной научно-практической конференции «Проблемы развития экономики и сферы сервиса в регионе». Сыктывкар, 2010, С.313 


\section{ФІНАНСОВИЙ КОНТРОЛЬ В УКРАЇНІ}

Тсшева Лариса

к.е.н., доцент кафедри економіки та менеджменту Харківський національний університет імені В. Н. Каразіна

\section{Алекссєва Валерія}

студентка 3 курсу

Харківський національний університет імені В. Н. Каразіна

\section{Пустовалова Олеся}

студентка 3 курсу

Харківський національний університет імені В. Н. Каразіна

Задля підтвердження ролі і значення будь-якої держави у регулюванні розвитку економіки та зростання добробуту суспільства, у всьому світі запровадженій механізм державного фінансового контролю.

Фінансовий контроль за своєю економічною суттю це функція управління, яка включає сукупність спостережень, перевірок за діяльністю об'єкта управління з метою оцінки його обгрунтованості й ефективності прийняття рішень і результатів їх виконання. Таким чином, можна сформулювати сутність фінансового контролю як систему заходів органів влади, спрямованих на забезпечення законності дій учасників господарського процесу під час складання, розгляду, затвердження, внесення змін, виконання бюджетів i звітування про їх виконання. Мета цього контролю - це виявлення недоліків у фінансовому процесі, а об'єктом фінансового контролю $є$ фінансові показники діяльності, які регламентують процес формування, розподілу, перерозподілу і використання грошових ресурсів та відображають законність їх кругообігу.

Класичним прикладом організації державного фінансового контролю $\epsilon$ Сполучені Штати Америки. В США чинна система державного фінансового контролю інкорпорована в державно-правову систему як необхідний елемент державного регулювання балансу повноважень законодавчої і виконавчої влади. Взаємодія двох гілок державної влади в цій сфері здійснюється з допомогою як парламентського контролю за діяльністю міністерств i відомств, так i адміністративного й фінансового контролю президента за діяльністю його адміністрації. Міністерство фінансів США реалізує міжвідомчий фінансовий контроль за допомогою спеціальних служб, до яких зокрема віднесено Податкову службу США. [1].

Провідними фінансовими контролюючими органами США $є$ Головне контрольне-фінансове управління, що відноситься до гілки законодавчої влади, та Адміністративно-бюджетне управління, що відноситься до складу адміністрації президента. Головне контрольно-ревізійне управління США було створене майже 80 років тому, як незалежний від федеральної адміністрації орган, 3 метою контролю за правильністю й ефективністю використання 
бюджетних коштів виконавчими органами, включаючи й Міністерство оборони. Це управління має доступ практично до всіх фінансових документів міністерств і відомств. В його штаті близько п'яти тисяч співробітників, більшість 3 яких працює у Вашингтоні і значно менша частка їх зайняті в регіональних бюро та зарубіжних представництвах.

Адміністративно-бюджетне управління - бюджетне бюро США, яке $\epsilon$ частиною адміністрації президента і завдання якого є допомагати формуванню координованого федерального бюджету для його подання до Конгресу. Коли бюджет прийнято, управління контролює його виконання та подає дані про поточне виконання федерального фінансування. Завданням адміністративнобюджетного управління $є$ також вивчення заявок на бюджетне фінансування федеральних органів та щоквартальне виділення коштів.

Саме складна система органів фінансового контролю США, де всі органи здійснюють незалежну діяльність, може здійснювати державну фінансову політику найбільш ефективно. Причиною цього є гнучкість такої системи, висока спеціалізація окремих органів і підрозділів, взаємний контроль за діяльністю таких органів, що зменшує корупцію [1].

Становлення інституту державного фінансового контролю в Україні відбулось одночасно 3 процесом державотворення і формуванням ринкової економіки. Статтею 346 Угоди про асоціацію між Україною та Європейським Союзом (підписана та ратифікована Свропарлатентом та Верховною радою України в 2014 році) передбачено, що співробітництво в галузі управління державними фінансами спрямовується на забезпечення розвитку бюджетної політики і надійних систем внутрішнього контролю та зовнішнього аудиту, що базуються на міжнародних стандартах, а також відповідають основоположним принципам підзвітності, прозорості, економності, ефективності та результативності.

Сьогодні державна політика у сфері державного фінансового контролю України спрямовується і координується Кабінетом Міністрів України через Міністерство фінансів. Ключовими інституціями фінансового контролю України $\epsilon$ державний фінансовий контроль, що своїй діяльності керується Конституцією України, Бюджетним кодексом України, іншими законодавчими актами, актами Президента України та Кабінету Міністрів України.

До державного фінансового контролю відносять учасників фінансових відносин (юридичні особи та фізичні особи, які беруть участь у формуванні, розподілі, перерозподілі та використанні фінансових ресурсів у державі) та суб'єктів державного фінансового контролю (державні контролюючі фінансові органи та суб' єкти суспільних фінансових відносин, зазначені вище).

Система державного фінансового контролю має будуватися на єдиних принципах, на єдиних нормах та нормативах функціонування й розв'язання поставлених завдань 3 чітким визначенням органів контролю та розподіленням ïx функцій і повноважень. Такими принципами $є$ незалежність, гласність, превентивність (попередження), дієвість, регулярність, об'єктивність та всеохоплюючий характер [2]. 
Фінансовий контроль, як економічна категорія, поділяється на види за певними критеріями на підставі яких виділяють попередній фінансовий контроль, поточний фінансовий контроль і наступний фінансовий контроль. Такі види контролю притаманні усім контролюючим органам.

Попередній фінансовий контроль здійснюється на етапі розгляду і прийняття рішень 3 фінансових питань, а поточний фінансовий контроль - це контроль за безпосередньою оперативною фінансовою діяльністю, тобто, за фінансовим процесом. Наступний фінансовий контроль - це контроль за фінансовими результатами діяльності.

В залежності від суб'єктів, що здійснюють фінансовий контроль, він поділяється на державний фінансовий контроль, внутрішній фінансовий контроль , громадський фінансовий контроль та аудит.

Ключовим компонентам фінансового контролю за управлінням та використанням державними та місцевими ресурсами $є$ державний фінансовий контроль, який здійснюють органи Офісу фінансового контролю (до 2019 року - Державна аудиторська служба України), уповноважений Кабінетом Міністрів України (урядовий контроль), державний зовнішній фінансовий контроль (аудит), який здійснює Рахункова палата від імені Верховної Ради України (парламентський контроль), та державний внутрішній фінансовий контроль, зокрема внутрішній контроль та внутрішній аудит, який забезпечується відповідно розпорядниками бюджетних коштів та внутрішнім аудитом в бюджетній сфері.

На відміну від Сполучених Штатів Америки, в Україні керівника вищого органу фінансового контролю призначає не законодавча гілка влади, а Кабінет Міністрів України, виконавчий орган. Тому, враховуючи світову практику, було б доцільно розглянути можливість залучення законодавчого органу України до процесу призначення керівництва вищого органу державного фінансового контролю. Враховуючи визначений нашою державою курс на децентралізацію, позитивний досвід таких країн, як Сполучені штати Америки і наявні проблеми 3 корупцією, $є$ необхідість розглянути можливість переходу української системи державного фінансового контролю на автономну модель. Автономна модель передбачає, що контролюючі органи можуть не входити до складу єдиної організаційної структури, призначатися законодавчим органом влади відповідної території та залишатись незалежними у зовнішніх та внутрішніх питаннях своєї діяльності .

Для того, щоб перейняти досвід Сполучених Штатах Америки у здійснені фінансового контролю, необхідно ухвалити ряд положень, наприклад: проголошення Рахункової палати України провідним органом державного фінансового контролю $з$ повноваженнями із проведення контрольних заходів i притягнення винних до відповідальності, посилення ролі Верховної Ради України у сфері контролю за діяльністю та функціонуванням Рахункової палати та передача частини повноважень Офісу фінансового контролю на місцевий рівень.

Відповідно до Закону України "Про основні засади здійснення державного фінансового контролю в Україні", державний фінансовий контроль 
забезпечується органом державного фінансового контролю через проведення державного фінансового аудиту, інспектування, перевірки закупівель та моніторингу закупівлі.

Відповідно до Закону України "Про Рахункову палату", Рахункова палата здійснює контроль за надходженням коштів до Державного бюджету України та їх використанням від імені Верховної Ради України. До повноважень Рахункової палати України не включено аудит власних надходжень органів місцевого самоврядування та доходів і видатків державних підприємств. Проведені аудити ефективності, але не в повній мірі відповідають міжнародним стандартам, рекомендації Рахункової палати в найбільших випадках мають загальний характер[3].

Механізм фінансового контролю в Україні, знаходиться на етапі свого становлення та реформування і не в повній мірі відповідає міжнародно визнаній практиці фінансового контролю. Державний внутрішній фінансовий контроль в Україні перебуває в процесі системного становлення. Зараз все ще триває перехід від карально-наглядового підходу в державному фінансовому контролі до системи контролю та превентивності, що передбачає досягнення чітко визначених результатів та забезпечення ефективного використання коштів платників податків [4].

Незважаючи на значну кількість органів державного фінансового контролю, учасники фінансових відносин нерідко припускаються порушень, які негативно впливають на стан державних фінансів. Серед таких порушень можна виокремити нецільове та/або неефективне використання бюджетних коштів, ухилення (свідоме і несвідоме) від виконання податкових зобов'язань, неподання (або несвоєчасне подання, або неправильне складання) фінансової звітності, знищення документації тощо.

Слід зазначити, що подальше реформування системи державного фінансового контролю в Україні має проходити з урахуванням досвіду провідних спеціалізованих міжнародних організацій.

Органами Держаудитслужби за попередні роки, проведено низку масштабних заходів державного фінансового контролю на виконання доручень Кабінету Міністрів України, а також за зверненням правоохоронних органів [5]. 3 метою підвищення рівня управління бюджетними ресурсами на місцях, оптимізації видатків місцевих бюджетів і зміцнення їх доходної частини упродовж січня-жовтня 2020 року органами Держаудитслужби проведено 90 заходів контролю з питань виконання місцевих бюджетів різних рівнів, з яких 4 ревізії та 86 державних фінансових аудитів. 


\section{млрд грн}

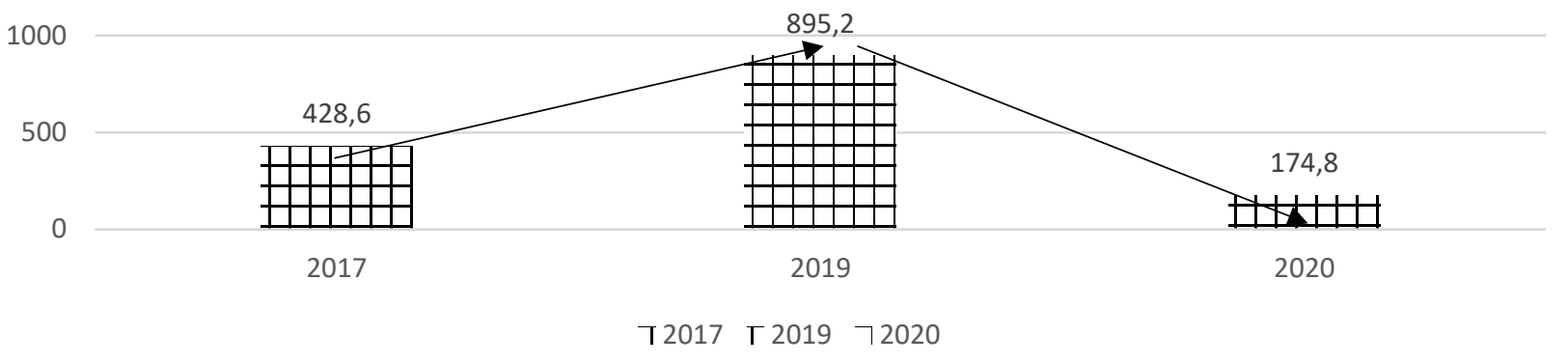

Рисунок 1.1 - Обсяги охоплених контролем фінансових та матеріальних ресурсів у 2017 - 2020 роках

Джерело: складено автором за $[6,7]$.

Так, у 2017-2018 роках під час перевірок охоплювалось в середньому 570,0 млрд грн фінансових ресурсів, а у 2019 році використано майже 895,2 млрд грн. I це $\epsilon$ позитивною тенденцією, проте у 2020 році обсяг фінансування та проведення перевірок значно зменшився через пандемію коронавірусу. Тому в порівняні з 2019 роком у 2020 році було охоплено контролем у 5 разів менше ресурсів.

Сума виявлених втрат ресурсів у середньому на один перевірений об'єкт контролю за 2019 рік становить майже 1,2 млн гривень. Загалом за результатами ревізій та перевірок виявлено втрат фінансових і матеріальних ресурсів на понад 1,7 млрд гривень. Відповідна динаміка наведена на рис. 2.2.

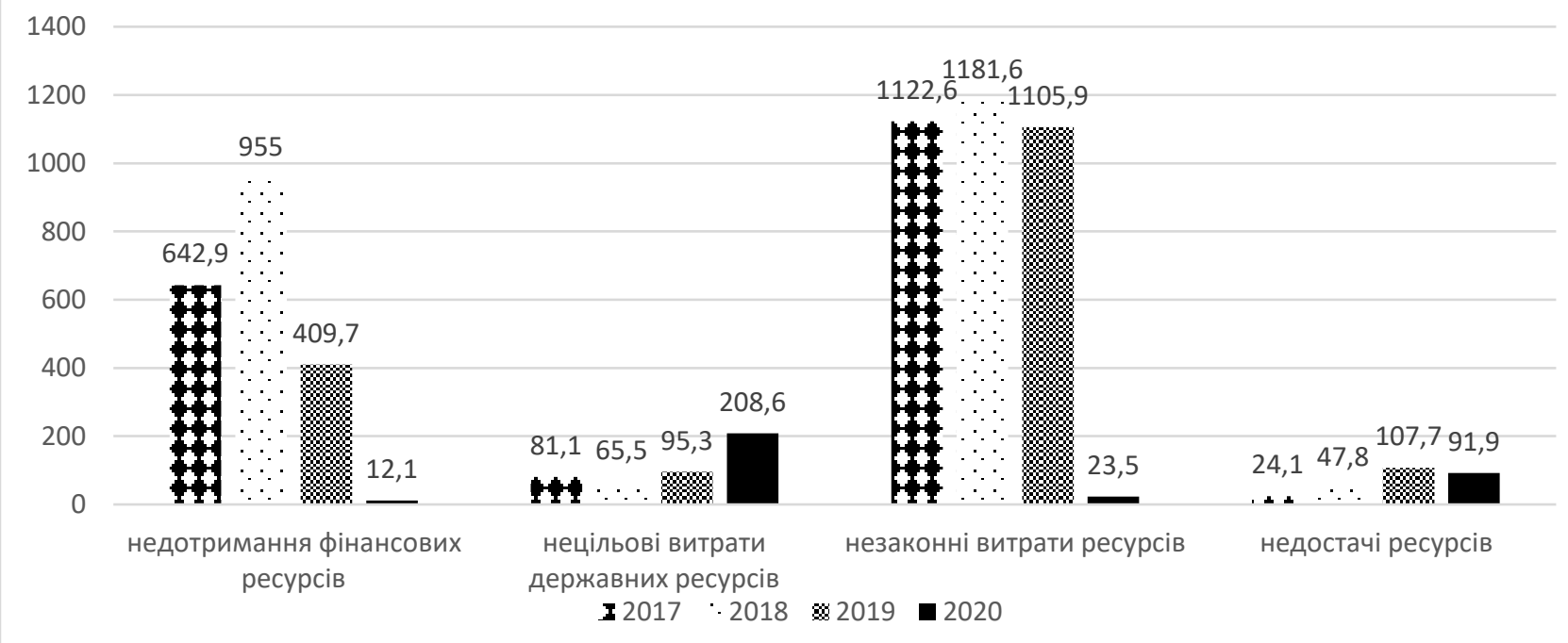

Рисунок 2.2 - Динаміка обсягів порушень, що призвели до втрат ресурсів, виявлених органами Держаудитслужби протягом 2017-2020 років

Джерело: складено автором за $[6,7]$.

Зокрема, внаслідок неправомірних дій окремих керівників, реалізації товарів, робіт та послуг за заниженими цінами, безоплатного надання в оренду природних і матеріальних ресурсів тощо бюджетами усіх рівнів, бюджетними установами та організаціями, підприємствами втрачена можливість отримати належні їм доходи на суму понад 409,7 млн грн, у тому числі бюджетами різних рівнів - близько 215,9 млн гривень. У 2020 році під час пандемії недоотримання 
фінансових ресурсів значно зменшилося, проте нецільові витрати державних ресурсів збільшилися більше ніж удвічі.

На сьогодні в Україні система фінансового контролю продовжує розвиватись шляхом формування нових органів та удосконалення вже існуючих. При цьому, якість управлінських дій , на жаль, не забезпечує високих результатів контролюючих функцій, а практична та наукова складова здійснення контролю, не встигає за потребами суспільства і не відповідає сучасним вимогам.

Причиною слабкості діючої системи контролю у фінансовій сфері $\epsilon$ проблеми координації органів фінансового контролю та їхньої співпраці 3 іншими органами державної влади. Недосконалість системи навчання та підвищення кваліфікації державних аудиторів зумовлює проблему кадрового забезпечення органив финансового контролю. Також, можна відмітити i відсутність співпраці органів фінансового контролю України з європейськими органами протидії фінансово-економічним правопорушенням, недостатній рівень розуміння органами державної та місцевої влади, а також суб'єктами господарювання, важливості функції державного фінансового аудиту, що сприяє відсутністю взаємодії між ними та органами контролю.

Проте, нажаль, слабкість теоретико-методологічної та практичної основи, яка протягом тривалого часу існувала в організації фінансового контролю в Україні, сприяла зростанню обсягів фінансових порушень за останні роки. Зокрема, до зниження ефективності фінансово-контрольних функцій держави призвели використання застарілих форм контролю, які не дають змоги державі оперативно й ефективно впливати на процеси, що відбуваються в економіці, забезпечувати контроль над найбільш пріоритетними напрямками фінансової діяльності. Адже, від ефективності державного фінансового контролю багато в чому залежить і добробут населення.

Таким чином, розглянувши стан фінансового контролю в Україні, можна дійти висновку, що на сучасному етапі фінансовий контроль потерпає серйозних змін. Отже, виконання основних завдань реформування цього виду контролю буде сприяти побудові в країні цілісної та ефективної системи державного фінансового контролю, а це, в свою чергу, призведе до зміцнення фінансової дисципліни , зменшення зловживання у сфері використання державних фінансів та рівня корупції.

\section{Список використаних джерел:}

1. Здійснення державного фінансового контролю в зарубіжних країнах / Даценко Г.В., Шпильова Д.В., Синиченко К.Г. - [Електронний ресурс]. Режим доступу до http://www.rusnauka.com/11_EISN_2010/Economics/64441.doc.htm pecypcy:

2. Державний фінансовий контроль: навч. посіб. / Л.В. Гуцаленко, В.А. Деревій, М.М. Коцупатрий. - К.: Центр учбової літератури, 2009. - 424 с.

3. Аналіз чинної нормативної бази системи контролю за використанням публічних фінансів в Україні / Марта Семеряк - [Електронний ресурс]. Режим доступу до ресурсу: https://ces.org.ua/wp-content/uploads/2018/04/PFCLegislation-Analysis_ukr.pdf ( дата звернення 25.03.2020) 
4. Перспективи розвитку правового регулювання фінансового контролю в Україні / I. I. Попадинець. // Науковий вісник Ужгородського національного університету. - 2017. - С. 35 - 37 с..

5. Модернізація механізмів фінансового контролю та аудиту як складових антикорупційної політики / Мельник В.М., Єлізаренко Н.О., Національний інститут стратегічних досліджень. - 2018.

6. Звіт про результати діяльності Дежавної аудиторської служби України, iї міжрегіональгних територіальних органів за 2019 рік - [Електронний pecypc].

Режим доступу до pecypcy: http://www.dkrs.gov.ua/kru/uk/publish/article/146977 ( дата звернення 26.03.2020)

7. Звіт про результати діяльності Дежавної аудиторської служби України, iii міжрегіональгних територіальних органів за 2020 рік - [Електронний ресурс]. Режим доступу до ресурсу: https://data.gov.ua/dataset/fae4be91-dd05-4c2e-845b25d1cf18b4ca/resource/6108c426-9bb5-4627-bfaf-a73e02d46710?inner_span=True 


\title{
THE INFLUENCE OF CLIMATE CHANGE ON THE ECOLOGICAL CONDITION OF THE OSKIL RIVER BASIN
}

\author{
Rybalova Olha, \\ Ph.D., Associate Professor, \\ National University of Civil Defence of Ukraine \\ Stupka Taisiia \\ student \\ National University of Civil Defence of Ukraine
}

An intensive use of surface water and an excessive anthropogenic impact predetermine the fact that most of the Siverskyi Donets basin rivers belong to class III (polluted) (by the average performance levels) [1] and category 4 (slightly contaminated) (by the environmental assessment of surface water quality for the respective categories) [2]. Changes in the water quality depend on the anthropogenic impact, climatic conditions, landscape and ecological features, as well as physical and geographical peculiarities of the river basin.

The authors of [3] state that a multivariate nature of water quality determines the complexity of its investigation. The research problem is aggravated by an insufficient justification of the theoretical and methodological bases and an ambiguous use of instrumental methods, which complicates the attempts of disclosing the mechanisms of water quality formation that are aimed at improving the control over water protection activities.

Obvious climatic changes due to an increase in average air temperatures and an increased variability of precipitation significantly affect the formation of water quality. Numerous studies predict that climate change may have considerable effects on water quality $[4,5]$ and on the biotic component of aquatic ecosystems $[6,7]$.

Miscellaneous conditions and factors influencing the formation of groundwater quality predetermine the need to study the factors that have the biggest impact. Studies in this area are topical due the fact that contemporary climate changes and an intensive use of water resources require identifying the largest sources of pollution of surface waters for further development of a complex of environment protection measures.

The largest left tributary of the Seversky Donets River is the Oskil River. Its length is $472 \mathrm{~km}$, the area of the basin - 14,800 km2 (according to other sources - 14,680 $\mathrm{km} 2$ ). The Oskil River flows into the Seversky Donets at $580 \mathrm{~km}$ from the mouth. [8].

The Oskil River basin is of cross-border importance because it flows within two countries - Russia and Ukraine. The total length of the river is $472 \mathrm{~km}$, of which 290 $\mathrm{km}$ flows through the territory of Kharkiv region. The total catchment area is 14,800 $\mathrm{km} 2$, of which $3,830 \mathrm{~km} 2$ are located in the Kharkiv region (fig.1). 


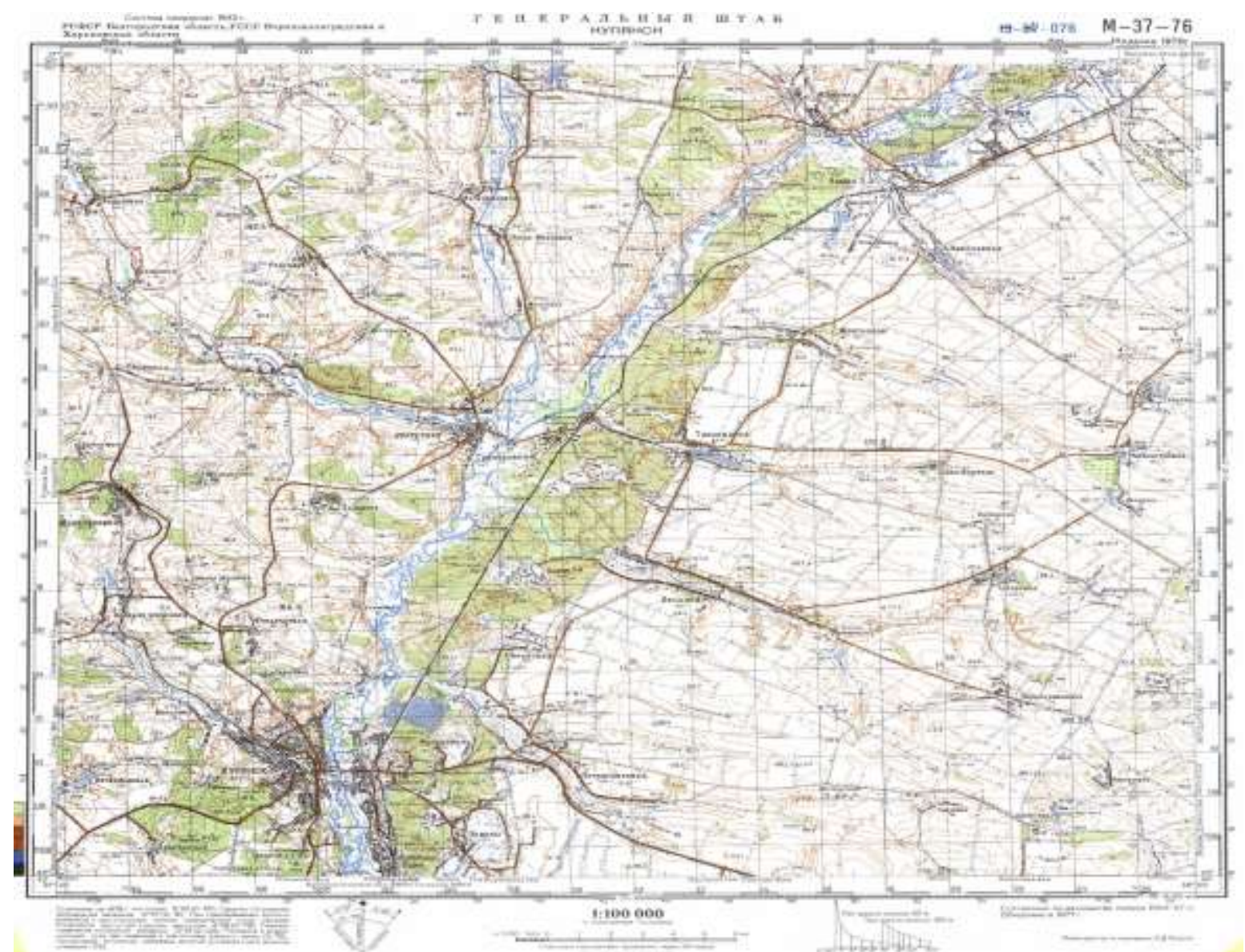

Figure 1.Map of the Oskil river basin in the Kharkiv region

The Oskil river is the largest (left) tributary of the Siverskyi Donets and is important for the whole river basin in Ukraine. The Oskil waters are used in the agricultural and industrial sectors and support the hydraulic system of the Siverskyi Donets-Donbas canal. The Oskil river basin has cross-border significance as it is located both in Russia and Ukraine.

The vast majority of rivers and reservoirs of the Kharkiv region degrades through an excessive human pressure that dominates over the ability of self-cleaning and selfhealing. Significant river changes have been caused by failure of legislation and rules for the use of land in water protection zones and coastal strips.

When planning water protection activities and identifying priority issues, it is important to assess the actual ecological state of a selected aquatic site and obligatorily consider pool features and factors that have the greatest influence on the formation of aquatic ecosystems.

Particularly important is research on climate changes, because the analysis of longterm observations on climate changes in the Kharkiv region have showed that in recent years, namely since 1992, there has been a tendency of the average air temperature to increase. Such changes may further provoke uncontrollable effects on aquatic sites since they have significant direct and indirect impacts, especially on such important characteristics as precipitation, water consumption, as well as hydrochemical and hydrobiological indicators.

Modern concepts of water management increasingly emphasize the preventive character of the necessary measures and recognize the importance of acting now to adapt to the effects of global warming in the future [9]. 
Ecological assessment is a prerequisite for environmental regulation of surface water quality, its preliminary stage. According to the method [2] according to the analytical quality control of surface waters of Kharkiv region according to the average annual indicators for 2019, the ecological index was calculated (Table 1).

Table 1.

Ecological assessment of water quality of Oskil river basins according to observations in 2019

\begin{tabular}{|c|c|c|c|c|c|c|}
\hline \multirow[b]{2}{*}{ Observation point } & \multicolumn{6}{|c|}{ Indices, categories, classes } \\
\hline & $\mathrm{I}_{\text {ecep }}$ & $\mathrm{K}_{\text {ecep }}$ & Кл & $\mathrm{I}_{\text {емакс }}$ & $\mathrm{K}_{\text {емакс }}$ & КЛ \\
\hline Oskil, village Krasny Oskil, bridge & 3,75 & 4 & 3 & 6 & 6 & 4 \\
\hline Oskil, Kupyansk & 3,6 & 4 & 3 & 5 & 5 & 3 \\
\hline Oskil, border with Russia & 3,46 & 4 & 3 & 5 & 5 & 3 \\
\hline
\end{tabular}

Assessment of the ecological condition of the watercourses of the Oskil river basin showed that they are in a very poor condition (3-4 quality class), especially small rivers, which are most sensitive to anthropogenic load.

The ranking of watercourses in the Oskil River basin in the Kharkiv region by the value of the integrated ecological index in 2019 showed that the river Solona is in the worst condition (5th grade, 7 th category). In general, almost all studied watercourses have poor quality, which corresponds to quality class 4 .

Analysis of the previous studies shows that many of them are devoted to the impact of climate changes on the quantitative and qualitative characteristics of water resources $[10,11]$. Examples of such studies indicate heterogeneity of climate changes and ambiguity of their effects on different aquatic sites, so when planning water protection measures it is necessary to study the natural conditions of the formation of a selected aquatic site.

The long-term dynamics of climate change have been studied by means of the following parameters: an average air temperature and precipitation from 1969 to 2018; a predictive model was built by the Holt-Winters method.

We have studied the Oskil hydrological parameters such as the runoff volume and water consumption for 65 years, from 1953 to 2018, and constructed predictive models.

Models built by the Holt-Winters method are widely used to develop long-term prognoses. The chosen method has advantages as it takes into account seasonality and the general tendency and uses a three-parameter exponential smoothing

While monitoring the average temperature in the Kharkiv region according to the State Committee for Hydrometeorology from 1969 to 2018 and building a predictive model, we have revealed an expected global warming by $1.9^{\circ} \mathrm{C}-$ from $7.8^{\circ} \mathrm{C}$ to $9.7^{\circ} \mathrm{C}$ - in 2030 (Fig. 2). The blue colour in Fig. 5 marks the observation data on the average temperatures from 1969 to 2018, the red colour indicates the forecast for the period until 2030 by the Holt-Winters method, and the green colour marks errors. Similar designations are found in Fig. 3, Fig. 4, and Fig. 5. 


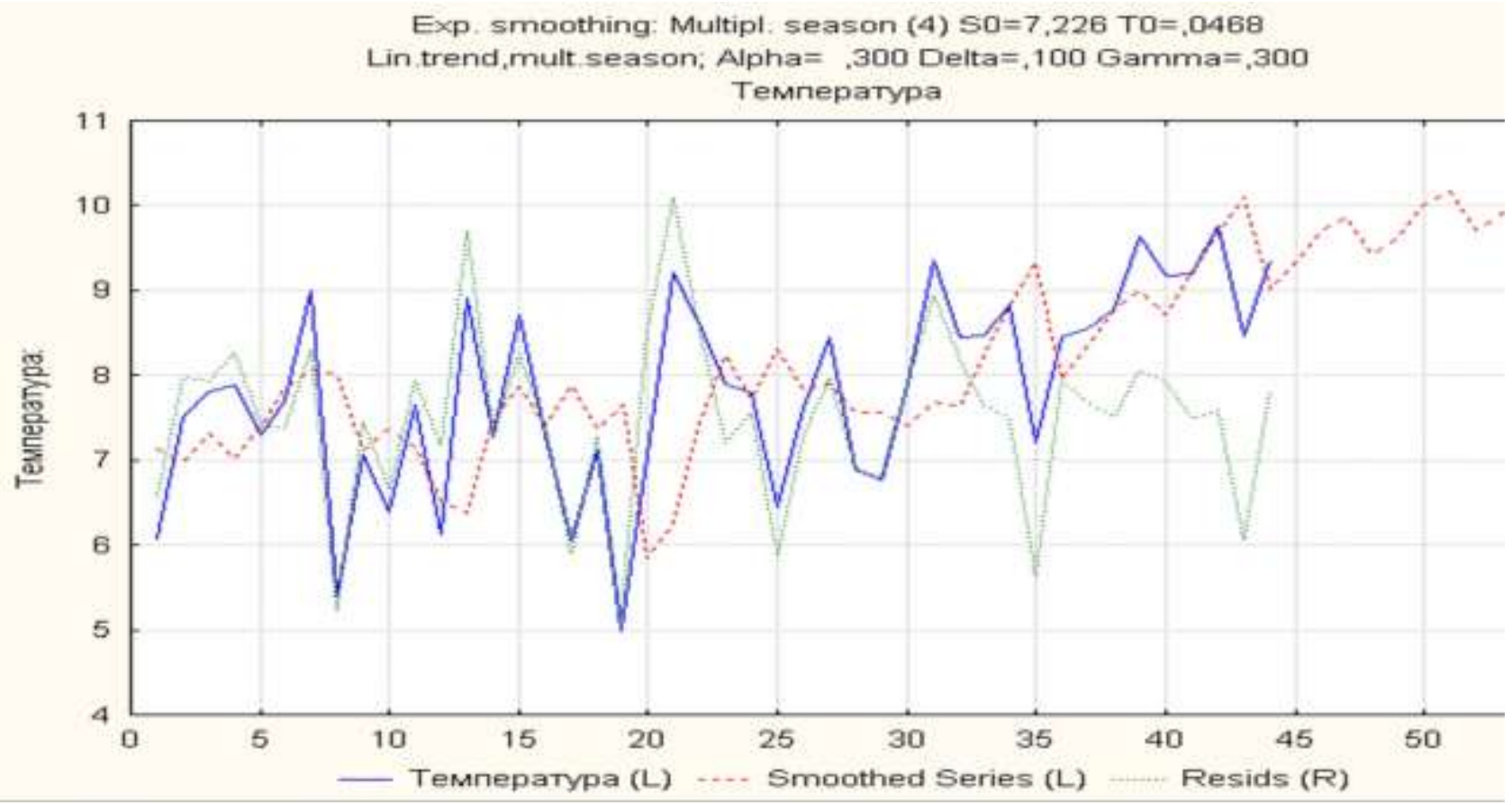

Figure 2. The forecast of an increase in the average temperature in the Kharkiv region

The monitoring of the average annual precipitation in the Kharkiv region, according to the State Committee for Hydrometeorology from 1969 to 2018, and the building of a predictive model have disclosed that there is an expected slight decrease in the amount of precipitation from $523 \mathrm{~mm}$ in 1969 to $504.8 \mathrm{~mm}$ in 2030 (Fig. 3).

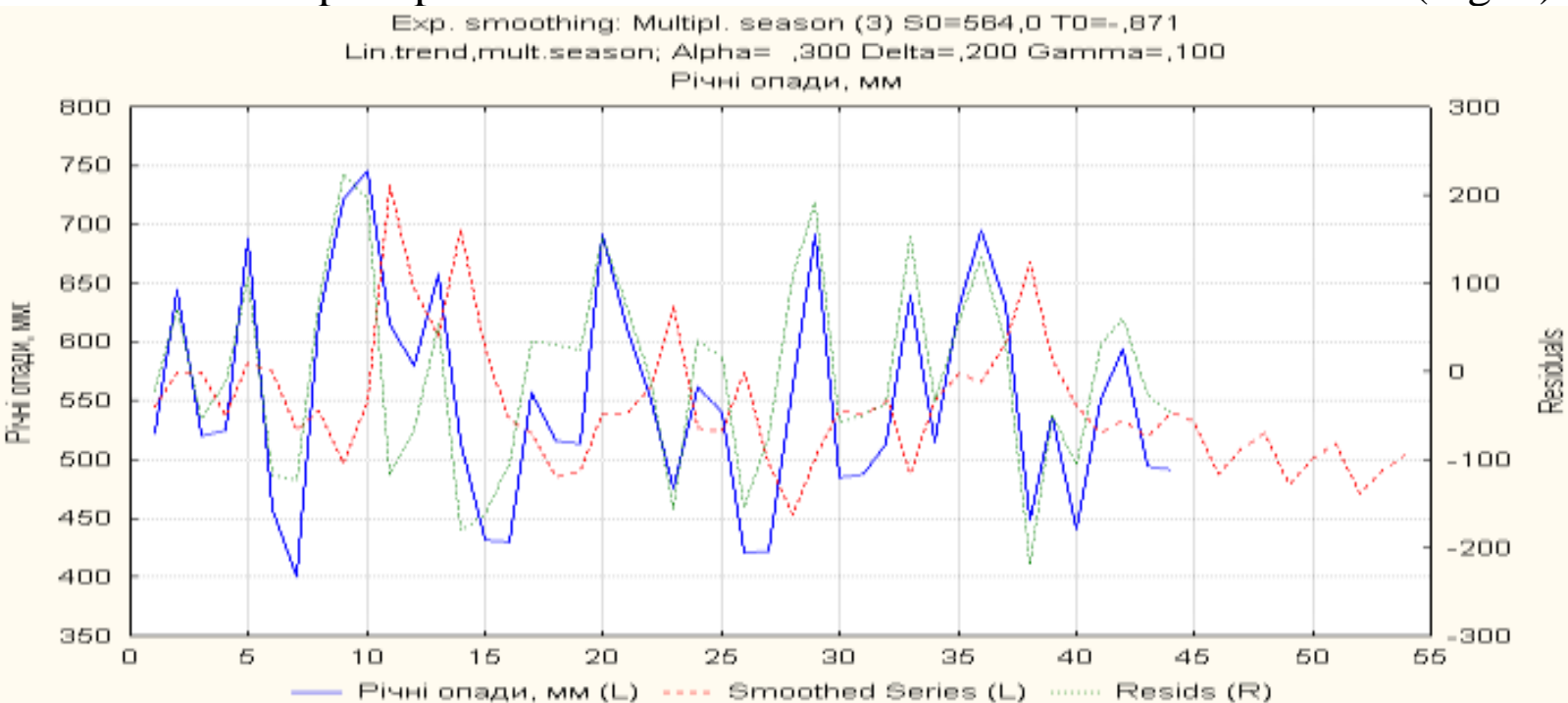

Figure 3. The forecast of a decrease in the average precipitation in the Kharkiv region

Studying the volume of the Oskil flow from 1924 to 2018 showed its considerable variability, and, according to the forecast model by the Holt-Winters method (Fig. 4), in 2030 , there is an expectation of $613.8 \mathrm{mln}^{3}$, which is well below the average volume for the years studied $\left(1159.7 \mathrm{mln}^{3}\right)$ 
Exp. smoothing: Muttipl. season (3) $\mathrm{SO}=44,76 \mathrm{TO}=., 370$

Lin.trend,mult.season: Apha $=.300$ Delta $=.400$ Gamma $=.400$

Витарти, м3\%, с.Чер. Оскіл

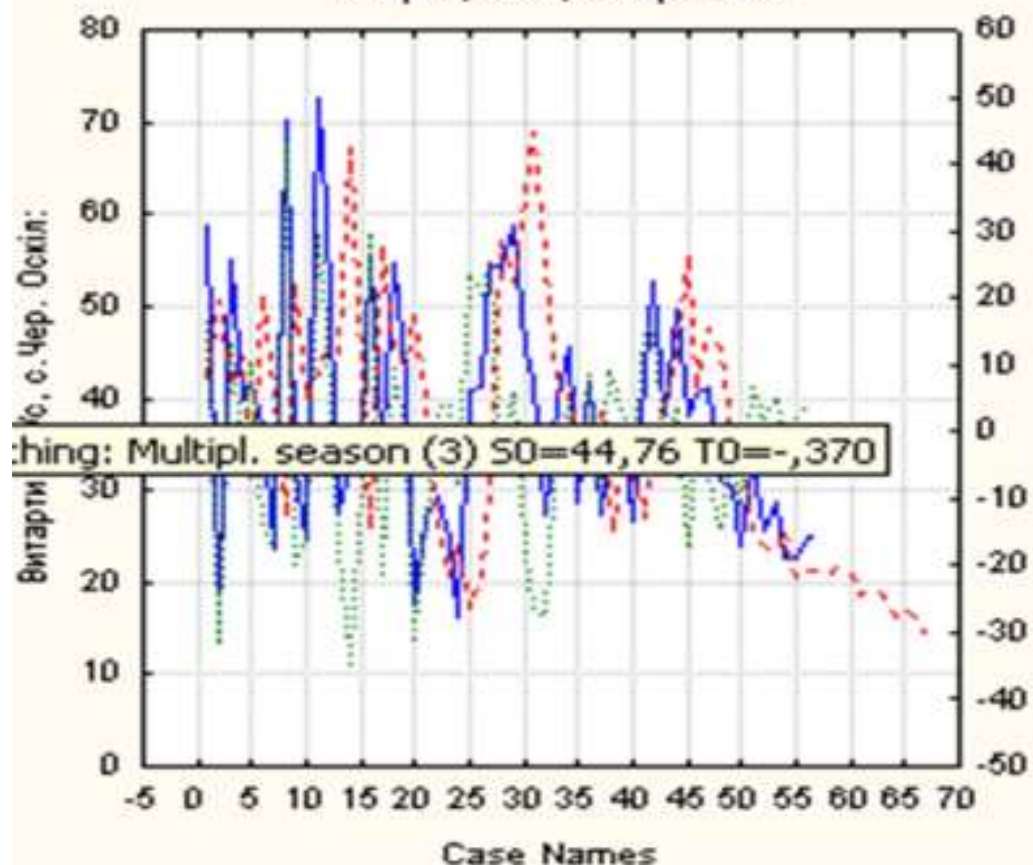

咅

Figure 4. The forecast of changes in the average water consumption from the Oskil river

Exp. smoothing: Multipl. season (3) $\mathrm{SO}=1060, \mathrm{TD}=-3,35$

Lin.trend,mult.season: Apha $=.400$ Deha $=.300$ Gamma $=.200$

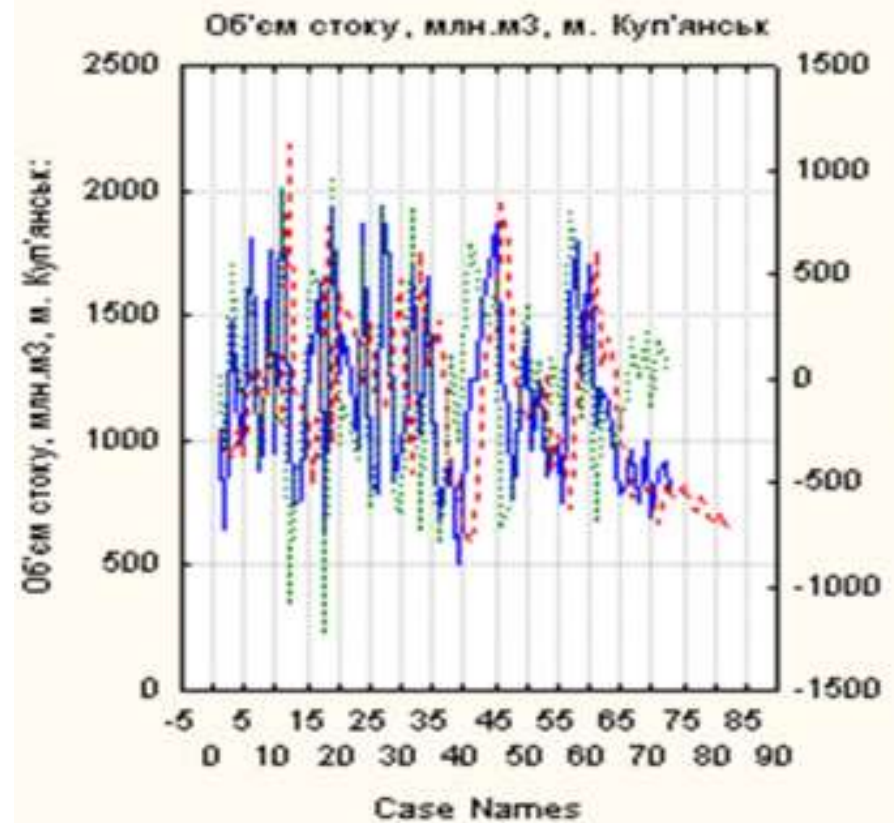

녹

- Bитарти, м3\%. с. Чер. Ocxin (L) (L)

... Smoothed Series (L)

(L)

Resids (R)

(R)

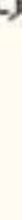


The Oskil River Basin is of cross-border importance, as it flows within two countries - Russia and Ukraine, so the assessment of the ecological status of the basins and the development of measures to improve it is a very important task.

The study has specified the long-term dynamics of the climatic factors and hydrological parameters of building predictive models by the Holt-Winters method. The results indicate that the climate change tends to increase the average temperatures. Another consequence is a decrease in the average amount of precipitation. The model, which was built with using the hydrological parameters of the runoff volume and water consumption, predicts their significant reduction in the future. These trends can have negative consequences for the environmental state, create risks, and increase infestations.

\section{References:}

1. Vasenko, O. H., Rybalova, O. V., Artem'iev, S. R. et. al. (2015). Intehralni ta kompleksni otsinky stanu navkolyshnoho pryrodnoho seredovyshcha. Kh: NUHZU, 419.

2. Romanenko, V. D., Zhukynskyi, V. M., Oksiiuk, O. P. et. al. (1998). Metodyka ekolohichnoi otsinky yakosti poverkhnevykh vod za vidpovidnymy katehoriiamy. Kyiv: Symvol-T, 28.

3. Snizhko, S. I. (2004). Teoriia i metody analizu rehionalnykh hidrokhimichnykh system. Kyiv: Nika-Tsentr, 394.

4. Hejzlar, J., Dubrovský, M., Buchtele, J., Růžička, M. (2003). The apparent and potential effects of climate change on the inferred concentration of dissolved organic matter in a temperate stream (the Malše River, South Bohemia). Science of The Total Environment, 310 (1-3), 143-152. doi: 10.1016/s0048-9697(02)00634-4

5. Webb, B. W., Clack, P. D., Walling, D. E. (2003). Water-air temperature relationships in a Devon river system and the role of flow. Hydrological Processes, 17 (15), 3069-3084. doi: 10.1002/hyp.1280

6. Beaugrand, G., Reid, P. C. (2003). Long-term changes in phytoplankton, zooplankton and salmon related to climate. Global Change Biology, 9 (6), 801-817. doi: 10.1046/j.1365-2486.2003.00632.x

7. Hiscock, K., Southward, A., Tittley, I., Hawkins, S. (2004). Effects of changing temperature on benthic marine life in Britain and Ireland. Aquatic Conservation: Marine and Freshwater Ecosystems, 14 (4), 333-362. doi: $10.1002 /$ aqc. 628

8. Ribalova, O. V., Korobkova G. V. (2016). Viznachennya vplivu prirodnih umov na ekologIchniy stan rIchki OskIl. Materials of the XII International scientific and practical conference, "Science and civilization", 16, 37-40.

9. NRDC. (2013). Climate Change and Water Resource Management. Available at: https://www.nrdc.org/resources/climate-change-and-water-resourcemanagement

10. Urama K. and Ozor N. (2016). Impacts of climate change on water resources in Africa: the Role of Adaptation. [online] Available at: http://www.sciencedirect.com/science/article/pii/S147470651300140X 
11. Jun, X., Shubo, C., Xiuping, H., Rui, X. and Xiaojie, L. (2010). Potential Impacts and Challenges of Climate Change on Water Quality and Ecosystem: Case Studies in Representative Rivers in China. Journal of resources and ecology. [online] Available at: http://agris.fao.org/agris-search/search.do?recordID=US201600004143 


\section{ПЕВЕРХНЕВИЙ СТІК У М. ОДЕСА ЗА ПЕРІОД 2000- 2019 РОКИ У ПЕРІОД ЗЛИВОВИХ ОПАДІВ}

\section{Ілікчісв Олег Геннадійович}

Аспірант2 року навчання

Одеський державний екологічний університет

Науковий керівник:

Тучковенко Юрій.Степанович

д. геогр. н., проф.

Одеський державний екологічний університет

Поверхневий стік - це процес переміщення вод атмосферного походження по земній поверхні.

Забруднення поверхневого стоку відбувається в результаті розчинення газів та пилу із приземних шарів атмосфери, змиву верхніх шарів грунту та зруйнованих дорожніх покриттів, промислових відходів, витоку нафтопродуктів, миття транспорту. На ступінь забруднення дощових та талих вод впливають фактори географічного розташування та кліматичних умов місцевості, інтенсивності та тривалості випадання атмосферних опадів, виду поверхневих покриттів територій, забруднення повітряного басейну та санітарного стану басейну водозбору, близького розташування промислових зон та автомобільних доріг. Забруднені дощові та талі води виступають значним чинником погіршення стану водних екосистем та порушення екологічної рівноваги водойм, що може завдати значних як економічних, так й екологічних збитків.

На території міста Одеса е дві станції біологічної очистки (СБО) стічних вод міста Одеси «Північна» $\mathrm{i}$ «Південна», які відповідають за випуски в море зливових і дренажних вод, поступаючих з території міста і його узбережжя.

Стічні води піддаються механічній та біологічної очистці, а потім скидаються в море або Хаджибейський лиман. Скидання в море проводиться на видаленні 300 м від берега на глибині 3,6 м у відносно мілководну зону Одеської затоки.

В останні роки, у зв'язку 3 тим що м. Одеса е найбільшим морським курортом України, наслідками змін клімату, питання впливу берегових антропогенних джерел на якість морських вод у Одеського узбережжя ПЗЧМ набуло особливої актуальність. У цьому контексті, пильну увагу фахівців, активістів громадських екологічних організацій приділяється ролі СБО «Північна», зливових і дренажних стоків міста в забрудненні морського середовища.

Для визначення кількості забруднюючих речовин у поверхневому стоці, були проаналізовані дані по дощовим опадам на станціях Одеса ГМЦ та Одеса Порт за період 2000-2019 рр.. 3 цих даних були вибрані дні з 2000 по 2019 роки коли був зливовий дощ інтенсивністю більше 10 мм. опадів. Для визначення змін 
кількості таких днів за різні періоди вони будуть порівнюватися у таблиці 13 даними кліматичного кадастру України за період 1961-1990 роки.

Таблиця 1.

Кількість днів по місяцям зливових опадів більше 10 мм. на території Одеси за період з 1961-1990 pр. та 2000-2019pp.

\begin{tabular}{|l|l|l|l|l|l|l|l|l|l|l|l|l|}
\hline $\begin{array}{l}\text { Місяц } \\
\text { ь }\end{array}$ & 1 & 2 & 3 & 4 & 5 & 6 & 7 & 8 & 9 & 10 & 11 & 12 \\
\hline $\begin{array}{l}2000- \\
2019\end{array}$ & 28 & 18,5 & 13 & 12 & 17,5 & 26,5 & 19 & 18,5 & 20,5 & 19 & 19 & 19,5 \\
\hline $\begin{array}{l}1961- \\
1990\end{array}$ & 6 & 5 & 4 & 5 & 6 & 8 & 6 & 4 & 4 & 3 & 5 & 5 \\
\hline
\end{tabular}

3 даних приведених у таблиці 1 можна зробити висновок що у сучасний період з 2000 по 2019 роки кількість днів коли відбуваються зливові дощі 3 кількістю опадів більше 10 мм. значно збільшилося ніж за період 1961-1990 роки. Кількість таких днів збільшилася у двічі. Це пов'язано зі змінами клімату які відбуваються в останні десятиріччя.

3 цих даних можна побачити що в лютому, травні та грудні на станції ГМЦ було більше днів з опадами більше 10 мм.. А в червні, липні та серпні таких днів було більше на станції Одеса порт, незважаючи на те що на цій станції не були враховані 2018 та 2019 роки. В усі інші місяці дані майже співпадають. Різниці в кількості днів на цих станціях показують що зливові дощі на території Одеси проходять не рівномірно. Наприклад якщо на станції Одеса ГМЦ було зафіксовано кількість опадів під час зливового дощу більше 10 мм, то на станції Одеса порт може бути зафіксовано менше 10 мм. опадів. Для порівняльного аналізу з даними кліматичного кадастру, слід знайти середню кількість днів за кожен місяць на обох станціях. Середня кількість днів покаже більш точну кількість днів для всієї території Одеси.

Для визначення обсягу дощової стічної води використовують формулу : $\mathrm{W}=10^{*} \psi^{*} \mathrm{~F} * \mathrm{H}, \mathrm{m}^{3} /$ рік

Де: $\psi$ - коефіцієнт стоку дощових вод

F -площа водозбірної території, га

Н- шар опадів, мм

Для розрахунків була взяті наступні вихідні дані, коефіцієнт стоку дощових вод 0,35, площа водозбірної території -5424,2 га( Площа водозбірної території СБО Північна), та сумарна кількість опадів у дні зливових опадів по роках за період спостережень. Розрахунок обсягу зливового стоку показаний в таблиці 2. 
Таблиця 2

Розрахунок обсягу зливового стоку на станції СБО Північна за 2000-2019 pp.

\begin{tabular}{|c|c|c|}
\hline Роки & $\begin{array}{c}\text { Середня кількість зливових } \\
\text { опадів, мм }\end{array}$ & $\begin{array}{c}\text { Обсяг зливового } \\
\text { стоку,м3 / рік, }\end{array}$ \\
\hline 2000 & 278,9 & 5294832,83 \\
\hline 2001 & 190,8 & 3622280,76 \\
\hline 2002 & 216,65 & 4113035,255 \\
\hline 2003 & 289,6 & 5497969,12 \\
\hline 2004 & 375,1 & 7121160,97 \\
\hline 2005 & 350,72 & 6658313,984 \\
\hline 2006 & 291,15 & 5527395,405 \\
\hline 2007 & 238,25 & 4523104,775 \\
\hline 2009 & 201,25 & 3820670,875 \\
\hline 2010 & 156,05 & 2962562,435 \\
\hline 2011 & 402,1 & 7633747,87 \\
\hline 2012 & 214,7 & 4076015,09 \\
\hline 2013 & 327,1 & 6209895,37 \\
\hline 2014 & 152,6 & 2897065,22 \\
\hline 2015 & 312,65 & 5935566,455 \\
\hline 2016 & 191,6 & 3637468,52 \\
\hline 2017 & 484,6 & 9199985,62 \\
\hline 2018 & 228,3 & 4334207,01 \\
\hline 2019 & 250,1 & 4748073,47 \\
\hline
\end{tabular}

3 результатів розрахунків можна зробити висновок що за період спостережень з 2000 по 2019 роки було в середньому 265,7 мм. зливових опадів на рік. Середньорічний стік зливових вод складає 5,04 млн. м3 / рік. 3 цих даних можна зробити висновок що кількість вод які виносяться поверхневим стоком 3 роками збільшилася, що в свою чергу збільшує кількість забруднюючих речовин які виносяться стоком в море.

\section{Список літератури}

1. Оценка влияния береговых антропогенных источников на качество вод Одесского района северо-западной части Черного моря / Тучковенко Ю.С., Иванов В.А., Сапко О.Ю.; НАН Украины, Морской гидрофизический институт, Одесский государственный экологический университет.- Севастополь, 2011. с. 169 , ил. 61 , табл. 43 , библ. 74.

2. Характеристика станцій біологічного очищення стічних вод міста Одеса як джерел біогенного забруднення морського середовища в сучасний період / Тучковенко Ю. С., Сапко О. Ю., Тучковенко О. А. ; Український гідрометеорологічний журнал, 2020, № 25, 127-135 doi:10.31481/uhmj.25.2020.12 , ISSN 2311-0902 (print), 2616-7271 (online) 


\title{
АНАЛІЗ РЕЖИМУ ЛІТНІХ ОПАДІВ В МІСТІ ПОЛТАВА ЗА ДВАДЦЯТИРІЧЧЯ 2001 - 2020 РР.
}

\author{
Дсрябіна Інна Олексіївна \\ викладач, спеціаліст вищої категорії \\ Кременчуцький льотний коледж \\ Харківського національного університету внутрішніх справ \\ Уманська Ольга Володимирівна \\ к.геогр.н., директор центру прогнозів \\ Одеський державний екологічний університет
}

Опади є однією з найважливіших характеристик погоди та клімату. В Полтаві спостерігається континентальний тип річного ходу опадів, за якого кількість опадів теплого періоду перевищує кількість опадів холодного періоду [1].

Дослідження середньої місячної кількості опадів в літні місяці показало досить нерівномірний їхній розподіл відносно кліматичної стандартної норми. За двадцятирічний період спостерігалися роки, коли місячна кількість опадів була значно нижче норми (червень 2003, 2007 рр., липень 2006 р., серпень 2010, 2015, 2018, 2019 рр.). Також відзначалися роки, коли середня місячна кількість опадів перевищувала кліматичну стандартну норму більше ніж в три рази (червень 2001, 2007 рр., липень 2003 р., серпень 2004, 2012 рр.)

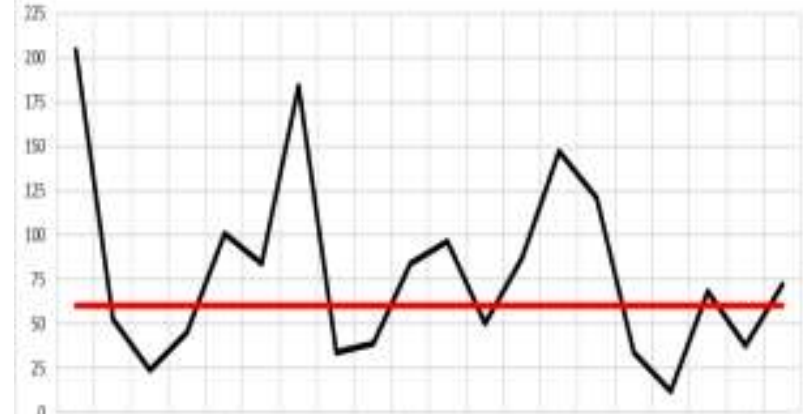

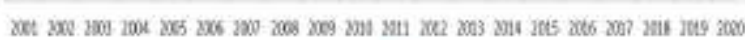

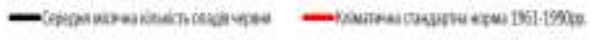

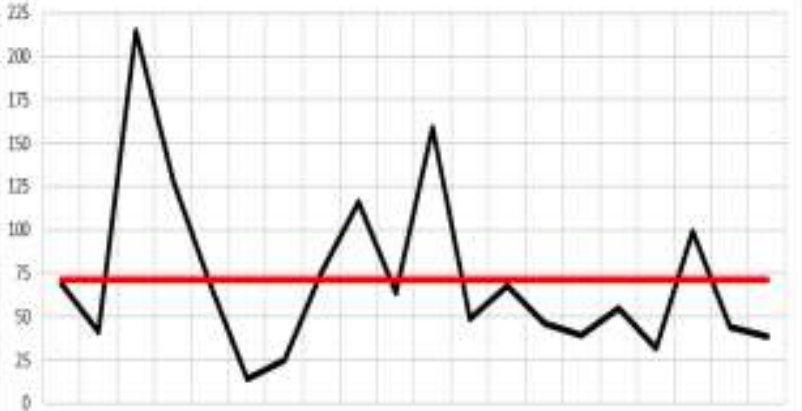

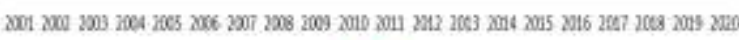

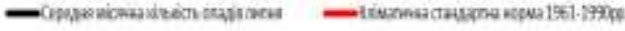

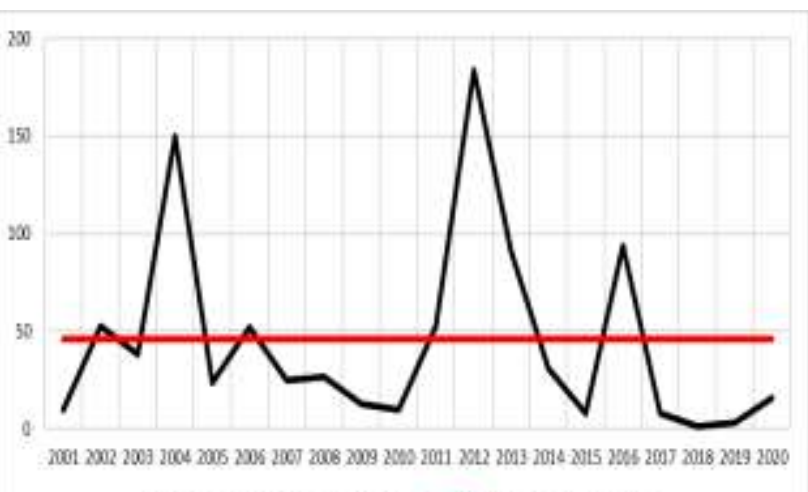

Рисунок 1. Середня місячна кількість опадів та їі відхилення від кліматичної стандартної норми 
Але загальна тенденція показує зменшення, відносно кліматичної норми, кількості опадів в останні роки в липні і серпні та невелике зростання у червні.

Також було досліджено, як змінилася кількість літніх опадів за останне десятиріччя в порівнянні з попереднім. I виявилося, що в червні та липні за період 2011-2020 pр. кількість опадів у порівнянні з періодом 2001-2010 pр. зменшилася майже на 13 та 19 мм. відповідно. В той час, коли в серпні середня місячна кількість опадів за останнє десятиріччя збільшилася на 9 мм.

Таблиця 1.

Середня місячна кількість опадів по періодах

\begin{tabular}{|c|c|c|c|}
\hline Роки & VI & VII & VIII \\
\hline $2001-2010$ & 85,2 & 81,6 & 40,2 \\
\hline $2011-2020$ & 72,7 & 62,9 & 48,9 \\
\hline Різниця & 12,5 & 18,7 & $-8,7$ \\
\hline
\end{tabular}

Під час дослідження було розглянуто ті роки, коли середня місячна кількість опадів була максимальною. Виявлено, що основною причиною великої місячної кількості опадів в ці роки були дні, коли добова кількість опадів наближалася до місячної кліматичної стандартної норми, або перевищувала їі.

Для прикладу розглянемо опади в червні. Максимальна їх кількість за двадцятирічний період спостерігалася в 2007 р. (184 мм.), 2014 р. (147,3 мм.) та 2015 р. (121 мм.). В 2007 році 2 та 29 червня випало 96,1 мм. та 44,8 мм. відповідно. В 2014 році 27 червня випало 55 мм., а в 2015 році 26 та 29 червня 43 мм. та 32 мм. відповідно.

Було виявлено, що усі ці опади спричинені однією синоптичною ситуацією. Над Західною Свропою розташовується субтропічний антициклон, що переміщується на північний схід, але який не є блокуючим (Рис. 2). Центр циклону над північчю континенту зміщений на схід і розташовується над Скандинавією або Баренцовим морем, а улоговина, спрямована у південному напрямку, є добре вираженою. Фронтальна зона проходить з Атлантики через Центральну Європу на Україну та захід Росії. Україна перебуває під впливом вузької витягнутої від центральних областей Росії та орієнтованої на південний захід улоговини циклону, атмосферні фронти, які з нею пов'язані, є доволі активними. На хвилі фронту утворюється циклон, що займає Полтавську, Харківську, Київську області. 


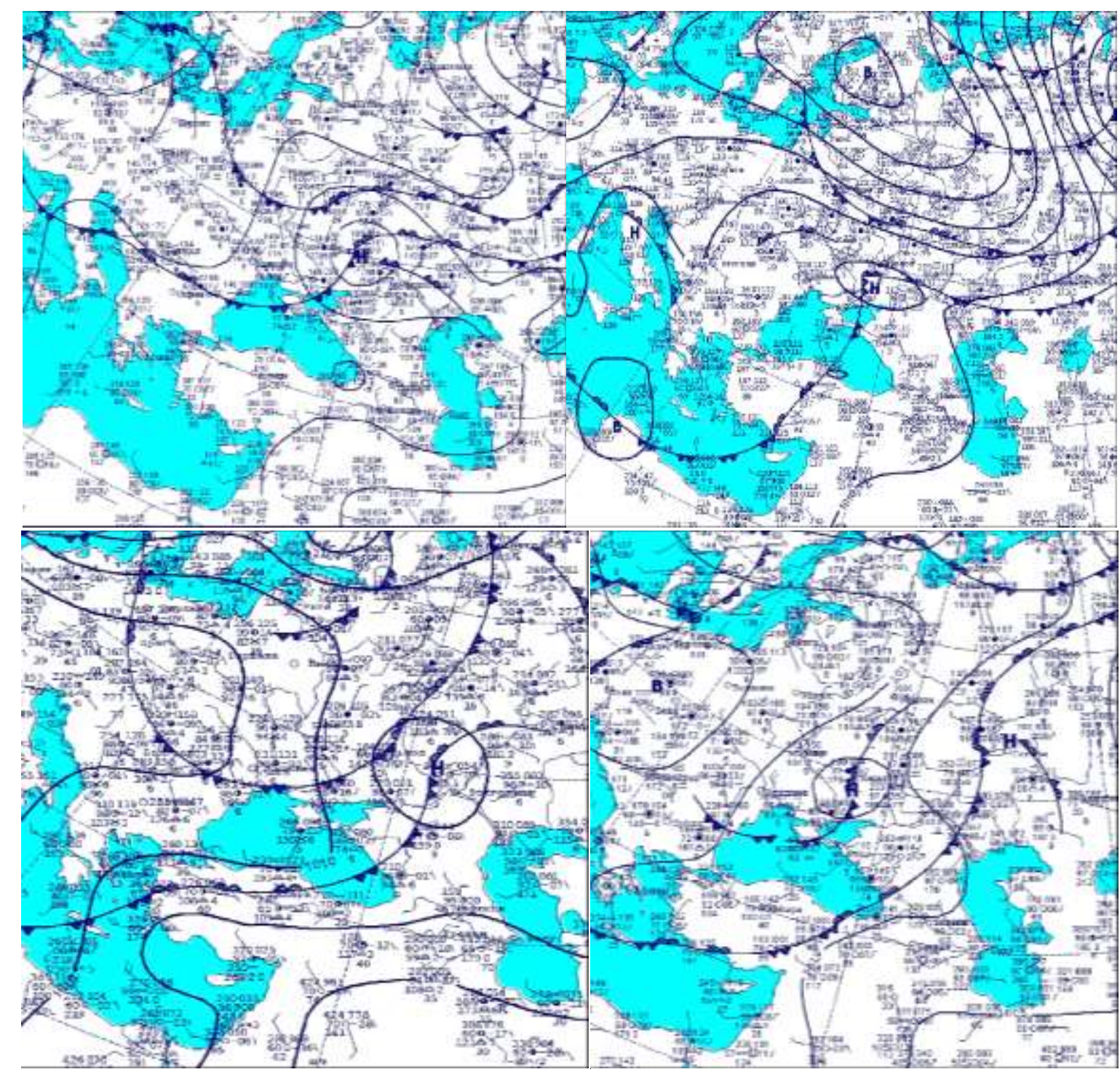

Рисунок 2. Приземна карта погоди за 27 червня 2014 року ( верхня зліва), 2 червня 2007 року(верхня справа), 29 червня 2007 року (нижня зліва), 29 червня 2015 року (нижня справа)

Дана синоптична ситуація належить до третього типу циркуляції за класифікацією Гесса-Березовського (GWL) [2,3]. Даний тип циркуляції є одним з найбільш характерних для випадіння опадів влітку, в тому числі в місті Полтаві (Рис.3). 


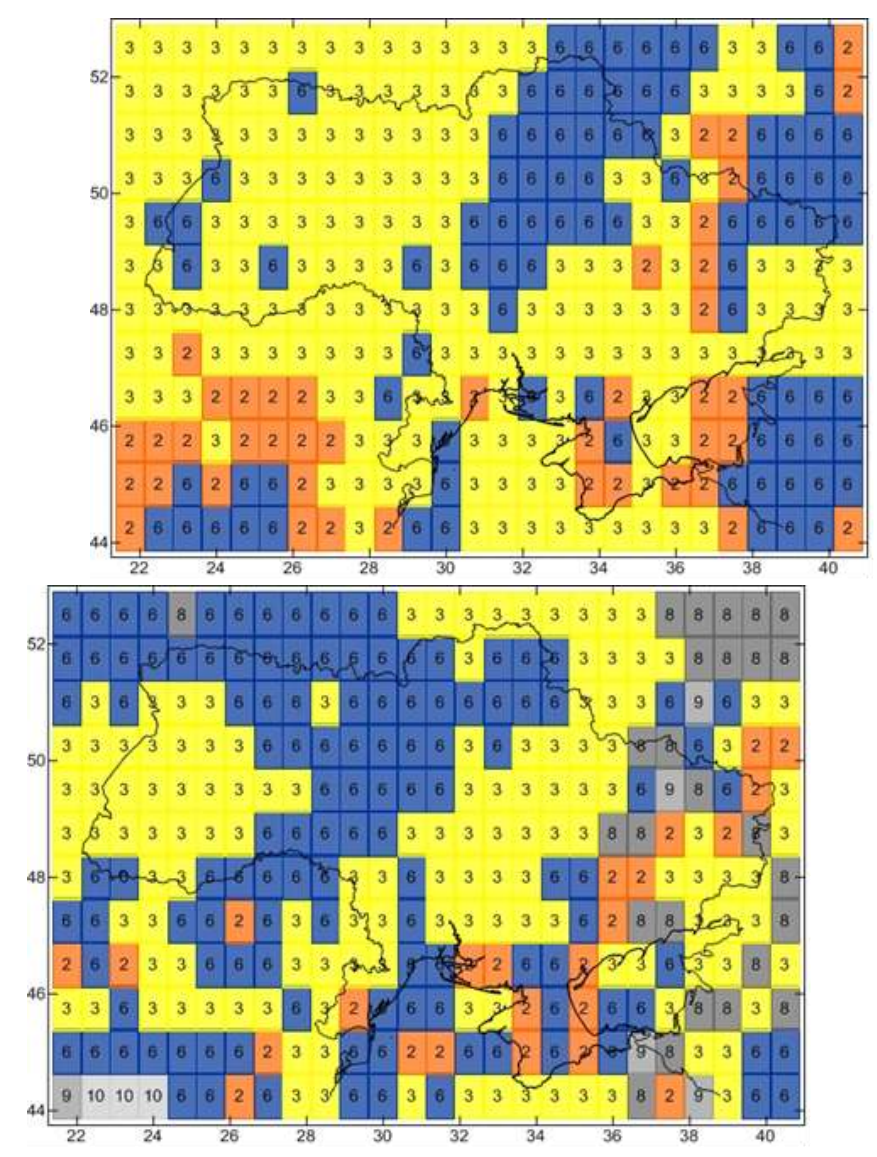

Рисунок 3. Четвертий за повторюваністю типи GWL для індексу RR1s (зліва) для індексу R10s (справа)

Отже, за останнє десятиріччя в Полтаві спостерігається тенденція до зменшення середньої місячної кількості опадів в літні місяці по відношенню до кліматичної норми. Частішають дні, коли за добу випадає кількість опадів, що досягає місячної норми. І все це є проявом регіональної зміни клімату.

\section{Література:}

1. Клімат України. За ред. В. М. Ліпінського, В. А. Дячука, В. М. Бабіченко. К.: Вид-во Раєвського. 2003. 343 с.

2. Хохлов В.М., Уманська О.В., Дєрябіна І.О. Об'єктивна класифікація атмосферних процесів для східноєвропейського регіону. Фізична географія та геоморфологія. 2018. № 90. С. 84-90.

3. Khokhlov V., Umanska O. European atmospheric circulation classification. Journal of Geography, Environment, Earth Sciences International. 2018. №3. JGEESI.41860. 


\title{
ПАМ'ЯТЬ ПРО УКРАЇНСЬКЕ КОЗАЦТВО: НАУКА ТА ПРАКТИКА (на матеріалах культурної спадщини Одеської області України)
}

\author{
Бачинська Олена \\ доктор історичних наук, професор, \\ завідувач кафедри історії України \\ Одеський національний університет \\ імені І.І.Мечникова
}

Полторак Володимир кандидат історичних наук, доцент доцент кафедри історії України Одеський національний університет імені I.I.Мечникова

Козацтво є феноменом не лише української, але й світової історії. Намагання знайти повний аналог цьому явищу не дали позитивних результатів. Козацтво на території України формувалось та існувало протягом XV - XIX ст. Про козаків в народній пам'яті та в державній політиці історичної пам'яті збереглись такі елементи нематеріальної та матеріальної культурної спадщини: історичні пісні та думи; мемуари та спогади сучасників; документи законодавчого характеру; топоніми; пам'ятки матеріальної культури, в тому числі монументальні. Останні можна поділити на групи: намогильні хрести, що залишились на козацьких похованнях; пам'ятники та меморіальні дошки, що встановлює видатним козацьким діячам держава; споруди та місця, пов’язані 3 історією козацтва.

На території Одеської області України презентовані всі зазначені види культурної спадщини. Так, багато документів з історії українського козацтва спогади про походи козацтва на міста Хаджибей (Одеса), Аккерман (БілгородДністровський), Ізмаїл, Кілія під керівництвом отаманів Б. Претвича, I. Сірка, С. Палія та інших [1].

Серед інших матеріалів i документів слід згадати публікації про задунайське козацтво, яке з'явилось після зруйнування Запорозької Січі у 1775 p. і осіло на території межиріччя Південного Бугу, Дністра та Дунаю (в той час територія Османської імперії) [2].

Значна кількість документів про українське козацтво зберігається в Державному архіві Одеської області. Вони мають документи законодавчого характеру, свідоцтва задунайських козаків, їхні свідчення про січове життя. Зазначені документальні матеріали стали основою для багатьох наукових досліджень 3 історії українського козацтва, в тому числі присвячені окремо 
Одещині [3]. Ці наукові досліження застосовуються у викладанні спеціальних авторських курсів з історії козацтва та історії України, історичного туризму та музеєзнавства.

Топоніми Одещини також свідчать про збереження пам'яті про козацтво. Наприклад, поблизу Одеси є населені пункти з назвами Усатове, Нерубайське, Старокозаче, Козацьке тощо.

Намогильні хрести т.зв. козацького типу на значному просторі в сільській місцевості території сучасної Одеської області. Багато з цих хрестів мають датування другої половини XVIII ст. Не всі з них пов'язані з козацькими поселеннями, не всі з них встановлені на могилах представників козацького прошарку. Однак у сприйняті сучасного жителі ці пам'ятки міцно асоціюються iз козацькою традицією. Таке сприйняття не $є$ випадковим, адже козацтво уособлювало волю, силу та мужність українського народу, тому належність до козацького середовища, викликала гордість в минулому i, навіть, для сучасного населення воно означає бути справжнім громадянином. Це має досить позитивні моменти у формуванні національної пам'яті, а саме:

- усвідомлення свого минулого, як окремої людини та належності до української спільноти;

- виникнення інтересу до козацтва та історії свого краю у дітей та підлітків;

- наочне ознайомлення та охорона унікальної матеріальної спадщини;

- формування погляду на своєрідність козацької верстви;

- сприйняття території Південної України як землі 3 козацькою історією [6].

На сучасному етапі одним 3 найголовніших завдань залишається збереження об'єктів культурної спадщини не лише від несприятливих вікових і природних умов, але й від руйнування під час процесів урбанізації. Науковцями були здійснені спеціальні експедиції для виявлення та фіксації таких пам'ятників на території сучасної Одеської області. Досліджено було понад 20 населених пунктів, зафіксовано понад 500 «козацьких» хрестів [4].

Іншим не менш важливим завданням $€$ «вписання» намогильних козацьких хрестів до цих процесів урбанізації: через розширення міської території та міської культури. Прикладом $є$ козацький цвинтар на Хаджибеївській дорозі (колишнє с. Куяльник, зараз в межах міста Одеси). Він потрапив до історіографіх під назвою Сотниківський завдяки прізвищу одного з похованих на ньому нащадків українських козаків. Цвинтар поступово поглинає сучасна житлова та промислова забудова. Він був внесений до переліку пам'яток місцевого значення як нововиявлений у 2016 році і став меморіальним місцем українського козацтва, яке зробило значний внесок в розбудову Одеси.

Пам'ятники та меморіальні дошки для збереження пам'яті про героїчне минуле свідомо встановлює видатним козацьким діячам держава. Тематика таких меморіальних споруд може бути різна i, навіть, залежатиме від часу іiі встановлення. До 90-х років XX ст. лише одиниці козацьких діячів були удостоєні пам'ятника від держави. На сьогодні ситуація поступово змінюється. 
Населення саме вимагає зберегти пам'ять козаків у держави. Так, пам'ятник, що мав узагальнювати образ козацтва, встановлений в Одесі у 1999 році в Старобазарному сквері, пов'язали з конкретною постаттю козацького отамана Антона Головатого - він на чолі козацького загону штурмував Хаджибей (майбутню Одесу), а його козаки працювали на будівництві одеського порту [5]. Аналогічний монумент одному із засновників населеного пункту - козацькому отаману - можна побачити в Біляївці (Захарі Чепіга).

Таким чином, пам'ять про козацтво в об'єктах культурної спадщини Одеської області має свою специфіку у вигляді намогильних козацьких хрестів та пам'яток встановлених державою на сучасному етапі. Обгрунтована джерелами та науковими дослідженнями, історія козацтва залишає пам'ять про себе у формі матеріальних (монументальних) та нематеріальних (власне, історична пам'ять) пам'яток.

\section{Список літератури:}

1. Український степовий кордон в середині XVI століття (Спогади барського старости Бернарда Претвича): [Доповідна записка подана королю Сигізмунду Августу в 1550 р.]. Запоріжжя: Тандем-У, 1997. 83 с.; Бачинська О.А., Гончарук Т.Г. Визначні українські козаки в історії Одеси та Одещини XVI - XIX ст. Одеса, 2009. 87 с. тощо.

2. Задунайська Січ: До 1000-ліття літописання та кн. справи в Україні / А. Д. Бачинська, О. А. Бачинська, Ф. К. Вовк, П. П.Короленко, О. І. Лазаревський; Одес. держ. наук. б-ка ім. М. Горького. Одеса, 1998. 392 с. (Невичерпні джерела пам'яті. Сер. зб. наук. ст., матеріалів та републ.; Т.2).

3. Одеса-козацька. Наукові нариси. [2-е вид. змінене та допов.]. Одеса: Фенікс, 2008. 237 с.

4. Надмогильні хрести запорозьких козаків / Відповідальний редактор І.В.Сапожников; Одес. держ. наук. б-ка ім. М. Горького. Одеса, 1998. 220 с. (Невичерпні джерела пам'яті. Сер. зб. наук. ст., матеріалів та републ.; Т.1).

5. Бачинська О.А., Гончарук Т. Г., Полторак В. М. Козацькими шляхами Одещини. Методичні рекомендації. Одеса, 2001. 14 с.

6. Полторак В. Одещина: 12 пішохідних мандрівок. Методичний посібник 3 питань впровадження програми патріотичного виховання...-Одеса, 2019. - 68 с. 


\title{
ЕКЛОЛІЧНИЙ СТАН ТА ІСТОРІЯ ВИКОРИСТАННЯ ВОД СІВЕРСЬКОГО ДІНЦЯ
}

\section{Рацлав Володимир Вікторович}

\author{
K.T.H., \\ доцент кафедри ТТПО,
}

СДПУ м. Слов'янськ

\begin{abstract}
ВСТУП
Стратегія регіонального розвитку Донбасу передбачає рівнозначність його соціальної, економічної та екологічної складових. I сьогодні, незважаючи на військовий конфлікт на сході України, як ніколи, потрібна зважена та розсудлива державна політика щодо ефективного використання природних ресурсів. Донбас $\epsilon$ невід'ємною часткою України, тому невідворотно вибрав шлях сталого, екологічно-безпечного та комфортного соціально-економічного розвитку регіону.

Сіверський Дінець $є$ транскордонною, важливішою та головною водною артерією сходу України, що забезпечує потреби у воді населення, сільське господарство та промисловий комплекс Луганської, Донецької та Харківської областей. Стан довкілля річки є важливішим водним ресурсом Донбасу найбільш техногенно навантаженого регіону України. Значна частина річки примикає до лінії зіткнення і зазнає екологічних порушень та катаклізмів від безпосереднього впливу військових дій. Окрім безпосереднього впливу військової техніки, використання боєприпасів, загрозу довкіллю спричиняють аварії та забруднення промислових підприємств регіону. Військовий конфлікт на сході України призвів до цілої низки небезпечних подій та наслідків:

- забруднення довкілля і впливів на грунти та ландшафти;

- погіршення стану поверхневих і підземних вод;

- надання шкоди рослинному і тваринному світу. ${ }^{1}$

У зв'язку з військовими діями, на тимчасово окупованій території було порушено екологічну рівновагу, виникло руйнування інфраструктури, що призвело до небезпечних змін стану навколишнього природного середовища, де проживало біля 5 млн. осіб. Особливо гострою проблемою водних запасів $\epsilon$ забруднення підземних водоносних горизонтів викидами вугільного виробництва, яке відбувається від закриття та затоплення шахт, що не працюють. Кілька місяців тому прийнято так званий закон «ЛНР» про проведення реструктуризації шахт. Фактично зроблено це для закриття шахт, що призведе не тільки до безробіття, але й до екологічного лиха. Через закриття та підтоплення шахт, що використовуються як сховища відходів, вибухів
\end{abstract}

${ }^{1}$ Оцінка екологічної шкоди та пріоритети відновлення довкілля на сході України. К.: ВАІTЕ.2017. 
боєприпасів та використання військової техніки, забруднюється не лише грунт, але й водні ресурси. ${ }^{2}$

Постала екологічна проблема зменшення та очищення забруднених поверхневих та підземних вод, які є водними ресурсами не тільки Донбасу, а і країни в цілому. Екологічний стан водних ресурсів в першу чергу залежить від здатності к самоочищенню. Попередня моніторингова оцінка стану поверхневих і підземних вод р. Сіверського Дінця виявила не « добрий» стан водних об'єктів. Майже чотири роки у всі сезони, води Дінця мають не задовільну прозорість. Ця брудна вода, яка скидається в Клебан-Бик, тече в Торець, а далі в Сіверський Дінець, а там вже - акваторія Азовського моря.

Політична ситуація в Донбасі, на територіях підконтрольних Україні, дозволяє провадити нормалізацію діяльності основних інститутів державного та місцевого управління 3 охорони навколишнього середовища, але заважає відновленню та функціонуванню систем та природоохоронних органів в зоні конфлікту.

\section{Дінець}

1.Історія екологічних проблем використання вод річки Сіверський

Проблеми екологічного стану вод Сіверського Дінця накопичувалися не одне століття. Ще в другій половині I тисячоліття до н. е. та в перших століттях нашої ери, племена що жили по берегах Дону (Танаїсу) і Дінця (Сіргіс) мали тісні економічні зв'язки та підтримували жителів поселень, розташованих в гирлі Дону. Дослідження Т. Н. Книповича, Д. Б. Шелова та інших археологів показали, що ще на рубежі V i IV ст. до н. е. на березі одного з притоків в дельті р. Дона виникає поселення, яке в IV-III ст. до н. е. являло собою великий греко-скіфське торгове місто. Однак обміління русла річки в цьому місці створило ряд труднощів для торгового судноплавства, і поселення було зниклим.

Новітня історія використання водних ресурсів річки Сіверський Дінець датується з початку XIX століття. В цей час відзначався швидкий процес росту промисловості в Донбаському регіоні, що спонукало початок постійного вивчення стану та устрою річки. Ріка була суднохідною від Дону до Білгородської губернії, по всій території України. Вперше сильно постраждала ріка ще в XVIII столітті, коли були вирубані вікові дуби, що ростуть уздовж його русла. У XIX столітті почалися розробки корисних копалин Донбасу, що також привели до забруднення і зниження рівня підземних вод. Сумарно ці фактори призвели до обміління річки і припинення судноплавства. 3 п'ятдесятих років XIX століття загальна довжина річки скоротилася на 20 км. До середини XIX століття в Сіверському Дінці було багато риби (осетри, вирезуби, соми, судаки, щуки, лящи та сазани), однак систематичне забруднення річки та іï притоків відходами і відпрацьованими водами, призвело до різкого скорочення фауни річки. Індекс забруднення води (ИЗВ) в наш час коливається за течією Дінця від

\footnotetext{
${ }^{2}$ Рацлав В.В. Моніторинг та дослідження хімічного стану якості поверхневих вод басейну річки Сіверський Дінець.Актуальные научные исследования в современном мире» Журнал № 4(60) часть 3. Апрель 2020. Переяслав - 2020. - 150с. С.118 - 128 .
} 
IV (забруднена) до V (брудна). Основні забруднюючі речовини - добрива, нафтопродукти, феноли, цинк, мідь.

\section{2. Історичні етапи використання вод ріки}

Як і багато других річок, Сіверський Дінець виконував велику роль в житті прадавніх людей. Річка не тільки була осередком води та їжі, а виконувала роль торгового шляху і кордону для захисту людей та способом їх пересування. До того ж, берега річки служили природними лініями розмежування між поселення народів, категорій етносу та племен, на яких заселялися з незапам'ятних часів древні люди. Уздовж усього русла Дінця археологами в процесі розкопок знайдені численні сліди перебування античної людини, починаючи з кам'яного і бронзового століття. До них відносяться: побутові реалії, кістяні, кам'яні та крем'яні знаряддя; керамічний посуд; жіночі прикраси 3 чорноморських молюсків; військове озброєння. Найдавнішими пам'ятками про добу палеоліту в басейні Сіверського Дінця є кам'яні вироби, знайдені Г. І. Горецьким та А. Д. Столяром в 1950 р. у хутора Хрящ та археологічні знахідки, які відносяться до шельської і ашельської епох раннього палеоліту. Кам'яні знаряддя праці тих епох були виявлені на березі Сіверського Дінця, в Ізюмському районі, в Харківській області, в Луганській області дивись мал.1

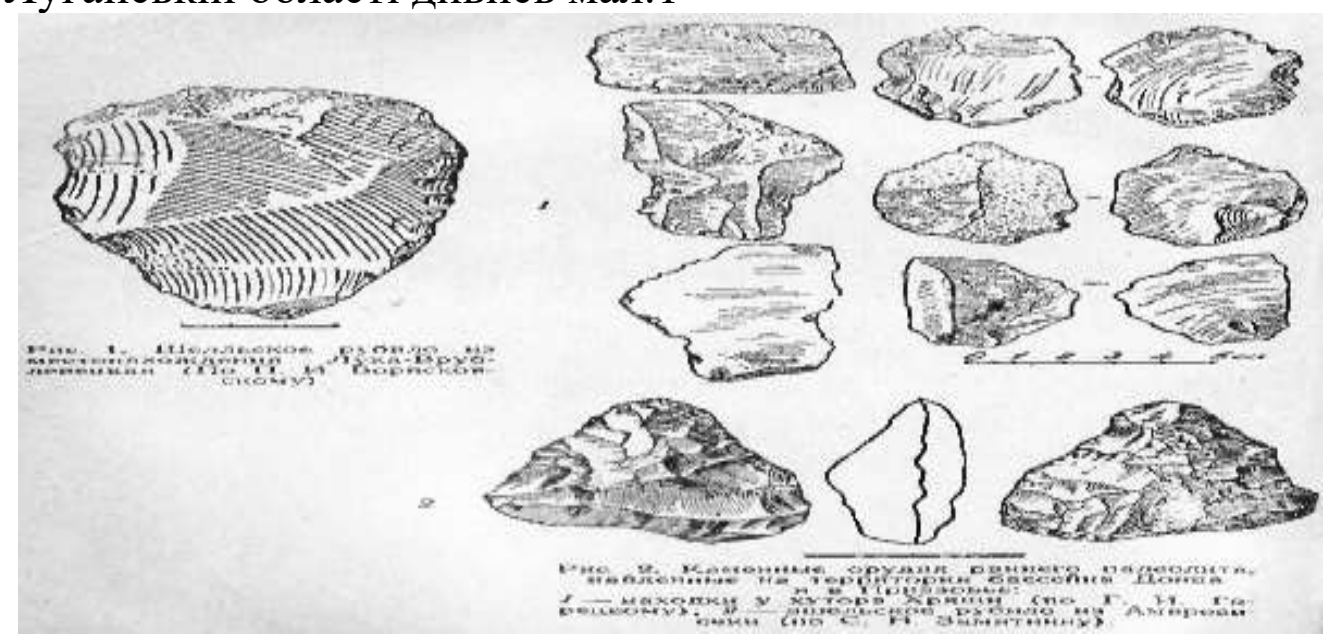

Малюнок 1 Знахідки на берегах річки Дінець

Знахідки найдавніших знарядь виробництва, які супроводжуються іноді кістковими залишками та іншими предметами, дають можливість з'ясувати основні риси і особливості життя первісних людей. На початку періоду 3 тваринного світу людина мала дуже примітивні знаряддя виробництва з каменю, головним чином 3 кременю. Тільки там, де кремінь не зустрічається або $є$ в невеликій кількості, первісна людина заміняла його іншими породами каменю, наприклад, такими, як кварцит, обсидіан (вулканічне скло), рогівки, діорит. Свідчення про населення в Донецькому басейні відносяться до мустьєрської епохи середнього палеоліту. Деякі з цих місць були досліджені в Луганській і Ростовській областях. Місцезнаходження було виявлено у с. Червоний Яр Луганської області, приблизно в 10 км на північний схід від м Луганська. Перші знахідки тут зробив співробітник Луганського музею А. С. Альбрехт ще в 1925 році, але місцезнаходження залишків цієї епохи було встановлено лише після дослідження С. Н. Замятніна в 1933 році. Дослідження Т. Н. Книповича, Д. Б. Шелова та інших археологів показали, що ще на рубежі V i IV ст. до н. е. на березі 
одного з притоків в дельті р. Дона виникає поселення, яке в IV - III ст. до н. е. являло собою велике греко-скіфське торгове місто. Солідну кількість капищ 3 кам'яними бовдурами на берегах свідчить про перебування в цих місцях скіфських, сарматських, аланських народів, племен сіверян, в'ятичів, половців. За версією Геродота, який оповідав про особливе значення жінок у сарматів, частково які втратили матріархат, легендарні амазонки розташовувалися саме на території Північного Дінця. Грецький географ Птоломей вказував координати річки Сіверський Донець на карті, під ім'ям Танаїс.

Улюблені місця, в яких скіфи, очевидно, неодноразово влаштовували свої тимчасові стоянки фіксуються в деяких випадках знахідками окремих речей. Розташовувалися кочовища зазвичай в заплаві, там, де були пасовища з хорошою травою і зручними водопоями. Місцями таких стоянок на Дінці, є околиці с. Петровського недалеко від впадіння р. Береки в Донець і околиці с. Райгородка поблизу впадіння в Донець р. Сухого Торця. Тут були знайдені наконечники скіфських стріл, частини кінської збруї та інші речі. (мал.2.2(51))

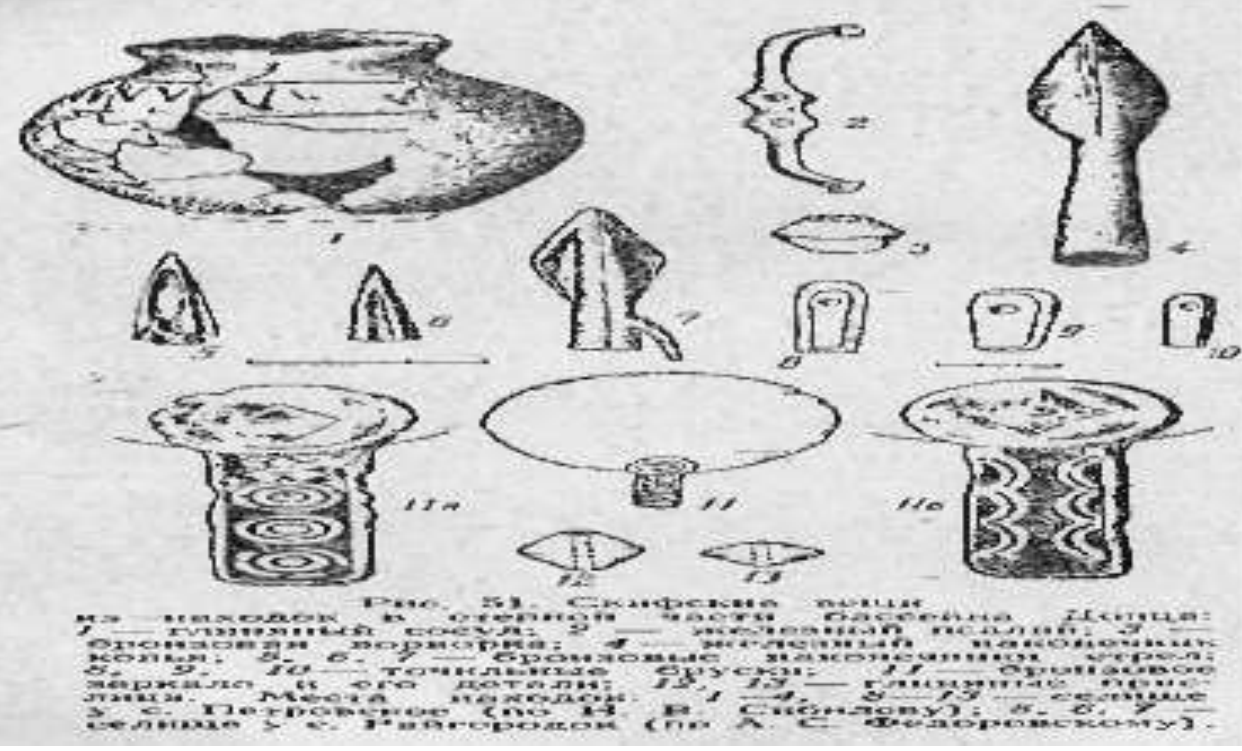

Малюнок 2(51) Скіфські знахідки

Скіфи займалися кочовим скотарством і залишили мало пам'ятників. Це поховання у вигляді курганів, в яких знайдено багато характерних бронзових предметів. 37 століття до н.е. весь басейн Сіверського Дінця $-\epsilon$ територія скіфського народу. 3 того часу з'являються перші письмові джерела. Геродот неодноразово згадує в історії Сіверський-Донець і скіфів, та й Геродот, і пізніше в російських літописах дуже часто плутають назви Дон і Донець. У той час Сіверський Донець часто вважався головною рікою, поряд з 218-кілометровим ділянкою Дону до його впадання в Азовське море, а сам Дон був просто його притокою.

Факти про річку стосуються також епохи мезоліту. Вчені виявили безліч пам'ятників епохи в басейні Сіверського Дінця. Найбільша щільність знаходиться в середній течії від Ізюму до Луганська. Всі пам'ятники мезоліту мають відмінні риси (численні призматичні ядра, сліди полювання на диких конях та ін.), що свідчить про етнічну однорідність племен, які там проживали. На стоянках мезоліту виявлені найдавніші орнаменти в розкопках басейну 3 
чорноморських молюсків, пофарбованих червоною охрою. У середині течії річки Сіверського Дінця з давніх часів відомо, завдяки багаторічним дослідженням Н. В. Сибилева і С. А. Локтюшева, велика кількість мезолітичних стоянок. Основна маса їх розташована від Ізюму до Луганська, але окремі стоянки $є$ і в інших місцях, в верхній та нижній течії річки. Стоянка Рогалик розташована в околицях хутора Рогалики на високому правому березі р. Свсуг, поблизу Якимівської балки, яку знайшли в 1926 р. група дослідників під керівництвом С. А. Локтюшева. На розкритій площі культурні залишки, що залягають окремими або невеликими скупченнями. Залишків будинків не виявлено, але в декількох місцях були зафіксовані округлі плями вогнищ. На стоянці знайдено велику кількість виробів з каменю (переважно вживався кремінь, рідше кварцит), кістяні вироби і кісткові залишки їжі, раковини з'їдених молюсків та прикраси.

Археологами виявлено неолітичні поселення. Про це $\epsilon$ свідчення одомашнення бика: в гирлі річки Оскіл, де був знайдений древній кантон, виритий зі стовбура дерева. Завдяки дослідженням ряду археологів, головним чином В. А. Городцова, П. П. Єфименко, Н. В. Сибилева і Д. Я. Телєгіна, на берегах Сіверського Дінця та його притоків відомо вже кілька десятків неолітичних стоянок.

У культурному шарі стоянок зустрічається багато виробів 3 кременю. Для місцевих стоянок розвиненого неоліту характерно поєднання великих і дрібних кам'яних знарядь. Відповідно до цього зустрічаються великі і дрібні нуклеуси. Велику роль в господарстві відігравали знаряддя деревообробки. Також були крем'яні сокири - різаки оброблялися тепер ретельніше, ніж в ранньому неоліті, за допомогою оббивки по всій поверхні знаряддя. Стали застосовуватися крем'яні свердла і клини. Знайдено подібні на ніж пластини, великі скребки, різних типів різці. Племена, що жили в басейні Сіверського Дінця в період бронзового століття охоплює повністю II тисячоліття до н. е. і перші століття I тисячоліття до н. е., вони мали свою металургійну базу. Відомо, що в Донбасі $\epsilon$ родовища міді, цинку i свинцю. Причому принаймні мідні родовища, представлені головним чином мідистих піщаників, безсумнівно, розроблялися ще в бронзовому столітті поблизу м. Бахмут, Донецької області, і в Фрунзенському районі Луганської області (в межах колишнього Слов'яносербського повіту).

Вельми рано з процесом видобутку заліза ознайомилися племена, які жили в басейні Дону і Дінця. Про це переконливо свідчить кілька археологічних знахідок. Ще в 1936 р під час розкопок Г. В. Підгаєцького на лівому березі р. Воронеж було виявлено поселення зрубної культури (середини II тис. До н. Е.) Із залишками місцевого металургійного виробництва. Тут знайдені уламки плавильних тиглів і шлаки від плавки мідної руди, а також шлаки, отримані при добуванні заліза.

Одним 3 місць, де племена, які жили в басейні Дінця, займалися ще на початку залізного віку видобутком руди і «варінням» заліза, були околиці с. Городища на території нинішньої Луганської області. Ще в 70-х роках XIX ст. харківський геолог А. Носов відзначив наявність тут слідів древніх розробок залізної руди. Це було підтверджено і сучасними геологічними дослідженнями. 
У 1950 р. А. Носов приступив до спеціального археологічного вивчення залишків стародавнього залізного виробництва у с. Городища. Археологічні розвідки і невеликі розкопки показали, що на південь від села, у балки Городня (струмок балки Городня впадає в р. Білу, яка $є$ притокою Луганки), де $є$ виходи залізної руди і залишки древніх плавильних горнів, збереглися сліди двох селищ. Одне відноситься до IV-III ст. до н. е., коли тут жили скіфські племена, а інше пов'язане з племенами салтівської культури (VIII-X ст. н. е.). При розвідках в 1957 р тут був знайдений кам'яний товкач для дроблення руди і зразки характерні скіфської і салтівської кераміки. Добуванням заліза в ранньому залізному віці займалися звичайно, далеко не на всіх, але на багатьох поселеннях в басейні Дінця. Такі племена як сармати, болгари, а також їхні сусіди теж були присутніми на берегах Дінця. До групи сарматських поховань відноситься i могила, виявлена на піщаному дні лівого берега Дінця у с. Яремівка Ізюмського району. Близько кістяка, що лежав у витягнутому положенні головою на південний схід, знайдені бронзові тригранні наконечники стріл скіфського типу i типовий сарматський горщик, прикрашений канелюрами. Інвентар більшості курганів, в яких поховані рядові члени родоплемінних сарматських громад, невеликий, але досить характерний. У похованнях зустрічаються залишки заупокійної їжі в вигляді кісток вівці, корови або коня, глиняний посуд, прикраси, деталі одягу, зброя, частини кінської збруї та інші речі. Крім мечів $і$ кинджалів, сарматські воїни широко застосовували лук і стріли, а також списи із залізними наконечниками. Такі наконечники виявлені в кургані у м. Слов'янськ і у ст. Квашино.

Знахідки ям для зберігання зерна свідчать про те, що осіли на берегах Дінця алани займалися вже не тільки скотарством, але і землеробством. У Салтівських комплексах Правобережного Цимлянського городища на Дону були знайдені залізні плужні сошники і чересла, а також мотики, серпи і коси. У колекції Донецького краєзнавчого музею разом з уламками посудин і вантажив від мереж зберігаються також серпи, знайдені на Салтівському поселенні у с. Маяки в Слов'янському районі. (мал.3 (105))

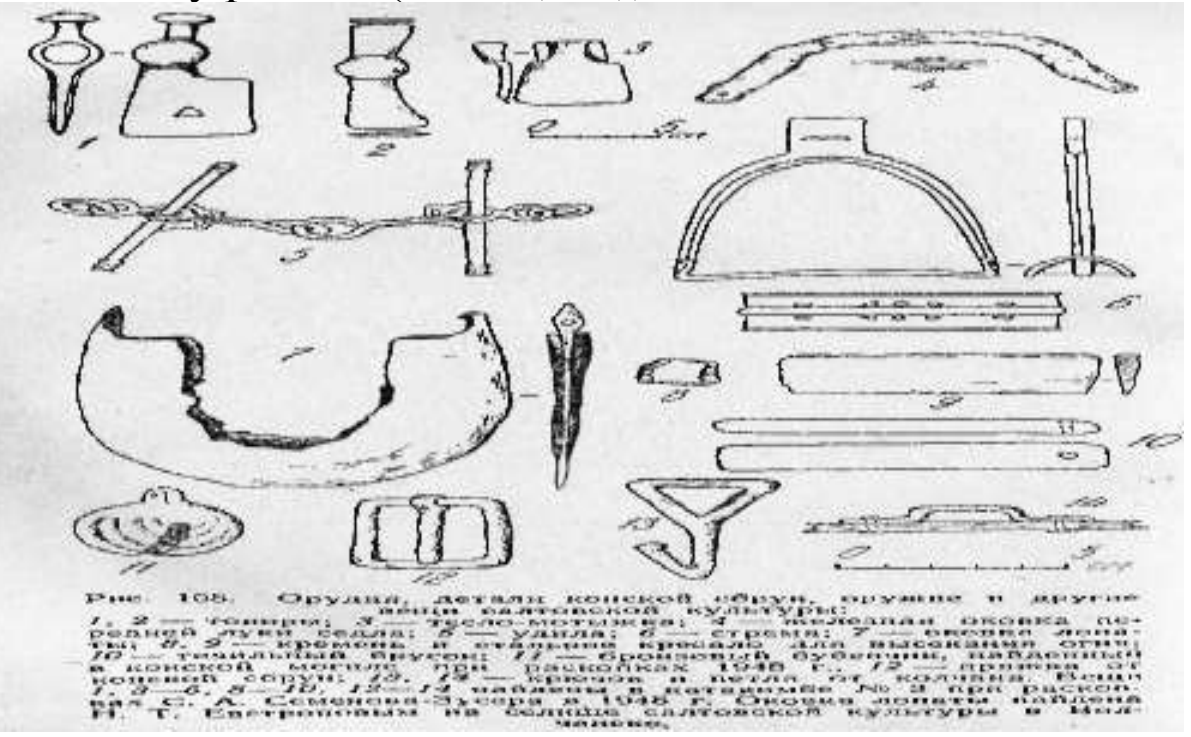

Малюнок 3(105) Знахідки салтівської культури 
Починаючи з VIII століття, в басейні річки починається панування хазар, що сприяло осілості кочівників, що супроводжувалося спорудженням на правому березі цілої лінії укріплених фортець. Разом з тим, 3 протилежного напрямку місцевість заселялася слов'янськими племенами в'ятичів і сіверян, що дали другу складову частину назви. Деякі історики вважають, що донецький басейн був одним 3 перших оплотів російської державності. В умовах зародження давньоруських князівств Київ і Хазарія розгорнули протиборство за володіння територією Донецького басейну, що завершилося торжеством київських підданих. Однак цей успіх зруйнував перепону для нападів кочових племен.

Судячи з археологічних даних, і у Донецькому городищі приблизно в другій половині X в, знову виникає російське поселення. Місто Донець згадується в Іпатіївському літописі під 1185 (6693) роком у зв'язку з розповіддю про втечу новгород-сіверського князя Ігоря Святославича 3 половецького полону.

Дуже докладно це питання останнім часом досліджував Б. А. Рибаков, який цілком переконливо довів, що Доном, або Великим Доном, принаймні в XII в. називали сучасний Сіверський Дінець і в нижній течії сучасного Дона (від впадіння в нього Сіверського Дінця до гирла). Сучасну річку Уди, на березі якої розташоване Донецьке городище, називали Донець або Малий Донець.

1828 р. у записках майора Крафта, який виконував рекогносцирувальні обстеження на Дінці, $\epsilon$ вказівки про глибини під час обстеження: «Глибина річки була надзвичайно велика, влітку і восени води в Дінці було також надзвичайно багато». Можна припустити, що весна не була маловодною, а літо і осінь були багатоводні.

1849 р. «У селі Вільхівка і Стрілецькій Слободі будинки, розташовані на березі Дону, були абсолютно затоплені розливом цієї річки». Значний розлив був на p. Вороні. Про характер весни $\epsilon$ такі відомості: «Нинішній розлив весняних вод стався по всій губернії (Тамбовської) з такою швидкістю і в такому розмірі, що подібному йому ніхто не пам'ятає». Очевидно, на Дінці також було високе весняне водопілля.

1876 р. На початку зими 1875-76 pp. була відлига погода, про що збереглися такі відомості: «У м. Бахмуті в ніч з 25 на 26 грудня внаслідок сильної відлиги і проливного дощу розтанув і випав на початку зими у великій кількості сніг, тому p. Бахмутка вийшла з берегів і розлилася по всій низинній частині м. Бахмут; причому вода пройшла в багато дворів жителів і навіть проникла в будинки».

1886 р. в Харкові 23 червня спостерігався катастрофічна злива, під час якої випало 132 мм опадів. Як показує аналіз багаторічних даних, характерні сезони (суворі або теплі, малосніжні або багатосніжні зими, дуже посушливі або занадто дощові літні сезони і ін.) В більшості випадків настають синхронно в басейнах Дніпра і Дінця.

\section{Висновки}

На сьогоднішній день Сіверський Донець - джерело прісної води для сходу України, головне джерело води для міст Харкова, Донецька, Луганська та ін. Розв'язання екологічної проблеми чистої питної води на сході Донбасу, можливо, через системну реалізацію державної політики в галузі водного 
господарства, використання ресурсів держави та регіонів із метою забезпечення інноваційно-інвестиційного розвитку водного господарства, що уможливить підвищення ефективності державного управління водними ресурсами на регіональному рівні. Ураховуючи вищевикладене, реалізацію заходів можливо упровадити через:

- ефективний, обгрунтований і збалансований механізм використання, охорони та відтворення водних ресурсів, забезпечення сталого розвитку регіональної системи моніторингу довкілля, зокрема й водних ресурсів;

- підвищення технологічного рівня водокористування, упровадження маловодних та безводних технологій, розроблення більш раціональних нормативів водокористування, будівництва, реконструкції та модернізації систем водопостачання та водовідведення;

- удосконалення стандартів і нормативів щодо використання водних ресурсів та лімітів забору води;

- реалізації водо та енергозберігальних технологій, які забезпечать підвищення функціонування водогосподарського комплексу;

- забезпечення потреб населення та галузей економіки в якісних водних pecypcax;

- зменшення обсягу споживання та відведення води;

- забезпечення та ефективний захист територій і населення від шкідливої дії збройного конфлікту;

- зниження рівня водоємності промислового виробництва;

- підвищення ефективності та забезпечення екологічної безпеки водокористування.

\section{Анотація}

Визначенні питання і проблеми екологічного використання водних ресурсів Донбасу, зроблено збір історичних відомостей про використання річки Сіверський Дінець. Обгрунтована потрібність прийняття послідовних дій з поліпшення екологічної ситуації на Донбасі, для цього на наш погляд необхідно вжити ряд науково обгрунтованих заходів:

- модернізацію використання та організацію охорони вод регіону в системі водопостачання та водовідведення;

- охорону та відновлення природно-заповідного фонду з урахуванням необхідності відтворення екосистеми, порушених військовими діями, які повинні завершитися їх реалізацією на практиці.

\section{Література}

1. Оцінка екологічної шкоди та пріоритети відновлення довкілля на сході України. К.: ВАITE.2017. С.87-88.

2. Рацлав В.В. Дослідження хімічного стану якості 3 проблемами екологічного використання підземних вод басейну річки Сіверський Дінець: Екологічні науки: науково-практичний журнал.-К. 2020.-№28-178c. 
3. Рацлав В.В. Моніторинг біоти та донних відкладів вод басейну річки Сіверський Дінець: Екологічні науки: науково-практичний журнал.-К. 2020.№29-180c.

4. Сіверський Донець: Басейн Здоров'я - людям життя! Київ, ВАITE, 2018.С. 30.

5. Водний Кодекс України / ВВР України. - 1995. - № 213/95.

6. Загальнодержавна цільова програма розвитку водного господарства та екологічного оздоровлення басейну річки Дніпро на період до 2021року :

7. http://sdbuvr.slav.dn.ua/download/DopovidyJuk.pdf

8. https://wikizero.com/uk/Сіверський_Донець

9. https://znaimo.com.ua/Сіверський_Донець

10. http://www.sdbuvr.slav.dn.ua/download/DopovidyJuk.pdf

11. http://www.ecoj.dea.kiev.ua/archives/2019/1/part_1/20.pdf

12. http://dalizovut.narod.ru/hramko/hramko.htm 


\title{
ДЕНЬ КОСМОНАВТИКИ: ПЕРША КОСМІЧНА ЛЮДИНА
}

\author{
Чернуха Олександр Васильович, \\ Доцент, кандидат історичних наук, \\ Харківський національний медичний університет
}

\section{Тесля Денис Сергійович,} Харківський національний медичний університет

100 років тому людина почала лише задумуватися про польоти до космосу. Поява ракетних технологій, які бурхливо розвивалися у другій половині XX століття, призвели до величезної кількості досліджень ближнього космосу. Саме в цьому році, а саме 12 квітня, буде відзначатися 60-та річниця польоту Юрія Гагаріна на кораблі «Восток-1» у космічний простір.

Друга Світова війна, що закінчилась розгромом Нацистської Німеччини, розділила світ на два воєнно-політичні блоки: з одного боку були союзники США, з іншого - держави комуністичного простору на чолі з СРСР. Ніяка зі сторін конфлікту не признавала свого певного відставання від конкурента. Була розпочата ракетно-ядерна гонка озброєнь. Саме створення більш швидких двигунів та міцних ракетних корпусів, що здатні витримати шлях до космосу, показував силу держави, бо ці технології могли використовуватися в ядерній зброї. Звичайно, що політ людини до космосу був зумовлений ще й з боку тяги людства до пізнавання нового.

Політ Гагаріна входив до радянської космічної програми «Восток», призначення якої полягало у створенні серії одномісних пілотованих космічних кораблів і виконанні перших випробувальних орбітальних польотів космонавтів на одномісному космічному кораблі «Восток» [1].

3 жовтня 1959 року в авіаційних частинах проводився відбір кандидатів в космонавти групою військових фахівців-медиків під керівництвом полковника медичної служби Євгена Карпова, що згодом став першим начальником Центру підготовки космонавтів (ЦПК) ВПС, в якому безпосередньо відбувалася підготовка космонавтів. У процесі першочергового відбору були розглянуті документи на 3461 льотчика. За анкетними даними для бесіди були відібрані 347 чоловік. 3 усіх кандидатів, які пройшли всі етапи медичного обстеження, мандатної комісією були відібрані 20 осіб. Саме стільки посад слухачівкосмонавтів передбачало штатний розклад військовою частиною 26266 (майбутній Центр підготовки космонавтів). Через відсутність достатньої тренажерної бази неможливо було готувати відразу всіх слухачів, тому було прийнято рішення відібрати з них шістьох для першочергової підготовки. Одним з них став Юрій Олексійович Гагарін [1].

Він народився у селі Клушино, Гжатського району Смоленської області 9 березня 1934 р. А до школи пішов лише у 1943 р., коли село звільнили від німців. Далі навчався в ремісничому училищі м. Люберці, де отримав спеціальність 
формувальника-ливарника, та одночасно у школі робітничої молоді. У 19511955 рр. Гагарін навчався у Саратовському індустріальному технікумі за спеціальністю “Ливарне виробництво", а у 1954-1955 pр. ще й в аероклубі. Закінчивши технікум і аероклуб, Ю.О. Гагарін у 1955 р. був направлений до Оренбурзького училища військових льотчиків. Училище він закінчив у 1957 р. та обрав службу на Півночі, куди через півроку приїхала і дружина Валентина [2].

У 1959 р. Юрій Гагарін подав рапорт про вступ до загону космонавтів, куди був зарахований 7 березня 1960 р. У Центрі підготовки космонавтів розпочалися інтенсивні заняття - фізпідготовка, заняття у класах і на тренажерах, вивчення техніки та робота на ній. Потім екзамени та держкомісія, яка призначила Ю.О.Гагаріна пілотом космічного корабля, а Г.С. Тітова - дублером [2].

3 квітня на пленумі ЦК КПРС було розглянуте і схвалене рішення про готовність до запуску в космос пілотованого людиною корабля під головування Микити Хрущова й 8 квітня державна комісія затвердила відповідне політне завдання: «Виконати один виток навколо Землі на висоті 180-230 кілометрів тривалістю 1 година 30 хвилин з посадкою в заданому районі. Мета польоту перевірити можливість перебування людини в космосі на спеціально обладнаному кораблі, перевірити обладнання корабля в польоті, перевірити зв'язок корабля з Землею, переконатися в надійності засобів приземлення корабля і космонавта» [3].

Вранці 11 квітня 1961 року ракета-носій «Восток-К» 3 прикріпленою до неї капсулою «Восток ЗКА» прибула до місця старту на космодромі Тюратам. О 10й годині за московським часом Юрій Гагарін і його дублер Герман Титов отримали план-завдання польоту, після чого пройшли медичне обстеження і о 6й вечора відправились на відпочинок. Наступного дня о 5:30 їх розбудили і після сніданку обох привезли на стартовий майданчик. Одягнувши скафандр, Гагарін увійшов до космічного корабля, о 7:10 включив радіозв'язок. Наступні дві години він провів за розмовами зі спостережним центром і о 9:07 12 квітня 1961 року за командою Сергія Корольова «Восток-1» почав політ. Через 10 секунд корабель вийшов на орбіту, після чого від нього відділилась капсула з космонавтом, з яким підтримувався двосторонній зв'язок. Перший політ людини у космос відбувався в автоматичному режимі і тривав 1 годину 48 хвилин, за які було здійснено один обліт навколо Землі на висоті від 175 до 302 км. О 1025, коли корабель перебував біля західного узбережжя Африки в районі Анголи розпочався спуск: від основного апарату відділився спеціальний модуль, який через конструктивний прорахунок, виявився зв'язаним з ним пучком дротів. О 10:35 у небі над Сгиптом дроти розірвались і модулі розділились, про що Гагарін, який попри 8-кратні перевантаження свідомості не втрачав, доповів у командний центр. На висоті 7 км від Землі він автоматично катапультувався і о 10:55 приземлився біля міста Енгельс у Куйбишевській (нині Саратовській) області Росії, за майже півтори тисячі кілометрів від запланованого місця. Першими Гагаріна виявили місцеві селяни, й невдовзі до місця його приземлення прибули військові місцевого ракетно-зенітного дивізіону і евакуювали разом із знайденим за 16 км обгорілим спусковим модулем до Куйбишева [3]. 
Після польоту у Юрія Гагаріна почалося нове життя. Він тепер - не тільки командир загону космонавтів. Його обрали депутатом Верховної Ради СРСР, головою або членом правлінь кількох товариств. А ще - навчання у Військовоповітряній інженерній академії ім. М.Є.Жуковського. Крім того, поїздки на запрошення багатьох країн, міст та підприємств. 3 грудня 1963 р. він став заступником начальника Центру підготовки космонавтів. І готувався до польоту на космічному кораблі “Союз”. Дипломний проект Гагарін захистив 17 лютого 1968 р., а вже у березні почав тренувальні польоти, щоб поновити навички пілотування. Останню перевірку проводив 27 березня 1968 р. полковник В.С.Серьогін. Цей політ завершився трагічно. Причини катастрофи достовірно не з'ясовані і донині [2].

Висновок. Політ першої людини у космос став тріумфом радянської космічної програми. Це було величезне досягнення для всього людства. 7 квітня 2011 року на спеціальному пленарному засіданні Генеральної Асамблеї ООН була прийнята резолюція, офіційно проголосила 12 квітня Міжнародним днем польоту людини в космос. Співавторами резолюції стали більш ніж 60 держав.

Більшість документів ще не знаходиться в вільному доступі, або знайти їх дуже важко, це дає перспективу на подальше дослідження як першого польоту людини в космос, так і в цілому перших космічних програм нашої цивилізації.

\section{Список літератури:}

1. "Научно-исследовательский испытательный центр подготовки космонавтов имени Ю.А.Гагарина". URL: http://www.gctc.ru/main.php?id=229 (Дата звернення 23.03.2021)

2. Національний технічний університет України "Київський політехнічний інститут імені Ігоря Сікорського". URL: https://kpi.ua/gagarin-about. (Дата звернення 23.03.2021)

3. ЦЕЙ ДЕНЬ В ICTOPIÏ. URL: jnsm.com.ua/h/0412M/ (Дата звернення 23.03.2021) 


\title{
АРХІТЕКТОР ОЛЕКСІЙ БЕКЕТОВ ТА ЙОГО СПАДОК
}

\author{
Чернуха Олександр Васильович, \\ доцент, к.і.н, \\ Харківський національний медичний університет

\section{Манаснкова Ксенія Андріївна,} \\ Студентка, \\ Харківський національний медичний університет
}

У цьому році 23 листопада виконується 80 років з дня смерті видатного українського архітектора Олексія Бекетова. На честь цього нижче буде описаний життєвий шлях та багатий творчий спадок цієї видатної людини.

Олексій Миколайович Бекетов народився 19 лютого (3 березня) 1862 року в Харкові. Батьком Олексія був академік Петербурзької академії наук Микола Миколайович Бекетов. Брат батька - Олексій Миколайович - також був вченим, а точніше ботаніком-дарвіністом [1].

Олексій навчався в Харківському реальному училищі, але крім цього ще й у приватній художній школі М.Д. Раєвської-Іванової. Після цього закінчив навчання із золотою медаллю на факультеті архітектури Академії мистецтв у Петербурзі [1, 2, 3].

Потім Бекетов повернувся в своє рідне місто і почав викладати в Харківському технологічному інституті, паралельно працюючи над архітектурними проектами $[2,4]$.

У Харкові Олексій Бекетов побудував понад чотири десятки громадських будівель. В їх число входять Юридична Академія (Пушкінська, 77), Художній музей (вул. Жон Мироносиць, 9), Будинок техніки (пл. Незалежності, 26), Будинок вчених (вул. Жон Мироносиць, 10), Театр ляльок (пл. Незалежності, 24), художній музей (вул. Жон Мироносиць, 11) і багато інших [1].

Також по проектам А.Н. Бекетова було побудовано близько шістдесяти будівель в інших містах і регіонах, наприклад в Криму (Сімферополь, Алушта), Києві, Ростові-на-Дону, Катеринославі, Лубнах, Новочеркаську, Бєлгороді, Баку, Донецьку та містах Донбасу (Горлівці, Макіївці та інших) [4].

Будівля Олександрівського комерційного училища в стилі неоренесансу стала архітектурним дебютом Олексія Бекетова. Проект поєднував в собі витонченість, строгість форм і раціональне планування. Зараз ця будівля належить Юридичної академії ім. Ярослава Мудрого [2, 4].

Ще одним цікавим реалізованим проектом Бекетова, за який він удостоївся звання академіка архітектури, стало будівництво Публічної бібліотеки в 18891901 роках, яка зараз називається бібліотека ім. Короленка. Серед достоїнств будівлі відзначали такі якості як комфортні вільні зали, органічна взаємодія книгосховища з іншими приміщеннями бібліотеки, література в які надходила завдяки роботі спеціального підйомного пристрою $[4,5]$. 
31911 по 1919 року по проектам Олексія Бекетова були побудовані такі будівлі, як будівля Харківського медичного товариства, Комерційний інститут і будівля Вищих жіночих медичних курсів. Зараз, в будівлі Харківського медичного товариства знаходиться Харківський інститут мікробіології та імунології ім. І. І. Мечникова (вул. Пушкінська, 14). Комерційний інститут після реорганізації став називатися Харківським національним економічним університетом ім. С. Кузнеця (пр. Науки 9-А), а будівля Жіночих медичних курсів стала навчальним корпусом Технічного університету сільського господарства (вул. Мироносицька, 92) [5].

Також одним із значущих напрямків в діяльності відомого архітектора було проектування і створення будівель фінансових установ. Для цього Олексій Бекетов вивчив будову будівель банків кількох європейських країн. Після цього по проектам Бекетова були зведені будівлі таких банків, як Комерційний, Земельний, Волзько-Камський і Торговий $[3,5]$.

Ще один напрямок діяльності Олексія Бекетова - проектування i спорудження житлових будинків. Більшість особняків, побудованих Бекетовим, знаходяться на вулицях Дарвіна і Жон Мироносиць. Це особняки сім'ї Алчевських (1893 p, 1896 р.), особняк А. А. Іозефовіч (1896 р.), І. Л. Залеського (1897 р.), особняк М. П. Соколова (1899 р.), I . І. Сомова (1899 р.), особняк П. В. Маркова (1901р.), Ф. П. Піснячевского (1903 р), А. І. Фенина (1909 р.), І. С. Ігнатіщева (1914р.) [5].

Помер видатний архітектор 23 листопада 1941 року в окупованому Харкові в віці 79 років. На честь нього в його рідному місті названа станція метро, встановлені кілька пам'ятників i його ім'я присвоєно Харківському національному університету міського господарства $[1,2,3]$.

Олексій Миколайович Бекетов прожив довге та плодотворне у творчому сенсі життя. За цей час він спроектував та збудував понад сотню будівель різного призначення. У їх художньому оформленні можна простежити вплив різних напрямків: бароко, італійського ренесансу, рококо, класики, модерну. Всі разом вони утворили неповторний архітектурний стиль Олексія Бекетова.

\section{Список літератури}

1. Бекетов, Алексей Николаевич. URL: https://ru.wikipedia.org/wiki/ Бекетов,_Алексей_Николаевич (дата звернення 05.03.2021).

2. Видатний архітектор Олексій Миколайович Бекетов : бібліогр. покажч. / уклад.: О. М. Штангей, Н. В. Марищук, техн. ред. О. М. Запорожченко. Харків : ХНУМГ, 2014, 51 c. URL: https://library.kname.edu.ua/images/ Бекетов_Олексій_Миколайович.pdf (дата звернення 06.03.2021).

3. Выдающиеся харьковчане. Бекетов Алексей Николаевич. URL: https://nikolsky.com.ua/ru/beketov-oleksij/ (дата звернення 08.03.2021).

4. Архітектор Бекетов. URL: http://kharkov.vbelous.net/famous/famart/beketov.htm (дата звернення 10.03.2021). 
5. Бекетовские здания: что построил в Харькове знаменитый архитектор. URL: https://mykharkov.info/news/beketovskie-zdaniya-chto-postroil-v-harkoveznamenityj-arhitektor-67479.html (дата звернення 15.03.2021). 


\title{
TEMPORAL LIMITS OF EXERCISE OF SUBJECTIVE LAW
}

\author{
Guyvan Petro \\ Professor of Poltava Institute of Business, \\ k. yu. Sciences, Honored Lawyer of Ukraine.
}

As you know, any social processes occur and develop over time. This applies both to human activity and to the objective phenomena of the material world. Time as an objective category, as a form of existence of matter is essential for civil relations. These relations themselves, the specific material rights and obligations of the participants, and finally, the legal acts that determine their proper behavior, arise, are realized and terminate at a certain time. at the same time, civil law does not operate with the notion of time as an objective phenomenon, but with certain moments or intervals of it, selected from the general incessant and irreversible course. There is no doubt that the timeliness of the exercise of subjective rights and the fulfillment of legal obligations is an important guarantee of the stability of material circulation, the proper satisfaction of its participants with their needs. Thus, civil legal relations can be qualified as real phenomena of the material world, which exist and manifest themselves over time, have a certain duration, sequence, which is determined by the time factor. The development of time problems in civil law is of great methodological importance, as time is a general legal category that serves almost all institutions of civil law [1, p. 38].

In the civil literature, the issue of temporal regulation of the implementation of subjective law within is devoted to the work of numerous researchers who analyzed the temporal component of the right of a person to perform their own productive actions and demand the necessary behavior from the counterparty. At the same time, certain aspects of the organization of interaction of subjects in time at the level of the creditor - the debtor continue to be not studied. For example, many disputes arise in the area of determining the place of time, which determines the proper exercise of the right and distinguishes it from abuse, based on the purpose and nature of the legal impact on the mediated relationship. The original problem of finding the necessary balance between the exercise of a subjective right against the purpose and the performance of actions outside the law, including temporal ones, also needs further research. Therefore, it is necessary to further study the issues of current problems of temporal mediation of material relations by identifying and studying the patterns of establishment, procedure and termination of powers of the person.

Any subjective right has value only due to the fact that it can be used to meet the own needs of the authorized person, ie due to the possibility of exercising the right [2, p. 11]. Thus, being a subject of a certain substantive law, a person inevitably receives the appropriate degrees of freedom, within which his behavior can turn the possibilities inherent in subjective law into the necessary material result. One of the factors that restricts the freedom of the entitled person in the exercise of subjective law may be 
time: subjective law has certain limits not only in content or method of its implementation, but also limited in time. Legal relations may be carried out in accordance with the limits established by law on the legality of the conduct of the subjects. These limits also include a specified period (term) for the exercise of rights and performance of duties. Civil law may set a deadline for the exercise of substantive law. After the expiration of this period, the realization of the right is impossible, and the subjective right is terminated. In this case, the possibility of exercising civil law is associated with the active initiative of the creditor, which he must take within the established limits. Failure to take action does not allow the entitled entity to achieve the goal of civil law - the realization of its substantive law. If the validity of the right is limited in time, accordingly limited by the term and the possibility of the creditor to perform these actions. Upon expiration of the right, the corresponding obligation shall cease. After the expiration of the term for the exercise of the substantive right, the creditor loses the opportunity to demand performance of the obligation from the debtor, and the latter is released from the obligation to perform it.

The terms of existence of legal relations, rights and obligations of their subjects are the legal tools that to a greater or lesser extent cover all civil law institutions. Strictly speaking, the content of any legal relationship, regardless of whether it is imperative or by the participants themselves, should clearly follow when the determined behavior of the subjects should take place. Otherwise, the relationship loses such a factor as certainty, which makes it impossible to implement its mandatory regulatory function. This is also true for situations where the validity period is not specified: the action or event outlined by law or by the participants themselves will determine a specific moment in time. The term (term) is postulated in most modern Ukrainian scientific works as a factor that triggers certain material relations (they begin, change or terminate). We consider such an approach very simplistic. In the context of this issue, the position of those researchers who postulate the term as a temporal factor that defines the boundaries of subjective civil law in time and is an integral part of its content as an intrinsic sub objective law is the limit of its existence [3, p. 25-26]. Today, the most vivid expression of this concept is VV Luts, who considers the terms of the temporal form of civil relations, a form of existence of subjective rights and responsibilities that constitute their content [4, p. 185].

The purpose or prerequisite of subjective civil law is considered to be a certain economic need, the realization of which is ensured by law. For example, the economic precondition of the right of the consumer of electric energy is his interest in receiving the given resource, interest of the person concerning use of property is realized through the corresponding right of the tenant, etc. Thus, in due course there can be a situation when the subjective right continues to exist, however its bearer has already lost interest in him, that is, the material premise of law has disappeared. This situation is most evident when the content of the subjective right is to take active positive actions by the right holder. Termination of interest, thus, will affect the exercise of the right - it will remain unrealized. Thus, the heir, given the composition and condition of the estate may ignore the possibility of applying for acceptance of the inheritance.

On the other hand, the failure of the authorized subject to exercise his right does not always indicate the loss of the purpose of the right, the material interest. In addition, 
the property premise of the right, which has ceased, may be subsequently restored, which from a certain point will be manifested in its implementation by the holder. Therefore, it would seem that the question of the existence of the precondition of the right and its exercise by the owner concerns only himself and does not affect the interests of other subjects, society. But this is only at first glance. Subjective civil rights are determined by the relevant rules of law, so even if they belong to a particular entity, they have a social (social) significance. At the same time, it is impossible to equate the private interest of the right holder in its exercise with the public interest determined by the norm regulating this right. Therefore, sometimes, even though the interest of the right holder remains with the passage of time, in the eyes of the law, he at the same time loses its social significance [3, p. 28]. Thus, it is the social aspect, and not the material interest of the bearer, that is decisive in establishing the legally defined terms of the existence of a subjective right.

Strictly speaking, each subjective right as a measure of the possible behavior of the managed entity has its limits. First of all, they concern the content of the powers of the carrier in relation to the methods and procedure for its implementation. In the literature, there has been and continues to be a discussion about the absence of such boundaries in the exercise of property rights. According to FK Savinya and his followers, the right of ownership by its nature is an unlimited right, it allows the subject to receive any benefit from the use of property, without taking into account any other circumstances. But, in fact, everything was not so clear. The legislation did not accept such assumptions, especially since they do not cover all cases of realization of property rights. Civilian scholars also pointed out the limitation of this right by law, and the power of the owner over the thing should be exercised within the limits set by law [5, p. 248]. Today, the dominant thesis in civilization is that the right of property cannot be used contrary to the law and moral principles of society, to the detriment of the ecological state, rights and interests of others. Otherwise, the exercise of property rights should be classified as abuse of rights [6, p. 420]. The corresponding rule is reflected in the Civil Code of Ukraine (see Article 319 of the Civil Code).

As we can see, the position on the limitation of any subjective right is quite indisputable today, if the limits of the right are not established, it is impossible to exercise it. But this applies only to the existence of limits on the conduct of the authorized person regarding the scope of the law (for example, it may be determined by law or contract) or the manner and nature of its implementation (in this regard, the limits of law must take into account the law). As for the duration of the subjective right as one of the factors influencing the limits of the conduct of the entitled person, the provision on the restriction of the right by certain terms is not general. In particular, as a rule, absolute civil rights are not normatively limited in time. But, in fact, the duration of even such subjective material rights of a person is not infinite: it is determined by the time of alienation or destruction of property, the death of the carrier, and so on. A separate assessment should be given to such binding substantive rights, the term of which is not set or determined at the time of the claim. It is necessary to recognize the erroneous point of view of researchers who consider these mandatory rights and obligations indefinite [7, p. 74].This obligation has a term of performance, although 
this term is not set by the participants, and it is related to the creditor's claim [8, p. 257258].

The legal relationship to distinguish a civil offense from an abuse of law has hardly been studied in the civil literature, and those scholars who have nevertheless considered this issue have different approaches to the issue of liability for abuse of subjective civil law. Thus, some of them deny the possibility of bringing a person who abuses his subjective right to responsibility, while others adhere to the opposite point of view [9, p. 20]. So, does this situation apply to the general rule that a protective relationship arises in the event that the right holder fails to fulfill his obligation? We believe so. As the law does not contain any reservations regarding these relations, a legal mechanism specific to the protection of the violated subjective right should be applied. Therefore, any person whose rights and interests have been violated by another person's improper exercise of his right may obtain his compulsory protection by compensating for the damage caused. Confirmation of this is found in the doctrine and legislation of some foreign countries, which have long introduced compensatory liability for damage in case of abuse of rights (harassment) in the form of compensation [10, p. 20-21].

At the same time, it should be noted that the commission of certain actions that do not follow from a person's subjective civil law (committed outside its content or duration) is not identical to the illegality of the act. Actions may be considered illegal if they contradict legal requirements. However, if the actions, although not based on the proper person's subjective right, but do not contradict the requirements of the law, meet the criteria of personal interest and do not harm the environment, other right holders, etc., their commission does not entail liability for the person who carried them out. However, it is impossible to agree with the point of view of some scholars on the need to recognize such actions as lawful [2, p. 31]. According to the provisions of civil law, the exercise of a right outside its existence in such cases should be considered illegal, and the requirements of the person who had such a right to enforce it should entail a refusal to protect the right. However, it is impossible to agree with that position $[11$, p. 76,80$]$ that the refusal to protect the right is a sanction against the entitled person, as such measures of influence do not meet the generally accepted criteria established by law for the application of protection measures or civil liability. Therefore, compensatory sanctions should be applied for abuse of rights or acts outside the law in case of material damage to the rights or interests of society or a particular person protected by law, which should be prescribed by law.

Thus, we can conclude that a civil term (term) is a measure of the social significance of a particular material relationship, as well as a means of stimulating the parties to the timely exercise of their rights and responsibilities, based on the interests of society. A right belonging to a certain person may be exercised by him only for a period established by law or contract. The exercise of powers that constitute the content of law outside its existence is impossible. Subjective authority is considered to have expired. Therefore, there can be no question of abuse. After all, such an action - abuse - occurs only in the presence of law, it is used against its purpose or public interest. But the abuse does not terminate the right, it can be carried out in the future with a legitimate purpose. On the contrary, the use of a right outside its scope cannot be 
qualified as an abuse of a right, because in fact no right exists anymore.Thus, the establishment of boundaries for the exercise of civil rights is not a restriction of these rights, but the regulation of existing material relations. Therefore, we must recognize that there is a gap in the current legislation of Ukraine on this issue, which needs to be addressed immediately. Again, the abuse of a right can be qualified only by the action of the right holder, which, being within the limits of subjective law, still does not meet the principles of reasonableness, good faith and justice. In normative form, this position is expressed in Art. 13 of the CCU, which deals with the illegality of acts committed within the framework of their right to harm others, cultural heritage, contrary to law or the moral principles of society. This fully applies to issues of abuse of rights during its duration.

\section{List of sources used:}

1. Luts V.V. Terms in civil law. Jurisprudence. 1989. №1. P.37-43.

2. Gribanov V.P. Limits of exercise and protection of civil rights. M .: Rossiiskoe pravo, 1992. $208 \mathrm{p}$.

3. Gurvich M.A. Deadlines in Soviet civil law. M. VYUZI. 1961. 80 p.

4. Civil law of Ukraine: Textbook. In 2 books. For order. O.V. Dzera, N.S. Kuznetsova. K .: Jurinkom Inter, 2002. Book I. 530 p.

5. Meyer D.I. Russian civil law (at 2 p.m.). According to the corrected and supplemented 8th ed., 1902. M .: Statut, 2000.831 p.

6. Malinovsky A.A. Problems of the legal definition of the term "abuse of rights". Problems of legal technique: Collection of articles / Ed. V.M. Baranova. Nizhny Novgorod, 2000. P. 420-425.

7. Stefanchuk M.O. The limits of the exercise of subjective civil rights: a monograph. K .: KHT Alerta, 2008. 184 p.

8. Guyvan P.D. Theoretical questions of terms in private law. Monograph. Kharkiv: Pravo, 2014. 632 p.

9. Porotikova O.A. The problem of abuse of subjective civil law. M $:$ Walters Kluver, 2007. 245 p.

10. Yatsenko T.S. Shikana as a legal category in civil law: Abstract. dis. ... cand. jurid. Science. Rostov on Don, 2001. 27 p.

11. Ioffe O.S, Gribanov V.P. Limits of exercising subjective civil rights. Soviet state and law. 1964. №7. Pp. 76-85. 


\title{
МІЖНАРОДНЕ СПІВРОБІТНИЦТВО КРАЇН В ГАЛУЗІ БОРОТЬБІ 3 ОРГАНІЗОВАНОЮ ЗЛОЧИННІСТЮ
}

\author{
Гусак Андрій Петрович, \\ доцент, кандидат юридичних наук, \\ доцент кафедри кримінального права і процесу \\ Волинського національного університету \\ імені Лесі Українки
}

\section{Веремчук Сергій Володимирович}

Приватний нотаріус Луцького міського нотаріального округу

Волинської області

Правопорушення на території держави підпадає під ï юрисдикцію. Ними займаються правоохоронні органи відповідної держави. Проте злочинна діяльність нерідко переходить кордони держав, тому постає необхідність спільної боротьби держав зі злочинністю. Ще з'являється потреба в міжнародному обміні досвідом боротьби зі злочинністю. 3 цією ціллю стали виникати спочатку двосторонні, а потім багатосторонні угоди в цій сфері, збиратися міжнародні конгреси та конференції, з'являтися міжнародні організації.

Ключовим чинником $є$ те, що положення юрисдикції держави щодо злочинів залишалися непорушним та міжнародна боротьба зі злочинністю зводилася до вирішення питань розмежування юрисдикції держав в разі колізій. Наприклад, через надання правової допомоги у кримінальних справах, включаючи розшук злочинців, вручення документів, збір речових доказів, допит свідків та інші слідчі дії, видачу злочинців, передачу засуджених осіб для відбування покарання в країні, громадянами якої вони є і т.п.[2, с.20].

Пізніше стала розширюватися і діяльність з обміну інформацією та досвідом боротьбі зі злочинністю. Якщо раніше вона зводилася до передачі відомостей про окремі правопорушників або злочинні групи, то згодом, особливо з ростом технічних можливостей, в такі обміни стали включатися всі напрямки боротьби зі злочинністю, як то: складання баз даних, наукові розробки про причини, тенденції, прогнози щодо злочинності та її запобігання.

Новий поворот міжнародного співробітництва в цій галузі дало виникнення організованої злочинності та особливо іiі інтернаціоналізація. Ці чинники стали однією з нових глобальних загроз, для подолання яких потрібні зусилля всього міжнародного співтовариства. Міжнародному праву були відомі окремі випадки, коли якась держава могла здійснювати юрисдикцію щодо деяких злочинів, наприклад піратства [4, с.42]. Але такі ситуації скоріше були винятком. На початку XX століття стала проявлятися тенденція до виділення злочинів міжнародного характеру, щодо яких важко встановити територіальну юрисдикцію якихось певних держав. Ці злочини завдають значної шкоди 
міжнародним відносинам і це стосуються всіх держав. Проти них міжнародне співтовариство вживає заходів, в тому числі вироблення i реалізацію універсальних, регіональних і двосторонніх конвенцій. Найбільшу небезпеку для міжнародного співтовариства являють злочини, як здійснюють самі держави, злочини, що посягають на міжнародний мир і безпеку. До них відносяться факти агресії, злочини геноциду і апартеїду, злочини проти людяності та військові злочини.

Отже, можна говорити про появу такої галузі права як міжнародне кримінальне право. Питання про його визначення $є$ досить спірним. Так, Л.В.Іногамова-Хегай дає наступне визначення: «Міжнародне кримінальне право являє собою систему правових принципів і норм, що регулюють відносини, які виникають у зв'язку з вчиненням міжнародних злочинів $i$ злочинів міжнародного характеру $i$ забезпечують взаємодію держав $i$ міжнародних організацій в боротьбі з ичими злочинами» $[3$, с.42].

Н.І.Костенко пропонує більш розгорнуте визначення. Він пише, що міжнародне кримінальне право являє собою систему загальновизнаних міжнародно-правових принципів і норм, що регулюють співробітництво між суб'єктами міжнародного права щодо попередження та притягнення винних осіб за вчинення міжнародних злочинів і злочинів міжнародного характеру, надання судової допомоги, проведення розслідування, кримінального переслідування i судового розгляду, застосування і виконання міри покарання, оскарження та перегляду судових рішень, надання правової допомоги у кримінальних справах $[5$, c.48-49].

Слід розрізняти три групи правопорушників сучасного міжнародного права: держави, які здійснюють міжнародні злочини; конкретні виконавці таких злочинів, що діють від імені держави; окремі особи або групи осіб, які вчиняють кримінальні злочини міжнародного характеру не від імені держави [6, c.429].

Об'єктом міжнародного співробітництва у сфері боротьби з організованою злочинністю $є$ така категорія загально кримінальних злочинів, які, по-перше, відбуваються в більшості своїй на території декількох держав або на території, що не підпадає під юрисдикцію якої-небудь однієї держави; по-друге, обтяжені іноземним елементом; по-третє, боротьба з такими злочинами не може бути ефективною без використання міжнародно-правових засобів [1, с.59; 6, с.431]. Така співпраця в практичному плані здійснюється, приміром, шляхом надання допомоги в розшуку злочинців, які переховуються на чужій території, видачу їх зацікавленій державі та отриманні необхідних матеріалів у кримінальній справі. Крім того, рамки співробітництва розширюються за рахунок обміну інформацією, вивчення проблем злочинності і боротьби 3 нею, надання практичної допомоги окремим державам у вирішенні проблеми злочинів міжнародного характеру.

3 числа основних домінант міжнародного права, до предмету нашого дослідження пряме відношення мають наступні: співпраця, невтручання у внутрішні справи один одного, рівність держав, сумлінне виконання міжнародних зобов'язань, принципи дотримання прав і свобод людини.

Дослідники, які займалися вивченням питань співробітництва держав у 
напрямку боротьбі зі злочинністю, вказують, що крім цих загальних для всіх напрямків співпраці у сфері міжнародної боротьби зі злочинністю державами напрацьовано ще кілька спеціальних принципів. Л.Н.Галенска, В.П.Зімін, В.П.Панов та інші автори називають різне число принципів і вказують їх під різними назвами. Проаналізувавши їхні роботи, можна скласти наступний список спеціальних галузевих принципів, характерних для даної сфери: співпраця здійснюється тільки в боротьбі з загально кримінальної злочинністю; невідворотність відповідальності за скоєне правопорушення; принцип подвійного інкрімінаціі злочинності; принцип виконання запитуваних дій за власним національним законодавством; принцип дотримання прав і свобод людини; принцип невидачі власних громадян; відмова у співпраці в справах політичного, військового, расового і релігійного характеру.

I загальні і спеціальні принципи держав строго виконуються в своїх відносинах з боротьби з загально кримінальної злочинністю. На закінчення можна зробити висновок про те, що в Україні необхідне вдосконалення законодавства для більш ефективної участі нашої країни в такому процесі як співробітництво в боротьбі з організованою злочинністю.

\section{Список літератури}

1. Войціховський, А. В. Міжнародне право : підручник. МВС України, Харків. нац. ун-т внутр. справ, 2020. - 544 с.

2. Волеводз А.Г. Правове регулювання нових напрямків міжнародного співробітництва в сфері кримінального процесу. К., 2002.

3. Иногамова-Хегай Л.В. Международное уголовное право. СПб, 2003.

4. Карпец И.И. Международная преступность. М., 1988.

5. Костенко Н.И. Международная уголовная юстиция. Проблемы развития. M., 2002.

6. Пронюк Н. В. Сучасне міжнародне право : навч. посіб. - 2-е вид., змін. та допов. К. : КНТ, 2010. - 344 с. 


\section{ПЕРСПЕКТИВИ РОЗВИТКУ ВІДНОСИН МІЖНАРОДНИХ ФІНАНСОВИХ ОРГАНІЗАЦІЙ 3 УКРАЇНОЮ}

Гусар Ольга Анатоліївна к.ю.н., доцент кафедри конституційного і адміністративного права Національний авіаційний університет

Устинова Ірина Петрівна к.ю.н., доцент, доцент кафедри конституційного і адміністративного права Національний авіаційний університет

Толкачова Ірина Анатоліївна к.ю.н., доцент кафедри конституційного і адміністративного права Національний авіаційний університет

Міжнародні фінансові організації вже досить давно зайняли своє місце в Україні серед установ, які фінансово підтримують нашу країну, надають технічну допомогу 3 метою проведення необхідних реформ, а також здійснюють необхідний контроль, для підтримки та розвитку державних i недержавних підприємств в різних галузях економіки, і звісно зміцнення фінансового сектору в цілому. Однак треба додати, що майбутній розвиток співпраці України з МФО неможливий без значних змін та перегляду сьогоднішньої концепції відносин та здійснення комплексного удосконалення основних елементів механізму валютно-фінансої системи.

Підтримка України у міжнародних фінансових організацій зумовлена такими чинниками: по-перше, Україна як держава на даний час фактично не має реального доступу на міжнародні фінансові ринки. Зовнішнє фінансування вона може отримати переважно з офіційних джерел. По-друге, політика Фонду, яка проводиться в Україні і пов'язана з грошовою підтримкою, спрямована на стабілізацію соціально-економічної ситуації в Україні. Кредити, що залучаються від МВФ, використовуються для підтримки курсу національної валюти та для фінансування дефіциту платіжного балансу України і покликані пом'якшити економічні труднощі у процесі проведення економічних реформ, які дають змогу забезпечити у перспективі економічне зростання у країні. Без проведення програми економічних перетворень фінансова підтримка з офіційних джерел не має сенсу, бо в цьому разі позичкові кошти використовуватимуться на фінансування тільки поточних проблем платіжного балансу, які без реформування економіки - збільшується.

Відносини МВФ $з$ Україною, як і 3 іншими пострадянськими республіками, будуються відповідно до трьома типами програм [8]. Програма першого типу створено спеціально для цих країн і країн Східної Європи. Вона $є$ своєрідною підготовчою програмою, відносно простою у своїх вимогах. 
Виконання такої програми не потребує складного інвестиційного апарату в країні. Це первісна програма - програма системної трансформації економіки (Systemic Transformation Fasility - STF), реалізація якої дає змогу країні і Фонду співпрацювати.

Наступний крок - це досить стандартна програма, яка називається «стендбай» (Stand- by). Це програма короткострокового фінансування. Як правило, вона триває від 12 до 13 місяців і спрямована на здійснення першочергових заходів, необхідних для досягнення макроекономічної стабілізації.

Після реалізації цієї програми країна може укладати з МВФ угоду про програму розширеного фінансування (Extanded Fund Facility - EFF). Вона розрахована три роки і спрямована на за кріплення досягнень початкової стабілізації за програмою «стенд-бай». Одночасно значно більше уваги приділяється структурним змінам в економіці, тим елементам, які становлять основу подальшого економічного зростання.

Міжнародним валютним фондом була розроблена програма шести етапного фінансування та кредитування України. Починаючи з 2014 року всі програмні питання між сторонами виконувалися в повному обсязі. Необхідно зазначити, що від постійного взяття кредитів суттєво збільшується зовнішня заборгованість, а значить збільшення зовнішнього боргу.

Співпраця України з МВФ має ряд позитивних і негативних наслідків. Позитивними наслідками є: впровадження реформ, метою яких є стабілізація української економіки і повернення на шлях зростання;зменшення дефіциту державного бюджету і поліпшення ситуації з платіжним балансом;стабілізація валютно-обмінного курсу гривні та посилення банківської системи; збільшення золотовалютних резервів Національного банку України, що в ідеалі, має дозволити істотно покривати імпорт; реструктуризація частини зовнішнього боргу.

До негативних наслідків співпраці України з МВФ можна віднести: кошти від МВФ можуть бути витрачені не на структурні реформи; витрачання коштів на фінансування дефіциту державного бюджету; зростання зовнішнього боргу держави; підвищення тарифів, які платить населення, в тому числі за газ і ін; фактично, повна зовнішня залежність від зовнішніх кредиторів; впровадження реформ, призводить до збіднення держави (розпродаж державних підприємств, розпродаж земель); збільшення рівня інфляції; вся фінансово-соціальна i економічна політика країни залежить від чергового траншу. [1].

Пріоритетні напрямки співробітництва МБРР з Україною містяться у відповідних Стратегіях допомоги групи Світового банку Україні - серед середньострокових програмах, що визначають обсяг, структуру, загальні принципи діяльності цієї організації в Україні та затверджуються Радою директорів Світового банку. Остання Стратегія партнерства 3 Україною на період 2018- 2023 рр. була ухвалена 3 жовтня 2018 р. Радою виконавчих директорів Світового банку. Стратегія передбачає програму інвестиційного кредитування на рівні 500 млн. дол. США щорічно. Очікується, що Міжнародна фінансова корпорація (IFC) з власних джерел надаватиме кредити в сумі до 400 млн. дол. США на рік [3]. 
Слід відзначити, що основними секторами впровадження стратегії партнерства $\epsilon$ наступні: муніципальна інфраструктура, енергетичний сектор, земельна реформа, державні фінанси, державний сектор, управління соціальним страхуванням, охорона здоров'я, охорона навколишнього середовища.

Можна констатувати, що поглиблення протиріч в розвитку світової фінансової системи, нездатність існуючої міжнародної фінансової архітектури запобігти глобальним і регіональні фінансові катаклізми і ефективно протидіяти настали криз викликає необхідність більш повного використання внутрішніх чинників у вирішенні боргових проблем. Особливого значення набуває вироблення національної стратегії управління державними кредитно-борговими відносинами, що враховує політику міжнародного співтовариства і використовує світовий досвід.[2]

Існує точка зору, що Україна в перспективі взагалі могла б відмовитися від державних зовнішніх запозичень. Ї̈̈ прихильники роблять виняток лише для соціальних проектів, фінансування яких з бюджету буде неможливо. Однак 3 огляду на політичний курс країни відносини України з МФО, очевидно, в найближчі роки не припиняться, але при цьому, необхідно розуміти, що можлива ï істотна трансформація.

Слід зазначити, що надається МВО фінансова допомога, по суті, відноситься до розряду суверенних запозичень (урядових позик). Суверенні запозичення - це крайній захід, до якої керівництво країни вдається, як правило, лише у виняткових випадках.

Вихідна невигідність суверенних запозичень полягає, перш за все, в тому, що виплата відсотків і погашення основної частини боргу здійснюється 3 доходів держбюджету, в той час як такі позики не виробляють фінансової норми прибутку. Крім того, як неодмінну умову для отримання фінансування, Фонд висуває уряду країни-позичальника ще й політичні вимоги. Дана обставина істотно ускладнює внутрішню ситуацію в Україні, яка змушена звернутися до МВФ за фінансовою підтримкою.

Отже, подальша співпраця 3 міжнародними фінансовими організаціями на економічно і політичних вигідних для України умовах вигідною назвати складно, але у с а м і т н е н н я і не взяття участі у гробалістичних світових процесах не може дати в подальшому відповідного статусу гравця на європейському та світовому полі.

Треба додати, що зараз все частіше в стосунках міжнародних фінансових організаціях і держав-членів виникають ситуації, коли економічні та навіть політичні переваги членства держави в таких МВФ і Групі Світового Банку перекреслюються мінусами жорсткого курсу, який міжнародні організації проводять по забезпеченню досягнення цілей, визначених їх установчими актами, а їх стратегія співпраці з державою-членом все більше нагадує втручання у внутрішні справи і іноді починає суперечити національним інтересам держави по реалізації національної стратегії ії економічного розвитку.

Саме право повинно служити засоби упорядкування відносин державного боргу й підвищення ефективності інструменту державного боргу в рішенні державних завдань за допомогою фіскальної, розподільної, контрольної та 
стимулюючої функцій. Сьогодні дослідження впливу зовнішнього боргу України є актуальним, і в подалі має вплинути на удосконалення відносин України 3 міжнародними фінансовими організаціями. Комплексне вирішення проблеми внутрішнього i зовнішнього державного боргу 3 урахуванням запропонованих заходів буде слугувати розвитку державних фінансів i поліпшенню фінансового становища України.

\section{Література:}

1. Устинова І.П., КУзьмін А.Р. ПРАВОВА ОСНОВА ВЗАСМОДІЇ УКРАЇНИ 3 МІЖНАРОДНИМИ ФІНАНСОВИМИ ОРГАНІЗАЦІЯМИ ЯК КОМПОНЕНТОМ ЄВРОІНТЕГРЦІЇ. Наукові праиі Наџіонального авіаційного університету. Серія: юридичний вісник «Повітряне і космічне право»: 2020, № 4(57), С. 96-103.

2. Мицюк C. B. Сучасний стан та перспективи співпраці України 3 міжнародними фінансовими організаціями / С. В. Мицюк, В. В. Мегей // Вісник Київського національного університету імені Тараса Шевченка. Економіка. 2015. - Вип. 12. - С. 31-38.

3. Міжнародний валютний фонд URL: https://mof.gov.ua/uk/mvf (дата звернення 20.04.2021р.) 


\section{ДИЛЕМА АДМІНІСТРАТИВНОЇ ВІДПОВІДАЛЬНОСТІ ЗА ВИГОТОВЛЕННЯ ТА ЗБЕРІГАННЯ САМОГОНУ}

\section{Левчук Вікторія Олександрівна}

Студентка юридичного факультету Донецький національний університет імені Василя Стуса

Науковий керівник:

Краковська Анжеліка Євгеніївна Завідувач кафедри теорії та іст. держави і права та адмін.права Донецький національний університет імені Василя Стуса

Однією із проблем, яка пов'язана на сьогодні 3 інститутом адміністративної відповідальності $€$ питання щодо правопорушень, пов'язаних із виготовленням або зберіганням самогону чи інших міцних спиртних напоїв домашнього вироблення. Зокрема, залишається відкритим питанням щодо того залишити статтю, яка передбачає адміністративну відповідальність за це правопорушення в Кодексі України про адміністративні правопорушення чи виключити १ї.

Дане питання регулюється Кодексом України про адміністративні правопорушення (далі - КУпАП). 3 точки зору Комітету 3 питань інтеграції України з Свропейським Союзом дане питання регулюються національним законодавством країн-членів Європейського Союзу та не підпадає під дію міжнародно-правових зобов'язань України у сфері європейської інтеграції. Таким чином воно має бути вирішено на внутрішньому рівні національного законодавства України.

Відповідно до статті 176 КУПАП «Виготовлення або зберігання без мети збуту самогону чи інших міцних спиртних напоїв домашнього вироблення, виготовлення або зберігання без мети збуту апаратів для їх вироблення - тягнуть за собою накладення штрафу від трьох до десяти неоподатковуваних мінімумів доходів громадян» [1]. Останні зміни до цієї статті були внесені ще у лютому 1997 року. 3 врахуванням змін, які відбулись на сьогодні в нашому суспільстві та державі, вже чимало років точаться дискусії навколо питання скасувати або ж ні адміністративну відповідальність за самогоноваріння. Зокрема, станом на сьогодні, питання скасувати чи ні відповідальність за самогоноваріння $є$ не вирішеним.

Одна із проблем, яку несе домашне виготовлення самогону безвідповідальність виробників, наслідки якої можуть бути досить негативними. Не можливо оминути і пункт, щодо продажу нелегального алкоголю, адже це досить пагубно впливає на економіку держави, яка в певній мірі будується на акцизному зборі з легального алкоголю.

Слід згадати, що старт антиалкогольних кампаній почався ще в СРСР в 1985-1987 роках, які несла у собі певні урядові заходи, щодо зниження споживання алкоголю серед населення. Втім згодом, засновником даної кампанії 
Михайлом Горбачовим було зазначено, що через допущені помилки, велика справа закінчилась безславно [2]. Однак, певні держави, які розформувались із СРСР, перейняли собі у законодавство певні норми, щодо регулювання питання незаконного виготовлення та зберігання самогону та апаратів для його вироблення.

Відповідно до статистики, у період 2018 року в судах України розглянули лише 197 справ про адміністративні правопорушення, які пов'язані із самогоноварінням. Якщо уточнити пошук у єдиному реєстрі судових рішень, то у 2018 році прийнято постанов за даною категорією справ - 4, у 2019 та 2020 роках - по 7м постанов [3]. Таким чином, відповідно до цих даних, адміністративна відповідальність за самогоноваріння, $є$ неефективною.

Взагалі, аби зважити всі плюси та мінуси даного питання, необхідно встановити вчених, практиків та законодавців щодо регулювання даного питання. Серед тих, хто стоїть на боці «за» скасування адміністративної відповідальності, передбаченою статтею 176 КУпАП, перш за все, необхідно виділити український парламент, адже парламентарі від «Слуги народу», а саме В.Ватрас, О.Федієнко, Р.Соха, А.Костюх, І.Фріс та М.Стефанчук вважають за доцільне скасувати адміністративну відповідальність за самогоноваріння, адже вважають наявну норму «застарілою». Так, автори Проекту Закону про внесення змін до Кодексу України про адміністративні правопорушення (щодо скасування правової норми, яка передбачає відповідальність за самогоноваріння) 2019 року зазначають, що скасування даного виду відповідальності забезпечить врегулювати так звану «дискримінацію», яка існує станом на сьогодні стосовно деякої частини громадян; а штрафи за виробництво в домашніх умовах для власного споживання виноградних і плодово-ягідних вин, медових напоїв, наливок і настойок нікому не загрожують [4]. Необхідно зазначити i те, що адміністративна відповідальність не повинна наставати для людей, які виготовляють даний вид напою для власного споживання, проте дане скасування адміністративної відповідальності не стосується не ліцензованого виробництва спиртного на продаж [5]. Втім, така думка $є$ цілком доцільною, адже це природне право кожної людини, яке не повинно обмежуватись державою, а кожна людина має право на власний розсуд користуватися плодами своєї праці для задоволення власних потреб. Дана позиція тлумачиться також і тим, що на разі у нашій державі геть збіднілий молочний ринок, і в ході цього пропонують додати певні зміни і до Податкового кодексу. Результатом своїх старань, народовладці бачать ФОПів-фермерів у ролі «молочно-спиртових» діячів, які в свою чергу повинні здавати отриману від худоби молочну продукцію, а за це їм буде передбачено певні пільги. Також парламентарі вважають, що так продаж самогону стане контрольованим та почне працювати на бюджет. Крім того, слід зауважити і той аспект, що наша країна повинна іти в ногу із іншими країнами, тому щодо врахування скасування відповідальності доцільним $є$ приклад Сполучених Штатів Америки, у яких у Федеральному кодексі стаття за самогоноваріння не передбачена [6].

А от серед тих, хто на боці «проти», можна виділити Завального М.В., Мельника М.I., Хавронюка М.I, Савченка Д.Г та інших. Дані науковці вважають, 
що у випадку скасування адміністративної відповідальності за самогоноваріння, може зрости криміногенна ситуація в країні, що вкрай важко вплине, зокрема, на здоров'я населення. Також, пропонують законодавче закріплення заборонених видів господарської діяльності або закріплення спеціальної норми, що забороняє виготовлення, зберігання та збут алкоголю домашнього виробництва [7]. Слід зазначити, що це вплине і на економічну ситуацію в країні, оскільки штрафи, які передбачені за незаконний збут, виготовлення та зберігання самогону, щорічно приносять у казну України певні кошти. Крім того, скасування адміністративної відповідальності за самогоноваріння не узгоджується 3 державною політикою охорони здоров'я; у будь-якому випадку виготовлення або зберігання без мети збуту самогону чи інших міцних спиртних напоїв домашнього вироблення передбачає їх наступне споживання як самою особою, що їх виготовила, так і членами іiі родини та іншими особами (тут може виникнути загроза серйозного розладу здоров'я, а іноді навіть смерті людини, оскільки в процесі виготовлення може бути використана недоброякісна сировина чи матеріали); негативно позначиться на кількості захворювань, пов'язаних із зловживанням алкогольними напоями тощо.

Отже, у висновку можна сказати, що перед прийняттям такого серйозного рішення, варто зауважити як найбільше думок науковців та інших політичних діячів, законодавців. Втім, зважуючи усі «за» та «проти», розуміємо, що основними аргументами прихильників легалізації домашнього виробництва самогону полягають у тому, що заборона самогоноваріння у домашніх умовах може підвищить корумпованість поліції і не дасть відчутних результатів у боротьбі із самогоноварінням. Однак, у випадку, коли держава все ж прийме дану правку до законодавства України про адміністративні правопорушення, українці почнуть поступово легалізовувати свої діяння, втім чи буде це масовим та постійним діянням неможливо передбачити, так як особливих аргументів, щодо вигідних пропозицій для населення, які могли б зацікавити більшість так і не було озвучено. Так, вирішити дану проблему можна лише на законодавчому рівні, шляхом внесення змін до Кодексу України про адміністративні правопорушення, так як наша країна повинна розвиватись. У зв'язку з чим пропонуємо підтримати думку наших законодавців і схиляюсь на їх бік (оскільки особливих наслідків норма, яка закріплена у статті 176 КУПАП, для громадян не несе) вважаємо доцільним виключити дану норму з КУпАП.

\section{СПИСОК ЛІТЕРАТУРИ:}

1. Антиалкогольна кампанія M. Горбачова. URL: https://uk.wikipedia.org/wiki/\%D0\%90\%D0\%BD\%D1\%82\%D0\%B8\%D0\%B0\%D0 $\% \mathrm{BB} \% \mathrm{D} 0 \% \mathrm{BA} \% \mathrm{D} 0 \% \mathrm{BE} \% \mathrm{D} 0 \% \mathrm{~B} 3 \% \mathrm{D} 0 \% \mathrm{BE} \% \mathrm{D} 0 \% \mathrm{BB} \% \mathrm{D} 1 \% 8 \mathrm{C} \% \mathrm{D} 0 \% \mathrm{BD} \% \mathrm{D} 0 \%$ B0_\%D0\%BA\%D0\%B0\%D0\%BC\%D0\%BF\%D0\%B0\%D0\%BD\%D1\%96\%D1\%8 F_\%D0\%9C._\%D0\%93\%D0\%BE\%D1\%80\%D0\%B1\%D0\%B0\%D1\%87\%D0\%BE $\% \mathrm{D} 0 \% \mathrm{~B} 2 \% \mathrm{D} 0 \% \mathrm{~B} 0$.

2. Кодекс України про адміністративні правопорушення: Закон України від 7 рудня 1984 року №8073-X. URL: https://zakon.rada.gov.ua/laws/show/8073110/conv\#n1889. 
3. Єдиний державний реєстр судових рішень. URL: https://reyestr.court.gov.ua/

4. Проект Закону про внесення змін до Кодексу України про адміністративні правопорушення (щодо скасування правової норми, яка передбачає відповідальність за самогоноваріння): Проект Закону України №2371 від 1 листопада 2019 року. URL: http://w1.c1.rada.gov.ua/pls/zweb2/webproc4_1 1id=\&pf3511=67269.

5. Пояснювальна записка до проєкту Закону України «Про внесення змін до Кодексу України про адміністративні правопорушення (щодо скасування правової норми, яка передбачає відповідальність за самогоноваріння) від 01.11.19 URL: http://w1.c1.rada.gov.ua/pls/zweb2/webproc4_1?id=\&pf3511=67269

6. Federal Criminal Code and Rules. West Publishing Company, NY 1999. 1465 p.

7. Завальний М.В. Щодо доцільності легалізації виготовлення самогону чи інших міцних спиртних напоїв домашнього вироблення без мети збуту// Науково-дослідний інститут публічної політики і соціальних наук, 2019. URL : https://pp-ss.pro/wp-

content/uploads/2020/06/\%D0\%97\%D0\%B0\%D0\%B2\%D0\%B0\%D0\%BB\%D1\%8 C\%D0\%BD\%D0\%B8\%D0\%B9.pdf 


\title{
ПРОБЛЕМИ ПРАВОВОГО РЕГУЛЮВАННЯ ВЕКСЕЛЬНОГО ОБІГУ В УКРАЇНІ
}

\author{
Мозолсв Олег Сгорович \\ студент 3 групи 4 курсу \\ Міжнародно-правового факультету \\ Національного юридичного університету \\ імені Ярослава Мудрого
}

Ринок цінних паперів України перебуває на етапі свого розвитку та становлення. Він займає значну частину сегменту української економіки. Серед багатьох видів цінних паперів, які на сьогодні існують, особливу актуальність набувають саме векселі. Адже із стрімким розвитком економічних відносин виникає брак обігу коштів в середині держави, а отже зростає попит на впровадження розрахунку векселями. Такий вид платежу зумовлюючи його специфіку та стрімкий розвиток, має регулюватись державою у відповідному порядку, проте стрімкий прогрес вексельного обігу в державі не знайшов ще досконалого нормативного регулювання, що у свою чергу зумовлює виникнення протиріч при його використанні $[1, \mathrm{c.6}]$.

Вексель, як один із фінансових інструментів, за своєю юридичною природою $\epsilon$ особливим видом цінних паперів, який опосередковує цілу низку різноманітних відносин у сфері господарювання.

В сучасних умовах фінансової кризи, коли має місце зменшення обігових коштів, використання векселів на підприємствах стає актуальним. В умовах фінансової нестабільності в період скорочення інвестицій та кредитування вексель може використовуватись як засіб відстрочки платежу, забезпечуючи збереження договірних зв'язків між суб'єктами господарювання. Використання вексельних форм розрахунків у зовнішньоекономічній діяльності слугує утриманню валюти в Україні [2].

Саме важливість розвитку вексельного обігу для економіки країни зумовлює актуальність питання щодо удосконалення правового регулювання в цьому напрямку.

Проблема вексельного обігу займає важливе місце в дослідженнях як зарубіжних, так і вітчизняних вчених. Серед зарубіжних науковців, які здійснили вагомий внесок у розв'язання даної проблеми на різних історичних етапах, слід відзначити насамперед Т. Батіщєва (Казахстан), Ф. Гудкова, В. Звєрєва (Росія), В. Тарасова (Білорусь) [3, с.113]. Серед вітчизняних науковців вказане питання розглядалося такими авторами, як О.В Дубицька, К.В. Кобин, В.І. Кравчишин, К.І. Крамаренко, В. Д. Манівчук, Н. Скочило, О.А. Харун, А. Ф. Шевченко та іншими.

Метою даної роботи $є$ дослідження проблем правового регулювання вексельного обігу в Україні на теперішній час та 3'ясування шляхів їх вирішення.

Нормативно-правова база, що регламентує вексельний обіг в Україні, представлена рядом нормативно-правових актів, здебільшого розроблених 
відповідно до положень Уніфікованого закону про переказні та прості векселі, ухваленого Женевською вексельною конвенцією 1930 року. Даний закон регулює випуск, обіг, погашення векселів та стягнення за векселем, а також повністю забезпечує права всіх сторін вексельного обігу.

Нині основними спеціальними документами, що регулюють вексельний обіг в Україні, є Закон України «Про цінні папери та фондовий ринок» і Закон України «Про обіг векселів в Україні». Відповідно до ст. 14 Закону України «Про цінні папери та фондовий ринок» вексель - цінний папір, який посвідчує безумовне грошове зобов'язання векселедавця або його наказ третій особі сплатити після настання строку платежу визначену суму власнику векселя (векселедержателю). Векселі можуть бути прості або переказні та існують виключно у документарній формі [4]. Крім цього, в системі вексельного обігу визначаються й інші види векселів. Так, наприклад, залежно від характеру угоди, що зумовила видачу векселя, розрізняють товарні (комерційні), банківські, фінансові векселі. Особливою формою векселя є також казначейські векселі - цінні папери, що перебувають в обігу від імені юридичних осіб, щоб забезпечити їм короткострокове фінансування [5, с.938].

Векселі на основі взаємної довіри суб' єктів ринкових відносин функціонують в обігу як розрахунковий засіб, боргове зобов'язання, та як різновид цінних паперів, що має значні переваги над правовими грішми. Ці особливості накладають специфічний відбиток на сферу обігу векселів у порівнянні з іншими цінними паперами, зокрема, векселі не знецінюються, в обігу перебувають визначений договором час, скорочують потреби в готівці, зменшують витрати грошового обороту і прискорюють його. Предметом вексельного зобов'язання можуть бути тільки гроші [6, с.86].

Однією 3 головних функцій вексельного обігу $\epsilon$ оформлення короткотермінового кредиту. Крім того, вексель виконує функцію платежу, адже він дає змогу отримати гроші ще до настання терміну платежу (вексель можна продати або закласти під заставу в комерційному банку). Окрім зазначених функцій, вексель здійснює функцію контролю за виконанням зобов'язань між суб'єктами господарювання, скорочення грошово-кредитної маси в обігу, а відтак і стримування темпів інфляції [6, с.87-88].

Як зазначають Харун О.А. та Дубицька О.В. обсяг дебіторсько-кредиторської заборгованості в країні перевищує ВВП (що тягне за собою низьку капіталізацію фондового ринку внаслідок недооцінки вартості компаній). Вексельні розрахунки мають беззаперечні переваги і є безінфляційними. Вони значно скорочують неплатежі та сприяють пожвавленню економіки[7, с. 521].

Рябіков О. стверджує, що головними перевагами векселів є: простота організації розміщення; найбільш оперативний спосіб залучення коштів; найдешевший механізм залучення коштів; інструмент, що дозволяє залучати будь-який обсяг фінансових ресурсів; платіжний засіб; перший крок у залучення коштів на відкритому борговому ринку. До основних недоліків векселів Рябіков О. відносить: низьку ліквідність вторинного ринку; кредитну історію векселя серед вузького кола інвесторів; короткостроковість запозичень; більш високу, у порівнянні 3 іншими інструментами, вартість запозичень; ризики 
документального обігу векселів (підробка, викрадення тощо) [8, с.18].

Враховуючи викладене важливість розвитку вексельного обігу в країні безперечна, але не можна не погодитися з Кобиним К.В., який наголошує, що сьогодні існує багато проблем щодо випуску та обігу векселів, як специфічного фінансового інструменту, що потребує відповідного регулювання [6, с.87].

Слушною є думка Шевченко А. Ф. Відносно того, що на сьогодні основними питаннями вексельного ринку є регіональна замкнутість вексельних розрахунків, технологічна неліквідність векселів, слабке регулювання вексельного ринку зі сторони держави, навіть при наявності такої кількості нормативних актів [9, c.19].

Отже, серед проблем вексельного обігу в Україні, які потребують правового врегулювання слід зазначити:

- низький рівень державного контролю за системою вексельних розрахунків, у тому числі через відсутність закріпленої на законодавчому рівні процедури державної реєстрації випущених векселів;

- відсутність єдиного державного реєстру векселів, що ускладнює контроль за їхнім випуском та обігом;

- негативний імідж векселів, недовіра громадян до векселю як до засобу платежу, пов'язана $з$ недостатньою правовою обізнаністю та прогалинами у нормативно-правовому регулюванні в цьому напрямку;

- високий рівень розвитку злочинності у сфері обігу векселів. Шахрайство шляхом видачі простого векселю завідомо не маючи наміру його оплатити, використовуючи назви зареєстрованих організацій із схожими назвами інших великих організацій. Також спеціальне створення ситуацій умисного банкрутства, розкрадання коштів акціонерів (вкладників). Поряд із цим, слабка захищеність вексельних бланків, можливість їх підробки;

- недосконалість механізмів притягнення осіб до відповідальності за порушення вексельного права.

Для подолання зазначених проблем доцільно вжити додаткових заходів правового регулювання вексельного обігу серед яких слід зазначити наступні:

- запровадження єдиного державного реєстру векселів, оскільки централізований облік, може суттєво підвищити контрольованість та регульованість вексельного ринку;

- підвищення державного контролю за системою вексельних розрахунків, нормативне врегулювання процедури державної реєстрації обігу векселів, що у свою чергу гарантувало б випущення векселів лише тими банками та юридичними особами які є платоспроможними;

- розробка на законодавчому рівні механізму протидії порушенням в сфері вексельного обігу;

- вдосконалення механізму захисту постраждалих осіб від злочинних дій в цій сфері. В даному випадку слушною є думка Крамаренко К.І., яка пропонує запровадити механізм захисту постраждалої особи від уникнення відповідальності особи, яка порушила права та інтереси іншої особи, зокрема це можливість арешту майна відповідача; відсутність права відповідача вимагати перенесення справи щодо опротестованого векселя; можливість розгляду позову 
за відсутності відповідача [1, с. 8];

- впровадження процедури встановлення кредитних рейтингів пропонованих випусків векселів. Можна погодитись 3 цього приводу з думкою Поляк Т.М., який зазначає, що емітенти векселів при проведення державної реєстрації повинні були б, звертатися до рейтингового агентства, яке б надавало відповідний рейтинг новому випуску векселів на визначену суму. Це дало б можливість інвесторам постійно одержувати необхідну інформацію про рейтинг векселів, які вони бажають придбати [10];

- підвищення правової обізнаності громадян в сфері вексельного обігу шляхом публічності та відкритості інформації щодо його обігу.

Таким чином, правове регулювання вексельного обігу в Україні представлено значною кількістю нормативно-правових актів, але при цьому залишаються проблеми, які потребують вирішення шляхом законодавчого врегулювання, що дозволило б повною мірою активізувати вексельний обіг та підвищити імідж векселя як платіжного інструменту.

\section{Список використаних джерел:}

1. Крамаренко К.І. Вексель, як сегмент українського ринку цінних паперів [Текст] / К.І. Крамаренко // Правові горизонти. - 2018. - Вип. 11 (24). - С. 5-9. [Електронний ресурс] - Режим доступу: https://essuir.sumdu.edu.ua/bitstreamdownload/123456789/70657/1/Kramarenko_Veksel.pdf

2. Кравчишин В.I. Використання векселів в Україні. Проблеми та шляхи удосконалення вексельного обігу. “Фінансовий ринок 2017”. ЛНУ Імені Івана Франка, ЕкфМ-52, 2017. [Електронний ресурс] - Режим доступу: http://libfor.com/index.php?newsid=3096

3. Скочило Н. Вексельний обіг в Україні: Проблеми становлення і розвитку // Українська наука: минуле сучасне, майбутнє.-2008.-№13.-С.113-117. [Електронний ресурс] - Режим доступу: http://dspace.wunu.edu.ua/bitstream/316497/

26546/1/\%D0\%A1\%D0\%BA\%D0\%BE\%D1\%87\%D0\%B8\%D0\%BB\%D0\%BE\%20 $\%$ D0\%9D.pdf

4. Про цінні папери та фондовий ринок: Закон України від 23.02.2006 p. №3480-IV. [Електронний ресурс] - Режим доступу: https://zakon.rada.gov.ua/laws/ show/3480-15\#Text

5. Манівчук В. Д. Перспективи розвитку вексельного обігу в Україні [Електронний ресурс] / В. Д. Манівчук // Молодий вчений. - 2017. - № 11. - С. 937-940. - Режим доступу: http://nbuv.gov.ua/UJRN/molv_2017_11_229

6. Кобин К.В. Деякі проблеми сучасного регулювання вексельного обігу в Україні на підставі зарубіжного досвіду про міжнародний вексельний обіг. Науковий вісник УжНУ. 2017. с.84-91. [Електронний ресурс] - Режим доступу: ttps://dspace.uzhnu.edu.ua/jspui/bitstream/lib/17371/1/ДЕЯКІ\%20ПРОБЛЕМИ\%20 СУ ЧАСНОГО\%20РЕГУЛЮВАННЯ\%20ВЕКСЕЛЬНОГО.pdf

7. Харун О.А. Перспективи розвитку вексельного обігу в Україні / О.А. Харун, О.В Дубицька // «Молодий вчений». - 2017. - № 6 (46). - С. 518 - 522. [Електронний ресурс] - Режим доступу: http://molodyvcheny.in.ua/files/journal/ 
2017/6/118.pdf

8. Рябіков О. Вексель як фінансовий інструмент // Фінансовий ринок України - 2008. - №5. - c.12-16

9. Шевченко А. Ф. Виникнення, становлення та розвиток вексельного ринку в Україні / А. Ф. Шевченко, О. М. Шевченко // Науковий вісник Полтавського університету економіки і торгівлі. Серія: Економічні науки. - 2011.-№ 2. - С. 1822. [Електронний ресурс] - Режим доступу: http://nbuv.gov.ua/UJRN/ Nvpusk_2011_2_3

10. Поляк Т.М. Вексельна форма безготівкових розрахунків між українськими підприємствами: проблеми та шляхи їі удосконалення / Т.М. Поляк // Стратегічні орієнтири. Сучасні тенденції фінансового ринку 2014. [Електронний ресурс] Режим доступу: http://libfor.com/index.php?newsid=2411 


\title{
ОСОБЛИВОСТІ ПРАВОВОГО РЕГУЛЮВАННЯ ЛІСОКОРИСТУВАННЯ У СІЛЬСЬКОГОСПОДАРСЬКОМУ ВИРОБНИЦТВІ
}

\author{
Мілімко Лариса Василівна, \\ к.ю.н., доцент, доцент кафедри \\ господарського, повітряного та космічного права, \\ Національного авіаційного університету, \\ Юридчиний факультет \\ Ткаченко Вероніка Валеріївна, \\ здобувач вищої освіти, \\ першого (бакалаврського) рівня, \\ Національного авіаційного університету, \\ Юридчиний факультет
}

Однією з найбільших цінностей України, безперечно, можна вважати ліси, які $є$ не тільки джерелом кисню, а й $є$ основною сировинною базою у промисловості та виробництві, де використовують деревину для технічних потреб або для виготовлення лікарських засобів, які використовуються будьякою особою. Без лісу та лісових ресурсів наше життя неможливо уявити тому, що саме вони несуть надзвичайно важливу екологічну цінність.

Екологічна цінність полягає в тому, що ліси виступають джерелом покращення клімату, місцем для життя звірів та птахів, захищають грунти від ерозії, а також використовуються в рекреаційних, культурно-оздоровчих та естетичних цілях, отже, їх використання в сільськогосподарському виробництві $\epsilon$ надзвичайно необхідним для розвитку галузі в цілому [2].

Враховуючи неймовірну потребу у лісах, дослідження особливостей правового регулювання лісокористування у сільськогосподарському виробництві $є$ надзвичайно актуальним та потребує наукового дослідження.

Аналіз останніх досліджень, свідчить про те, що використання лісових ресурсів для потреб сільського господарства безпосередньо не досліджувалося в науці екологічного права, але аспекти правового регулювання використання лісових ресурсів досліджували: С. С. Алексєєв, Г. І. Балюк, Н. В. Бондарчу та інші. Тому з огляду на те, що ця тема $є$ не досить популярною серед науковців, але, водночас, $є$ дуже важливою, варто ії дослідити, оскільки є ряд особливостей у даній сфері лісокористування.

Як вже зазначалося раніше, у сільському господарстві широко використовуються лісові ресурси. Для того щоб дослідити особливості правового регулювання лісокористування у зазначеній сфері потрібно здійснити аналіз поняття, що таке ліс. Відповідно до ст. 3 Лісового кодексу України ліс це сукупність землі, рослинності, в якій домінують дерева та чагарники, тварин, мікроорганізмів та інших природних компонентів, що в своєму розвитку біологічно взаємопов'язані, впливають одне на одного і на довкілля [1]. 
Згідно Лісового кодексу існує розмежування загального та спеціального лісокористування.

При загальному лісокористуванні, особи мають право вільно перебувати в лісах, на безоплатній основі збирати дикорослі трав'яні рослини, квіти, ягоди, горіхи, інші плоди, гриби, при умові що вони збирають для власного споживання.

Щодо спеціального лісокористування, то у суб'єкта господарювання в окремих випадках виникає необхідність отримання земельної ділянки лісового фонду в користування або у власність. Саме на праві спеціального лісокористування дозволяється заготовляти деревину під час рубок головного лісокористування, заготовляти живицю, другорядні лісові матеріали (пень, луб, кора, деревна зелень тощо).

Також на праві спеціального лісокористування здійснюються, так зване побічне лісокористування, для прикладу, випасання худоби, розміщення пасік i вуликів, заготівля сіна, деревних соків, збирання і заготівля дикорослих ягід, грибів, горіхів, плодів дерев, лікарських рослин і технічної сировини, лісової підстилки та очерету, розміщення туристичних таборів, баз відпочинку та спорудження в лісах для цих цілей будівель некапітального типу строком до 1 року. Таке побічне лісокористування здійснюються на підставі лісового квитка, який видається лісогосподарськими підприємствами на строк, погоджений 3 відповідною місцевою радою.

Після закінчення строку дії спеціального дозволу на лісокористування складається акт про результати спеціального використання лісових ресурсів (акт огляду обсягів та місць спеціального використання лісових ресурсів). Порядок заготівлі другорядних лісових матеріалів та здійснення побічних лісокористувань здійснюється відповідно до постанови Кабінету Міністрів України від 23 квітня 1996 р. № 449.

Спеціальне лісокористування для потреб сільськогосподарського виробництва діє тільки на платній основі та здійснюється за встановленими Кабінетом Міністрів України таксами на деревину лісових порід, що відпускається на пні та на живицю, затвердженими постановою Кабінету Міністрів України від 20 січня 1997 р., а також збором за спеціальне використання лісових ресурсів та користування земельними ділянками лісового фонду, затвердженими постановою Кабінету Міністрів України від 6 липня 1998 p. № 1012. Відповідно до ч. 2 ст. 56 Земельного кодексу України можуть передаватися у приватну власність замкнені земельні ділянки лісового фонду загальною площею до 5 гектарів у складі угідь особистих селянських, фермерських та інших господарств [2].

Варто зазначити, що для сільськогосподарського використання лісових ресурсів, які перебувають у приватній власності громадян України, не передбачено одержання спеціальних дозволів для їхніх власників. При цьому повинні додержуватися права й обов' язки лісокористувачів та екологічні вимоги, передбачені законодавством.

Отже, проаналізувавши особливості правового регулювання використання лісових ресурсів для потреб сільськогосподарського виробництва, можемо 
зробити висновок, що правові засади використання лісових ресурсів в сільському господарстві $\epsilon$ надзвичайно розгалуженими та охоплюють собою як закони, так і підзаконні нормативно-правові акти, серед яких ключову роль відіграють Лісовий кодекс України та Земельний кодекс, які окреслюють законодавчі засади в даній сфері, спрямовані на раціональне використання лісових ресурсів, захист i охорону лісів, що $є$ важливим для забезпечення екологічної безпеки під час ведення сільського господарства. Вважаємо, що законодавство в даній сфері на сучасному розвитку права $є$ практично оптимальним і не потребує кардинальних оновлень.

\section{Список літератури:}

1. Лісовий кодекс України: Кодекс України від 21.01.1994 № 3852-XII // БД «Законодавство України» / BP України. URL: https://zakon.rada.gov.ua/laws/show/3852-12\#Text

2. Земельний кодекс України: Кодекс України від 25.10.2004 № 2768-III // БД «Законодавство України» / BP України. URL: https://zakon.rada.gov.ua/laws/show/2768-14\#Text

3. Про затвердження Порядку поділу лісів на категорії та виділення особливо захисних лісових ділянок : Постанова Кабінету Міністрів України від 16.05.2007. № 733. Офіиійний вісник Украӥни. 2007. № 37. С. 207. Ст. 1483.

4. Науково-практичний коментар Лісового кодексу / за ред. Г. І. Балюк. Київ: Юрінком Інтер, 2009. 480 с.

5. Бондарчук Н. В. Актуальні питання правового режиму лісів України. Часопис Київського університету права. 2012. № 4. С. 276-279. 


\title{
СТАНДАРТИЗАЦІЯ І НОРМУВАННЯ У ГАЛУЗІ ЕКОЛОГІї
}

\author{
Мілімко Лариса Василівна, \\ к.ю.н., доцент, доцент кафедри \\ господарського, повітряного та космічного права, \\ Національного авіаційного університету, \\ Юридчиний факультет

\section{Стукало Вікторія Іванівна} \\ здобувач вищої освіти, \\ першого (бакалаврського) рівня, \\ Національного авіаційного університету, \\ Юридчиний факультет
}

Вступ. Актуальність проблеми. Розв'язання сучасних екологічних проблем можливе шляхом запровадження ресурсоефективних технологій екологічно чистого виробництва та поширення найкращого виробничого досвіду, яке відбувається законодавчо визначеним стимулюванням модернізації та впровадження екологічних стандартів на підприємствах, що формують системи екологічного управління, у поєднанні з поліпшенням екологічних характеристик виробленої продукції. Впровадження оновлених екологічних стандартів та нормативів, їх гармонізація з міжнародними та європейськими стандартами стає одним 3 найбільших пріоритетів державної екологічної політики 3 огляду на прагнення запобігти погіршенню якості навколишнього природного середовища, вичерпування природних ресурсів, глобальне потепління тощо. 3 огляду на вищезазначене, актуальними стають питання науково-правового дослідження поняття стандартизації та нормування у галузі екології з метою визначення їх важливості для всієї системи національного законодавства та екологічного законодавства зокрема.

Питання стандартів як джерел екологічного права України традиційно розглядаються в працях вчених-правників та екологів. До них належать: B.I. Андрейцев, Г.I. Балюк, М.М. Бринчук, Н.С. Гавриш, А.П. Гетьман, O.I. Остапенко, О.О. Погрібний, К.А. Рябець, В.І. Семчик, В.М. Тюн, О. М. Хіміч, В.О. Шамрай, С.В. Шарапова, Ю.С. Шемшученко, В.К. Шкарупа та ін. Попри велику кількість наукових праць, що стосуються стандартизації та нормування у галузі екології, на сьогодні ця проблема ще не знайшла належного вирішення, а тому потребує поглибленого осмислення.

Описова частина. Екологічні стандарти, як різновиди нормативнотехнічних документів, містять в собі еколого-правові ідеї та відповідно можуть здійснювати вплив на формування і розвиток галузі екологічного права в цілому. Проте, розглядаючи екологічні стандарти як джерела екологічного права, слід враховувати, що, маючи у своїх положеннях еколого-правові ідеї, екологічні стандарти залишаються нормативно-технічними документами, а це наводить на 
питання співвідношення технічних норм із соціальними (правовими) та чи можуть взагалі технічні норми впливати на правовідносини. У літературі, присвяченій дослідженню цих питань, були висловлені різні, іноді прямо протилежні погляди. Одні вчені вважають, що всі норми поділяються на технічні та соціальні. Правові норми регулюють відносини між людьми, технічні ж норми регулюють відносини людей до предметів природи, знарядь і засобів праці й тому не є нормами соціальними [1, с. 142].

Професор В.I. Андрейцев розглядає екологічні стандарти як юридично значущі нормативно-технічні документи, які містять екологічні вимоги, правила i норми та є обов'язковими для виконання [2, с. 145]. Схоже визначення надає дослідниця Н.С. Гавриш, пропонуючи під стандартами розуміти нормативнотехнічні документи, що встановлюють мінімальні вимоги до певної діяльності чи об'єктів [3, с. 400]. Згідно із зазначеними визначеннями складно відповісти на питання, чи $є$ екологічні стандарти нормативами або навіть нормативноправовими актами. Для відповіді на це питання слід розглянути визначення екологічних стандартів у положеннях законодавства.

Відповідно до положень ст. 32 Закону України «Про охорону навколишнього природного середовища» [4], екологічні стандарти визначають поняття i терміни, режим використання й охорони природних ресурсів, методи контролю за станом навколишнього природного середовища, вимоги щодо запобігання забрудненню навколишнього природного середовища, інші питання, пов'язані 3 охороною навколишнього природного середовища та використанням природних ресурсів. Положеннями ст. 33 цього ж Закону визначено, що екологічні нормативи встановлюють гранично допустимі викиди та скиди у навколишнє природне середовище забруднюючих хімічних речовин, рівні допустимого шкідливого впливу на нього фізичних та біологічних факторів.

Ці положення Закону підтримуються також позицією професора B.I. Андрейцева, на думку якого за допомогою нормування встановлюються якісні та кількісні показники, можливі рівні (гранично допустимі показники (величини) можливого впливу), а також нормативи [2, с. 145]. Іншими словами, екологічне нормування охоплює саме кількісні показники, що містяться в екологічному законодавстві, зокрема: гранично допустимі концентрації забруднюючих речовин, гранично допустимі викиди та скиди забруднюючих речовин у навколишнє природне середовище тощо. Натомість екологічні стандарти вміщують в себе поняття, терміни, методи контролю за станом навколишнього природного середовища тощо, тобто питання, пов'язані 3 охороною навколишнього природного середовища та використанням природних ресурсів.

Як зазначає Л.О. Бондар, екологічні нормативи можуть міститись тільки у нормативно-правових актах, правових актах управління чи договорах, що мають обов'язковий характер для сторін. Екологічні нормативи не можуть міститися в актах рекомендаційного характеру, таких як державні стандарти України. Також дослідник звертає увагу на те, що екологічне законодавство не передбачає повної відмови від екологічно небезпечної діяльності: діяльність, що забруднює чи справляє інший негативний вплив на довкілля, може бути правомірною, якщо 
при цьому дотримуються екологічні нормативи. Такі нормативи встановлюють критерії безпечності довкілля і визначають гранично допустимі показники негативного впливу на нього екологічно небезпечної діяльності [5].

Оскільки екологічні нормативи містяться тільки у нормативно-правових актах, то їхня правова природа $\epsilon$ однозначною - екологічні нормативи $\epsilon$ обов'язковими до виконання. Нормуванням $є$ нормативно-правове закріплення результатів наукових досліджень наслідків антропогенної дії господарської чи іншої діяльності на довкілля. Самі результати наукових досліджень не мають обов'язкового правового характеру. Однак вони стають такими після їх затвердження відповідними державними органами. Затверджені нормативи набувають юридичної сили, їх дотримання суб'єктами природоохоронних відносин є обов'язковим, а перевищення нормативів свідчить про порушення екологічного законодавства.

Щодо правової природи екологічних стандартів, за словами Л.О. Бондаря, це питання сьогодні не чітко визначене в українському законодавстві. 3 одного боку, відповідно до статті 32 Закону України «Про охорону навколишнього природного середовища» [4] державні екологічні стандарти є обов'язковими до виконання. Якщо проаналізувати деякі спеціальні закони, там також можна побачити пряму вказівку на обов'язковість стандартів. Зокрема, відповідно до статей 18 та 19 Закону України «Про енергозбереження» [6] державні енергетичні стандарти є обов'язковими для виконання. Вони є основою для застосування економічних санкцій за нераціональне використання паливноенергетичних ресурсів, виробництво енергетично неефективного обладнання та матеріалів. Крім того, Закон України «Про будівельні норми» [7] у статті 11 передбачає, що у разі, якщо в будівельних нормах є посилання на стандарти, ці стандарти є обов'язковими до застосування.

Висновок. Таким чином, обгрунтовано юридичну природу стандартів та нормативів шляхом аналізу наукових та законодавчих підходів до їх розуміння як джерел екологічного права. Взято до уваги, що хоча в сучасних наукових дослідженнях в Україні не завжди стандарти розглядаються як джерела екологічного права, однак у законодавстві екологічні стандарти визначаються як обов'язкові до виконання нормативно-технічні документи. Обгрунтовано, що екологічні нормативи мають однозначну правову природу - вони $\epsilon$ обов'язковими до виконання.

\section{СПИСОК ВИКОРИСТАНИХ ДЖЕРЕЛ:}

1. Коваленко Б.В. Стандарти як складовий елемент системи джерел екологічного права України. Правова позищія. 2017. № 1 (18). С. 139-147.

2. Андрейцев В.І. Екологічне право України: розвиток наукових доктрин. Конституційні засади аграрного, земельного та екологічного права: 20 років розвитку: матеріали «круглого столу» (Київ, 27.05.2016р.); КНУ ім. Т. Шевченка. Чернівці : Кондратьєв А.В., 2016. 377 с.

3. Погребной А.А., Каракаш И.И. Земельное право Украины: учебное пособие / под ред. Погребного А.А. и Каракаша И.И. К., 2002. 448 с. 
4. Про охорону навколишнього природного середовища: Закон України від 25.06.1991 № 1264-XII // БД «Законодавство України» / BP України. URL: https://zakon.rada.gov.ua/laws/show/1264-12\#Text.

5. Бондар Л.О. Законодавчі основи стандартизації та нормування у царині охорони довкілля. Правове регулювання екологічної стандартизації та сертифікації. URL: http://ecopravo.host-ua.org.ua/nauk/uprav/ekonorm.htm.

6. Про енергозбереження: Закон України від 01.07.1994 № 74/94-ВР // БД «Законодавство України» / BP України. URL: https://zakon.rada.gov.ua/laws/show/74/94-\%D0\%B2\%D1\%80.

7. Про будівельні норми: Закон України від 05.11.2009 № 1704-VI // БД «Законодавство України» / BP України. URL: https://zakon.rada.gov.ua/laws/show/74/94-\%D0\%B2\%D1\%80. 


\title{
СУТНІСТЬ ПРОФЕСІЙНОЇ ПРАВНИЧОЇ ДОПОМОГИ В ДІЯЛЬНОСТІ АДВОКАТУРИ
}

\author{
Обловацька Наталія Олександрівна \\ старший викладач кафедри публічного та приватного права \\ Київський університет імені Бориса Грінченка
}

Статтею 59 Конституції України встановлено, що кожен має право на професійну правничу допомогу [1].

3 об’єктивної точки зору, право на професійну правничу допомогу - це сукупність правових норм, що регулюють відносини щодо надання професійної правничої допомоги [2, с. 159]. Із суб’єктивної точки зору, право на професійну правничу допомогу - це гарантована нормативно-правовими актами можливість особи надавати або отримувати професійну правничу допомогу 3 метою забезпечення прав, свобод та законних інтересів особи, яка потребує такої допомоги [2, с. 160]. На думку В.М. Ісакова, право на професійну правничу допомогу забезпечує можливість кожному звернутися до особи, що має професійні знання (професіонала) у сфері права (адвоката) з метою отримання належної правової інформації та/або ефективного захисту своїх прав та інтересів $[3$, c. 8$]$.

Метою дослідження є визначення сутності професійної правничої допомоги в діяльності адвокатури.

Згідно ст. 131-2 Конституції України для надання професійної правничої допомоги в Україні діє адвокатура [1]. П.1 та п.3 ст. 10 «Професійна правнича допомога при реалізації права на справедливий суд» Закону України «Про судоустрій і статус суддів» також передбачає, що кожен має право на професійну правничу допомогу [4]. Для надання професійної правничої допомоги діє адвокатура. Забезпечення права на захист від кримінального обвинувачення та представництво в суді здійснюються адвокатом, за винятком випадків, установлених законодавством України.

Відповідно до ст. 2 Закону України «Про адвокатуру та адвокатську діяльність» [5], адвокатура України - недержавний самоврядний інститут, що забезпечує здійснення захисту, представництва та надання інших видів правової допомоги на професійній основі, а також самостійно вирішує питання організації і діяльності адвокатури в порядку, встановленому вищезазначеним Законом. Адвокатуру України складають всі адвокати України, які мають право здійснювати адвокатську діяльність.

Держава покладає обов’язок щодо надання правничої допомоги на осіб, які на професійній основі здійснюють таку діяльність, а саме на адвокатів. Така діяльність адвоката може характеризуватися шляхом використання понять «правова допомога», «юридична допомога», «правнича допомога», але обов'язково у поєднанні із терміном «професійна» [6, с. 144].

Здійснювати професійну правничу допомогу може адвокат, тобто фізична особа, яка має повну вищу юридичну освіту, володіє державною мовою, має стаж 
роботи в галузі права не менше двох років, склала кваліфікаційний іспит, пройшла стажування (крім випадків, встановлених Законом України «Про адвокатуру та адвокатську діяльність»), склала присягу адвоката України та отримала свідоцтво про право на заняття адвокатською діяльністю.

Значною рисою професійної правничої допомоги як виду допомоги в діяльності адвокатури є пріоритет прав, свобод і законних інтересів особи, яка отримує таку допомогу, для задоволення іiі індивідуальних інтересів [7, с. 122].

Зміст професійної правничої допомоги становлять дії 3 використанням засобів правового характеру, які здійснюються адвокатом, на підставах і в порядку, не заборонених законодавством України.

Особливими ознаками професійної правничої допомоги в діяльності адвокатури є:

- професійна правнича допомога є різновидом професійної діяльності, яка здійснюється адвокатом;

- передбачає надання правових послуг, зокрема:

1) надання правової інформації, консультацій і роз'яснень з правових питань, правовий супровід діяльності юридичних і фізичних осіб, органів державної влади, органів місцевого самоврядування, держави;

2) складення заяв, скарг, процесуальних та інших документів правового характеру;

3) захист прав, свобод і законних інтересів підозрюваного, обвинуваченого, підсудного, засудженого, виправданого, особи, стосовно якої передбачається застосування примусових заходів медичного чи виховного характеру або вирішується питання про їх застосування у кримінальному провадженні, особи, стосовно якої розглядається питання про видачу іноземній державі (екстрадицію), а також особи, яка притягається до адміністративної відповідальності під час розгляду справи про адміністративне правопорушення;

4) надання правової допомоги свідку у кримінальному провадженні;

5) представництво інтересів потерпілого під час розгляду справи про адміністративне правопорушення, прав і обов'язків потерпілого, цивільного позивача, цивільного відповідача у кримінальному провадженні;

6) представництво інтересів фізичних і юридичних осіб у судах під час здійснення цивільного, господарського, адміністративного та конституційного судочинства, а також в інших державних органах, перед фізичними та юридичними особами;

7) представництво інтересів фізичних і юридичних осіб, держави, органів державної влади, органів місцевого самоврядування в іноземних, міжнародних судових органах, якщо інше не встановлено законодавством іноземних держав, статутними документами міжнародних судових органів та інших міжнародних організацій або міжнародними договорами, згода на обов'язковість яких надана Верховною Радою України;

8) надання правової допомоги під час виконання та відбування кримінальних покарань; 
9) захист прав, свобод i законних інтересів викривача у зв'язку 3 повідомленням ним інформації про корупційне або пов'язане 3 корупцією правопорушення.

Адвокат може здійснювати й інші види адвокатської діяльності, не заборонені законом.

- може надаватися адвокатом на оплатній або безоплатній основі.

Професійна правнича допомога в діяльності адвокатури як діяльність відбувається в межах відносин між суб'єктом отримання, а саме, фізичною чи юридичною особами, та суб'єктом надання допомоги - адвокатом. Останній зобов'язаний діяти в межах повноважень, наданих йому клієнтом, у тому числі 3 урахуванням обмежень щодо вчинення окремих процесуальних дій. Документами, що посвідчують повноваження адвоката на надання правової допомоги, можуть бути: договір про надання правової допомоги; довіреність; ордер; доручення органу (установи), уповноваженого законом на надання безоплатної правової допомоги.

Незнання фізичною чи юридичною особами своїх прав, свобод та законних інтересів, наявності юридичних та/або фактичних перешкод для самостійного використання своїх правових можливостей, обумовлює потребу в наданні ій професійної правничої допомоги. Зокрема, згідно ст. 52 Кримінального процесуального кодексу України [8], участь захисника $є$ обов'язковою у кримінальному провадженні щодо особливо тяжких злочинів. У цьому випадку участь захисника забезпечується 3 моменту набуття особою статусу підозрюваного. В інших випадках обов'язкова участь захисника забезпечується у кримінальному провадженні:

- щодо осіб, які підозрюються або обвинувачуються у вчиненні кримінального правопорушення у віці до 18 років, - 3 моменту встановлення факту неповноліття або виникнення будь-яких сумнівів у тому, що особа $є$ повнолітньою;

- щодо осіб, стосовно яких передбачається застосування примусових заходів виховного характеру, - 3 моменту встановлення факту неповноліття або виникнення будь-яких сумнівів у тому, що особа $є$ повнолітньою;

- щодо осіб, які внаслідок психічних чи фізичних вад (німі, глухі, сліпі тощо) не здатні повною мірою реалізувати свої права, - з моменту встановлення цих вад;

- щодо осіб, які не володіють мовою, якою ведеться кримінальне провадження, - 3 моменту встановлення цього факту;

- щодо осіб, стосовно яких передбачається застосування примусових заходів медичного характеру або вирішується питання про їх застосування, - 3 моменту встановлення факту наявності в особи психічного захворювання або інших відомостей, які викликають сумнів щодо її осудності;

- щодо реабілітації померлої особи - 3 моменту виникнення права на реабілітацію померлої особи;

- щодо осіб, стосовно яких здійснюється спеціальне досудове розслідування або спеціальне судове провадження, - 3 моменту прийняття відповідного процесуального рішення; 
- у разі укладення угоди між прокурором та підозрюваним чи обвинуваченим про визнання винуватості - з моменту ініціювання укладення такої угоди.

Відповідно до ст. 45 КПК захисником є адвокат, який здійснює захист підозрюваного, обвинуваченого, засудженого, виправданого, особи, стосовно якої передбачається застосування примусових заходів медичного чи виховного характеру або вирішувалося питання про їх застосування, а також особи, стосовно якої передбачається розгляд питання про видачу іноземній державі (екстрадицію).

Для отримання оплатної професійної правничої допомоги між адвокатом та особою, яка потребує допомоги (клієнтом), укладається договір про надання професійної правничої допомоги, за яким одна сторона (адвокат, адвокатське бюро, адвокатське об'єднання) зобов'язується надавати професійну правничу допомогу іншій стороні договору (клієнту) на умовах і в порядку, що визначені договором, а клієнт зобов'язується оплатити надання такої допомоги винагороду (гонорар) та фактичні витрати, необхідні для виконання договору, у випадку, якщо така оплата передбачена договором.

Безоплатна правнича допомога - допомога, яка повністю або частково надається за рахунок коштів Державного бюджету України, місцевих бюджетів чи інших джерел [9]. Після прийняття рішення про надання безоплатної вторинної правничої допомоги Центр з надання безоплатної вторинної правової допомоги призначає адвоката, який надає допомогу на постійній основі за контрактом. У разі неможливості надання безоплатної вторинної правничої допомоги адвокатом, який надає таку допомогу на постійній основі за контрактом, Центр з надання безоплатної вторинної правової допомоги укладає договір з адвокатом, включеним до Реєстру адвокатів, які надають безоплатну вторинну правову допомогу.

Отже, професійна правнича допомога, виступаючи юридичною гарантією прав і свобод, є важливим елементом механізму забезпечення прав і свобод людини та громадянина. При цьому професійна правнича допомога в діяльності адвокатури $є$ професійною діяльністю адвокатів, на оплатній чи безоплатній основі, що спрямована на сприяння фізичним та юридичним особам у реалізації прав, свобод і законних інтересів з метою покращення їх правового становища.

\section{Список літератури:}

1. Конституція України від 28.06.1996 р. № 254к/96-ВР. Відомості Верховної Ради України. 1996. № 30. ст. 141.

2. Литовченко Л. А., Чуйко О. В. Поняття «право на правову допомогу» та «правова допомога» у контексті конституційного та цивільно-процесуального законодавства. Науковий вісник Дніпропетровського державного університету внутрішніх справ. 2011. № 4. С. 152-161.

3. Ісакова В. М. Право на правову допомогу: поняття, особливості, гарантії: автореф. дис. ... канд. юрид. наук. Харків, 2013. 19 с.

4. Про судоустрій і статус суддів: Закон України від 02.06.2016 р. № 1402VIII. Відомості Верховної Ради України. 2016. № 31. Ст. 545.

5. Про адвокатуру та адвокатську діяльність: Закон України від 5.07.2012 p. № 5076-VI. Відомості Верховної Ради України. 2013. № 27. Ст.282. 
6. Заборовський В. В. Професійна діяльність адвоката - це правова, юридична чи професійна правнича допомога? Науковий вісник Ужгородського національного університету. Серія: Право. 2016. Вип. 38. Т. 2. С. 140-145.

7. Панченко В. Ю. Юридическая помощь (вопросы общей теории): монография. Красноярск: Сиб. федер. ун-т, 2011. 279 с.

8. Кримінальний процесуальний кодекс України від 13.04.2012 p. № 4651- VI. Відомості Верховної Ради України. 2013. № 9-10. Ст. 88.

9. Про безоплатну правову допомогу: Закон України від 02.06.2011 p. № 3460VI. Відомості Верховної Ради України. 2011. № 51. Ст. 577. 


\title{
ПРАВА ЛЮДИНИ: ІСТОРИЧНІ ПЕРЕДУМОВИ Й ВПЛИВ НА СУЧАСНІСТЬ
}

\author{
Сіда Софія Сергіївна, \\ Студентка за ОР «Бакалавр» \\ Інституту права \\ Київського національного університету \\ імені Тараса Шевченка
}

Права людини, з’явилися під час Англійської буржуазної революції в армії Олівера Кромвеля, проте на той час цей термін так і не було використано. На думку авторки, найбільш актуально описує права людини член Британського парламенту XIX ст., філософ та соціолог - Джон Стюарт Мілль: «Якщо ми називаємо щось правом людини, то маємо на увазі, що вона обгрунтовано претендує на свій захист із боку суспільства в своїй можливості володіти цим правом, силою закону, або через освіту й формування суспільної думки» [2]. Тим самим науковець підкреслює необхідність ефективного апарату управління для захисту цих прав, однак суспільство, як окрема одиниця, відіграє все ж таки головну роль.

Вперше, юридичне закріплення прав людини відбулось після Великої французької революції. Згодом починають з'являтись схожі акти й вже в ХX ст. дане юридичне закріплення стає масовим. Найбільший вплив зіграли дві світові війни, людство зрозуміло, що ведення війни, регулювання конфліктів, зброї, винесення цінності людського життя на перший план - має бути підгрунтям функціонування сучасного суспільства. В 1948 році Організацією Об’єднаних Націй приймається «Загальна декларація прав людини», хоч це й не є офіційним юридичним документом, але декларацію погодилось підписати більшість країн світу [1].

У результаті аналізу історичних факторів та загальних тенденцій появи прав людини, науковці формують так звані «покоління». Внаслідок Всесвітньої конференції з прав людини прийнято Віденську декларацію 1993 року, де сказано: «Усі права людини $є$ універсальними, неподільними, взаємозалежними, і пов'язаними між собою» [3]. 3 цієї взаємозалежності та пов'язаності й виникають покоління, які тим чи інакшим чином доповнюють, вдосконалюють та випливають одне з одного.

Наразі виділяють три покоління прав людини, однак деякі дослідники схильні до виокремлення ще й четвертого. Отже, розглянемо підгрунтя та передумови формування кожного.

Основна частина прав першого покоління формується приблизно на межі XVII - XVIII століть. Однак початок цього формування сягає давніх часів, це зокрема Велика Хартія Вольностей, Білль про права, Habeas Corpus Act. У всіх цих актів є одна спільна риса - вони не надають права народу, а забирають їх у держави [4]. Це зумовлено тим, що феодальне суспільство розуміє, що така інституція, як держава не може бути джерелом влади, адже це приведе до іï 
свавілля, тому перш за все, ним має стати сам народ беручи участь у політичному житті. Лише після Великої французької революції, в серпні 1789 року приймається Декларація прав людини і громадянина, де права надаються вже безпосередньо особам. В Декларації закріплюються такі основоположні права людини: люди народжується рівними й вільними, джерелом влади та суверенітету повинен бути сам народ, дозволено робити усе, що прямо не заборонено законом, а законом, у свою чергу, обмежуються лише шкідливі для суспільства дії, жодна людина не може бути покарана, заарештована, якщо цього не передбачає закон, людина вільна у своїх особистих політичних або релігійних поглядах і не може через це зазнавати будь-яких переслідувань [5]. Для нас ці права здаються очевидними й безумовними, але для тогочасного суспільства закріплення подібних принципів стало великим здобутком.

Права другого покоління прийнято називати соціально-економічними, а також культурними. Ці права засновані, в першу чергу, на ідеях загальної рівності та однакового доступу до соціальних та економічних благ. Дане покоління виникає під впливом Першої світової, по ії̈ закінченню суспільство більше уваги приділяє економічному добробуту, демократизації та гуманізації, а також, підвищенню культурного розвитку [2]. Основні права цього покоління закріплені в Міжнародному пакті про економічні, соціальні та культурні права, сюди входять право народу на самовизначення, право на працю, відповідні умови для іiї здійснення та отримання доходу, право на відпочинок, на соціальне забезпечення, страхування та медичну допомогу, на освіту, вступ до професійних спілок, на материнство і забезпечення дітей відповідною кількістю харчів, одягу, на участь у культурному житті, тощо. [6]. Усі права другого покоління є об'єктивними та сформованими, здебільшого, за вимогою часу.

Права третього покоління, як їх ще називають - колективні права, сформовані внаслідок впливу попередніх. Можна сказати, що вони $є$ ключем до подолання всіх бар'єрів у ефективній реалізації прав другого покоління. Поняття гідності та свободи інтерпретується вже під іншим кутом, з'являється поняття солідарності в суспільстві. Ці права не надаються окремому індивіду, а реалізують в межах колективу, народу, звідси й їхня назва. До них відносять право на всебічний розвиток, на безпечне навколишне середовище, на користування суспільними благами та історичним спадком людства i, що значно виділяє третє покоління - право на доступ до інформації [2].

Розглянувши усі три покоління прав людини можна сказати, що у виникненні та розвитку прав людини наявна чітка логіка, що зумовлена часом, історичними подіями, бурхливим розвитком суспільства й ще численними факторами. Перше покоління прав людини закладає фундамент, воно вказує людству основоположні права та надає народу владу на участь у справах держави. За допомогою другого покоління в суспільстві встановлюється рівність в доступі до основних благ, з'являється поняття соціального забезпечення від держави, можливість вільно здійснювати економічну діяльність та забезпечувати себе, сім'ю, відкриваються двері у світ культури та належної освіти. Третє покоління, що диктує права цілому колективу, державі, заради спільного користування благами та покращення реалізації прав попередніх 
поколінь. Авторка впевнена, що третім поколінням еволюція прав людини не завершиться, адже саме суспільство розвивається на даний момент із космічною швидкістю й права людини повинні відповідати всім вимогам суспільства.

\section{Список літератури}

1. Теорія права: Курс лекцій: Навчальний посібник для юридичних фак. Вузів. - К.: Вентурі, 1996. - 208 с.

2. Еволюція прав людини. URL:// Council of Europe ///https://www.coe.int/uk.

3. Віденська декларація. URL:https://zakon.rada.gov.ua.

4. Скакун О.Ф. Теорія держави і права / О.Ф. Скакун; пер. з рус. - Х. : Консум, 2008. $-656 \mathrm{c}$

5. Віденська декларація URL:https://zakon.rada.gov.ua.

6. Міжнародний пакт про економічні, соціальні i культурні права URL:https://zakon.rada.gov.ua.

7. Teremtsova, N. (2019). The problem of differentiation between private and public law. Journal Transition Studies Review, 26(2), 15-22. 


\section{ПРЕТЕНЗІЙНИЙ ПОРЯДОК ВРЕГУЛЮВАННЯ ГОСПОДАРСЬКИХ СПОРІВ: ПЕРЕВАГИ І НЕДОЛІКИ}

Хатнюк Наталія Сергіївна професор кафедри публічного та приватного права, д.ю.н., доцент Факультету права та міжнародних відносин Київського університету імені Бориса Грінченка

\section{Саган Дарина Олександрівна} студентка III курсу

Факультету права та міжнародних відносин Київського університету імені Бориса Грінченка

Претензія - це письмова вимога однієї сторони договору до іншої щодо відновлення або захисту порушених прав (виконання зобов'язання, сплату боргу, неустойки тощо), які випливають із договірних відносин між ними. Тобто, це документ, призначений для відновлення порушеного права та законних інтересів підприємства.

Можливість вживання заходів досудового врегулювання господарського спору зафіксовано в статті 19 Господарського процесуального кодексу (далі ГПК України) України.

Сторони вживають заходів для досудового врегулювання спору за домовленістю між собою або у випадках, коли такі заходи $є$ обов'язковими згідно із законом. Особи, які порушили права і законні інтереси інших осіб, зобов'язані поновити їх, не чекаючи пред'явлення претензії чи позову. [6].

У разі необхідності відшкодування збитків або застосування інших санкцій суб'єкт господарювання чи інша юридична особа - учасник господарських відносин, чиї права або законні інтереси порушено, з метою безпосереднього врегулювання спору з порушником цих прав або інтересів має право звернутися до нього з письмовою претензією, якщо інше не встановлено законом [5].

Стаття 222 Господарського кодексу Україні (далі - ГК України) передбачає положення щодо досудового порядку реалізації господарсько-правової відповідальності.

Зазначене положення встановлює вимоги щодо змісту претензії. В ній повинно зазначатися:

- повне найменування і поштові реквізити заявника претензії та особи (осіб), якій претензія пред'являється;

- дата пред'явлення і номер претензії;

• обставини, на підставі яких пред’явлено претензію; 
• докази, що підтверджують ці обставини;

- вимоги заявника з посиланням на нормативні акти;

• сума претензії та її розрахунок, якщо претензія підлягає грошовій оцінці;

- платіжні реквізити заявника претензії;

- перелік документів, що додаються до претензії [5].

Претензія та відповідь на претензію підписується повноважною особою заявника претензії або його представником та надсилається адресатові рекомендованим або цінним листом або вручається адресатові під розписку. Строк розгляду становить один місяць дня іiї одержання претензії.

Господарський кодекс України передбачає спеціальні строки щодо пред'явлення та розгляду претензії. Наприклад, у спорах про перевезення претензії можуть пред'являтися протягом шести місяців, а претензії щодо сплати штрафів і премій - протягом сорока п'яти днів.

Перевізник розглядає заявлену претензію і повідомляє заявника про задоволення чи відхилення іiї протягом трьох місяців, а щодо претензії 3 перевезення у прямому змішаному сполученні - протягом шести місяців. Претензії щодо сплати штрафу або премії розглядаються протягом сорока п'яти днів [5].

Якщо документи наявні у другої сторони, вони можуть не додаватися. Всі інші документи, що підтверджують вимоги заявника, додаються в оригіналах чи належним чином засвідчених копіях.

Важливим фактором досудового врегулювання господарських спорів $\epsilon$ можливість застосування цієї стадії процесу лише за бажанням суб'єктів господарювання.

Існують певні винятки із цього правила. Такими нормативними актами як Кодекс торговельного мореплавства від 9 грудня 1994 р., Повітряний кодекс від 4 травня 1994 р., постанова Кабінету Міністрів України від 6 квітня 1998 р. № 457 «Про затвердження Статуту залізниць України», наказ Міністерства транспорту України від 14 вересня 1997 р. № 363 «Про затвердження Правил перевезень вантажів автомобільним транспортом в Україні» та інші, які регулюють відповідні правовідносини, що пов'язані з переміщенням вантажу передбачено спеціальний порядок вирішення спорів в досудовому порядку [3].

Такий крок як пред’явлення претензії закріплено і в деяких доволі давніх нормативно-правових актах, що досі є чинними на території України. Зокрема, обов’язковість пред’явлення претензії передбачено в Інструкціях № П-6 і № П7 , що регулюють приймання продукції виробничо-технічного призначення $\mathrm{i}$ товарів народного споживання за кількістю та якістю. 
При розгляді претензії підприємства та організації в разі необхідності повинні звірити розрахунки, провести судову експертизу або вчинити інші дії для забезпечення досудового врегулювання спору.

Сторона, яка пред'являє претензію, зацікавлена в отриманні ії стороноюборжником. Тож, належними доказами відправлення претензії вважаються розрахунковий документ (касовий чек, розрахункова квитанція тощо), а також опис вкладення в поштовий конверт із підписом працівника поштового зв'язку та відбитком календарного штемпеля.

Про результати розгляду претензії заявник повідомляється у письмовій формі. Коли претензію відхилено повністю або частково, заявникові повинно бути повернуто оригінали документів, одержаних 3 претензією, а також надіслано документи, що обгрунтовують відхилення претензії, якщо їх немає у заявника претензії.

Претензійний порядок врегулювання господарських спорів має свої переваги та недоліки. До недоліків фахівці відносять:

- відсутність можливості отримання акта преюдиційного характеру: ухвали чи рішення суду, в яких безпосередньо встановлюються факти, що мали місце при виникненні певних правовідносин, наприклад, договірних, i, відповідно, дається юридична оцінка вчиненим діям (резолютивна частина рішення);

- немає жодної гарантії на позитивне вирішення конфлікту;

- ймовірно, що винна сторона не відповість у встановлений законом термін на претензію або просто проігнорує їі. Це дасть їй можливість затягнути вирішення спору й виграти мінімум 2-3 місяці до звернення до суду;

- претензійний порядок дасть винній стороні можливість спотворювати обставини справи, перекручувати факти на свою користь, давати неповний перелік документів, приховувати обставини справ й ухилятися від відповідальності;

- визнання або навіть часткове визнання претензії ще не свідчить, що вимоги будуть виконані. [1, с. 91].

На мою думку, переваг у претензійного порядку врегулювання спорів більше ніж недоліків, а саме:

- збереження коштів, адже при застосуванні претензійного порядку не потрібно сплачувати державне мито, витрати на інформаційнотехнічне забезпечення судового процесу, у разі необхідності і витрати на проведення експертизи;

- збереження часу, адже судовий розгляд справи може зайняти місяці. Більше того, не виключено, що відповідач буде оскаржувати рішення 
суду першої інстанції в апеляційному порядку, а ця процедура може зайняти ще кілька місяців;

- процедура $є$ більш комфортною для сторін, адже вони можуть самостійно обирати час та місце для обговорення та вирішення справи. Тим більше, найчастіше все вирішується за допомогою телефонного зв’язку, інтернету, факсу тощо;

- збереження хороших зв'язків та партнерські відносини між сторонами, що є важливим для можливої майбутньої співпраці.

Ми підтримуємо позицію Бондаренко-Зелінської Н. Л., що основне призначення цих процедур полягає в тому, що за їх допомогою відбувається фільтрування тих правових спорів, які дійсно потребують повного судового розгляду від тих, які можливо вирішити в позасудовому порядку. Їх вибір $\epsilon$ невипадковим, він обумовлений прагненням європейських держав забезпечити ефективний захист прав своїх громадян та повну ліквідацію правових конфліктів на добровільних засадах [2, с. 164].

Підсумовуємо вищезазначене, можна визначити, що підприємства та організації, чиї права і законні інтереси порушено, з метою безпосереднього врегулювання спору з порушником цих прав та інтересів мають право звернутися до нього з письмовою претензією. Коли сторони доходять взаємної згоди, конфлікт вичерпано, в іншому випадку зацікавлена сторона може звертається до господарського суду.

Суть претензії полягає в тому, щоб переконати боржника виконати свої зобов'язання добровільно, таким чином уникнувши подальшого звернення до суду. Тому в тексті претензії мають бути викладені як вимоги про погашення заборгованості, так i можливі негативні наслідки для боржника у разі несвоєчасного задоволення вимог [4, с. 68]. Існування претензійного порядку вирішення господарських спорів $є$ цілком виправданим, адже він може значно пришвидшити врегулювання спорів між контрагентами, зекономити кошти сторін, зберегти хороші партнерські зв’язки тощо.

\section{Список літератури:}

1. Баран С.О. Переваги та недоліки досудового порядку врегулювання господарських спорів / Баран С.О. // Збірники наукових праць. - 2014. - Режим доступу: http://elar.naiau.kiev.ua/jspui/handle/123456789/10019

2. Зелінська Н.Л. Запровадження альтернативних способів врегулювання спорів: європейський досвід для України / Н.Л. БондаренкоЗелінська // Приватне право і підприємництво : збірник наукових праць - Вип. 8. - К. : НДІ приватного права і підприємництва НАПрН України, 2009. - С. 162-166. - Режим доступу: http://library.nlu.edu.ua/POLN_TEXT/SBORNIKI_2010/PPP_8_2009/BondarenkoZ elinska.pdf

3. Прокопенко Я. Досудовий (претензійний) порядок врегулювання господарських спорів: ретроспектива та тенденції сьогодення. Підприємництво, господарство і право. 2009. № 6 (162). С. 44-46. 
4. Савченко О. Досудове врегулювання господарських спорів / О. Савченко // Підприємництво, господарство і право. - 2016. - № 6. - С. 66-70. - Режим доступу: http://nbuv.gov.ua/UJRN/Pgip_2016_6_14

5. Господарський кодекс України від 16 січня 2003 року №436-IV. Відомості Верховної Ради України (ВВР), 2003, № 18, № 19-20, № 21-22, ст.144. - Режим доступу: https://zakon.rada.gov.ua/laws/show/436-15\#Text

6. Господарський процесуальний кодекс України : Закон України від 06.11.1991 p. № 1798-XII. - Режим доступу: https://zakon.rada.gov.ua/laws/show/1798-12\#Text 


\title{
СУЧАСНИЙ ПОГЛЯД НА ПРИНЦИПИ НАДАННЯ МЕДИЧНОЇ ДОПОМОГИ ІЗ ЗАСТОСУВАННЯМ ТРАНСПЛАНТАЦЇ̈
}

\author{
Шкляр Іванна Володимирівна \\ аспірант кафедри конституційного права та прав людини Національної \\ академії внутрішніх справ \\ м. Київ, Україна
}

Аналізуючи суспільні відносини у сфері надання медичної допомоги із застосуванням трансплантації доцільно дослідити принципи надання такої допомоги, адже це те що підкреслює соціальну значущість права у правовій та демократичній державі.

Небувалий прогрес за останні роки спостерігається в наданні медичної допомоги із застосуванням трансплантації. Хоча медична допомога сама по собі не була загальновизнаним невід'ємним правом протягом століть, а лише для заможних верств населення становила привілей і тільки з другої половини 20-го століття поступово почало складатися уявлення про право на охорону здоров'я, а відповідно і право на медичну допомогу, як невід'ємне право кожного хто цього потребує незалежно від майнового стану, місця проживання або інших ознак. Сама трансплантація органів розпочала свою історію як спосіб порятунку життя людей у середині 20-го століття, включаючи в себе найновітніші досягнення медичних технологій та медицини в цілому. Те що здавалося десятиліттями нездійсненною мрією почало розвиватися активними темпами.

Поняття «принцип»у науковій літературі визначається по-різному, інколи воно розглядається як наукова теорія, певна методологічна чи нормативна установка, правило, постулат, гносеологічний феномен, що не існує у природі, $\mathrm{i}$ як закон, який використовується як організатор емпіричного матеріалу або як функція засобу пояснення будь-якого факту [1, с.81-82].

Л.С. Явіч називав принципами права такі начала, відправні ідеї його буття, які виражають найважливіші закономірності та підвалини цієї суспільноекономічної формації, є однопорядкові за сутністю права і становлять його головний зміст, наділені універсальністю, вищої імперативністю i загальнообов’язковістю, відповідають об'єктивній необхідності зміцнення пануючого способу виробництва, а також що юридичний (правовий) принцип лише термінологічно може уточнюватися [2, с.10-11].

Муртазаєва Г.Н., Некрасов В.А. визначаючи загальні принципи, на основі яких передбачається здійснювати юридичну регламентацію трансплантації органів і тканин, вважаємо за доцільне використовувати загальноправовий науковий підхід, згідно якому розрізняють принципи права i принципи правового регулювання. Стосовно трансплантації принципами права можуть вважатися ті основні положення, що вже знайшли втілення в нормативноправових актах. В той же час принципи правового регулювання — це керівні ідеї, передумови, які можуть бути використані як базис для побудови норм права. 
Взаємозв'язок принципів права i принципів правового регулювання ілюструється фактом, відповідно до якого принципи права, будучи своєрідним каркасом законодавчих актів, запроваджуються в життя за рахунок попереднього визначення принципів правового регулювання. Цікава точка зору, при якій в основу правового регулювання операцій по пересадці органів і тканин покладені принципи оптимальної турботи про інтереси донора і колегіальність. Перший 3 них відображає пріоритет інтересів донора при спірних питаннях трансплантації, відповідно до іншого - найбільш складні питання, пов'язані з процедурою встановлення діагнозу хвороби та способів лікування, вирішуються консиліумом лікарів [3, с. 208-209].

Прийняття керівних принципів 15 березня 1991 року на 44-ій сесії Всесвітньої організації охорони здоров'я (ВОО3) із трансплантації вплинули на внесення змін до кодексів поведінки прийняття нових, практику в трансплантології, а також на законодавство держав. Еволюція у сфері трансплантології вимагала перегляду Принципів, ураховуючи сучасні реалії, саме із цієї причини Всесвітня асамблея охорони здоров'я ухвалила 21 травня 2010 року резолюцію WHA63.22, на підставі якої вона затвердила оновлений варіант Керівних принципів ВООЗ [4].

У резолюції WHA63.22 містяться посилання на резолюції WHA40.13, WHA42.5 i WHA44.25 про отримання та трансплантацію органів і на резолюцію WHA57.18 про внесення змін до Керівних принципів ВООЗ із трансплантації [5].

Керівні принципи ВООЗ із трансплантації людських клітин, тканин і органів 2010 р. містять 11 принципів. Метою Керівних принципів ВОО3 із трансплантації людських клітин, тканин і органів $є$ надання впорядкованої, прийнятної структурної основи для процедур набуття та трансплантації людських клітин, тканин і органів у лікувальних цілях із дотриманням етичних принципів [6].

Класифікацію існуючих принципів трансплантації анатомічних матеріалів людині в Україні було зроблено Новицькою М.М., згідно якою науковець ділить ïx на три групи: а) загальноправові принципи, які властиві правовій системі держави загалом, закріплені в Конституції України та без яких існування правопорядку у державі було б неможливим; б) медичні принципи, що $є$ підгрунтям охорони здоров'я в державі загалом; в) суто трансплантологічні принципи $[7,205]$. Слід погодитися із запропонованим розподілом науковя.

До загальноправових відносять такі принципи: демократизму, законності, гуманізму, рівності всіх перед законом, взаємної відповідальності держави та особи, втілення соціальної справедливості та інші.

До медичних принципів, що $є$ підгрунтям охорони здоров'я, а питання застосування трансплантації до галузі медичного права, слід віднести такі:

- принцип рівної можливості на отримання медичної допомоги;

- принцип безоплатності надання медичних послуг;

- принцип кваліфікованості медичної допомоги, що надається;

- принцип відповідності медичної допомоги рівню сучасної науки та техніки;

- принцип заборони заподіянню шкоди здоров'ю пацієнта; 
- принцип відповідальності держави за стан надання медичних послуг населенню;

- тощо.

Аналізуючи суто трансплантологічні принципи, якими керуються при наданні медичної допомоги необхідно виділити принцип людяної гідності і солідарності, який засуджує покупку частин тіла людини для трансплантації та експлуатацію найбідніших та найуразливіших груп населення і торгівлю людьми внаслідок подібної практики. Принципи справедливого та рівноправного розподілу органів-трансплантантів, слід забезпечити їх доступність для пацієнтів за медичними показаннями. А враховуючи, що при прижиттєвому донорстві пріоритетом слід вважати інтереси донора необхідно виділити принцип оптимальної турботи про інтереси донора, який відображає пріоритет інтересів донора при спірних питаннях трансплантації. Також необхідно виділити принцип колегіальності, згідно з яким, найбільш складні питання, пов'язані 3 процедурою встановлення діагнозу хвороби і способів лікування, вирішуються консиліумом лікарів.

В доповнення до перерахованих принципів медичного права необхідно в якості керівних ідей з правового регулювання саме трансплантації органів та тканин виразити наступні принципи:

- Принцип поваги і дотримання прав пацієнта;

- Принцип дотримання черговості згідно «листа очікування»;

- Принцип декормерціалізації пересадок органів та тканин людини; 38].

- Принцип інтеграції в міжнародні трансплантологічні співтовариства [8, с.

Суто на законодавчому рівні, принципи надання медичної допомоги iз застосуванням трансплантації закріпленні у статті 4 Закону України «Про застосування трансплантації анатомічних матеріалів людині», де основними принципами застосування трансплантації є:

- добровільності;

- гуманності;

- анонімності;

- надання донорських органів потенційним реципієнтам за медичними показаннями;

- безоплатності трансплантації для донора та реципієнта;

- дотримання черговості (крім родинного та перехресного донорства);

- достойного ставлення до тіла людини у разі посмертного донорства;

- безперервності отримання медичної допомоги особами, яким трансплантовано анатомічні матеріали[9].

Таким чином, сучасний погляд на принципи надання медичної допомоги із застосуванням трансплантації анатомічних матеріалів людині надає можливість сформувати правове поле в рамках якого здійснюєтья реалізація права на медичну допомогу використовуючи такий метод лікування як оперативне втручання із застосуванням пересадки органів чи тканин людини. 


\section{Список використаних джерел:}

1. Голованов, В.Н. Законы в системе научного знания [Текст] / В.Н. Голованов - М.: Мысль, 1970. - 231.

2. Явич Л.С. Право развитого социалистического общества. Сущность и принципы [Текст] / Л.С.Явич. - М.:Юрид.лит., 1978. - 224.

3. Муртазаєва Г.Н., Некрасов В.А. «Трансплантація органів і тканин людини: принципи правового регулювання»/ Г.Н. Мурзаєва, В.А. Некрасов// Медичне право України: правовий статус пацієнтів в Україні та його законодавче забезпечення (генезис, розвиток, проблеми і перспективи вдосконалення). Матеріали II Всеукраїнської науково-практичної конференції 17-18.04.2008,м. Львів. - 2008. - ст..208-209.

4.Трансплантациячеловеческихклеток,тканейиорганов.URL:http://www.who. int/ transplantation/ru/.

5. Резолюция WHA63.22 «Трансплантация органов и тканей человека». URL : http://apps.who.int/gb/ebwha/pdf_files/WHA63/A63_R22-ru.pdf?ua=1.

6. Руководящие принципы ВОЗ по трансплантации человеческих клеток, тканей и органов.

URL

http://www.who.int/transplantation/Guiding_PrinciplesTransplantation_ WHA63.22ru.pdf?ua $=1 \& u a=1$.

7. Новицька М.М., Адміністративно-правове регулювання трансплантації анатомічних матеріалів людині в Україні: Дис... канд.юрид.наук: 12.00.07 Суми.:СумДУ, 2019. - 267c.

8. Сальников В. П. Общие принципы правового регулирования трансплантации органов и тканей человека / В. П. Сальников, С. Г. Стеценко. // Юрист. - М. - 2000. - No6. - С. 38.

9. Закон України «Про застосування трансплантації анатомічних матеріалів людині» від 17 травня 2018 року [Електронний ресурс]. - Режим доступу: https://zakon.rada.gov.ua/laws/show/2427-19/print 


\title{
BLOCKCHAIN AS AN ESTABLISHED TREND IN THE DEVELOPMENT OF INFORMATION TECHNOLOGIES: CASES OF DEFI AND NFT CRYPTOCURRENCIES
}

\author{
Brodovska Ilona \\ $\mathrm{PhD}$ in Economics, limited liability company "Financial company Abcolute \\ finance" \\ Smereka Svitlana \\ $\mathrm{PhD}$ in Economics, Associate Professor of the Trade and Entrepreneurship \\ Department \\ Western Ukrainian National University \\ Schuchmann Vadim \\ Student of \\ Western Ukrainian National University
}

Within the period of the fourth industrial revolution, the world economy progresses in the context of the general computerization and the IT technologies development. This has led to the emergence of the digital economy, e-commerce and modern financial instruments of virtual market, the most important of which are the DeFi and NFT cryptocurrencies. The data on their operation is based on the blockchain technology. Blockchain is a technology for processing and storing of information and identifying of customers (blockchain). Blockchain technology was founded in 2009 together with the creation of Bitcoin cryptocurrencies and gained the widespread popularity for the development of other cryptocurrencies, such as Ethereum, Ripple, Litecoin. [3] As of today, the blockchain is used in many areas, including banking, public administration, law, health, real estate, and energy. We consider it appropriate to highlight the following features of the blockchain technology:

1) decentralization - information is stored on the computers which are the members of the network;

2) transparency - information on the operations within the entire history of the system is stored;

3) stability - inability to make adjustments "with retrospective effect", but only to implement a new agreement;

4) provability -the cryptographic confirmation of each transaction;

5) saving time and resources - round-the-clock operation of the system;

6) logic in computing - the ability to program;

7) security - information is stored using cryptography.

However, the blockchain system has its drawbacks. Inasmuch as the data is stored on all computers of the participants, the large amount of data is required to register 
transactions, which causes the increased demands to the computer and the speed of the Internet connection. In addition, the service of operations in the blockchain system is characterized by the high energy consumption, inertia of market players, the lack of the legal framework and the need to reach a consensus between a huge number of network participants.

So, in our opinion, a blockchain is a distributed register that is based on the modern cryptographic algorithms and has a computational logic.

Blockchain systems are decentralized, i.e all transactions are processed by a large number of system participants which are called miners. As a rule, they can be anyone who has specialized software and equipment. The main functions of miners are to save a copy of data, confirm transactions in the system, check the operations performed by other miners. [1]

To sum up the above noted, the blockchain is often used to work with NFT and DeFi cryptocurrencies. As of today there are more than 2,500 types of cryptocurrencies ("virtual" money). Cryptocurrency is virtual (electronic) assets in the form of tokens, which are protected and encrypted using the special algorithms. The first cryptocurrency Bitcoin appeared in 2008-2009 against the background of the financial crisis, which caused the inflation, mass bankruptcy of financial institutions, loss of deposits in the population and a decline of trust to the dollar. Cryptocurrency continues to develop and provides an opportunity to analyze the dynamics of supply and demand of different types of electronic units. [3]

The following types of cryptocurrencies which are the largest in terms of capitalization should be distinguished: Bitcoin, Ethereum, Ripple, Doge, Litecoin.

The most popular and most expensive cryptocurrency is Bitcoin, which is about 62 thousand dollars, with a market capitalization of 1.4 trillion dollars, and the number of coins in circulation - more than 19 million.

There are two types of systems based on the electronic money:

- systems that use digital money, which is stored in the form of files on the owner's computer;

- systems that use digital money stored on a smart card. [2]

NFT can be called as the main trend of the blockchain in 2021.

NFT is the abbreviation for the non-fungible token, ie non-interchangeable token. The token itself is a record in a blockchain (key). If a usual token can be replaced by another without any consequences, then in the case of NFT everything is more complicated: the token cannot be replaced without disrupting the system. [4]

This technology was created in 2017 on the blockchain platform Ethereum. It is believed that for the first time NFT tokens were implemented in the game CryptoKitties (purchase of unique cat characters). By purchasing a digital pet, you become its owner and know that other users will not have such a creature.

The uniqueness of the NFT token is a key feature that makes the technology ideal for the registration of the ownership rights on anything.

Thus, the NFT token is a certificate of uniqueness which provides one more opportunity to support your favorite artists and brands. 
In early 2020, the American magazine Forbes began researching a new sector of "decentralized finances", called DeFi and gave a new impetus to the development of the cryptocurrency industry.

Decentralized Finances (DeFi) refers to the ecosystem of the financial applications (projects) developed on the different blockchains. The most popular projects are built on the Ethereum, Tron, Kava network, however, there are the DeFi systems on the Bitcoin blockchain, which are made on the basis of RSK (Rootstock - smart contracts in the bitcoin network). The goal of the DeFi development is to transfer the existing financial system to the blockchain, which will make it accessible and open to the whole world.

In fact, DeFi is a financial instrument in the form of services and applications created on a blockchain. In other words, it is the open access for a large number of people to the decentralized credit provision and new investment platforms.

In order to obtain a loan, it is necessary to pledge a cryptocurrency (ETH, TRON, BAT, USDC, WBTC, USDT or other) at an already known interest rate and the platform pays up to $66 \%$ of the value of the pledged assets. The credit is issued in DAI tokens, which the platform deliberately issues for a specific request. The issue of DAI is regulated by the CDP smart contract (collateralized debt position) [5].

That is, if the client takes 55\% of the DAI when mortgaging ETH, the liquidation will occur when the cost of provision (ETH) falls by $35 \%$ or more percent. This situation can be avoided by monitoring the exchange rate of the crypto-asset that secures the loan and, in the event of a drawdown, either repaying the liability yourself or increasing the provision by increasing the ETH. Another solution is to send a smaller share of DAI on pledge then the probability of liquidation of the position will decrease.

Summarizing the above mentioned, it should be noted that:

1) Blockchain is a revolutionary technology that is used in all spheres of public life and allows you to do without intermediaries;

2) Cryptocurrency is a model of a secure, stable, open and transparent monetary system;

3) Studies of the international practice of cryptocurrency use have shown that highly developed countries clearly regulate, control and tax it. Countries with weaker economies are not yet ready for the use of the virtual currency or even ban it;

4) The direction of DeFi may become a new milestone in the development of the cryptocurrency market, the main difference of which is the provision of liquidity, which is so lacking in the highly volatile cryptocurrency assets. DeFi is becoming a serious alternative to the banking sector and is able to replace the traditional technologies of the current financial system with open source protocols (smart contract);

5)Staking, which is a digital analogue of the traditional lending, provides the additional benefits to the investors in terms of risk reduction, through their control over their funds and at any time gives the access to information about the status of the smart contract, as well as ensures the redistribution and replacement of the capital by the debt liabilities;

6) The introduction of the sharding system will significantly increase the capacity of protocols and, accordingly, the speed of transactions, minimizing the cost of 
commissions and will be an additional guarantee to prove that the experiment with the market of decentralized finances will be successful;

7) Such non-interchangeable token as NFT, ie a file certifying the ownership of a certain product that exists only on the Internet, can be considered as the main trend of the 2021 blockchain.

\section{Refrences}

1. Davydova I. V. (2017) Tekhnolohiia blokchein: perspektyvy rozvytku v Ukraini / I. V. Davydova // Chasopys tsyvilistyky. - Vyp. 26. - S. 38-41. - Rezhym dostupu: http://nbuv.gov.ua/UJRN/Chac_2017_26_10 (data zvernennia 15.04.2021).

2. Panasyuk V., Burdeniuk T., Muzhevych N. (2021) Osoblyvosti tsyfrovoi transformatsii obliku. Halytskyi ekonomichnyi visnyk. Tom 68. № 1. S. 70-76.

3. Savchenko M. V., Korolenko V. O., Poroshyna O. V. (2019) Suchasnyi stan kryptovaliuty na hlobalnii ekonomichnii areni ta yii perspektyvy rozvytku v Ukraini ta sviti / Ekonomika i orhanizatsiia upravlinnia. - Vyp. №4 (36). - S. 48-57 URL: https://jeou.donnu.edu.ua/article/download/7762/7760 (data zvernennia 17.04.2021).

4. NFT: shcho tse take i yak pratsiuie (2021) URL: https://bazilik.media/nft-shchotse-take-i-iak-pratsiuie/ (data zvernennia 17.04.2021).

5. Chto takoe De-Fi y kak na эtom zarabotat? (2021) URL: https://blog.trusteeglobal.com/ru/chto-takoe-de-fi-i-kak-na-etom-zarabotat/ (data zvernennia 16.04.2021). 


\title{
SIMULATION OF THE TRAINING PROCESS OF THE MANAGEMENT STAFF OF THE METALLURGICAL ENTERPRISE
}

\author{
Voronina Alevtyna \\ $\mathrm{PhD}$, Associate Professor \\ Dniprovsk State Technical University \\ Kamianske, Ukraine \\ Andreieva Nataliia \\ Undergraduate \\ Dniprovsk State Technical University \\ Kamianske, Ukraine
}

The process of modernizing knowledge and skills must be ongoing. We believe that the main elements of working with staff should be: emphasis on quality staff development; application of group teaching methods; creating a favorable environment for a successful career and creativity; career advancement, first of all initiative workers; encouraging their active position, and, as a consequence, the formation of a new corporate culture.

The vocational training process should be based on such basic aspects as:

- training, selection and effective placement of skilled workers in accordance with modern business needs;

- full use of the potential of the company's staff.

The implementation of this direction is possible with the introduction of a sound system of motivation and based on the principle of individual approach to each employee; reduction of psychological tension in employees.

We believe that an effective process of professional training of staff can be implemented through:

- improvement of teaching methods and implementation of new training programs;

- advanced training and timely training of employees with a focus on promising organizational tasks. In this case, staff training should be carried out by moving from fragmentary training to integrated and holistic development of personal qualities of the employee.

As in modern conditions of management the enterprises need the worker with the general preparation who will be able to master in optimum terms a task of any complexity and to solve a problem with which did not face earlier;

- expansion of staff rotation and internship programs; 
- introduction of scientifically based methods of selection and hiring of employees;

- development and implementation in practice of preservation programs in the organization of experienced and promising employees;

- development of internal communications. This problem can be solved by expanding the practice of round tables, meetings and other methods of group work, a wide rotation of staff and the introduction into the practice of management of modern information technology and more.

We believe that in order to expand the opportunities and practical results of the procedure of professional training of staff, it is advisable to use several forms of professional training. Thus, we consider it appropriate to propose a model for the development of professional training of personnel. 1 [1, p. 86].

The model provides for the renewal of the process of professional training of personnel in the workplace through the introduction of professional training, the use of advanced training, self-study and non-formal training for career growth.

The introduction of this model of professional development of personnel in production will make it possible to achieve such a qualification level of personnel of the organization that will meet modern production needs.

We believe that the system of staff development and training should focus on the competency approach, as this approach focuses on the formation of competencies in employees, which contribute to improving the efficiency of the enterprise.

Analysis of the personnel development system of the enterprise showed that the most desirable for the enterprise is an "innovative worker" who has such personal characteristics as intellectual development, high professional competence (mathematical literacy, basic competencies in science and technology, etc. [2, p.15]), versatile ingenuity, innovative activity. 


\section{Conceptual principles of professional staff training}

\section{Regularities of introduction of} professional training:

- $\quad$ systematic formation of the staff training process;

- compliance of the personnel training management system with the requirements of the production system;

- optimal combination of centralization and decentralization of personnel training management;

- proportional combination of a set of subsystems and elements of the learning management system;

\section{Principles of introduction of professional training:}

- the principle of efficiency and scientificity;

- the principle of economy;

- principle of perspective (focus on professional growth and selfstudy);

- the principle of optimality (compliance of the proposed measures for training with the necessary and mandatory level of professionalism);

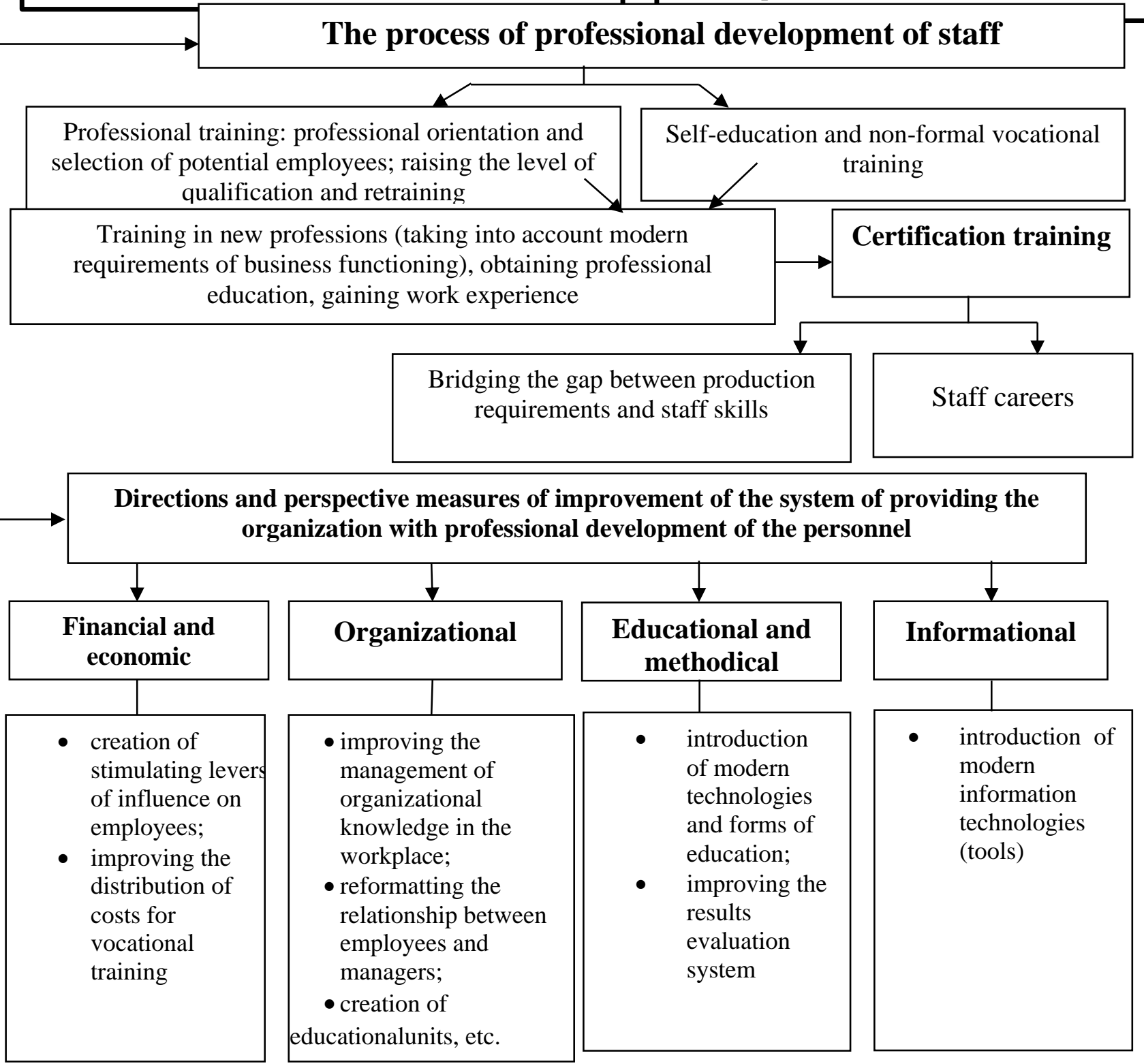

Fig.1 Model of the process of professional development of staff

The basic requirements for the ideal employee are given in Fig. 2. 


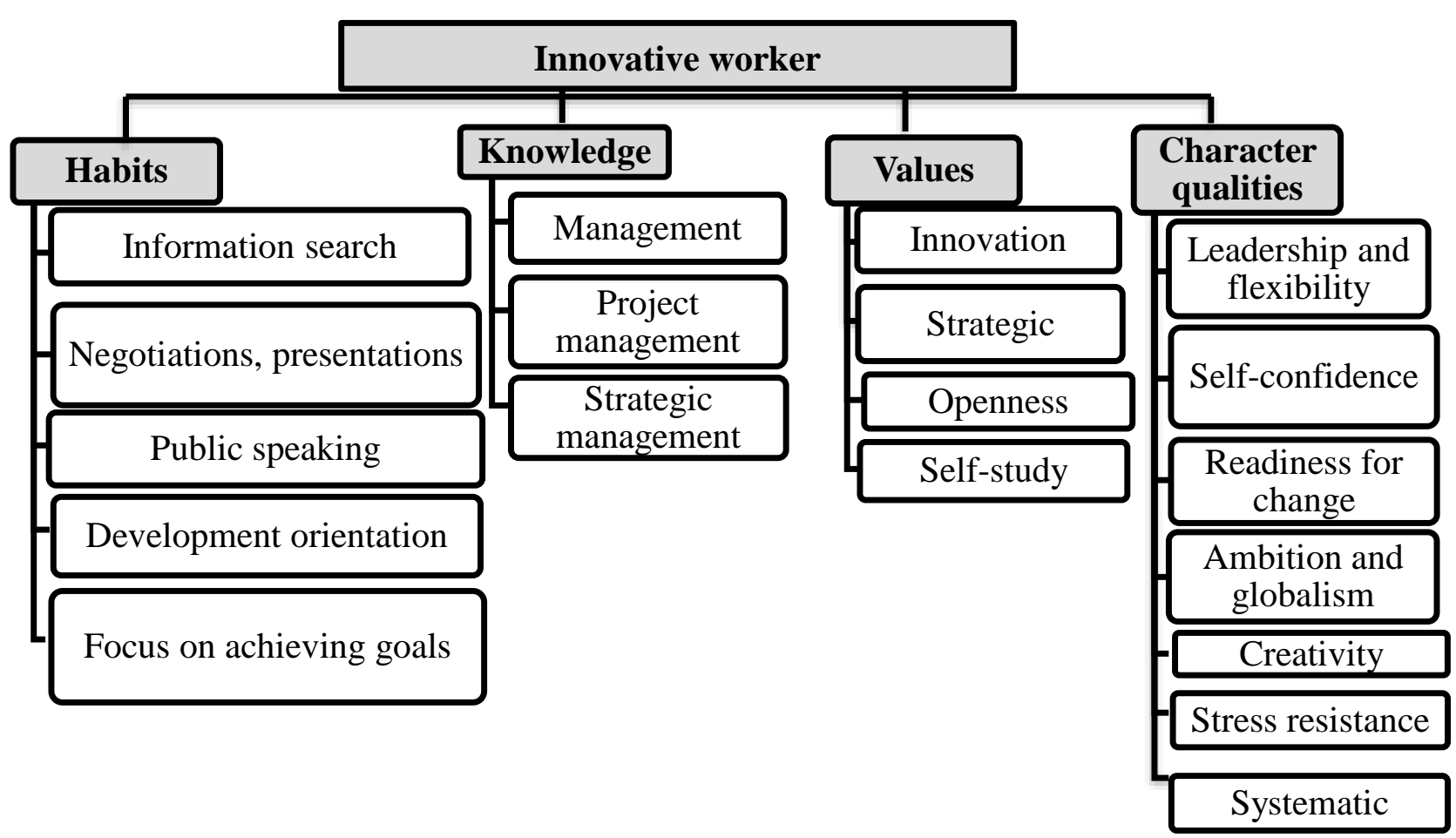

Fig. 2. Basic requirements for the ideal employee of the enterprise

These requirements can serve as a guide for the development of competencies of innovative workers based on the expansion of basic clusters of employee qualities. We offer a three-level model of competencies of the "innovative employee", which is developed on the basis of the basic requirements for the ideal employee (Fig. 3).

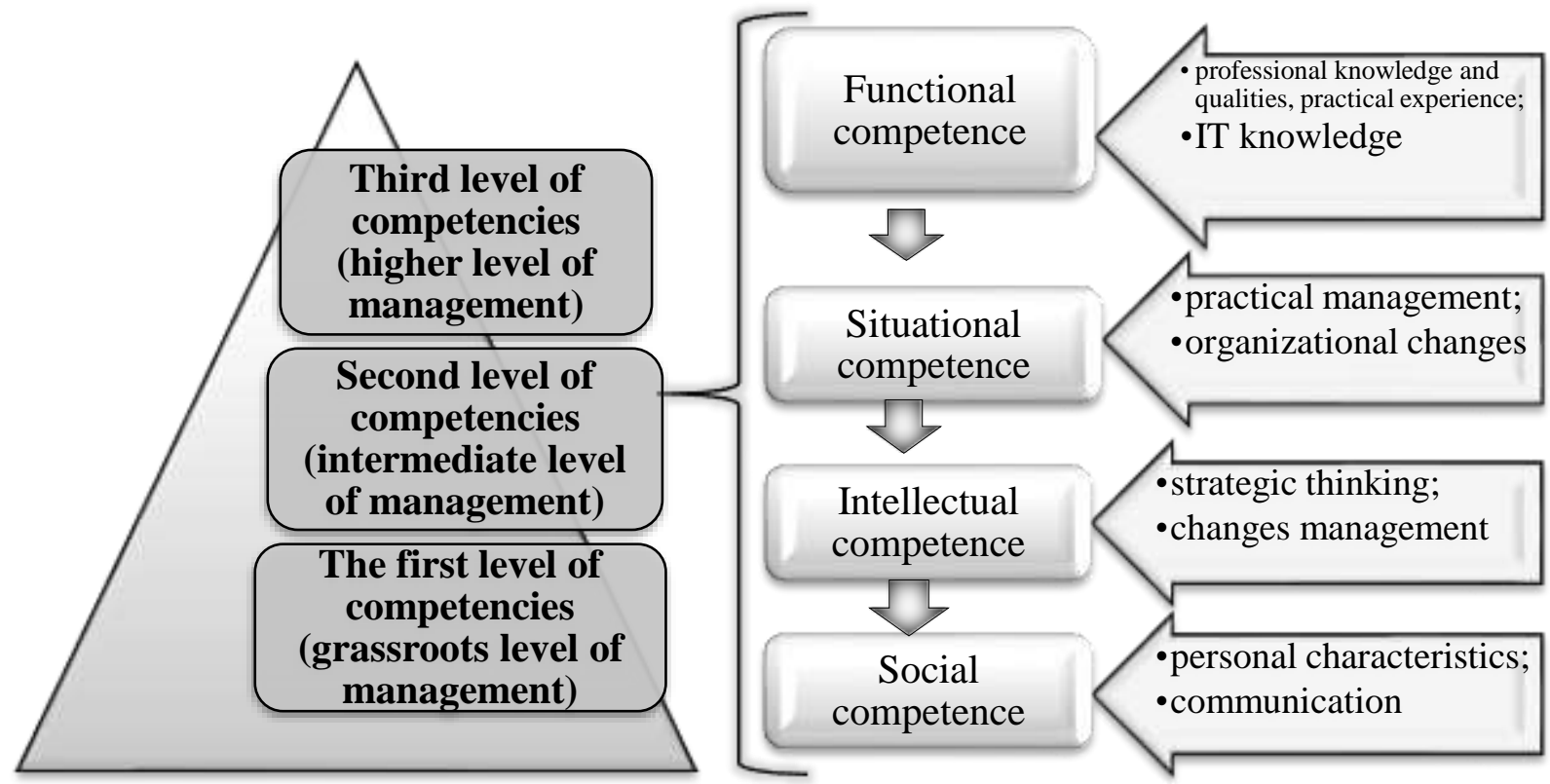

Fig. 3. Three-level model of competencies of the "innovative worker"

Within the model, it is proposed to consider the sum of the following components:

functional, situational, intellectual and social competence. The level of 
development of these groups of competencies is directly proportional to the level of management to which the employee belongs. It should be emphasized that not all competencies will be equally inherent in all categories of "innovative workers" of the enterprise. The proposed list of competencies is typical for the formation of an "innovative employee" who holds (may hold) managerial or administrative positions at the enterprise (manager, head of a specialized unit, specialist), etc. The model allows you to identify a set of knowledge, skills and abilities that an employee lacks for promotion or quality performance of their duties and is a guide for further development and formation of "innovative employee".

Given that the company operates in difficult political and economic conditions, has financial difficulties, and uses a policy of optimizing the number of employees, the system of employee development should be built on the introduction of budget and effective methods of training. Under such conditions, the creation of an electronic corporate library at PJSC "Dnieper Metallurgical Plant" becomes relevant, which will solve the problem of finding timely financial support for current and future needs of the company in updating, mastering new knowledge of employees of any management level.

As a result of the creation of an electronic corporate library, the company will be able to optimize the learning process, improve the skills of management staff through the introduction of modern methods of implementing these processes and achieve a three-tier model of competencies by the most budget method.

\section{List of sources}

1. Berezkina A.Y. Modeling the process of professional development of personnel of domestic enterprises / A. Y. Berezkina, K.M. Nikolaeva // Scientific and practical journal "Regional Economy and Management". $\neg$ Zaporozhye, 2016.-№1.-P.84-88

2. Voronina A.V. Personnel policy of enterprises in terms of European integration / A.V. Voronina, K.M. Nikolaeva // XIII International Conference "Modern interdisciplinary research: history, present, future". - K.: Publishing House "Agrar Media Group », 2016.- C.14-16 


\section{СПІВРОБІТНИЦТВО ГРОМАД ЯК ІНСТРУМЕНТ ІНФРАСТРУКТУРНОГО РОЗВИТКУ ТЕРИТОРІЙ}

\section{Камашев Анатолій Володимирович}

Аспірант

Миколаївський національний аграрний університет

Після фінального етапу процесу децентралізації в Україні - новоутворенні громади мають перелік питань, які складно вирішувати самостійно, а саме: збір, утилізація та переробка сміття, забезпечення якісного централізованого водопостачання та водовідведення, ремонт та прибирання доріг, організація пасажирських перевезень, утримання пожежної охорони тощо, надання якісних соціальних послуг, тощо.

Переформатування та передача майна 3 районів новим адміністративним одиницям викликала стурбованість щодо спроможності підтримання існуючих об'єктів інфраструктури конкретною громадою самостійно, особливо коли до завершального етапу, то й чи інший об'єкт забезпечував послугами населенні пункти, які знаходяться зараз в різних громадах та фінансувалися з районного бюджету.

Одним 3 ефективних інструментів вирішення даного питання $\epsilon$ співробітництво громад, механізм якого передбачений Законом «Про співробітництво територіальних громад», прийнятим ще у 2014 році.

Відповідно до Закону, співробітництво територіальних громад - це відносини між двома або більше територіальними громадами, що здійснюються на договірних засадах у визначених цим Законом формах з метою забезпечення соціально-економічного, культурного розвитку територій, підвищення якості надання послуг населенню на основі спільних інтересів та цілей, ефективного виконання органами місцевого самоврядування визначених законом повноважень. [1]

3 часу прийняття ним скористалися майже півтори тисячі громад. Вони уклали 672 договори про співробітництво. Найбільше громади співпрацюють у сферах надання адміністративних послуг, житлово-комунального господарства, управління побутовими відходами. Основними перевагами співробітництва громад $\epsilon:$ [2]

1) Здатність залучати приватні інвестиції та брати участь у проектах публічно-приватного партнерства;

2) Можливість укладання більш вигідних контрактів 3 приватними юридичними особами;

3) Підвищення освоєння інвестицій та довіра з боку кредиторів, завдяки чому можна швидше отримувати позики та залучати кошти 3 фондів СС та інших зовнішніх джерел;

4) можливість покращувати адміністративні послуги шляхом залучення більш кваліфікованого персоналу та здійснення акумуляції наявних ресурсів; 
5) створення нових робочих місць та залучення інвестицій у порівнянні із фрагментарними діями окремих органів місцевого самоврядування;

6) зменшення виробничих витрати та забезпечення заощадження коштів завдяки обсягам діяльності (збільшення кількості одиниць «продукції» відносно виробничих витрат);

7) зменшення кількість осіб, які отримують послуги 3 економічно обгрунтованою вартістю (завдяки розширенню сфери дії);

8) підвищення рівню довіри серед кредиторів та здатність залучати зовнішнє фінансування як від держави, так і від приватних партнерів (завдяки покращенню співвідношення між витратами та вигодами проектів).

Цей інструмент дає можливість об'єднати управлінські і фінансові, майнові ресурси, щоб втілити ті проекти, які одній громаді не під силу або не рентабельно. Врешті, територіальні громади зможуть досягати максимальних результатів за рахунок ефективно використовувати бюджетних коштів та інших ресурсів.

\section{Список літератури:}

1. Закон України про співробітництво територіальних громад. [Електронний ресурс]. Режим доступу: https://zakon.rada.gov.ua/laws/show/1508 $-18 \#$ Text

2. [Електронний ресурс]. - Режим доступу: https://decentralization.gov.ua 


\title{
ІННОВАЦІЙНИЙ МЕНЕДЖМЕНТ ЯК ОДИН I3 НАПРЯМКІВ РОЗВИТКУ СУЧАСНОГО БІЗНЕСУ
}

\author{
Котлубай Вячеслав Олексійович \\ кандидат економічних наук, доцент, доцент кафедри національної \\ економіки \\ Національний університет «Одеська юридична академія»
}

\begin{abstract}
Редіна Свгенія Валентинівна кандидат економічних наук, доцент, доцент кафедри національної економіки

Національний університет «Одеська юридична академія»
\end{abstract}

Швидкі темпи технологічних змін, великі ризики ведення сучасного бізнесу внаслідок замалого життєвого циклу товарів та постійних змін уподобань споживачів, а також складність спрогнозувати на середню та довгострокову перспективу результатів від впровадження управлінських рішень $\epsilon$ характерними ознаками сучасного етапу розвитку економіки.

Посилення світових глобалізаційних процесів призводить до визнання рівня економічного розвитку як головного фактору щодо визначення місця відповідної країни на світовій арені.

Все це призводить до того, що одним з найважливіших факторів, який може слугувати гарантом економічної стабільності та прогресуючого розвитку країни в цілому та окремих економічних агентів, зокрема, $є$ інновації.

У сучасних умовах жорсткої конкуренції забезпечення інноваційного розвитку вітчизняного бізнесу $\epsilon$ ключовою передумовою його виживання, динамічного зростання та виходу на міжнародні ринки в умовах глобальної конкуренції, про що свідчать світові економічні тенденції.

Сучасні трансформаційні процеси національної економіки України визначають необхідність для бізнесу знаходити діяльність, засновану на принципах максимальної економії. Загальна тенденція до скорочення часу на випуск інноваційного продукту та отримання прибутку в найкоротші терміни $\epsilon$ головним мотиваційним фактором для бізнесу. [1]

Активне запровадження інноваційних підходів до розвитку системи управління бізнесом, незважаючи на значні перешкоди, що стоять перед їх впровадженням, дозволяє оптимізувати всі внутрішні процеси управління та виробництва в організації, узгодити організаційну структуру компанії з ії місією та цілями, щоб максимізувати вигоди. Для цього пропонується використовувати метод форсайт. Цей метод містить елементи активного впливу на майбутнє (шляхом визначення зон досліджень і появи технологій у конкурентів та партнерів, які можуть принести найбільші економічні вигоди або втрати i здійснення ранньої концентрації ресурсів на цих напрямках). Практика застосування цього методу, за кордоном носить більш глобальний рівень, проте запровадження його у вітчизняний бізнес також має право на існування. Це у 
свою чергу призводить до необхідності підготовки вітчизняних фахівців 3 цього напрямку.

Одним із найважливіших інструментів для засвоєння нових ринків збуту та впровадження нового продукту $\epsilon$ інноваційний менеджмент. Комплексне використання нових принципів управління $є$ важливим для підвищення ефективності інновацій. Найважливішими є:

- створення умов, необхідних для пошуку та розвитку інновацій;

- визначення першочергових завдань інноваційної роботи залежно від мети і стратегічних завдань компанії;

- спрощення системи управління 3 метою прискорення процесу "пошук виробництво - збут";

- підвищення ефективності вирішення інноваційних завдань за принципом мінімізації матеріальних та часових витрат на їх виконання.

Аналіз інноваційних систем управління інноваціями повинен бути тісно пов'язаний з типом інноваційної стратегії - 3 одного боку, та структурою, технологією, персоналом та іншими параметрами компанії - 3 іншого. [2]

Дослідження CB Insights показують, що ефективні новатори в п'ять разів частіше мають культуру інновацій, ніж менш успішні інноваційні компанії. Тому необхідно створити передумови для розвитку корпоративної культури, яка має на меті всебічно підтримувати та розвивати інноваційні навички у всіх функціональних підрозділах бізнес-структури, стимулювати інновації, незалежно від кінцевого успіху інноваційних рішень.

Якщо говорити про бізнес $з$ надання послуг, то в умовах ведення діяльності у висококонкурентному середовищі саме ревеню-менеджмент може стати гарантією підвищення конкурентоспроможності та успішності такого бізнесу. Тому ефективним $є$ повсюдне застосування ревеню-менеджменту, тобто технології формування цінової політики на основі прогнозування попиту, спрямованої на забезпечення високої прибутковості бізнесу. Основне завдання даної технології можна сформулювати як досягнення оптимального співвідношення між попитом на послуги і відповідною пропозицією.

Цікавим також є застосування у якості принципу розвитку сучасного бізнесу впровадження використання нової концепції споживання - LOHAS-концепції (Lifestyles of Health and Sustainability - орієнтація на здоровий і стійкий спосіб життя). Основними цілями концепції LOHAS є: збереження та відновлення потенціалу навколишнього середовища, збереження, розвиток та відтворення людини та суспільства в цілому (покращення якості життя, зокрема гарантування здоров'я та природних умов) тощо. [3]

Створити інноваційну структуру та культуру управління, в яких напрямки технологічного розвитку будуть інтегровані в загальні стратегічні плани, а політика зростання безпосередньо пов'язана 3 постійним розвитком перспективних продуктів та проникненням у нові сфери бізнесу. Це повинно базуватися на децентралізації креативного управління та широкому застосуванні принципів малого бізнесу, заснованому на використанні так званих "венчурних капіталів" - вільних ресурсів компанії та їі філій. 
Підводячи підсумок треба зазначити, що для ефективного розвитку сучасного бізнесу в умовах євроінтеграції, єдиним шляхом підвищення рівня своєї конкурентоспроможності є застосування світового досвіду у створенні умов для підтримки та розвитку інноваційного менеджменту. Це в першу чергу стосується залучення додаткових фінансових ресурсів в необхідному обсязі 3 максимальним ефектом за мінімальною вартістю і на потрібний термін.

\section{Список літератури:}

1. Жук О.С. Інноваційна діяльність як стратегічний пріоритет діяльності підприємств. Проблеми та перспективи розвитку інноваційної діяльності в Україні: матеріали XI Міжнародного бізнесфоруму (Київ, 22 березня 2018 р.) / відп. ред. А.А. Мазаракі. Київ. 2018. С. 90-92.

2. Малюта Л.Я. Стратегічне управління інноваційним розвитком підприємства: навчальний посібник. Тернопіль. 2016. 232 с.

3. Бойко М.Г., Романчук Л.Д. Інноваційний вектор діяльності підприємства курортно-рекреаційної сфери. Проблеми та перспективи розвитку інноваційної діяльності в Україні: матеріали XI Міжнародного бізнесфоруму (Київ, 22 березня 2018 р.) / відп. ред. А.А. Мазаракі. Київ. 2018. С. 40-43. 


\section{ОСОБЛИВОСТІ МЕТОДИКИ ВИКЛАДАННЯ СПЕЦДИСЦИПЛННИ «МЕНЕДЖМЕНТ МИСТЕЦТВА»}

\section{Нікітенко Костянтин Вікторович}

Доктор історичних наук, доцент, завідувач кафедри менеджменту мистецтва у Львівській національній академії мистецтв, м. Львів, Україна.

Аналізуючи проблематику менеджменту мистецтва слід брати до уваги та розуміти його визначальні особливості: непростий процес адаптації теорії традиційного, класичного менеджменту до завдань та викликів, які стоять перед митцями або мистецько-культурними інституціями. Важко не погодитися 3 висновком дослідників Ф. Колбера та I. Еврара: «На нашу думку, артменеджмент знаходиться між теоретичною структурою (менеджмент) i соціальним сектором (мистецтво), тому про нього можна говорити як про піддісціпліну, яка значно відрізняється від загального менеджменту» [1, с.8]. Зокрема, фундаментальний конфлікт інспірований вже в самому визначенні ефективності роботи арт-менеджера. Якщо в будь-якій іншій галузі основним показником якості роботи управлінця є отриманий внаслідок його діяльності прибуток, то в мистецтві все не $\epsilon$ настільки однозначним. Адже для багатьох митців питання грошової винагороди взагалі не $є$ суттєвими та визначальним для ïx творчості. Мотивація їх діяльності може полягати в зовсім іншій площині: це і моменти самореалізації, і прагнення слави, іноді навіть поштовхом для творчості можуть стати різноманітні прикордонні стани та застарілі психосоматичні травми.

Конфлікт має також і ще один аспект: далеко не завжди високоякісне мистецтво знаходить свого глядача, i навпаки, масова культура (завдяки цілеспрямованій промоційній діяльності) в сучасному суспільстві, орієнтованому, насамперед, на споживання, досить часто до мистецтва взагалі не має жодного стосунку. Розрекламовані «зірки» з'являються і непомітно «гаснуть» (насамперед це стосується музичної індустрії, в якій, завдяки розвитку сучасних технологій вже взагалі неважливо чи $\epsilon$ у «зірки»-виконавця навіть музичний слух або й чи чує вона взагалі). Подібне «мистецтво широкого вжитку» стає не більше ніж недовготривалою розвагою та способом заробляння грошей. Тож головною проблемою функціонування арт-менеджменту, сучасні дослідники вважають забезпечення єдності між теорією i практикою менеджменту та сучасним мистецтвом.

Зауважимо, що як неможливо достеменно назвати ім'я першого менеджера (адже ще на самому початку історичного розвитку людства управлінці давнини реалізовували надзвичайно сміливі й масштабні креативні, організаційні проекти), так і неможливо визначити точну дату виникнення конфлікту між створенням взірців високого мистецтва та отриманням суто комерційного прибутку від продажу продукту масового. Приміром, давні єгиптяни творили вічні пам'ятки, можна сказати, «створювали майбутнє», навіть якщо у короткостроковій перспективі масштабні культурні проекти не лише не обіцяли 
жодних прибутків, але й змушували всю державу працювати з повною віддачою, на межі економічного виснаження. Втім, давні часи залишили також інші взірці мистецького менеджменту. Так, у Давньому Римі мистецькі цінності були сформульовані гранично чітко: «хліба та видовищ». Відповідно, культурний продукт перетворений на інструмент політичного впливу - упокорення та маніпулювання масами.

XX століття стало періодом революційних змін не лише у галузі науковотехнічних революцій, але й у поглядах на мистецтво. Так, якщо раніше, критеріями мистецтва були якість (краса) роботи і майстерність (талановитість) майстра, лише наприкінці XIX століття до цієї класичної формули додали ще й право на суб'єктивну інтерпретацію уявлення про світ автора роботи, то у сучасному світі, за влучним висловом Енді Уорхола: «кожен має право на 15 хвилин слави». Різноманітні нескладні варіації на теми звичайних побутових предметів (варто згадати, приміром, легендарний «Фонтан» Марселя Дюшана, який у 1917 році фактично проголосив початок принципово нової ери в мистецтві), не лише отримали право бути проголошеними високим мистецтвом, але й принести їх творцям чималий дохід. Відповідно, надзвичайно зросла роль вдалого менеджменту. Можна навіть сказати, що саме завдяки продуманій промоції, створенні красивої «легенди» навколо культурного об'єкта, споживач сприймає культурний продукт.

Можна згадати, як у 1970-ті роки Малькольму Макларену за допомогою вдалого менеджменту вдалося не лише створити життєздатний музичний гурт із людей без жодної фахової освіти або досвіду, але й спричинити справжню панкреволюцію та появу нового музичного стилю. Макларен став спонсором, менеджером і головним ідеологом не лише гурту «Sex Pistols», але й всього нового рок-напряму. Адже всі інші панк-гурти, які у величезній кількості створювали (і створюють) під впливом творчості «Sex Pistols», лише копіюють (з незначними варіаціями) їх стиль, який миттєво став канонічним. Основою іміджу гурту Макларен зробив свідому провокацію, максимальний епатаж, суспільний виклик, що гарантувало широкий резонанс, гостру полеміку, а разом iз тим i безкоштовну, але надзвичайно дієву рекламу. Альбоми 3 записами «Пістолетів» миттєво стали дефіцитом, кожен англієць прагнув почути скандальні пісні. За кількістю продаж сингл «God Save the Queen» зайняв перше місце в Англії: лише за декілька тижнів продано понад 150 тис. платівок. Якщо на перші концерти гурту приходило лише 35-40 глядачів, то вже за декілька місяців бажаючих послухати, а головне - побачити творчість «Пістолетів» були тисячі.

Псевдомузиканти, які не знали навіть основ нотної грамоти, легко отримували контракти на шалені по тих часах суми. Фірма EMI у 1976 році запропонувала гурту контракт на суму 40 тис. фунтів, у наступному році фірма «А\&M» вже 150 тис. фунтів [2, с. 5, 17]. У 2006 році група була включена до американського Залу слави рок-н-ролу. Так новаторський підхід, сміливий пошук нових форм, певна революційність і свідома провокаційність творчості, на тлі аналізу загального суспільно-політичного та економічного контексту, 
вкупі з певною унікальністю й харизматичністю митців стали прикладом вдалого менеджменту.

Критерії мистецтва не визнають жодних штучних рамок. Провокаційний «Фонтан» Дюшана (який був звичайнісіньким собі пісуаром, що купили в крамничці сантехніки) за підсумками рейтингу найвидатніших творів мистецтва XX століття, що був складений у 2004 році «Daily Telegraph», впевнено посів перше місце, випередивши навіть праці Пікассо та Енді Уорхола.

Зауважимо, що, на відміну від країн Заходу, митці в СРСР тривалий час перебували на узбіччі цивілізаційних процесів. Культурне життя перебувало під абсолютним контролем держави. Нові мистецькі форми, що не вписувалися у задушливі рамки офіційної ідеології, практично не мали шансів дійти до свого споживача, перебували під постійною загрозою заборони. Варто згадати хоча б відвідування М. Хрущовим виставки художників-авангардистів студії «Нова реальність» у грудні 1962 року. Роботи художників дуже відрізнялися і по духу, і по суті від залізобетонних канонів соціалістичного реалізму. Прогнозовано, що виставка, яка не була покликана висвітлювати свято робітників і колгоспниць, закінчилася скандалом. Вже наступного дня, виконуючи недвозначну вказівку лідера партії, газета «Правда» надрукувала розгромну статтю, яка стала початком чергового погрому в культурі. Цього разу спрямованого на боротьбу 3 «формалізмом» та «абстракціонізмом» у СРСР. Отже спроби творити справжнє мистецтво, а не лише малювати портрети «вождів» партії, могли принести художникам серйозні проблеми, репресії й навіть звинувачення в «антирадянщині». Будь-який менеджмент у такому контексті легко трансформувався в кримінальне переслідування за статтею «спекуляція».

Лише проголошена «перебудова» наприкінці 1980-х років радикально змінила уявлення про митця, глядача, творчість і менеджмент. Важливою стала комерційна складова мистецьких проектів. Нові часи вимагали докорінного переосмислення сутності мистецтва. Класична формула менеджменту мистецтва, яка була сформульована директором одного з німецьких театрів: «Ми робимо це заради втіхи, а не грошей (але для втіхи ми потребуємо грошей!» [3, с. 41] стала актуальною і для мешканців СРСР. Так, наприкінці 1980-х - початку 1990-х рр. максимально загострилася проблема поєднання творчості та комерції, яку споконвіку намагалися вирішити менеджери мистецтва розвинутих країн.

Часи принципових бунтарів, які працювали виключно заради високої ідеї, демонстративно протиставляючи себе світу комерції, відходили у минуле. Акції були скеровані насамперед на максимальну епатажність, що, в свою чергу, гарантувало широкий розголос, i, відповідно, якнайширшу рекламу. Фактично мистецтво свідомо приносили у жертву комерційному успіху. Зокрема, подібним чином побудував свою кар'єру колишній киянин, а згодом мешканець Москви, художник-акціоніст Олег Кулік.

Саме у зв'язку з тим, що шокувати тогочасне суспільство вже не було настільки легким завданням, акціоністам доводилося обирати максимально провокаційні, навіть інколи непристойно-огидні форми. Саме так народився перформанс - людина-собака Олега Куліка. Сенс акції (вперше відбулася в листопаді 1994 року), на відміну від перформансів часів СРСР (приміром, арт- 
групи «Мухомори»), полягав не у критиці панівної ідеології, боротьбі за права людини або привертанні уваги до якихось суспільно-політичних проблем, а виключно в самому шоу. Зауважимо, що «шоу» було доволі нескладним: абсолютно голий чоловік на центральних вулицях Москви вдавав із себе агресивну собаку. Кулік голосно гавкав, кидався на людей, намагався покусати перехожих, шукав на собі паразитів тощо - демонстрував максимально «собачу» поведінку. Незважаючи на той факт, що «шоу» тривало лише близько тридцяти хвилин, суспільний резонанс був шаленим - народилася нова «зірка» $[4$, с. 269 280].

Риторичним залишається також питання, а чи взнав би світ про існування б, приміром, швейцарської художниці Міло Муар, якби не їі регулярні оголені перформанси. Заради скандальної самореклами художниця в голому вигляді й на громадську транспорті їздила, i музей відвідувала, i 3 туристами фотографувалася тощо. Втім, справжня слава (хоча й доволі специфічного характеру) прийшла до Міло Муар після перформансу, який вона влаштувала у 2014 році в Німеччині на виставці сучасного мистецтва Art Cologne. Оголена художниця спочатку помістила до своєї піхви декілька наповнених фарбою яєць, а потім «знесла» їх на великий аркуш паперу. Яйця розбилися, фарба розтіклася й створила певний візерунок, який художниця гордо назвала «картиною». Зауважимо, що скандальний перформанс мав не лише етично-естетичну, але й релігійну складову - був приурочений до Великодня. Як наслідок - розміщене в інтернеті відео, на якому був відображений весь процес «малювання картини», лише за перші десять днів зібрало понад 2 млн переглядів [5].

Зауважимо, що фактично подібне «мистецтво» знову повертає споживачів культурного продукту до Давнього Риму з його канонічною формулою «хліба та видовищ». У зв'язку з чим, безперечно, не можна не погодитися з висновком В. Алєксєєвського щодо надзвичайно високої відповідальності менеджерів мистецтва: «Арт менеджмент на сучасному етапі можна трактувати як своєрідну культуру керівництва, яка притаманна розвинутій гуманістичній цивілізації, що прагне глобалізувати зусилля людства як ноосферне явище» [6, с.24]. Адже саме менеджери мистецтва значною мірою відповідальні за формування смаків та ідеалів соціуму. Втім, як відверто наголосили у свої̆ праці «Основи менеджменту» відомі дослідники С. Робінс та Д. ДеЧенцо: «Добрі менеджери можуть перетворити солому на золото» [7, с.53].

Саме тому менеджерам мистецтва варто бути надзвичайно обережними, некритично застосовуючи у своїй практиці закони та принципи «класичного» менеджменту. Перетворення «соломи на золото», коли норми моралі свідомо приносять у жертву прибутковості того або іншого проекту, може спричинити деградацію не лише мистецьких норм, але й самого суспільства.

Приміром, російська дослідниця Г. Новікова у навчальному посібнику «Технології арт-менеджменту» раз у раз невтомно наголошує на тому, що одним із завдань професійного арт-менеджера $є$ створення «зірки» (добре, що хоч беручи це слово у лапки) [8]. Зауважимо, що, дійсно, якісна стратегія може зробити «зірку» практично з будь-якого продукту, але якщо з усього спектру складових успіху обирати лише швидкі фінансові дивіденди, то на виході 
матимемо комерційно привабливі, але сумнівні проекти, які буде дуже тяжко назвати «ноосферним явищем».

Саме тому на завершальному етапі мистецького проекту необхідною умовою $\epsilon$ проведення експертизи та аналізу творчих, педагогічних i фінансових результатів. Акцентування виключно на фінансовій складовій звужує використання всього спектру технологій мистецького менеджменту, зводячи все до примітивних маніпуляцій суспільною думкою.

Отже, менеджмент мистецтва має свої особливості, що відрізняють його від класичного менеджменту. Зокрема, діяльність фахівців даної сфери вимагає глибоких знань не лише в галузі економічної науки, але й наявності достатньої бази з історії вітчизняної та закордонної культури, а також і загального високого рівня ерудиції й культури. Естетичне виховання, грунтовні знання та відповідна освіта дозволяють враховувати не лише фінінасові, але й соціальні результати своєї професійної діяльності. Адже в сучасному світі мистецтво вже ніяк не може виступати суто розважальним елементом (рівень «хліба та видовищ» притаманний рабовласницькому суспільству), натомість виховна функція мистецтва виступає потужним чинником, що забезпечує розвиток людства у відповідності з принципами гуманістичної цивілізації.

\section{Список літератури:}

1. Колбер Ф., Эврар И. Арт-менеджмент - наука третьего тысячелетия. Арт-менеджмент. 2002. № 3. С. 3-10.

2. Кокарев А. Панк-рок от А до Я. М.: Музыка, 1992.80 с.

3. Гагоорт Г. Менеджмент мистецтва: підприємницький стиль. Львів: Літопис, 2008. 358 c.

4. Древс-Силла Г. Телесные опыты человека-собаки: «Собака Павлова» Олега Кулика. Русская литература и медицина: Тело, предписания, соииальная практика: Сб. статей / под ред. К. Богданова, Ю. Мурашова, Р. Николози. М.: Новое издательство, 2006. С. 269-280.

5. Ha Art Cologne голая швейцарская художница «отложила» яйца с краской URL: http://www.novate.ru/news/3169/ (дата звернення: 20.04.2021).

6. Алексеевский В.С. Социокультурная концепция общей теории менеджмента. Менеджмент в России и за рубежом. 2004. № 2. С. 21-36.

7. Робінс С., ДеЧенцо Д. Основи менеджменту / Пер. з англ. А. Олійник та ін. К.: Видавництво Соломії Павличко «Основи», 2002. $671 \mathrm{c.}$

8. Новикова Г.Н. Технологии арт-менеджмента: Учебное пособие. М.: Изд. дом МГУКИ, 2006. 178 с. 


\section{PLACENTAL MORPHOMETRIC INDICES IN WOMAN WITH PLACENTAL DYSFUNCTION}

Marynchyna Iryna candidate of medical science Bukovinian State Medical University

Rykhlo Inna

Student

Bukovinian State Medical University

Ratushna Iryna

Student

Bukovinian State Medical University

Placenta dysfunction (PD) is a key problem of obstetrics, neonatology and pathological anatomy, diseases of ante- and perinatal period, since functional failure of this organ leads to threatening miscarriage, fetus growth and development retardation (FGDR) or

its death.

We conducted morphometric study of placentas from 30 lying-in women, who had the background of placental dysfunction (study group) and 25 lying-in women with physiological pregnancy (control group) in gestation period of 36-40 weeks.

Having assessed the form of placentas, we found out that in women with placental dysfunction complications the placentas were round in shape in $7(28 \%)$ cases, whereas in women with physiological pregnancy course this morphological parameter is observed in $19(63,3 \%) .18$ (72\%) placentas in the main group were oval; it's twice higher than the same parameter in control group - $11(36,7 \%)$.

Studying the umbilical attachment variations we researched that in women with placental dysfunction central attachment occurred only in 8 (32\%) lying-in women, and in women with physiological pregnancy course it was noted in $18(60 \%)$. Lateral umbilical cord attachment was observed in $13(52 \%)$ pregnant of the main group, but in physiological pregnancy course only $10(33,3 \%)$ pregnant had this variation of umbilical attachment. The marginal attachment rate is rather high in women with PD in comparison with the control group $-4(16 \%)$ to $2(6,8 \%)$.

The average weight of the placenta in patients with placental dysfunction was $388,58 \pm 12,4$, in the control group $-492,8 \pm 24,4 \%$ ( $p<0.05$ ). Difference between the average weight indices and gestation norm probably may occur due to the fact that the effective implementation of the placenta compensatory-adaptive reactions is possible only at adequate functioning of the utero-placental vessels. The average area of the placenta in the lying-in women of the main group was $241,21 \pm 5,16 \mathrm{~cm}$, in the control 
group $-234,8 \pm 5,2 \mathrm{~cm}$. The tendency of the placentas to become thinner was also observed $-1,77 \pm 0,2 \mathrm{~cm}$ and $1.9 \pm 0,4 \mathrm{~cm}$. Macroscopically the afterbirth flattening and thinning was observed in this pathology.

The analysis of placentas morphometric peculiarities showed that in women with placental dysfunction placentas differ in shape, among which oval is dominant. The eccentric umbilical cord attachment is more frequent; flattening and thinning of the afterbirth occurs, it indicates reduction of weight, size and thickness of the placenta.

\section{References:}

1.A Peguero, L Fernandez-Blanco, E Mazarico, L Benitez, A Gonzalez, L Youssef, F Crispi, S Hernandez, F Figueras, Added prognostic value of longitudinal changes of angiogenic factors in early-onset severe pre-eclampsia: a prospective cohort study, BJOG: An International Journal of Obstetrics \& Gynaecology, 10.1111/14710528.16383, 128, 2, (158-165), (2020).

2.Alys R. Clark, Tet Chuan Lee, Joanna L. James, Computational modeling of the interactions between the maternal and fetal circulations in human pregnancy, WIREs Mechanisms of Disease, 10.1002/wsbm.1502, 13, 1, (2020)

3.J.M. Raunig, Y. Yamauchi, M.A. Ward, A.C. Collier

Placental inflammation and oxidative stress in the mouse model of assisted reproduction

Placenta, Volume 32, Issue 11, 2011, pp. 852-858.

4.Sebastiaan W. Nij Bijvank, Willy Visser, Johannes J. Duvekot, Eric A. Steegers, Mireille A. Edens, Danielle W. Roofthooft, Arnold G. Vulto, Lidwien M. Hanff

Ketanserin versus dihydralazine for the treatment of severe hypertension in earlyonset preeclampsia: a double blind randomized controlled trial

European Journal of Obstetrics \& Gynecology and Reproductive Biology, Volume 189, 2015, pp. 106-111 


\title{
KERDO INDEX AS AN INDICATOR OF THE STATE OF THE VEGETATIVE NERVOUS SYSTEM IN STUDENTS WITH GASTROESOPHAGEAL REFLUX DISEASE AND AUTOIMMUNE THYROIDITIS
}

\author{
Pasiieshvili Tamara \\ $\mathrm{PhD}$, Associate Professor, \\ Kharkiv National Medical University, Ukraine \\ Pasiyeshvili Lyudmila \\ Doctor of Medical Sciences, Professor, \\ Kharkiv National Medical University, Ukraine \\ Zhelezniakova Natalia \\ Doctor of Medical Sciences, Professor, \\ Kharkiv National Medical University, Ukraine \\ Kovalyova Olga \\ Doctor of Medical Sciences, Professor, \\ Kharkiv National Medical University, Ukraine
}

The development and course of a chronic non-infectious disease of internal organs is accompanied by changes in the indices of the autonomic nervous system, leads to an increase in clinical symptoms, the appearance of asthenic or asthenoneurotic syndrome, determines the duration and effectiveness of the remission stage.

Violations of the autonomic nervous system are determined by calculating the Kerdo index, which represents the ratio of diastolic blood pressure and heart rate: Kerdo index $=$ (1-diastolic blood pressure/heart rate) $\mathrm{x} 100$.

Purpose of the study: to establish the nature of changes in the autonomic nervous system in a student environment with gastroesophageal reflux disease and autoimmune thyroiditis.

Materials and methods. Examined 207 patients aged from 18 to 25 years, students of Kharkov universities. Among the examined 120 patients had gastroesophageal reflux disease in combination with autoimmune thyroiditis; 45 - isolated course of gastroesophageal reflux disease and 42 - isolated autoimmune thyroiditis. Patients were representative by sex, age, social status (students) and duration of the disease (from first diagnosed to 3 years).

Results and its discussion. Calculation of the Kerdo index in persons with a combined course of gastroesophageal reflux disease and autoimmune thyroiditis made it possible to establish the prevalence of sympathicotonia in the group $(9.2 \pm 2.3)$. At the same time, erosive damage to the esophageal mucosa in these patients led to the peri-orientation of the autonomic nervous system towards parasympathicotonia: the Kerdo index was $(-2.1 \pm 1.1)$. Thus, sympathicotonia in patients with comorbidity of 
gastroesophageal reflux disease and autoimmune thyroiditis was the result of esophagitis without the presence of erosions (Kerdo index $=11.2 \pm 2.4$ ). The isolated course of gastroesophageal reflux disease was accompanied by sympathicotonia (10.1 \pm 1.8 ), and isolated autoimmune thyroiditis - by vegetative balance (eutonia) - (0.7 \pm 1.3). The development of sympathicotonia or parasympathicotonia is associated with the severity of the onset of the pathological process. Thus, sympathicotonia occurs most often in response to stress, which was observed in patients with concomitant pathology and isolated gastroesophageal reflux disease: diagnostics of diseases was carried out with the need to stay in a hospital during the scientific process, adherence to the rules of behavior and nutrition in the future. At the same time, the clinical symptoms were characterized by tachycardia, increased blood pressure, sweating, sleep disturbances, and emotional lability. Parasympathicotonia was diagnosed with erosive lesions of the esophageal mucosa and the clinical manifestations of the underlying disease were "colored" with bradycardia, hypotension, drowsiness, general weakness, and decreased of working capacity.

The observation of the patients 2-3 months after inpatient treatment, regardless of the prevalence of para- or sympathicotonia, revealed a "vegetative tail" - the presence of vegetative dysfunction in the form of general weakness, decreased performance, impaired concentration, pulse lability and pressure.

Conclusions. The course of chronic non-infectious diseases of internal organs is accompanied by the activation of the autonomic nervous system, which can occur with a predominance of the sympathetic or parasympathetic parts of it. At the same time, dysregulation of the autonomic nervous system leads to the emergence of additional clinical symptoms and "delays" the recovery period of patients through the persistence of asthenic syndrome.

\section{References:}

1. Fisher, T. A., Petrov, S. A., Dotsenko, E. L., \& Suhovei, Y. G. (2018). Dinamika émotsional'nogo sostoianiia i fiziologicheskikh parametrov organizma pri dlitel'nom akvatermal'nom vozderstvii [Dynamics of the emotional state and physiological parameters of the organism during long-term aqua-thermal impact]. Voprosy kurortologii, fizioterapii, $i$ lechebnoi fizicheskoi kultury,95(3), 57-62. https://doi.org/10.17116/kurort201895357

2. Martsenyuk, V. P., Vakulenko, D. V., \& Vakulenko, L. O. (2013). Kerdo informative index to determine the level of violations of autonomic regulation at osteochondrosis of the cervical s pine. Medical Informatics and Engineering, (1), 4247. https://doi.org/10.11603/mie.1996-1960.2013.1.418

3. Kerdo, I. (1966). Ein aus Daten der Blutzirkulation kalkulierter Index zur Beurteilung der vegetativen Tonuslage. Actaneurovegetativa, 29(2), 250-268. 


\title{
OPTIMIZATION OF HERNIOPLASTY METHOD FOR PATIENTS WITH INCARCERATED INGUINAL HERNIA
}

\author{
Slonetskyi B. \\ Doctor of Sci(Med),Professor \\ Department of surgery of dentistry faculty \\ BOGOMOLETS NATIONAL MEDICAL UNIVERSITY \\ Kiev, Ukraine \\ Kotsiubenko V. \\ Surgeon \\ Surgical department №1 \\ Kiev City Emergency Hospital \\ Kiev,Ukraine
}

Yaroshuk D.

$\mathrm{PhD}(\mathrm{Med})$,Assistant of Professor of Department of surgery of dentistry faculty BOGOMOLETS NATIONAL MEDICAL UNIVERSITY

Kiev, Ukraine

Verbytskyi I.

$\mathrm{PhD}$ (Med),Assistant of Professor of Department of emergency Shupyk National Healthcare University of Ukraine

Kiev, Ukraine

Incarcerated inguinal hernia is one of the difficult problem of modern emergency herniosurgery, which is associated with the peculiarities of the incarceration (duration, organ and degree of its destruction), and with the severity and number of comorbid diseases $[1,2]$. To date, there is a discussion about the choice of allohernioplasty for patients of reproductive age, because the analysis of immediate and long-term results often differ $[3,4]$.

The purpose of the study is to analyze the preconditions and consequences of the use of different methods of allohernioplasty for patients of reproductive age with incarcerated inguinal hernia, taking into account the peculiarities of blood flow in the a. testicularis.

Materials and methods of reserch. The results of surgical treatment of 67 patients of reproductive age with incarcerated right inguinal hernia without signs of disorder of the passage through the digestive tract, Nyhus type II and III, were analyzed. The first group (36 patients) were undergo Liechtenstein procedure, and the second group (31 patients) were undergo laparoscopic hernioplasty (TAPP). Sonographic monitoring was performed by the Toshiba Aplio 300 (linear scanner 7, $5 \mathrm{MHz}$ ). The linear velocity of blood flow in the a. testicularis was determined at the level of superficial ring of the inguinal canal. Investigation were provided on postoperative days 21 and 60 . 
Results of the reserch. Comparative analysis of the linear blood flow velocity in the a. testicularis in patients of reproductive age with right-sided incarcerated inguinal hernias identified a significant decrease to $17.2 \pm 1.1 \mathrm{~cm} / \mathrm{s}$ compared to the healthy side $-20.1 \pm 0.9 \mathrm{~cm} / \mathrm{s}$. A monitoring of the linear velocity of blood flow in the a. testicularis in the postoperative period in patients of the first group found that on the postoperative day 21 compared with the preoperative period observed an increase to $18.2 \pm 1.3 \mathrm{~cm} / \mathrm{s}$, and 60 days to $18.6 \pm 1.5 \mathrm{~cm} / \mathrm{s}$. In patients of the second group, as opposed to the first, the restoration of blood flow in the testicular artery was more pronounced and amounted to $21.6 \pm 0.8 \mathrm{~cm} / \mathrm{s}$ on day 21 and $19.2 \pm 1.1 \mathrm{~cm} / \mathrm{s}$ on day 60 .

Conclusion. 1. An incarcerated inguinal hernia is accompanied by a significant ( $\mathrm{p}$ $<0.05$ ) decrease in the linear velocity of blood flow in the testicular artery to $17.2 \pm 1.1$ $\mathrm{cm} / \mathrm{s}$.

2. The use of TAPP hernioplasty for patients of reproductive age of the second group with incarcerated inguinal hernias Nyhus type II and III without signs of disorder of the passage through the digestive tract, in compare to patients of the first group - hernioplasty by Liechtenstein , is accompanied by better recovery of blood flow in a.testicularis in postoperative period.

\section{References:}

1.Huerta S. Inguinal hernia repair in centers of excellence. Hernia. 2019, Jul. 5. (Epub ahead of print.) DOI: 10.1007/s10029-019-01998-6.

2. Fenglin Zhao,Min Liu,Jie Chen,Cuihong Jin,Fuqiang Chen,Jinxin Cao,Yuchen Liu. Clinical effects of prosthetic mesh in the treatment of incarcerated groin hernias.Minerva Chir.2019 Dec;74(6):458-464.DOI:10.23736/S0026-4733.18.078240 .

3.Jing Liu,Yingmo Shen,Yusheng Nie,Xuefei Zhao,Fan Wang,Jie Chen. If laparoscopic technique can be used for treatment of acutely incarcerated/strangulated inguinal hernia?.World J Emerg Surg.2021,

$\mathrm{Feb}$ 6;16(1):5.DOI:10.1186/s13017-021-00348-1.

4.Fuqiang Chen,Min Liu,Cuihong Jin,Fan Wang,Yingmo Shen, Fenglin Zhao,Jie Chen. Tension-free mesh repair for incarcerated groin hernia: a comparative study.Urent Innovation,2020 Aug;27(4):352-357. DOI:10.1177/1553350620901392 


\section{ДИАГНОСТИКА НАРУШЕНИЙ ВЕГЕТАТИВНОГО БАЛАНСА У ШКОЛЬНИКОВ СТАРШИХ КЛАССОВ ПО ДАННЫМ ОПРОСНИКА ВЕЙНА А.М.}

Горбанёва Елена Петровна,

д.м.н., доцент, Волгоградская государственная академия физической культуры

Рябчук Юлия Васильевна,

студент,

Волгоградская государственная академия физической культуры

В статье рассматривается проблема вегетативных нарушений среди школьников старших классов. В исследовании используется метод опроса Вейна А.М. с целью выявления признаков вегетативных изменений, в первую очередь, возникающих на фоне излишнего напряжения нервной и сердечно-сосудистой систем, у учащихся в процессе учебной деятельности.

Актуальность. Сегодня многими авторами отмечается ярко выраженная тенденция к росту патологий сердечно-сосудистой системы среди школьников (Горелов А.А., Румба О.Г., Богоева М.Д., 2011) [1]. Особенно ярко это прослеживается в постпубертатном периоде развития у старшеклассников. Интенсификация образовательного процесса и высокие нагрузки, запускающие реакции стресса, на фоне еще не сформированных до конца функциональных систем организма школьника ведут к возникновению преморбидных состояний [2].

В данном возрасте, по данным Богоевой М.Д., нарушения проявляются, прежде всего, в снижении физической работоспособности, в уменьшении экономичности функционирования сердечно-сосудистой системы и устойчивости организма к гипоксии, в возникновении гипотонических состояний и вегетососудистой неустойчивости, что влечёт за собой развитие вегето-сосудистой дистонии (ВСД) [3].

Данные состояния, возникающие у подростков, являются причиной снижения их уровня физического развития и могут спровоцировать дальнейшее усугубление ситуации, заключающееся в развитии новых и закреплении уже имеющихся патологических состояний.

В этой связи, актуальной является проблема ранней диагностики еще пока предпатологических состояний, которые могут наблюдаться у школьников подросткового возраста.

Цель исследования. Исследование проводилось на базе лицея № 2 города Волгограда. В качестве исследуемых выступали учащиеся 16-17 лет в количестве 41 человек. 
Целью исследования было возможное выявление признаков, характерных для вегето-сосудистой дистонии. В качестве основного метода исследования был применен метод стандартизированного опроса, основанный на субъективной оценке симптоматики. Учащимся был предложен опросник Вейна А.М. для выявления признаков вегетативных изменений, бальная оценка которого направленна на выявление и определение степени нарушений вегетативного статуса [4].

Результаты исследования и их обсуждение. Напряженные социальнопсихологические отношения присущие большинству школьников старших классов в совокупности с предстоящим выбором учебного заведения высшей ступени образования являются, по данным Багнетовой Е.А., мощными стрессогенными факторами, негативным образом влияющие на общее состояние учащихся. Прежде всего, это проявляется в перенапряжении нервной и сердечнососудистой систем.

Все это предъявляет высокие требования к адаптационным возможностям организма подростка и может повлечь за собой дальнейшие нарушения его психических и физиологических функций.

Опросник для выявления признаков вегетативных изменений А.М. Вейна построен таким образом, что на базе полученных ответов можно судить о таких характеристиках вегетативной устойчивости, как лабильность системы терморегуляции, вестибулярного аппарата, признаки тревожности, болевые симптомы. Балльная шкала позволяет оценить степень выраженности данных вегетативных дисфункций.

По результатам данного опроса были выявлены различные состояния вегетативного статуса у учащихся. Значения исследуемых варьировались от 0 до 63 баллов при максимальном значении в 63 балла. По условиям данного опроса, если общее количество баллов равно или более 15 баллов, предполагается наличие синдрома вегетативной дисфункции, что и было выявлено у 61 \% от всех опрошенных (Рис. 1).

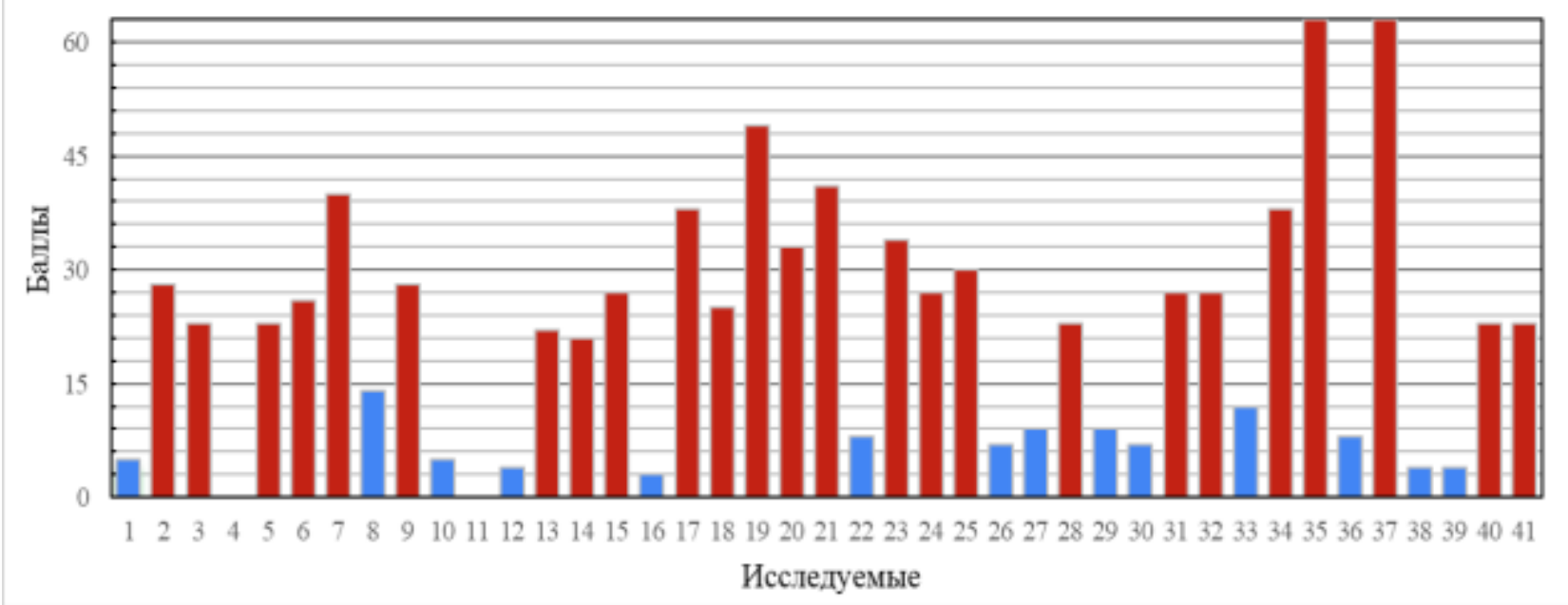

Рисунок 1. Значения баллов учащихся, полученных в результате опроса 
Относительно высокий процент учеников с выявленными признаками ВСД скорее всего связан с выраженными состояниями напряжения, вызванными повышающейся в конце учебного года умственной нагрузкой и нестабильным эмоциональным состоянием присущем данной возрастной группе. Среднее значение по всей группе учащихся составило $22 \pm 2,48$ балла, что выходит за границы обозначенной нормы.

Кругляниным К.Д. были выделены три степени вегетативной дисфункции в зависимости от набранных баллов [5]. Так, к легкой степени дизадаптации автор отнес значения от 16 до 29, к средней - от 30 до 45, тяжелой - от 46 до 65 баллов. В нашей группе исследуемых у троих была выявлена тяжелая степень дизадаптации: 49 баллов и у двоих по 63 балла, что составляет 7 \% от группы. К средней степени дизадаптации были отнесены 7 человек - $17 \%$. Группу, чьи значения соответствовали легкой степени дизадаптации составили 15 учащихся (37\%). Школьники в количестве 16 человек были без признаков ВСД (39\%).

Об отклонениях в состоянии системы терморегуляции можно судить по вопросам, выявляющим склонности к покраснению или побледнению лица, похолоданию, онемению, изменению окраски частично или целиком дистальных конечностей. Для наибольшего количества опрошенных (17 человек) характерны онемение или похолодание пальцев кистей, стоп. Такие значения говорят о перераспределении общего кровотока в пользу других органов относительно конечностей.

Следует также отметить, что для каждого второго исследуемого характерна повышенная потливость. Это напрямую может зависеть от эмоционального статуса исследуемого. В исследовании принимали участие школьники, находящиеся уже в постпубертатном периоде, для которых характерно созревание апокриновых потовых желез, участвующих в психогенном потоотделении. Соответственно, учащимся, бурно реагирующим на различные ситуации, находящимся в депрессивных состояниях или же в момент нервного напряжения, будет свойственно явление гипергидроза.

Нарушения в деятельности проводящей системы сердца у данных школьников были выявлены в восьми случаях. Опрошенные утвердительно ответили на вопрос о наличии у них ощущения «замирания», «остановки сердца». Данный факт не следует игнорировать, необходимо провести дополнительные обследования, позволяющие выявить нарушения проводящей системы сердца, например, применить метод электрокардиографии.

У 15-ти опрошенных часто наблюдаются затруднения при дыхании, а именно: чувство нехватки воздуха, учащенное дыхание. Причем, у половины школьников (7) данные признаки психогенного характера и проявляются только при волнении. У остальных (8 человек) отмеченные особенности возникают на фоне длительного пребывания в душном помещении. Возможно, это связано с введенными ограничительными мерами в школе в связи с COVID-19, поскольку, школьники вынуждены находиться строго в своих классах и не покидать помещения без особой необходимости, и все это при условии постоянного использования средства индивидуальной защиты органов дыхания. 
Вышеперечисленные условия также могли повлиять на возникновение предобморочных состояний, которые у себя отмечают 5 учеников, ранее отметивших у себя гипоксические состояния в душных помещениях.

Нарушения в функции желудочно-кишечного тракта выявлены у минимального количества испытуемых - у четырех человек.

На вопрос «бывают ли у Вас приступообрзные головные боли?» утвердительно ответили 27 человек, что составило $66 \%$. Школьники отмечали у себя пульсирующие, сжимающие, локальные и обширные головные боли. У этих же школьников наблюдается снижение работоспособности, быстрая утомляемость и нарушения сна. Данные показатели также вероятнее всего связаны с большими нагрузками в школе в конце четверти и приближающимися экзаменами.

Выводы. В результате проведенного анализа можно сказать, что проблема вегетативных нарушений является актуальной для обследованной группы. При этом, стоит отметить, что только одна исследуемая в процессе исследования призналась в том, что знает о наличии у нее синдрома ВСД. Большинство же школьников не обладают достаточной информацией о состоянии своего здоровья, что еще раз подчеркивает значимость ранней диагностики и выявления признаков вегетативных нарушений уже в подростковом возрасте.

Дозированная систематическая физическая нагрузка станет мощным фактором коррекции и профилактики выявленных в ходе опроса начальных нарушений, так как физическая нагрузка будет способствовать нормализации баланса вегетативной нервной системы и нормализации локального и общего кровотока [6].

\section{Список литературы:}

1. Горелов, А.А. Коррекция состояния здоровья студентов специальной медицинской группы с нарушениями сердечно-сосудистой системы на занятиях физической культурой / А.А. Горелов, О.Г. Румба, М.Д. Богоева // Научнотеоретический журнал «Ученые записки». - 2011. - № 3 (73). С. 37-41.

2. Багнетова, Е.А. Сравнительный анализ показателей функционального и психологического состояния старшеклассников и студентов в аспекте факторов риска учебной среды / Е.А. Багнетова, И.А. Кавеева // Современные проблемы науки и образования. - 2013. - №2. С. 417-454.

3. Богоева, М.Д. Построение процесса физического воспитания студентов специальной медицинской группы с ограниченными возможностями сердечнососудистой системы: автореф. дис. канд. пед. наук: 13.00.04 / Мария Дмитриевна Богоева. Смоленск: «СГАФКСиТ», 2011. - 25 с.

4. Алипов, Н.Н. Корреляции между показателями вариабельности ритма сердца и балльной оценкой вегетативного статуса по шкале Вейна у студентов РНИМУ / Н.Н. Алипов, И.С. Антонов, В.Н. Алипова, А.И. Белякова-Бодина, Т.Е. Кузнецова, О.В. Сергеева, С.А. Гордеев, Г.В. Ковров, С.И. Посохов // Вестник Российского государственного медицинского университета. - 2013. - № 3. С. 55 58. 
5. Круглянин, К.Д. Разработка комплексного алгоритма прогноза и профилактики метеоклиматической дизадаптации: авторф. дис. Канд. Мед. Наук: 14.03.11 / Константин Дмитриевич Круглянин. Москва, 2020. - 25 с.

6. Данилова, А.М. Физическая культура как метод профилактики вегетососудистой дистонии у студентов специальной медицинской группы / A.M. Данилова, А.Н. Красильников, П.В. Леус // OlymPlus. - 2016. - № 2 (3). С. 22-24. 


\section{РОСЛИННІ ЕФІРНІ ОЛІї - АЛЬТЕРНАТИВНІ КОНСЕРВАНТИ ТА СТАБІЛІЗАТОРИ ЇЖІ (ОГЛЯД ЛІТЕРАТУРИ)}

\section{Міхсєв Андрій Олександрович,}

к.б.н., доцент

Буковинський державний медичний університет м. Чернівці, Україна

Кожен живий організм потребує їжі, щоб жити. Їжа містить багато поживних речовин, таких як вуглеводи, жири, білки, вітаміни або мінерали, які засвоюються організмом для отримання енергії, росту і підтримання життя. На жаль харчові продукти мають досить обмежений термін зберігання і щоб його збільшити застосовуються у великих кількостях стабілізатори та консерванти, які можуть шкідливо впливати на організм людини [1]. Окрім того, продовження термінів зберігання, використання пакування збільшує ризик забруднення харчових продуктів різноманітними патогенами. Проблема забруднення продуктів харчування різноманітними патогенами мікробного походження останніми десятиліттями стала важливим питанням охорони здоров'я, особливо у країнах, що розвиваються [2]. При цьому збудники інфекційних захворювань, що передаються через продукти харчування, спричиняють важкі захворювання, які можуть мати масовий характер і вражати всі вікові категорії населення. Лише в США щороку реєструється до 48 мільйонів випадків харчових отруєнь та до 3000 випадків смерті через такі отруєння [3]. Тому постає питання стосовно підвищення антимікробної стійкості окремих збудників харчових інфекцій як до консервантів, так і антимікробних засобів, i, відповідно, шляхів подолання цієї резистентності з одночасним тривалим збереження продуктів без втрати їх якості [4]. Адже збудники, що потрапляють у запаковані чи консервовані продукти, здатні виживати значно довші терміни, ніж зазвичай, без втрати своєї патогенності [5]. Окрім того, масове використання антибіотиків у тваринництві призводить до контамінації харчових продуктів резистентними бактеріями, що викликаю важко виліковні інфекції та суттєво послаблює дієвість антибіотиків при лікуванні інфекцій у людей [6].

Останніми роками багато споживачів приділяють якості їжі все більше уваги саме через наявність в ній саме консервантів та стабілізаторів штучного походження. При цьому суттєво зросло зацікавлення аналогічними речовинами природнього походження які можуть стати альтернативними звичайним хімічним сполукам [7]. Адже деякі синтетичні консерванти можуть бути шкідливими як для людини, так і довкілля, тому все більше споживачів купують та вживають продукти в органічними компонентами та консервантами, такими як ефірні олії [8, 9]. Це можливо завдяки відомим їх антимікробним, противірусними та протигрибковими властивостям [10, 11]. Різноманітні ефірні олії часто використовуються в різних галузях харчової, парфумерної та 
косметичної промисловості, адже використання синтетичних замінників ефірних олій викликає занепокоєння через повідомлення про їх побічні ефекти.

Метою даного короткого огляду $є$ аналіз доступних літературних джерел стосовно можливості використання рослинних олій, зокрема ефірних, в якості стабілізаторів та консервантів в харчовій промисловості, а також з'ясувати перспективи можливого використання ефірних та рослинних олій для продовження терміну збереження продуктів та безпеки при вживанні в їжу.

Ефірні олії - це концентровані суміші летких сполук, які можна отримати 3 різних частин рослин [12]. Вони є природнім джерелом багатьох біологічно активних сполук, які володіють антиоксидантними, протимікробними та іншими властивостями $[13,14,15,16,17]$.

Використання різноманітних рослинних та ефірних олій в харчуванні, харчовій промисловості та при збереженні продуктів харчування має досить тривалу історію $[18,19,20,21,22]$.

Застосування рослинних олій та ефірних компонентів $є$ важливим аспектом збереження харчових продуктів. Зокрема це може стосуватися досліджень таких ефірних олій, як олія з майорану (Origanum majorana L.), коріандру (Coriandrum sativum L.), парфумерного імбиру (Hedychium spicatum Ham. ex Smith), мирра (Commiphora myrrha (Nees) Engl.) та іланг-ілангу (Cananga odorata Hook.f. \& Thomson) [23]. Ці олії мають приємний запах, володіють антиоксидантною активністю, здатні пригнічувати ріст та розвиток плісені, зокрема A.flavus, a також суттєво зменшують продукцію афлатоксинів. Їх використання для збереження продуктів від псування плісенями вже показало ефективність на 50\% вищу, ніж синтетичні компоненти, такі як саліцилова, галова та аскорбінова кислоти.

Використання ефірних олій у ковбасних та м'ясних виробах здатне перешкоджати появі цвілі на цих продуктах, зокрема - олії отриманої 3 традиційної приправи базиліку (Ocimum basilicum) [24]. Проведені in vitro дослідження показали високу ефективність цієї олії по відношенню до пліснявих грибків Penicillium sp. та Aspergillus sp. Ефірні олії пряно-ароматичних рослин можуть бути ефективними консервантами та створювати в композиції 3 продуктами харчування смакову i ароматичну гармонію, що визначає їх актуальність у м’ясній промисловості $[25,26]$. Окрім пліснявих грибків, ефірні олії з різноманітних рослин (традиційних прянощів), здатні перешкоджати i бактеріальному псуванню м’ясних та ковбасних виробів [27, 28, 29].

Антифунгальні властивості суміші 3 ефірних олій кориці (C. zeylanicum), copго (C. citratus), базиліку (O. gratissimum), лавру (P. racemosa), гвоздичного дерева (S. aromaticum) та імбиру (Z. officinale) також були показані при їх застосуванні в якості природніх консервантів під час приготування твердих сирів [30]. Ці олії продемонстрували високу протигрибкову ефективність відносно різних видів цвілевих грибків, зокрема родів Aspergillus, Penicillium, Fusarium та Scopulariopsis. Серед усіх досліджуваних екстрактів (ефірних олій) найвищу активність проявляла олія 3 гвоздичного дерева, що спостерігалося як в лабораторних умовах (дослідження in vitro), так i безпосередньо у готових продуктах при їх тривалому зберіганні. Автори роблять висновок про 
можливість застосування рослинних олій як альтернативу використанню хімічним консервантам, проте наголошують на потребі вивчення токсичності цих олій та безпеки вживання людиною.

Гвоздична олія та гірчична олія, отримані з гвоздики (Syzygium spp.) і гірчиці (Brassica spp.) проявляють виражені протигрибкові властивості щодо відомих видів цвілі [31, 32, 33]. Лабораторні випробування ефірних олій показали здатність пригнічувати ріст плісені, що може бути використано у харчовій промисловості при тривалому зберіганні і зернобобових [34]. Їх використання може суттєво збільшити терміни зберігання таких фруктів, як полуниця, інгібувати продукцію афлатоксинів, а також має перспективи при медичному використанні завдяки приємному запаху, легкості отримання, широкому спектру біологічної активності і до них не виникає ефекту «звикання» [35].

Традиційний продукт у багатьох країнах світу - кава, як відомо, містить цілу низку біологічного активних речовин: від пуринових алкалоїдів (кофеїн, теобромін і теофілін) до дубильних речовин, олій та вуглеводів. Олія, яку отримують $з$ кавових зерен здатна проявляти біологічну активність стосовно пліснявих грибів, таких як A.flavus, A. niger, P. citrinum, P. chrysogenum та E. amstelodami [36]. Випробування із застосуванням екстрактів, отриманих із сирої кави та кавової гущі показали їх здатність пригнічувати ріст плісені упродовж досить тривалого терміну - 21 день, що робить ці речовини перспективними у плані тривалого зберігання продуктів.

Ефірні олії, які містяться в квітах гібіскуса (чай каркаде) (Hibiscus sabdariffa) і насінні чорного кмину (Nigella sativa) суттево інгібують ріст та розвиток пліснявих грибків роду Aspergillus [37]. Дослідження стосувалися таких розповсюджених забруднювачі харчових продуктів, як A. flavus та A. parasiticus. При цьому різні концентрації олій проявляли ще й метаболічні ефекти на вищевказані плісені і суттєво знижували їх здатність продукувати афлатоксини, зокрема афлатоксин В1. Ефективність олії з гібіскуса була удвічі вищою, ніж у кмину. Досліджувані олії не проявляли токсичності при випробуванні на лабораторних тваринах $\mathrm{i}$ можуть бути використані в якості природніх консервантів та стабілізаторів у харчовій.

Виражені протигрибкові властивості також показали суміші ефірних олій 3 відомих - аніс (Pimpinella anisum), гвоздика (Syzygium aromaticum), чебрець (Thymus vulgaris) та маловідомих рослин - пеумус (Pёuтus boldus), полео (Lippia turbinata) [38]. Дослідження відносно таких важливих забруднювачів харчових продуктів, як плісняві грибки роду Aspergillus - A. flavus і A. parasiticus виявило здатність суттєво інгібіювати їх розвиток на арахісі, а також знижувати продування ними афлатоксинів. Автори пропонують використовувати суміші олій із вказаних рослин як природніх консервантів арахісу при тривалому зберіганні та транспортуванні, а також не виключають можливості їх використання у медицині при лікуванні грибкових інфекцій.

Одним із важливих аспектів збереження продуктів $є$ застосування ефірних олій в якості консервантів при виготовленні хлібобулочних виробів, які $\epsilon$ важливою складовою здорового харчування, проте характеризуються 
обмеженим терміном зберігання, а їх мікробне псування не тільки впливає на якісні характеристики, але й також загрожує здоров'ю споживачів $[39,40]$.

Таким чином, підсумовуючи короткий огляд літератури, варто зауважити позитивні моменти використання рослинних ефірних олій в якості консервантів та стабілізаторів харчових продуктів. Їх застосування має багатолітню історію, суттєво покращує харчо-смакові властивості самої їжі, практично не впливає на якість продуктів. Проте, на відміну від хімічних та синтетичних консервантів і стабілізаторів, рослинні ефірні олії практично не $є$ шкідливим для людини, а їх відомі лікувальні властивості переконливо свідчать про високий потенціал при використанні 3 метою збереження та запобігання псування різноманітних харчових продуктів (хліба, овочів та фруктів, м'ясних, ковбасних виробів тощо). Тому, на нашу думку, рослинні та ефірні олії можуть бути перспективними в плані пошуків натуральних консервантів та стабілізаторів харчових продуктів, що не становлять загрози здоров'ю людини.

\section{Література.}

1. Sharma, S. (2015). Food preservatives and their harmful effects. International journal of scientific and research publications, 5(4), 1-2.

2. Bajpai, V. K., \& Baek, K. H. (2016). Biological efficacy and application of essential oils in Foods-A Review. Journal of Essential Oil Bearing Plants, 19(1), 1-19.

3. Silva, F., \& Domingues, F. C. (2017). Antimicrobial activity of coriander oil and its effectiveness as food preservative. Critical reviews in food science and nutrition, 57(1), 35-47.

4. Vergis, J., Gokulakrishnan, P., Agarwal, R. K., \& Kumar, A. (2015). Essential oils as natural food antimicrobial agents: a review. Critical reviews in food science and nutrition, 55(10), 1320-1323.

5. Bondi, M., Lauková, A., de Niederhausern, S., Messi, P., \& Papadopoulou, C. (2017). Natural preservatives to improve food quality and safety. Journal of Food Quality, 2017.

6. Andremont, A. What to do about resistant bacteria in the food-chain? Bull World Health Organ 2015; 93: 217-218.

7. Calo, J. R., Crandall, P. G., O'Bryan, C. A., \& Ricke, S. C. (2015). Essential oils as antimicrobials in food systems - A review. Food Control, 54, 111-119.

8. Prakash, B., Kedia, A., Mishra, P. K., \& Dubey, N. K. (2015). Plant essential oils as food preservatives to control moulds, mycotoxin contamination and oxidative deterioration of agri-food commodities - Potentials and challenges. Food Control, 47, 381-391.

9. Prakash, B., \& Kiran, S. (2016). Essential oils: a traditionally realized natural resource for food preservation. Current Science, 110(10), 1890-1892.

10. Khorshidian, N., Yousefi, M., Khanniri, E., \& Mortazavian, A. M. (2018). Potential application of essential oils as antimicrobial preservatives in cheese. Innovative Food Science \& Emerging Technologies, 45, 62-72.

11. Delesa, D. A. (2018). Traditional medicinal plants for industrial application as natural food preservatives. Int. J. Adv. Res. Biol. Sci, 5(4), 85-94.

12. Baser, K. H. C., \& Buchbauer, G. (2015). Handbook of essential oils: science, technology, and applications. CRC press. 
13. Chouhan, S., Sharma, K., \& Guleria, S. (2017). Antimicrobial activity of some essential oils - present status and future perspectives. Medicines, 4(3), 58.

14. Sharifi-Rad, J., Sureda, A., Tenore, G. C., Daglia, M., Sharifi-Rad, M., Valussi, M., ... \& Sharifi-Rad, R. (2017). Biological activities of essential oils: From plant chemoecology to traditional healing systems. Molecules, 22(1), 70.;

15. Swamy, M. K., Akhtar, M. S., \& Sinniah, U. R. (2016). Antimicrobial properties of plant essential oils against human pathogens and their mode of action: an updated review. Evidence-Based Complementary and Alternative Medicine, 2016.

16. Pandey, A. K., Kumar, P., Singh, P., Tripathi, N. N., \& Bajpai, V. K. (2017). Essential oils: sources of antimicrobials and food preservatives. Frontiers in microbiology, 7, 2161.

17. Perricone, M., Arace, E., Corbo, M. R., Sinigaglia, M., \& Bevilacqua, A. (2015). Bioactivity of essential oils: a review on their interaction with food components. Frontiers in microbiology, 6, 76.

18. Preedy, V. R. (Ed.). (2015). Essential oils in food preservation, flavor and safety. Academic Press.

19. Pavela, R., \& Benelli, G. (2016). Essential oils as ecofriendly biopesticides? Challenges and constraints. Trends in plant science, 21(12), 1000-1007.

20. Falleh, H., Jemaa, M. B., Saada, M., \& Ksouri, R. (2020). Essential oils: A promising eco-friendly food preservative. Food Chemistry, 127268.

21. Bhavaniramya, S., Vishnupriya, S., Al-Aboody, M. S., Vijayakumar, R., \& Baskaran, D. (2019). Role of essential oils in food safety: Antimicrobial and antioxidant applications. Grain \& oil science and technology, 2(2), 49-55.

22. Mishra, R. (2019). Essential Oils: An Emerging Trend in Food Preservation. EC Nutrition, 14, 07-10.

23. Prakash, B., Singh, P., Kedia, A., \& Dubey, N.K. (2012). Assessment of some essential oils as food preservatives based on antifungal, antiaflatoxin, antioxidant activities and in vivo efficacy in food system. Food Res Int., 49(1), 201-208.

24. Saggiorato, A.G., Gaio, I., Treichel, H., de Oliveira, D., Cichoski, A.J., \& Cansian, R.L. (2012). Antifungal activity of Basil essential oil (Ocimum basilicum L.): evaluation in vitro and on an Italian-type sausage surface. Food Bioprocess Technol., 5(1), 378-384.

25. Назарчук, Т. Д., \& Юхно, В. М. (2018). Застосування гірчичного комплексу у технології сардельок з метою подовження терміну їх зберігання. Актуальні питання технології продукції тваринництва, 245.

26. Sharma, H., Mendiratta, S. K., Agarwal, R. K., \& Gurunathan, K. (2020). Biopreservative effect of blends of essential oils: natural anti-oxidant and anti-microbial agents for the shelf life enhancement of emulsion based chicken sausages. Journal of Food Science and Technology, 1-11.

27. Khorsandi, A., Ziaee, E., Shad, E., Razmjooei, M., Eskandari, M. H., \& Aminlari, M. (2018). Antibacterial effect of essential oils against spoilage bacteria from vacuum-packed cooked cured sausages. Journal of food protection, 81(8), 13861393.

28. Badia, V., de Oliveira, M. S. R., Polmann, G., Milkievicz, T., Galvão, A. C., $\&$ da Silva Robazza, W. (2020). Effect of the addition of antimicrobial oregano 
(Origanum vulgare) and rosemary (Rosmarinus officinalis) essential oils on lactic acid bacteria growth in refrigerated vacuum-packed Tuscan sausage. Brazilian Journal of Microbiology, 51(1), 289-301.

29. Pateiro, M., Munekata, P. E., Sant'Ana, A. S., Domínguez, R., RodríguezLázaro, D., \& Lorenzo, J. M. (2021). Application of essential oils as antimicrobial agents against spoilage and pathogenic microorganisms in meat products. International Journal of Food Microbiology, 337, 108966.

30. Sessou, P., Farougou, S., Ahounou, S., Hounnankpo, Y., Azokpota, P., Youssao, I., \& Sohounhlou, D. (2013). Comparative study of antifungal activities of six selected essential oils against fungal isolates from cheese wagashi in Benin. Pak $\mathbf{J}$ Biol Sci., 16(23), 1751-1757.

31. Chen, C., Cai, N., Chen, J., \& Wan, C. (2019). Clove essential oil as an alternative approach to control postharvest blue mold caused by Penicillium italicum in citrus fruit. Biomolecules, 9(5), 197.

32. Debonne, E., Van Bockstaele, F., Samapundo, S., Eeckhout, M., \& Devlieghere, F. (2018). The use of essential oils as natural antifungal preservatives in bread products. Journal of essential oil research, 30(5), 309-318.

33. Arasu, M. V., Viayaraghavan, P., Ilavenil, S., Al-Dhabi, N. A., \& Choi, K. C. (2019). Essential oil of four medicinal plants and protective properties in plum fruits against the spoilage bacteria and fungi. Industrial Crops and Products, 133, 54-62.

34. Belasli, A., Ben Miri, Y., Aboudaou, M., Aït Ouahioune, L., Montañes, L., Ariño, A., \& Djenane, D. (2020). Antifungal, antitoxigenic, and antioxidant activities of the essential oil from laurel (Laurus nobilis L.): Potential use as wheat preservative. Food Science \& Nutrition, 8(9), 4717-4729.

35. Saxena, A., Sharma, L., \& Maity, T. (2020). Enrichment of edible coatings and films with plant extracts or essential oils for the preservation of fruits and vegetables. In Biopolymer-Based Formulations (pp. 859-880). Elsevier.

36. Nonthakaew, A., Matan, N., Aewsiri, T., \& Matan, N. (2015). Antifungal activity of crude extracts of coffee and spent coffee ground on Areca palm leaf sheath (Areca catechu) based food packaging. Packag Technol Sci., 28(7), 633-645.

37. El-Nagerabi, S.A.F., Al-Bahry, S.N., Elshafie, A.E., \& AlHilali, S. (2012). Effect of Hibiscus sabdariffa extract and Nigella sativa oil on the growth and aflatoxin B1 production of Aspergillus flavus and Aspergillus parasiticus strains. Food Control, 25(1), 59-63.

38. Passone, M.A., Girardi, N.S., Ferrand, C.A., \& Etcheverry, M. (2012). In vitro evaluation of five essential oils as botanical fungitoxicants for the protection of stored peanuts from Aspergillus flavus and A. parasiticus contamination. Int Biodeter Biodegr., 70, 82-88.

39. Gavahian, M., Chu, Y. H., Lorenzo, J. M., Mousavi Khaneghah, A., \& Barba, F. J. (2020). Essential oils as natural preservatives for bakery products: Understanding the mechanisms of action, recent findings, and applications. Critical reviews in food science and nutrition, 60(2), 310-321.

40. Debonne, E., Van Bockstaele, F., Samapundo, S., Eeckhout, M., \& Devlieghere, F. (2018). The use of essential oils as natural antifungal preservatives in bread products. Journal of essential oil research, 30(5), 309-318. 


\title{
ДІАГНОСТИКА І ЛІКУВАННЯ ТРАВМ АРТЕРІЙ ДІТЕЙ ТА ДОРОСЛИХ
}

\author{
Петров Віталій,
}

Асистент кафедри хірургії та трансплантології Львівський національний медичний університет імені Данила Галицького

\section{Яремкевич Роксоляна}

К.мед.н., асистент кафедри хірургії та трансплантології Львівський національний медичний університет імені Данила Галицького

Травми артерій (ТА) зустрічаються нечасто, вони супроводжують не більше 0,6\%-4,1\% цивільних травм дітей і дорослих. В той же час, це захворювання наражає хворих на високий ризик інвалідизації i життєвозагрожуючих ускладнень (1-3). Тому методи точної діагностики та ефективного лікування ТА вимагають якнайширшого дослідження, а позитивні результати - врахування у практиці.

Вітчизняні та закордонні фахівці постійно приділяють увагу особливостям надання допомоги хворим із ТА різного виду, локалізації і об'єму травми, враховують часовий фактор, супутню патологію, звертають увагу на переваги i обмеження сучаних методів діагностики і лікування, тим самим покращуючи результати і вихід потерпілих (2-7). Незважаючи на суттєві досягення в цій царині, дані літератури про відмінності допомоги хворим різного віку відносно обмежені.

В дані роботі проведено аналіз результатів обстеження та лікування 222 потерпілих з ТА, віком від 9 д. до 84 р., медіана 32,0 р., квартилі віку (21 р.; 71р.). Пацієнти знаходились на лікуванні у відділенні судинної хірургії Львівської обласної клінічної лікарні. Критерієм виключення були травми грудної аорти і наслідки ін'єкційного зловживання наркотичними середниками.

У потерпілих були ТА ніг (n=99, 44,6\%), рук (n=78, 35,1\%), шиї $(\mathrm{n}=16,7,2 \%)$, обличчя $(\mathrm{n}=12,5,4 \%)$, живота $(\mathrm{n}=10,4,5 \%)$ і грудної клітки $(\mathrm{n}=8,3,6 \%)$. Обставини виникнення ТА: побутові травми $(\mathrm{n}=101,45,5 \%)$, міжособистісні конфлікти $(\mathrm{n}=45,20,2 \%)$, ятрогенні ушкодження $(\mathrm{n}=35,15,8 \%)$, нещасні випадки на виробництві $(\mathrm{n}=7,3,1 \%)$, дорожньо-транспортні пригоди $(\mathrm{n}=9,4,1 \%)$, інші (вкл. спортивні травми, самоушкодження, казуїстичні випадки $-\mathrm{n}=25,11,3 \%$ ). ТА настали внаслідок гострих травм у $\mathrm{n}=154(69,4 \%)$ i тупих травм у $\mathrm{n}=53$ $(23,9 \%)$ хворих, в $\mathrm{n}=15(6,7 \%)$ механізм травми встановити не вдалось. Потерпілих чоловічої статі $\mathrm{n}=185$ (83,3\%).

Фізикальні методи обстеження застосовано у $\mathrm{n}=222$ (100\%), ультразвукова діагностика (УЗД) - n=111 (50\%), катетризаційна ангіографія (КА) - n=14 (6,3\%), некатетеризаційна ангіографія (НКА) - n=9 (4,05\%). У трьох (1,35\%) випадках примінено пульсоксиметрію. Пацієнти отримали три види лікування - хірургічне у $\mathrm{n}=202$ (91\%), консервативне у $\mathrm{n}=17(7,65 \%)$ і ендоваскулярне у трьох $(1,35 \%)$ випадках. По складності втручання на судинах, хірургічні операції були 
простими (лігування, шовна пластика) у $n=96$ (47,5\%) і складними (анастомоз кінець-в-кінець, протезування) у n=99 (49\%) хворих.

У хворих, яким виконували оперативні втручання, діагноз травми i вид ушкоджень судин верифікували під час інтраопераційного огляду артерій (n=202, 91\%). В решті випадків вид ушкоджень встановили на підставі візуалізаційних методів обстеження (УЗД, КА і НКА). Виявлено три види ТА - 3 частковими надривами чи надрізами $(\mathrm{n}=116,52,3 \%), 3$ повним розривом чи перерізом $(\mathrm{n}=58,26,1 \%)$, без надривів чи надрізів $(\mathrm{n}=24,10,8 \%), \mathrm{y} n=24(10,8 \%)$ вид посттравматичних змін не встановлено.

Віковий поділ потерпілих провели згідно класифікації віку за V. Quinn (1994), a саме: I (немовлята, $\leq 2$ р., $n=9,4,05 \%$ ), II (раннє дитинство, 3-6 p., n=2, 0,9\%), III (дитинство, 7-12 p., n=9, 4,05\%), IV (підлітковий вік, 13-18 p., n=25, 11,3\%), V (молодий вік, 19-40 p., n=108, 48,6\%), VI (зрілий вік, 41-65 p., n=55, 24,8\%), VII (похилий вік, $\geq 66$ p., n=14, 6,3\%).

Діагноз ТА встановлювали на підставі лише фізикального огляду потерпілого, або за даними фізикального огляду в поєднанні з результатами інструментальних обстежень. Фізикальне обстеження застосовано всім хворим, при цьому у 40,1 $\pm 3,3 \%$ цього методу було достатньо для встановлення діагнозу TA і обрання способу лікування. Згідно даних юніваріантного аналізу, один метод обстеження - фізикальна діагностика без застосування інструментальних методів - менш часто примінялась підліткам $\left(16 \pm 7,3 \%, \chi^{2}=6,8, p<0,01\right)$ і частіше дорослій молоді $\left(49,1 \pm 4,8 \%, \chi^{2}=7,1, \mathrm{p}<0,01\right)$. Результати юніваріантного аналізу про вплив віку на вибір методів обстеження не підтверджено даними мультиваріантного аналізу (модель GLM).

Абсолютні і відносні симптоми ТА спостерігались 3 однаковою частотою у дітей та дорослих $\left(\chi^{2}=6,5, \mathrm{p}=0,48\right)$, абсолютні симптоми виявлено у 75,2 $2,39 \%$,

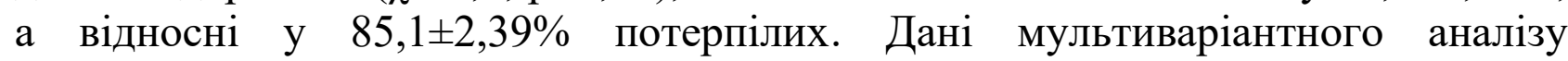
підтвердили, що вік не впливав на вид виниклих симптомів ТА. У потерпілих різного віку ТА практично завжди проявлялись одночасним поєднанням кількох симптомів $(91,4 \pm 1,9 \%)$, одним із яких був щонайменше один абсолютний симптом (62,6 $\pm 3,3 \%)$, або два і більше відносних симптомів ТА без абсолютного симптома $(22,1 \pm 2,8 \%)$. Невелика частка потерпілих із ТА мали ізольовано один симптом TA $(8,6 \pm 1,9 \%)$. Модель GLM показала, що вік хворого не впливав на вид симптомів потерпілого, тоді як вид симптомів ТА залежав від механізма i топографії травми.

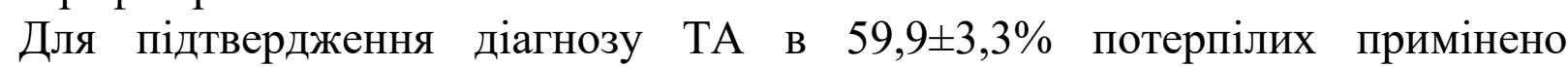

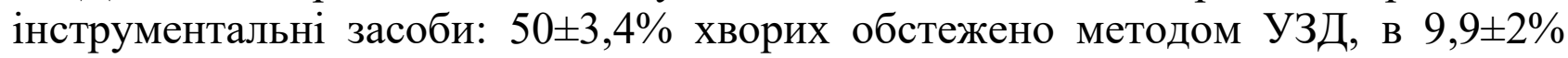
проведено КТ або МРТ. Для підлітків і дорослих спостерігається збільшення застосування УЗД від 25,1士4\% протягом попередніх десятиліть (1992-2000, 20012010 р.p.) до $68 \pm 4 \%$ протягом останнього десятиліття (2011-2019 р.p.) (Z=5,4, $\mathrm{p}<0,05)$. На противагу цьому, при підозрі на ТА в дітей молодшого віку, лікарі звертались до УЗД однаково часто $(68,2 \pm 9,9 \%)$ як протягом попередніх, так і протягом останнього десятиліття госпіталізації $(Z=0,7, p=0,5)$.

КА і НКА застосовано однаково часто серед дітей та дорослих $\left(\chi^{2}=1,6, p=0,2\right)$. В дитячому віці КА із виключно діагностичною метою не примінялась 
пацієнтам, молодшим семи років. Протягом попередніх десятиліть (1992-2000, 2001-2010 р.р.) лікарі звертались до КА з діагностичною метою, тоді як протягом останнього десятиліття (2011-2019 р.р.) КА приміняють не для діагностики ТА, а 3 діагностично-лікувальною метою $\left(\chi^{2}=7, \mathrm{p}<0,01\right)$.

Для лікування потерпілих різного віку застосовано хірургічне лікування у $90,99 \pm 1,92 \%$, значно менша частка пацієнтів лікована консервативно $(7,66 \pm 1,78 \%)$ та ендоваскулярними методиками $(1,35 \%, 95 \%$ ДІ 0,26-3,29\%). Вікова категорія, до якої належав потерпілий, впливала на рішення лікарів, який спосіб лікування доцільно обрати. Цей висновок отриманий юніваріантним аналізом $\left(\chi^{2}=112, \mathrm{p}<0,01\right)$ і підтверджений мультиваріантним (модель GLM) аналізом. Відмінності у лікуванні стосувались дітей I і II груп, яких найчастіше

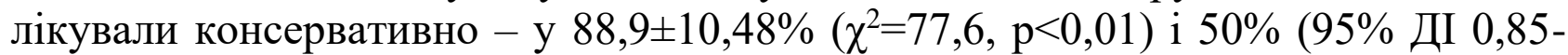
$99,15 \%)\left(\chi^{2}=4,7, \mathrm{p}<0,01\right)$ відповідно. Крім того, у V групі було небагато хворих, яких лікували консервативно $(0,9 \%, 95 \%$ ДІ 0-3,59\%). Водночас, консервативне лікування застосували якщо травмуючий чинник призводив до ТА з частковим порушенням цілісності $(10,3 \pm 2,8 \%$ проти $7,66 \pm 1,78 \%$ середнього показника, $\left.\chi^{2}=0,4, p=0,4\right)$, і втричі частіше якщо ставались ТА без порушення цілісності судин $\left(20,8 \pm 8,3 \%\right.$ проти $7,66 \pm 1,78 \%$ середнього показника, $\left.\chi^{2}=6,6, p<0,05\right)$.

Частки простих і складних операцій між потерпілими різних груп не відрізнялись $\left(\chi^{2}=27,5, \mathrm{p}=0,07\right)$. Прості операції виконано у $48,45 \pm 3,59 \%$, а складні операції у $51,55 \pm 3,59 \%$ оперованих пацієнтів. Ці дані свідчать про можливість їх застосування хворим різного віку, базуючись на спільних принципах хірургії ушкоджених судин (розмір артерій, наявність колатерального кровопостачання цільового органу, ступінь та протяжність пошкодження артерій). Проте методики виконання судинних анастомозів хворим різного віку відрізнялись, а саме: дітям, які молодші підліткового віку, виконували анастомози артерій лише методикою одиночних швів, тоді як підліткам і дорослим примінили методику безперервного шва.

Для протезування артерій застосували венозні протези у 92,3 $\pm 3,2 \%$ i синтетичні у $7,35 \pm 3,2 \%$ оперованих цією методикою дітей і дорослих $\left(\chi^{2}=0,14\right.$, $\mathrm{p}=0,7)$. Протезом вибору слугувала $\mathrm{v}$. saphena magna для хворих різних вікових груп, iї імплантовано у $72,1 \pm 5,44 \%$ дітей і дорослих $\left(\chi^{2}=1,4, p=0,24\right)$. На синтетичні протези припало $8,2 \pm 3,5 \%$ всіх протезів, при цьому їх не застосовували дітям до підліткового віку, а середній вік дорослих потерпілих, яким імплантовано синтетичні і венозні протези не відрізнявся $(\mathrm{Z}=0,85, \mathrm{p}=0,4)$.

Таким чином, діагностичний пошук ТА подібний для дітей та дорослих різного віку, тоді як лікувальні засади відрізняються, в першу чергу, за рахунок потерпілих перших років життя.

\section{Список літератури}

1. Kirkilas, M., Notrica, D. M., Langlais, C. S., Muen-, J. T., Zoldos, J., \& Graziano, K. (2016). Outcomes of arterial vascular extremity trauma in pediatric patients. Journal of Pediatric Surgery, 51(11), 1885-1890. https://doi.org/10.1016/j.jpedsurg.2016.07.001

2. Xu, Y., Xu, W., Wang, A., Meng, H., Wang, Y., Liu, S., Li, R., Lu, S., \& Peng, J. (2019). Diagnosis and treatment of traumatic vascular injury of limbs in military and 
emergency medicine: a systematic review. Medicine (Baltimore), 98(18), e15406. https://doi.org/10.1097/MD.0000000000015406

3. Feliciano, David V. (2017). Pitfalls in the management of peripheral vascular injuries. Trauma Surgery and Acute Care Open, 2(1), 1-8. https://doi.org/10.1136/tsaco-2017-000110

4. Boyko, V., \& Zamyatin, P. (Eds.). (2009). Politravma. Rukovodstvo dlya vrachey v 4-h tomah [Polytrauma. A Guide for Physicians in 4 Volumes]. [in Russian] Harkov-Chernovtsyi.

5. Mousa, A., Zakaria, O., Hanbal, I., Sultan, T., El-Gibaly, A., Zakaria, M., Nasr, M., Bosat, B., Sharabi, A., Neinaa, M., El-Hamid, M., Daoud, M., Amin, M., Odeh, A., Alhaieg, O., Farhan, M., Bubshait, M., \& Al-Mulhim, A. (2018). Operative management of non-iatrogenic pediatric and adolescence peripheral arterial trauma: an experience from a resource challenged setting. Asian Journal of Surgery, 42(7), 761767. https://doi.org/10.1016/j.asjsur.2018.09.012

6. Perkins, Z. B., De'Ath, H. D., Aylwin, C., Brohi, K., Walsh, M., \& Tai, N. R. M. (2012). Epidemiology and outcome of vascular trauma at a British major trauma centre. European Journal of Vascular and Endovascular Surgery, 44(2), 203-209. https://doi.org/10.1016/j.ejvs.2012.05.013

7. Li, Z., Zhao, L., Wang, K., Wang, J., Zhao, Y., Ren, W., Cheng, J., Zhao, Y., \& Ren, W. (2014). Characteristics and treatment of vascular injuries: a review of 387 cases at a Chinese center. Int J Clin Exp Med, 7(12), 4710-4719 


\title{
ФОРМУВАННЯ ВНУТРІШНІХ ТА ЗОВНІШНІХ «Я- КОНЦЕПЦІЙНИХ» ОРІЕНТИРІВ ОСОБИСТОСТІ УЧАСНИКІВ АТО/ООС
}

\author{
Сальнікова Тетяна Вікторівна, \\ аспірант кафедри психології діяльності \\ в особливих умовах \\ Харківський Національний Університет \\ цивільного захисту України
}

В даний час українська державність відчуває цілу низку досить негативних зовнішніх та внутрішніх політико-економічних впливів, які позначаються на психологічному стані мешканців нашої країні. Серед таких чинників провідне місце займають часті надзвичайні ситуації і подій, серед яких першочергово за своїм стресогенним впливом виділяють так звані соціальні катастрофи, особливо, військові конфлікти та активні бойові дії [1]. Одним із прикладів надзвичайної ситуації такого характеру, яка має визначну інтенсивність та стресогенні активність $\epsilon$ військові дії на сході нашої держави, через що майже все населення в тій чи іншій мірі зазнає досить значного стресогенного впливу (тимчасово окуповане населення, тимчасово переміщені особи, військові тощо). В переліку цих категорій кількісно досить значним прошарком $€$ військовослужбовці та ветерани АТО.

3 огляду на вищевказане, на сьогоднішній момент соціально-політичного розвитку нашої держави слід визначити, що у вітчизняному суспільстві виокремилися досить дієва та значна соціальна група населення - діючі ветерани проведення бойових дій в умовах локальних конфліктів. Слід вказати, що в повному обсязі правовий та соціальний статус даної когорти населення ще й на сьогодні невизначений, через що дані особи неспроможні в повній мірі отримати вкрай необхідну для них соціально-психологічну медико-реабілітаційну допомогу, яка була б спрямована на повноцінне та по всебічне інтегрування даних осіб в активне та взаємодієте існування в умовах мирного середовища. Проведення даних заходів для цієї когорти осіб зумовлюється й специфікою професійної діяльності військовослужбовців (особливо при перебуванні в зоні проведення активних бойових дій), яка різко вирізняється від інших професійних категорій постійним та значним стресогенним перенавантаженням, високими психічними та емоційними напруженнями, які цілковито обумовлені специфічністю та умовами професії військового.

Специфічними структурними компонентами професійної діяльності військовослужбовців $є$ різко екстремальні стресогенні умови, які спроможні досить значно психоемоційно впливати на саму особистість людини шляхом різких психоемоційних перенавантажень та психофізичних й емоційних стресогенних чинників, через що учасників АТО/ООС відносять до групи осіб із підвищеними ризиками розвитку значної соціально-психофізіологічної дезадаптації [2] і зниження усіх психофізіологічних резервів організму. Дані 
чинники спроможні «запускати» виникнення та розвиток негативних незворотних змін фізичного та психоемоційного стану організму, що постає на заваді нормальному співіснуванні та співтоваристві таких осіб в «мирному» соціумі та адаптації їх до таких умов [3]. Слід вказати, що перенесений в умовах бойових дій травматичний стрес без проведення адекватної психофізіологічної реабілітаційної та адаптаційної підтримки із залученням відповідних професіональних спеціалістів не припиняє свій психотравмуючий вплив, «накопичуючись» через переживання нових стресів, що пов'язані iз необхідністю соціальної адаптації, непорозуміннями з оточуючими, труднощами в самореалізації та професійній реабілітації, зниженню можливостей самореалізації тощо [4]. Ці механізми значно «поглиблюють» первинний стрес, який цілковито поглинає усю особистість учасника АТО/ООС і стає певною внутрішньою Я-«концепцією» таких осіб [5]. Дані напрацьовані та штучно створені й інтегровані в психічну сферу особистості настанови, які цілковито поглинають усю сутність особини, необхідно якнайшвидше долати за допомогою залучення певної психореабілітаційної та психосоціальної роботи шляхом напрацювання у цих осіб певних цілісних психологічних внутрішніх та зовнішніх орієнтирів [6, 7]. Проведення цих заходів повністю залежить від адекватного формування й розвитку певної «Я-Концепції» особистості учасників АТО/ООС [8, 9], у процесі формування якої відбувається самоусвідомлення, формування та створення певної цілісної, внутрішньо та зовнішньо єдиної «Яособистості» $[10,11]$.

Особливого значення для реалізації такої «Я-Концепції» особистості учасників АТО/ООС набуває ретельне вивчення та аналіз їх проблем побутового, медико-соціального, професійного, сімейного та іншого характеру, після яких реалізується певна напрацьована індивідуальна реабілітаційно-абілітаційна програма за допомогою реалізації певних «Я-Концепційних» тренінгових технологій.

Головними перевагами таких «Я-Концепційних» тренінгів за К. Рудестамом [12] $\epsilon$ :

- прийняття цінностей і зовнішніх та внутрішніх потреб інших особин;

- можливість напрацювання дієвого зворотного зв'язку;

- можливість адекватно сприймати оточуючих та напрацьовувати певні корекційні «Я-Концепційні» внутрішні та зовнішні орієнтири;

- можливість ідентифікувати себе та свої вчинки з оточуючими;

- полегшення процесу саморозкриття, самовдосконалення, самореалізації та самодослідження й інтроспекції.

Окрім цього, «Я-Концепційні» тренінги, що й визначено О. Євтіховим, не просто допомагають провести аналіз певного досвіду, а й спрямовують особу на «відчуття самого себе та свого «Я»» та бути певним «скульпторами» своєї цілісної, внутрішньо та зовнішньо єдиної «Я-особистості» [13] із певними адекватними та пропорційними психологічними внутрішніми та зовнішніми орієнтирами. 


\section{Список літератури.}

1. Ануфрієва Н. М., Зелінська Т. Н., Туриніна О. Л. Соціальна психологія: навч.-метод. комплекс. К.: МАУП, 2006. 200 с.

2. Комар 3. Психологічна стійкість воїна: підручник для військових психологів. К.: Stabilization Support Services, 2017. 184 с.

3. Соціально-психологічні технології управління військовими колективами: навч.-метод. посіб. / Т. Л. Грицевич, О. С. Капінус, Т. М. Мацевко, П. П. Ткачук. Львів: НАСВ, 2018. 256 с.

4. Військова психологія і педагогіка: підручник; за заг. ред. Л. А. Снігур. Луцьк: ПВД «Твердиня», 2010.576 с.

5. Балашова С. П., Васильєв С. П., Дубровинський Г. Р. Практичний курс військової психології: навч. посіб. Ч. 2. К.: Київський національний університет імені Тараса Шевченка, 2013. 172 с.

6. Алгоритм роботи військового психолога щодо психологічного забезпечення професійної діяльності особового складу Збройних Сил України (методичні рекомендації). К.: НДЦ ГП ЗСУ, 2016. 147 с.

7. Інформаційно-комунікативні технології в гуманітарній сфері Збройних Сил України: досвід, проблеми, перспективи: підручник. К.: НАОУ, 2007. 491 с.

8. Вітенко І. С., Борисюк А. С., Вітенко Т. І. Соціально-психологічний тренінг: цикл вправ для підготовки лікарів - медичних психологів: навч.-метод. посіб.; за ред. проф. І. С. Вітенка. Чернівці: Книги XXI, 2008. 124 с.

9. Збірник методик для діагностики психологічної готовності військовослужбовців військової служби за контрактом до діяльності у складі миротворчих підрозділів: Методичний посібник / О. М. Кокун та ін. К.: НДЦ ГП 3СУ, $2011.281 \mathrm{c.}$

10. Сіверський В. А. Особливості формування «Я-концепції» в юнацькому віці // Зб. наукових праць К-ПНУ імені Івана Огієнка, Інституту психології імені Г. С. Костюка НАПН України. Проблеми сучасної психології. 2013. Вип. 22. С. 520-530.

11. Купчишина В. Психологічні особливості розвитку «Я-концепції» майбутніх офіцерів-прикордонників у процесі професійної підготовки // Вісн. Національної академії Державної прикордонної служби України. 2017. Вип. 3. С. 107-119.

12. Рудестам К. Групповая психотерапия: психокоррекционные группы : теория и практика. 2-е издание. М.: Прогресс. 1993. 368 с.

13. Евтихов О. В. Практика психологического тренинга. СПб.: Речь. 2005. 256 c. 


\title{
ВІРТОПСІЯ - СУЧАСНИЙ МЕТОД ДОСЛІДЖЕННЯ ТРУПІВ ПРИ СУДОВО-МЕДИЧНІЙ ЕКСПЕРТИЗІ
}

\author{
Щепанський Сергій Олександрович, \\ Лікар судово-медичний експерт \\ Київського міського клінічного бюро \\ судово-медичної експертизи
}

На жаль, сьогодення в Україні $є$ не дуже привітним для сучасних методів дослідження в структурі судово-медичної експертизи. Тому залишається лише спостерігати за розвитком сучасних методів дослідження у більш розвинутих країнах, які успішно поспівають за прогресом інноваційних технологій та своєчасно використовують його у своїх цілях.

Віртопсія - методика посмертного дослідження тіла, яка об'єднує проведення класичного патологоанатомічного або судово-медичного розтину з попередніми використанням КТ і / або МРТ дослідження всього тіла без застосування контрастних речовин.

В таких країна, як: Германія, Франція, Великобританія, США, Ізраїль, Австралія - віртопсія вже рутинно використовується для проведення скринінгового дослідження практично всіх трупів для вирішення питання про необхідність подальшого секційного дослідження.

Йди нога в ногу з шаленим бумом технологічного прогресу неодмінно варто, адже від цього залежить наше майбутнє. Віртопсія удосконалює якість проведення «класичних» розтинів, які ,все ж таки, в світовій практиці поки що залишаються «золотим стандартом» визначення причини смерті. Тому, слід вважати, якщо $є$ можливість вдосконалення даного виду експертиз - іiї потрібно використовувати вчасно, а не через проміжок часу, коли світова практика перейде на більш вдосконалені методи дослідження, або винайдуть «еліксир безсмертя», коли віртопсія вже не буде в пріоритеті сьогодення.

Із зарубіжних джерел відомо про позитивні відгуки, які викликає віртопсія, в тому числі, про нові ознаки різних видів смертей, які вже не змінюються впродовж століть. Для того, щоб викликати довіру у потребі розуміння впровадження віртопсії вже сьогодні, приведу декілька випадків, які чудово описують іï̈ цінність.

КТ-дослідження трупа дівчинки, 5 років. Після викрадення тіло було виявлено в спортивній сумці, залишеній в густих заростах чагарнику. При огляді трупа на місці були виявлені: волога серветка в порожнині рота, колото-різана рана на правій бічній поверхні грудної клітини, колоті рани на животі, сліди крові в піхві, пошкодження дівочої пліви і шкіри заднього проходу. Перед «традиційним» розтином було прийнято рішення про проведення КТдослідження трупа 3 метою візуалізації кісткової травми і ранових каналів і визначення рівня розташування стороннього предмета в ротовій порожнині, так як традиційне судово-медичне дослідження області ротоглотки технічно є дуже складним через іiі анатомічну важко-доступності. Використання комп'ютерного 
томографа в якості досекційного метода дослідження допомогло судовомедичному експерту спланувати майбутній розтин, дало можливість оцінити стан «важкодоступних» зон для подальшого секційного дослідження трупа. Наочні КТ-зображення допомогли зафіксувати становище рентген-контрастного стороннього предмета в ротовій порожнині; непрямі рентгенологічні ознаки вказували на наявність ще одного, але вже неконтрастного стороннього предмета в просвіті правого головного бронха. Візуалізація перелому рогу під'язикової кістки достовірно підтвердила факт його прижиттєвого походження і виключила можливість випадкового утворення при витягуванні і обробці гортаннопід'язичного комплексу [1].

При віртопсії у випадку утоплення було встановлено наявність рідини (середовища утоплення) не тільки в пазусі клиноподібної кістки, а й в навколо носових пазухах (обох верхньощелепних, лобової, в порожнині решітчастого лабіринту), що дозволило виявити нову ознаку утоплення, яка істотно доповнює ознаку В.А. Свєшнікова, описану автором ще в 1965 році, - наявність вільної рідини в пазусі клиноподібної (основної) кістки.

Віртопсія в трьох випадках вогнепальної травми виявила великі діагностичні можливості в візуалізації і об'ємній уяві ранових каналів, локалізації сторонніх предметів (куль, дрібних металевих і кісткових осколків), багато в чому перевершують традиційне дослідження, коли при відділенні м'яких тканин найчастіше втрачається початкове положення і фіксація кісткових уламків [2].

Неоціненні можливості віртопсії при дослідженні трупів новонароджених, коли, крім виключення травматичних ушкоджень, достовірно встановлюються ознаки живонародженості за ступенем розправлення легень і поширенню повітря в шлунково-кишковому тракті, а також ознаки зрілості немовляти за ступенем вираженості ядер окостеніння [3]

I це лише початок нової ери діагностики причини смерті з використанням віртуальної можливості сучасних технологічних механізмів, яка буде лише вдосконалювати рівень розуміння тих, чи інших механізмів та функцій реагування людського організму на ушкоджуючі фактори, як зовнішнього, так i внутрішнього середовища.

Незаперечні переваги досекціоної та альтернативної віртопсії:

1. Збереження тіла, що не зазнає аутопсії, що вкрай важливо для представників багатьох релігій і громад.

2. Виявлення ознак прижиттєвих ушкоджень у випадках асфіксії, механічної травми, впливу полум'я, утоплення.

3. Успішне використання в випадках масової загибелі людей і для проведення скринінгового дослідження трупів у випадках раптової смерті для вирішення питання про подальшу тактику.

4. Тривимірна реконструкція при посмертній МСКТ дає унікальну можливість використовувати метод для вирішення питань медикокриміналістичної ідентифікації знаряддя травми і реконструкції обставини події 
при вогнепальній, тупій травмі i пошкодженнях, що заподіяні гострими предметами.

5. КТ-дослідження, будучи оператор-незалежним методом, дає можливість виключити людський фактор у випадках неуважних, нагальних та технічно помилкових розтинів трупів.

6. В значній мірі знижується ризик зараження персоналу моргу (лікарів, лаборантів і санітарів) туберкульозом, гепатитом, ВІЛ та іншими небезпечними інфекційними захворюваннями.

7. Результати віртуальної аутопсії можуть зберігатися в цифровому форматі тривалий час, що дозволяє ретроспективно проводити повторне експертне дослідження без ексгумації трупа і в випадках кремації останнього.

I на послідок, хочеться добавити, що не варто гаяти час, потрібно як найшвидше втілювати у роботу самі передові новації теперішньої технології. Залишилося лише вирішити одне питання - «Як?», адже передові технології потребують необмежного фінансування і є вкрай затратними для теперішньої, вже сформованої системи - «класичного» варіанту розтинів і визначення таким шляхом причини смерті.

\section{Список використаних джерел:}

1. . Клевно В.А., Чумакова Ю. В., Курдюков Ф.Н., Дуброва С.Э., Ефременков H.В., Земур М.А. Возможности посмертной компьютерной томографии (виртуальной аутопсии) в случае смерти от механической асфиксии. Судебная медицина. 2018;4(4):22-26.

2. Levy A.D., Harcke H.T., Jr. Essentials of forensic imaging: A text-atlas. CRC Press; 2010.

3. Туманова У. Н., Федосеева В. К., Ляпин В. М., Щеголев А. И., Сухих Г. Т. Выявление скоплений газа в телах плодов, мертворожденных и умерших новорожденных при посмертном компьютерно-томографическом исследовании. Consilium medicum. 2016;18(13):26-33. 


\title{
ASSOCIATIVE METHODS IN TEACHING ENGLISH \\ ASSOCIATIVE METHODS IN TEACHING ENGLISH
}

\author{
Gusak Liudmyla \\ Doctor of Pedagogy, \\ Professor of the Foreign \\ Languages Department for Humanities \\ of Lesia Ukrainka Volyn National University, \\ Ukraine
}

\section{Hedz Svitlana}

$\mathrm{Ph} . \mathrm{D}$. in Philology, associate professor.

Head of the Foreign

Languages Department for Humanities of Lesia Ukrainka Volyn National University,

Ukraine

Smalko Liudmyla

Ph.D. in Pedagogy, associate professor of the Foreign Languages Department for Humanities of Lesia Ukrainka Volyn National University,

Ukraine

\section{Gusak Oksana}

Master of the Department of Higher School Pedagogy and Social work of Lesia Ukrainka Volyn National University, Ukraine

Speaking of modern teaching technologies at primary school, which are focused on the psychological characteristics of young learners and activation of their reserves, we cannot but mention the intensive methods of teaching, which form the core of associative learning strategy. The purpose of intensive associative learning is to assimilate maximum amount of educational material in a minimum period of studies.

Recent researches assert that methods based on associations in regard to the development of creative thinking of young learners demonstrate their high efficiency. The relationship between concepts of associativity and creativity can be described as follows: on the one hand, scholars recognize the importance of associative processes in the creation of creative product, but on the other hand, the association is regarded as a unit of psychological analysis of creativity (D. Gilford, E. Torens, S. Mednyk, G. Eysenck and others) [1]. Having analyzed the relationship between individual's creativity and imaginative association, we can claim that the main point, where these two concepts intersect, is an associative symbol. 
The main associative methods are the method of graphic associations, method of sound (phonetic) associations, complex associative method, method of associative symbols and others. All of them help pupils to overcome a number of difficulties in language acquisition in a fundamentally new way, help children to absorb better even the basics of their native language (Ukrainian, in our case).

The method of graphic associations suggests that when memorizing spelling of words it is just enough to draw a picture, which illustrates the word and outplay the letter you want to remember in it. The method of sound (phonetic) associations is rather beneficial when we are searching for some kind of sound correspondence between words or the endings of words, which are to be memorized, especially when the phrase or a specific word of a rhyme is apt. It has much in common with mnemonics technique.

The word mnemonic derived from the Greek word Mnemosyne, referring to the ancient Greek goddess of memory. Mnemonics are techniques or devices, such as a rhyme or an image, that serve to enhance the storage and recollection of information contained in memory. Children who are primarily visual or verbal learners are able to create a picture, word, rhyme, or sentence that is attached to an idea they already have. By using mnemonics, a learner can develop better ways to take in information so that it will be much easier to remember. Mnemonic techniques include peg words (words associated with numbers used to remember lists of items), keywords (associating a similar-sounding word with a targeted word), acronyms (using the first letter of each word in a list to construct a word), acrostics, that is creating a sentence where the first letter of each word is the targeted information, and loci (storing information you want to remember in carefully visualized locations).

One of the effective associative learning strategies is offered by I. Barynkina. This strategy falls into the category of associative method of combination. The researcher concluded that the words are easily remembered, when they are accompanied with illustrations, for example, fantasy cartoon characters. [2]

I. Matiuhin assumes, that the associative method of combination is the ability to sort out and link information to remember it with vivid, unusual images, images based on associative ideas. This method allows to increase the amount of the lexicon to be remembered almost twice, and develop not only mechanical memory but also imagination of primary school children. [6]

R. Ibragimova suggests to implement thesaurus method of teaching primary school children by using associative word fields. The method lays emphasis on the linguistic picture of the world and leads pupils to enhancing their lexicographical culture. [5]

Another interesting and effective method of learning a foreign language is the method of mindmapping (construction of associative maps, mind maps), which was offered by the English scientist, writer and businessman Tony Buzan. [3] Among the translation (into Ukrainian) options of «mindmapping» the most accurate, in our opinion, is a version of T. Vorobiova, who calls it Map of associations, since the method of constructing these maps reflects primary associative thinking process [7]. Associative maps (mind maps) are the reflection of our mental images and facilitate cognitive processes. They connect our mental images with the net of associations that exist in our brain and memory. In childhood, the two hemispheres of the brain work together - the left is responsible for verbal, abstracted, symbolic activities, and the right 
serves as a synthesis center of intuitive perception.[4] Therefore, little children can quickly and easily memorize and learn new and sometimes very complex information using mind-mapping. Method of mind-mapping is a brain-friendly way to study, memorize and recollect educational material. Drawing a mind-map is a technique that is very suitable to elicit vocabulary. It uses associations that are very personal and unique which makes it easy to remember. It is easy to add new words so it can be used in several lessons.

\section{References}

1. Anchukova, N. Y. 2002. "Obraznoe assotsyirovaniie kak psikhologicheskii mekhanizm razvitiia lichnosti muzykanta”. Dis. ... kand. ped. nauk. Khabarovsk.

2. Barynkina, Y. V. 1999. "Pedagogicheskiie usloviia razvitiia sposobnostei shkolnikov k izucheniiu inostrannykh yazykov na nachalnom etape obucheniia". Dis. kand. ped. nauk : 13.00.01. Brian. gos. ped. un-t im. akad. I. H. Petrovskogo.

3. Buzan, T. 2003. Mind Maps for Kids : an Introduction London : Harper Thorsons.

4. Edwards, B. 2001. The new drawin the right side of the brain. HarperCollins.

5. Ibragimova, R. E. 1999. „Lingvodidakticheskie i psikhologicheskie osnovy semantizatsii i aktivizatsii leksikona mladshikh shkolnikov metodom assotsiativnogo polia” Dis. kand. ped. nauk: 13.00.02. Bashkir. gos. un-t.: Ufa.

6. Matiuhin, I. Yu., Slonenko, T. B. 2000. Sekrety zapominaniia angliiskikh slov. Donetsk : Stalker.

7. Vorbiova, T. V. 2014. "Formuvannia kreatyvnyh zdibnostei molodshyh shkoliariv u protsesi rozviazuvannia navchalnyh zavdan". Dys. kand. ped. nauk 13.00.09. Ternopil. 


\title{
THE REALIZATION OG THE PRINCIPLE OF THE CONTINUITY IN THE INSTITUTIONS OF PRESCHOOL AND GENERAL SECONDARY EDUCATION IN CONTEMPORARY UKRAINE
}

\author{
Veligura Olena \\ Master's degree of the speciality \\ «The musical education science and upbringing» \\ Specialist in educational methods \\ The Communal institution \\ «Semenivska children's music school» \\ Semenivska City Council \\ Chernigiv region
}

Today the problem of the continuity in the education of Ukraine is very important and being of great importance. The main question is the elaboration and the introduction of the continuity in the institutions of preschool and general secondary education.

The continuity is an object of the investigations in the different field science: philosophy, psychology, pedagogical science, aesthetic and musical upbringing.

Among the scientists which are discussed of the continuity in the philosophy aspect we are distinguished that like E. Baller, G. Isaenko, B. Kedrov. They are substantiated the concept «the continuity in the training» and it will be the subject of the different pedagogical investigation of the contemporary scientists. The problem of the continuity are researched the Ukrainian scientists: S. Amonashvili,

T. Andreeva, A. Bogush, V. Kotirlo, V. Kuznetsova, N. Moyseyuk, G. Nazarenko, O. Savchenko. They are distinguished some conditions for the creation the comfortable climate of the pupils of the first form: providing of the emotional climate, the construction educational processes with consideration the individual peculiarities of a child.

Among the Ukrainian psychologists which are substantiated the psychologicteaching bases we are distinguished next: Ya. Kolominskiy, G. Kostyuk, G. Lyublinska, and among the foreign scientists next: L. Vigotskiy, V. Davidov, D. Elkonin and O. Zaporozhets.

The continuity in the aestetic and musical upbringing studed that scientists: Aronina, R. Ljubar, L. Kurisheva. The preparation of the children preschool age to the training are discussed Ya. Komenskiy, S. Rusova, v. Suhomlinskiy, K. Ushinskiy.

The function of the institution of preschool education and school researched $M$. Antonets, A. Bogush, N. Bushujeva, V. Kotirlo, I. Lapshina, N. Mangeliy, L. Poriadchenko, S. Ufimtseva, T. Forostjuk, O. Chepka.

The continuity is the priority direction of the modernization of contemporary education. The continuity of the modern education is considering as the method

The continuity was of a great importance in the function of such educational structures as the institutions of the preschool education, the institutions of general 
secondary education and the institutions of primary art education, since is foreseeing gradual forming necessary knowledge, skills, their renewal and deepening on every stage. As the pedagogical principle it is mean the intimate connection of the forms, the methods, the substance and the components of the training on all educational stages. That method are implement the knowledge, the skills on the higher level.

Ya. Komenskiy are confirmed that all next is necessary be based on the preliminary. A. Bogush thinking the continuity by the view from below to up. T. Bondarenko determined by the continuity the gradual passing from preliminary age period to new. This is the connection just received experience with preceding. O. Bohinich determined the continuity by the connection and the perspective every component education, that ensuring effective development by the child. A scientist thinking that this are the goals, the tasks, the contents, the methods and the forms of organization. She is distinguished the types of the continuity: physical, intellectual, emotional, social and personal.

However, the problem of the continuity is not sufficient decided in their practical sense. The principle of the continuity was offered to the introducing in the institutions of the primary art education, the preschool education and the general secondary education by Ministry of culture and information politics of Ukraine, by Ministry of the science and education of Ukraine. Some scientifics elaborated the educational programms for the institutions of the corresponding profile.

Thus, was elaborated, systematized and published in Kiyv next educational textbooks and contemporary programs:

1. Veligura, O. O. (2019). Between the preschool and the primary school: educational materials for the music head of the preschool institutions and the teachers of the music art of the schools different types. Kyiv: NPU named M.P.Dragomanov, 42.

2. Veligura, O. O. (2017). Educational program for the academic singing for primary specialized children's art educational institutions. Kyiv: NPU named M.P.Dragomanov, 60.

3. Veligura, O. O. (2017). Educational program for music instrument (fortepiano) for primary specialized children's art educational institutions. Kyiv: NPU named M.P.Dragomanov, 55.

4. Veligura, O. O. (2017). Educational organized recommendations for the programs. Kyiv: NPU named M.P.Dragomanov, 35.

5. Veligura, O. O. (2017). On the threshold of the realization the principle of continuity: educational materials for the music head of the preschool institutions, for English teachers and the music art of the schools different types. Kyiv: NPU named M.P.Dragomanov, 27.

6. Veligura, O. O. (2017). The principle of continuity in the study of the musical reading and writing: educational materials for the music head of the preschool institutions, for English teachers and the music art of the schools different types. Kyiv: NPU named M.P.Dragomanov, 83.

7. Veligura, O. O. (2019). The singing in drawings: educational materials for the music head of the institutions preschool education, for teachers of music art of the schools different types and the teachers subject «Singing». Kyiv: NPU named M.P.Dragomanov, 18. 
8. Veligura, O. O. (2020). The educational program of elementary sublevel of the primary art educational from the misic art, the instrumental form - piano. 4 years. Kiyv, Ukraine: NPU named M.P.Drahomanova. 103 p.

9. Veligura O. (2020). The educational program of elementary sublevel of the primary art educational from the music art, form of the choral singing. 4 years. Kiyv, Ukraine: NPU named M.P.Drahomanova. 70p.

10. Veligura O. (2020). The educational program of elementary sublevel of the primary art educational from the music art «Reading notes from the letter». 4 years. Kiyv, Ukraine: NPU named M.P.Drahomanova. 68p.

11. Veligura O. (2020). The educational-visual text-book «The musical reading and writing in the drawings» for the art schools' teachers and the institutions of general secondary education. Kyiv, Ukraine: NPU named M.P.Dragomanova. 64p.

12. Veligura O. (2020). The educational text-book «Piano.com.ua» for the teachers with the subject « Piano» of the art schools and the musical directors of the institutions preschooler educational. Kyiv, Ukraine: NPU named M.P.Dragomanova. 52p.

My own educational text-books have innovationative methodical systems, the interesting approaches and the methodical viewing. They are comfortable and effective for the training the children from fourth to eighth years, to development their abilities, creative potential and their possibilities.

\section{Reference}

1. Велігура О. О. Між дошкіллям та початковою школою: навчальні матеріали для музичних керівників дошкільних установ та вчителів музичного мистецтва шкіл різного типу. Київ: НПУ імені М. П. Драгоманова, 2019. 42с.

Veligura, O. O. (2019). Between the preschool and the primary school: educational materials for the music head of the preschool institutions and the teachers of the music art of the schools different types. Kyiv: NPU named M.P.Dragomanov, 42.

2. Велігура О.О. Навчальна програма із академічного сольного співу для початкових спеціалізованих дитячих мистецьких навчальних закладів. Київ : НПУ імені М. П. Драгоманова, 2017. 60с.

Veligura, O. O. (2017). Educational program for the academic singing for primary specialized children's art educational institutions. Kyiv: NPU named M.P.Dragomanov, 60.

3. Велігура О.О. Навчальна програма з музичного інструменту (фортепіано) для початкових спеціалізованих дитячих мистецьких навчальних закладів. Київ : НПУ імені М.П.Драгоманова, 2017. 55c.

Veligura, O. O. (2017). Educational program for music instrument (fortepiano) for primary specialized children's art educational institutions. Kyiv: NPU named M.P.Dragomanov, 55.

4. Велігура О.О. Навчально-організаційні рекомендації до програм. Київ : НПУ імені М.П.Драгоманова, 2017. 35с.

Veligura, O. O. (2017). Educational organized recommendations for the programs. Kyiv: NPU named M.P.Dragomanov, 35.

5. Велігура О. На порозі реалізації принципу наступності: Навчальні матеріали для музичних керівників дошкільних установ, вчителів англійської мови та музичного мистецтва шкіл різного типу. Київ : НПУ імені 
М.П.Драгоманова, 2017. 27c.

Veligura, O. O. (2017). On the threshold of the realization the principle of continuity: educational materials for the music head of the preschool institutions, for English teachers and the music art of the schools different types. Kyiv: NPU named M.P.Dragomanov, 27.

6. Велігура О. Принцип наступності у вивченні музичної грамоти: Навчальні матеріали для вчителів музики загальноосвітніх навчальних закладів та викладачів музичних шкіл (шкіл мистецтв). Київ: НПУ імені М.П.Драгоманова, 2017. 83c.

Veligura, O. O. (2017). The principle of continuity in the study of the musical reading and writing: educational materials for the music head of the preschool institutions, for English teachers and the music art of the schools different types. Kyiv: NPU named M.P.Dragomanov, 83.

7. Велігура О. Спів по малюнках: Навчальні матеріали для музичних керівників закладів дошкільної освіти, вчителів музичного мистецтва шкіл різного типу та викладачів предмету «Сольний спів» мистецьких шкіл. Київ: НПУ імені М.П.Драгоманова, 2019. 18c.

Veligura, O. O. (2019). The singing in drawings: educational materials for the music head of the institutions preschool education, for teachers of music art of the schools different types and the teachers subject «Singing». Kyiv: NPU named M.P.Dragomanov, 18.

8. Велігура О. Освітня програма елементарного підрівня початкової мистецької освіти з музичного мистецтва, інструментальний клас - фортепіано. 4 роки. Київ: НПУ імені М.П.Драгоманова, 2020. 103с.

Veligura, O. O. (2020). The educational program of elementary sublevel of the primary art educational from the misic art, the instrumental form - piano. 4 years. Kiyv, Ukraine: NPU named M.P.Drahomanova. 103 p.

9. Велігура О. Освітня програма елементарного підрівня початкової мистецької освіти з музичного мистецтва, клас хорового співу. 4 роки. Київ: НПУ імені М.П.Драгоманова, 2020. 70с.

Veligura O. (2020). The educational program of elementary sublevel of the primary art educational from the music art, form of the choral singing. 4 years. Kiyv, Ukraine: NPU named M.P.Drahomanova. 70p.

10. Освітня програма елементарного підрівня початкової мистецької освіти 3 музичного мистецтва «Читання нот 3 листа». 4 роки. Київ: НПУ імені М.П.Драгоманова, 2020. 68c.

Veligura O. (2020). The educational program of elementary sublevel of the primary art educational from the music art «Reading notes from the letter». 4 years. Kiyv, Ukraine: NPU named M.P.Drahomanova. 68p.

11. Велігура О. Музична грамота в малюнках: Навчально-наочний посібник для викладачів мистецьких шкіл та закладів загальної середньої освіти. Київ: НПУ імені М.П.Драгоманова, 2020. 64c.

Veligura O. (2020). The educational-visual text-book «The musical reading and writing in the drawings» for the art schools' teachers and the institutions of general secondary education. Kyiv, Ukraine: NPU named M.P.Dragomanova. 64p. 
12. Велігура О. Фортепіано. com.uа: Навчальний посібник для викладачів 3 предмету «Фортепіано» мистецьких шкіл та музичних керівників закладів дошкільної освіти. Київ: НПУ імені М.П.Драгоманова, 2020. 52с.

Veligura O. (2020). The educational text-book «Piano.com.ua» for the teachers with the subject « Piano» of the art schools and the musical directors of the institutions preschooler educational. Kyiv, Ukraine: NPU named M.P.Dragomanova. 52p. 


\title{
THE COMMUNICATIVE APPROACH TO TEACHING THE FOREIGN LANGUAGES AT THE ESTABLISHMENTS OF HIGHER EDUCATION OF THE MINISTRY OF INTERNAL AFFAIRS OF UKRAINE
}

\author{
Zelenska Olena \\ Doctor of Pedagogy, Full Professor, Professor \\ Lviv State University of Internal Affairs
}

The educational system is one of the most important factors of the society activity and it has a direct influence on the progress of its social and economic development. The modernization of the educational system is the basis of the dynamic economic growth and the social development of the society, the factor of the wellbeing of the citizens and security of the state. Those changes that are taking place in the sphere of education testify to the fact that the educational paradigm is directed towards a personality oriented one, the leading component of which is the key competences which are necessary for the personality improvement and development, for the active life position and social adaptation. A modern specialist must have the ability of the creative self-realization, be ready not only for a normal stable life, but for the changes of the work conditions, for the social mobility, for the strategic projecting the vector of their professional career, for the moral self-regulation, and for the changes of the life mode. In this connection the aspects of the strategy and tactics of the further improvement of training the specialists, and also the development of the new concept of the state policy in the sphere of education are extremely topical. Thus, taking into account that the establishments of higher education are the main sources of training the qualified specialists, particularly for the organs of internal affairs of Ukraine, the system of education of the educational establishments of the Ministry of Internal Affairs of Ukraine needs the new pedagogical technologies and methods of organizing the process of forming new knowledge, professional skills and abilities of the law enforcement officers [1, p. 69]. The process of the professional training of the cadets is a complex as to its structure, multi-aspect, and multi-functional system of the didactic influence on the cadet's personality with the aim of forming the relevant skills and abilities necessary for the effective realization of the future professional activity.

The changing of the social order on mastering a foreign language defined the new approaches to the aim of teaching, to defining the educational process as the foreign language speech and cognitive activity, and presented a requirement to rethink the existing methodical concept of teaching the foreign language at the non-linguistic establishment of higher education. Considering the modern demands to mastering the foreign language by the law enforcement officers the process of it's acquiring is considered as forming the communicative competence, the level of which must be not lower then that which allows to use the language practically, and the aim of teaching is acquiring and using the foreign language as a means of expressing one's thoughts. For the specialists who have higher education, including the law enforcement officers, 
the foreign language becomes not only the means of obtaining information from the original sources, but also the means of the professional communication which has a certain pragmatic effect. Because under condition of foreign language teaching at the non-linguistic establishment of higher education forming not only the general, but the special communicative competence in the professional and industrial spheres of the communication in connection with the needs of the professional activity in the sphere of the future speciality is necessary.

The complex approach to realizing the aims of teaching the foreign language (practical, and educational) foresees, alongside with the language acquisition, enhancing the linguistic literacy of the cadets, their in-depth acquaintance with culture of the country the language of which they learn, developing thinking, memory and feelings, forming the socio-valuable qualities of the personality. The methods of teaching the language are a complex dynamic system that has a multi-component character which also has different levels and develops in the spheres of linguistics, pedagogy, psychology, and sociology. The language tendencies of the Council of Europe in the context of the globalization foresee the certain demands, among which is to give the priority to those methods of teaching the foreign languages which oriented to developing the oral expression using the audio- and video-materials, and interactive means $[2,113]$.

In different times various methods and educational means were used for teaching the foreign languages at the establishments of higher education. The grammartranslations method, the direct method, the audio-lingual method, the method of suggestopedia, the group and communicative methods, etc. were used; such technical teaching aids as a tape-recorder, audio recordings, video recordings were applied, nowadays the priority is given to the computer and computer programmes. Namely, the methodical thought did not stand still. The teachers of the foreign languages and the methodists were always in search for the new, more perfect methods, and forms of teaching the foreign languages, and it always practically had the primary goal - to form the skills and abilities first of all of the oral speech, expressing one's thoughts, the ability to communicate. This goal remains. It is only necessary to concretize the purpose of using the foreign language at the non-linguistic establishment of higher education - for developing the communicative and professional competences of the cadets. Though, in our opinion, it is not rationally to give the priority only exceptionally to one method, it is always necessary to take into consideration who teaches, who is taught and what is taught. It is also worth to remember that whatever method or form of teaching is used if they contribute to achieving the set goal, they have the right to exist.

The topicality of the communicative approach to teaching the foreign languages is confirmed by the very intensive development of the communicative linguistics during the last dozens of years. The communicative approach to teaching the foreign language, the formation of the communicative potential of the personality condition the practical aim of teaching - mastering the foreign language intercultural communication by means of forming and improving the communicative competence, i.e. the readiness to realize the interpersonal, intercultural communication by means of the foreign language, namely taking into consideration the socio-cultural norms of behaviour and 
character of the interaction of the partners who belong to different linguo-cultural communities [3, p. 220]. The communicative competence is the basis of the communicative approach in teaching the foreign languages.

Considering the communicative method of teaching the foreign language we must state that the followers of this method recognize the necessity for the students and cadets to master the linguistic structures and vocabulary. But it is not enough, because the students and cadets can know the rules how to use the language, but can be unable to use the language. When we communicate we use the language for fulfilling some functions, such as the argumentation, conviction, negation, proposition, etc. Moreover, we fulfill these functions in the limits of the social context. The speaker will choose the certain forms to express their thoughts which are based not only on their intention, the level of their emotions, but also on the fact to whom they apply and in what relationship with the interlocutor they stay. For example, the speaker will argue differently with his/her friend and his/her employer. Moreover, because the communication is a process it is not enough for the students and cadets to have knowledge of the forms, meanings and functions of the foreign languages. They must be able to use this knowledge for obtaining the meaning during the conversation, i.e. they must have the developed cognitive abilities. It is through the interaction of the speaker and the listener (or the reader or writer) that this meaning becomes understandable. The listener gives the speaker the feedback to make it clear if he/she understood what the speaker said. The act of the communication is committed in this way. The foreign language communicative competence is the ability of the student to participate in the communication with the aim of realizing the speech intentions, using knowledge, skills and habits adequately and relevantly. The ability to speak competently means not only to know the rules of the language, but also to speak knowing how to say it and under what conditions to say it [4, p. 138]. The communicative competence as a multi-aspect phenomenon consists of several competences. It embraces the linguistic, verbal-cognitive, verbal-communicative, socio-linguistic, intercultural, informational, linguo-culturological, socio-cultural, strategic, discourse, compensatory and social competences.

The communicative speech competence is realized in fulfilling various types of the speech activity, namely: reception, oral and written speech (production), interaction and the translation activity (mediation). The communicative methodology is based on the principle of the complex training of all the types of the speech activity (auditing, reading, speaking, and writing) under conditions of realizing the communicative tasks in the educational speech situations. Such situations at the establishments of higher education can concern, first of all, the professional activity of the future specialists, particularly of the law enforcement organs, and also the everyday life, because the communication concerns not exceptionally the job, but various aspects of the human life. The linguo-country study competence of the students and cadets, their acquaintance with culture, life and customs of the native speakers must also be taken into account.

The communicative purpose of the educational process orients the teaching to the oral communication as the most prior form of the speech and mental activity. The process of learning the foreign language by the cadets testifies to the fact that if they 
can work on the original professionally oriented text using a dictionary, understand the content of the information and reproduce it in various forms: the answers to the questions; reproducing the content of the text; doing the exercises concerning the text, etc., what concerns the oral speech, particularly if these are the topics related to their future profession the cadets have many difficulties. It happens even then when they know the grammatical forms, vocabulary and the subject. To speak appears to be difficult. That is why the main effort of the teachers of the foreign language must be directed towards teaching the cadets to communicate, speak, express one's thoughts, to argument them, to agree, to negate, to accept, etc. To think in the foreign language is the ideal.

Lets consider some tasks that can be successfully used for developing the skills of the oral communication. The communicative tasks are inseparable from stimulating the speech and mental activity under conditions of the communicatively oriented teaching the foreign languages. Such tasks are created, first of all, on the basis of the game, imitative and free training. Forming the communicative competence demands using such tasks, exercises and situations that combine the dialogical and monological, productive and reproductive speech. These exercises must be based on the acquired and worked off language material, so that the main attention should be based on the content during speaking; they must be adequate to the defined aim and conditions of its achievement; they must fit the character of the skills and abilities that are forming and developing, the psychological and linguistic peculiarities of their acquiring. Such exercises oriented to developing and improving the skills and abilities of the oral speech and that are approximate as to their content to the real communicative actions include the tasks concerning guessing, filling in the informational lagoons, ranking the information, business games, discussions, conversations, project cases, oral reports, dialogue speech [5].

What concerns the business or role games their most essential advantages over the other forms of the educational activity are that they: activate the cognitive activity; develop the imagination, create the conditions for the individual creative improvisation, activate the implicit, reserve possibilities, promote the formation of the practical (industrial, professional) skills; raise the efficiency of the training; are a certain social and psychological training, because they teach the professional and social communication. Namely, the usage of the business and role games can contribute, on the one side, to the deeper mastering of the cadets' future speciality, and on the other side, to forming the stable speech skills, creating the dynamic and flexible socially essential stereotypes in the situations that are maximally approximate to the reality, i.e. to raise the efficiency of teaching the oral speech (dialogical and monological) in general.

Besides the business and role games one may use the modeling of the communicative situations, imitating the business activity during training, the result of which is obtaining the verbal and non-verbal product after solving the certain problems, which were set by the teacher, by the cadets. For example, it can be the description of the crime scene, its sketching and commenting the sketch. Or making an identi-kit of the imaginary criminal and explaining why it helps to conduct the investigation.

The perspective forms of training can also be as follows: 
- the problem presentation of the issue (the opposite treating some law enforcement or legal problems);

- the dilemma (the cadets are proposed to choose the alternative variant for example, to explain why it is more important to prevent a crime than to solve it);

- the questions which are connected with the future material that will be learned further; the teacher asks the cadets to express their opinion about the new issues taking into account their knowledge, erudition, intuition, or guess;

- the tasks based on the logical thinking (for example, the cadets are proposed to find the exit from the existing situation);

- the controversial situation (the cadets propose a better in their opinion variant, explain their understanding of it, and the teacher then resumes their "dispute", and explains the adequacy of the decisions and situations);

- the method of the "bridges" (this method makes it possible to define the links between the phenomena, and the questions; it is necessary for the cadets to deeply get into the essence of the problem, and use the obtained earlier information well).

Certainly there are also conferences, discussions, competitions, round tables, new technologies, etc.

Thus, forming the cadets' communicative competence contributes to the successful usage of the foreign language in the real professional communication. The communicative direction of the educational process orients this process to the oral communication as the most prior form of the speech and mental activity. Various tasks, exercises, and forms can be used for developing the skills of the oral communication, among which are business and role games, modeling the professional communicative situations, dialogical speech, discussions, oral reports, etc.

\section{References}

1. Монастирський В.М. Історичний процес становлення і розвитку педагогіки в правоохоронних органах та їі роль у професійній підготовці працівників міліції України на сучасному етапі. Проблеми освіти. К.: НМЦ ВО Міністерства освіти і науки України, 2003. Вип. 33. С. 68-79.

2. Токменко О. Мовні тенденції Ради Європи в контексті глобалізації. Іноземні мови в навчальних закладах. К.: Держ вид-во “Педагогічна преса”, 2004. № 2. C. 112-115.

3. Зеленська О.П. Іншомовна міжкультурна комунікація - вимога гуманістично орієнтованої вищої освіти. Функциональная лингвистика: сб. науч. работ. Симферополь: Крымский республиканский ин-т последипломного педагог. образования, 2012. № 3. С. 218-220.

4. Pyrozhenko O.V., Ivanova T.V. Individualized Teaching Aimed at the Development of Communicative Competence in a Foreign Language of University Students. Стратегії та методи навчання мовам для спеціальних цілей. К.: Київ. нац. ун-т ім. Т. Шевченка, 2001. С. 138.

5. Зеленська О.П. Деякі вправи для навчання іншомовного усного мовлення здобувачів вищої освіти освітнього рівня «магістр» у нелінгвістичній магістратурі. Вісник Чернігівського національного педагогічного університету. Серія: педагогічна. 2018. Вип. 155. С. 38-42. 


\title{
ЭКОЛОГИЧНАЯ МУЗЫКА ИЛИ МУЗЫКАЛЬНАЯ ЭКОЛОГИЯ (ПЕДАГОГИЧЕСКИЙ АСПЕКТ)
}

\author{
Айтуарова Ажар Толикбаевна \\ Кандидат искусствоведения, доцент \\ кафедры музыкального образования и хореографии \\ Казахский национальный педагогический университет имени Абая
}

Взаимосвязь таких понятий как экология и музыка может рассматриваться в различных аспектах. Здесь речь может идти - во-первых, о воспитании любви к природе, к окружающей среде, ко Вселенной, к душе человека через музыкальное искусство, через те возможности, который предоставляет самое нематериальное из всех видов искусств - музыка (педагогический ракурс).

Во-вторых - рассматривать экологическое отношение к самой музыке - a именно к тем музыкальным творениям, которые оставили нам как композиторы классической музыки, так и традиционные народные творцы. Весьма очевидно, что современные интересы как молодежи, так и государства сместились в сторону мгновенного получения прибыли, а именно к коммерцизации искусства (духовно-этический ракурс: сохранности духовных ценностей традиционной музыки и классической мировой).

Также очевиден и третий аспект: воссоздание гармонического единения человека и окружающего мироздания, Космоса через глубокое прочувствование и понимание мировоззренческих основ традиционного музыкального мышления (философский ракурс).

Очевидно, что эти три аспекта взаимосвязаны и взаимообтекаемы - наше бережное отношение к музыкальным шедеврам, их грамотное распространение среди современной аудитории - неизбежно несут в себе заряд положительной энергии по отношению и ко внутреннему миру человека (сохранение его лучших качеств), к окружающему мирозданию, а значит и к природе.

Рассмотрим первый аспект - воспитание экологической культуры через музыку.

В этой области на сегодняшний день существуют две неотложные задачи. Первая - подбор музыкального материала, способствующего формированию основ экологической культуры. Вторая - выбор и анализ методов музыкального воспитания на предмет связи с экологическими проблемами.

В арсенале педагога, ведущего уроки музыки в Казахстане - множество музыкальных произведений, посвященных картинам природы. Пейзажные, жанровые, камерные и симфонические, произведения традиционных жанров и опусы академических композиторов. Это и кюи известных мастеров: «Саржайлау» Таттимбета, «Булбул» Дины, «Сарыарка» Курмангазы, «Жезкиик» Ыхласа. Из наиболее подходящих для детского восприятия композиторских опусов можно назвать пьесу «Жайлаудағы тан» Е.Брусиловского, фрагменты сюиты Ж.Дастенова «Эскизы Ала-Тау». Пейзажные зарисовки изобразительного 
характера особенно хороши для детского восприятия. Запоминается вторая часть - «Долина тюльпанов» - с ее «весенними» трелями, глиссандо, выразительной мелодией восточного характера, а также атмосферная третья часть - «Песня в горах».

Не менее выразительны темы симфонической поэмы «Жайлауда» К.Мусина, романса «Булбул» Л.Хамиди и песни «Ақ көгершін» А.Жубанова. При этом подавляющая часть данных произведений воплощает образы положительного наклонения. Авторы музыки выражают любование, восхищение картинами природы. Выразительные мелодии, прозрачная фактура, не перегруженная массивными аккордами, элементы звукоподражания голосам природы - таков комплекс основных выразительных средств. Подобные иллюстрации незаменимы в воспитании эстетического и музыкального вкуса детей, в формировании основ патриотизма, любви к родному краю, в воспитании эстетического отношения к окружающему миру.

Сюжет древнего кюя-легенды «Аксак кулан» затрагивает важную тему сосуществования человека и природы. При прослушивании кюя необходимо обратить внимание детей на скорбный характер музыкальной темы, подчеркнуть, что неправильное отношение к окружающей природе привело героев легенды к несчастью. В противовес данному кюю можно предложить светлый и легкий кобызовый кюй «Жезкиик» в обработке А.Жубанова. Контрастная атмосфера мрачного кюя «Аксак кулан» и танцевальной мелодии «Жезкиик» оставят эмоциональный след в памяти учащихся.

Аналогично, на основе принципа контраста и метода сравнения можно построить занятие, посвященного кобызовой музыке. Два ярко характерных произведения, воплощающих полярные эмоциональные состояния - «Таутұрген таңы» Г.Жубановой и «Арал мұңы» А.Раимкуловой. Пьеса Газизы Жубановой звучит в исполнении кобыза в сопровождении фортепиано. Фортепианное вступление создает легкое весеннеее настроение, в коротких мотивах угадываются птичьи голоса. Кобыз ведет вдохновенную мелодию гимнического характера в тональности D-dur.

Казахское традиционное музыкальное искусство можно представить формой трансляции социального и воспитательного опыта через освоение каждым поколением духовной культуры, знаний и навыков отношения к окружающей среде, людям, культурным ценностям, образцам поведения (мы переходим к следующим аспектам заявленной тематики). Оно в полной мере, наряду с другими институтами, формирует ценностные установки, способы ориентации человека в социуме и, конечно, этнические нормы воспитания.

Нормы этнического воспитания выражены, подчас, в традиционной культуре прямо, в форме назидания. Песни-назидания, представленные у казахов как песни-наставления «нақыл», песни-завещания «өсиет», песни-размышления «толғау», свадебные песни жанра «Беташар» и другие образцы, излагаемые в стиле «терме» несут огромный воспитательный заряд. Четкое определение «хороших» и «плохих» поступков, описание встречающихся в жизни поступков и мгновенная их оценка с точки зрения традиционных норм морали, советы и 
определение целей жизненного пути каждой личности - такова суть музыкальных назидательных жанров.

Этномузыка казахов играла весьма важную роль в системе традиционного воспитания. Неповторимое воссоединение философской, дидактической и эстетической сторон традиционной музыки казахов может и сейчас послужить богатым источником и средством действенного, высоко нравственного воспитательного воздействия на подрастающее поколение ( в том числе и экологического) [1; 80 ].

Кроме того, музыкальные творения (обрядовые и бытовые музыкальные жанры, инструментальная и вокальная этномузыка) являются ценнейшим источником для воссоздания основ миропонимания и мировосприятия различных национальностей. Для казахской традиционной картины мира, как отмечают многие исследователи, было характерно космологическое понимание музыки, когда в самой сути музыкального творения была заложена гармонизирующая сила, способная со-творить вселенную и весь Космос. Как отмечает С.Аязбекова,«Гармония мира определяется Гармонией музыки, где музыка выступает в уникальной роли: как структурирующее ядро культуры, ментальное ядро Социума, гармонизирующее ядро Универсума» [2; 34] Вспомним такие казахские кюи-легенды как «Шыңырау», «Қорқыт», «Аққу». В этих источниках мы видим древние мифологизированные космогонические представления протоказахов о мироздании, о Вселенной, отображенные, кроме того, и в самой музыке. (Например, через пространственные фактурные формы).

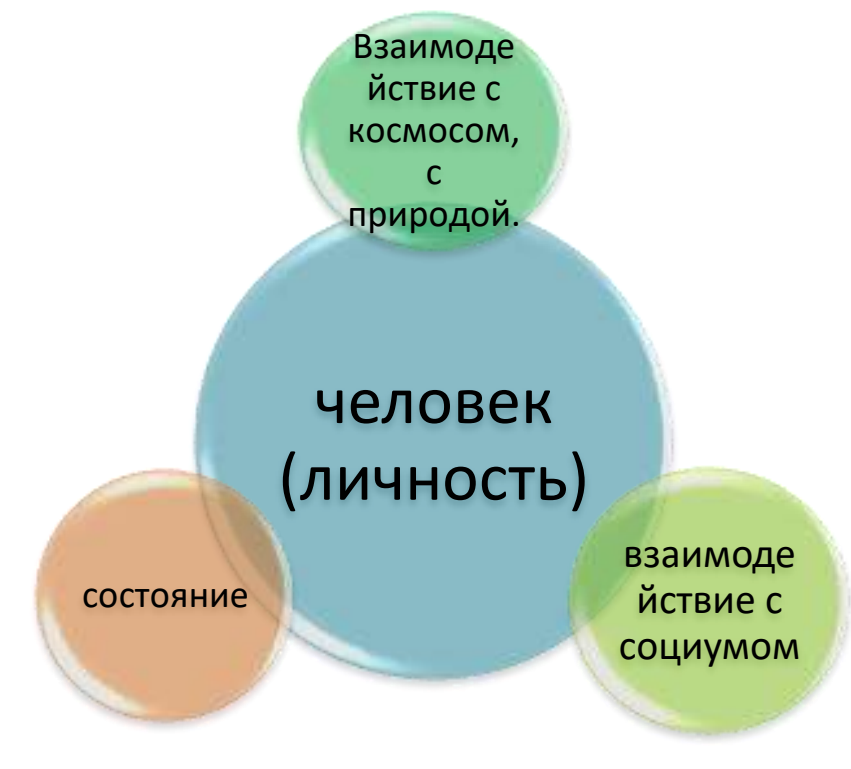

Этномузыкальное искусство казахов, в силу своей нематериальной, чисто звуковой природы (звуковые волны), несет в себе неизмеримо большие возможности. Оно, как это было доказано многими казахстанскими исследователями, благодаря сохранившимся интонационным и структурным формам, не подвергающимися генеральным изменениям, продолжает нести свои сакральные функции (обрядовая лирика). Оно также продолжает гармонизировать не только внутреннее состояние человека, но и весь 
неявленный мир, Космос, Вселенную. Оно - единственный свидетель бережного отношения древнего сознания с окружающим миром, которое было характерно для тенгрианства (исконной религии тюрков). В музыке казахов отражены жизненный опыт, творческая одаренность, эстетические и нравственные установки, мудрость этноса. И вместе с тем она космична, продолжая сохранять в себе огромный потенциал гармоничного и универсального жизнебытия личности и окружающего мироздания.

\section{Список литературы:}

1. Айтуарова A.T. Потенциал союза этнопедагогики, этнопсихологии и этномузыки.//«Поиск» №1 Серия гуманитарных наук. (Научный журнал Министерства образования и науки). №1 (1) - №1, 2013. С.- 76-81.

2. Аязбекова С.Ш. Картина мира этноса: Коркут ата и философия музыки казахов. Алматы, 1999, с. 34.

3. Валиуллина Р.Н. Музыканты и экологическая культура // Инновационные процессы: традиции и современное состояние культуры и искусства: мат-лы респ.науч.-практ.конф. - Алматы: Құрманғазы атындағы қазақ ұлттық консерваториясы.- Қазақша, орысша. - с.64-68.

4. Какимова Л.Ш. Музыкальность в русле проблемы музыкальных способностей в хороуправленческой деятельности педагога-музыканта // Вестник КазНПУ имени Абая. Серия «Художественное образование: искусство - теория - методика». № 4 (37), 2013

5. Музыка. Учебная программа для 1-4 классов общеобразовательной школы. Авторы: Райымбергенов А.И., Райымбергенова С.Ш., Байбосынова У.М. Астана: Национальная академия образования им. И.Алтынсарина, 2013 


\title{
МУЗИЧНО-ПЕДАГОГІЧНА ДІЯЛЬНІСТЬ Г.СКОВОРОДИ У ХАРКІВСЬКОМУ КОЛЕГІУМІ (ДО 300-РІЧЧЯ ВІД ДНЯ НАРОДЖЕННЯ)
}

\author{
Бакай Світлана Юріївна \\ канд. пед. наук, доцент \\ кафедри дошкільної педагогіки і фахових методик \\ Харківського національного педагогічного університету \\ імені Г.С.Сковороди
}

В історії педагогічної думки XVIII ст. одне з чільних місць посідає науковопедагогічна спадщина, просвітницька i культурно-громадська діяльність визначного українського філософа, педагога-гуманіста, поета, музиканта, просвітителя й народного наставника Григорія Савича Сковороди. Різні аспекти його поглядів і сьогодні плідно вивчаються та творчо використовуються в науковій та навчально-виховній роботі з молоддю у вищих і середніх освітніх закладах України, творчих професійних і громадських колективах різної спрямованості.

Із палицею, сопілкою та флейтою, торбою за плечима пройшов Г.Сковорода шляхами Слобідської України, увібравши у свої помисли дух народного волелюбства та козацького завзяття. Його біографія - це історія ненастанних шукань духовно багатогранної людини, що в тісному єднанні 3 народом, у повсякденній просвітницькій праці знаходила зміст свого існування, невтомно пропагувала та впроваджувала в життя ідеали правди, добра, духовної краси й гуманізму.

Історичні джерела свідчать, що вагому роль у становленні світогляду юнака відіграли його батьки, селяни-трудівники 3 с. Чорнухи на Полтавщині, де 3 грудня 1722 року народився майбутній педагог, філософ і музикант. Батьки Г.Сковороди були з простого козацького роду, особливих матеріальних статків не мали, були чесні й працьовиті. У родині міцно зберігалися традиції національного українського виховання, батьки хлопця часто запрошували до хати кобзарів і лірників, слухали історичні, повстанські, козацькі пісні та інші матеріали народної творчості.

Відомий дослідник багатогранної творчої спадщини Г.Сковороди Д.Багалій, аналізуючи рукописні козацькі переписи, що зберігалися у Харківському історичному архіві, знайшов відомості щодо батьків Г.Сковороди.

Сьогодні, ці справи зберігаються у центральному державному історичному архіві України. У фондах Генеральної військової канцелярії та скарбової канцелярії знаходиться ревізійна книга зі списками малоземельних козаків сотенного м. Чорнух Лубенського полку за 1733 р., в яку записаний батько Григорія - «Савка Сковорода», а за ревізією 1743 р. під номером 49 згадується мати Григорія «двір Пелагеї Сковородихи, син якої знаходиться в півчих». 
Слід зазначити, що архітектори В.Тертичний і Ю.Чернов у 1970 р. створили проект меморіальної садиби Г.Сковороди у с. Чорнухи, яка являє собою типову для української козацької родини садибу XVIII ст.

Вивчення архівних документів, вітчизняних історико-педагогічних і сучасних джерел свідчить, що особливо плідним у викладацькій діяльності видатного українського педагога, філософа, музиканта й просвітителя XVIII ст. Григорія Сковороди був Харківський період. Протягом десятиріччя (1759-1769) він вчив студентську молодь у Харківському колегіумі - широко відомому на той час вищому навчальному закладі Слобожанщини.

Одержані загальноосвітні, педагогічні та музичні знання, бажання присвятити себе боротьбі за національне виховання й освіту молодого покоління викликали у Г.Сковороди інтерес до роботи вчителя, потребу в педагогічній діяльності, надавати учнівській молоді різнобічні знання в галузі музичного мистецтва, знайомити 3 народною пісенною творчістю, 3 національно-культурним середовищем.

Свою безпосередню історію колегіум веде від 1722 р., коли випускник КиєвоМогилянській академії Єпіфаній Тихорський, який згодом став бєлгородським єпископом, відкрив школу при бєлгородському Миколаївському монастирі. У 1726 р. за підтримки князя М. Голіцина школа була переведена до Харкова, і на основі цього закладу було відкрито Харківський колегіум.

Джерела свідчать, що в колегіумі Г.Сковорода викладав грецьку мову, синтаксис і поетику, а в 1768 р. читав курс християнського добронравія, який передбачав вивчення катехізису (християнського віровчення в запитаннях $\mathrm{i}$ відповідях). На вчителювання він дивився як на педагогічно корисну справу, яка приносила особисту радість і сприяла народному просвітництву.

Стосовно змісту, методів і засобів освіти просвітянин мав свій погляд, його лекції, бесіди, діалоги та інші форми занять не були схожими на звичайне викладання в тодішніх навчальних закладах. Перед педагогом була відкрита перспектива розвитку загально-педагогічних і музичних знань, умінь і навичок учнівської молоді, творчого спілкування з нею. Студенти поважали Г.Сковороду за глибокі знання, шляхетність, демократичні взаємовідносини, 3 інтересом відвідували його заняття.

У Центральному державному історичному архіві м. Києва (ЦДІАУ) вдалося знайти невідомі раніше документи - каталоги школи поетики за 1759-1760 та школи синтаксису за 1763-1764 навчальні роки, підписані Г.Сковородою. У каталозі школи поетики зазначено за списком 39 учнів, віком від 12 до 22 років, а у каталозі школи синтаксису за списком було 96 учнів, віком від 10 до 19 років, батьки яких були духовного сану.

Ці документи свідчать, що учні розподілялись за різними протопопіями (церковними округами): Ахтирською, Бєлгородською, Богодухівською, Бороменською, Водолазькою, Зміївською, Ізюмською, Карпівською, Краснокутською, Краснопольською, Курською, Лебединською, Миропольською, Печенізькою, Полтавською, Салтівською, Сумською, Харківською, Хотменською, Чугуївською. Отже, контингент учнів колегіуму охоплював досить широкі регіональні межі тогочасної України. 
У ЦДІАУ каталоги школи поетики і синтаксису представлені у вигляді таблиць 3 7-ми граф, де Г.Сковорода записував дані щодо кожного учня:

периа графа - ім я, прізвище, якого чину батько та з якого міста;

друга якого віку учень;

третя в якому віці зараховано до школи;

четверта які знання отримав до цього;

n`мma які знання отримує на цей час;

uоста оцінка навчальних здібностей учнів;

сьома залишився у школі або відраховано.

Аналіз змісту каталогів показує, що Г.Сковорода надавав особливого значення виявленню різних ступенів підготовки учнів, спираючись на їхні індивідуальні здібності. До оцінки здібностей учнів педагог підходив диференційовано, давав кожному індивідуальну психолого-педагогічну характеристику, поділяючи учнів на: «гораздо понятлив», «очень понятлив», «весьма понятлив», «весьма остер», «понятлив», «остер», «годен», «не понятлив», «не годен», «весьма не понятлив», «самая негодница», «самая бестолковица», «туп». Нище наводимо зразок каталогу школи поетики, де Г.Сковорода розподіляв учнів за різними ступенями розумового розвитку.

Каталог учнів школи пї̈тики Харківського колегіуму

таблиця 1 /вересень-липень 1759/60 навч. рік/

\begin{tabular}{|c|c|c|c|c|c|c|}
\hline $\begin{array}{l}\text { Ім'я, } \\
\text { прізвище, } \\
\text { якого чину } \\
\text { батько }\end{array}$ & $\begin{array}{l}\text { Скільк } \\
\text { и } \\
\text { років } \\
\text { від } \\
\text { народ- } \\
\text { ження } \\
\end{array}$ & $\begin{array}{l}\text { Коли } \\
\text { зарахов. } \\
\text { до } \\
\text { школи }\end{array}$ & $\begin{array}{l}\text { Що } \\
\text { вивчав } \\
\text { раніше }\end{array}$ & $\begin{array}{l}\text { Що } \\
\text { вивчає } \\
\text { зараз }\end{array}$ & $\begin{array}{l}\text { Розумний } \\
\text { чи ні }\end{array}$ & $\begin{array}{l}\text { Залишився } \\
\text { у школі } \\
\text { або } \\
\text { вибув }\end{array}$ \\
\hline \multicolumn{7}{|c|}{ Харьковская протопопия } \\
\hline $\begin{array}{l}\text { Василий } \\
\text { Тарановский } \\
\text { села } \\
\text { Безлюдовка } \\
\text { Покровской } \\
\text { церкви } \\
\text { священника } \\
\text { Иоанна сын }\end{array}$ & 13 & $\begin{array}{l}1758 \\
13 \text { янв. }\end{array}$ & $\begin{array}{c}\mathrm{C} \\
\text { И } \\
\mathrm{H} \\
\mathrm{T} \\
\mathrm{a} \\
\mathrm{K} \\
\mathrm{C} \\
\text { И } \\
\mathrm{C}\end{array}$ & $\begin{array}{l}\text { П } \\
\text { о } \\
\text { э } \\
\text { Т } \\
\text { И } \\
\text { К } \\
\mathrm{a}\end{array}$ & Понятлив & В школе \\
\hline
\end{tabular}

Аналіз каталогу показує, що Г.Сковорода 3 39-ти учнів визначив найбільш здібних до знань з поетики 21 особу, а недостатньо здібних - 18. Усі учні були залишені в школі. Далі наводимо зразок каталогу школи синтаксису. 
Каталог учнів школи синтаксису Харківського колегіуму

/вересень-липень 1763/64 навч. рік/

\begin{tabular}{|c|c|c|c|c|c|}
\hline $\begin{array}{l}\text { Ім'я, } \\
\text { прізвище, } \\
\text { якого чину } \\
\text { батько } \\
\end{array}$ & $\begin{array}{l}\text { Скільки } \\
\text { років від } \\
\text { народження }\end{array}$ & $\begin{array}{l}\text { Що } \\
\text { вивчав } \\
\text { раніше }\end{array}$ & $\begin{array}{l}\text { Що } \\
\text { вивчас } \\
\text { зараз }\end{array}$ & $\begin{array}{l}\text { Розумний } \\
\text { чи ні }\end{array}$ & $\begin{array}{l}\text { Залишився } \\
\text { у школі або } \\
\text { відбув }\end{array}$ \\
\hline $\begin{array}{l}\text { Города } \\
\text { Харькова } \\
\text { Отставного } \\
\text { писаря } \\
\text { Кондрата } \\
\text { сын Александр } \\
\text { Кондратович }\end{array}$ & 16 & $\begin{array}{l}\text { Г } \\
\mathrm{p} \\
\mathrm{a} \\
\mathrm{M} \\
\mathrm{M} \\
\mathrm{a} \\
\mathrm{T} \\
\text { И } \\
\text { К } \\
\mathrm{a}\end{array}$ & $\begin{array}{l}\mathrm{c} \\
\text { И } \\
\mathrm{H} \\
\mathrm{T} \\
\mathrm{a} \\
\text { К } \\
\mathrm{c} \\
\text { И } \\
\mathrm{C}\end{array}$ & $\begin{array}{l}\text { Самая } \\
\text { бестолковица }\end{array}$ & В школе \\
\hline
\end{tabular}

Аналіз каталогу синтаксису свідчить, що з 96-ти учнів найбільш здібних до навчальних занять було 30, здібних - 38, недостатньо здібних - 16, а майже не здібних - 12. Результати останньої графи каталогу показують, що Г.Сковорода не відрахував зі школи жодного 3 12-ти майже не здібних учнів, вважаючи педагогічно доцільним допомогти цим учням отримати в школі знання відповідно до рівня їхніх здібностей.

У 1762 р. в листі до М.Ковалинського Г.Сковорода дав більш глибоку психолого-педагогічну характеристику одному з учнів Якову Правицькому: «юнак хороший, не заздрісний, простий, дуже жадібний до істинної науки, задоволений своїми здібностями, від природи по-справжньому порядний, м`який, людяний. Це ті якості, що спонукали мене полюбити його. Такого ж складу, як мені здається, і Василь Білозер. Поки я їх вважаю такими, до того часу їх любитиму».

Педагог рекомендував непомітно пробуджувати розум учнів і допомагати їм оволодівати необхідними знаннями і навичками. Він на практиці здійснював свої методи виховання і завжди досягав бажаних результатів.

Так, щоб М.Ковалинський успішно оволодів латинською мовою, Г.Сковорода майже щодня писав йому листи цією мовою, а той повинен був відповідати йому тією ж мовою. Навчаючи учня мовам, педагог виховував і прищеплював йому власний ідеал життя і щастя, який обгрунтовував у своїх філософських та мистецько-педагогічних працях.

У листах 1762-1764 рр. до М.Ковалинського Г.Сковорода розповідав також про досвід проведення різних форм музичних занять - індивідуальні уроки співу та колективні заняття 3 хором у супроводі органу. Під час занять педагог формував спеціальні уміння й навички, а також розвивав творче мислення i серйозне ставлення до майбутньої професії.

У процесі індивідуальних уроків співу кожен студент виконував самостійне завдання, користуючись допомогою викладача. На думку Г.Сковороди, така організація навчання дозволяла врахувати та розвивати творчі здібності й 
обдарування студента, складати та виконувати індивідуальний план роботи 3 ним, а також допомагала здійснювати контроль за ходом та наслідками навчально-виховного процесу.

У листі від 01.10.1762 p. щодо колективних занять педагог писав М.Ковалинському: «Сам я проводитиму 3 хлопцями навчання в супроводі органа, тим часом подбай про те, щоб трохи підготувати до співів по нотах нашого Максимка». У ході колективних занять Г.Сковорода формував у студентів уміння й навички багатоголосної музики, розвивав музичний слух вихованців, використовуючи матеріали народнопісенної творчості закладав основи національної музичної культури молоді.

Просвітянин проводив колективні музичні заняття і у формі прогулянок на природу, спрямовуючи учнів на вивчення матеріалів народної творчості, зокрема пісень, присвячених любові до рідної української землі, поваги до людей, засудженню аморальних вчинків, соціальної несправедливості.

Педагогічно корисним у цьому аспекті є його лист від 1763 р., в якому розповідається про розвиток музичних здібностей та обдарувань учнів у ході вечірніх прогулянок на лоно природи: «Після вечірньої молитви я дуже хотів би відновити вчорашню прогулянку. Після виходу з храму ти зайди до мене або прямуй вчорашньою мальовничою долиною по тих низинних місцях, по яких ми вчора поверталися, але йди повільно, щоб я міг тебе наздогнати. Я приведу із собою і велику частину хору, тобто моїх співаків-хлопців. Візьму і того автора, здібності якого приносять мені найбільшу втіху».

Про те, що Г.Сковорода писав музику і його твори співали й виконували, $\epsilon$ згадка в листі 1963 р. до М.Ковалинського: «...склав я епіграму... Мені здається, вона...гідна бути проспіваною сьогодні» . Слід зазначити, що під час музичних занять Г.Сковорода складав і використовував власні пісні, спрямовані на виховання високих моральних якостей студентів.

Так, у листі до М.Ковалинського 1767 р. він зазначав: «Посилаю нову мою пісню. Ось вона: «Бездна бездну призивает». Ця пісня не $\epsilon$ великий камінь, а дуже маленький камінець, проте небезкорисний для виховання благочестя». Г.Сковорода наголошував на важливості виховання за допомогою пісенної творчості загальнолюдських моральних якостей особистості, підкреслював, що „благочестя та доброчесність робить людину щасливою і зберігає щастя».

У процесі діяльності просвітянин приділяв багато уваги і такій формі роботи, як етичні бесіди, що підтверджується його висловлюваннями в листуванні 3 М.Ковалинським. «...Я зможу легко навідатись до тебе і з тобою, вельми дорогим мені, віч-на-віч вести найприємнішу бесіду», або «Уже три дні, як готова обіцяна мною ода. Щодо мене, то я не проводив би жодного дня без бесіди 3 тобою», писав Г.Сковорода. «Всяк бесідник, - говорив педагог, - есть сеятель, ...разговор - есть сообщение мислей и будто взаимное сердец лобызание».

У листі 1784 р. Михайло з вдячністю згадує про бесіди з учителем, які сприяли його духовному розвитку, виховували людські почуття: «Дуже дякую Вам за любов Вашу до мене; ще більше дякую за дружні бесіди, які нагадують мені найсолодші, блаженні часи безжурності, молодості і простоти...Якби мені 
вдалося усамітнитися від всього і просити Вас розділити залишок життя разом зі мною...Скрипочку або флейту хорошу пришлю Вам...».

Спираючись на природні нахили і здібності свого учня, Г.Сковорода постійно надавав корисні педагогічні поради: «Чим більше успіхів досягнеш у вивченні літератури, тим кращі успіхи будеш потім здобувати в будь-якій науці, а зокрема у музичному мистецтві», «Чим повільніше будеш вивчати, тим плідніше навчання», «Варто читати не так багато щодо кількості, як багато щодо якості», - підкреслював педагог.

Уроки музики просвітянина були різні за своїм змістом і методикою, вони захоплювали учнів, розвивали музичний слух, формували вокально-хорові знання, уміння й навички, виховували почуття ритму та інші елементи музичного сприйняття. Любов Г.Сковороди до музичного мистецтва, потреба в музиці як засобу розвитку духовності особистості передавалася учням у процесі слухання духовної та народної музики, сприяли формуванню у вихованців основ національної музичної культури.

У 1768 р. при Харківському колегіумі для дворян, купців та різночинців були відкриті додаткові класи. Педагог почав викладати в цих класах курс християнського добронравія, що передбачав вивчення катехізису християнського віровчення в запитаннях і відповідях.

У ЦДІА збереглося донесення Г.Сковороди з проханням від 7.07.1768 p. на ім`я харківського губернатора генерал-майора Свдокима Олексійовича Щербініна прийняти його на посаду вчителя катехізису в додаткові класи Харківського колегіуму з жалуванням п`ятдесят карбованців на рік.

Губернатор, який, за свідченням М.Ковалинського, був «наділений природним здоровим розумом, любитель наук, талантів, співу, музики, в якій і сам добре розумівся», і поряд з цим особисто знав Г.Сковороду як визначного філософа, педагога й музиканта 08.07.1768 р. підтримав його прохання i дозволив зарахувати Г.Сковороду на посаду вчителя катехізису.

У цьому ж архіві зберігся табель (розклад) занять учнів у додаткових класах за 1768-1769 навчальний рік. Аналіз табеля свідчить, що учні навчалися 6 днів 3 7.00 до 17.00 годин щоденно. Під час занять отримували знання з грецької, латинської, французької, німецької та італійської мов; російської та латинської граматик; вивчали арифметику, геометрію, філософію, історію, географію і катехізис, студіювали поезію, риторику та богослов я, а також мистецькі дисципліни - архітектуру, живопис та малювання. Цей розклад подано в додатках до дослідження.

Із загального розкладу занять учнів у додаткових класах Харківського колегіуму за 1768/1769 навчальний рік вважаємо за доцільне розглянути розклад ранкових і денних занять 3 дисциплін, які викладав Г.Сковорода. 
Таблиця 3

Розклад занять учнів додаткових класах Харківського колегіуму за 1768/69 навч. рік

\begin{tabular}{|c|c|c|c|c|c|c|c|}
\hline $\begin{array}{l}\text { Навчальні } \\
\text { предмети }\end{array}$ & & понеділок & вівтор & середа & четвер & п'ятниця & субота \\
\hline $\begin{array}{l}\text { Грецька } \\
\text { Мова }\end{array}$ & Ранок & $7^{00}$ & 700 & $7^{00}$ & $7^{00}$ & $7^{00}$ & $7^{00}$ \\
\hline \multirow{2}{*}{$\begin{array}{l}\text { Російська } \\
\text { поезія } \\
\text { риторика }\end{array}$} & Ранок & $10^{00}$ & $10^{00}$ & $10^{00}$ & $10^{00}$ & $10^{00}$ & $10^{00}$ \\
\hline & День & $14^{00}-14^{30}$ & $12^{00}$ & $14^{00} 14^{30}$ & $12^{00}$ & $14^{00}-14^{30}$ & $12^{00}$ \\
\hline \multirow[t]{2}{*}{$\begin{array}{l}\text { Латинська } \\
\text { поезія }\end{array}$} & Ранок & $9^{00}$ & $9^{00}$ & $9^{00}$ & $9^{00}$ & $9^{00}$ & $12^{00}$ \\
\hline & День & $13^{00}-13^{30}$ & $12^{00}$ & $13^{00} 13^{30}$ & $12^{00}$ & $13^{00}-13^{30}$ & $12^{00}$ \\
\hline \multirow[t]{2}{*}{$\begin{array}{l}\text { Латинська } \\
\text { риторика }\end{array}$} & Ранок & $9^{00}$ & $9^{000}$ & $9^{000}$ & $9^{00}$ & $9^{00}$ & $9^{00}$ \\
\hline & День & $13^{00}-13^{30}$ & $12^{00}$ & $13^{00} 13^{30}$ & $12^{00}$ & $13^{00}-13^{30}$ & $12^{00}$ \\
\hline Катехізис & День & $12^{00}$ & $12^{00}$ & $12^{00}$ & $12^{00}$ & $12^{00}$ & $12^{00}$ \\
\hline
\end{tabular}

У процесі вивчення поезії, риторики та богослов я під час лекцій та інших форм занять студенти отримували знання в галузі світської й духовної музичної освіти, а в ході виступів з музичними концертами на урочистих зборах в колегіумі, концертів на приватних вечірках шляхом виконання кантів, псалмів, світських пісень, гри в оркестрі набували практичних музичних умінь і навичок.

Джерела свідчать, що у розвитку особистості Г.Сковорода відводив також важливу роль набуттю учнями знань 3 дисциплін мистецького циклу. До аналізованого табеля входило вивчення архітектури, живопису та малювання.

Таблиця 4

Розклад мистецьких дисциплін у додаткових класах

Харківського колегіуму1768/1769 навч. рік

\begin{tabular}{|c|c|c|c|c|c|c|c|}
\hline $\begin{array}{l}\text { Навчальні } \\
\text { предмети }\end{array}$ & & $\begin{array}{l}\text { понеділо } \\
\text { к }\end{array}$ & $\begin{array}{l}\text { вівторо } \\
\text { к }\end{array}$ & середа & четвер & п'ятниця & субота \\
\hline $\begin{array}{l}\text { Архітектур } \\
\text { a }\end{array}$ & День & $14^{00}-15^{00}$ & $14^{00} 15^{00}$ & $14^{00} 15^{00}$ & $14^{00} 15^{00}$ & $14^{00}-15^{00}$ & $14^{00}-15$ \\
\hline Живопис & День & $16^{00}-17^{00}$ & $16^{00} 17^{00}$ & $16^{00} 17^{00}$ & $16^{00} 17^{00}$ & $16^{00}-17^{00}$ & $12^{00}$ \\
\hline Малювання & Ранок & $11^{00}-11^{30}$ & $12^{00}$ & $11^{00} 11^{30}$ & $12^{00}$ & $11^{00}-11^{30}$ & $11^{00} 11^{30}$ \\
\hline
\end{tabular}

Педагог-музикант добре розумів, що використання на уроках музики зразків українського фольклору відкривало перед учнями можливість залучення до величезного багатства поетичних народнопісенних традицій, основ народної мудрості, закладених багатьма попередніми поколіннями.

Виконуючи на заняттях народні пісні, Г.Сковорода прилучав учнів до рідної музичної мови, яка була основою музичного виховання й освіти народу. Все це давало можливість повернути втрачені зразки пісенної народної музики, що була 
щедрим носієм етичного й естетичного багатства української національної культури.

Виконуючи на заняттях народні пісні, Г.Сковорода прилучав учнів до рідної музичної мови, яка була основою музичного виховання й освіти народу. Все це давало можливість повернути втрачені зразки пісенної народної музики, що була щедрим носієм етичного й естетичного багатства української національної культури. Він також нагадував своїм учням деякі народні афоризми, пов язані 3 музикою, серед них: «Здоров `я, розум і сопілка - мудра спілка» або «як музика іскриста, то й душа чиста», підкреслював, що недарма в народі кажуть, що людина, яка тримає в руках скрипку, не здатна заподіяти зла.

Під час занять Г.Сковорода спирався на матеріали народної творчості, використовуючи з цією метою пісні, колядки, байки, щедрівки, прислів `я, казки та ігри, приказки, що необхідні, на його думку, для «розвитку найбільш витончених і шляхетних почуттів у серцях молодого покоління», а також давав їм образні оцінки, наприклад: «премудрая пословица», «прекрасную слыхал пословицу».

Сьогодні в меморіальному музеї Переяслав-Хмельницького державного культурного заповідника зберігаються різні народні музичні інструменти XVIII ст., зокрема ліра, цимбали, кобза й бандура, якими майстерно й досконало володів Г.Сковорода.

Цікаві матеріали експонуються в літературно-меморіальному музеї Г.С.Сковороди в с. Сковородинівка Харківської області, зокрема:

1. Копії двох палиць Г.С.Сковороди, що, за свідченням директора музею Міцай Н.I., зберігалися в Харківському історичному музеї. Більша 3 них - 3 навершям благословляючої руки, вирізана 1774 р. самим філософом, менша - 3 рукояттю у вигляді крота, була передана доктором Тараздаровим з Полтави.

2. Копія скрипки XVIII ст., яку подаровано музею одним з нащадків друга Г.Сковороди Якова Правицького. За сімейною легендою саме на ній грав Г.Сковорода.

\section{3. Типовий одяг селянина XVIII ст.}

Таким чином, в процесі музично-педагогічної викладацької діяльності у Харківському колегіумі, Г.Сковорода спирався на індивідуальні музичні особливості студентів, їхні нахили та інтереси, радив кожному студенту формувати в собі «істинну людину». Діяльність педагога була підкорена розв'язанню ряду взаємодоповнюючих завдань, спрямованих на духовне очищення i збагачення вихованців, виявлення «сродності» та розвиток природних музичних нахилів і здібностей кожної особистості, виховання національного художнього смаку студентської молоді.

\section{Список літератури:}

1. Бакай С.Ю. Музично-педагогічні ідеї та просвітницька діяльність Г.С.Сковороди на Слобожанщині. Дис. канд. пед. наук :13.00.01. Х., 2004. 263 с. 2. Григорій Сковорода. Повна академічна збірка творів / Григорій Сковорода; за ред. проф. Леоніда Ушкалова. 2-ге вид., стер. Харків : Видавець Савчук О. О., 2016. 1400 с. 


\title{
ПРОЦЕС ВИКОРИСТАННЯ ІНФОРМАЦИЙНИХ ТЕХНОЛОГІЙ НА УРОКАХ МУЗИКИ В ЗАГАЛЬНООСВІТНІЙ ШКОЛІ
}

\author{
Дудик Романа Володимирівна \\ кандидат мистецтвознавства, доцент \\ Навчально-науковий інститут мистецтв \\ Прикарпатський національний університет \\ імені Василя Стефаника ( м. Івано-Франківськ)
}

Одним 3 основних досягнень XXI століття $є$ створення єдиного інформаційного простору та віртуальної реальності. Сьогодні людство охоплює нове інформаційне середовище, основна риса якого - інтерактивність. Таким чином, інформаційні технології 3 кожним роком все більш активно впроваджуються в усі галузі нашого життя та культури в цілому. Високий рівень інтерактивності, який демонструє інформаційні технології, «сприяє створенню ефективного навчально-пізаавального середовища, тобто середовища для вирішення різних дидактичних завдань. Основною особливістю даного середовища $\epsilon$ те, що воно придатне як для колективної, так і для індивідуальної форм навчання та самоосвіти. Крім цього, дане середовище комбінує функції комп'ютерного навчання 3 використанням мультимедіа та індивідуальних комунікацій» [3].

У сучасній освіті розробка програм навчальних предметів із використанням інформаційних технологій стала обов'язковою вимогою. У державному освітньому стандарті викладені рекомендації щодо організації сучасного уроку 3 використанням комп'ютера та інформаційно-комунікаційних технологій на основі діяльного підходу. Проект передбачає створення єдиної інформаційної освітньої системи, що включає в себе електронні бібліотеки, відеотеки, цифрові навчальні ресурси та їх каталоги, мультимедійні засоби, створені педагогами i самими учнями тощо. Створення учнями нових комп'ютерних програм частіше всього здійснюється у позашкільній діяльності, яка менш регламентована конкретним змістом і обмеженим часом уроку.

Згідно цього, програми позашкільної освіти дозволяють створювати і реалізовувати творчість школярів безпосередньо на заняттях спеціальності «Музичне мистецтво», що дозволяє розвивати інтелектуальні та творчі здібності учнів, необхідних для успішної соціалізації та самореалізації особистості. Успішна соціалізація школяра в умовах інформатизації може здійснюватися тільки у відкритому середовищі, яка передбачає активну позицію учнів у створенні й вдосконаленні свого навчального простору [4].

Урок музичного мистецтва в середній загальноосвітній школі - унікальний сам по собі, і традиційно є одним 3 найбільш складових уроків. Поява нових музичних напрямків і засобів зумовила виникненню різних версій, поглядів щодо оновлення змісту цього предмету та методів навчання школярів. До нових 
технологій і методів навчання можна віднести інформаційно-комунікаційні технології, які передбачають активне використання та створення цифрових навчальних ресурсів, проектні технології креативного характеру, проте, 3 урахуванням етнографічної та фольклорної приналежності.

Кожен етап уроку музики повинен взаємодіяти один з одним, підкорятися сценарію, спрямованого на пізнання школярем образно-змістовної сторони музики. Варто згадати слова В. Сухомлинського: «Музичне виховання - це не виховання музиканта, а, перш за все, - виховання людини» [7].

Швидко змінюється соціальна ситуація, природно тягне й за собою і зміни самого змісту предмету - «Музичне мистецтво». Так, наприклад, фактор стихійного розвитку музичного середовища дуже впливає на формування музичного смаку учнів. Крім того, сильно змінилися і самі учні. Дослідники підкреслюють, що сучасному поколінню властиві жорстокість, егоїзм, перевага комфортних умов існування, прагнення до новизни, неординарності, ексклюзивізму. Всі ці соціально-психологічні особливості необхідно враховувати при розробці навчальних програм і педагогічних технологій викладання предметів навчальної галузі «Мистецтво».

Сучасний учень - це, перш за все, «мобільна» особистість, яка намагається змінюватися у відповідності з вимогами часу. Світ технічних засобів, програмних систем, гаджетів повинен заповнити не тільки індивідуальний простір школяра, а й увійти в інформаційне навчальне середовище школи. Оперу, мюзикл чи балет, простіше «скачати», ніж відвідувати театр опери чи балету. I чим далі, тим більше: з'являються нові моделі телефонів, смартфонів і планшетів, реєструються нові соціальні мережі, завдяки яким, учні також можуть засвоювати шкільний матеріал з допомогою різних додатків.

Сучасний учитель музики повинен не тільки знати музично-комп'ютерні технології, але і бути професійним фахівцем, уміло й правильно використовувати їх у своій роботі. Йому необхідно вміло працювати 3 різним програмним забезпеченням та володіти спеціальними технічними засобами. До таких програмних засобів можна віднести такі, як звукові редактори, програми для зведення аудіо і MIDI-даних, а також нотно-видавничі системи та інші програми. Таке програмне забезпечення дозволяє синтезувати звук, створювати аранжування та оригінальні композиції, виконувати звукорежисерську роботу, зводити аудіо- та MIDI-дані, займатися нотно-видавничою діяльністю тощо.

Найбільш ефективним відбувається процес застосування інформаційних i комунікаційних технологій, які дозволяють навчити школяра самостійно шукати інформацію, виділяти в ній істотні властивості, узагальнювати, систематизувати i представляти iï у найбільш оптимальному варіанті. На уроках музики застосування комп'ютера дозволяє значно розширити кругозір учнів про різні музичні твори, підкреслити різницю виконання одних і тих же творів, виділити особливості звучання різних інструментів тощо.

Навчальний процес предмету «Музичне мистецтво» грунтується на розвитку творчих здібностей учнів, їх емоційності і сприйнятливості, інтелектуальної сфери та художнього смаку. Особлива увага приділяється оволодінню художньопрактичними вміннями та навичками в різноманітних видах творчої діяльності, 
«освоєння жанрового і стильового розмаїття музичного мистецтва, специфіки виразних засобів музики й мови, взаємозв'язку з життям» [1].

Пріоритетним у розвитку творчого мислення учня на уроці музичного мистецтва $\epsilon$ процес створення повної гармонії та взаєморозуміння між мистецтвом і учнем. Це досягається шляхом створення певних умов на уроках, де враховані національні та регіональні особливості, можливості для навчальної продуктивної співпраці заактивною участю кожного школяра зокрема.

Педагог є активним учасником творчого життя учнів, при тому, що всі соціальні зміни, наукові та практичні досягнення відображаються як в самому мистецтві, так і в методиках його викладання, відновлених відповідно до сучасних вимог, тим самим, покращуючи якість навчання учнів як в образотворчому, так і музичному мистецтві тощо [6].

Сервіс Інтернету відкриває сьогодні кожному студенту, вчителю, батькам, тобто всім учасникам навчального процесу багатогранні можливості: соціальні мережі, форуми, (мікро) блоги, сервіси соціальних новин та соціальних закладок, фото і відео-канали тощо.

У процесі навчання як на уроках, так і в позаурочній діяльності, на наш погляд, доцільно використовувати такі засоби ІКТ: віртуальні галереї та музеї, вебсайти з розділу мистецтва, електронні підручники і електронні книги, системи дистанційного навчання, відеохостинг «Ютьюб», відкриті колекції графічних, аудіо та відео, системи відеозв'язку і телеконференції, пошукові системи, офісні пакети, засоби для розробки презентацій, електронну пошту.

Освітні інформаційні технології на базі сучасних технічних засобів.

Технічні засоби навчання - сукупність технічних пристроїв із дидактичним забезпеченням, що забезпечує у навчально-виховному процесі обробку інформації з метою оптимізації.

Комn'ютер - цей програмований електронний пристрій, здатний обробляти дані та проводити математичні обчислення. Комп'ютер значно розширив можливості представлення навчальної інформації. Можливість застосування мультимедійних форматів (комп'ютерної графіки, звуку в поєднанні з сучасними засобами відеотехніки), дозволяє моделювати різні ситуації та середовища, виводячи заняття на якісно більш високий рівень.

Використання додаткових технічних засобів, таких як мультимедійний проектор і інтерактивна дошка, можуть додатково підвищити рівень засвоєння навчальної інформації учнями за допомогою іiї візуалізації.

Можна виділити основні можливості використання комп'ютера в навчальному процесі:

- робота з навчальними програмами;

- виконання математичних обчислень;

- пошук інформації;

- моделювання різних процесів тощо.

Мультимедійний проектор (відеопроектор) - технічний засіб, призначений для проектування різних зображень на великий екран із джерела відеосигналу.

Мультимедійний проектор дозволяє:

- користуватись будь-якими комп’ютерними додатками; 
- використовувати на заняттях навчальні відеофайли;

- демонструвати презентацію для аудиторії;

- використовувати матеріали глобальної мережі Інтернету тощо.

Застосування проектора у навчальній діяльності дозволяє збільшити рівень наочності навчального процесу [5].

Графопроектор - цей технічний засіб для проектування на екран зображень, нанесених на файли (кодограми) стандартного формату А4. Графопроектор може бути також використаний при демонстрації інших прозорих об'єктів (колб, пробірок тощо), динамічних ілюстрацій хвильових і оптичних явищ, хімічних реакцій тощо.

Слайд-проектор - технічний засіб, призначений для проектування статичної інформації з точною кольоровою передачею щодо носія інформації (слайду) й автоматичним підстроюванням фокусу різкості зображення.

Як і мультимедійний проектор, графопроектор і слайд-проектор дозволяють збільшити наочність матеріалу, що викладається.

Інтерактивна дошка - це сенсорний екран, приєднаний до комп'ютера, 3 якого зображення передається на дошку за допомогою мультимедійного проектора.

Для роботи інтерактивної дошки необхідно встановити в комп'ютері спеціальне програмне забезпечення. Тільки в цьому випадку, сенсорний екран реагуватиме на дії користувача. Для нанесення записів на дошку призначені спеціальні маркери. При торканні дошки сигнал передається на комп’ютер, i програмне забезпечення виконує необхідну дію. Писати можна безпосередньо на екрані. Інтерактивні дошки бувають прямої та зворотної проекції. При прямій проекції проектор установлюється перед дошкою на підставці або на стелі. При зворотній проекції проектор установлюється за дошкою.

У процесі навчання, так само, можливе використання аудіопрогравачів, відеопрогравачів, DVD-плеєрів тощо.

Характеризуючи сучасний стан музичного навчання в загальноосвітній школі на різних щаблях освіти, зазначимо таке. Стійка тенденція інформатизації освіти в даній галузі відкрита, як на лице. Позитивним явищем можна вважати масштабні можливості мережі Інтернет щодо доступу, поширення та обміну інформацією (нормативної, інструктивної, навчальної, методичної тощо) між вчителями музичного мистецтва, батьками, адміністрацією навчальних закладів держави. Збільшується зацікавленість учителів музики в професійному спілкуванні, в рамках соціальних мереж загального користування (Facebook, Twitter, Instagram), персональних сайтів, учительських порталів, клубів, мережевих навчальних спільнот тощо.

Слід зазначити, що поступово зростаюча чисельність уроків музичного мистецтва різного напрямку (відкриті, підсумкові, концерти тощо), методичних розробок та іншої подібної інформації, використовується вчителями музики різних шкіл у глобальній мережі для вільного доступу та обговорення. Таким чином, посилюється і рівень впливу неформальної чи додаткової музичної освіти на стан процесу навчання музичного мистецтва в загальноосвітній школі. Інакше кажучи, загальноосвітні школи широким спектром позашкільної діяльності, де 
залучення до мистецтва необов'язкове, все ж впливає на розвиток музичних інтересів дітей та підлітків.

Широке розповсюдження інформаційно-комунікаційних технологій активізує участь молоді в численних олімпіадах, конкурсах і фестивалях різного рівня: від міського до міжнародного. Наприклад, відзначимо, певну позитивну роль таких реалізованих проектів засобами масової інформації, як «Танці 3 зірками», «Великі танці», «Голос країни», «Битва хорів», «Співуча родина» та ін. Тут, як правило, проходить процес творчих досягнень дітей та бажань батьків на швидкий успіх, до будь-яких результатів без вдумливої, серйозної та кропіткої роботи, яка необхідна при досягненні виконання зразків музичного мистецтва, навіть у системі загальної освіти [2].

Сучасним підліткам засоби інформаційно-комунікаційних технологій необхідні для вирішення комунікаційних і пізнавальних завдань. Для вчителів же, - важливий процес оволодіння ефективними методиками навчання, адекватними психологічними й віковими особливостями та можливостями учнів в умовах сучасної школи.

Таким чином, інформаційні технології $є$ важливим фактором успішного здійснення освіти майбутнього вчителя музики, що забезпечує формування інформаційно-комунікативної компетентності, сприяє ефективному розвитку самостійної інформації, комунікативної, художньо-творчої та дослідницької діяльності.

Зміст підготовки майбутнього вчителя музики в галузі інформаційних i комунікаційних технологій включає знання, вміння та навички, напрямки творчості, а також позитивні мотивовані відносини, які пов’язані з трьома важливими сферами професійної діяльності - освоєнням інформаційних технологій, психолого-педагогічних компетенцій та досвіду електронного музикування.

\section{Список літератури}

1. Алексеева Л. Л. Олесина Е. П. Ассоциация педагогов искусства как фактор повышения качества образования [Электронный журнал] / Педагогика искусства: электронный научный журнал, 2016. №3. URL: http://www.arteducation.ru/sites/default/files/journal_pdf/alekseeva_olesina_186_0.pdf

2. Алексеева Л. Л. Предметы искусства в системе современного общего образования детей (на примере предмета «Музыка») [Электронный журнал] / Педагогика искусства: электронный научный журнал, 2014. №1. URL: http://www.art-education.ru/electronic-journal/predmety-iskusstva-vsistemesovremennogo-obshchego-obrazovaniya-detey-na-prime-0.

3. Емельянова Т. В. Информационные образовательные технологии в школе // Код доступа: http://festival.1 september.ru/articles/312893/.

4. Мащенко М. В. Социально ориентированное обучение информатике / Наука и перспективы. 2016. № 3 [Электронный журнал]. URL: nip.esrae.ru/1 1- 47. 
5. Меньшикова Н. А. Мультимедиа реклама музыкального произведения как средство формирования интереса учащихся к классическому искусству / Музыка в школе, 2007, № 4.

6. Музыкальное образование: учебное пособие для студентов высших и средних учебных заведений / Л. Л. Алексеева, Е. Д. Критская, Л. В. Школяр и др.; науч. ред. Л. Л. Алексеева. М.: «Русское слово - учебник», 2014.

7. Рудницька О. П. Педагогіка: загальна та мистецька: навч. посібник. Тернопіль: Навчальна книга - Богдан, 2005. 360 с. 


\title{
РОБОТА НАД ПОМИЛКАМИ НА УРОКАХ УКРАЇНСЬКОЇ МОВИ
}

\author{
Дудина Богданна Володимирівна \\ Студентка 3 курсу \\ Національний педагогічний університет імені М.П. Драгоманова, \\ Київ, Україна
}

\section{Строганова Ганна Миколаївна}

Доцентка, кандидатка педагогічних наук Національний педагогічний університет імені М.П. Драгоманова

«Едина справжня помилка - не виправляти свойх минулих помилок» Конфучій

На сучасному етапі розвитку методичної науки проблема роботи над помилками на уроках української мови є невід'ємною складовою освітнього процесу, спрямована на формування та засвоєння міцних знань. Адже аналіз помилок та їх виправлення, постійна робота над їх усуненням є запорукою підвищення грамотності учнів.

На жаль, перехід на дистанційне навчання, зумовлений пандемією, став неабияким випробуванням для вчителів та учнів. Але кожна проблема - це також привід до якісних змін, пошук нових можливостей освоєння сучасних новітніх технологій не зовсім ще знайомої форми навчання. Під час дистанційного навчання педагоги мають знайти нові методи роботи над помилками. Знання різних видів помилок, уміння вдумливо працювати з чернеткою та редагувати написане допоможуть зробити учнівське мовлення точним і правильним.

Дослідженню теми ефективної роботи над помилками на уроках української мови присвячено праці таких вітчизняних та закордонних психологів, педагогів, методистів та лінгводидактів: О. Бєляєв, Л. Божович, М. Вашуленко, Л. Виготський, П. Гальперін, Г. Грицак, Н. Дика, Д. Діордіца, С. Дорошенко, С. Жила, К. Климова, Г. Костюк, Д. Кравчук, Л. Мацько, В. Мельничайко, М. Пентилюк, О. Потапенко, О. Риженко, О. Рудницька, I. Синиця, Н. Сулименко, І. Хом'як, В. Цимбалюк, Г. Шелехова та ін.

У проаналізованій нами методичній літературі не виявлено чітко розроблених алгоритмів та механізмів роботи над помилками відносно вікових категорій учнів та сформованості їх мовних компетентностей.

Метою роботи $є$ дослідження особливостей ефективної роботи над помилками на уроках української мови.

Робота над помилками - це діяльність учнів, спрямована на аналіз i виправлення допущених недоліків. Класифікація мовних помилок. Досвід роботи вчителів виокремлює основні причини помилок учнів. Робота над помилками може мати різну форму організації: самоперевірка, робота в парах, робота в групах, робота з усім класом. Приклади роботи над помилками, що найчастіше зустрічаються в освітньому процесі. Організувати активну діяльність 
учнів під час дистанційного навчання можна за допомогою різноманітних онлайн-ресурсів. Найбільш дієві вправи, що допоможуть краще розпізнавати орфографічні, пунктуаційні, стилістичні, лексичні, граматичні помилки. Розроблено поради та засоби для подолання страху учнів перед помилками.

Досвід роботи вчителів виокремлює основні причини помилок учнів:

- недостатньо знань;

- невміння застосувати знання на практиці(не розпізнають орфограму, пунктограму);

- $з$ психологічного погляду ще однією причиною може бути те, що думка випереджає рухи рук (діти читають не те, що написали, а те, що хотіли написати);

- хвилювання, неуважність.

Написання диктантів учнями допоможе краще розпізнавати орфограми та пунктограми. Також можна виконувати такі вправи:

- вставити пропущені літери;

- згрупувати слова за орфограмами;

- пояснити орфограму, пунктограму;

- вставити пропущені розділові знаки;

- скласти свій приклад з аналогічною пунктограмою.

Стилістичні, граматичні та лексичні помилки діти бачать нечасто. Найбільш дієвими завданнями до вправ будуть:

- дібрати синоніми до слова;

- знайти зайве слово;

- поєднати слова в реченні (всі слова в неозначеній формі);

- побудувати речення за схемою тощо.

За умов дистанційного навчання вчителям складно повноцінно провести онлайн-урок роботи над помилками. Організувати активну діяльність учнів можна за допомогою різноманітних онлайн-ресурсів:

- ресурси для створення ментальних мап (Mindomo, MindMeister, Coggle);

- ресурси зі створення презентацій (Canva, Prezi, Beautiful.ai);

- ресурси зі створення текстів, завдань, інформаційні ресурси (Classtime, Kahoot, Quizlet, LearningApps.org, МійКлас);

- можливість накладати на відео тести (TEDEd, Edpuzzle);

- онлайн-дошка (Flipgrid, Padlet, Lino).

На основі відомих порад подолання страху учнів перед помилками пропонуємо такі:

1. Необхідно пояснити школярам, що помилятися - природньо.

2. Надати можливість учням самим виправляти свої помилки.

3. Навчатись за формулою: ризик - помилка - досвід - навичка - результат.

4. У жодному разі не озвучувати помилку учня перед однокласниками.

5. Переконатись, що, проаналізувавши помилку, дитина зрозуміла іiі.

6. Старатись приділяти увагу кожній дитині у класі.

7. Хвалити дітей за їхні успіхи.

Отже, робота над помилками дає позитивний результат, якщо вона проводиться систематично, правильно організовано, а дії учнів контролює вчитель. У сучасних умовах навчання педагог не повинен забувати про 
різноманітні цифрові ресурси та програми, інноваційні методи та прийоми, які допоможуть зацікавити дітей та зробити дистанційне навчання легким та ефективним.

Перспективи подальших пошуків у напрямі дослідження полягають у проведенні науково-дослідної роботи 3 метою створення сучасних методів оптимальної роботи над помилками в умовах дистанційного навчання.

\section{Список літератури:}

1. Вебінар: «Як організувати ефективну роботу над помилками на уроках української мови». 28 січня 2021 року. URL: https://www.youtube.com/watch?v=r Oduyl3aNx0\&t=3050s

2. Державний стандарт базової середньої освіти. 30 вересня 2020 року. URL: https://www.kmu.gov.ua/storage/app/uploads/public/5f7/5e6/b1e/5f75e6b1ee0d8989 401323.doc

3.

Класифікація мовних помилок. URL: https://naurok.com.ua/klasifikaciyamo vnih-pomilok-196451.html

4. Концепція Нової української школи. 27 жовтня 2016 року. URL: https://mon.gov.ua/storage/app/media/zagalna\%20serednya/nova-ukrainska shkolacompressed.pdf

5. Ознайомлення 3 вимогами до мовлення. Помилки у змісті й побудові висловлювання. URL: https://disted.edu.vn.ua/courses/learn/737

6. Положення про дистанційну форму здобуття повної загальної середньої освіти від 28 вересня 2020 року. URL: https://zakon.rada.gov.ua/laws/show/z0941$20 \#$ n22

7. «Чому учні бояться помилок i чому боятися не варто?». URL: https://naurok.com.ua/post/chomu-uchni-boyatsya-pomilok-i-chomuboyatisya-nevarto 


\section{ЗАСТОСУВАННЯ ХОЛДИНГ-ТЕРАПІЇ В РОБОТІ 3 ДІТЬМИ, ЩО МАЮТЬ РОЗЛАДИ АУТИЧНОГО СПЕКТРУ}

Завітренко Долорес Жораївна, кандидат педагогічних наук, доцент Центральноукраїнський педагогічний університет імені В.Винниченка

Бабенко Дар'я Андріївна

Студентка 3 курсу

Факультету педагогіки та психології Центральноукраїнський педагогічний університет імені В.Винниченка

Анотація: : У статті здійснено короткий огляд пращь щцодо аспектів проблем виховання аутичної дитини, розкрито сутність та ефективність методу «холдинг-терапії», визначено етапи проведення корекиійної роботи при застосуванні даного методу. Особливу увагу присвячено ролі батьків у вихованні дитини з РДА.

Ключові слова:спеціальна педагогіка,діти з ООП, аутизм, корекція девіантної поведінки, холдинг-терапія.

Актуальність: За останні десятки років кількість дітей з аутизмом стрімко зросла. Проблема їх девіантної поведінки та соціальної адаптації постала у суспільстві досить гостро. Їх деструктивна поведінка може нанести шкоду не лише їм самим, але і оточуючим, тому необхідно шукати все нові і нові шляхи до подолання цієї проблеми.

В наші дні ще не існує єдиного, універсального та ефективного методу корекції цього розладу. Науковці постійно намагаються розробляти та застосовувати на практиці нові способи терапії. Холдинг-терапію можна вважати відносно новим, ефективним та надзвичайно цікавим методом корекції поведінки дітей $з$ аутичним спектром розладів.

Метою цієї статті $є$ теоретичний аналіз та опис методу холдинг-терапії як засобу корекції поведінки аутичної дитини.

Аналіз наукової літератури показав, що дослідженнями методу холдингтерапії займалися в основному закордонні вчені, а саме: М.Дж.Велч, І.Перекопп, М.Запнелла, М.М.Ліблінг та інші. Також частково цікавилися цим питанням вітчизняні науковці: О.С.Нікольська, Є.Р.Баєнська, И.Д.Антонова.

Виклад основного матеріалу: Метод холдинг терапії був розроблений американським доктором медицини, психіатром і дослідником Мартою Дж. Велч. Спочатку цей метод називався «холдинг-терапією» (від англ. Hold - тримати), а пізніше був перейменований автором в «метод регуляторного зв'язку». В наші дні метод використовується для корекції широкого спектру розладів дитячого 
поведінки, але його відкриття і початкове використання було націлене на практичну допомогу сім'ям, які виховують аутичних дітей.

За описом Велч, сеанс холдинг-терапії має певні етапи: мати бере дитину на руки і утримує іiі в положенні, яке дозволяє їй встановити прямий зоровий контакт. Спочатку дитина досить спокійно може віднестись до цього, але через деякий час вона почне чинити опір. Батько, перебуваючи поруч 3 матір'ю, допомагає стримувати опір дитини. При цьому обоє батьків намагаються пояснити дитині, як важливо бути всім разом, говорять про свої почуття, тобто утримують іï не стільки фізично, скільки емоційно, аж до того моменту, коли вона перестає протистояти батькам, встановлює зоровий контакт, розслабляється, починає посміхатися, проявляє ніжність. [2] Цей момент називається «стадією дозволу». Зазвичай на цьому етапі сеанс холдингу завершується.

У 1983 в публікації доктора Велч, було висвітлено дослідження, яке описувало перші спроби застосувати новий метод терапії на практиці. Науковець співпрацювала з 4 родинами, що мали дітей з РДА. Оскільки діти відвідували педагогічні заняття, тому не лише батьки, а й фахівці (які працювали 3 цими дітьми) відзначили, що на тлі холдингу у вихованців поліпшувалася увага, дослідницька активність, здатність до контакту, зменшувалася частка стереотипної поведінки. Всі четверо дітей з РДА в подальшому змогли навчатися в школі.[3]

Новий метод терапії поведінки аутистів спричинив справжній фурор у спеціальній педагогіці. В Німеччині і Чехії холдинг-терапію популяризувала доктор І.Прекопп [1]. У своїй першій публікації вона висвітлила результати роботи 337 родинами, що мають дітей з РДА. 3 них 8 сімей відмовилися від запропонованої холдинг терапії. В інших сім'ях дітям були поставлені різні діагнози, але всі вони були в поєднанні з розладами аутичного спектру. Вік дітей варіювався від 2,5 до 17,5 років.

Холдинг проводився 1-2 рази на день, спочатку - тільки під наглядом фахівця. В результаті вже через 6 місяців всі діти, незалежно від віку, стали спокійнішими, вони стали більш охоче йти на контакт. У жодної дитини не зросла тривожність,

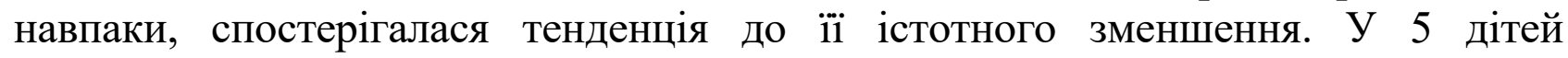
підвищився інтерес до того, що відбувається в навколишньому середовищі, у 3 дітей з ехолаліями з'явилося фразове мовлення, вони навчилися відповідати на запитання, 1 дитина 3 вираженою м'язовою гіпотонією стала енергійнішою, почала активно рухатися. Ніхто з матерів, що брали участь в експерименті, не виявив бажання припинити холдинг в майбутньому.

Пізніше І. Прекопп доповнила холдинг терапію деякими прийомами сімейної терапії, і розповсюдила свій метод роботи ( «холдинг по Прекопп») на сім'ї, які виховують дітей з різними відхиленнями емоційного розвитку [1].

Надзвичайно цікавим можна вважати досвід італійського лікаря М. Запнелли. Спочатку він не враховував роль сім'ї у корекційній роботі з аутичними дітьми. 3 дітьми займалися в основному фахівці. Але тривала робота протягом восьми років та педагогічні дослідження продемонстрували, що прогрес у своєму розвитку мали лише ті діти, яких активно емоційно підтримували батьки. Решта вихованців не могли зберегти набуті навички після того, як закінчувався курс корекційної 
роботи. Отже, Запнелла зробив висновок, що роль родини у процесі корекції поведінки дитини з ООП є дуже важливим фактором.

Варіант холдинг-терапії, який використовував М. Запнелла, вчений називав «ускладненим холдингом», оскільки провокував батьків на продовження контакту «обличчям до обличчя» 3 дитиною вже після того, як «класичний» холдинг був завершений. Паралельно $з$ роботою «в домашніх умовах» мала проводитися робота 3 психологами та педагогами[4].

Обговорення механізмів холдинг терапії, в першу чергу, передбачає пояснення феномена «дозволу», тобто вдалого завершення першого терапевтичного сеансу.

Згідно з дослідженнями, ставлення до холдингу у аутичної дитини двояке. Так, наприклад, на стадії опору дитина може кричати і всіляко демонструвати дискомфорт, але при цьому міцно триматися за маму. Або, в тому випадку, коли дитина вирвалася з материнських обіймів, вона не тікає, а стоїть поруч і чекає, коли іiї знову візьмуть на руки.

Можна припустити, що відчуття небезпеки, пов'язане з незрозумілою дитині ситуацією «утримування», постійно конкурує (під час першого холдингу) 3 відчуттями комфорту і захищеності, що виникають з тієї причини, що тримають іiі мама і батько - основні "гаранти" iіi безпеки.

Після проведених багатьох спостережень різними науковцями, було виявлено, що традиційна схема холдинг-терапії «конфронтація, опір, розслаблення» пізніше доповнювалася подальшою активною, позитивною емоційною взаємодією між батьками і дитиною.

Важливо зазначити, що холдинг-терапія розглядається лише як частина системної психолого-педагогічної корекції аутизму, є допоміжними засобом.

Висновок: Отже, холдинг-терапія - новий, ще досить мало вивчений, але оригінальний та досить ефективний метод корекції, що застосовується при роботі з дітьми, які мають аутизм. Найголовнішим при застосуванні цього методу є вдале проведення першого сеансу терапії, а в подальшому - регулярне його застосування. Це не самостійний метод роботи, а лише один з елементів корекції.

На жаль, у вітчизняній спеціальній педагогіці це питання ще не достатньо висвітлене, тому необхідна подальша активна робота 3 дослідження холдингтерапії.

\section{Бібліографія}

1. Либлинг М.М. Холдинг терапия как форма психологической помощи семье, имеющей аутичного ребенка. // Дефектология. - 1996. - №3. - С. 56-66.

2. Никольская О.С. Аффективная сфера как система смыслов, организующих сознание и поведение. М.: МГППУ, 2008. - 464 с.

3. Welch M. Retrieval from Autism in Mother-Child Holding Therapy // Tinbergen N., Tinbergen E. Autistic Children. New Hope for a Cure. Hemel Hempstead: Allen \& Unwin, 1983.

4. Zappella M. I bambini autistici. l'holding e la l'amiglia. Roma: Nuova Italia Scientifica, 1987. 


\title{
ВИДИ ЛІКАРНЯНОЇ АНІМАЦІї ЯК ЕЛЕМЕНТ РЕКРЕАЦІЙНОЇ ПРОГРАМИ
}

\author{
Кос Ольга Іванівна \\ Асистент кафедри спеціальної освіти \\ та соціальної роботи \\ Львівського національного університету \\ імені Івана Франка
}

Анімаційна діяльність в лікарняному закладі $€$ невід'ємною частиною відновлювальної, культурної і розважальної діяльності пацієнта. У світовій практиці комплекс послуг по задоволенню духовних потреб хворого, а також його батьків називається лікарняною анімацією. Анімація в лікарні - відносно нове поняття, хоча термін «анімація» існує ще з часів Стародавнього Риму (в перекладі з латинської animal - душа; animato - збуджений, живий; animatio духовність).

У медичному просторі анімація бадьорить, активізує, надихає пацієнтів. Слід зазначити, що анімація - важлива складова стаціонарного лікування, тобто процес відновлення фізичних і духовних сил тіла. Цей процес відбувається в організмі будь-якого пацієнта, незалежно від того, яка в нього хвороба і скільки часу перебуває у стаціонарі. Основу анімаційного оздоровчого і рекреаційного процесу складають об'єкти відпочинку: власне адміністрація медичного закладу, лікарі, аніматори, волонтери.

Лікарняна анімація - комплекс культурно-розважальних програм, які поєднані з лікувально-оздоровчими заходами в умовах медичного закладу. Такі програми спрямовані на відпочинок, дозвілля, відновлення духовних і фізичних сил пацієнта. За допомогою якісних рекреаційних програм можна лікувати, відволікати від повсякденних турбот, покращувати настрій, тобто відновлювати життя, силу та енергію.

3 точки зору системного підходу лікарняна анімація - це задоволення конкретних потреб пацієнта в спілкуванні, русі, культурі, творчості, приємного проведення часу, розваг. Спектр таких потреб надзвичайно широкий, пацієнти та їх батьки мають змогу обирати потрібні їм заходи та акції, що проводяться в стаціонарі для відновлення свого здоров'я.

Виокремлюють види лікарняної анімації, які відповідають різним потребам пацієнтів:

- Анімація в русі: задовольняє потребу хворого в прогулянці, поєднується 3 приємними враженнями.

- Анімація через переживання: вгамовує потребу відчувати нове, незвідане, стимулює до відкриттів, а також у подоланні страхів

- Анімація через спілкування: вдовольняс потребу в спілкуванні з новими цікавими людьми, відкриває для себе внутрішній світ людини і самопізнання через спілкування. 
- Анімація через заспокоєння: угамовує потребу пацієнта в психологічному розвантаженню від повсякденної втоми за допомогою релаксації, усамітнення, контакту з природою, перегляд відеофільмів.

- Культурна анімація: задовольняє потребу хворого в духовному розвитку особистості через залучення до молитви, звернення до екзистенційних тем.

- Творча анімація: вгамовує потреби в мистецтві, демонстрації власних конструктивних здібностей i встановленні контактів 3 однодумцями, через спільну творчість.

Анімаційна програма - це план фізкультурно-оздоровчих, культурномасових, пізнавальних, релаксаційних занять, об'єднаних спільною метою і планом. Крім концепції рекреаційної програми часто використовують анімаційні події (акції, ярмарки), які є частиною рекреаційної програми. Наприклад, якщо складати анімаційну програму на день, то вона буде вміщувати декілька заходів: майстер-класи, консультації/бесіди, відеолекторії, розваги/ігри і т.д. Процес сприйняття запропонованих анімаційних програм залежить від багатьох чинників: від учасників та глядачів, їх настрою та самопочуття на момент проведення програми. Ось чому важливо диференціювати пацієнтів, мати кілька різних програм або заходів, готових задовольнити потреби хворого. Реалізація рекреаційної програми повинна бути правильно організована, щоб досягти оптимального результату. У кожного аніматора 3 команди $є$ своя сфера діяльності та відповідальності:

1. Організатор фізкультурно-оздоровчих заходів відповідає за гімнастику, зарядку, вправи для правильного розслаблення та дихання, рухливі ігри, змагання, прогулянки на свіжому повітрі і т.д.

2. Організатор розважальних програм займається розробкою сценаріїв, підготовкою і проведення різних культурно-розважальних заходів, майстерок, вистав і т.д.

3. Менеджер служби анімації організовує і координує роботу команди, співпрацює 3 благодійними фондами, громадськими організаціями, адміністрацією медичної установи.

Реальні рекреаційні анімаційні програми часто бувають складними за своєю природою, і ці типи анімації є частиною таких заходів. Таке поєднання робить ці програми більш насиченими, цікавими, значущими і корисними для зміцнення, відновлення здоров'я, тому в співвідношенні з звичним проведенням дозвілля часто досягається найбільш оздоровчий ефект.

Створення рекреаційних програм включає такі функції лікарняної анімації:

- Адаптативна, що дозволяє перейти від повсякденного життя до спокійного перебування в умовах лікарняного стаціонару.

- Рекреаційна, що стимулює до відновлення, і розвитку фізичних сил, допомагає розслабитися.

- Компенсаційна, яка звільняє пацієнта від фізичного і психологічного болю, втоми від медичних маніпуляцій.

- Стабілізуюча, яка викликає позитивні емоції і стимулює до психологічної стабільності. 
- Інформаційна, що дозволяє отримати нову інформацію про захворюваність та можливості лікувального процесу.

- Рекламна, що залучає більшу кількість пацієнтів та їх батьків до взаємодії.

- Освітня, що забезпечує закріплення яскравих вражень.

Така різноманітність функцій рекреаційної анімації призвела до різноманітності видів анімаційних заходів, а також значну різноманітність рекреаційних програм.

Програма організації рекреаційної програми складається з урахуванням особливостей індивідуальних потреб пацієнта або групи хворих в певний період часу. Потреби пацієнта детерміновані та обмежені стосунками в лікарняному середовищі. Бажання хворого $є$ основою його інтересів. Безпосередній вибір анімаційних заходів багато в чому залежить від особистості людини, іії потреб, настрою, стану та самопочуття. В основі організації рекреаційної програми лежать певні принципи:

- добровільний вибір заходів;

- попередня готовність до участі;

- перелік видів заходів;

- зміна видів заходів;

- поєднання участі в заходах з обов'язковими маніпуляціями.

Основним завданням лікарняної анімації - формування у пацієнтів хорошого, веселого настрою. Правильно організована рекреаційна програма $є$ корисна тим, що майже завжди стимулює до творчості, кмітливості, дії, спілкування. Колективна взаємодія, часткова конкуренція, притаманна багатьом ігровим заняттям, майстеркам, виховує цінну здатність координувати свої дії 3 партнерами, знаходити раціональні способи подолання ситуації, що склалася. Лікарняна анімація дійсно корисна тільки тоді, коли вона дає пацієнтам масу позитивних емоцій та вражень. Тому одним з основних завдань анімації в медичному закладі $\epsilon$ диверсифікація спектру анімаційних послуг, диференційований підхід до заходів і, як наслідок, створення умов для вільного вибору пацієнтом рекреаційних форм.

Як бачимо, в лікарняній анімації - важливим $є$ соціокультурний фактор. I хоча він орієнтований в основному на активних пацієнтів та їх батьків, що знаходять можливість взяти участь в заходах рекреаційної програми, він не знижує, а збільшує відновлюючий та оздоровчий процес. Саме активні пацієнти досягають ефективного лікувального ефекту навіть якщо їх перебування в стаціонарі $є$ короткострокове. Анімаційна діяльність створює всі умови для рекреації, прискорює оздоровчі процеси в організмі, розвиває гуманні відносини між людьми, підвищує їх культурний та інтелектуальний рівень. Крім того, лікарняна анімація за принципом ланцюгової реакції та реклами залучає до рекреаційних програм і так званих «черепах» або «равликів», тобто пацієнтів, що пасивно ставляться до різноманітних заходів та акцій. 


\section{ПСИХОЛОГО-ПЕДАГОГІЧНИЙ СУПРОВІД ДІТЕЙ 3 ОСОБЛИВИМИ ОСВІТНІМИ ПОТРЕБАМИ В УМОВАХ ІНКЛЮЗИВНОГО НАВЧАННЯ}

\section{Олефір Наталія Віталіївна,} старший викладач

кафедри дошкільної та початкової освіти КЗВО «Дніпровська академія неперервної освіти» ДОР м. Дніпро, Україна

Для забезпечення повноцінного перебування дитини з особливими освітніми потребами в закладах загальної середньої освіти 3 інклюзивною формою навчання, необхідний відповідний психолого - педагогічний супровід, адже якість освітнього процесу значною мірою залежить від того, наскільки враховуються і реалізуються потенційні можливості навчання та розвитку кожної дитини, іiі індивідуальні особливості. I якщо робота в таких закладах буде правильно спланована та проводитись систематично, то це забезпечить захист права кожної дитини, а особливо дитини з обмеженими можливостями здоров'я, на отримання якісної освіти.

Діти з порушеннями психофізичного розвитку вимагають спеціального підходу до їх навчання, розвитку, виховання, особливих педагогічних умов при організації навчальної і виховної діяльності за рахунок реалізації психологопедагогічного супроводу.

Відповідно до цього в процесі реалізації такого супроводу повинні бути визначені конкретні форми, зміст, технології діяльності фахівців: комплексна діагностика, розвиваюча і корекційна діяльність, консультування та освіта педагогів, батьків, інших учасників освітнього процесу.

Велике значення в отриманні якісних результатів роботи 3 дітьми 3 обмеженими можливостями здоров'я має координованість впливів усієї створеної групи супроводу на дітей з особливими освітніми потребами. А саме, керівника закладу, вчителя, корекційного педагога, асистента вчителя, асистента дитини, психолога, реабілітолога, лікарів та батьків. Багато залежить від комплексного підходу всіх членів команди до планування і реалізації корекційно - розвивальних заходів.

Основні напрями психолого-педагогічного супроводу в системі інклюзивної освіти:

- попередження виникнення проблем розвитку дитини;

- допомога дитині у вирішенні актуальних завдань розвитку, навчання i виховання;

- психологічне забезпечення індивідуальних освітніх програм;

- розвиток психолого-педагогічної компетентності батьків і педагогів.

Завдання психолого-педагогічного супроводу в системі інклюзивної освіти:

- створити для дитини емоційно сприятливий мікроклімат у класі під час спілкування з дітьми та педагогічним персоналом; 
- вивчати індивідуальні особливості розвитку дітей у єдності інтелектуальної, емоційної та поведінкової сфер їхнього прояву;

- надавати допомогу дітям, які мають особливі освітні потреби;

- своєчасно проводити ранню діагностику і корекцію порушень розвитку;

- підвищувати психологічну компетентність вихователів, батьків із питань виховання і розвитку дитини [2, с. 30$]$.

Основні принципи організації психолого-педагогічного супроводу дітей у системі інклюзивної освіти:

- пріоритет інтересів і потреб дітей та учнів;

- безперервність супроводу;

- мультидисциплінарність [2, с. 31].

До основних технологій психолого-педагогічного супроводу відносяться:

- побудова адекватної можливостям дитини послідовності і глибини подачі програмного матеріалу в контексті адаптації освітньої програми для різних категорій дітей 3 особливими освітніми потребами по кожній окремій компетенції або по предмету;

- технологія проведення міждисциплінарних консиліумів фахівців, що в свою чергу сприяє вибудовуванню пріоритетів і визначенню стратегії медичного та психолого-педагогічного супроводу, як в конкретні моменти, так і на тривалі періоди, а також оцінці ефективності тієї чи іншої стратегії супроводу;

- технологія оцінки особливостей і рівня розвитку дитини, з виявленням причин і механізмів його проблем, для створення адекватної абілітації та супроводу дитини та іï сім'ї;

- технологія внутрішньо групових взаємин, для вирішення завдань супроводу всіх суб'єктів інклюзивного освітнього простору;

- технологія розвиваючої роботи з дітьми з особливими освітніми потребами, при необхідності, з іншими суб'єктами інклюзивного освітнього простору;

- технологія підтримки учасників освітнього процесу (педагогів, батьків), психологічної роботи з батьківськими і учительським очікуваннями.

Важливим аспектом кожної технології $є$ міждисциплінарний характер, взаємозв'язок діяльності кожного фахівця з іншими фахівцями супроводу, а також певна включність безпосередньо в педагогічну діяльність [4].

Вся команда, на протязі всього періоду знаходження дитини з особливими освітніми потребами в закладах загальної середньої освіти, має вивчати можливості такої дитини, ії потреби, залучається до вивчення їх індивідуальних особливостей, займається плануванням роботи 3 нею і безумовно моніторингом не тільки досягнень дитини в усіх сферах розвитку, а й моніторингом реалізації тієї індивідуальної програми розвитку, яка розробляється для цієї конкретної дитини.

Рекомендації вчителям закладів загальної середньої освіти для успішної роботи з дітьми, які мають особливі освітні потреби:

- ознайомитися 3 анамнезом, мати уявлення про основні види порушень психофізичного розвитку дитини;

- вивчити стан уваги, стомлюваності, темп роботи кожної дитини; 
- ураховувати стан слуху, зору, особливості, моторики та загального фізичного розвитку учня;

- бути добре ознайомленим із приладами, які використовують його учні 3 порушеннями зору та слуху, перевіряти придатність слухових апаратів, стежити за чистотою окулярів;

- навчитися визначати, оцінювати та створювати навчальне середовище для дітей з різними потребами;

- зрозуміти важливість цілеспрямованого залучення до роботи 3 дітьми членів родини, установлення з ними партнерських стосунків;

- вивчати головні принципи та стратегії колективної командної роботи;

- навчитися спостерігати за дітьми, оцінювати їх розвиток під час занять;

- закінчувати заняття, коли діти втомилися чи неуважні;

- навчитися адаптувати навчальні плани, методики, матеріали та середовище до специфічних потреб дітей;

- створювати оптимальні умови для спілкування, сприяти налагодженню дружніх стосунків між дітьми і формуванню колективу;

- формувати в дітей досвід стосунків у соціумі, навичок адаптації до соціального середовища, поваги до людей [3, с. 99-100].

Таким чином, психолого-педагогічний супровід - комплексна технологія, особлива культура підтримки і допомоги дитині у вирішенні завдань розвитку, навчання, виховання та соціалізації.

Водночас кожен педагог має пам'ятати, що вчителі та їхні вихованці навчаються впродовж усього життя. Використовуючи творчий підхід у педагогічній діяльності, вчитель може досягти найкращого результату сформувати особистість, здатну навчатися із задоволенням упродовж усього життя і досягти своєї мрії.

\section{Список літератури:}

1. Колупаєва А. А., Таранченко О. М. Педагогічні технології інклюзивного навчання/ А. А. Колупаєва., О. М. Таранченко. - Харків: Вид-во «Ранок», ВГ «Кенгуру», 2018. - 160 с. - (Інклюзивна освіта).

2. Кравченко Г. Ю. Інклюзивна освіта в ДНЗ/ Г. Ю. Кравченко, Г. О. Сіліна. - Х.: Вид-во «Ранок», 2014. - 176 с. - (Серія «Сучасна дошкільна освіта»).

3. Кравченко Г. Ю. Інклюзивна освіта/ Г. Ю. Кравченко, Г. О. Сіліна. - Х.: Вид-во «Ранок», 2014. - 144 с. - (Серія «Наша школа»).

4. Назарова Н. М. Спеціальна педагогіка/ Н. М. Назарова. - М. - 2008. - 400 c. 


\title{
САМООЦІНКА ДІТЕЙ ПЕРЕДШКІЛЬНОГО ВІКУ ЯК ПСИХОЛОГО-ПЕДАГОГІЧНИЙ ФЕНОМЕН
}

\author{
Подоляка Наталія Сергіївна \\ Магістрантка,
} Криворізький національний педагогічний університет

Коломоєць Таміла Григорівна

Кандидат соціологічних наук, доцент, Криворізький національний педагогічний університет

Формування навичок самооцінки дітей передшкільного віку сьогодні виноситься науковцями на якісно новий рівень, оскільки все більшої актуальності набуває формування у процесі навчання та виховання свідомої особистості, здатної критично мислити та адекватно оцінювати свою життєву позицію, вчинки та поведінку.

На сьогоднішній день в наукових колах існують різні підходи до визначення поняття «самооцінка». Як вказує Є. Дядюкіна, «більшість дослідників (У. Джеймс, К. Роджерс, І. Кон, А. Петровський, Г. Ліпкіна та ін.) розглядають самооцінку як оцінку особистістю самої себе, своїх здібностей, якостей і місця серед людей» [1]. У вказаних науковців значна кількість досліджень зосереджена в основному на цьому поняття з позиції самосвідомості.

Першим поняття «самооцінка» в науковий оборот ввів Уільям Джеймс, для якого це був«образ самого себе» у структурі особистості. На думку вказаного дослідника, структура особистості складається з трьох частин [1]:

1) її складові елементи;

2) відчуття й емоції відносно цих елементів (самооцінка);

3) вчинки, що обумовлені цими елементами особистості.

На думку С. Гончаренка,«самооцінка -це судження людини про міру наявності в неї тих чи інших якостей, властивостей у співвідношенні їх з певним еталоном, зразком. Самооцінка - вияв оцінного ставлення людини до себе. Самооцінка є результатом передусім розумових операцій - аналізу порівняння, синтезу» $[2$, с. 296$]$.

Самооцінка та самоконтроль розглядаються як єдине ціле, коли мова йде про процес навчання особистості чому-небудь, а також про питання формування життєвого досвіду. М. Фіцула дає досить багатогранне визначення самооцінки, розглядаючи іiі як метод підвищення навчально-пізнавальної діяльності й контролю за цією діяльністю, а також як критичне ставлення особистості до власних здібностей та можливостей,як об'єктивну оцінку досягнутих успіхів та результатів [3, с. 154].

За твердженням М. Боришевського, самооцінка також виступає елементом самосвідомості та являє собою емоційно насичені оцінки особистістю самої себе як особи, своїх власних здібностей, етичних якостей і вчинків [4]. 
Ю. Козерук та Я. Свсейчик характеризують самооцінку з позиції взаємини людини з іiі оточенням, іiі критичність, а також вимогливість до самого себе, відношення до успіхів і невдач. За твердженням вказаних авторів, самооцінка тим самимчинить вплив на якість та ефективність діяльності людини, на розвиток її як особистості[5, с. 163].

Самооцінка, на думку М. Пастухової, також пов’язана з однією з ключових потреб особистості - потребою в самоствердженні, що формується на основі відношення іiі фактичних досягнень до того запланованих завдань (так званого рівня домагань), тобто того, які цілі особистість перед собою ставить, на що вона претендує [6, с. 461].

Поняття самооцінки також досить часто науковцями відноситься до більш широкої теорії особистості «Я-концепції», яка трактується дослідниками як сукупність усіх уявлень особистості про себе, поєднана 3 його оцінкою цих уявлень. Відповідно, описову складову «Я-концепції» дослідники вважають «образом Я» («картиною Я»), а складову, пов'язану зі ставленням особистості до самого себе,- самооцінкою (прийняттям себе) [7, с. 42].

О. Леонтьєв характеризує самооцінку як здатність формувати у індивіда потребу з одного боку, відповідати рівню власних особистісних оцінок, а 3 іншого -рівню вимог оточуючих [8, с. 117].

С. Рубінштейн, у свою чергу, також характеризує самооцінку як основоположне складне структурне явище, що грунтується на оцінках індивіда іншими і оцінюванні самим індивідом цих інших. Основу самооцінки становлять прийняті особистістю цінності, які на внутріособистісному рівні визначають механізм саморегуляції поведінки [9].

А. Захарова характеризує самооцінку як центральне утворення особистості, через яке відбувається становлення особистості та індивідуальності. Самооцінка аналізується як системне утворення, що є компонентом самосвідомості [10].

І.Чеснокова характеризує самооцінку як результат взаємодії емоційноціннісного само ставлення особистості та її сфери самопізнання. Людина при цьому включається в регуляцію поведінки, а також відбивається рівень знання особистістю себе i ставлення до себе, що $є$ необхідною внутрішньою психологічною умовою тотожності та константності особистості [11, с. 144].

Л.Бороздіна трактує самооцінку як наявність критичної позиції індивіда по відношенню до того, чим він [12, с. 99-101].

Таким чином, дослідження показало, що більшість авторів одностайні у визнанні багатоплановості структури самооцінки, iі складності, а також постійного розвитку. Процес усвідомлення себе відбувається у єдності когнітивної оцінки своїх можливостей, досягнень і емоційних реакцій, переживань $з$ приводу цієї оцінки, тобто, самоставлення.

Спостереження i оцінювання міркувань дітей передшкільного віку допомагають визначити певні тенденції і специфічні особливості у формуванні їх оцінки та самооцінки. Вони полягають в тому, що при оцінюванні своїх друзів i самих себе дитина не називає якихось особистісних, характерних рис. Ї̈̈ оцінка носить скоріше загальний, недиференційований характер: «поганий», «хороший», «розумний», «дурний». Більшість дітей середнього, а часом і 
старшого дошкільного віку застосовують ці поняття неадекватно, так як вони ще не $\epsilon$ сформованими. Поняття «хороший», «розумний», «слухняний» дитина застосовує як тотожні. Також для дитини поняття «поганий», «нерозумний» мають на увазі поняття «неслухняний».

У дитини в передшкільному віці в зміст уявлень про себе саму входить відображення своїх властивостей, якостей, можливостей. Відомості та інформація накопичуються поступово за допомогою одержуваного досвіду дитиною, творчої діяльності, спілкування з дорослими і друзями.

Дослідження також показало, що у передшкільному періоді оцінка i самооцінка мають, скоріше, емоційний характер, що грунтується на емоціях дорослих стосовно даної дитини. Діти помічають, що серед дорослих найпозитивнішу оцінку заслуговують ті діти, у відносинах з якими проявляється слухняність, повага, довіра, любов, тобто позитивні емоції.

Отже, оцінка та самооцінка дітей передшкільного віку носить нестійкий, неусвідомлений характер та багато в чому залежить від емоційнопсихологічного стану оточуючого середовища на певні їх вчинки та поведінку взагалі. Тому 3 педагогічної точки зору дуже доречним буде урахування провідного педагогічного досвіду щодо формування у дітей ще з передшкільного віку позитивного ставлення до добрих вчинків і гарної поведінки, що можуть бути прикладом для наслідування іншими дітьми та формування позитивної самооцінки у дітей ще з цього періоду становлення особистості.

\section{Література:}

1. Дядюкіна Є. В. Самооцінка як міждисциплінарне поняття. Науковий вісник Донбасу. 2011. № 1. URL : http://nbuv.gov.ua/UJRN/nvd_2011_1_21

2. Гончаренко С. Український педагогічний словник. Київ : Либідь, 1997. 376 c.

3. Фіцула М. М. Педагогіка : навч. посібник. Київ : Академвидав, 2006. 559 с.

4. Боришевський М.Й. Особистість у вимірах самосвідомості. Суми: Еллада, 2012. $608 \mathrm{c}$.

5. Козерук Ю. В., Євсейчик Я. О. Самооцінка як фактор становлення особистості студента. Вісник Чернігівського нащіонального педагогічного університету. Серія : Педагогічні науки. 2015. Вип. 124. С. 163-165.

6. Пастухова М.В. Теоретические аспекты психологического изучения самооцінки личности. Известия Самарскогонаучного иентра Российской академии наук. 2010. № 5. Т. 12. С. 460-462.

7. Бернс Р. Чтотакое Я-концепция.Психологиясамосознания: Хрест. / Ред. Д. Я. Райгородский. Самара: Бахрах-М, 2003. 393 с.

8. Леонтьев А. Н. Деятельность. Сознание. Личность.Москва : Политиздат, $1975.368 \mathrm{c}$.

9. Рубинштейн С. Л. Основы общей психологии.СПб.: Питер, 2002. 720 с.

10. Захарова А. В. Психология формирования самооценки. Минск, 1993. 100 c. 
11. Чеснокова И. И. Проблема самосознания в психологии. Москва : Наука, 1977. $144 \mathrm{c}$.

12. Бороздина Л. В. Что такое самооценка? Психологический журнал. 1992. T. 13. № 4. C. 99-101. 


\title{
СОЦАЛЬНО ЗНАЧИМІ НАВИЧКИ В ОСВІТНЬО- ПРОФЕСІЙНИХ ПРОГРАМАХ ПІДГОТОВКИ ФАХІВЦІВ 051 ЕКОНОМІКА
}

\author{
Разуменко Дмитро Олегович
}

кандидат педагогічних наук, доцент,

Харківський національний педагогічний університет імені Г.С. Сковороди

В умовах сьогодення постає вузловим питанням проблема розвитку особистості в професії, що передбачає взаємодію і комунікування. До таких належить і кваліфікація бакалаврів економіки та фінансів, економіст, вчитель економіки та фінансової грамотності [2]. Професії, які відповідають указаним кваліфікаціям, вимагають конструкту і балансування професійних і соціально значимих гнучких навичок. Робота з кадровим персоналом відтепер передбачає iз застосуванням методів логістики, 3 оцінкою професійних і особистісних навичок. Хоча категорія соціально значимих i гнучких навичок набуло поширення із середини 1960-х років, але в Україні така практика оцінки кадрового потенціалу набула поширення лише у 2000-х роках. Соціально значимі гнучкі навички слугують своєрідним орієнтиром кадрових служб організацій і установ в оцінці перспектив і карти професійного розвитку потенціалу кандидата.

Зазначимо тут, що соціально значимі гнучкі навички - це універсальні компетентності, які інколи важко виміряти звичними інструментами чинних систем оцінювання. Досить часто міра прояву гнучких навичок залежить від типу особистості, персональних властивостей характеру, темпераменту, бажання розвиватися кар'єрно, формувати і підтримувати свою репутацію. Часто гнучкі навички проявляються в критичних умовах. Для діяльності в ситуації невизначеності і в умовах постійних змін такі групи навичок вкрай актуальні. Тому гнучкі навички ще називають ситуативними [1].

Серед груп соціально значимих гнучких навичок варто звернути увагу на такі: уміння працювати в команді і автономно, критичне і креативне мислення, навички ергодизайну (оптимально розподіляти фактичні ресурси сил, часу, матеріально-технічні та інші під час планування і реалізації професійних завдань), відповідальність, послідовність у вчинках і словах, професійна дисципліннованість.

Сучасні освітньо-професійні програми підготовки здобувачів вищої освіти вже використовують у змісті формулювання компететностей і відповідних програмних результатів навчання. Так, особливостями ОПП першого бакалаврського рівня «Економіка та фінанси», 05 Соціальні, поведінкові науки, 051 Економічні науки, розробленої у Харківському національному педагогічному університеті імені Г.С. Сковороди, визначено: «мультидисциплінарність 3 орієнтацією на розвиток фінансово-аналітичної грамотності, бізнескомунікативних умінь та розвитку відповідальності» [2]. Серез загальних компетентностей в представленій ОПП виокремлено здатність 
застосовувати знання у практичних ситуаціях, до креативного та критичного мислення, здатність приймати обгрунтовані рішення, навички міжособистісної взаємодії, виявляти ініціативу та підприємливість, свідомо та соціальновідповідально діяти на основі етичних міркувань [2]. Відповідно сформульовано і групи програмних результатів навчання, а саме: 13, 14, 15, 20 [2].

Доцільно зазначити, що соціально значимі компетентності формуються не лише ресурсами ОПП. Частіше гнучкі навички розвиваються у позааудиторній роботі, у соціальних практиках волонтерства і підтримки соціально незахищених верств населення. До того ж, кожен заклад вищої освіти пропонує цілий арсенал цікавих конструктивних форматів комунікувань: майстер-класи, круглі столи, тренінги, імітаційні та неімітаційні ігри. Використання Web-сервісів розкриває нові перспективи в розвитку гнучких навичок, зокрема: розширення кола $\mathrm{i}$ географії професійного спілкування, інтернаціоналізація вищої освіти, долучення до самореалізації у неформальній освіті,

\section{Література}

1. Освітній ХАБ міста Києва [ Електронний ресурс ] URL : https://eduhub.in.ua/news/shcho-take-hard-skills-i-soft-skills-yak-nas-ocinyuyerobotodavec

2. ОПП першого бакалаврського рівня «Економіка та фінанси», 05 Соціальні, поведінкові науки, 051 Економічні науки, Харківський національний педагогічний університет імені Г.С. Сковороди [ Електронний ресурс ] URL : http://smc.hnpu.edu.ua/files/Osvitni_programi/Osvitni_programu_bakalavr/2020_rik/ Ekonomika_ta_finansi.pdf 


\title{
УКРАЇНСЬКИЙ ПЕДАГОГ ЯК СУБ'СКТ МОДЕРНІЗАЦІї: РЕЗОНИ ДЛЯ ЗМНН У ПЦДИЩЕННІ КВАЛІФІКАЦї
}

\author{
Скрипник Марина Іванівна, \\ кандидат педагогічних наук, \\ доцент, доцент кафедри філософії і освіти дорослих \\ ДЗВО «Університет менеджменту освіти» \\ НАПН України
}

Які зміни мають відбутися у підвищенні кваліфікащзї в Україні, щзоб педагог реалізував освітні тренди XXI cm.? Особлива відповідальність нинішнього етапу змін у вітчизняній освіті визначається низкою актуалітетів, серед яких: законодавчі: ухвалення та початок імплементації базових законодавчих актів на державному рівні («Закон про освіту», «Закон про вищу освіту», Концепція Нової української школи); безпекові: вітчизняна освіта у сучасному глобальному контексті є питанням національної безпеки. Серед чинників, що визначають актуальні для національної безпеки проблемні зони в освітній системі, 3 яких випливають критерії національної безпеки в освітній сфері, виділяються такі: рівень вивчення суспільствознавчих предметів (історія, політична та правова системи, єдині національні цінності); рівень знання іноземних мов; рівень опанування природничих наук, математики, а також практичних навичок, необхідних для освоєння сучасних професій, у тому числі пов'язаних із забезпеченням національної безпеки; доступність середньої освіти (в українських умовах - негативні наслідки можливого погіршення рівня доступності та якості середньої освіти); ступінь соціальної нерівності (в українських умовах - між багатими й бідними, між містом та селом); здатність системи залучати, готувати й винагороджувати висококваліфікованих учителів; ступінь відповідності знань i навичок, які дає система освіти, потребам економіки й завданням, що стоять перед державою і суспільством [1]; глобалістики: глобальні тенденції, які будуть у найближчий час впливати на освіту, як-то: перша - зростання так званої гігономіки (Gig Economy), яка проявляється в тому, що все більше людей надають перевагу роботі на себе, перед зайнятістю на традиційній роботі; другий глобальний тренд пов'язаний 3 прагненням сучасної людини до індивідуальної самореалізації; третій полягає в децентралізації глобального освітнього ринку. Нинішні споживачі освітніх послуг самі вирішують, що, коли та в який спосіб вони хочуть вивчати. Дистанційна освіта на основі інформаційних технологій дозволяє врахувати ці тенденції. Потрібно також відзначити підвищення ролі неформальної онлайносвіти для професійного зростання фахівця; наукові: вагомим джерелом освітніх змін є інтеграція наукових розробок та освітньої практики, врахування в цьому процесі нового типу раціональності для осмислення духовної та матеріальної діяльності, а також цінностей особистості; освітні: створення відкритої системи неперервного зростання особистості упродовж життя та побудова життєвих 
пріоритетів на цьому шляху.

Теоретичний аналіз наукової літератури, дисертаційних досліджень 3 цього аспекту дав можливість визначити, що модернізації освіти (в тому числі й вищої) в Україні присвятили свої праці Н. Дем'яненко, В. Кремень, С. Курбатов, В. Луговий, В. Майборода, Н. Побірченко, О. Сухомлинська, Ж. Таланова. Зосередимося на ключовому понятті: модернізація як перехід від традиційного аграрного суспільства до світського, урбанізованого, індустріального; перехід від стабільного суспільства, до суспільства, яке безперервно змінюється [2;3]. Підкреслимо, що спосіб здійснення модернізації - реформа [3]. Підставою для обговорення поняття «модернізації» в окресленому аспекті є позиція ученого М. Михальченка, який наголошує, що «трансформація, зміна, розвиток можуть бути орієнтовані на зміну реалій куди завгодно: уперед, назад, убік, по колу і т. д. Модернізація ж орієнтує суспільство i його структури, сфери на вдосконалювання, просування вперед, на розроблення й реалізацію нових цілей, завдань, пріоритетів, стратегій. Модернізація - це творчо-перетворювальна функція розвитку. Але специфічна - як засіб оновлення суспільств. Модернізація дійсно є незавершеним проектом і проектом, що ніколи не завершується в глобальному вимірі. Суспільство, яке завершило модернізаційний проект, може вирушати на історичний смітник» [4].

Таким чином, на відміну від поступального розвитку, модернізація - якісний перехід об'єкта 3 одного конкретного стану в інший. Модернізація освіти складний, цілісний процес соціокультурної діяльності, що полягає в досягненні керованої, позитивної, якісної зміни соціальної освітньої системи. На думку дослідника Є. Пінчука, зміст модернізації не зводиться лише до інновацій, оскільки вони складають лише частину повного циклу модернізаційного процесу. Модернізація освіти - це системна якісна зміна, що включає до себе інноваційні процеси, інформатизацію, нові технології та методи комп'ютеризації, і при цьому міняє через нові завдання домінанту розвитку внутрішнього потенціалу освіти [5].

Аналіз наукової літератури з проблеми модернізації освітньої діяльності XXI ст. в Україні доводить, що це $є$ системний комплексний процес упровадження євроінтеграційних змін у систему підготовки, підвищення кваліфікації учителів. Для української системи освіти існує низка ключових проблем, серед яких: забезпечення формування інноваційної людини 3 інноваційним мисленням, інноваційною культурою, здатної до інноваційної діяльності; утвердження в освіті принципу дитиноцентризму; перехід до толерантної педагогіки; здійснення підготовки громадянина України до життя в умовах глобального простору, формування свого роду глобалістської людини; виховання у громадян України сучасної системи цінностей, що сприяли б максимальній самореалізації кожного з них, утвердженню національної єдності [6].

У цій статті зосередимо увагу на обтрунтуванні напрямів вагомих зрушень у прочесі підвищення кваліфікації педагогічних прачівників (ПКПП) в Україні для продуктивного розв'язання проблеми модернізаиії загальної середньої освіти XXI $\mathrm{cm}$. з позииї суб'єктності. Досягнення мети зумовлює постановку та вирішення 
таких завдань: інтегрувати філософсько-соціологічні, психолого-педагогічні підходи до визначення понять «суб'єктність», «суб'єктність педагога»; визначити через суб'єктність педагога ключові тенденції модернізації української освіти XXI ст. у секторі загальної середньої освіти; окреслити значущі проблеми й виклики ПКПП, які перешкоджають модернізації загальної середньої освіти з позиції суб'єктності.

Для досягнення поставленої мети та розв'язання визначених завдань використано комплекс взаємопов'язаних та взаємодоповнювальних методів дослідження, зокрема: загальнонаукові - аналіз, синтез, порівняння та узагальнення, що стали необхідними для вивчення праць вітчизняних i закордонних науковців, офіційних і нормативних документів; конкретнонаукові - метод термінологічного аналізу, використаний при висвітленні понятійнотермінологічного апарату дослідження; структурно-типологічний, що дав змогу систематизувати особливості та тенденції модернізації освіти 3 позиції суб’єктності у секторі загальної середньої освіти України; структурнофункціональний, що дозволив виявити особливості процесу модернізації 3 позиції суб’єктності у секторі загальної середньої освіти України; емпіричні педагогічне спостереження, опитування, анкетування, бесіда, обговорення дослідницьких проблем зі слухачами курсів підвищення кваліфікації педагогічних працівників - для обгрунтування актуальних проблем і викликів ПКПП, які перешкоджають модернізації загальної середньої освіти в Україні 3 позиції суб' єктності, та окреслення вагомих зрушень у ПКПП для продуктивного розв'язання проблеми модернізації загальної середньої освіти; метод наукової екстраполяції, що забезпечив визначення можливостей творчого використання досвіду модернізації змісту педагогічної освіти в післядипломній освіті України.

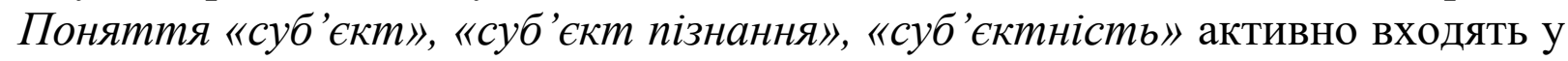
предметне поле досліджень психолого-педагогічної науки XX ст., що пояснюється зміною орієнтирів освіти та ставлення до учасників освітнього процесу. Як зазначає дослідниця О. Галян у роботі «Суб’єктність особистості школяра у педагогічному дискурсі XX століття: постановка проблеми», «починаючи з 20-х років XX ст., у вітчизняній філософській, психологічній та педагогічній науці як альтернатива безсуб'єктній парадигмі, де пізнання i діяльність пояснювалися без активної ролі людини, поступово обгрунтовується антропологічна парадигма, суб'єктний підхід, орієнтація на вільний, індивідуальний, творчий розвиток дитини, формування у неї активної життєвої позиції. Саме ці наукові конструкти стали основою формування уявлень про суб’єктність особистості у сучасному розумінні» [7].

Питання становлення і розвитку суб'єктності у сучасної вітчизняній i закордонній гуманітарній науці розглядаються як в класичних, так і некласичних типах наукової раціональності, що пояснюється впливом екзистенціальної та постмодерністської філософії. Дослідження, які стали доступними тепер, проведені в напрямі екзистенціального підходу до сучасної психологічної антропології (М. Хайдеггер, Ж. П. Сартр, Л. Бінсвангер); у річищі Его-психології (А. Фрейд, О. Кернберг); у теорії об'єктних відносин (М. Кляйн, М. Балінт, Х. Кохут); у річищі структурно-аналітичної та постмодерністської парадигм (Ж. 
Лакан, Р. Самюелз, Ж. Дельоз, Ф. Гваттарі). Традицію вітчизняної психології суб'єкта сформовано працями В. Татенко [8], Т. Титаренко [9] та ін. Загалом аналіз соціально-філософської, психолого-педагогічної літератури з проблеми дозволив узагальнити стан наукового опрацювання проблематики становлення $\mathrm{i}$ розвитку суб'єктності у сучасній вітчизняній і закордонній науці, зокрема визначено, що в науці досягнуто таких результатів:

- схарактеризовано багатозначну категорію «суб'єктність» незалежно від професійної діяльності людини (Б. Ананьєв, О. Анісімов, О. Асмолов, А. Брушлинський, Є. Ісаєв, О. Осницький, С. Рубінштейн, В. Петровський, О. Сергієнко, В. Слободчиков, В. Татенко, А. Хоменко та ін.);

- висловлено ідею про різні аспекти формування суб'єктності в процесі фахової підготовки (Н. Аристова, І. Бех, А. Бойко, С. Гришина, Т. Гущина, Н. Свдокимова, Е. Зеєр та ін.);

- сформульовано концепцію суб'єктності в контексті педагогічної акмеології (А. Деркач, I. Коновальчук, О. Королюк, Н. Кузьміна, О. Манолова, А. Маркова, С. Пальчевський та ін);

- досліджено різні аспекти суб'єкт-суб'єктної взаємодії в контексті фахової підготовки майбутніх учителів (О. Абдулліна, В. Андрущенко, Є. Бондаревська, С. Вітвицька, Б. Гершунський, С. Гончаренко, О. Дубасенюк, М. Євтух, І. Зязюн, В. Кремень, І. Зимняя, Л. Мітіна, А. Маркова, С. Савченко, О. Шмирко та ін.);

- обгрунтовано теоретико-методологічні засади суб'єктно-діяльнісного підходу (К. Абульханова-Славська, В. Бодрова, Л. Рибалко, В. Сластьонін та ін.);

- з'ясовано проблему формування суб' єктності в процесі розвитку особистості (I. Бех, А. Деркач та Е. Сайко, Л. Березовська);

- описано об'єктивну потребу формування андрагогічної суб'єктності вчителя в системі післядипломної педагогічної освіти (С. Пілюгіна).

Попри значну кількість і доволі розлоге тематичне коло напрацювань із проблеми суб'єктності в науках про освіту залишається дискусійним питання наукового підгрунтя та методичного забезпечення педагогічних умов формування суб'єктності педагога в процесі підвищенні кваліфікації для реалізації ним освітніх трендів Нової української школи.

Понятійне трактування понять «суб'єкт», «суб'єктність», «суб'єктність педагога» звертає увагу насамперед на філософський контекст дослідження проблем суб'єкта та суб'єктності, що пов'язано з ідеєю Р. Декарта про «модус субстанції» - «тіло, що мислить», концепцією трансцендентального суб'єкта I. Канта, теорією суб'єктивності Г. Гегеля, науковими положеннями Г. Фіхте щодо «справи-дії» (Thathandlung) як вольового акту самопокладання тощо. Сучасна 
філософська думка розглядає суб'єкт як носій діяльності, свідомості та пізнання, суб'єктність - як соціальну форму людської активності, тобто наголошено на діяльнісно-перетворювальному аспекті особистісного розвитку $[10 ; 11]$.

Постнекласичний етап розвитку соціогуманітарного знання зумовлює розгляд суб'єктності у вимірі множинності, ціннісної зумовленості, відкритої подієвості існування. На думку С. Шехавцової [11], психологічний контекст поняття «суб'єктність» пов'язано із розумінням трьох аспектів категорії суб'єкт: організація життя та діяльності, спосіб вирішення суперечностей та вдосконалення (А. Брушлинський); феноменом надситуативної активності як прояву суб'єктності, яка показує якісну своєрідність людини як вільної, відповідальної істоти, здатної до цілепокладання та розвитку (В. Петровський); визнанням суб'єктності як властивості особистості здійснювати взаємозумовлені зміни у світі, в інших людях, в людині (О. Волкова).

3 позиції педагогіки суб'єктність досліджено як: якісний стан особистості педагога, що констатує найвищий рівень професійного розвитку особистості педагога (С. Кашлєв); інтегровану якість, що містить компоненти різних структур організації особистості та ступенів психічного розвитку (Ф. Махаметзянова); особливу форму вияву й організації активного ставлення вчителя до себе як суб'єкта відносин з оточенням, ставлення до учнів як унікальних суб'єктів, до професійної діяльності як креативної й інноваційної (О. Мешко, Г. Мешко); цілісну аксіологічну характеристику особистості, яка розкривається в сукупності діяльностей та їхній продуктивності, самоорганізації своєї поведінки, здатності зіставляти задум і реалізацію, актуальне і потенційне, в умінні перетворювати себе та навколишню дійсність (Т. Ольхова) та ін. [11; $12]$.

Інтегруючи філософсько-соціологічні, психолого-педагогічні підходи, визначаємо:

суб'єкт (лат. Subjectus - лежить внизу, що знаходиться в основі) - людина як джерело пізнання і перетворення дійсності; носій активності, осмислено здійснює зміни у світі, інших людей і в себе самого як іншому;

основна характеристика суб'єкта - свідомий носій суб'єктивної реальності та центром буття людини. В. Петровський визначає суб'єктність як властивість індивіда бути суб’ єктом активності [13];

- концепт «суб’єктність» - якісна властивість учасників соціальної дії та взаємодії;

- суб'єктність індивіда проявляється у дії, як особливій активності, через яку актор відтворює себе і своє буття у світі;

- у педагогіці суб’єктність визначається, як високий ступінь рефлексії учнів; 
- суб'єктна позиція - авторство людини у власній життєдіяльності, виражене у втіленні в реальність самостійно поставлених цілей і усвідомлених прагнень, спрямованих на розвиток себе, інших, умов життя, самої діяльності;

- змістовні характеристики суб'єктності педагога будуть змінюватись залежно від носія дії;

- суб'єктність педагога: індивідуальна визначається індивідуальними характеристиками (активність, адаптивність, дієвість, самомотивація, цілепокладання, стратегічність, самоусвідомлення, рефлективність, абстрактне мислення, відповідальність, раціональність); соціальна - масштабами соціуму (довіра, адаптаційно-інноваційний потенціал, здатність консолідації для вирішення соціально-значущих інтересів, рівні розвитку людського потенціалу, якості життя, демократії, прогресу, гендерної рівності, інновацій, свободи);

- становлення суб“єктності як рух етапами: потреба в самостійності дій («Я хочу сам»); самостійне володіння нормою дії («Я можу сам»); здатність ставити мету діяльності й регламентувати норму дії («Я дію сам»); усвідомлення культурних й особистісних смислів власної діяльності («Я розумію, навіщо я дію»); творення нових реалій діяльності й способів дії («Я реалізую себе в діяльності для інших»).

Найголовнішим джерелом змін задля реалізації ідей Нової української школи є розвиток суб'єктності педагогів, бо:

- по-перше - професійна діяльність педагогів - це пізнання не лише науковометодичних систем, а пізнання діалектики взаємодії суб'єктів освітнього процесу, протилежних за своїми індивідуальними властивостями та соціальними характеристиками;

- по-друге - діалектика професійної діяльності педагога не лише грунтується на знанні етапів становлення суб“єктності («Я хочу сам»; «Я можу сам»; «Я дію сам»; «Я розумію, навіщо я дію»; «Я реалізую себе в діяльності для інших»), а задає суб'єктний вектор для творення нових реалій в освітній діяльності й способах професійних дій;

- по-третє - розвиток суб'єктності педагога визначає головну домінанту змін Нової української школи: Особистість - вибір - свобода. Цю концептуальну тріаду можна розглядати як маркер суб'єктності. Ситуація вибору в освітньому процесі створює умови для усвідомлення педагогічними працівниками особистісної ідентичності, яку розуміємо: по-перше, як індивідуальність свідоме відчуття власної унікальності й власного окремого існування; по-друге, тотожність і иілісність - відчуття внутрішньої тотожності, безперервності між тим, чим особистість була в минулому й чим обіцяє стати в майбутньому; по- 
третє, єдність і синтез - відчуття внутрішньої гармонії та єдності; по-четверте, соціальна солідарність - відчуття внутрішньої солідарності 3 ідеалами суспільства й соціальної підгрупи, відчуття того, що власна ідентичність має сенс для професійної діяльності й що вона відповідає їх очікуванням i сприйняттю [14].

Ключові тендениії модернізаиії з позииії суб'єктності у секторі загальної середньої освіти України:

- 1-2 роки - підвищення уваги до професіоналізачії діяльності педагога з точки зору формування професійного мислення: активізація досліджень та імплементація альтернативних моделей підвищення кваліфікації задля якіснішого забезпечення професійних потреб педагогів. У зв'язку з цим актуальності набуває модель формування професіонального мислення майбутнього педагога, розроблена колективом науковців під керівництвом Лі Дж. Шульмана [15]. Педагогічна епістемологія ученого представлена трьома концепціями: зростання учительського знання, педагогічний зміст знання, база знань учителя, дослідження яких системно вивчається у таких роботах: В. Грачової, де студіюється специфіка педагогічної освіти, досліджується проблема професіоналізації учителів, аналізується моделі формування професійного мислення майбутнього педагога, розробленої колективом науковців під керівництвом Лі Дж. Шульмана [15]; Т. Кошманової, яка зупиняється на визначенні й характеристиці поняття «педагогічно-змістові знання з фахового предмета», введеного Лі Дж. Шульманом до наукового обігу [16];

- 3-5 років - перегляд теорії й практики освіти, адекватної новому світу (у такій філософії повинні сполучатися три основних підходи: (1) психологічна теорія людської особистості, якій треба «давати освіту»; (2) соціальна теорія про суспільство, яке ми намагаємося створити або зберегти, як гідне вмістилище розповсюджуваних ідеалів культури; (3) світогляд або космологія, теорія про місце людини у всесвіті, де вона виступає як глядач і як актор. У системі освіти, призначеної для Нової Епохи, запропонована модель східно-західної філософії займе своє належне місце. Такими ми бачимо елементи теорії освіти:(а) Суб'єктивне Планування - теорія творчого саморозвитку індивідуума; (б) Об'єктивне Планування - теорія суспільства, у якому люди могли б гідно жити);

- 5 і більше років - сприяння культурі інновацій (для стимулювання інновацій та адаптації до постійно змінюваних економічних потреб суспільства, заклади середньої освіти мають структуруватися таким чином, щоб забезпечити свою гнучкість і водночас утверджувати принцип дитиноцентризму). 
Значущі проблеми й виклики ПКПП, які перешкоджають модернізаиії загальної середньої освіти в Україні з позииії суб'єктності.

Проблеми $i$ виклики, які розв'язуються (які ми розуміємо і знаємо як вирішувати):

a) персоналізація: за результатами професійного розвитку педагогів як набуття ними професіоналізму - системи практично орієнтованих форм інтелекту («realworld» intelligence): емоційного (Emotional Intelligence - EQ), культурного (Cultural Intelligence - CQ), практичного (Practical Intelligence - PQ), соціального (Social Intelligence - SQ) - структуризація інтегративних програм ПК (інтегрування суміжних наукових напрямів, галузей, дисциплін) відповідно до рівня розвитку здібностей, пов'язаних із важливими професійно-особистісними сферами життєтворчості педагога;

б) конкурентні рефлексивні моделі ПК: новітні рефлексивні моделі ПК (он-лайн курси, експрес-курси тощо), вступаючи у напружену конкурентну боротьбу 3 традиційними моделями ПК, зорієнтовано на персоналізацію ПК відповідно до розвитку у педагога системи практично орієнтованих форм інтелекту («realworld» intelligence).

Складні проблеми та виклики (які ми розуміємо, але їхнього вирішення ще не знаємо): комбінування формальної та неформальної освіти дорослих (створення SMART-середовища (самокерованого, мотивованого, адаптованого, ресурсно збагаченого, технологічного), яке сприятиме розвитку системи практично орієнтованих форм інтелекту («real-world» intelligence) шляхом методів проблемного навчання (Problem Based Learning, PBL), розвитку креативності).

Небезпечні проблеми й виклики (які є складними не тільки у плані вирішення, а й навіть у частині свого формулювання):

а) балансування професійного розвитку та професійного вигорання (запобігання ситуацій, коли педагоги в процесі професійної діяльності та ПКПП реалізують діяльність на такому рівні напруги сил, коли переживання повноти самореалізації гаситься втомою і виснаженням);

б) підтримання релевантності підвищення кваліфікації (міра відповідності отримуваного результату у процесі ПК бажаному суб'єктивному рівню педагога).

Вагомі зрушення у ПКПП для продуктивного розв'язання проблеми модернізаиії загальної середньої освіти з позииії суб 'єктності.

Часовий горизонт для впровадження 1 рік і менше:

a) створення діагностичного інструментарію визначення професійного розвитку педагогічних праиівників для дослідження системи практично орієнтованих форм інтелекту педагогів;

б) розроблення варіативних програм відповідно до системи практично орієнтованих форм інтелекту педагогів, пов'язаних із важливими професійноособистісними сферами їх життєтворчості.

Часовий горизонт для впровадження 2-3 роки:

a) освітня аналітика - застосування в ПКПП аналітики, спрямованої на збір та систематизацію курсів (елективних, он-лайн тощо) для створення інформаційного ресурсу для вибору кращих суб'єктивних практик та 
розширення можливості для активізації освітнього процесу шляхом конкурентоздатності;

б) адаптивне рефлексивне навчання - спеціалізоване забезпечення, яке адаптуються до рефлексивних потреб педагогів у процесі ПКПП з урахуванням психічної активності, саморегуляції активності, самокерування.

Часовий горизонт для впровадження 4-5 років:

а) мейкерспейси (Makerspace) - креативні простори-майстерні, поєднання лабораторії та майстерні, місця для суб'єктів освітнього процесу (втілення ідей; проведення експериментів; вивчення, застосування на практиці та вдосконалення нових навичок; створення та розповсюдження кращих освітніх практик; місця для цікавого спілкування, продуктивного проведення часу);

б) афективні технологї навчання дорослих (апелюють до ідеї технологій, спрямованих на моделювання спектру людських емоцій).

Отже, чи йдеться про те, що проблематика суб'єктності в українській освіті змінить підвищення кваліфікації педагогів? Мова йде про набагато більше: про те, як модернізація освіти у концептах Нової української школи потребує істотного інтелектуального опрацювання й інвестицій у підготовку i перепідготовку педагогів, які мають подолати в освіті завченої безпорадності (феномен відкритий американським психологом Мартіном Селігманом в 1967 р.), коли індивід не робить спроб поліпшити свій стан (не намагається уникнути негативних стимулів або отримати позитивні); є пасивним, відмовляється від дії, не бажає змінювати небажане середовище або уникати його, навіть коли 3'являється така можливість. Нарешті, варто вітчизняним організаторам підвищення кваліфікації педагогів замислитися над співвідношенням андрагогічних принципів та їх присутністю у реаліях освітнього процесу, де має бути почуття свободи, віри суб’єктів у потенціали змін.

\section{Список літератури}

1. Безпекові виміри освітньої політики: світовий досвід і українські реалії: Аналітична доповідь. К., $2017 . \quad$ C. $61-62$. URL : http://www.niss.gov.ua/content/articles/files/Osvita_Bezpeka-40c41.pdf

2. Модернізація і розвиток, Теорії модернізації, Теорія конвергенції ... URL : pidruchniki.com/12560607/sotsiologiya/modernizatsiya_rozvitok

3. Тименко М. М. Термінологічне поле 3 проблеми трансформаційних процесів в освіті у працях вітчизняних та зарубіжних науковців/М. М. Тименко //Педагогіка і психологія. 2017. № 3 (96). С. $38-44$.

4. Михальченко М. Політична реальність в Україні: трансформація, модернізація, революція? / М. Михальченко // Сучасна українська політика. Політики і політологи про неї. К., 2005. Вип. 7. С. 19.

5. Пінчук Є. А. Модернізація української системи освіти як теоретикофілософська і практична проблема: Автореф. дис. ... д-ра філос. наук / Є. А. Пінчук; НАПН України, Ін-т вищої освіти. К., 2010. 33 с.

6. Національна доповідь про стан і перспективи розвитку освіти в Україні / Нац. акад. пед. наук України ; [редкол.: В. Г. Кремень (голова), В. І. Луговий 
(заст. голови), А. М. Гуржій (заст. голови), О. Я. Савченко (заст. голови)] ;за заг. ред. В. Г. Кременя. Київ : Педагогічна думка, 2016. С. 19.

7. Галян О. І. Суб'єктність особистості школяра як інтердисциплінарна наукова проблема / O.І. Галян // Неперервна професійна освіта : теорія і практика // Науково-методичний журнал. 2015. № 1-2 (42-43). С. 23.

8. Татенко B. A. Психология в субъектном измерении: [монография] / В. А. Татенко. К. : Видавничий центр "Просвіта",1996. 404 с.

9. Титаренко Т. М. Життєві домагання особистості/ Титаренко Т.М. та ін. К.: Педагогічна думка, 2007. 453 с.

10. Ломов Б. Ф. Методологические и теоретические проблемы психологии / Б. Ф. Ломов. М: Наука, 1984. 409 с.

11. Шехавцова С. О. Теоретичні і методичні засади формування суб'єктності майбутніх учителів у процесі фахової підготовки: Автореф. дис. на здобуття наук. ступеня докт. пед. наук: 13.00.04 - теорія і методика професійної освіти/С. О. Шехавцова. Старобільськ, 2017. 47 с.

12. Галян О. І. Суб'єктність особистості школяра у педагогічному дискурсі XX століття: постановка проблеми / О.I.Галян. // Science and Education a New Dimension. Pedagogy and Psychology, III(22), Issue: 45, 2015 www.seanewdim.com URL : https://u.to/YaRDGw

13. Петровский В. А. Идея свободной причинности в психологии личности / В. А. Петровский // Психология личности / Под. ред. В. А. Петровского. СПб: Питер, 2003. С. 436 - 448.

14. Турецька X. I. До проблеми діагностичних критеріїв особистісної ідентичності / Х.І. Турецька // Філософія, соціологія, психологія : зб. наук. праць. - Івано-Франківськ : ВДВ ЦІТ Прикарпат. нац. ун.-ту ім. В. Стефаника, 2008. Вип.13. Ч.2. С. $258-266$.

15. Shulman Lee S. Knowledge and Teaching: Foundations of the New Reform / Lee S. Shulman // Harvard Educational Review. Vol. 57. No. 1. (Feb., 1987). P. 121; Shulman Lee S. Those Who Understand : Knowledge Growth in Teaching / Lee S. Shulman // Educational Researcher. Vol. 15. No. 2. (Feb., 1986). P. 4 - 14.

16. Кошманова T. С. Розвиток педагогічної освіти у США (1960-1998рp.) [монографія] / Т. С. Кошманова. Л. : Світ, 1999. 488 с. 


\title{
ГРА ЯК ЗАСІБ ФОРМУВАННЯ ЛІДЕРСЬКИХ ЯКОСТЕЙ У ДІТЕЙ ПЕРЕДШКІЛЬНОГО ВІКУ
}

\author{
Сухіна Таісія Сергіївна \\ Магістрантка,
} Криворізький національний педагогічний університет

\author{
Коломосць Таміла Григорівна \\ Кандидат соціологічних наук, доцент,
} Криворізький національний педагогічний університет

В сучасних умовах динамічного глобалізаційного розвитку діти передшкільного віку не менше, ніж дорослі, потребують особливих якостей, які допомагають у досягненні бажаного, формують здорову самооцінку, підвищують здатність до комунікацій з оточуючими, у тому числі, засобами впливу та відстоювання власної думки. І одна з головних якостей, яку дитина має формувати $з$ дитинства, - здатність активно взаємодіяти з соціумом, самостійно й ініціативно розв'язувати життєві задачі і проблеми, з якими вона стикатиметься в майбутньому. Лідерські якості підносять бачення дитини на рівень ширшого світогляду, роблять її вчинки ефективнішими, формують майбутню особистість, що здатна досягати великих результатів.

Питання формування лідерських якостей особистості висвітлені у працях вітчизняних та зарубіжних науковців: Д. Алфімов, К. Берд, Е. Богардус, М. Вебер, В. Врум, Ф. Гальтон, П. Друкер, Л. Картер, В. Ковальчук, Р. Кричевський, Д. Крюгер, К. Левін, Р. Лорд, А. Лутошкін, С. Максименко, Б. Паригін, А. Петровський, О. Романовський, Р. Стогділл, С. Сміт, Ф. Тейлор, Л. Уманський, А. Файоль, Ф. Фідлер, Д. Філліпс, Р. Хаурс, Ф. Хміль, Г. Хоуманс, О. Чернишов та ін. Існує також низка досліджень у напряму розвитку i формування лідерських якостей у передшкільному віці, зокрема, таких науковців, як: В. Ануфрієва, С. Аркін, І. Волков, С. Геллер, М. Заброцький, Б. Паригін, Л. Уманський, Ю. Чернишенко, А. Чернишов та ін.

Проте, на нашу думку, недостатньо уваги приділено формуванню лідерських якостей дошкільників засобами сюжетно-рольової гри, що обумовлює пошук необхідного методичного інструментарію та проведення наукових розвідок у цьому напрямі.

Метою дослідження визначено формування уявлення про можливості розвитку лідерських якостей у дітей передшкільного віку засобами сюжетнорольової гри.

У передшкільному віці відбувається інтенсивний розвиток дитини, активно формуються особистісні якості, на які дитина буде спиратися в дорослому житті. Це відноситься також і до лідерських якостей, таких як дисциплінованість, самостійність, витримка, наполегливість, завзятість, рішучість i відповідальність. Ці якості допомагають дитині ще у передшкільному віці відповідати за свої вчинки і поведінку, дозволяють навчитися без сторонньої 
допомоги управляти своїм життям.

Науковці, вивчаючи питання лідерства, на протязі досить тривалого періоду намагаються визначити набір особистісних лідерських якостей в різних вікових періодах, в різних соціальних групах тощо. Зокрема, Є. Аркін, розглядаючи взаємовідносини дітей в дитячому садку, вказував, що дитячі лідери іноді більшою мірою, ніж педагогічний персонал, задають тон життя дітей у дитячих садках. Авторитет лідера і сила його впливу часто перевершують вплив дорослих [1]. Вказаний дослідник основною лідерською якістю вважав ініціативність i наголошував, що дитина не тому стає лідером, що його полюбила маса, а маса полюбила його за те, що він став ії лідером: сила лідера полягає в тому, що він «живить» дитячу активність і сам «харчується» нею.

Т. Сенько відзначає, що діти передшкільного віку з високою та середньою успішністю в індивідуальній пізнавальній діяльності, як правило, мають сприятливу позицію в групі - входять до категорії «лідери» або «особи, яким віддається перевага». Проте науковець вказує і на те, що діти 3 високою успішністю в пізнавальній діяльності можуть потрапити також і в категорію «неприйнятих». Статус цих дітей залежить і від особистісних якостей, і від поведінки, але багато в чому визначається цілями, завданнями спільної діяльності, іï успішністю, ціннісними орієнтаціями групи. Тому в одних випадках діти з високим рівнем інтелектуального розвитку користуватимуться симпатією і будуть популярними, а в інших - ні [2].

О. Смірнова й С. Калягіна [3] відзначають, що в основі лідерства дошкільнят у більшій мірі лежить емоційне ставлення до однолітків, а не розвиток інтелекту, вольових якостей і організаторських здібностей, як це проявляється у дорослих. Діти стають лідерами на основі проявів чуйності, доброти, дружелюбності, взаємодопомозі, емоційності по відношенню до інших. Такі якості вказані дослідники пропонують формувати на основі ігрових, пізнавальних i комунікативних засобів.

Багато дослідників єдині в тому, що лідерські якості у дошкільному віці можна розвинути різними видами пізнавальної діяльності, такими як: ігрова (сюжетно-рольові, рухливі, дидактичні, ігри-змагання на прогулянках), трудова, пізнавальна.

За рахунок гри у дітей можуть формуватися: організаторські здібності, відповідальність, успішність у пізнавальній діяльності, наполегливість, вміння домовлятися, бажання скрізь бути першим, вміння встановлювати правила гри.

Також позитивним впливом ігрової діяльності на формування лідерських якостей $є$ те, що у грі можуть бути ситуації, які можуть швидко видозмінюватися після взаємодії суб'єкта з ними (подальше розгортання гри невідоме та залежить від того, як себе поведуть учасники гри), а також швидке пристосування дій та реакцій дітей до нових умов гри. Також ігри сприяють розумовому, фізичному i моральному розвитку дитини та забезпечують психологічне розвантаження після стресових ситуацій.

Таким чином, лідерські якості $є$ фундаментом успіху дитини в їі соціальному оточенні, тому їх формування важливе для організації освітнього процесу в 3ДО, 
що сприяє цілеспрямованому розвитку необхідних соціально значущих особистісних рис і якостей кожної дитини.

\section{Література:}

1. Аркин Е. А. Об изучении детского коллектива. Москва, 1927. 270 с.

2. Сенько Т. В. Зависимость положения дошкольников в группе сверстников от форм их личностного поведения. Вопросы психологии. 1991. №5. С.23-28.

3. Смирнова Е. О., Калягина Е. В. Отношение популярных и непопулярных дошкольников к сверстникам. Вопросы психологии. 1998. № 3. С.50-61. 


\title{
ПСИХОЛОГІЧНІ МЕХАНІЗМИ-МЕТОДИКИ ВЗАЕМОДІЇ ЗАКЛАДІВ ЗАГАЛЬНОЇ СЕРЕДНЬОЇ ТА ПОЗАШКІЛЬНОЇ ОСВІТИ В ЕСТЕТИЧНОМУ ВИХОВАННІ ПІДЛІТКІВ
}

\author{
Серих Лариса Володимирівна, \\ кандидат педагогічних наук, доцент, \\ завідувач кафедри теорії і методики змісту освіти \\ КЗ Сумський обласний інститут післядипломної педагогічної освіти,
} Суми, Україна

Основою взаємодії закладів загальної середньої та позашкільної освіти в естетичному вихованні підлітків $є$ єдність процесів набуття ними художньоестетичної освіти та естетичної культури, переходу від суто споживання інформації до розвитку світоглядної позиції засобами мистецтва й формування на їх тлі гуманістичних ціннісних орієнтацій, які детермінують поведінку та будь-яку діяльність підлітків (Серих, 2015).

Визнаємо, що проблема естетико-виховного потенціалу взаємодії закладів загальної середньої та позашкільної освіти в естетичному вихованні підлітків $\epsilon$ складною й передбачає високий результат естетичного виховання, дотримання пріоритетних підходів до наукового аналізу чинників і фактів, тому вимагає широкого вибору механізмів реалізації подальшого дослідження. Зокрема, актуальними $\epsilon$ питання психологічних можливостей закладів освіти як інституцій естетичного виховання дітей та учнівської молоді. Тому, усвідомлюємо, що вирішення окреслених завдань передбачає насамперед, розглянути психологічні механізми взаємодії закладів загальної середньої та позашкільної освіти в естетичному вихованні підлітків (Серих, 2016).

Дослуховуючись до думки психологів, виховання особистості полягає у реалізації психологічних механізмів формування особистості, які є необхідною умовою успіху перетворення виховних вимог суспільства у внутрішні регулятори поведінки $i$ діяльності підростаючої особистості (П. Ігнатенко, В. Поплужний, Н. Косарєва, Л. Крицька, А. Бойко, І. Зимня та ін.).

Оскільки виховна система покликана орієнтуватися на формування в підлітків здатності протистояти негативним впливам середовища, педагог вчить учнів одночасно опору $\check{u}$ адаптаціï до навколишнього середовища. Дослідженням доведено, що взаємини учнів у дитячому колективі, їх ставлення до навколишнього середовища і самовідносини підлітків детермінуються взаєминами «вчитель-учень».

Це підкреслює визначальну роль в освітньо-виховному процесі особистості педагога, який цілеспрямовано й регульовано здійснює вплив на учнів шляхом використання механізмів переконування, навіювання, наслідування (Реан, 2016; Скрипченко, 2008; Чумак, 2011; Язиков, 2012). 
Переконування як механізм і метод впливу, слід відрізняти від переконання як властивості, компонента психіки, що включає в себе знання, поєднані з щирою впевненістю в їх істинності. Структурне переконування, указує М. Лукашевич, включає в себе теоретично обгрунтовані (логічні) прийоми, за допомогою яких певна інформація, що надається, органічно вплітається у сферу інтересів підлітків. При цьому доводиться істинність чи хибність певних інформаційних меседжів, їх значущість (Лукашевич, 1998; Маслоу, 1999; Скрипченко, 2008).

Навіювання (сугестія) - метод вплив передусім на почуття, а через них - на розум і волю особистості, зазначають О. Скрипченко, Л. Долинська, 3. Огороднійчук, унаслідок чого відбувається сприймання інформації з певного джерела досить некритичне і малоусвідомлене. Навіювання грунтується на властивості слова «оживляти», активізувати наявні й формувати нові асойіаціï. А це означає, що через слово учень може засвоїти не тільки відповідні поняття, а й образ поведінки. Науковці визнають традиційне використання навіювання, бо воно пов'язане як з філологічними, так і психологічними властивостями дітей. Навіюваність притаманна учням будь-якого віку, але чим молодша дитина, тим легше воно піддається їй, незважаючи на те, що сприймання навіюваних ідей належить до пасивних, навіть дещо автоматизованих процесів. Певна частина інформації може засвоюватись несвідомо, без включення активного мислення. Прикладом навіювання $є$ звернення вчителя до першоджерела, документа, посилання на авторитетного педагога, тоді підлітки сприймають інформацію як цілком надійну, а оскільки транслятором цієї інформації є педагог, ефект навіюваності дедалі зростає (Скрипченко, 2008).

Отже, результати наукового дослідження стану й прогнозування тенденцій, обгрунтування й проєктування практичних засобів досягнення взаємодії закладів загальної середньої та позашкільної освіти в естетичному вихованні підлітків свідчать про доцільність і ефективність застосування цих психологічних механізмів взаємодії закладів загальної середньої та позашкільної освіти в естетичному вихованні підлітків.

\section{Список літератури:}

1.Лукашевич, М. П. (1998). Виховні механізми та технологї: Навчальнометодичний посібник. Київ: ІЗМН.

2.Маслоу, А.Г. (1999). Мотиващия и личность: пер. А.М. Татлыбаевой. СПб.: Евразия.

3.Реан, А. А. (2016). Психология личности. СПб: Питер.

4. Сєрих Л. В. (2015). Взаємодія загальноосвітніх та позашкільних навчальних закладів в естетичному вихованні підлітків: монографія. Суми: НІКО.

5. Серих Л. В. (2016). Естетичне виховання: середовищний підхід: навчально-методичний посібник. Київ-Суми: НІКО.

6. Скрипченко О. В., Долинська Л. В. \& Огороднійчук 3. В. (2005). Загальна психологія. Київ: Либідь. 


\title{
ДО ПРОБЛЕМИ ТЕХНОЛОГЇ РОЗВИТКУ КРИТИЧНОГО МИСЛЕННЯ У ПРОЦЕСІ НАВЧАННЯ УЧНІВ ПОЧАТКОВИХ КЛАСІВ
}

\author{
Тупальська Галина Олексіївна, \\ викладач кафедри теорії і методик початкової освіти \\ Рівненського державного гуманітарного університету
}

Постановка завдання: На сучасному етапі розвитку демократичних засад в українському суспільстві, побудови громадянського суспільства в Україні надзвичайно важливо всіляко сприяти виробленню в людей уміння критично мислити, об'єктивно оцінювати різноманітні явища, процеси, події. Тому сьогодні актуальною є проблема розвитку критичного мислення, особливо в дітей молодшого шкільного віку.

Упровадження концепції «Нова українська школа»-найважливіша причина, що спонукає педагогів модернізувати свої підходи до організації навчальної діяльності. Тому основна мета школи навчити учнів не лише відтворювати знання, а й застосовувати їх для вирішення життєвих проблем.

Мета дослідження полягає у аналізі та обгрунтуванні технології формування критичного мислення у процесі навчання учнів початкових класів.

Огляд наукових досліджень. Дослідженню критичного мислення присвячено праці багатьох науковців. Цей феномен у своїх наукових працях досліджували Д. Дьюї, Д. Клустер, М. Ліпман, Р. Пауль, Д. Брукфілд, Д. Халперн, А. У. Бідл, Д. Х. Кларк, Р. Енніс, Е. Норріс, Е. Глассер, Д. Халперн. Серед українських учених вивченню цього питання приділяють значну увагу В. Козира, T. Воропай, О. Пометун, С. Терно, О. Тягло. Критичне мислення не має єдиного тлумачення серед науковців (О. Бєлкіна-Ковальчук, А. Бутенко, Т. Воропай, I. Загашев, М. Ліпман, В. Попков, В. Ружиейро, О. Тягло, Д. Халперн, Ч. Темпл, I.O. Загашев, С.I. Заір-Бек, I.В. Муштавинская, О.В. Фёдоров та ін.), але ці погляди не суперечать один одному, а демонструють багатоаспектність цього феномену.

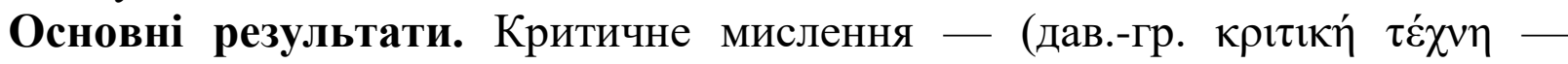
«мистецтво аналізувати, судження») — це наукове мислення, суть якого полягає в ухваленні ретельно обміркованих та незалежних рішень. Головним чином йому притаманні такі властивості, як усвідомленість та самовдосконалення.

3 точки зору прагматики критичне мислення розглядається як науковий підхід до розв'язування широкого кола проблем - від буденних до професійних. Ідея розвитку критичного мислення зародилася у США, сягає своїм корінням у праці відомих американських психологів XX ст. У. Джемса та Дж. Д'юї. Засновник Інституту Критичного мислення Метью Ліпман визначав критичне мислення як кваліфіковане, відповідальне мислення, що виносить правильні судження, тому що засноване на критеріях, виправляє себе (самовдосконалюється) та враховує контекст. 
Найбільш розгорнутим формулюванням критичного мислення $\epsilon$ широко відоме визначення Американської філософської асоціації (APA-Delphi): «Критичне мислення - це цілеспрямоване, саморегулююче судження, яке завершується інтерпретацією, аналізом, оцінкою і інтерактивністю, також як поясненням очевидних, концептуальних, методологічних, або контекстних міркувань, на яких грунтується це судження». [1]

На думку А. Бизяєвої, критичне мислення важливе для педагога в організації освітнього процесу - воно допомагає вирішувати кілька важливих завдань: відбір змісту навчального матеріалу, вибір форм і методів організації пізнавальної діяльності учнів в контексті розвитку їх особистості. [2]

Як доводить практика, формувати зазначені вміння можна за допомогою різноманітних форм і методів індивідуальної, групової та колективної роботи. Завдяки цьому формуються навички самостійності, суб'єктної індивідуальності, унікальності, різноплановості, що дозволить військовослужбовцю бути внутрішньо незалежним від стилів педагогічної діяльності викладача й успішно адаптуватися до навчальних умов.

Першочергове завдання сучасної освіти полягає не в наданні учням інформації, а в тому, щоб розвивати в них критичний спосіб мислення. Адже освіту зорієнтовано на майбутнє, яке не може бути наперед визначеним.

Від рівня розвитку критичного мислення залежить якість розв'язування завдань, формулювання висновків, оцінювання чогось та прийняття рішень.

Як відомо, навчання у початковій школі $є$ провідним видом діяльності учня [2; 3] і основною формою розвитку пізнавальної активності. 3 одного боку, під час навчального процесу школярі здобувають нові знання, які розширюють їхній світогляд, з іншого-у процесі активної пізнавальної діяльності розвиваються особистісні характеристики і навчальні можливості учня, завдяки яким він може самостійно і творчо не лише використовувати запас знань, а й шукати нові, задовольняючи свої потреби у пізнанні.

Технологія розвитку критичного мислення уміщує унікальний набір прийомів і технік, які дозволяють на уроці створювати ситуацію мислення. Матеріалом для такої ситуації можуть служити навчальні тексти, параграфи підручників, уривки наукових статей, художні твори, відео-фільми. Мета цієї технології - навчити такого сприйняття навчального матеріалу, в процесі якого інформацію, яку отримує учень, можна розуміти, сприймати, порівняти 3 особистим досвідом і на ії грунті формувати своє аналітичне судження.

Технологія включає прийоми, за допомогою яких можна інтенсифікувати процес читання наукових текстів, прослуховувати лекції тощо.

Технологія надає значну увагу формуванню здібностей викладати свої думки на письмі. Прийоми, пов'язані з вирішенням цієї проблеми, дають змогу організовувати, оформляти та ініціювати процес мислення учня, а отримані результати можуть служити матеріалом для діагностування вчителем цього процесу.

Для такого підходу надзвичайно важливим $є$ застосування форм групової роботи, що сприяє формуванню здібностей мислення. У процесі такої роботи учні формують свої думки, зрозуміло висловлюють їх. Відкриті діалоги на уроці 
виховують в учнів віру в свої сили, вміння відстояти свою думку шляхом дискусій, порівнянь, узагальнень; удосконалюють мовлення, поглиблюють знання.

У процесі роботи за технологією учень опановує прийоми роботи 3 інформацією та активного використання їх у самостійній роботі.

Перша фаза - евокація, «виклик»- актуалізація пізнавальних процесів.

На цьому етапі вчитель вирішує три завдання:

- Пробудити, викликати зацікавлення, схвилювати, спровокувати учнів думати, згадувати те, що вони знають.

- Актуалізувати мислення учнів, пам'ятаючи, що навчання —це активна діяльність.

- Визначає мету та завдання навчання, формує інтерес учнів і розуміння мети вивчення даної теми (питання, проблеми), розвиває внутрішню мотивацію до цілеспрямованого навчання; підтримує пізнавальну активність учнів.

Система завдань і дій учителя й учня на стадії виклику

\begin{tabular}{|l|l|}
\hline \multicolumn{2}{|c|}{ Дії вчителя } \\
\hline Провокація учня & \multicolumn{1}{c|}{ Даї учня } \\
\hline Ставить запитання & Відповідь на провокацію \\
\hline Моделює ситуацію активізації знань учнів & Намагається дати відповіді \\
\hline Формулює навчальну мотивацію & Формулює перші гіпотези \\
\hline
\end{tabular}

Друга фаза - «усвідомлення» - засвоєння змісту.

Головними завданнями цього етапу є:

- підтримка зацікавленості, викликаної на першому етапі;

- стимулювання старання учнів;

- відстеження засвоєння нових знань.

Система завдань і дій учителя на стадії усвідомлення

\begin{tabular}{|l|l|}
\multicolumn{1}{|c|}{ Дії вчителя } & \multicolumn{1}{c|}{ Даї учня } \\
\hline $\begin{array}{l}\text { Пропонує виконати завдання у } \\
\text { друкованому зошиті }\end{array}$ & Виконує завдання \\
\hline $\begin{array}{l}\text { Пропонує читання, обговорення, } \\
\text { дискусію }\end{array}$ & $\begin{array}{l}\text { Включається у процес вивчення інформації, } \\
\text { аналізу, обговорення }\end{array}$ \\
\hline Організовує роботу в парах, групах & Бере участь у груповій роботі \\
\hline Вчить працювати в колективі & Вчиться працювати в колективі \\
\hline Стимулює мотивацію навчання & $\begin{array}{l}\text { Слухає, ставить запитання, виділяє головне, } \\
\text { проявляє індивідуальність }\end{array}$ \\
\hline
\end{tabular}

\section{Tретя фаза- «рефлексія» - розміркування.}

На цьому етапі вчитель вирішує два важливих завдання:

- Спонукання учнів висловлювати своїми словами отриману інформацію, бо ми краще запам'ятовуємо те, що формуємо в особистому контексті.

- Сприяння обміну ідеями між учнями, в результаті чого збагачується словниковий запас та активізуються здібності до самовияву.

На цьому етапі уроку відбувається:

- осмислення учнями нового матеріалу; 
- адаптація нових понять в особистій системі знань учня, тобто зміна вже існуючого уявлення;

- реструктуризація сформованих зв'язків, що формує місце для нової інформації;

- засвоєння й закріплення знань.

Система завдань і дій учителя на стадії рефлексії

Табл. 3

\begin{tabular}{|l|l|}
\hline \multicolumn{1}{|c|}{ Дї̈ вчителя } & \multicolumn{1}{c|}{ Дї̈ учня } \\
\hline Керує підбиттям підсумків уроку & Узагальнює вивчений матеріал \\
\hline Ставить нові завдання & $\begin{array}{l}\text { Ставить запитання, які потребують вивчення } \\
\text { наступних тем }\end{array}$ \\
\hline Оцінювання учнів & Оцінює свою діяльність \\
\hline
\end{tabular}

Знання мають тривалий характер, якщо учень переформулює ідею, інформацію, пояснення чого-небудь із використанням особистого словника, що створює особистий осмислений контекст вивченого. Використання в цей час різноманітних засобів інтегрування нової інформації призводить до більш гнучких конструкцій, які можна ефективніше і цілеспрямованіше застосовувати в майбутньому.

Людина, яка критично мислить, вмітиме:

- $\quad$ визначати проблему;

- $\quad$ перевіряти використану інформацію;

- проаналізувати твердження, що лежить в основі інформації;

- $\quad$ враховувати альтернативні точки зору;

- визначати наявність підтексту в інформації;

- $\quad$ синтезувати здобуті знання;

- $\quad$ зробити висновки;

- $\quad$ прийняти оптимальне рішення.

Висновок. Отже, перед НУШ постає завдання виховати людину незалежну, вільну, здатну самостійно осмислювати явища навколишньої дійсності, відстоювати свою власну думку перед будь-ким і будь-де. Цілком зрозуміло, що підвалини цих якостей повинні закладатися в початковій школі з перших років навчання дітей, а потім продовжувати розвиватися у середній школі та у вищому навчальному закладі. Тому саме технологія розвитку критичного мислення допомагає готувати дітей нового покоління, які вміють розмірковувати, спілкуватися, чути та слухати інших. Практичне використання вправ з розвитку критичного мислення в початковій школі забезпечує такі позитивні зміни в учнів, як підвищення інтересу до навчання, прояв активності на уроках тощо.

\section{Література:}

1. Facione, P.A. (1990). Critical Thinking: A Statement of Expert Consensus for Purposes of Educational Assessment and Instruction (The Delphi Report).

2. Бєлкіна О.В. Критичне мислення учнів початкових класів (Закінчення). Практична психологія та соціальна робота. 2005. № 5. С. 37 -40.

3. Бизяева А.А. (2004) Психология думающего учител: Педагогическая рефлексия. Псков: ПГПИ. 
4. Козира В. М. (2017) Технологія розвитку критичного мислення у навчальному процесі. Тернопіль: Астон 


\title{
ВИКОРИСТАННЯ ІНТЕРАКТИВНИХ МЕТОДІВ НАВЧАННЯ МЕНЕДЖЕРІВ ОСВІТИ ЯК УМОВА ВДОСКОНАЛЕННЯ ЇХ ІННОВАЦІЙНОЇ ДІЯЛЬНОСТІ
}

\author{
Хлєбнікова Таліна \\ кандидат педагогічних наук, доцент, \\ доцент кафедри наукових основ управління \\ Харківського національного педагогічного \\ університету імені Г. С. Сковороди, \\ м. Харків, Україна

\section{Тищенко Тетяна} \\ кандидат філологічних наук, професор, \\ професор кафедри української літератури \\ та журналістики \\ імені професора Леоніда Ушкалова \\ Харківського національного педагогічного \\ університету імені Г. С. Сковороди, \\ м. Харків, Україна
}

\section{Гречаник Олена}

кандидат педагогічних наук, доцент, завідувач кафедри наукових основ управління Харківського національного педагогічного університету імені Г. С. Сковороди, м. Харків, Україна

Гнучкість і мобільність сучасного менеджера дозволяють йому своєчасно (або з випередженням) реагувати на зміни, що відбуваються в зовнішньому конкурентному середовищі. Виходячи із цього, можна зробити висновок про те, що креативність, інновації, нестандартний підхід до звичайних речей дає організаціям помітну конкурентну перевагу. Сьогодні кожна організація постає перед вибором: шукати інноваційні нестандартні рішення і ставати лідером на ринку або слідувати сформованим у певній сфері традиціям ведення бізнесу й управління організацією, поступаючись своїми позиціями конкурентам. Заклади освіти мають готувати фахівців-управлінців із урахуванням потреб роботодавців, змін зовнішнього середовища. Інновації в освітній діяльності - це використання нових знань, прийомів, підходів, технологій для отримання результату у вигляді освітніх послуг, що відрізняються соціальною та ринковою затребуваністю [1, с. 23].

Інноваційна діяльність педагога й менеджера освіти - це один із стратегічних напрямів в освіті, який має вирішальне практичне значення. Відповідно до цього будь-які реформи й інновації у сфері освіти можуть бути реалізовані лише тоді, 
коли вони внутрішньо прийняті та підтримані педагогами й керівникамипрактиками.

Погоджуючись із твердженням Б. Сазонова про те, що головними факторами успішності нововведення є особистість інноватора та середовище впровадження [2, с. 85], підкреслюємо суб' єктивну роль керівника закладу освіти (3О) у процесі здійснення інноваційної діяльності, тому що професіоналізація із розповсюдження нововведень виступає результатом розвиненості професійних прийомів, серед яких головним є не лобіювання цієї інновації, а формування інноваційного потенціалу педагога.

Інноваційна діяльність керівника закладу освіти є такою складовою його творчої діяльності, що пов'язана з розробленням і впровадженням наукових результатів із метою пошуку власного місця в соціально-економічній системі суспільства [3]. Аналіз цього визначення дає підстави для кількох важливих висновків:

- наукова та інноваційна діяльність студента є органічно поєднаними та взаємодоповнюючими сферами;

- науково-методична діяльність є основою (фундаментом) інноваційної діяльності та зорієнтована на вдосконалення його особистих професійних навичок. Вона формує його інтелектуальний потенціал;

- інноваційна діяльність спрямована на досягнення певного соціальноекономічного ефекту в окремій сфері діяльності з метою створення власного іміджу й забезпечення в майбутньому бажаного місця роботи.

Виходячи із вище викладеного, треба зазначити, що неабиякого значення в процесі організації навчання здобувачів другого (магістерського) рівня вищої освіти зі спеціальності 073 «Менеджмент» (освітня програма «Управління навчальним закладом»). Воно спрямоване на активне і глибоке засвоєння матеріалу, що вивчають, розвиток уміння виконувати комплексні завдання. Зараз викладачі Інституту підвищення кваліфікації педагогічних працівників i менеджменту освіти ХНПУ імені Г.С. Сковороди використовують замість звичайних лекцій інтерактивні методи навчання, які передбачають імітаційні та рольові ігри, дискусії, що моделюють ситуації, максимально наближені до реальних життєвих ситуацій. Також проводять вебінари, завдяки яким студенти під час пандемії в умовах змішаного навчання мають можливість поспілкуватись iз професіоналами, керівниками підприємств i $і$ х відділів, провідними науковцями й т. д.

Ще одним сучасним методом навчання, який використовують в освітньому процесі, є навчання шляхом співпраці. Він ефективний під час роботи в малих групах. Цей метод ставить своїм завданням ефективне засвоєння навчального матеріалу, вироблення здатності сприймати різні точки зору, уміння співпрацювати й розв'язувати конфлікти в процесі спільної роботи. Особливістю інноваційних методів навчання $є$ зміна ролей викладача та здобувача вищої освіти. За традиційного передавання інформації від викладача до студента останній є об’єктом, на який спрямована дія. Завдяки використанню інноваційних методів здобувач вищої освіти сам стає суб'єктом освітнього процесу, який має здатність змінювати його. Викладач, використовуючи 
інноваційні методи, також стає носієм нової ролі, не властивої традиційним технологіям навчання. Викладач $є$ не тільки джерелом, носієм знання, яке передає його здобувачам вищої освіти, а й наставником, який ініціює їх творчі пошуки. Креативне, нестандартне мислення стало головною якістю ефективного менеджера, необхідною йому для управління організацією та іiі ресурсами, планування й організації колективної роботи над різними проектами, а також для виконання функцій мотивації персоналу й контролю. Такий спосіб мислення дозволяє створювати нові нестандартні підходи й рішення, що особливо важливо для організації, яка хоче залишатися успішною на ринку. Не можна говорити про те, що інноваційні методи, які використовують в освітньому процесі, мають повністю замінити традиційне передавання інформації та знань від викладача до студента, ці два види навчання мають співіснувати один із одним, взаємодоповнюючи один одного. Тільки в цьому випадку можна вести мову про підготовку компетентних фахівців, які будуть затребувані на ринку праці [4].

Одним із головних завдань навчання менеджерів освіти $є$ забезпечення такого рівня мотивації, постановка здобувачів вищої освіти в таку ситуацію, яка передбачає вибір між ремісницьким і творчим, авторським ставленням до власної діяльності, створення умов для самоактуалізації, самореалізації особистості. Навчання, на наш погляд, може переслідувати поряд із іншими завданнями таке: спонукати до розширення, з одного боку, уявлення про сучасні процеси, ідеї, з іншого боку - до пошуку, до діяльності завдяки прийняттю, визнанню або, можливо, відторгненню, у тому числі й на асоціативному рівні, інформації, яку отримують.

Це завдання можна виконати, якщо погоджені мета й місце, зміст і форми інформації, що отримують, іï пряме й опосередковане використання в освітньому процесі. Суттєвого значення набувають методи активного навчання: неімітаційні й імітаційні. Використання імітаційних методів пов'язане iз застосуванням навчальних ігор. Гра дозволяє розв'язувати різноманітні задачі, вона $є$ формою навчання й одночасно наповнена певним змістом. У ході гри реалізують прямі та непрямі цілі. Значущість прямих цілей - розв'язання певних задач - відступає перед значущістю цілей латентних. Таким чином, гру використовують для узгодження і прийняття певних цінностей, як у плані комунікацій, так і в плані визначення підходів, варіантів і технологій розв'язання професійних задач, вона сприяє формуванню критичності мислення, виводить його з рамок набору вмінь і навичок в особистісну сферу.

Логіка розвитку сучасного особистісно зорієнтованого навчання вимагає не тільки системи організації навчального процесу, але й умов, що максимально полегшать шлях просування здобувача освіти в навчанні. Щоб він міг успішно навчатися, отримувати знання, навички навчальної діяльності, засвоювати соціально значущі цінності, норми, щоб він міг самостійно вибирати свій життєвий шлях і реалізовувати його, йому необхідна педагогічна допомога в навчанні.

Вирішити це питання ми пропонуємо, використовуючи метод проектів педагогічну технологію, орієнтовану не на інтеграцію фактичних знань, а на їхнє застосування та придбання нових (зокрема і шляхом інформальної освіти). 
Активне включення студента у створення тих чи інших проектів дає йому можливість освоювати нові способи людської діяльності в соціокультурному середовищі. Дослідницький проект може бути за змістом монопредметним (виконують на матеріалі конкретного предмету), міжпредметним (інтегрують суміжну тематику декількох предметів, наприклад, управління освітньою діяльністю, теорія і практика управління закладом освіти, психологія менеджменту).

Проектну гру можна проводити в режимі інтенсивної групової роботи [5].

Мета гри: спроектувати модель системи педагогічної допомоги дитині в навчанні залежно від типу 30.

У ході гри можуть бути розглянуті основні напрями педагогічної допомоги, виявлені суб' єкти, здатні професійно надати допомогу в подоланні перешкод, які виникають у школяра, визначені умови розвитку системи. До результатів гри можна віднести такі результати: мотиваційний, змістовний, організаційноуправлінський.

Мотиваційний результат полягає в актуалізації установки на гуманізацію освітнього процесу. Бажання допомогти дитині підштовхне студентів до переосмислення переживання власної професійної недостатності, особистої незадоволеності в можливості здійснювати цю діяльність.

Змістовний результат полягає в здійсненні аналізу освітніх, соціальних, емоційно-психологічних перешкод, які заважають дітям у навчанні, та визначенні загальних напрямів і завдань педагогічної допомоги учням в умовах 3О. Увагу необхідно приділяти суб'єктам педагогічної допомоги й функціям управлінських кадрів (відділам освіти, директорам шкіл та їх заступникам).

Організаційно-управлінський результат може бути представленим у проектних завданнях, пов'язаних із запуском системи педагогічної допомоги учням у навчанні.

Так, завдання для групи студентів, які представляють роль районного відділу освіти, передбачає:

1) створення при відділі освіти групи з розвитку системи педагогічної допомоги учням у навчанні, функції, якої полягають у створенні програми педагогічної допомоги учням, координації діяльності спеціалістів: лікарів, психологів, логопедів, соціальних педагогів, інспекторів з опіки, співробітників інспекції у справах неповнолітніх;

2) створення лабораторії, яка буде вивчати ефективність педагогічної допомоги учням;

3) організація курсової та міжкурсової підготовки вчителів.

Завдання групі студентів, які виконують роль директорів 30, може орієнтовно бути таким:

1) створення творчих груп і розроблення комплексно-цільової програми педагогічної допомоги учням;

2) продумування можливості накопичення банку даних про індивідуальні особливості школярів;

3) визначення системи виявлення утруднень учнів у навчанні;

4) виокремлення суб'єктів і педагогічних засобів для роботи 3 різними 
групами учнів;

5) обгрунтування (у разі необхідності) уведення нової посади та джерел іiі фінансування.

Завдання для студентів, які виконують роль психологів, передбачає створення банку методик із вивчення особистісних сфер учня, розроблення рекомендацій вчителю щодо роботи з різними проблемними групами учнів.

Завдання для групи студентів, які виконують роль учителів-предметників, полягають у розробленні технологічної картки з виявлення утруднень учнів у навчанні та шляхів їх подолання.

У разі потреби можна створити інші групи або розширити завдання для запропонованих.

Отже, використання інтерактивних методів і технологій дозволяє формувати такий освітній простір у закладі освіти, що забезпечує вдосконалення інноваційної діяльності керівника закладу освіти, уміння продукувати нові ідеї та регулювати інноваційні процеси.

\section{Список літератури}

1. Чупрова Л. В. До питання про інноваційні методи навчання у вузі. Збірник конференцій НДЦ. Сочіосфера. 2012. № 23. С. 32-35.

2. Сазонов Б. В. Субъект в процессах нововведений. Нововведения как фактор развития : сборник трудов. Москва, 1987. С. 84-94.

3. Даниленко Л. І. Управління інноваційною діяльністю в загальноосвітніх навчальних закладах : монографія. Київ : Міленіум, 2004. 358 с.

4. Григораш О.В. Інформаційне забезпечення інноваційної діяльності педагогів закладу загальної середньої освіти. $\Lambda O G O \sum$ : зб. наук. пр. 3 матеріалами I-ї Міжн. наук.-практ. конф. «Debats scientifiques et orientations prospectives du developppement scientifique» (05 лют. 2021 р., Франція, Париж). Vol. 5. P. 47-51.

5. Хлєбнікова Т. М. Організація особистісно зорієнтованого навчання в системі післядипломної освіти : монографія. Харків : Основа, 2019. С. 74. 


\title{
МЕТОДИКА ФОРМУВАННЯ ПАТРІОТИЧНИХ ПОЧУТТІВ МОЛОДШИХ ШКОЛЯРІВ НА УРОКАХ «Я ДОСЛІДЖУЮ СВІТ» В НОВІЙ УКРАЇНСЬКІЙ ШКОЛІ
}

\begin{abstract}
Хом'як Ольга Анатоліївна, кандидат педагогічних наук, доцент доцент кафедри початкової та дошкільної освіти ПВН3 «Міжнародний економіко-гуманітарний університет імені академіка Степана Дем'янчука»

Баланович Жанна здобувачка першого ступеня вищої освіти (бакалаврського) педагогічного факультету ПВНЗ «Міжнародний економіко-гуманітарний університет імені академіка Степана Дем'янчука»
\end{abstract}

Одним із ключових завдань Нової української школи (НУШ) є запровадження інтегрованого навчання на засадах компетентнісного підходу. У початковій школі це здійснюється, насамперед, через інтегрований курс «Я досліджую світ». Інтегрований курс «Я досліджую світ» повністю реалізує зміст освітніх галузей Державного стандарту початкової освіти: «Громадянської та історичної», «Соціальної і здоров’язбережувальної», «Природничої» - із залученням змісту інших галузей: «Технологічної», «Мовно-літературної», «Математичної». Він має на меті розширити елементарні знання учнів про предмети і явища природи та соціуму; розкрити в доступній формі зв'язки між неживою і живою природою та впливом людини на природу; виховувати любов до Батьківщини; формувати вміння аналізувати, оцінювати, систематизувати, узагальнювати об'єкти та явища, визначати закономірність зв'язків між ними; виробляти практичні уміння і навички.

На уроках вчитель спонукає учнів самостійно ставити запитання, проводити дослідження, робити висновки, формулювати та обговорювати ідеї. Важливим елементом $\epsilon$ створення комфортного навчального середовища, де учні можуть вільно висловлювати свої думки, обговорювати та конструктивно критикувати ідеї один одного, де поважають думки один одного і не бояться говорити. Крім того, учні пропонують пояснення на основі досліджуваних фактів, використовують спостереження, планують i проводять експерименти, розробляють способи апробації своїх ідей, вчаться використовувати способи перевірки, розширення та підтвердження думок, або набувають уміння відмовитися від хибної ідеї, навчаються презентувати результат своєї діяльності.

Теоретичний аналіз наукових психолого-педагогічних джерел засвідчує, що сьогодні проблему патріотичного виховання розглядають на державному програмному, концептуальному та практичному рівнях, що широко окреслено в низці державних документів: Конституції України, Законах України «Про освіту», «Про загальну середню освіту», Національній доктрині розвитку освіти 
України у XXI ст., низці концепцій розроблених у період незалежної України. Детальний аналіз цих документів свідчить, що підгрунтям важливих напрямів виховання повинні бути принципи гуманізму, демократизму, єдності сім'ї та школи з метою забезпечення всебічного розвитку гармонійної особистості. У цих освітніх документах конкретизовано сучасне розуміння патріотизму.

Метою статті $\epsilon$ теоретичне обгрунтування особливості методики формування патріотичних почуттів молодших школярів на уроках «Я досліджую світ» в початковій школі.

Сучасне формування патріотизму здійснюється в умовах національного виховання, яке розуміють як формування гармонійно-розвиненої, високоосвіченої й, соціально-активної й національно свідомої людини, наділеної глибокою громадянською відповідальністю, здоровими інтелектуальнотворчими й духовними якостями, родинними й патріотичними почуттями, працьовитістю, господарською кмітливістю, підприємливістю й ініціативою.

Україна на сучасному етапі переживає складні часи. Події, які відбуваються на сході країни, переконливо доводять необхідність здійснення національнопатріотичного виховання підростаючого покоління. Неабияка роль в цьому процесі відводиться освітньому закладу, який має стати осередком становлення громадянина-патріота України, готового самовіддано розбудовувати незалежну, демократичну державу, дбати про іiі національну безпеку, підвищення добробуту людей, сприяти єднанню українського народу та встановленню миру й злагоди в суспільстві. Школа - це життєвий простір дитини; тут вона не просто готується до життя, а живе. Тому виховна робота планується так, щоб сприяти становленню особистості як творця і проектувальника життя, гармонізації та гуманізації стосунків між учнями і педагогами, школою та родиною, керуючись ідеями самоцінності дитинства, демократичного діалогу між поколіннями. Важливу роль у цьому відіграє позакласна робота. Її мета полягає у задоволенні інтересів і запитів дітей, розвитку їх творчого потенціалу, нахилів і здібностей у різних сферах діяльності та спілкування. Домінуюча роль в іiі організації належить класному керівнику, який $є$ передусім організатором позакласних виховних заходів. Саме на вчителя покладається велична місія навчання, розвитку i, що найважливіше, виховання дітей. Кожен педагог має демонструвати власними вчинками та плекати в учнів любов як до свого рідного краю, так і до всієї багатонаціональної України.

Мета патріотичного виховання - це виховання свідомого громадянина, патріота, набуття школярів соціального досвіду, високої культури міжнаціональних взаємин, формування в учнів потреби та вміння жити в громадському суспільстві, духовності та фізичної досконалості, моральної, художньо-естетичної культури. Патріотичне виховання в школах спрямовується на залучення учнів до глибинних пластів національної культури і духовності, формування у дітей та молоді національних світоглядних позицій, ідей, поглядів i переконань на основі цінностей вітчизняної та світової культури. Воно здійснюється на всіх етапах навчання в школі, забезпечується всебічний розвиток, гармонійність і цілісність особистості, розвиток ії здібностей та обдарованість, збагачення на цій основі інтелектуального потенціалу народу, 
його духовності і культури, виховання громадянина України, здатного до самостійного мислення, суспільного вибору і діяльності, спрямованої на процвітання України. В основу виховання мають бути покладені принципи гуманізму, демократизму, єдності сім'ї і школи, наступності та спадкоємності поколінь. Національно-патріотичне виховання молодших школярів дозволяє 3 першого класу формувати і розвивати свідоме ставлення дітей до своєї країни вміння цінувати і поважати події минулого і сучасні досягнення нашого народу, розрізняти поняття добра i зла. Покоління, у якого виховано почуття патріотизму, готове до подвигу, відстоювання інтересів своєї країни.

Патріотичне виховання молодших школярів буде ефективним, якщо:

- здійснювати його ненав'язливо;

- поступово і дозовано впливати на почуття, переконання та діяльність вихованців;

- не нав'язувати патріотичні погляди зовні, але давати зразки кращого прояву патріотичних почуттів;

- залучати до участі у виховній роботі класу, школи батьків та громадськість;

- систематично використовувати ефективні елементи народної педагогіки, традиції національного виховання.

Становлення української держави сьогодні відбувається в непростих умовах: анексія Криму, АТО, загрози сепаратизму, зубожіння народу тощо. Але український народ пройшов нелегкий шлях до отримання повної свободи, витримав нелюдські випробування (голодомор, чисельні матеріальні та людські втрати в ході II світової війни, чорнобильська трагедія тощо). Яким буде майбутнє нашої держави у великій мірі залежить від нас та прийдешніх поколінь. Тому, одним із першочергових завдань, які стоять перед школою, і початковою, зокрема - це формування в учнів почуття патріотизму та національнопатріотичної свідомості як найважливішої духовно-моральної й громадянської цінності. Критеріями сформованості національно-патріотичної свідомості молодшого школяра вважаються: ступінь особистісного ставлення до української мови та використання ii у різних сферах діяльності; ступінь активності в утвердженні цінностей української культури, ступінь прояву внутрішнього стану особистості у відношенні до природи, власного здоров'я та здоров'я оточуючих.

Процес громадянського виховання учнів має бути безперервним і починатися (правильніше продовжуватися, так як насправді розпочинається ще в дошкільних навчальних закладах) у загальноосвітніх з першого уроку першого класу. Саме в початковій школі поглиблюються знання молодших школярів про родину, рідний край, державу, Батьківщину, державні та народні символи тощо, формується самоусвідомлення дітьми своєї приналежності до народу України. Успішним патріотичне виховання учнів початкових класів можна назвати лише тоді, коли діти чітко засвоїли і дотримуються загальноприйнятих норм і правил поведінки, бережно відносяться до довкілля, дотримуються чистоти, піклуються про власне здоров'я та здоров'я оточуючих, 3 повагою ставляться до родини, 
сусідів, однокласників, знайомих і незнайомих людей незалежно від їх віри чи національності, усвідомлюють свою національну належність та пишаються цим.

Методів виховання є багато, але не всі вони є дієвими в початковій школі. Під методами виховання слід розуміти найважливіші способи взаємопов'язаної діяльності вихователя і вихованців, які спрямовані на усвідомлення школярами сутності суспільних цінностей, розвиток позитивних ставлень до них, вироблення відповідних навичок i звичок поведінки, їх корекцію i вдосконалення, підтримку розвитку індивідуального потенціалу особистості.

У процесі розвитку педагогічної науки здійснювалися різні підходи до класифікації методів виховання, їх упорядкування. Класифікація методів - це побудована за певною ознакою система методів. Класифікація методів допомагає педагогу усвідомлено обрати і ефективно застосувати відповідно до завдань і реальних обставин ті чи інші методи виховання.

За класифікацією Нелі Мойсеюк виділяються групи методів виховання:

I група - методи усвідомлення цінностей патріотичного виховання (любов до Батьківщини, здоровий спосіб життя, піклування про природні багатства рідної землі). В основі цих методів лежить слово. Слово - могутня зброя в умілих руках педагога. Провідну роль у формуванні патріотизму відіграють такі вербальні методи, як розповідь, бесіда, роз'яснення, повідомлення, диспут тощо. Діти люблять слухати розповіді, які учитель подає артистично, супроводить цікавим ілюстративним матеріалом, відеофільмами, музичними записами. Періодично під час розповіді педагог звертається із запитаннями до учнів, просить їх прокоментувати почуте, дати свою оцінку події тощо. Бесіда дає свій позитивний ефект, коли вона $є$ інтерактивною. При цьому школярі обговорюють поставлене учителем запитання чи проблему у парах, групах, приходять до спільної думки і висловлюють ії. У ході бесіди школярі вчаться аналізувати ідеї, оцінювати події, вчинки та формувати власне ставлення до навколишньої дійсності та своїх обов'язків. Під час бесід варто використовувати такі методи інтерактивного навчання, як мозковий штурм, асоціативний кущ, займи позицію, коло ідей тощо.

Учні 3-4 класів можуть брати участь у диспутах, основне призначення яких тренування розуміння і уміння обговорювати певні проблеми. Наприклад, «Кому потрібен здоровий спосіб життя», адже не секрет, що серед молодших школярів $\epsilon$ діти, яким подобається хворіти. Під час хвороби вони відчувають підвищену турботу і занепокоєння батьків, $є$ можливість поніжитися в ліжку тощо. Тому під час такого диспуту, діти зможуть усвідомити та переконати інших у необхідності бути здоровим.

II група - методи організації діяльності та формування досвіду суспільної поведінки. Це тренування, привчання, доручення, педагогічна вимога, ситуація вільного вибору, ігровий метод.

Тренування передбачає багаторазове повторення дій і вчинків. Наприклад, щодення ранкова гімнастика, догляд за посадженими деревами, клумбами тощо.

Привчання - метод, що забезпечує інтенсивне формування певної якості. Наприклад, не запізнюватися на заняття, прибрати своє робоче місце, активно працювати в колективних творчих справах, дотримувати даної обіцянки. 
Одним із методів виховання є доручення, яке передбачає вправляння учнів в позитивних діях і вчинках. Це і посильна допомога тим, хто іiі потребує, догляд за могилою героя, пам'ятником, пришкільною ділянкою тощо. Але слід пам'ятати, що ефективність доручення як методу залежить від організації контролю за його виконанням.

Педагогічна вимога - метод впливу, під час якого педагог може стимулювати або гальмувати дії вихованців. Це вимоги-поради, прохання (допомогти товаришеві у навчанні), довір'я, натяк (коли потрібен незначний вплив, може бути здійснений у жартівливо-доброзичливій формі, наприклад, поступитися місцем у транспорті старшій людині), схвалення, умова, недовіра (не виконав важливе завдання, отже можеш підвести ще раз), осуд (негативна оцінка конкретних дій чи вчинків 3 метою гальмування їх та стимулювання виправлення).

Ситуація вільного вибору - метод, що моделює ситуацію реального життя (наприклад, маленька дитина рве квіти на клумбі, твої дії).

Ігрові методи є провідними для молодших школярів, відповідають їхнім віковим особливостям, $€$ природним засобом навчання i виховання. Найважливіше - це органічне включення ігор у навчально-виховний процес. Різноманітність ігрових засобів дає можливість учителеві обрати ту гру, яка найкраще відповідає меті патріотичного виховання. Звичайно, що формуванню патріота сприяють народні рухливі ігри, ігри, пов'язані із традиціями і звичаями українського народу, це дидактичні ігри, ребуси, кросворди, вікторини, тощо.

Великий виховний вплив на особистість учня є робота над проектами, під час яких діти досліджують особливості рідного краю, знайомляться з видатними людьми, досліджують минуле держави та проектують іiі майбутнє. Тому проектна діяльність молодших школярів $\epsilon$ важливою як під час уроків, так і в позаурочний час.

III група - це методи стимулювання поведінки і діяльності. До них відносяться методи заохочення, змагання і дуже обережно - покарання.

Заохочення у вигляді схвалення, подяки, привітання, нагороди стимулюють бажання діяти ще краще, збуджують позитивні емоції. Але тут важливо дотримуватися правила «золотої середини», щоб не перехвалити чи недооцінити діяльність учня.

Змагання - це метод спрямування природної потреби школярів у суперництві на виховання позитивних якостей особистості. Організація змагань молодших школярів, конкурсів, турнірів, де учні можуть продемонструвати свої знання 3 української мови та літератури, природи, історії та життя рідного краю сприятиме вихованню патріотизму.

Покарання як метод педагогічного впливу в початковій школі має використовуватися дуже обережно, в крайніх випадках i в основному у несхвалення дії чи вчинку учня.

IV група - методи педагогічної підтримки, а саме: взаємна довіра, спільне проведення виховних заходів, ігор, діагностика індивідуального розвитку, вихованості тощо. Важливе значення у цьому відводиться створенню ситуації 
успіху, створення умов для самореалізації особистості Форми патріотичного виховання молодших школярів можуть бути різноманітні:

- За кількістю учасників: індивідуальні, парні, групові та масові.

- За місцем проведення: урочні, позаурочні, позакласні, позашкільні, родинне виховання.

- За напрямками виховання: естетичні, фізичні, розумові, моральні, трудові, екологічні тощо.

Важливе місце слід відвести колективним творчим справам, проектній діяльності, театралізації, гуртковій роботі, екскурсіям, спортивним змаганням, проведенням акцій, виставок, українських вечорниць, свят, фольклорних фестивалів, ярмарок тощо [1].

Молодший шкільний вік $є$ періодом, коли формується система світогляду, етап реальної життєдіяльності, підготовка до дорослого життя впровадженням в освітню діяльність культурно-художніх традицій краю, які роблять ії більш зрозумілою, близькою для школярів, позаяк в цьому віці вони турбуються про свою школу та рідний край, цей вік $є$ особливо сприятливим для становлення етнічної свідомості, психологічного тяжіння до поняття «ми».

Сучасні науковці по-різному підходять до поняття патріотизм як педагогічної категорії - кваліфікують його як принцип, сукупність почуттів, якостей, систему ідей тощо. Зупинимося конкретніше на цьому питанні.

Так, О. Вишневський виокремив три різновиди патріотизму: етнічний (в основі лежить почуття власної причетності до свого народу, рідної культури, історії); територіальний (грунтується на любові до місцевості, в якій людина народилася, до природи, клімату, ландшафту); державницький (формування в учнів вищого патріотизму, зокрема державницького світогляду i державницького почуття, яке нерозривно пов'язане 3 питанням громадянськості). Науковець подає таку ієрархію цінностей: людина - родина громада - нація (держава) - людство [2]. Деякі вчені розглядають патріотизм як моральне почуття, моральний принцип, інші вважають його сукупністю почуттів, принципів і якостей.

Проблему формування в учнів патріотичних почуттів, національної самосвідомості розглядають в контексті загального процесу виховання молодого покоління дослідники I. Бех, А. Богуш, Ю. Руденко трактуючи поняття патріотизм як сукупність таких цінностей: гідність, гордість, справедливість, працелюбність, відповідальність, правдивість.

Отже, сучасні науковці виокремлюють такі структурні компоненти почуття патріотизму: духовно-моральне переживання та любов до рідної землі; гуманістичні загальнолюдські та національні цінності; морально-естетичні ідеали особистості; творчо-перетворювальну діяльність на благо Батьківщини.

У Концепції громадянської освіти зазначено: «Національно-патріотичне виховання дітей і молоді - це комплексна системна і цілеспрямована діяльність органів державної влади, громадських організацій, сім'ї, освітніх закладів, інших соціальних інститутів щодо формування у молодого покоління високої патріотичної свідомості, почуття вірності, любові до Батьківщини, турботи про благо свого народу, готовності до виконання громадянського і конституційного 
обов'язку із захисту національних інтересів, цілісності, незалежності України, сприяння становленню іiі як правової, демократичної, соціальної держави. Найважливішим пріоритетом національно-патріотичного виховання $\epsilon$ формування ціннісного ставлення особистості до українського народу, Батьківщини, держави, нації» [6].

3 патріотизмом органічно поєднується національне виховання громадянина, що формується на засадах громадянських та національних цінностей, вбирає в себе любов до свого народу, віру в його духовні сили і майбутнє, готовність до життя і праці в ім'я народу, свідомого служіння інтересам Батьківщини України, це і переосмислення моральних і культурних цінностей, історії, традицій, звичаїв, обрядів, символіки тощо.

Сучасному громадянському вихованню має бути властива випереджувальна роль у демократичному процесі. Воно має стати засобом відродження національної культури, припинення соціальної деградації, стимулом пробудження таких моральних якостей, як совість, людяність, почуття власної гідності, засобом самоорганізації особистісної відповідальності, гарантом громадянського миру і злагоди в суспільстві.

У контексті педагогічної проблеми «Формування патріотичних почуттів молодших школярів на уроках «Я досліджую світ» в НУШ» учителі ставлять перед собою такі завдання:

- формування в учнів найбільш значущих для українського народу цінностей: патріотизм, соціальна справедливість, первинність духовного щодо матеріального, гуманізм, працелюбство, взаємоповага;

- виховання в дитини свого власного «Я», віри у свої сили, талант, здібності;

- виховання творчої, соціально активної особистості, здатної бережливо ставитися до природи, світу, речей, самої себе, інших людей, розуміти значення життя як найвищої цінності.

Таким чином робимо висновок, що громадянське виховання є стрижневим основоположним, що відповідає загальним вимогам і викликам сучасності, закладає підгрунтя для формування національної свідомості нинішніх i прийдешніх поколінь, які розглядатимуть державу як запоруку власного особистісного розвитку, що спирається на ідеї гуманізму, соціального добробуту, демократії, свободи, толерантності, виваженості, відповідальності, здорового способу життя, готовності до змін.

Саме патріотизм повинен об'єднувати українців, зберегти те, що протягом століть було нашою метою, - незалежну державу. У початкових класах закладається основа національної свідомості учнів, любов до рідної землі, своєї «малої Батьківщини», виховується патріотична гордість за минуле і сучасне України, любов до рідної мови, формується духовно розвинена, творча, працелюбна особистість.

\section{Список літератури}

1. Мойсеюк Н. Є. Педагогіка. Київ: Саммит-книга, 2007. 656 с. 
2. Вишневський О. Сучасне українське виховання : пед. нариси. Львів, 1996. 238 c.

3. Бех І. Д., Чорна К. І. Національна ідея в становленні громадянина-патріота України. Програмно-виховний контекст. Київ, 2014. 48 с.

4. Богуш, А. М. Дошкільна лінгводидактика. Теорія і методика навчання дітей рідної мови в дошкільних навчальних закладах : підручник. 2-е вид., доп. Київ : Видавничий Дім «Слово», 2015. 704 с.

5. Руденко Ю. Патріотичне виховання учнів : концепція. Освіта. 2001. С. 10-15. 6. Концепція виховання дітей та молоді у національній системі освіти. Інформаційний збірник МО України. 1996. № 13. С. 10-31. 230. 


\title{
РОЛЬ ДУХОВНО-МОРАЛЬНИХ ЦІННОСТЕЙ У ПРОЦЕСІ ПІДГОТОВКИ МАЙБУТНІХ ФАХІВЦІВ 3 ФІЗИЧНОЇ РЕАБІЛІТАЦЇ̈
}

\begin{abstract}
Хорошайло Олена Станіславівна,
кандидат педагогічних наук, доцент, завідуюча кафедри лінгвістики

Донбаський інститут техніки та менеджменту 3ВО Міжнародний науково-технічний університет імені академіка Ю.Бугая,

Краматорськ, Україна

\section{Сігова Ануш Генадіївна}

кандидат педагогічних наук, доцент, завідуюча кафедри фізичної терапії та ерготерапії

Донбаський інститут техніки та менеджменту ЗВО Міжнародний науково-технічний університет імені академіка Ю.Бугая, Краматорськ, Україна
\end{abstract}

Розвиток соціально-економічних перетворень в Україні, інтеграція іiі в освітнє європейське середовище, створює потрібність у фахівцях нового якісного рівня. Особу гостроту й актуальність набувають питання, що стосуються підготовки майбутніх фахівців 3 фізичної реабілітації. I перед вищими навчальними закладами постає завдання щодо підготовки майбутніх фахівців з фізичної реабілітації до професійної діяльності та формування в них загальнолюдських моральних цінностей.

Теоретико-методологічна розробка сутності духовності та особливостей духовно-моральних цінностей знайшла відображення в наукових положеннях філософів (В.Баранівський, М.Бердяєв, Л.Буєва, С.Кримський, А.Кузнєцова, Л.Олексюк, Г.Сковорода, В.Соловйов та ін.); психологів (І.Бех, М.Боришевський, Т.Бутковська, О.Зеліченко, С.Рубінштейн, А.Титаренко та ін.); педагогів (В.Беспалько, Т.Власова, О.Олексюк, М.Роганова, Г.Сагач, В.Серебряк, В.Шадриков, Г.Шевченко та ін.). Аналіз сучасної наукової літератури та теоретико-експериментальних досліджень свідчить про значний інтерес до проблеми духовності та моралі, виховання духовно-моральних цінностей у студентів, що підкреслює iï актуальність.

Проблеми морального розвитку особистості та духовності значно актуалізувалися в наш час - період радикальних змін у житті суспільства. Занепад духовних цінностей призвів до посилення тенденції зростання жорстокого індивідуалізму, прагматизму, зверхнього ставлення до людини i приниження іiі гідності, зневаги до рідної культури та історико-культурних традицій [1].

Успішність професійної діяльності фахівця з фізичної реабілітації багато в чому залежить від його готовності до даної діяльності, від рівня сформованості професійних умінь та моральних цінностей. Професійна спрямованість 
майбутніх фахівців у сфері реабілітології формується внаслідок впливу низки об'єктивних та суб'єктивних факторів:

- наявного освітньо-професійного простору;

- суб'єктивної системи очікувань та переваг, ідеальних образів професії;

- визнання пацієнта значущою людиною, особистістю [2].

Як узагальнену детермінанту становлення професійної спрямованості можна розглядати професійно насичене освітнє середовище, з якого студенти, майбутні лікарі - реабілітологи, черпають уявлення про об'єкт та особливості майбутньої діяльності, ії завдання і функції, вимоги до особистості, шляхи отримання освіти та оволодіння необхідними вміннями, ціннісне ставлення до оточуючих тощо.

До педагогічних умов становлення професійної ідентичності майбутніх фахівців з фізичної реабілітації відносять:

- особистісно-орієнтований зміст освіти;

- раннє включення у процес професійної діяльності;

- використання форм і методів навчання та виховання, заснованих на високій активності та особистісної включеності студентів в освітній процес;

- діалогічний підхід у взаємодії викладача і студента, що забезпечує поєднання емоційно-ціннісного та професійно-особистісного досвіду викладача та студента [3].

Духовно-моральні цінності детермінують поведінку людей, у багатьох аспектах визначають їх взаємовідношення - міжособистісні, групові та соціальні. Завдяки їм відбувається опосередкування їх виробничої, соціальнополітичної та культурно-естетичної діяльності, іiі гуманізація та орієнтація на загальнолюдські цінності.

Важливо так будувати реабілітаційний процес, спілкування 3 хворими людьми, щоб за бажанням якнайкраще виконати реабілітаційні заходи, не втратити здатність співчувати, радіти спілкуванню 3 людьми. Тому для підготовки фахівців нового якісного рівня, необхідно, щоб процес професійної підготовки включав формування духовних цінностей студентів спеціальності «фізична реабілітація».

\section{Література:}

1. Шевченко Г. П. Духовність і цінності життя /гол. ред. Г. П. Шевченко / Духовність особистості:методологія, теорія і практика: зб. наук. праць. Луганськ : Вид-во Східноукр. нац. ун-ту ім. В. Даля,2004. - Вип. 5. - С. 3-15.

2. Бойчук Т. В. Актуальні проблеми професійної підготовки фахівців фізичної реабілітації / Т. В. Бойчук, О. С. Левандовський // Фізична та фізіотерапевтична реабілітація. Реабілітаційні СПА-технології: матеріали науково-практичної конференції, 29-30 квітня 2009 р. - Севастополь. - С. 11-12
3. Кукса
В. Переорієнтація
професійної
самосвідомості студентафізреабілітолога / В. Кукса // Теорія і методика фіз. виховання і спорту. - 2002. - № 4. - C. 40-47 


\section{ЗАСТОСУВАНHЯ ARNICA MONTANA В ГOMEOПАТÏ̈ ТА ФITОТЕРАПIÏ}

\section{Нестеренко Марія Андріївна,}

студентка

Національний фармацевтичний університет,

Ярних Тетяна Григорівна

д.ф.н., професор

Національний фармацевтичний університет,

\section{Олійник Світлана Валентинівна}

к.ф.н., асистент

Національний фармацевтичний університет

Arnica montana - багаторічна рослина, відома науці під назвою арніка гірська. Зростає в гірських районах Європи і Північної Америки.

Арніка здавна використовувалася в якості лікарської рослини. Перше задокументоване використання нових або сушених квітів арніки в медичних цілях датується 1500-ми роками. 3 суцвіть робилися компреси для лікування розтягувань і ударів. Листя арніки жували швейцарські гірські гіди, щоб захистити себе від викликаної підйомом втоми. Цей досвід передавався 3 покоління в покоління.

На сьогоднішній день хімічний склад арніки гірської до кінця ще не вивчений. У складі рослини присутні флавоноїди, які надають цілющий вплив на серце і систему кровообігу, ефірне масло, що володіє ранозагоювальну, дезинфікуючим і протизапальним ефектом, проціанід, поліпшуючі роботу серця, а також ряд інших елементів [1-2].

Активні сполуки цієї рослини, особливо сесквітерпенові лактони, відповідають за різні лікарські застосування.

Сесквітерпен-лактони, флавоноїди та фенольні кислоти - класи, що найбільше сприяють властивостям arnica montana.

Хоча сесквітерпен-лактони надають протизапальну та знеболюючу дію, флавоноїди та фенольні кислоти надають цій квітці антиоксидантну та протимікробну дію.

Геленалін та його складні ефіри - це типи сесквітерпен-лактонів, які багато містяться в квітниках arnica montana. Кверцетин-глюкозид, патулетин-глюкозид, кемпферол-глюкозид, кемпферол-глюкуронід, 6-метоксикемпферол-глюкозид та гіспідулін є флавоноїдами. 
Хлорогенова кислота, 3,5-дикафеоїлхінова кислота, 1-метокси-оксалоїл-3,5дикафеоїльхінова кислота та 4,5-дикафеоїльхінова кислота - це кілька фенольних кислот, які можна знайти в цій траві [1-2].

Місцеве застосування мазей та гелів 3 арніки може допомогти полегшити гострі м'язові болі, розтягнення зв'язок, тендиніт, скутість, фіброміалгію тощо.

ÏÏ клінічна ефективність для полегшення болю та запалення робить arnica montana потенційною альтернативою нестероїдним протизапальним препаратам.

Тепер же найбільш поширеним безрецептурним засобом і єдиною формою випуску, схваленої і регульованою Управлінням із санітарного нагляду за якістю харчових продуктів і медикаментів США, є гомеопатичний препарат arnica montana. Гомеопатичні лікарські засоби отримують 3 натуральних речовин (наприклад, речовин рослинного, мінерального та тваринного походження), але їх унікальність полягає у високому ступені розведення [3].

Згідно гомеопатичної теорії, подібне лікується подібним, тобто, хвороба може бути вилікувана речовиною, що викликає симптоми, подібні до симптомів хвороби. Гомеопати також підтверджують справедливість закону мінімальної дози, який свідчить, що чим нижче доза лікарського засобу, тим вище його ефективність [4-5].

Арніка - популярний в холістичній медицині засіб від болю, пов'язаного 3 травмою, оперативним втручанням і запаленням. Дослідження, проведене на марафонцях показало, що у спортсменів, які приймали арніку гірську, відразу після бігу м'язи боліли менше, ніж у тих, хто приймав таблетки плацебо. Інші дослідження показали, що арніка $\epsilon$ ефективною альтернативою нестероїдних протизапальних препаратів, які застосовуються для посттравматичного i післяопераційного знеболювання [6].

Крім того, arnica montana добре відома своєю протинабряковою дією, особливо коли набряк викликаний розтягуванням зв'язок, м'язовою напругою, укусами комах або переломом.

Очевидно, арніка ефективно бореться 3 поширеними симптомами остеоартриту, такими як біль і скутість суглобів. Дослідження, проведене на 174 людях із артрозом рук, показало, що при щоденному застосуванні олії / настойки / гелю на основі арніки по ефективності в плані полегшення болю і поліпшення рухливості рук не поступався гелю з ібупрофеном.

Арніка допомагає прискорити процес загоєння синців. Вважається, що арніка стимулює вироблення лейкоцитів, які сприяють виведенню застійної крові i рідини з ураженої області. Пластичні хірурги оцінили ефективність арніки, що сприяє зменшенню синців після косметичних хірургічних процедур.

У дослідженні, що включало операції ринопластики носової кістки, пацієнтам призначали пероральну періопераційну дозу арніки. У цих пацієнтів було прискорене післяопераційне загоєння, швидке відновлення екхімозу та швидша зміна кольору синців до нормального стану [6-7].

Ці відтворювані спостереження доводять ефективність арніки гірської у загоєнні рубців та синців. Його склади можуть застосовуватися в операціях 3 підтяжки обличчя та ринопластики та для загоєння глибоких ран. 
Як антиоксидант, арніка може полегшувати стан при акне, екземі і псоріазі. Arnica montana також вважається ефективним зволожуючим засобом. Чистий екстракт арніки гірської на шкіру наносити не слід. Але якщо змішати арніку 3 маслом-основою або кремом, вийде засіб для сухої шкіри [6].

У той час як алопатичні лікарські засоби можна приймати протягом тривалого часу 3 метою профілактики та запобігання симптомів, до гомеопатичних засобів такий підхід не застосовний. Гомеопатія працює за принципом стимул-реакція. Дія гомеопатичного препарату стимулює цілющу реакцію. Згідно з цим принципом, щоб запустити в організмі процес одужання, знадобиться все кілька доз ліки. Приймати їх тривалим курсом без контролю лікаря не можна [8].

Гомеопатична арніка випускається в препаратах для місцевого застосування і перорального прийому в різній концентрації (т.зв. потенції), діапазон розведень - від 3 Х до 30С.

Зазвичай для лікування легкого удару або травми може бути досить кілька разів нанести на хворе місце низькопотентний засіб для місцевого застосування на основі арніки. Перед нанесенням рекомендовано перевірити засіб на невеликій ділянці шкіри, щоб переконатися у відсутності алергічних реакцій. Для лікування травм середнього і високого ступеня тяжкості, можливий прийом пероральної форми арніки.

При помірних травмах достатньо кілька днів приймати arnica montana перорально в низьких потенціях 2-3 рази на день. При більш важких травмах ефективною може бути підвищена кратність прийому препарату більш високої потенції, наприклад, 30X або 30С [9].

Існує кілька запропонованих механізмів, за допомогою яких функціонує арніка. Вони включають інгібування прозапальних цитокінів (інтерлейкін-1, TNF- $\alpha$ ) та транслокацію NF- $\beta$ i NF-AT (ядерний фактор активованих Т-клітин). NF-ß і NF-AT $\epsilon$ клітинними хімічними речовинами, які беруть участь у запальних процесах.

Геленалін пригнічує транслокацію NF-AT у спеціалізованих клітинах імунної системи (Т-клітини). Так арніка отримує свої імунодепресивні властивості.

Кілька досліджень на мишах показали, що лікування арнікою показало 4,5кратне пригнічення вироблення оксиду азоту та падіння рівнів ферментів оксиду азоту синтази та циклооксигенази-2. Все це $є$ явними ознаками зменшення запалення в організмі.

Однак геленалін $\epsilon$ вибірково цитотоксичним. Дослідження показують, як цю властивість геленаліну можна застосовувати для лікування раку на молекулярному рівні [10].

Цитотоксичність арніки може викликати одне занепокоєння - трава може мати певні побічні ефекти.

Управління 3 санітарного нагляду за якістю харчових продуктів i медикаментів США вважає чисту арніку небезпечною. У вигляді натурального рослинного препарату арніка зазвичай наноситься місцево, оскільки при прийомі всередину можливі серйозні побічні ефекти. Гомеопатичні форми арніки гірської сильно розбавлені, тому вони в цілому безпечні. Проте, побічні ефекти не 
виключені: може виникнути тремор, слабкість, запаморочення, нудота, пошкодження печінки, пошкодження нирок, серцева аритмія і розлад шлунковокишкового тракту [2-3].

Слід дотримуватися обережності при зовнішньому застосуванні арніки, можлива поява висипу. Тривале застосування може викликати на шкірі подразнення, лущення, пухирі або екзему.

\section{Висновки}

Arnica montana посідає важливе місце в медичній, косметичній та харчовій промисловості. Арніка має знеболюючі та протизапальні властивості. Ця трава $€$ ефективним засобом від синців, болів у м'язах, загоєння ран, укусів комах, болів у суглобах, запалення, випадіння волосся, геморою та розтягнення зв'язок, хоча ще не всі перевірені медичною наукою.

Вона вважається отруйною, якщо приймати у великій кількості. Отже, гомеопатична медицина використовує рослину у розведеннях від $3 \mathrm{X}$ до $30 \mathrm{C}$. Таким чином, арніку застосовують в багатьох гомеопатичних мазях, гелях, настоянках, кремах та таблетках.

\section{Список літератури:}

1. Priyanka K. et al. Arnica montana L. - a plant of healing: review. Journal of Pharmacy and Pharmacology 2017, 69: 925-945.

2. Ahmad M. et al. Neuro-pharmacological and analgesic effects of Arnica montana extract. Int J Pharm Pharm Sci 2013; 5: 590-593.

3. Final Report on the Safety Assessment of Arnica Montana Extract and Arnica Montana. International Journal of Toxicology 2001, 20(Suppl. 2): 1-11.

4. Мотич О., Москаленко О. Положення гомеопатичних лікарських засобів у світі і в Україні. Вісник фармакологї̈ і фармаиії. 2015. № 12. С. 38-39.

5. Богер С. Оригинальная Materia Medica К. фон Беннингхаузена. Смоленск: Гомеопатическая медицина, 2012. 430 с.

6. Lannitti T. et al. Effectiveness and safety of Arnica montana in post-surgical setting, pain and inflammation. Am J Ther 2014; 23: 1-17.

7. Huber R. et al. Arnica and stinging nettle for treating burns - a selfexperiment. Complement Therap Med 2011; 19: 276-280.

8. Пімінов А. Ф., Зеленін Ю. В. Гомеопатія і дерматологія - шляхи розвитку. Вісник фармації. 2011. № 3 (27). С. 179.

9. Новейший справочник лекарственных препаратов / сост. Л. Н. Деревянченко. Харьков: Книжный Клуб «Клуб Семейного Досуга»; Белгород: ООО «Книжный клуб “Клуб семейного досуга"», 2010. 416 с.

10. Camargo R. A. et al. Effect of the oral administration homeopathic Arnica montana on mitochondrial oxidative stress. Homeopathy 2013; 102: 49-53. 


\title{
О НЕОБХОДИМОСТИ ПОЛИМОДАЛЬНОГО ДЕЙСТВИЯ ГЕПАТОПРОТЕКТОРОВ ДЛЯ КОМОРБИДНЫХ ПАЦИЕНТОВ
}

\author{
Трутаева Людмила Николаевна \\ аспирант \\ кафедра клинической фармакологии,
}

Институт повышения квалификации специалистов фармации, Национального фармацевтического университета, Харьков, Украина

Цубанова Наталья Анатольевна доктор фармацевтических наук, профессор, кафедра клинической фармакологии, Институт повышения квалификации специалистов фармации, Национального фармацевтического университета, Харьков, Украина

Эффективная терапия коморбидного пациента, который имеет 2-4 хронических заболевания, является одной из наиболее тяжелых проблем в современной медицине и фармации [1]. С одной стороны каждое из диагностируемых заболеваний требует назначения 3-5 лекарственных средств со специфической активностью, соответственно это 12-18 препаратов ежедневно, с другой стороны назначения более 5 лекарственных средств считают полипрагмазией, которая может затруднять любую терапию появлением побочных эффектов [2,3].

Эффективным путем избежания полипрагмазии и развития нежелательных реакций является разработка и внедрение лекарственных препаратов с полимодальным фармакологическим действием, когда один лекарственный препарат эффективно влияет на две и более патологии, но внедрение таких лекарственных средств занимает в 2-3 раза больше времени, более затратно экономически и других ресурсов. Поэтому новый способ исследования полимодальных по фармакологическим действиям лекарственных средств в условиях моделирования новой экспериментальной коморбидной патологии является научно и экономически обоснованным.

Наиболее часто у больных встречаются хронические заболевания печени и поджелудочной железы.

Проблема рациональной и эффективной терапии пациентов с патологией пищеварительной системы является одной из ведущих в медицинской практике и гепатологии в частности [4]. Несвоевременная и неадекватная терапия, не направленная на все аспекты патогенеза заболеваний печени, провоцирует тяжесть и прогрессирующий характер печеночной патологии, по данным современных клиницистов, требует необходимости проведения трансплантации донорской печени, как последнего критического шага в лечении пациента гепатологического профиля $[5,6]$. 
Вопрос адекватной терапии указанной когорты больных усложняется такими факторами, как коморбидность - заболевания гепатобилиарной системы достаточно часто являются вторичными и развиваются на фоне острых или хронических заболеваний пищеварительной системы, в первую очередь поджелудочной железы. Применение лекарственных препаратов, часто необоснованно и нецелесообразно, явления полипрагмазии, приводят к значительным поражений печени лекарственными средствами [7].

Например, большинства известных гепатопротекторных средств, содержит одно действующее вещество, не способное влиять на все патогенетические аспекты лекарственного гепатита, также имеются побочные эффекты, противопоказания и риски негативного взаимодействия $\mathrm{c}$ другими лекарственными препаратами, существенно ограничивая возможности их использования [8].

Аналогичная ситуация с лекарственными препаратами, которые применяют при заболеваниях поджелудочной железы, действие которых направлено только на контроль гликемии и не учитывает сопутствующих заболеваний $[9,10]$.

Вышеупомянутое обосновывает поиск новых способов доклинического изучения перспективных лекарственных средств с полимодальным фармакологическим действием.

\section{Список литературы:}

1. Patel RS, Manikkara G, Chopra A. Bipolar Disorder and Comorbid Borderline Personality Disorder: Patient Characteristics and Outcomes in US Hospitals. Medicina (Kaunas). 2019 Jan 14;55(1):13. doi: 10.3390/medicina55010013. PMID: 30646620; PMCID: PMC6358827

2. Masnoon N, Shakib S, Kalisch-Ellett L, Caughey GE. What is polypharmacy? A systematic review of definitions. BMC Geriatr. 2017 Oct 10;17(1):230. doi: 10.1186/s12877-017-0621-2. PMID: 29017448; PMCID: PMC5635569.

3. Onder G, Marengoni A. Polypharmacy. JAMA. 2017 Nov 7;318(17):1728. doi: 10.1001/jama.2017.15764. PMID: 29114834.].

4. Liang FF, Wang J, Li L, Yuan Y, Xie WR, Wu LH, He XX. [Chronic liver disease increases with damage to intestinal barrier function]. Zhonghua Gan Zang Bing Za Zhi. 2018 Aug 20;26(8):612-617. Chinese. doi: 10.3760/cma.j.issn.10073418.2018.08.010. PMID: 30317794.

5. Goldberg D, Ditah IC, Saeian K, Lalehzari M, Aronsohn A, Gorospe EC, Charlton M. Changes in the Prevalence of Hepatitis C Virus Infection, Nonalcoholic Steatohepatitis, and Alcoholic Liver Disease Among Patients With Cirrhosis or Liver Failure on the Waitlist for Liver Transplantation. Gastroenterology. 2017 Apr;152(5):1090-1099.e1. doi: 10.1053/j.gastro.2017.01.003. Epub 2017 Jan 11. PMID: 28088461; PMCID: PMC5367965.

6. Vassallo GA, Tarli C, Rando MM, Mosoni C, Mirijello A, Agyei-Nkansah A, Antonelli M, Sestito L, Perotti G, Di Giuda D, Agnes S, Grieco A, Gasbarrini A, Addolorato G; Gemelli OLT Group. Liver Transplantation in Patients with Alcoholic Liver Disease: A Retrospective Study. Alcohol Alcohol. 2018 Mar 1;53(2):151-156. doi: 10.1093/alcalc/agx097. PMID: 29206894 
7. Roy DN, Goswami R. Drugs of abuse and addiction: A slippery slope toward liver injury. Chem Biol Interact. 2016 Aug 5;255:92-105. doi: 10.1016/j.cbi.2015.09.018. Epub 2015 Sep 26. PMID: 26409324.

8. Gómez-Lechón MJ, Tolosa L, Donato MT. Metabolic activation and druginduced liver injury: in vitro approaches for the safety risk assessment of new drugs. $\mathbf{J}$ Appl Toxicol. 2016 Jun;36(6):752-68. doi: 10.1002/jat.3277. Epub 2015 Dec 22. PMID: 26691983.

9. Jermendy G. Inkretintengelyen ható antidiabetikumok és a pancreas betegségei (pancreatitis, pancreascarcinoma) [Incretin-based antidiabetic treatment and diseases of the pancreas (pancreatitis, pancreas carcinoma)]. Orv Hetil. 2016 Apr 3;157(14):523-8. Hungarian. doi: 10.1556/650.2016.30409. PMID: 27017851.

10. Trivedi CD, Pitchumoni CS. Drug-induced pancreatitis: an update. J Clin Gastroenterol. 2005 Sep;39(8):709-16. doi: 10.1097/01.mcg.0000173929.60115.b4. PMID: 16082282.]. 


\title{
EMOTIVE-EXPRESSIVE UNITS IN THE BRITISH COMEDY "LOVE ACTUALLY" AND PECULIARITIES OF THEIR REPRODUCTION INTO UKRAINIAN
}

\author{
Arkushenko Anastasiia \\ Bachelor \\ Petro Mohyla Black Sea National University
}

The film industry is in its heyday in the modern world, therefore film translation is gradually becoming one of the most popular types of translation. Filmmaking implements the entertaining, informative and educational functions of mass communication, through which it forms and changes the mental perception, the function of organizing behavior and communication between recipients of cinematic content. New dubbing studios are actively working and constantly appearing in Ukraine, as well as high-quality translations of foreign cinematographic products.

Film translation is a special type of literary translation, because in addition to the lexical features of the communicative act, it contains extralinguistic factors that constitute a problem for the translator. Problems of reproduction of film texts for foreign, foreign-cultural audience are one of the most actual problems of the theory and practice of translation. Considering the film production market in Ukraine, we can clearly determine that the most popular types of translation today are dubbing, voiceover and subtitling. Despite the great variability, the choice of translation method for a film depends on many factors namely financial conditions, the genre of the film product, distribution format, as well as the audience for which the product is intended.

The study of emotions is a relevant topic for a number of sciences, as they are manifested in all areas of human activity, including speech. From a linguistic point of view, the linguistic expression of emotions is carried out by an emotive unit. In emotional communication the expression of emotional states of interlocutors comes to the fore and in emotive communication, on the contrary, a certain emotional state of listeners is evoked through linguistic means. The expressiveness of an utterance is primarily a property of a linguistic unit to intensify the logical and emotional meaning of an utterance, to act as a means of subjective expression of the language by the author of the utterance. The attributes of expression are considered to be the ability of a word to be a carrier of evaluation, to reflect the attitude of the speaker to the subject of an utterance and to carry out a certain emotional impact. On the material of the analyzed film "Love Actually" and its translation, it can be stated that expressiveness is peculiar to all levels of language, the classification of means of expressivization of the communicative act includes:

1. Phonetic and phonological means. This group also combines a psychological aspect, because the combination of pronunciation, vocabulary and extralinguistic means helps to create a "speech image" of the speaker. Psychological pause is an 
important means of conveying the feelings, mood and intentions on a phonetic level. Within the framework of the researched film, the pauses hold the attention of listeners to the importance of the content of the already said specific word or sentence. This element was also recreated by the actors in the Ukrainian voice-over: A relationship based on the President taking what he wants and casually ignoring all those things that really matter to, erm... Britain. Стосунки грунтуються на тому, що президент бере саме те, щзо хоче і мимохідь ігнорує усе, щзо важливо для... Британії. Intonation and tones (High fall, Low fall, Fall-rise, High rise) help to express the mental state of the speaker, which makes the speech of the characters emphatic.

2. Morphological means. Lexemes formed by means of certain prefixes and suffixes acquire a new meaning. Suffixes, as a rule, do not change the lexical meaning of a word, but give it stylistic connotations: pretty sizeable - широкий; skinny тоron - xyда дуреna. The suffix -ish denotes a negative evaluation of what is said, which is amplified if this suffix is added to the noun base: that dullish party - така нудна вечірка. The use of the suffix -ie in the jargon of youth creates positive connotations, and is also used in the formation of words to denote people of old age: "A golden oldie for a golden oldie"- Старий шлягер для героя, що старішає. The emotional and evaluative component of prefixes in the semantics of adjectives in the film is expressed by such morphemes as: in-; un-; extra-; im-, and the words formed from them have both positive and negative color: unbelievable - неймовірно; ипехресted несподівано; she's extraordinary - вона чудова. The author's neologisms, which repeatedly occur in the speech of the characters is a real "challenge" for the translator, as it is very important not to lose the imagery and emotional charge of such a unit. The phrase half-pint of churly is a difficult task for a translator. Since this concept is not fixed in English dictionaries, the translator used linguo-ethnic adaptation and translated a fragment of the text into a language that is understandable to the Ukrainian-speaking audience, like овочевий гуляи.

3. Grammatical and syntactic means. Syntactic means of creating expressiveness include emphatic grammatical constructions. In our analysis we have identified:

3.1. Monosyllabic noun, verb and adjective sentences (Helpful-Переконала; No. Little scamps - Hi, дияволята);

3.2. Emphatic construction with the pronoun it at the beginning of the sentence acts as a means of intensifying the meaning of one of the structural elements (It's a terrible, terrible mistake, chubs... - Це жахлива, жахлива помилка, гладенький);

3.3. Expressive structures formed as a result of ellipse transformation (Beautiful muffin for a beautiful lady - Булочка для прекрасної панночки);

3.4. Emphatic inversion is a violation of the established sequence of a sentence members (So, come on, it's someone at school. Right? - Це, мабуть, дівчинка зі школи?). In the English language inversion is an accurate way to introduce an expressively marked sentence into the dialogue, but for the Ukrainian language it is not such a rare phenomenon, so in most cases, in order to convey emotionality, the translator performs an equivalent translation;

3.5. Emphatic repetitions, including its variants such as anaphora and epiphora (No nappies, no teenagers, no scary wife - No diapers, no teenagers, no horrible wife). 
3.6. Address. By naming the addressee of the speech, the speaker attracts attention, encourages the perception of his words, as well as enhances their expressiveness.

The study of emotive discourse is directly related to the characteristics of emotive vocabulary, the high "density" of which acts as its specific feature. During the assignment of lexical units to the emotive discourse, we applied psychological and linguistic approaches, while the linguistic motivation is inherent in the word itself and is an integral component of its meaning. Within this vocabulary, according to linguists, the following groups are distinguished:

1. Words that directly denote feelings: love, hate, revenge;

2. Words in the meaning of which the assessment of a phenomenon or object is given: sneaky; horrible; beautiful; funny; enigmatic; secret;

3. Words in which the emotional attitude to an object or phenomenon is expressed in grammatical ways, by special suffixes and prefixes: young lady, bun, nuts, inconvenient; kiddo.

The film dialogue also contains such units at the grammatical level, which bring emotional meaning only in combination with nouns and other parts of the sentence. These include:

1. The intensifying and motivating particles: a bit; so; pretty; such;

2. Words used in assessing the phenomenon, object and action: I should be easier than the last lot - I will not bother you; Ready in the flashiest of flashes - Everything will be done faster than the wind.

Exclamations, having no grammatical and lexical meaning, function as linguistic signs of expression of the individual attitude of the speaker to the situation.

Regarding the expressive vocabulary in the film, colloquial words are widely used, which give the speech liveliness and unique style. This group includes: slang (bro братан; pal - приятель; chuт - чувак); vulgarisms (crap - дурощі; that's bullshitие повна хрінь); jargon (popsters, відстій).

Experts use the communicative-pragmatic method of translation to reproduce emotive vocabulary, as its application is intended for the translation of belles-lettres style and films. Thus, the methods of reproduction are as follows: direct or equivalent translation (Oh, look, don't be a moron - Не будь кретином): contextual replacement (Right, the Christmas party, not my favourite night of the year and your unhappy job to organise - Тож, різдвяна вечірка - не найспокійніша ніч у рочі, а ти, бідолашна, усе організуєш). When it often becomes impossible to use a literal dictionary equivalent in the translation process, the translator uses various transformations, such as concretization (Nobody wants some politician stealing the kids' thunder - Нікомy не потрібно, аби слизький політик украв у дітей свято); addition (Wives and family and stuff? - Дружсин, родичів запрошуємо?); complete replacement of original words (Yo, what's up with your shoes, bro? - Йоу, братан, щзо за відстій?). The translator also uses phraseological units to give the sentence an emotional effect and adapt it to the Ukrainian audience: Right. Right. I understand that but I have decided...not to. Not this time. - Правильно. Правильно. Я розумію, та я вирішив не перегинати... палицю. Цього разу.

Linguistics studies not only the general linguistic means of our communication, but also the psychological sphere of speech and this part of the science is quite interesting 
and important for the translation of cinematographic products. Thus, in order to implement a film in another language, a film translator must correctly understand the communicative intention of the author, predict the reaction of the viewer of the original and find in the target language such linguistic means that will cause a similar reaction in the mind of the recipient of the source language. For this purpose, it is necessary to follow the general ways of implementing expressive units in translation, which differ at each language level.

\section{References:}

1. Кузенко Г.М. “Кінопереклад як особливий вид художнього перекладу (на матеріалі англійської мови).” Одеський лінгвістичний вісник, Т.3, 2017

2. Кузенко Г.М. "Мовні засоби вираження емотивності." Наукові записки НаУКМА, Т. 18: Філологічні науки, 2000.

3. Сербиновская, Александра. Обучение переводу с английского языка на русский: эмфатические конструкции. Изд-во Южно-российского политехнического университета, 2006.

4. Бурячок, А. А. Оиінна лексика в украӥнській літературній мові. Наук. думка, 1967.

5. Block, James. "Studies in the phenomenology of emotions." Abnormal and Social Psychology, vol. 54, 1957.

6. Daneš, František. Cognition and Emotion in Discourse Interaction : A Prelimenary Survey of the Field. Berlin, 1987.

7. Ekman, Paul. Expression and the Nature of Emotion. Lawrence Erlbaum Associates: Publishers, 1984. 


\section{КІНЕМАТОГРАФІЧНА КАТЕГОРІЯ ПЛАНУ ЯК ЗАСІБ ПІДСИЛЕННЯ ПСИХОЛОГІЗМУ В ПРИГОДНИЦЬКОМУ РОМАНІ Є. ГУЦАЛА «УЛЮМДЖІ»}

\section{Бульбачинська Ольга Іванівна}

Тимчасово не працюю

Спроба дослідити роман С. Гуцала «Улюмджі» 3 погляду кінопоетики дала можливість усебічно простежити кінематографізм його художнього мислення. Твір насичений психологізмом, тому найбільш потенційними для його розкриття $\epsilon$ план, правильне виокремлення якого доповнить розкриття основної думки художнього твору. За допомогою плану спостерігаємо в кадрі важливі деталі, які служать емоційним і психологічним навантаженням. О. Брайко твердить: «У вербальному художньому тексті плани унаочнюються завдяки опису інтер'єру, екстер'єру, ландшафту, пленеру й відповідним значущим письменницьким указівкам, а також емоційному, інтелектуальному, психологічному навантаженню просторових $\mathrm{i}$ предметних образів» [3, c. 42]. Ця кінематографічна категорія допомагає автору виокремити важливі деталі, які доповнюють розкриття основної думки твору. Ю. Лотман дає визначення цього поняття, яке варто взяти за основу для подальшого дослідження: «План - це не просто величина зображення, а відношення його до рамки (величина плану на маленькому кадрі плівки i на великому екрані однакова)» [8, с. 316]. Спостерігаємо, що дослідник не розмежовує поняття «кадр» і «план», а вказує на їхню нероздільну єдність, і це буде визначальним для аналізу твору, адже план несе емоційне та психологічне навантаження, допомагає реципієнту виокремити важливі деталі кадру. О. Брайко дає кінематографічну класифікацію планів за В. Горпенком, яку вважає усталеною з теоретичного погляду: дальній - фігура людини вміщується більше по вертикалі кадру; загальний - людина на весь зріст по вертикалі; «американський», або другий середній - тулуб людини; середній людина по пояс; крупний - людина по груди. Деталь - якісь дрібнички об’єкта, менші, ніж крупний план» [цит. за 4, с. 42]. Найбільш використовуваним, на думку дослідників, є крупний план, через який передається уявлення про певну дію, пов'язану з предметом [7]. Е. Россе поділяє погляди науковців, що техніку крупного плану в кінематографії було запропоновано Д. В.Гріффітом для ефективнішого демострування вроди виконавців головних ролей. Американський оператор Г. Толанд запропонував ефект «глибокого фокуса», у якому «кожна деталь переднього, середнього, заднього плану перебуває у фокусі, тобто додає епізоду насиченості, динамічності й виразності» [2, с. 51].

Н. Агафонова визначає різновидом дальнього плану панораму, яка може мати три рівні: 1) панорама огляду - траєкторія погляду; 2) панорама супроводу - камера стежить за переміщенням об'єкта, визначає темп; 3) панорама- «перекидання» різкі рухи, погляд з одного на другий об'єкт [1, с. 24]. Крім цього вказує, що 
деталь плану натомість $є$ «лаконічною композицією, <..> служить образотворчим пластичним образним акцентом» [1, с. 25].

Як видається, використання митцями різних планів у художньому тексті допомагає реципієнту краще зрозуміти внутрішній світ персонажа, адже середній і крупний плани дають змогу читачу «відчути» його переживання. Своєю чергою, деталь вказує на навколишнє середовище, незначний об'єкт у ньому, який також має вплив на зображуване. Використання планів різних типів можна розглядати як модель психологічної та драматичної проникливості [4], за допомогою якої увиразнюється кут зору (ракурс).

У романі «Улюмджі» важливу роль відіграє план. Так, використання середнього плану в епізоді зображення пошматованого тіла Худжірті апелює до уяви читача, а кольорові деталі психологічно доповнюють кадр: «Вгледівии стільки басаманів на оксамитово-шоколадній шкірі, з-під якої випирали міцні обручі ребер, Улюмджі навіть відвела погляд, соромлячись $і$ не вірячи, щзо Худжірті не тільки з обличчя страхітливо потворний, а й груди його посічено, а й плечі порубцььовано, а й руки пошрамовано» [6, с. 93]. Використання плану допомагає охопити образ персонажа цілісно, а відтак і збагнути важливі деталі розвитку всього епізоду: «Худжірті показав свої руки - важкі та чорні, у вузлах жил, начебто гадюки повузлували - й не тільки руки, а груди, живіт, шию, скроні, чоло» [6, с. 104]. Кольорові акценти підкреслюють працьовитість персонажа, а наративна камера рухається знизу вгору, зосереджуючи увагу на деталях.

Ближній план спостерігаємо в епізоді зображення Ерні, батька Убуша, де кадри поєднані перехресним монтажем, а наративна камера збоку від персонажа допомагає охопити картину панорамно: «Згорблений Санал Бараєв сидів на возі з віжками в руці, / дивився на дорогу, / дивився на осінній степ,/ але не бачив, ні дороги, / ні степу, / ні віжок у руиі. Бо перед сивим зором невідчіпно стояла жахлива картина, / батька мертвими руками обіймає Батнасан» [6, с. 249]. Поєднання кінематографічних засобів передає драматизм настрою епізоду. У наступних кадрах увага зосереджується на арці, відбувається плавний перехід на крупний план обличчя 3 виокремленням деталі та кольоровим акцентом: «Ерні тримав у руиі бортхо з недопитою аркою, безбарвні сльози сочилися з його посивілих очей» [6, с. 178]. Знову абстрактні поняття знаходять емоційне вираження в пластичній фізичній формі. Подальші картини подаються застосуванням дальнього плану: «Кінь сіро-молочної масті наблизився до хазяїна, схилився так, щзо його біла грива торкнулася снігової шапки волосся» [6, c. 178]. Лише з додаванням кольору та плану, використанням візійної метафори митцеві вдалось досягнути бажаного емоційного впливу на читача. Завершується монтажна фраза символічно, оскільки вибір світло-тінних відтінків передає невідомість майбутнього та трагедію теперішнього i зв'язок між ними: «Стариий чабан дивився сивими прозорими очима, в яких пеленою стояв туман» [6, с. 178].

Використання дальнього плану та його укрупнення спостерігаємо в епізоді зустрічі Убуша з вовками, де виокремлення деталі підвищує емоційність кадру: «Слідом за ним <..>, появився і другий вовк, майже такий самий великий. чей 
вовк якось дуже дивно переставляв лапи. Так, наче забував, яку лапу за якою слід йому переставляти, а тоді вовчі лапи немов підламувались, $i$ він розгойдувався то в один бік, то в другий» [6, с. 237]. Наступні кадри характеризуються поверненням наративної камери на персонажа з використанням загального плану і також зосередженням уваги читача на деталі: «Убуш ніколи не розлучався з маля - й зараз міцно стискував руків'я своєї безвідмовної пастушої зброї» [6, с. 237].

Крупний план використовується при розповіді Семена Романовича про молоді роки: «3 портфеля, де лежать вірші, Семен Романович дістає глянцевий лист паперу, на якому перефотографовано діаграму. Безліч кубиків иієї діаграми сполучено між собою лініями. В кубиках написано: як називалася справа, в якій брав участь господар, а також указано рік. Справи всякі, та й роки - від nіслявоєнних по нинішні〉 [6, с. 178]. Така стрімка покрокова деталізація кадру немов пластично розкриває історію життя персонажа й педантичність, з якою Семен Романович ставився до соціальних обов'язків. Глянцевий лист сприймається символічно, оскільки це доказ глянцево-зразкової роботи персонажа, який і досі з трепетом згадує молоді роки. У монтажній фразі автор поєднав два часових виміри, у яких живе Семен Романович: теперішнє (любов до поетичного слова) та минуле (зразок недаремно прожитого життя). Спостерігається авторська повага до персонажа через вказування по батькові, що одразу налаштовує на його важливу роль у суспільстві.

Отже, аналіз роману «Улюмджі» крізь призму кінематографічності яскраво засвідчує придатність застосування категорій поетики кінематографу для реконструкції особливостей творчого мислення Є. Гуцала. Найбільш потенційними з них $є$ план, що сприяє відтворенню психологізму зображуваних картин, зокрема почуттів, емоцій, страждань персонажів.

\section{Список використаної літератури}

1. Агафонова Н. А. Общая теория кино и основы анализа фильма. Минск : Тесей, 2008. 392 с.

2. Бордмен Адам Оллсач. Ілюстрована історія кіно. Львів : Видавництво Старого Лева, 2019. 107 с.

3. Брайко О. Кінематографічний потенціал літературного тексту: моделювання простору у творчості В. Дрозда. Слово і час. 2015. №10. С. 41-56.

4. Брайко О. Кінематографічний темпоритм образів у прозі Володимира Дрозда. Слово і час. 2016. № 2. С. 54-72.

5. Бордмен Адам Оллсач. Ілюстрована історія кіно. Львів : Видавництво Старого Лева, 2019. 107 с.

6. Гуцало Є. Улюмджі: роман; Милосердя по-американськи: Повість; Родео на акулі: Оповідання. Київ : Радянський письменник, 1988. 564 с.

7. Эйзенштейн С. Избранные произведения в шести томах. Москва : Искусство, 1964. Т. 2. 568 с

8. Лотман Ю. Структура художественного текста. Москва : «Искусство», $1970.388 \mathrm{c}$. 


\title{
ОСОБЛИВОСТІ ПЕРЕКЛАДУ АНГЛІЙСЬКИХ АБРЕВІАТУР У ДИСКУРСІ ЦИФРОВОЇ СТОМАТОЛОГІї
}

\author{
Данилюк Людмила Всеволодівна, \\ доцент Полтавський інститут \\ економіки і права
}

\section{Рябокінь Наталія Олександрівна, доцент Полтавський інститут економіки і права}

Січова Діна Юріївна, викладач Полтавський інститут економіки і права

Останнім часом кількість вживання різноманітних абревіацій значно збільшилася. Це простежується у всіх наукових та науково-популярних стилях. Професійна медична та стоматологічна література не $\epsilon$ виключенням.

У даній роботі було розглянуто та здійснено переклад абревіатур, що були використані у інструкцію до нового програмного забезпечення лікарської системи для отримання оптичних цифрових відбитків CEREC Primescan. Були використані наступні методи перекладу: транскодування, переклад повною формою слова або словосполученням, передача англійського скорочення еквівалентним українським скороченням, транскодування повної (вихідної) форми відповідного скорочення.

Зроблено висновки, що поява і становлення абревіації як словотвірного способу у дискурсі стоматології - це лише один з елементів тієї великої кількості перетворень, яких зазнає ділова англійська мова на сучасній стадії свого розвитку. Саме тому це $\epsilon$ перспективним напрямком досліджень мови у перекладацькому аспекті.

У англійській мові широкого вжитку набули різноманітні скорочення. Останнім часом кількість вживання різноманітних абревіацій значно збільшилася. Це простежується у всіх наукових та науково-популярних стилях. Професійна медична та стоматологічна література не $є$ виключенням. Для вищенаведених галузей абревіації єодними з основних способів словотвору. Звісно, для кожної галузі, процессу творення нових слів шляхом скорочення лексичних одиниць проходять по-різному, саме тому і виникають труднощі у їх перекладі[1]. Саме тому існує необхідність у дослідженні даної проблеми, а саме, специфіки утворення абревіатур в англійській мові і аспекти їх перекладу та вживання в різних типах словосполучень.

Лексичні скорочення поділяються на абревіатури, усічення та контамінації. Абревіатури поділяються на акроніми й абревіації. Акронім - це слово, яке 
утворюється 3 першої літери або літер складного слова чи словосполучення: CAD / CAM Computer-Aided Design та Computer-Aided Manufacture (автоматизоване проектування /автоматизоване виробництво). Дана абревіація вимовляється як одне слово, а не окремо по літерах, відповідно до правил англійської мови. Абревіації містять здебільшого приголосні та вимовляються як окремі літери англійського алфавіту [3].

В наш час існує чимало способів перекладу абревіатур 3 англійської мови українською. До основних належать [2]:

1) транскодування (транскрибування або транслітерування);

2) переклад повною формою слова або словосполученням;

3) передача англійського скорочення еквівалентним українським скороченням;

4) транскодування повної (вихідної) форми відповідного скорочення.

На даний момент проводиться значна кількість досліджень 3 вивчення абревіації, але в дискурсі стоматології кількість таких робіт не є значною. Саме тому у даному дослідженні нами було розглянуто чимало нових абревіатур, які широко використовуються у дискурсі стоматології, а саме у цифровій стоматології. Нами було обрано напрям цифрової стоматології через те, що ця галузь активно розвивається, кожен рік стоматологічні компанії випускають нове обладнання, програмне забезпечення, протоколи, матеріали для опису методики роботи 3 ними активно застосовуються нові абревіації. Цим і викликаний дослідницький інтерес до даної тематики.

Було проаналізовано інструкцію до нового програмного забезпечення лікарської системи для отримання оптичних цифрових відбитків CEREC Primescan та здійснено переклад абревіатур, які найчастіше зустрічалися 3 використанням усіх вищезазначених методів перекладу:

CAD/CAM (Computer-AidedDesign/Computer-AidedManufacture) -CAD/CAM автоматизоване проектування /автоматизоване виробництво

CR (centric relation) - ЦС(центральне співвідношення)

OVD(Occlusal Vertical Dimension) - ВРО (вертикальний розмір прикусу)

PIC (point of initial contact)- TIK (точка ініціального контакту)

In Lab SW (in Lab software) - програмне забезпечення in Lab

STL (stereolithography) - СЛГ (стереолітографія)

MT (minimalthickness) - MT (мінімальна товщина)

AD (attachment diameter) - ДП (діаметр прикріплення)

AT (attachment height)-ВП (висота прикріплення)

GS (gingival spacing) - ЯВ (ясенна відстань)

PCS (proximal contacts strength) - ПЩК (проксимальна щільність контактів)

PM (preparation margin) - МП (межі препарування)

SC (screw channel) - КГ (канал гвинта)

GMUJ (gingiva mask upper jaw) - ЯМВЩ (ясеннева маска верхньої щелепи)

MUA(multi unit abutment) - АМЮ (абатмент мультиюніта)

AJS (automatic jawscan) - АСЩ (автоматичне сканування щелепи)

$\mathrm{BR}$ (bite registration) - РП (регестрація прикусу) 
Зважаючи на вищенаведені приклади, абревіація не $є$ випадковим явищем для наукового стилю, вона значно полегшує сприймання інформації та дає можливість за коротший проміжок часу донести зміст певного повідомлення. Поява і становлення абревіації як словотвірного способу у дискурсі стоматології - це лише один з елементів тієї великої кількості перетворень, яких зазнає ділова англійська мова на сучасній стадії свого розвитку. Саме тому це $\epsilon$ перспективним напрямком досліджень мови у перекладацькому аспекті.

\section{References:}

1. Kisil S. Functions of abbreviations in modern English. Education, science and production: development and prospects: materials of the I All-Ukrainian scientificmethodical conference, Shostka, April 21, 2016. Sumy: Sumy State University, 2016. P. 76-77.

2. 2. Karaban V. Translation of English scientific and technical literature. Grammatical difficulties, lexical, terminological and genre-stylistic problems. Vinnytsia: New book, 2004. $576 \mathrm{p}$

3. 3. Korneva Z., Glinka N. The latest abbreviations and acronyms in English economic texts and their translation into Ukrainian. Scientific Bulletin of Volyn National University. Lesya Ukrainka. 2008. № 4. S. 308-312. 


\title{
ВЖИВАННЯ ГЕРУНДІЯ В НАУКОВО-ТЕХНІЧНОМУ ДИСКУРСІ
}

\author{
Поліщук Анжеліна Володимирівна, \\ Старший викладач Національного університету \\ біоресурсів і природокористування України
}

Берко Марія Олегівна, Студентка II курсу Національного університету біоресурсів і природокористування України

Одним із показників рівня володіння англійською мовою фахівцями нефілологічних спеціальностей, їх граматичної компетентності - $\epsilon$ вільне вживання в усній та письмовій формах спілкування неособових форм дієслова.

Герундій хоч і поступається за частотою вживання в науково-технічних текстах інфінітиву, дієприкметникам: Participle I, Participle II, але вважається найскладнішою неособовою формою дієслова, оскільки подібної форми немає у рідній мові, а при перекладі часто вимагає застосування складних лексикограматичних трансформацій. Походить він від латинського «gerere» - «нести», «діяти»; поєднує властивості іменника та дієслова. Складність засвоєння цього матеріалу студентами не філологами розпочинаються з уміння ідентифікувати форми герундія, які, як відомо, співпадають з Participle I та розуміння їх функцій у реченні. Слід пам'ятати, що Participle I виконує в реченні всього дві функції: означення та обставини і важливо не плутати при перекладі форми герундія та дієприкметника теперішнього часу на початку фрази, оскільки вони виступають різними членами речення: підметом та обставиною відповідно.

Отже, Gerund має чотири форми - одну просту і три складних. Проста форма - investigating, складні - being investigated, having investigated, having been investigated. Indefinite Gerund (проста форма) вказує на одночасність 3 дією присудка, тоді як Perfect Gerund - на дію, що відбулася раніше дії присудка. Надалі слід розглядати його зі студентами у порівнянні 3 англійським інфінітивом, оскільки ці форми дуже схожі за значенням та виконують одні й ті самі функції в реченні (підмета, додатка, означення, іменної частини присудка, обставини). До того ж, інфінітив і герундій часто однаково перекладаються та мають іноді ті самі правила вживання (після деяких дієслів, у функції додатку до іменників, на кшталт: have no intention of going/=to go; there are different ways of doing/=to do, або у функції підмета - it's no use talking about/= тощо). Та дуже важливо знати й розрізняти семантичні розбіжності у їх вживанні, наприклад, після таких дієслів, як to remember, to stop, etc.

За синтаксичними функціями в реченні, герундій - подібний інфінітиву. Може вживатися в ролі:

1) Підмета - Providing conditions for experimentations is one of his main tasks. Забезпечення умов для проведення дослідів - одне з його головних завдань. (Перекладатися іменником або інфінітивом). 
2) Іменної частини присудка (предикатива) - Her main duty was checking and recording temperature during the experiment. - Ïї головним обов'язком було перевіряти та реєструвати температуру під час досліду.

3) Додатка (прямий і прийменниковий) - They insist on studying aerodynamic resistance. - Вони наполягають на вивченні аеродинамічного опору.

4) Означення - He had the pleasure of assisting you during the experiment.

5) Обставини (часу, способу діï, умови, причини, мети) - On carrying out their experiment they discovered new elements. - Провівши дослід, вони виявили нові елементи.

Оскільки герундій містить в собі дісслівні властивості, то він

а) має категорію стану: активний, пасивний та може вказувати на час дії по відношенню до дії присудка (Indefinite Gerund, Perfect Gerund);

б) перехідний може мати прямий додаток: They insisted on recording temperature;

в) може визначатися обставиною, вираженою прислівником: They insisted on recording temperature immediately.

Маючи властивості іменника, герундій

a) може мати означення у вигляді присвійного займенника: He insists on their completing the experiment.

б) перед ним може стояти прийменник: After completing the experiment they made the following conclusions. - Після завершення експерименту вони зробили наступні висновки.

Звичайно ж, що варіант перекладу буде залежати від його граматичної форми та синтаксичної функції в реченні.

Особливі труднощі у студентів нефілологічних спеціальностей викликає вживання та переклад герундіального комплексу. Так називають конструкцію, що складається 3 іменника (у присвійному чи загальному відмінку) або займенника (присвійного чи в об'єктному відмінку) і герундія, який стоїть відразу за ними, і вказує на дію, яку виконує чи зазнає особа або предмет, означені таким іменником або займенником.

Герундіальний комплекс являє собою один складний член речення, який може виконувати синтаксичну функцію підмета, додатка (прийменникового $\mathrm{i}$ безприйменникового), означення, обставини.

Такий зворот часто перекладається 1) підрядним реченням (відповідно до його функції в реченні), де займенник чи іменник $є$ підметом, а герундій присудком, причому особова форма дієслова залежить від форми самого герундія: Indefinite чи Perfect, а також категорії стану: Active - Passive. Іноді такі звороти можуть перекладатися і 2) простими реченнями:

e. g. They insisted on the equipment being tested at once.

1) Вони наполягали на тому, щоб це обладнання було випробовувано відразу.

2) Вони наполягали на негайному випробовуванні цього обладнання.

e. g. The possibility of ethylene being converted into aromatic hydrocarbons is slight. 
1) Можливість того, що етилен перетвориться в ароматичні сполуки, незначна.

2) Можливість перетворення етилену в ароматичні сполуки незначна. [1, с. 84].

Розглянемо деякі підрядні речення з герундіальним комплексом.

The scientist's recognizing a problem is the first step to its solution. (Складний підмет) - Визнання вченим проблеми $є$ першим кроком до ії вирішення.

There was no hope of our obtaining good results of this experiment. (Складне означення) - Не було ніякої надії, що ми отримаємо хороші результати цього експерименту/досліду.

He insisted on them undertaking theoretical explorations. (Складний додаток) Він наполягав на тому, щоб вони проводили теоретичні дослідження.

After their having calculated all the results of the experiment the bioinformatics data were published in an International journal. (Складна обставина) - Після того, як вони зробили обчислення всіх результатів експерименту, ці дані 3 біоінформатики були опубліковані в міжнародному журналі.

Звичайно, навчити студентів основним закономірностям перекладу складних граматичних конструкцій, включно з герундієм - не складно та необхідно постійно заохочувати їх до творчого підходу в пошуках засобів адекватного перекладу автентичної фахової літератури: простих і комплексних граматичних, лексико-граматичних трансформацій. Оскільки для «адекватного перекладу наукових текстів необхідно вміло користуватися всіма типами та способами перекладацьких трансформацій, мати знання про досліджувану галузь та добре знати термінологію, а також враховувати жанрово-стилістичні та синтаксичні особливості тексту» [2, с. 145].

\section{Список літератури:}

1. Пумпянский А. Л. Чтение и перевод английской научной и технической литературы: Лексика, грамматика, фонетика, упражнения. Минск : ООО «Попурри», 1997. 608 с.

2. Поліщук А. В. Комплексні перекладацькі заміни в англо-українському перекладі наукових текстів. Науковий вісник Національного університету біоресурсів і природокористування України. Серія: Філологічні науки. Київ : “Міленіум", 2015. Вип. 225. С. 139-147. 


\title{
ХУДОЖНИКИ ІКОН: КРИТЕРІЇ ТА ВИМОГИ
}

\author{
Galuyko Roman
}

$\mathrm{PhD}$ of Philosophy, Associate Professor Ivan Franko National University of L'viv

Галуйко Роман кандидат філософських наук, доцент кафедри теорії та історії культури Львівський національний університет ім. Івана Франка

Будь-яка людина, яка виконує ту чи іншу роботу, або працює у певній сфері повинна бути добре обізнаною у своїй справі. Загалом, кожна професія, спеціалізація чи галузь науки вимагає необхідних знань, умінь та навичок для виконання певних завдань. А така сфера мистецтвознавства, як іконопис вимагає обізнаності не лише у галузі мистецьких наук, але також знання і певних богословських аспектів у справі створення ікон. Крім того, художник, який працює у сакральній сфері, виокремлюється з-поміж інших митців, що працюють в інших галузях мистецтвознавства. Проте, у справі написання ікон упускається одне 3 найважливіших питань - спосіб життя іконописця (християнський високодуховний), внутрішній моральний стан духу під час підготовки створення ікони. Усе це має велике значення на кінцевому етапі створення сакрального продукту.

Дослідники, зазвичай, пишуть про техніку та способи написання ікон, зосереджуючи свою увагу на підготовці матеріалу для створення ікон $[9$, с.289$303 ; 11$, с.386-404; 12, с.424-436; 3, с.436-451; 2, с.33-45], ведуть суперечки про доцільність використання того чи іншого стилю в іконописному зображенні $[10$, с.417-424], $є$ навіть довідник для іконописців як робити найменування та надписи на іконах [14].

Так, наприклад, Т. Єрьоміна, розповідаючи про мистецтво створення ікон відсилає читача до “Ермінії" Діонісія Фурнографіота (1707-1733pp.), де виокремлює такі глави: “Як роботи відбитки із зображень”, “Як підготовляти вугілля для малювання", "Про приготування пензлів", “Як перепалювати i розводити гіпс", “Як гіпсувати ікони" і т. д. [4, с.30], опускаючи при цьому важливу, на наш погляд, пропедевтичну частину - духовно-морального аспекту приготування іконописця.

Але на самому початку «Ермінії» (іконописний правильник) автор рекомендує іконописцю звершити ряд молитов перед іконою Одигитрії i висновує: “тоді з Божою допомогою зрозуміє свою справу дуже добре..." [1, с.78]. А розуміння своєї справи це запорука успіху. "Молодий художник, котрий вирішив стати іконописцем, повинен жити активним церковним життям, приймати участь у таїнствах Церкви, вивчати богослов'я...." [6, с.40]. Проте не 
всі дослідники погоджуються з таким твердженням. Так, наприклад, Д. Степовик до процесу іконотворення, що розпочинається з благословення і відбувається 3 читанням особливих молитов має певні зауваження. "Іконотворення перетворюється на ритуал, щось на зразок однієї з треб, хоч офіційно процес творення ікон не віднесено до требників і не прирівняно до требів і обрядів, загальноприйнятих у Церкві” [13, с.160].

Майстри Візантії залишили нам єдину загальну православну іконописну мову Святих Отців, що стала канонічною вже в перші віки християнства [15, c.328-329]. При цьому $H$. Чернишов наголошує: "Не відчувши цей святоотцівський принцип свободи всередині канону, ми беззаперечно впадаємо то у стилізацію, то у вільне самовираження. Вихід можливий лише при істинному засвоєнню святоотцівських традицій життя і творчості” [15, с.329]. Відтак підкреслюється важливий зв'язок між життям іконописця та його богоугодною справою - написання ікон, адже “яка користь розмірковувати, наприклад, про ісихазм в іконописі лише на основі прочитаних книг, коли сам живеш іншим життям?...” [6, с.42].

Ще одним важливим зауваженням є аналіз безавторства (не підписування художниками робіт) ікон. Архімандрит Зенон пояснює: "Іконописець - це людина, яка створює сюжет в рамках церковного канону і своїм в ньому нічого не вважає, - жоден з іконописців свої ікони не підписує, тому що мистецтво Церкви - соборне" [6, с.37]. В. Лєпахін наголошує, що іконописці були переконані в тому, що їх талант належить Богові, через них Святий Дух проявляє Божу волю. С. Алєксєєв пояснює це так: “Авторство іконописця спеціально приховується, оскільки ікона - творіння соборне; іконопис - не самовираження, а служіння й аскетичне ділання. Якщо на завершеній картині художник ставить свій підпис, що означає не лише авторство, але й міру відповідальності за творіння, то на іконі надписується ім'я того, чий лик явленний на іконі. В онтологічному розумінні тут відбувається поєднання імені та образу" [2, с.48].

Як бачимо, праведне життя іконописця було запорукою допомоги дії Святого Духу у процесі написання ікони. Яскравим прикладом допомоги Святого Духа у праці іконописця описано у житі першого руського іконописця - преп. Аліпія Печерського. До Аліпія прийшов благочестивий чоловік та замовив намісну ікону Успіння Пресвятої Богородиці. Через хворобу та неміч Аліпій не зміг іiі написати. На допомогу святому прийшов світлий юнак (ангел - Р.Г.) та написав замовлену ікону. Аліпій промовив до ангела: “Добре ти зробив. Бог допоміг тобі написати так благоліпно (красиво - Р.Г.), і Він Сам зробив це тобою” [5].

При цьому слушним є зауваження проф. Н. Покровського: “пам'ятки древності мають слугувати у наш час матеріалом, що надихає і направляє художника на шлях національної творчості, але при цьому не сучасне удосконалювання у художній техніці, ані особистий талант і настрій художника не можуть бути принесені у жертву традиції” [8, с.274]. Іконописне мистецтво відрізняється від інших видів мистецтв тим, що Святий Дух невидимо, але реально присутній на іконах святих. Святі через Святого Духа чують молитви молільників та через Святий Дух звершуються чудеса [7, с.45]. 3 цього В. Лєпахін висновує, що Святий Дух підносить до Першообразу шанування, яке ми 
віддаємо іконі; допомагає іконописцеві зобразити незображуване, виразити невимовне, описати неописуване; забезпечує реальне перебування святого на іконі; невидимо перебуває у молитовному спілкуванні перед іконами i чудотворіннях [7, с.46]. Але при цьому, на жаль, приходиться визнати, що багато ікон і навіть цілі іконостаси написані так, що заважають молитві [6, с.30-32]. Основна ж функція ікони - викликати у людини молитовний настрій. У такому ключі розуміння процесу створення ікон варто прийняти до уваги думку архімандрита Зенона, що "іконопис - церковне служіння, а не творчість у тому значенні, як його розуміють світські художники. Народжуючись з Літургії, ікона $\epsilon$ iii продовженням і живе вона лише у богослужінні" [6, с.34].

Як бачимо, вимоги до художника-іконописця $\epsilon$ набагато більшими $\mathrm{i}$ суворішими аніж до звичайного художника: аскетичний спосіб життя, обізнаність у богослов'ї як науці та святоотцівській традиції - складають християнську церковну культуру іконопису.

\section{Список літератури}

1. Ерминия или наставление в живописном искусстве, составленное иеромонахом и живописцем Дионисием Фурнографиотом 1701-1755год. - М.: Издательство Владимирского Братства, 1993. - 238с.

2. Алексеев С. Иконописный канон и иконописный подлинник / С. Алексеев // Зримая Истина. Книга о православной иконе для семьи и школы. - СПб.: Ладан, 2006. - c.33-45.

3. Балов А. Золотобойный промисел в Пошехонском уезде / А. Балов // Богословие образа. Икона и иконописцы. Антология. / сост. А. Н. Стрижев. - М.: Паломникъ, 2002. - c.436-451.

4. Еремина Т. Мир иконописцев. / Т. Еремина. - М.: ТЕРРА - Книжный клуб, 2005. - 416с.; 32 с. ил.

5. Житіс преподобного отца нашого Аліпія іконописця (30/17 серпня) // Режим доступу: http://www.lavra.ua/index.php?option=comcontent\&task=view\&id $=209 \&$ Itemid $=58$.

6. Зенон (Теодор), архим. Беседы иконописца / архимандрит Зенон, пред. С. Аверинцева СПб.: Издательство ВІВ $\Lambda \mathrm{IOПО} \Lambda \mathrm{I} \Sigma$, 2003. - 142c.

7. Лєпахін В. Ікона та іконічність / Валерій Лєпахін; пер. $з$ рос. Т. Тимо. Львів: Свічадо, 2001. - 288с.

8. Покровский Н. Новое церковное искусство и церковная старина / Н. Покровский // Богословие образа. Икона и иконописцы. Антология. / сост. А. Н. Стрижев. - М.: Паломникъ, 2002. - с. 263-274.

9. Прохоров С. Об иконописи и ее технеке / С. Прохоров // Богословие образа. Икона и иконописцы. Антология. / сост. А. Н. Стрижев. - М.: Паломникъ, 2002. - c.289-303.

10. Пыжов К., архим. К познанию православной иконописи / архимандрит Киприан // Богословие образа. Икона и иконописцы. Антология. / сост. А. Н. Стрижев. - М.: Паломникъ, 2002. - с.417-424.

11. Ровинский Д. Обозрение мастерства иконника / Д. Ровинский // Богословие образа. Икона и иконописцы. Антология. / сост. А. Н. Стрижев. - М.: Паломникъ, 2002. - c.386-404. 
12. Рябушинский С. Заметки о реставрации икон / С. Рябушинский // Богословие образа. Икона и иконописцы. Антология. / сост. А. Н. Стрижев. - М.: Паломникъ, 2002. - с.424-436.

13. Степовик Д. Мистецтво ікони: Рим, Візантія, Україна / Д. Степовик. - К.: «Наукова думка» НАН України, 2008. - 466с.

14. Филатов В., Камчатнова Ю. Наименование и надписи на иконных изображениях: Справочник для иконописцев. Издание 2-е. - М.: ПРО-ПРЕСС, 2006. - 352c.

15. Чернишев Н. Связь Истины и красоты / Н. Чернишев // Богословие образа. Икона и иконописцы. Антология. / сост. А. Н. Стрижев. - М.: Паломникъ, 2002. - c.326-331. 


\title{
ИСЛАМ ҚҰҚЫҒЫНДАҒЫ ИСТИСХАБ ДӘЛЕЛІ
}

\author{
Адилбаев Алау Шайкимович \\ $\mathrm{PhD}$, Қауымдаст. Профессор \\ Нұр-Мүбарак ЕИМУ
}

\section{Адилбаева Шамшат Амангелдиевна \\ $\mathrm{PhD}$, Қауымдаст. Профессор Нұр-Мүбарак ЕИМУ}

Истисхаб сөзінің тілдік мағынасы (الاسنِصنحَابُ жүру, айырылмас дос болу, үнемі соңында жүру, үздіксіз ілесу, бірге жүру, серік болу. ${ }^{4}$

Терминдік мағынасы - қандай да бір мәселенің әуел баста бекіген нормасы, өзін өзгертуші нақты дәлел табылмайынша, сол күйінде жалғаса беруі. ${ }^{5}$

Осыған орай мынадай екі байлам жасалады:

1. Әуел баста бар екендігі белгілі бір жағдайдың жалғасыпжалғаспағандығына қатысты күмән туындаса истисхаб жолы арқылы бұрынғы бар болғандығын назарға ала отырып, ол жағдайдың жалғасып жатқандығына қатысты шешім шығарылады;

2. Әуел баста бар болмағандығы белгілі бір жағдайдың кейіннен туындаптуындамағандығына қатысты күмән туындаса, истисхаб жолы арқылы бұрын жоқ болуына байланысты, қазір де оның жоқ екендігіне қатысты шешім шығарылады.

Осы екі жағдайға мысал келтірейік:

- Егер бір адам ешқандай айыбы жоқ деп бір затты сатып алып, кейін бір айыбы бар деп оны қайтарып бергісі келсе, сатып алып жатқан кезде сол затта қандайда да бір айыптың болып-болмағандығына қатысты сатушымен дауласатын болса, сатушыдан сөзін растайтын дәлел келтіруін талап ете алмайды. Өйткені, негізгі ереже бойынша заттың айып-кемшіліктен ада болуы. Қандай да бір дәлел келтірмейінше, ол жағдайдың жойылмағандығы қабыл етіледі. Сондықтан өз уәжін дәлелдеу сатушыға емес алушыға жүктеледі.

- Бір адам аңшылыққа үйретілген деген бір аңды (ит немесе бүркіт секілді) сатып алып, содан кейін оның аңшылыққа үйретілмегендігін біліп, ол аңды иесіне қайтарғысы келсе, уәжін дәлелдеуге міндетті емес. Өйткені, ол аңның аң аулауға үйретілгендігін дәлелдеу сатушының міндеті. Өйткені, қандайда бір аңның негізгі ерекшелігі аң аулауды білмеуі. Ал, білу ерекшелігі оған үйрету арқылы ғана жүзеге асады. Сондықтан арада дау туындағанда оның білетіндігін дәлелдеу сол аңды аңшылыққа үйретілген деп сатқан адамның мойнына

\footnotetext{
3 Терминдік мағынасын шектеп алмас үшін, оның қазақша атауын араб тіліндегі түпнұсқасын өзгертпей, «истисхаб» деп белгілеуді абзал көрдік.

${ }^{4}$ Усул әл-Фиқь фи суәл уә жәуәб. Саид Хусейн ас-Садр. - 2376.

${ }^{5}$ Исламский энциклопедический словарь. А.Али-заде, Ансар 2007 .- 7956.
} 
жүктеледі ${ }^{6}$.

Осыған орай, бір келісім немесе сауда-саттық, бір аңның яки жәндіктің, өсімдік немесе қандайда бір жейтін, ішетін яки тұтынатын нәрсенің т.б. жалпы бір істің үкімін білгіміз келсе, сол іс-әрекетке қатысты қандайда бір діни мәтін келіп жетпесе «әл-Аслу фил-әшйаи әл-Ибаха» (кез-келген нәрсенің негізі - оның мүбах болуы) деген қағидаға сүйене отырып оның мүбах ${ }^{7}$ екендігіне үкім беріледі.

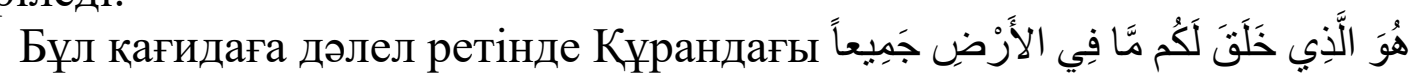

«Ол - жердегі (яғни, жердің асты-үстіндегі) бүкіл нәрсені сендер үшін

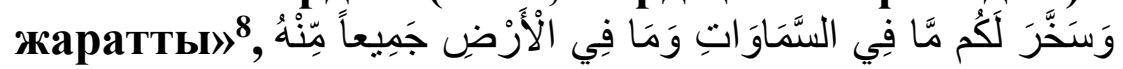

«Көктер мен жердегі барлық нәрсені Өзінен (сый ретінде) сендерге бағындырып қойды» $\mathbf{9}^{\text {, }}$ - деген аяттар көрсетіледі. Бұл жерде адам баласы үшін жаратылғандығын басты назарға бере отырып, айтуы оның мүбах екендігін көрсетеді ${ }^{10}$.

\section{Истисхабтың құқықта дәлел ретінде саналуы}

Истисхаб қандай да бір мәселеге қатысты дәлел табылмаған жағдайда қолданылады. Барлық мәзһабтар истисхаб дәлеліне сүйене отырып үкімдер шығарған. Бірақ, қолдану ерекшелігіне байланысты ғалымдар оны әр түрлі атаумен қолданған. Тіпті, қиясты дәлелге санамаған захирилер мен имамия мәзһабтарының өзі истисхабқа жүгіне отырып, көптеген мәселеге қатысты үкім шығарған. Теориялық тұрғыдан истихсанды дәлел ретінде алмаған шафиғилер де истисхабты өзге мәзһабтарға қарағанда көбірек қолданған. Өйткені, өзге мәзһабтардың әдет-ғұрып пен истихсанға негіздей отырып үкім шығарған мәселелерде имам Шафиғи истисхаб дәлелін қолданған. Ханафи мен мәлики ғалымдары көбіне қияс, истихсан секілді ижтихад тәсілдеріне көбірек жүгінгендіктен, истисхабты өзгелерге қарағанда аз қолданған.

Истисхабтың дәлелдігіне қатысты ғалымдардың көзқарастары әр түрлі. Солардың ең негізгі екеуі мыналар:

1. Ханафи мен мәлики ғалымдары истисхаб дәлелін бір мәселенің керісінше жағдайы мәлім болмайынша ескі күйінде қалатындығын дәлелдеу мақсатында айғақ ретінде қабылдайды ${ }^{11}$.

Осыған орай, истисхаб арқылы адам жаңа құқық иеленбейді, керісінше ескі құқығынан айырылудың алды алынады. Бұл «мәфкуд» (жоғалып кеткен адам) мәселесінде жақсы көрініс тапқан. «Мәфқуд» деп не өлі, не тірі екені беймәлім күйде жоғалып кеткен адамға айтылады. Егер бір адам хабарсыз жоғалып кетсе, сот арнайы зерттеулер өткізіп, ол адам қайтыс болды деген үкім шығармайынша, оның әйелі заңды жұбайы болып есептеледі. ${ }^{12}$ Қысқасы, жоғалған адамға тән

\footnotetext{
6 3. Шағбан. усулул-фиқь. - 188-189 б.

7 Мүбах - жасалып-жасалмауына қатысты діни тұрғыдан ешқандай кедергі жоқ, жауапкердің өз еркіне қалдырылған іс-әрекеттер.

8 «Бақара» сүресі, 29

9 «Жәсия» сүресі, 13

10 У. әз-Зухәйли. әл-Уәжиз. - 113 б.

11 Ф. Атар. - 2296.

12 Исламский шариат. Абдур Рахман И. Дои. - 112 б.
} 
жүретін құқықтары, өлгені дәлелденбейінше, тірілерге жасалған үкім жүреді. Мал-мүлкі мұрагерлерге үлестіріліп берілмейді, әйелі басқаға тұрмысқа шыға алмайды. Өйткені, жоғалған кезде оның тірі екені нақты белгілі болған. Өлгендігі дәлелденбейінше, «тірі» деп қабылданады. Бірақ, артта қалдырған мирасшыларының, әсіресе жұбайының тап болатын қиыншылықтарын жеңілдету үшін жоғалған кісіні сот арқылы өлген деп үкім шығаруға болады. Ханафилардың тұжырымы бойынша сондай үкім шығару үшін жоғалған адамның замандастарының қайтыс болуы немесе 90 жасына жетуі шарт қойылады. Мәликилердің тұжырымы бойынша адам жоғалған уақытынан төрт жыл өтуі керек. Соғыс кезінде жоғалғандар үшін күтілетін мерзім - соғыс бітіп, жауынгерлер мен тұтқындардың оралғандарынан бастап бір жыл өтуі керек.

Алайда, жоғалған кісі табылған жағдайда ол жаңа құқық иеленбейді. Бұл уақыт аралығында мұра немесе өсиет ету жолымен оған қандайда бір мүлікті иелену құқы өтпейді. Осыған орай, оның жоғалып кеткен кезеңінде мұрагер болатын бір туысы қайтыс болса, оның үлесі ықтияттылық үшін бөлек алынып қойылады. Егер аман-есен оралса оны алады. Егер сот ол жайлы қайтыс болды деп үкім шығарса, онда ол үшін қалған үлес өзге туыстар арасында жаңадан бөліске салынады. Өз дүние-мүлкіндегі құқы сот тарапынан өлгеніне қатысты шешім шыққанға дейін жалғасады да қайтыс болғандығына қатысты шешім шығарылған кезде ғана мұрагерлеріне үлестіріліп беріледі. Яғни, ол һәм мұрагер hәм мұра қалдырушы бола алмайды.

Ханафи және мәлики мазхабы бойынша истисхаб ол үкімді жоюда емес, керісінше бекітуде дәлел ретінде қолданылады. Сондықтан ханафилерде истисхабтың бұл мағынасы жоқ нәрсеге емес бар екендігі белгілі нәрсенің болмысын сақтау үшін дәлел саналады. ${ }^{13}$

2. Мәлики, шафиғи, захири мен шиғалардың көпшілік ғалымдары истисхабты бір нәрсені әрі жою үшін әрі дәлелдеу үшін де айғақ деп қабылдайды. Олардың көзқарасы бойынша жоғалып кеткен адам басқаларындағы өз ақысын алады. Истисхабқа сүйене отырып оның аман екендігіне қатысты үкім беріліп, басқаларға мұрагер бола алады әрі өзіне біреу өсиетпен мүлік қалдырса оны иелену құқын алады, дүние-мүлік иеленуге қатысты ескі құқықтары жалғаса береді. Олардың көзқарасында қайтыс болғандығы айқындалғанға дейін тірі ретінде қарастырылып, тірі адамға тиесілі бүкіл құқықтарға иелене алады. Өйткені, негізгі қағидаға орай оның тірі болуы, өлгендігі дәлелденбейінші осы негізге қарай истисхаб жасалады ${ }^{14}$.

Шафиғи мен ханбали ғалымдарының көзқарасы бойынша бұрын бар болып кейіннен оның жалғасып-жалғаспағандығына қатысты күмән туындаған дәреттің, некенің немесе мүлікке иеліктің жалғасуына исхаихаб жолымен үкім шығарылады. Олар: «Егер истисхаб дәлелге саналмаса, аталған жәйттардың осылайша жалғасатындығына қатысты үкім шығарыла алмас еді», - дейді ${ }^{15}$.

\footnotetext{
13 Уәнбату әз-Зухаили. әл-Усул әл-фиқһ. - 108 б.; Абдул Азим Шарафуддин. - 31 б.; Таснил усул. әш-Шаши. - 200 б.; Муғжам мусталахат усул фиқь. - 24 б.

14 У. әз-Зухәйли. - 115-116 6.

${ }^{15}$ Ф. Атар. усулул фикь. -230 б.
} 


\section{Истисхабтың түрлері}

1. Тыйым салатын қандайда бір дәлел табылмайынша бір нәрсені пайдалану немесе қандайда бір істі жасаудың мүбах екендігіне қатысты шешім қабылдау ибахасы. Бұны фиқһ методологиясында «истисхабу әл-Ибахати әл-аслияти лил әшйа» деп атайды.

Егер бір жануарлардың, өсімдіктердің, заттардың, сусындардың, амаләрекеттің, келісімнің немесе бүйрықтын үкімін білгіміз келсе, бірақ ол туралы мәтінде (Құран мен хадисте) еш нәрсе айтылмаса, біз оны мубах деп білеміз. Себебі, әрбір нәрсенің негізі, оны харам қылатын дәлел келмесе рұқсат болып табылады. Ал, егер бір нәрсенің харамдығына дәлелі болмаса, онда ибаха етілген нәрсенің үкімі дәлел бола алатынына, Аллаһ Тағаланың рұқсат берген мына:

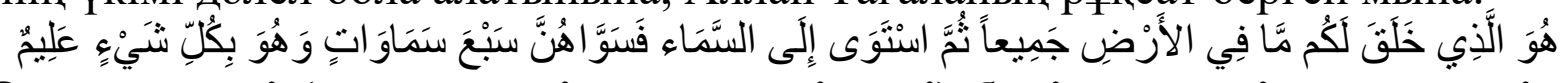

«Ол - жердегі (яғни, жердің асты-үстіндегі) бүкіл нәрсені сендер үшін жаратты. Содан соң (қалауы мен құдіретін) көкке бағыттап, оны жеті қабат аспан етіп жүйеге келтірді. Ол - барлық нәрсені толықтай білуші» 16 сөзіндегі келген үкімге истисхаб жасаумен рұқсат етіледі.

Бұл аятта адам баласына болмыстағы барлық нәрсенің бағындырылғандығы баяндалған. Кез келген нәрсе адам баласы үшін ерекшеленіп бағындырылса, онда жаратылыста харам болмаған барлық нәрсе адамзат үшін руқсат етіліп жаратылды деген мағынаны білдіреді. Аллаһ тағала адам баласы үшін Өз мейірімінен жер бетінде көптеген ризықтар жаратты. Бұл аятта, жер бетіндегі ризықтардың харамдығы дәлелденбейінше, халал және таза екендігі айтылуда, себебі Алла тағала мейірімін меңзеп тұр. Және бұл аятқа сүйеніп, бүкіл харам және зиянды нәрселерге тыйым салынғандығын айтуға да негіз бар. Өйткені, Аллаһ адамзатқа пайдасы бар нәрселерді жаратқандығын айтуда.

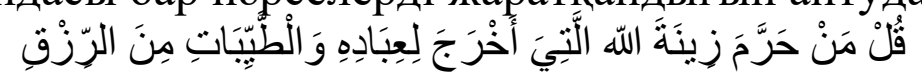

«(Уа, Мұхаммед! Оларға): «Аллаһтың құлдары үшін жаратқан адам көркі киім-кешекті және таза әрі пайдалы адал ризықтарды кім харам ете алады?»-деп айт.» ${ }^{17}$

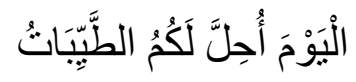

«Бүгін сендерге таза әрі дәмді нәрселер адал етілді» ${ }^{18}$. Бұл жердегі «таза» деген сөз ибахалықты емес, жақсы деп танылған нәрселерді меңзеуде.

Жоғардағы аяттарға сүйене отырып, егер бір нәрсенің харам екендігі білдірілмесе, оның халал (адал) болатынын аңғарамыз.

Олай болса, мужтахид бір мәселе туындағанда оның үкімдерін діни дәлелдерден немесе қияс әдісіне яки маслахат (қоғамның пайдасын көздеу) ұстанымына қарай зерттейді. Ол дәлелдердің бірінен оған қатысты үкім таппаса, жоғарыда аталған «кез-келген нәрсенің негізі - оның мүбах болуы» деген ұстанымға сай оның мүбах екендігіне үкім береді.

Истисхабтың бұл түрін жетекшілікке алуға қатысты ғалымдар бір пікірде, бірақ кейбір ғалымдар бұның истисхаб деп аталына келеспейді ${ }^{19}$.

\footnotetext{
${ }^{16}$ Бақара сүресі 29 аят.

17 «Ағраф» сүресі 32 аят.

18 "Маида» сүресі 5 аят.

19 3. Шағбан, - 189 б.
} 
2. Қандайда бір дәлел табылмайынша жауапқа тартылмау истисхабы.

Ислам құқығы бойынша бір адамның жауапты екендігін дәлелдейтін нәрсе табылмайынша оның жауапты емес екендігі негізге алынады. Кінәсі дәлелденбеген адамға немесе шариғат негіздерімен міндеттелмеген нәрсеге истисхаб жасауды айтады. Сондай-ақ, айыпталушының кінәсін сотта заң бойынша дәлелденгенше оны кінәсіз деп санау принципі. Яғни, адамның кінәсі дәлелденбейінше, оған кінә тағылмайды.

Бұл ережеге адам арының кінәсіз және міндеттерден бос екеніне байланысты шариғаттың міндеттері мен оның ішіндегі реттелген құқықтары жатады. Асылында, шариғаттың міндеттері мен құқықтарын негізі бойынша адамның ары таза әрі міндетсіз болып табылады. Егер шариғатта бес уақыт намаз бекітілген болса, онда алтыншы уақыттың парыздығы негізге теріс келеді әрі дәлелді талап етеді. Сол секілді шариғатта Рамазан айында ораза ұстау парыз екендігі белгілі, ал Шаууәл айындағы ораза уәжиб деу, негізге қайшы келіп, дәлелді талап етеді. Осыған қатысты тағы бірнеше мысал келтіре кетейік:

- Егер бір адам екінші бір адам маған қарыз деп шағымданып, бірақ оның қарыздар екенін дәлелдей алмаса әлгі адамның қарыз емес екендігіне қатысты үкім шығарылады. Өйткені, негізгі ереже бойынша қарыздар екеніне дәлел келтірілмейінше оның қарыздар емес екендігі тұжырымға алынады.

- Егер саудада серіктес екі адам пайданың түсуіне қатысты дауласатын болса, сауданы тікелей жүргізуші серіктес «ешқандай пайда түспеді» десе, екінші серіктес оның пайда түсіргенін делелдей алмаса, істі тікелей жүргізуші тараптың сөзі негізге алынады. Негізгі ереже пайданың түспеуі, өйткені пайданың түсуі басқа себептерге тәуелді. Сондықтан дәлел табылмайынша негізге сай истисхаб жасалынады.

- Бір әйел мен еркек өздерінің үйленгендіктерін дәлелдей алмаса, олар үйленбеген деген тұжырым жасалады. Өйткені, негізі нәрсе оның жоқ болуында. Бұл истисхаб түріне де ғұламалар бір ауыздан келіскен.

3. Себебі жойылғанға дейін діни һәм ақли тұрғыдан бар екендігі үкімінің өзгеріссіз саналу истисхабы. Мысалы, себебі яки құжаты бар кезде дүниемүлікке ие болу құқығының жалғасуы. Ол сауда келісімінің қолында болуымен дәлелденеді. Сол секілді неке қиылғаннан кейін ерлі-зайыптылардың бір-біріне адал болулары, қарызданған адамның қарызын өтегенге дейін жауапкершіліктің мойнында қалуы осы истихабқа негізделеді. Түсініктірек болу үшін бірнеше мысал келтіре кетейік

- Алу-сату, мұрагерлік сепкілді себептерге байланысты бір адамның мүлікке иелену ету құқын айғақтайтын құжат болса, қанша уақыт өтсе де мейлі қандайда бір себепке байланысты ол мүліктен айрылғандығын айғақтайтын дәлел табылғанға дейін оның меншіктік құқы жалғаса береді.

- Неке келісімі негізінде құрылған отбасы қанша уақыт өтсе де ерлізайыптылықтың бұзылғандығын көрсететін қандайда бір дәлел жоқ болса, ол заңды некенің жалғасып жатқандығы қабылданады.

- Бір адамның мойнында қарызы болса, қарызын өтеуі қажет. Оның қарызын өтегендігіне қатысты қандайда бір айғағы жоқ болса, оның әлі де қарыздар екендігі үкімі жалғаса береді. 
Олай болса діни һәм ақылдық тұрғыдан бір жағдайдың бар болып, кейіннен өзгергендігіне қатысты дәлел жоқ болса, ол жағдайдың жалғасып жатқандығына қатысты тұжырым жасалады. Истисхабтың осы түрін де ғалымдар бірауыздан қабылдаған ${ }^{20}$.

Фиқһ ғалымдары истисхабқа сүйене отырып кейбір ережелер бекіткен солардың ішіндегі ең маңыздыларына қысқаша тоқтала кетейік:

1. Негізінде бір жағдайдың өзгергендігіне қатысты дәлел табылғанға дейін, бұрынғы жағдайды сол күйі қалады. Бұл ережеге қатысты мысал жоғалған адамның қайтыс болғанына қатысты дәлел табылғанға дейін ол тірі деп саналады.

\section{2. Негізінде барша нәрсе мүбах. Бір нәрсенің үкіміне қатысты нақты} дәлел табылмайынша ол негізінде мүбах деп саналады.

Егер бір жануарлардың, өсімдіктердің, заттардың, сусындардың, амаләрекеттің, келісімнің немесе бұйрықтын үкіміне қатысты діни мәтіндерде (аятхадис) мәлімет кездеспесе оның мүбах екендігіне қатысты үкім беріледі. Бұған қатысты мысалдар мен дәлелдер жоғарыда келтірілген болатын.

\section{3. Айқын нәрсе күмәнмен жойылмайды}

Егер бір нәрсенің бар екеніне көзіміз жетіп сенімді болып, кейін оның бар екендігіне күмәндансақ, оған бар деген үкім беріледі. Өйткені, бар екендігіне қатысты алғашында сенімділік болған. Оның жойылғандығы күмәнді болғандықтан негізге алынбайды. Сондықтан бар екендіген қатысты нақты көз жеткізлген сенімді нәрсе күмәнді нәрсе үшін тасталмайды. Сондықтан ғалымдар бұл жайлы: «Айқын нәрсе (яқин) күмәнмен жойылмайды», - деген. Бұған қытысты фиқһ кітаптарында мынадай мысалдар келітірілген:

- Дәрет алғандығын нақты білген адамның ойына дәретінің бұзылыпбұзылмағандығы жайлы күмән туындаса, алдында дәреттің бар екендігі нақты мәлім болғандықтан дәреті бар деген тұжырым жасалады.

- Ораза айында таңға жақын бір нәрсе ішіп-жеген адам таңның атуынан бұрын немесе кейін жегенін нақты білмей күмәнданса, ол күнгі оразасын қаза етудің қажеті жоқ. Өйткені, ол тамақ жеуді бастаған кезде таңның әлі атпағандығы нақты белгілі еді. Бірақ жеп болған кезде таңның атып-атпағандығы күмәнді. Ондай жағдайда, керісінше жағдай нақты дәлелденге дейін нақты білінген жағдай негізге алынады. Алайда, мәселе күмәнді күйде қалмай таңның атуынан кейін ішіп-жегендігі нақтыланса, сол күнгі оразасын қайта ұстау қажет, кәффәрат қажет емес.

\section{Истисхаб - дәлелдердің соңғысы}

Истисхабтың анықтамасы мен түрлеріне жіті назар аударған кезде оның жаңа бір үкім бекітпейтіндігі нақты көрінеді. Қайта керісінше бұрын бар болған бір үкімнің жалғасын тапқандығын қабыл етуге истисхаб делінеді. Сондықтан ғалымдар: «Истисхаб жоқ нәрсені бар деп қабылдауда емес, бар нарсені сол күйі қалдыруда дәлел болып табылады», - деген.

\footnotetext{
20 3. Шағба. - 190-191 б.
} 
Яғни, бір мәселеде Кітап, Сүннет, Ижмағ және Қияс дәлелдерінен арнайы үкім табылмаған жағдайда мүжтәһид ғалымдары «истисхаб» дәлелі арқылы шешім шығара алады. ${ }^{21}$ Басқаша айтқанда, анық дәлел табылмаған жерде истисхаб уәж ретінде қолданылып, пәтуа беру үшін соңғы сүйенетін негіз болып табылады. ${ }^{22}$ Осыған орай, Хорезми «әл-Кафи» атты кітабында: «Истисхаб пәтуа шығарар кезде ең соңғы кезекте жүгінілетін негіз. Өйткені, пәтуа беретін адам өзінен бір мәселенің үкімі жайлы сұралғанда алдымен оның үкімін Құраннан, сосын сүннеттен, сосын ижмадан, сосын қиястан іздейді. Олардан бір үкім таппаса онда оң немесе теріс үкімді «жағдайға қатысты истисхабтан» шығарады. Егер күмән алдында бар болған үкімнің жойылыпжойылмағандығына қатысты туындаса, негізгі ұстанымға орай оның жойылмағандығында. Егер күмән бір жағдай немесе үкімнің болып-болмағанына қатысты туындаса, оның болғандығы негізге алынады» ${ }^{23}$, - деген екен.

Қорыта айтар болсақ, истисхаб дәлелі фиқһ ғалымдары үшін үкімі белгісіз мәселелерді шешуде бір кеңдік пен жеңілдік жасап, мәелелерді тез әрі оң шешуге қолғабыс етеді. Сонымен қатар, бұл дәлел ислам дінінің кең дін екендігін, үкімдерінің адамдарға қиындық келтірмеу үшін бекітілген адам табиғатына сай дін екендігін көрсетеді.

Міне, осылайша, ханафи әрі өзге де фиқһ ғалымдарының үкім шығарар кезде басшылыққа алып, жүгінген дәлелдерін қысқаша болса да баяндап шықтық. Бұның бәрі бізге мұсылман құқық жүйесінің кең, кез келген уақыт пен кеңістіктегі қажеттіліктерді өтей алуға оңтайлы екенін көрсетеді. Оның принциптері кейіннен туындаған кез-келген мәселелерді оң шешуге тиімді де әрдайым динамизмін сақтай алатын күрделі де сан-салалы жүйе. Кейбіреулердің білместікпен айтқанындай бір ғасырға ғана тән, қатып-семіп қалған жүйе емес. Сонымен қатар, Құран мен сүннетті негізге алған мұсылман ғалымдарының туындаған жаңа мәселелерді шешуге қатысты үлкен күш-жігер жұмсап, мейлінше исламның рухына қайшы әрекет етпеуге бар мүмкіндіктерін сарп еткендіктерін, діни мәселелрді шешудің кез келген адамның жасай беретін емес, соған лайық болған мужтахид ғұламалардың ғана жасай алатын күрделі әрі ғылыми ізденіс пен біліктілікті талап ететін ісі екеніне көз жеткіземіз.

\section{Пайдаланылған әдебиеттер:}

1. Саид Хусейн ас-Садр, Усул әл-Фиқһ фи суәл уә жәуәб.

2.А.Али-заде Исламский энциклопедический словарь., Ансар 2007.

3.Исламский шариат. Абдур Рахман И. Дои.

4.Уәһбату әз-Зухаили. әл-Усул әл-фиқһ.

5.Ислам ғылымхалы. Хайреттин Өзтүрк. Алматы: Хикмет баспа үйі, 2010.

\footnotetext{
${ }^{21}$ Ислам ғылымхалы. Хайреттин Өзтүрк. Алматы: Хикмет баспа үйі, 2010. - 295-296 б.

${ }^{22}$ ИльМ УсуЛЬ АЛЬ-ФИқһ Наука об основах исламской юриспруденции, книга подготовлена по материалам книги «FIKIH USÛLÜ» Doç. Dr. Fahrettin Atar, İstanbul 1988. 1-е издание. Перевод с турецкого Т.Хабибуллин - М.: ООО «Издательская группа «САД», 2005.

${ }^{23}$ Шәукәни, Иршадул-фухул, 28-беттен алған 3. Шағбан.- 1916.
} 
6.ИЛЬМ УСУЛЬ АЛЬ-ФИҚһ Наука об основах исламской юриспруденции, книга подготовлена по материалам книги «FIKIH USÛLÜ» Doç. Dr. Fahrettin Atar, İstanbul 1988. 1-е издание. Перевод с турецкого Т.Хабибуллин - М.: ООО «Издательская группа «САД», 2005. 


\section{ДІНИ ЭКСТРЕМИЗМНІН ЖАСТАР САНАСЫНА ӘСЕРІ}

\section{Сманова Нуржамал Әбдішукүрқызы}

Сарыағаш медресе колледжінің ұстазы

Тәуелсіздік орнағалы, міне 30 жылға аяқ бастық. Осы уақыт ішінде жасы да, кәрісі де білім жинап, ақыл тоқтатып үлгереді. Жастар халық санының 21\% құрайды, яғни елімізде орта жастағы адам саны 4 млн-нан асады. Кез келген елде болсын жастар араласпайтын іс болмайды. Мәдениетте, әлеуметтік қатынастарда, приоритеттік мақсаттарда, саясаттың бөлігіне, дінаралық қатынастарда да жастар қоғамының маңызы зор. Бүгінгі уақытта жастар өміріндегі этноаралық және дінаралық құндылықтар өзгеріске ұшырап барады. Бірақ Алматы, Шымкент, Астана секілді қала жастарында заманауи тұрғыда білім алу мүмкіндігі жоғары саналады. Халық саны көп болған қалаларда да оқыс оқиғалардың жиі болып тұратыны белгілі жайт. Қазіргі уақытта еліміздегі басты кедергілердің бірі - жастардың жат ағымның жетегінде жүруі. Осындай жағдайлардың орын алуына бірнеше мысал келтіруге болады:

- интернет желісінің әсерінен жастардың психологиялық қиындықтарға тап болуы;

- әлеуметтік жағдайдың төмен болуы, қажетті діни білімнің болмауы, батысқа еліктеушілік;

- аталмыш проблемаларды жат ағымдардың тиімді пайдалануы;

- елімізде мектептерде діни сауаттылықты арттыру бойынша жүргізілетін жұмыстардың жеткіліксіздігі;

- қоғамдағы жұмыссыздықтың белең алуы және т.б. жағдайлар. Діни экстремизм мен теріс ағымдардың алдын алу үшін профилактикалық жұмыстардың көптеп жүргізілуі аса қажет. Теріс ағымның соңынан жүрген жастар қандай іспен айналысады?

Негіздері бойынша «Саудаласу - сүннет, сүннетті атқарып жүрміз» дейді, бірақ асылында адамдармен қарым-қатынас жасайтын белігілі бір орындарды таңдайды. Мобильді телефон жасайтын себептері, мысалы «айфон» жөндетуге апарасыз. Содан кейін ол оның қымбат тұратын ұялы телефон екенін біліп алады, кейін сізге 15 минут күте тұрыңыз дейді де, соңынан сізді барынша сөзге тартуға тырысады. Сол секілді, машинаның автобөлшектерін сатумен жан бағады. Осылайша, «сізге қандай тауар қажет, тауып бере аламын» деп сөзге шүйіркелете, өз насихаттарын бастайды. Жастарға аса қауіпті болатын жат ағымдар жетерлік. Атап айтқанда: «Уахабия», «Хизбут Тахрир», «Сәләфизм», «Йегова күәгерлері», «Кришна санасы қоғамы» және т.б.

Діни дағдарыс көбейіп, қоғамға зиян ағымдар күннен-күнге еселеп жатқанына дінтанушылар алаңдауда. Рухани проблеманы бөлек алып қарастырғанмен, ол өзге қоғамдық-экономикалық қатынастармен біте байланысып жатқандықтан, бірден шешіле салмайды.

Шынында, экстремистік ұйымдардан келетін қауіпті қайтаруда әкімшіліктегі әлеуметтік салаға қатысы бар басқармалар, Дін істері және 
азаматтық қоғам министрлігі, ҰҚК мен Ішкі істер басқармаларында жүйелі бағдарлама, сол бойынша жұмыстар ұйымдастырылуы керек.

Теріс ағымдар мен экстремизмнің алдын алу бағытындағы ең көлемдісі, нәтижелі шығатыны - интернет пен әлеуметтік желілердегі рухани сауатын ашу сабақтарында, діни тақырыптағы өзекті мәселелерді талдауда дәстүрлі ислам ұстанушылар басымдылық танытулары қажет. Осы бағытта қарапайым сабақтардан бастап, ғұламалар сабақтарына дейін қажет еткен тілде жамағат талабы қамтамасыз етілуі тиіс. Терроризм (ланкестік) - саяси мақсатқа жету жолында жастарды ерікті түрде иландыру әдістері.

Көздеген мақсатына жетуде, миссионерлік ұйымдар тұрғылықты халық басым ораналасқан елді мекендерде тұрып, халықтың салт-дәстүрін, мәдениетін, болмысымен қатар рухани дүниетанымдық жүйесін анықтау барысында жетерліктей дәрежеде толыққанды зерттейді. Қоғамдағы түрлі келеңсіз жағдаяттарға байланысты: өмірге көз қарасы бұлынғыр, түрлі сынақтарға тап болып, шешімін табуда қиындыққа шыдамай, діни сауаттылығы таяз жастар осы топтардың үгіт насихатына иланып қалатыны сөзсіз. Қоғамдағы орын алып жатқан ланкестік әрекеттер жастарға дінді жеткізгенде оның діни психологиясын зерттеп, оның әлсіз тұстарын анықтайды. Кез келген қоғамда адамның діни болмысымен қатар, қоршаған ортадағы болып жатқан келеңсіз жағдаяттарға байланысты өз орнын табуда оны лидерлік дәрежеге жеткізген сыңай танытып оны көздеген мақсатына пайдалануда жылы шырай танытып, өз мүддесін іске асыруда барынша қолдау көрсетеді. Сауатсыздық пен надандықта бұрыс іс әрекетін анғарған кезде тығырыққа тіреліп ланкестік ұйымның мүшесіне айналады.

Күніміздегі лаңкестік ұйымдардың алдыңғы қатарында орын алған топтардың ең қауіптісі саяси билікке жетуде кез келген әрекетке баруда мемлекетін, ата-анасын (отбасын) тіпті өмірін сарп етуге дайын екендігінің куәсі болдық.

1992 жылдың 15 қаңтарда «Діни сенім бостандығы және діни бірлестіктер» атты қабылдаңған заңдағы «Барлық діндер мен діни бірлестіктер заң алдында бірдей» деген бөлімін миссионерлік ұйымның өз мүддесін іске асыруда қолайлы жұмыс жасауға жол ашты. Сонымен қатар күніміздегі пайдасынан зияны басым, күніміздің ақпарат көзі болып саналатын ғаламтор желісінде ақпараттық-насихат сепаратизммен лаңкестіктік әрекетті іске асырудағы белсенділік танытуда. Қазақстанда тыйым салынған ұйымдардың «жахилия», «жихад» ұғымы бүгінгі күннің қатыгездік пен зұлымдықты еске түсіретін термин сөздерге айналды. Сондықтан да күнімізде Ислам дінінің әмірлерінен бұрын бұл терминге қызығушылық әлдеқайда жоғары. Ислам дінін өз мүддесіне қолданушы лаңкестік ұйымдардың теориялық аспектілері кеңінен талқылануда.

Қорыта айтқанда, басқа да қылмыс түрлерін болдырмаумен қатар алдын алу. Күнімізде ланкестік ұйымдар Қазақстанмен қоса Орта Азияны да мүлт қалдырмады десекте болады. Түрлі экстремизмге қарсы негізделген әрекеттер қылмыстық жауапкершілікке тартылады. 


\section{ПАЙДАЛАНЫЛҒАН ӘДЕБИЕТТЕР ТІЗІМІ}

1. «Қазақ Энциклопедиясы»

2. Қалмахан Ержан, Мұратхан Махмет. «Салыстырмалы диндер және ағымдар». - Алматы: «Нұр-Мүбарак» баспасы,2017.

3. Сағынкүл Қонар. «Діндер тарихы» - Алматы: 2011.

4. Аникин Д.П. История религий. - М., 2007.

5. Айтбаев О. Дінтану. - Карағанды, 2009. 


\section{TWO QUANTUM ABSORPTION OF POLARIZED RADIATION IN n-GaP}

Muminov Islombek Arabboyevich, doctoral student of Fergana State University, Uzbekistan

Qo'chqorov Mavzurjon Xurshidboyevich, teacher of the Kokand State Pedagogical Institute, Uzbekistan

Ravshan Rustamovich Sultanov teacher of the Kokand State Pedagogical Institute, Uzbekistan

\section{Temurbek Tulhin ogli Tashkhodjayev} master's student of Fergana State University

Nonlinear absorption of light in a semiconductor with a degenerate valence band, due to direct optical transitions between subbands of heavy and light holes and depending on the state of polarization of the radiation, was studied in [1-8]. In these researches, it is taken to account that nonlinearity in the dependence of the singlephoton absorption coefficient on intensity occurs due to resonance absorption saturation. This saturation is due to the photoinduced change in the distribution functions of current carriers in the region of the momentum space near the surface $E_{X_{3}^{C}}(\boldsymbol{k})-E_{X_{1}^{C}}(\boldsymbol{k})-\mathrm{h} w=0$ corresponding to the resonance condition. Here

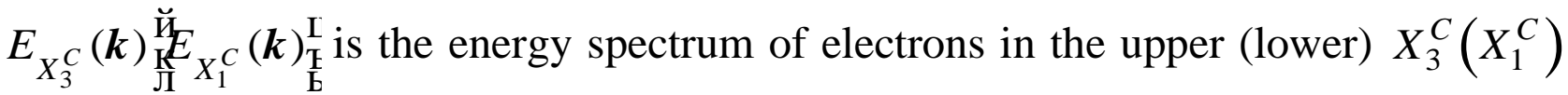
subzone of the semiconductor conduction band, $w$ is the frequency of light.

However, the issue of absorption of polarized radiation in a semiconductor with a complex zone consisting of two subbands (branches) [9], between which there is an energy gap, remains open. The solution of this issue is devoted this work.

Next, we consider two quantum absorption of polarized radiation in $\mathrm{n}-\mathrm{GaP}$ type semi-conductors, due to direct optical transitions between the subbands of the conduction band without taking into account the effect of coherent absorption saturation [10], i.e. consider the absorption of polarized radiation, where it is assumed that the photon energyh $w$ satisfies the inequalities, where $E_{g}$ is the band gap, $\mathrm{D}_{s o}$ is the spin-orbit splitting of the valence band.

Due to the smallness of the wave vector of the photon compared to the wave vector of the electron (hole) formed as a result of absorption, when calculating the $\mathrm{N}$-photon absorption coefficient of light $(K(N w, T))$, we can assume $\boldsymbol{q}<\boldsymbol{k}$ and assume $\boldsymbol{q}=0$. Then, according to $[2,3]$, the $\mathrm{N}$ photon absorption of light coefficient can be written as 


$$
\begin{aligned}
& K(\mathrm{~N} w, T)=N \frac{2 p}{\mathrm{~h}} \frac{\mathrm{h} w}{I} \Gamma \\
& \left.\left.\left.\mathrm{r}_{\mathrm{r}, m= \pm 1 / 2 ; m \ddot{y} \pm 3 / 2}^{\mathrm{r}}\left(f_{\mathrm{X}_{1}^{C}, \boldsymbol{k}}^{(\mathrm{N})}-f_{\mathrm{X}_{3}^{C}, \boldsymbol{k}}^{(N)}\right)\right|_{\mathrm{X}_{1}^{C} ; \mathrm{X}_{3}^{C}} ^{(\mathrm{N})}(\boldsymbol{k})\right|^{2} d\left(E_{\mathrm{X}_{3}^{C}, \boldsymbol{k}}-E_{\mathrm{X}_{1}^{C}, \boldsymbol{k}}-N \mathrm{~h} w\right)\right)^{\prime}
\end{aligned}
$$

where $M_{\mathrm{X}_{1}^{C} ; \mathrm{X}_{3}^{C}}(\boldsymbol{k})$ is the matrix element of the optical transition from the state $\left|\mathrm{X}_{1}^{C}, \boldsymbol{k}\right\rangle$ to $\left|\mathrm{X}_{3}^{C}, \boldsymbol{k}\right\rangle, \boldsymbol{k}$ is the wave vector of electrons, $I=\frac{n_{w} w^{2} A_{0}^{2}}{2 p c}$ is the light intensity, $E_{l \boldsymbol{k}}$ is the energy spectrum of electrons in the subzone $l\left(l=X_{3}^{C}, X_{3}^{C}\right), f_{l k}^{(N)}$ is their nonequilibrium distribution function for N-photon absorption of light, $n_{w}$ - is light refraction index at frequency $w$. Other quantities are well known.

It is clear from the last relation that to determine the spectral or temperature dependence of the optical parameters of a semiconductor, for example $K(\mathrm{~N} w, T)$, it is necessary to calculate the composite matrix elements of the considered optical transitions and we will analyze them below for specific cases.

In the future, to calculate $K(2 \omega, T)$ in the case of absorption of linearly polarized light, we choose the following geometry of the experiment $\vec{e}=\left(0,0, e_{z}\right)$, i.e. light propagates across to the main axis of symmetry of $\mathrm{n}-\mathrm{GaP}$. Then

$$
K(2 \omega, T)=\frac{2 \hbar \omega}{I}\left(\frac{e A_{0}}{c \hbar}\right)^{2} \sum_{k}\left|\overrightarrow{e p}_{31}\right|^{2} f\left(E_{1 \vec{k}}\right) \delta\left(E_{3 \vec{k}}-E_{1 \vec{k}}-2 \hbar \omega\right),(* 6)
$$

where the intersubband matrix element of the momentum operator for the vertical optical transition will be as

$$
\begin{aligned}
& \vec{e}_{31 .}=\frac{m_{0}}{\hbar}\left\langle X_{3}^{(C)} \mid \vec{\nabla}_{\vec{k}} \hat{H}(\vec{k}) X_{x}^{(C)}\right\rangle=\frac{m_{0}}{\hbar}\left[P e_{z} \sigma_{y}^{(31)}+\eta \sigma_{x}^{(31)} D\left(e_{x} k_{y}+e_{x} k_{y}\right)\right], \\
& \text { where } \eta=\sqrt{\frac{\Delta^{2}}{\Delta^{2}+4 P^{2} k_{z}^{2}}}, \sigma_{z}^{(31)}=\frac{2 P k_{z}}{\sqrt{\Delta^{2}+4 P^{2} k_{z}^{2}}}, \sigma_{y}^{(31)}=-i, \sigma_{x}^{(31)}=\frac{\Delta}{\sqrt{\Delta^{2}+4 P^{2} k_{z}^{2}}} .
\end{aligned}
$$

$f\left(E_{X_{3}^{(c)}}(\vec{k})\right)$ is distribution function of electrons with energy $E_{X_{1}^{(c)}}(\vec{k})=E$.

\section{The spherical approximation. Energy spectrum}

$$
E_{X_{3}, X_{1}}(\vec{k})=A_{3,1} k_{z}^{2}+B_{3,1} k_{\perp}^{2} \pm \frac{\Delta}{2},
$$

Next, we consider the following geometry of the experiment: $e_{z}=0, e_{x} \neq 0, e_{y} \neq 0$ , where

$$
\left|\overrightarrow{e p}_{31}\right|^{2}=\frac{m_{0}^{2}}{\hbar^{2}} \eta^{2} D^{2}\left(e_{x} k_{y}+e_{x} k_{y}\right)^{2} \frac{\Delta^{2}}{\Delta^{2}+4 P^{2} k_{z}^{2}}
$$

Then the light absorption coefficient in the spherical approximation in the energy spectrum will be as

$$
K_{\|}(2 \omega, T)=\frac{2 \cdot 2 e^{2} P^{2}}{c n_{\omega} \omega \hbar^{2}\left(A_{3}-A_{1}\right)} k_{\omega} f\left(k_{\omega}\right),
$$


where $f\left(k_{\omega}\right)=\exp \left(\frac{E_{F}-A_{1} k_{\omega}^{2}-\frac{\Delta}{2}}{k_{B} T}\right)$. From the law of conservation of energy $\delta\left(E_{3 \vec{k}}-E_{1 \vec{k}}-2 \hbar \omega\right)$ we have $k_{\omega}^{2}=\frac{2 \hbar \omega-\Delta}{\left(A_{3}-A_{3}\right)}$.

Next, choose the following geometry of light absorption: $e_{z} \neq 0, e_{x}=0, e_{y}=0$, then it is easy to get that $\left|\overrightarrow{e p}_{31}\right|^{2}=\frac{m_{0}^{2}}{\hbar^{2}} P^{2} e_{z}^{2}$. Then the light absorption coefficient is determined by the formula

$$
K_{\|}(2 \omega, T)=\frac{e^{2}}{c n_{\omega} \hbar} \frac{k_{B} T}{B} \frac{1}{k_{z}^{(\omega)}} \cdot \mathrm{e}^{\frac{\hbar \omega-A k_{z}^{2}}{k_{B} T}} \cdot e^{\frac{E_{F}}{k_{B} T}}
$$

Now choose the following light absorption geometry that satisfies the conditions $e_{z}=0, e_{x} \neq 0, e_{y} \neq 0$. Then the intersubband absorption coefficient of polarized radiation is determined by the ratio

$$
K_{\perp}(\omega, T)=\frac{4 \pi^{2} e^{2}}{c \hbar n_{\omega}} \frac{1}{(2 \pi)^{2}} \int d k_{x} k_{y} d k_{z} \frac{m_{0}^{2}}{\hbar^{2}} D^{2}\left(e_{x} k_{y}+e_{x} k_{y}\right)^{2} \frac{\Delta^{2}}{\Delta^{2}+4 P^{2} k_{z}^{2}} \cdot\left(E_{3 \vec{k}}-E_{1 \vec{k}}-2 \hbar \omega\right) .
$$

Из закона сохранения энергии волновой вектор электронов, участвующих в межподзонных оптических переходах зависит от частоты света и от зонных параметров: $k_{z}^{(\omega)}=\frac{1}{2 P} \sqrt{4 \hbar^{2} \omega^{2}-\Delta^{2}}$. Тогда для спектральной и температурной зависимости $K_{\perp}(\omega, T)$ имеем

From the law of energy conservation, the wave vector of electrons participating in intersubband optical transitions depends on the frequency of the light and on the band parameters: $k_{z}^{(\omega)}=\frac{1}{2 P} \sqrt{4 \hbar^{2} \omega^{2}-\Delta^{2}}$. Then for the spectral and temperature dependence of $K_{\perp}(\omega, T)$ we have

$$
K_{\perp}(2 \omega, T)=\frac{e^{2}}{32 c n_{\omega} \hbar} \frac{D^{2}}{P^{2}}\left(\frac{k_{B} T}{B}\right)^{2}\left(\frac{\Delta}{\hbar \omega}\right)^{2} \frac{1}{k_{z}^{(\omega)}} \cdot \mathrm{e}^{\left(\frac{\hbar \omega-A\left(k_{z}^{(\omega)}\right)^{2}}{k_{B} T}\right)} \mathrm{e}^{\frac{E_{F}}{k_{B} T}}
$$

where $n_{\omega}$ is the refractive index of light for $\mathrm{n}-\mathrm{GaP}$ at the frequency $\omega$. This shows that the spectral dependence of $K_{\perp}(\omega, T)$ is inversely proportional to $k_{z 0}$, and therefore when $\hbar \omega \rightarrow \Delta$ it has a root feature of the type $\left[\left(\frac{\hbar \omega}{\Delta}\right)^{2}-1\right]^{-1 / 2}$, which arises due to the presence of a "camel's back" in the lower subband $X_{1}$. If the light propagates along the main axis of symmetry of $n-G a P$, then 


$$
K_{\perp}(\omega, T)=\frac{1}{8} \frac{e^{2}}{c \hbar} \frac{1}{n_{\omega}}\left(\frac{k_{B} T}{B}\right)^{2} \frac{D^{2}}{P^{2}} \frac{\Delta}{\hbar \omega} \exp \left(\frac{E_{F}}{k_{B} T}\right) \exp \left(\frac{\hbar \omega-2 A k_{z}^{(\omega)}}{k_{B} T}\right) \text { and the above }
$$

root feature is not. This is due to the absence of a "camel's back" in the $X_{1}$ and $X_{3}$ subzones in the direction perpendicular to the main axis of symmetry in n-GaP.

Further, the intersubband light absorption coefficient is investigated in the approximation $A_{+}=\frac{1}{2}\left(A_{3}+A_{1}\right), B_{+}=\frac{1}{2}\left(B_{3}+B_{1}\right)$, when the electron energy spectrum has the form

$$
E_{X_{3}, X_{1}}=A_{+} k_{z}^{2}+B_{+} k_{\perp}^{2} \pm\left(\frac{\Delta^{2}}{4}+P^{2} k_{z}^{2}\right)^{1 / 2}
$$

In this case, the intersubband matrix element of the pulse operator takes the form

$$
\left|\overrightarrow{e p}_{31}\right|^{2}=\frac{m_{0}^{2}}{\hbar^{2}} D^{2}\left(e_{x} k_{y}+e_{x} k_{y}\right)^{2} \frac{\Delta^{2}}{\Delta^{2}+4 P^{2} k_{z}^{2}},
$$

From the law of conservation of energy we get

$$
k_{z}^{(\omega)}=\frac{\Delta}{2 P}\left[\left(\frac{\hbar \omega}{\Delta}\right)^{2}-1\right]^{1 / 2} .
$$

Then $K_{\perp}(2 \omega, T)$ in this case it is defined as in case 2.1 , where in the results it is necessary to make the following replacement $A_{+} \leftrightarrow=A, B_{+} \leftrightarrow B$, i.e.

$$
K_{\perp}(2 \omega, T)=\frac{e^{2}}{32 c n_{\omega} \hbar} \frac{D^{2}}{P^{2}}\left(\frac{k_{B} T}{B_{+}}\right)^{2}\left(\frac{\Delta}{\hbar \omega}\right)^{2} \frac{1}{k_{z}^{(\omega)}} \cdot \mathrm{e}^{\left(\frac{\hbar \omega-A_{+}\left(k_{z}^{(\omega)}\right)^{2}}{k_{B} T}\right)} \mathrm{e}^{\frac{E_{F}}{k_{B} T}}
$$

So for various geometry of the experiment, the relations for the spectral and temperature dependences of the absorption coefficient of polarized radiation in a semiconductor camel's back band structure were derived and limited only to qualitative analysis due to the absence of experimental results.

In conclusion, we note that a similar problem can be solved for hole conduction tellurium, since one subband of the valence band in which has a camel's back structure. This case requires separate consideration.

[1] E.L.Ivchenko. // FTT, 14, 3489 (1972).

[2] R.Y. Rasulov. Diss. on the competition degr. of. DSci. (St.-Ptersburg, 1993). Chap. 3.138 p.

[3] S.D.Ganichev, E.L.Ivchenko, R.Ya.Rasulov, I.D.Yaroshetsky, B.Ya.Averbukh. FTT, 35, 198 (1993); R. Ya. Rasulov. FTT, 35, 1107 (1993).

[4] D.A. Parshin, A. R. Shabaev. JETP, 92, 1471 (1987).

[5] S.D.Ganichev, S.A.Emelyanov, E.L.Ivchenko, E.Yu.Perlin, Ya.V.Terentev, A.V. Fedorov, I.D. Yaroshetsky. JETP, 91, 729 (1986). 
[6] R.Y.Rasulov, G.H.Khoshimov, H.Holitdinov. FTP, 30, 274, (1996).

[7] R.Ya.Rasulov. FTP, 22, 2077 (1988).

[8] R.Ya.Rasulov. FTT, 35, 1674 (1993).

[9] E.L.Ivchenko, R.Ya.Rasulov. Symmetry and real band structure semiconductors. Fan, Tashkent. (1989). 126 p.

[10] V.R.Rasulov, R.Ya.Rasulov, Eshboltaev I.M. FTT. 59. 453-457 (2017). 


\section{LEGAL CULTURE OF YOUTH}

Khlon $\mathbf{O}$.

Ph.D., Associate Professor KYIV NATIONAL UNIVERSITY OF TRADE AND ECONOMICS

The lack of legal culture, or its low level leads to political and legal uncertainty of citizens, legal nihilism, even legal radicalism. This is especially evident in the emergence of new pseudo-legal or non-legal constructions of the lawyer's consciousness, which takes various forms: legal infantilism; legal negativism conscious disregard for the requirements of the law, and their violation; legal nihilism and populism; legal consciousness, acquires a criminal attitude. Thus, recently there has been a tendency to increase the role of administrative influence on all aspects of public life, team methods of solving complex problems of state building, which "creates conditions for the restoration of old political structures and promotes authoritarian-democratic or even purely authoritarian regime" [ 1, P. 4]. This tendency in general slows down the development of democratic processes, threatens the national security of our state, its sovereignty and independence. [2, p. 168].

In addition, the legal culture and its mastery by citizens, acts as a guarantor of national security of the state of Ukraine. The strategic importance of the legal culture is that without a high level of legal culture of the population, officials, legislators and law enforcement agencies there can be no democratic, legal state, and therefore an independent and sovereign Ukraine. It may be deprived of the main support of its own people, it will not be accepted by the world community, built on legal principles. [2, p. 174]. Relevant trends should be taken into account primarily in the formation of moral and legal consciousness of future lawyers.

It should be borne in mind that the mere presence of a certain amount and legal knowledge does not determine the level of legal awareness. Only comprehensive and interconnected actions will form future lawyers' awareness of the need to maintain their own professional activity in the legal field. In this regard, in the organization of the educational process in educational institutions it is necessary to create new methods for timely diagnosis and development of legal awareness of future lawyers. In order to form elements of legal culture, the ability to resist immoral acts, corruption, it is necessary to develop and implement appropriate disciplines. During practical classes not theoretically, but in the process of solving problems, modeling complex professional situations, discussions, it is necessary to trace the process of formation of legal awareness and moral development of future lawyers [3, p. 51].

All this creates the preconditions for the formation of professional skills among those who receive legal education and the possibility of avoiding mistakes in their further activities. Accordingly, in this case, the proper organization of activities and professionalism of the relevant persons will determine the conditions for building trust 
among the population, belief in the rule of law, promote a high level of legal culture among young people in the legal field.

Note that legal awareness is a specific reflection of the legal, social, political reality of society, real relations existing in this society, which significantly affects the legal awareness of future lawyers, legal education, organization of work on the development of moral and psychological qualities, social and patriotic orientations. The combination of scientific training with the rights and opportunities of a law degree should stimulate the process of moral and social socialization of the individual and be expressed in the high legal culture of law enforcement officers, the formation of professional legal awareness, compliance with law, professional and universal ethics [3, p. 51].

\section{References:}

1. Медведчук В.В. Політико-правові перспективи соціал-демократичного реформування в Україні // Право України. — 2000. — № 11.

2. Сербин Р.А. Стратегічний потенціал правової культури // Науковий вісник [Текст] : наук.-теоретичний журнал / засновник Київський національний університет внутрішніх справ. - 2002, № 3. - К.: Київський національний університет внутрішніх справ, 2002. - 251 с. (167-174 (-))

3. Диса О.В. Проблеми формування правової свідомості майбутніх юристів // Філософські, методологічні та психологічні проблеми права [Текст]: тези доп. наук.-теорет. конф., Київ 26 січня 2008 р. / редкол.: Є.М. Моісеєв, О.М. Джужа, В.М. Костицький [та ін.]; передмова О.М. Джужі. - К.: Київський національний університет внуртішніх справ, 2008. - 200 с. 


\title{
THE INFLUENCE OF THE SOCIAL ENVIRONMENT ON THE FORMATION OF ADOLESCENT INDEPENDENCE
}

\author{
Polishchuk D. \\ Doctoral candidate of the Department of Psychology \\ National Pedagogical Dragomanov University (Ukraine)
}

At the present stage of educational development, the education of an active, creative person who can easily adapt in the information space, independently analyze and process the received information, navigate the news flow, overcome various difficulties, be creative and take the initiative is especially important. The need to study independence is also relevant in connection with the complex socio-political processes in the country and the need to understand the limits of personal responsibility for the effectiveness of the own lives.

The problem of independence becomes especially relevant in adolescence, in one of the most important periods of a person's life, which is characterized by numerous mental and social changes and is sensitive to the development of many personal qualities. After all, it is during this period that the transition from the system of external management to self-government takes place, and the need for independent choice acquires the signs of a mental neoplasm.

A number of Ukrainian researchers have paid attention to the study of the phenomenon of independence. Thus, G.Kostyuk [1] argues that the child's independence is manifested in its relationship with the environment and is formed in the learning process, because those internal contradictions that are so acutely felt by the adolescent, can be successfully resolved in the learning process.

Considering independence as a volitional quality of personality, S.Maksymenko [2] emphasizes that the studied phenomenon is manifested in the ability to critically evaluate their own actions and deeds, and the actions of others, it is also important not to succumb to negative influences of others. According to the researcher, independence is an important volitional quality of a person, which manifests itself as the ability to set new goals and perform them without motivation and help from others. An independent person is creative in solving life's problems, looking for new ways out of various situations.

According to E.Aliyeva [3], independence is an integrated personality trait that has a multi-component structure and is characterized by a combination of specific personality traits (self-confidence, low levels of anxiety and frustration, internal locus of control, creativity, willpower, purposefulness, responsibility, activity and selfrealization). An independent personality, according to the researcher, is able to actively influence vital events and manage personal life on the basis of their own value orientations.

Thus, we can state that independence is seen as a volitional quality, as a property of a moral person, as a manifestation of activity, which is manifested in the relationship with the environment, in creativity, in learning. 
As part of our dissertation research, we developed a questionnaire that contains 13 questions that allow adolescents to analyze the development of their own independence, identify qualities that contribute to its development, as well as identify the impact of the learning environment on the development of independence.

The results of a survey we conducted among adolescents in grades 6-9 showed us how adolescents understand the concept of independence. It should be noted that children give almost the same interpretation of the phenomenon under study, which acquires a deeper understanding at the end of adolescence. Thus, children define the concept of independence as "doing their own homework", "not asking for help from others", "thinking independently, making decisions", "opportunity to earn money", "fulfilling their responsibilities", "ability to provide for themselves" , "ability to cook for yourself", "responsibility", "not to be afraid of the new", "shopping on your own", "ability to travel around the city", "responsibility for actions", "earn money", "ability to solve problems on their own", "material independence", "responsibility", "ability to set goals for themselves", "to make decisions for one's future".

Our study showed that with this understanding of the concept of independence, $43.16 \%$ of adolescents consider themselves completely independent, $40 \%$ of children consider themselves partially independent, and $16.84 \%$ express their dependence on parents or inner circle.

Also important in our study was what personal qualities adolescents attribute to independent people. According to modern adolescents, independence in behavior is achieved through: determination, concentration, positivity, diligence, will, intelligence, confidence, leadership, responsibility, honesty, courage, intuition, purposefulness, logical thinking, openness, self-organization and others.

We also analyzed adolescents' responses to the question "What would you like to be more independent of?", which we divided by age groups. Thus, adolescents at the age of 11 believe that they need to expand the boundaries of their independence "in life", "on trips", "in shopping". Children who have reached the age of 12 believe that they can "go home and to other cities", "walk", "study" on their own without parental supervision, and also want to "play on the computer until night". Adolescents at the age of 13 are convinced that they can independently "spend money", "travel", "meet new people". At the age of 14, adolescents believe that they need to "live separately", "have a high-paying job", "more freedom", "not depend on their parents". And at the age of 15 , teenagers want to have more independence in "making decisions in choosing the future", "choosing friends", and in general can already "live independently".

Thus, we can trace the desire of adolescents to separate from parental care in spending their free time, in spending finances of their choice, as well as in the desire to live separately from their parents.

At the same time, we decided to investigate the problem of excessive independence and asked the children to answer the question of the questionnaire "In what would you like to show less independence?". Among the answers of adolescents, it turned out that they are overburdened with the independence given to them in terms of household (cooking, cleaning, etc.). Adolescents also want to lose responsibility for caring for younger siblings. And as for studying at school and solving a variety of complex issues - adolescents want to coordinate it all with their parents. We also received interesting 
data from those teenagers who above all want material independence from their parents and all the accompanying benefits - for some reason they do not want to study and work to get everything they want. These teenagers do not realize what they need to develop independence and believe that they already have everything.

Of course, we cannot agree with them, because we believe that the development of independence in various fields should last a lifetime, and it develops especially rapidly during school. Therefore, the next point we decided to investigate the impact of the educational process in school on the development of adolescent independence. The age dynamics of the influence of educational institutions on the development of adolescents' independence is presented in Table 1.

Table 1.

Age dynamics of the influence of the educational process at school on the development of adolescents' independence (\%)

\begin{tabular}{|l|c|c|c|c|c|}
\hline & $\begin{array}{c}11 \\
\text { years }\end{array}$ & 12 years & 13 years & 14 years & 15 years \\
\hline Yes & 70 & 70,83 & 63,63 & 22,73 & 43,75 \\
\hline Partially & 10 & 16,67 & 13,64 & 22,73 & 6,25 \\
\hline No & 20 & 12,50 & 22,73 & 54,54 & 50 \\
\hline
\end{tabular}

Interpreting the data in the table, we can conclude that in early adolescence, $70 \%$ of children are convinced that the educational process in school affects the development of their independence. Throughout adolescence, this figure gradually decreases and at the end of adolescence, children claim that school has little effect on the formation of independence skills ( $43.75 \%$ of respondents), and the main foundations for the development of the phenomenon are laid in the family circle.

Based on the children's answers, we can make the assumption that in early adolescence, the child's leading activities are focused on learning, and, therefore, to be independent for children means to do homework independently. As children grow older, they become aware of the personal side of independence, it is no longer tied purely to school, but acquires personal characteristics such as "conscious responsibility for the future", "you can take care of yourself and be responsible for your actions", "confidence", "self-sufficiency", "balance", "moderation", "determination", "seriousness", "criticalness", "purposefulness", "calmness", "tolerance", "intuition", etc.

Thus, our study made it possible to understand how adolescents understand the phenomenon of independence, what they have to do with the development of independence, as well as how it affects the development of independence of adolescent learning in school. And although during adolescence there is a certain decrease in the influence of school on the formation of personality in the understanding of adolescents, but at the end of adolescence almost half of adolescents believe that the educational process stimulates the development of independence and therefore personality development in general. 
We believe that today it is an important task to form independence in adolescents as a personal quality that will set and achieve goals, make moral and volitional choices, defend their views, values and beliefs, which will be the subject of our further scientific research.

\section{References:}

1. Kostyuk, G. Educational process and mental development of personality. Kyiv, 2013

2. Maksimenko, S. Genesis of personality realization. Kyiv, 2006.

3. Aliyeva, E. Psychological factors of formation of students' ability to make independent life choices. Kyiv, 2017. 


\section{ВПЛИВ ЕМОЦЙНО-ВОЛЬОВОЇ СФЕРИ ОСОБИСТОСТІ СПЕЦІАЛІСТА НА ВИКОНАННЯ ТРУДОВИХ ОБОВ'ЯЗКІВ}

\section{Бередіна Олена Василівна}

студентка кафедри психології, Приватне Акціонерне Товариство «ВНЗ «Міжрегіональна Академія Управління Персоналом» Харківський інститут, м. Харків, Україна

Останнім часом все більший розвиток отримує твердження, що головним елементом конкурентоспроможності будь-якої компанії є ії персонал. Менеджер в компанії - ключовий елемент, що забезпечує функціонування компанії в сучасних ринкових умовах. Саме від успішної діяльності менеджера залежить успіх самої компанії. I тому, дуже важливо приділяти якомога більше уваги розвитку менеджера як особистості, так і як професіонала.

Досліджуючи трудову діяльність менеджерів, можна відзначити наявність розрізнених думок вчених про успішність менеджера. Останні дослідження даної теми відображені в роботах таких вчених, як Н.С. Пряжников, О.Н. Родіна, Н.В. Самоукіна, В.А. Бодров, Е.А. Клімов.

Розглядаючи ступінь розробленості зазначеної теми, необхідно відзначити, що в даний час у науковій літературі відсутні комплексні напрямки вивчення емоційно-вольових якостей особистості та їх впливу на успішність i ефективність діяльності. «Успіх у професійній діяльності проявляється насамперед у досягненні працівником значимої мети i подоланні або перетворенні умов, що перешкоджають досягненню цієї мети»[1, с. 137].

Питання успішності менеджера в теперішній час є досить актуальними. Ця обставина свідчить про те, що існує потреба в додатковому вивченні впливу емоційно-вольових якостей спеціаліста на успішність і ефективність його діяльності.

При цьому величезне значення мають саме емоційно-вольові якості менеджера, тому що саме вони формують ключові якості менеджера, який хоче стати ефективним керівником. Саме через необхідність виявлення взаємозв'язку емоційно-вольових якостей менеджерів і успішності їх діяльності тема дослідження $є$ актуальною в даний час.

3 метою дослідження впливу емоційно-вольової сфери особистості спеціаліста на виконання трудових обов'язків була обрана успішність діяльності спеціалістів компанії ТОВ НВО «Світло Шахтаря». Дослідження включало теоретичний, діагностичний, корекційно-розвивальний i аналітичний компоненти.

Предметом дослідження стали емоційно-вольові якості спеціаліста як фактори успішності його діяльності. 
При вивченні емоційно-вольових якостей особистості використовувалися наступні методики:

1. методика дослідження вольової організації особистості (М. Гуткін, Г. Міхальченко, А. Прудило[2, с. 175 - 182]);

2. методика самооцінки вольових якостей Н. Е. Стамбулової;

3. методика дослідження мотивації до успіху Т. Елерса;

4. проективна методика;

5. методика виконання KPI (Key Performance Indicators, ключові показники ефективності) співробітників.

Комплексне використання цих методів дозволило проаналізувати дану тему у всьому іiі різноманітті.

Аналіз результатів дослідження показав, що співробітники, які мають високі показники KPI, крім успішного виконання своїх трудових обов'язків, мають високі показники розвитку емоційно-вольових якостей особистості.

Отримані результати дослідження вольових якостей менеджерів і рівня їx мотивації до успіху дозволили зробити висновок, що чим вище керівна посада, яку займають управлінці, тим вище їхня мотивація до успіху і рівень розвитку вольових якостей.

Для організації розвитку емоційно-вольових якостей менеджерів в компанії ТОВ НВО «Світло Шахтаря» була розроблена та задіяна програма розвитку емоційно-вольових якостей з урахуванням рекомендацій Осипової А.А.[3].

Основними компонентами корекційної програми стали серія тренінгів та впровадження спортивних занять.

Програма тренінгів була розрахована на одну діагностичну зустріч та три заняття по 5,5 годин кожна, загальна кількість - 20 годин.

Отже, після проведення корекційної роботи з підвищення вольових якостей особистості значно змінилися показники успішності виконуваної роботи. Вихідними даними послугували дані, отримані до та після проведення корекційної роботи за методикою дослідження вольової організації особистості. Отримане емпіричне значення t-критерія Стьюдента знаходиться в зоні значущості.

Також в ході дослідження було виявлено тісний взаємозв'язок між рівнем розвитку емоційно-вольових якостей особистості менеджера і успішністю його діяльності: чим вище рівень розвитку даних якостей, тим вище успішність i ефективність його діяльності в компанії.

Підводячи підсумки дослідження, слід визначити, що такі якості, як рішучість, самостійність, наполегливість, відповідальність і вміння організувати свою діяльність $\epsilon$ найбільш значущими якостями та найбільш впливаючими на успішність діяльності.

Отже, емоційно-вольові якості менеджера не тільки є природними, але й піддаються розвитку, тому необхідна серйозна психологічна переорієнтація на використання методів управління в ім'я інтересів людей, а не тільки заради виробництва. 
I тому цілком правомірна постановка завдання розвитку особистісного потенціалу, як фактора, якій системно визначає ефективність діяльності самого менеджера, його персоналу та діяльності організації в цілому.

Також слід зауважити, що практична значущість полягає в доповненні сформованих теоретичних даних про емоційно-вольові якості менеджера та їх взаємозв'язок з успішністю й ефективністю діяльності. Для цього запропонована програма розвитку емоційно-вольових якостей менеджера може бути застосована на практиці не тільки в ТОВ НВО «Світло Шахтаря», але і в інших компаніях.

\section{Список літератури:}

1. Самоукина H.В. Психология профессиональной деятельности. URL: https://www.studmed.ru/view/samoukina-nv-psihologiya-professionalnoydeyatelnosti_e69e1dfc2ef.html

2. Твоя профессиональная карьера: учебник / Под ред. С.Н. Чистяковой, Т.И. Шалавиной. - М.: Просвещение, 2000. - 191 с.

3. Осипова А.А. Общая психокоррекция. Учебное пособие. - М.: Сфера, 2002. $-510 \mathrm{c}$. 


\section{MOTHERHOOD IN ADOLESCENCE AS A SOCIO- PEDAGOGICAL PROBLEM}

Kulichenko Tetiana Student of Oles Honchar Dnipro National University

The problem of early motherhood is quite relevant today. This is a social problem caused by a numerous factors: modern children grow up earlier (early puberty) - a biological factor that parents need to pay attention to, but the problem of early motherhood lies largely in social reasons, such as the impact of social networks, where you can often see the eroticization of the female body, the coverage of romantic and sexual relationships of different couples, including celebrities, as well as the demonstration of female beauty through bright images with makeup and bold outfits all of this leads to the desire of teenage girls to grow up and feel all the benefits life. Stressful situations in the family also lead to the problem of early motherhood, but the main problem is the ignorance of adolescents about the culture and consequences of sexual relations.

It is also worth noting that society has become more tolerant of premarital sexual relationships. Against this background, there is a decrease in the age of onset of sexual life and, accordingly, an increase in the number of adolescent pregnancies and abortions. This is proved by the results of researches of V. Brutman, O. Bazhenova, L. Baz, I. Ilyin, O. Kopyl, M. Rodionova.

Considering motherhood in adolescence as a socio-pedagogical problem, it is necessary to understand the age characteristics of the girl. Despite the possibility of physical procreation, a young mother is usually unable to provide for herself and a child. Tthe birth of a child forces to interrupt, postpone or leave school altogether. The following events also play a significant role: at school (or other educational institution, such as college), a pregnant teenage girl is under very strong moral pressure, both from teachers and students [1]. In addition, there are many cases when a girl faces condemnation, even from relatives, resulting in a desire to hide the pregnancy. After a while, she stops attending school, chatting with friends and, as a result, she is left alone. The real state of loneliness is usually accompanied by symptoms of certain psychological disorders that take the form of negative emotions or even neuroses. During pregnancy, such symptoms negatively affect not only the health of the expectant mother, but also the development of the child. Different people have different reactions to loneliness. Some lonely people complain, for example, of sadness and depression, others say they feel fear, others report bitterness and anger, and if you add the emotional fluctuations caused by the hormonal background of a pregnant teenage girl, loneliness and isolation in such a difficult period of life can cause very negative consequences [2].

Refusal to attend high school in favor of starting one's own family is a common reason for dropping out of school. The vast majority of underage mothers did not have 
time to get a secondary education. When they stop studying, they often lose the opportunity to continue it in the future. According to various studies, pregnant teenage girls who have not dropped out of school generally study well. Those young mothers who manage to finish school are little different from girls who have not even thought about motherhood [4]. However, a small percent of girls continue to study in higher education, and higher education is important in life because it provides an information base without which it is possible to develop professionally, but only a few succeed. It should also be noted that during the years of study at the university the skills of communication with people, with management, mind and intuition are hardened.

In most cases, young mothers treat their pregnancy negatively because it is unplanned and therefore becomes a source of negative emotions. This is supported by ill health, changes in appearance and the destruction of plans and hopes. The child's movements and shocks cause irritation and fatigue. The mother's attitude to the child during pregnancy leaves a lasting mark on the development of her psyche, and if we emphasize that the psyche of the adolescent is not formed - we get the problem multiplied by two. Scientific papers indicate that children injured in the womb remain hypersensitive to stressors, fearful, closed, and angry [1]. The emotional position of girls in this group is characterized by a lack of mood, depression, a tendency to feel detached from life.

If a child is perceived as a certain toy, they play with it, but when it breaks down, the toy becomes isn't interesting. And perhaps the child is perceived as a given, the karma of the relationship between man and woman, then it becomes a certain aggravating element that you either get used to it or at the right time you get rid of it [3].

As already mentioned, one of the problems of adolescent mothers is the difficulty of interacting with the environment, low self-esteem, and as a result, insecurity. Girls seek approval and support from loved ones - they are in a vulnerable state depending on their opinion. Only after the birth of a child is there a full understanding that this event will leave an imprint on the whole life, that there is no way back, life will not be as it was before [5]. The young mother has no education, no profession, perhaps her professional dreams will never come true, and most likely there will never be the future she had hoped for; the minor mother believes that her child is to blame for all this. In this case, the newborn baby will not receive the necessary physical and emotional contact with the mother, and this is necessary for the harmonious development of the child.

Speaking of early pregnancy, it is worth focusing on another aspect. For the most part, pregnancy is hidden for a long time, girls hopefully do not go to doctors, as a result of which there is a possibility of not receiving the necessary medical care at certain stages of pregnancy. Artificial abortion in adolescence is a phenomenon that is increasing every year. Such an operation is very stressful, it causes depression and it is clear that even a stranger in the person of a social worker, teacher or psychologist could be very useful in this situation. However, today girls at best face the sympathy of a gynecologist, but, unfortunately, more often with his indifference. In the worst case with condemnation. In this case, the stress is exacerbated by the images of doctors. Abortion also causes irreparable damage to a woman's reproductive function. 
Childbirth in adolescence is often complicated. Young mothers usually give birth to premature babies, which also causes many problems in the future, because such babies need special care, which requires the provision of the necessary medicines. The mother whose baby had such an accident, also needs psychological help and emotional support. In general, anemia, fetal growth retardation, premature and difficult childbirth are considered common problems of pregnant minors. The general trend is as follows: the younger the pregnant woman, the greater the risk of complications.

Thus, the Internet and social networks are the most accessible and popular among young people sources of information about the relationship between the sexes. Erotic scenes that can be seen in the photos have become commonplace. The modern sexual information industry largely focuses the individual on sexual relations for pleasure, rather than forming a feeling like love in a relationship. Hence the perverted view of the younger generation on sexual culture. Sexual permissiveness is one of the reasons for young motherhood. Today this problem acquires an interdisciplinary character, but special attention is paid to its study in pedagogy and social pedagogy. Researchers characterize the term "young motherhood" as a socio-cultural phenomenon, the essence of which is to give birth, birth, care and upbringing of mothers by young mothers.

\section{REFERENCES}

1. Archakova, T. Early motherhood: a psychological problem or a social construct / T. Archakova // Electronic journal "Psychological Science and Education". - 2012. № 1 . - P. 6

2. Brutman V. Dynamics of a woman's mental state during pregnancy and after childbirth / Brutman V., Filippova G., Khamitova I. // Questions of Ukraine. - 2002. № 1. - P. 59-69.

3. Konik M. Fatherhood as a factor in the formation of the principles of Christian family education / M. Konik // Anthropological Studies. Series: Philosophy. - 2018. Vip. 36. - P. 57-68.

4. Martsenyuk T. Gender aspects // Ukrainian Sociological Journal. - 2013. - № 1/2. - P. 58.

5. Filippova G. Psychology of motherhood: a textbook / G. Filippova. - M .: Published in University of Psychology, 2012. - 240 c. 


\section{EXPERIENCE IN USING OF CISCO NETWORKING ACADEMY MATERIALS IN CYBER SECURITY BACHELOR TRAINING}

Elizarov Anatoly, Ph.D., Associate Professor Kiev National Aviation University

Natalie Gulak, Ph.D., Associate Professor Kiev National Aviation University

\section{Hellen Dubchak,}

Senior lecturer

Kiev National Aviation University

Training of bachelors in cyber security is highly relevant in today's environment. The authors of the proposed materials, being teachers of the Department of Computerized Information Security Systems of the National Aviation University, at the same time present the international program CISCO NETWORKING ACADEMY as certified instructors.

Briefly about the program

In 1997, Cisco donated networking equipment to a local school. But no one knew how to work on it, so the equipment was not used. Cisco Networking Academy has quickly grown from a single school to a growing community of students, educators, employers, non-governmental organizations, Cisco employees, and customers. Now training is taking place in 180 countries. The corporation works with 28,400 faculty members from 11,800 academies around the world to create the best curriculum for today's environment.

The Cisco Networking Academy has been organized and operates at the Department of Computerized Information Security Systems of the National Aviation University since 2007. Initially, the materials of the Cisco Networking Academy program were presented in fact only by one basic CCNA course (computer network administration course), were used at the department as an additional source to improve the level of students' knowledge and receive international certificates in the form of optional courses. However, this process was not massive and did not bring tangible results.

\section{Current situation}

About four years ago, we were able to include the official certified Cisco Networking Academy materials in the curricula for training bachelors in the field of cyber security, moreover, from the coming academic year, we will be presenting these 
materials for students of all specializations in the field of cyber security for three departments at the request of their leadership

It should be noted that the Cisco Networking Academy program is now represented not only by the computer network administration course - CCNA, but also significantly expanded to related areas of training for IT specialists: programming, the basics of cyber security, etc., which we actively use.

A curriculum fragment for training cyber security bachelors is presented in Table 1.

Table 1

A curriculum fragment

\begin{tabular}{|c|l|c|c|}
\hline № & \multicolumn{1}{|c|}{ Discipline name } & Semester & Note \\
\hline 1 & \multicolumn{1}{|c|}{ Professional training cycle } & 3 & 4 \\
\hline & \multicolumn{1}{|c}{$\ldots$} & & \\
\hline 2.1 .8 & Secured computer systems and networks & 5,6 & $\begin{array}{l}\text { For all } \\
\text { specializations }\end{array}$ \\
\hline & \multicolumn{1}{|c|}{$\begin{array}{l}\text {. } \\
\text { Operating systems and their protection } \\
\text { technologies }\end{array}$} & 6,7 & $\begin{array}{l}\text { For all } \\
\text { specializations }\end{array}$ \\
\hline 2.1 .11 & \multicolumn{1}{|c|}{.. } & 3 & \\
\hline 2.1 .16 & Programming basics & 4 & \\
\hline & Network technologies basics & 4 & \\
\hline 3.4 & Cycle free choice disciplines of student & & \\
\hline & $\underline{\text { nntroduction to Internet of things }}$ & 7 & \\
\hline 3.11 & $\begin{array}{l}\text { Communicating networks building basics } \\
\text { based on Cisco technology }\end{array}$ & & \\
\hline & & & \\
\hline
\end{tabular}

Thus, six disciplines are presented for bachelors, which are based on the certified material of the Cisco Networking Academy program, including two of them - elective. Two more similar academic disciplines are presented for magister.

The authors did not have the goal of revealing in detail the contents of all the presented academic disciplines - we will present briefly only on the disciplines related to the administration of computer networks.

The preparation of students in this direction begins with the discipline "Network technologies basics" in the fourth semester and continues within the framework of the two-semester discipline "Secured computer systems and networks". In the fifth semester students are presented the course "Introduction to Networks v.7".

The general course content is shown in Fig.1. 


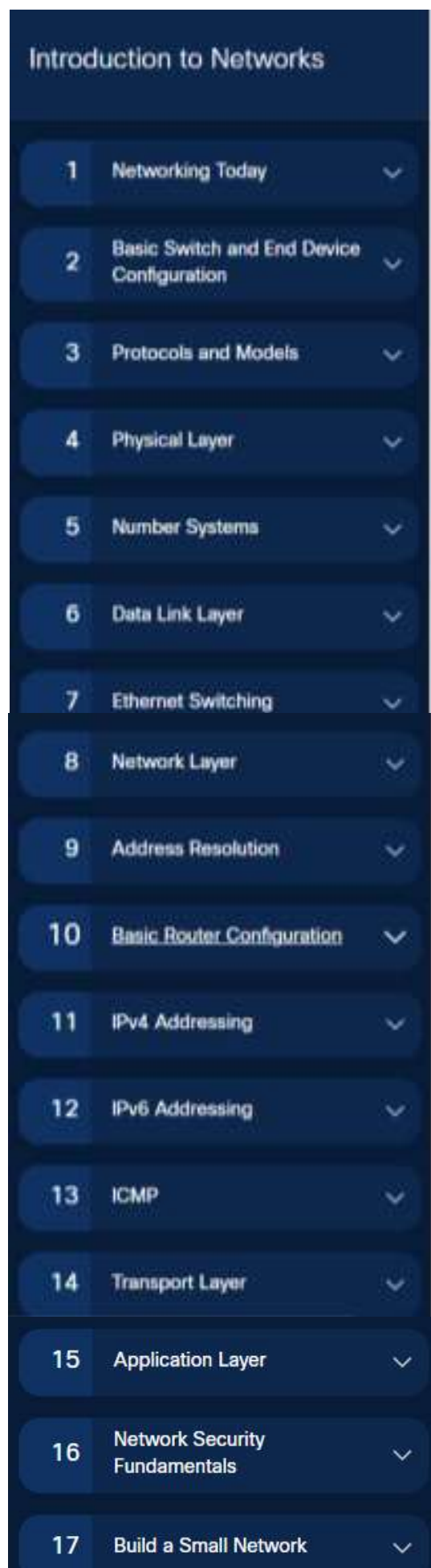

Fig.1.The general course Introduction to Networks v.7 content.

Each of the seventeen sections, in turn, is divided into topics and individual paragraphs (Fig.2). 


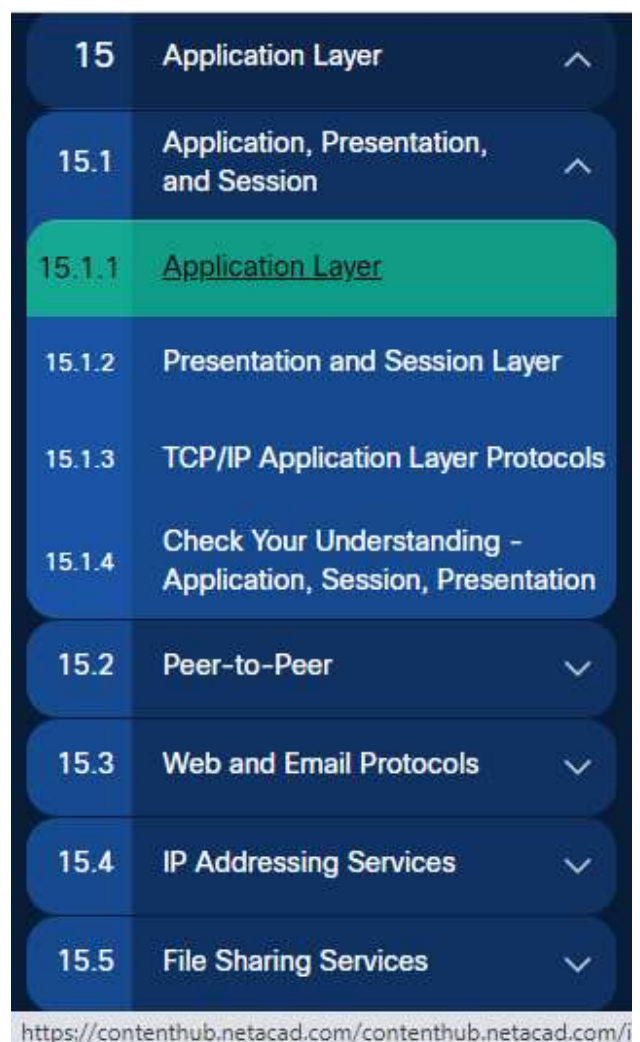

Fig.2. Splitting of the Application Layer section into topics and paragraphs.

An example of paragraph content is shown in Fig.3.

As shown in the figure, the presentation layer formats data for the application layer, and it sets standards for file formats. Som well-known standards for video include Matroska Video (MKV), Motion Picture Experts Group (MPG), and QuickTime Video (MOV). Some well-known graphic image formats are Graphics Interchange Format (GIF), Joint Photographic Experts Group (JPG), and Portable Network Graphics (PNG) format.

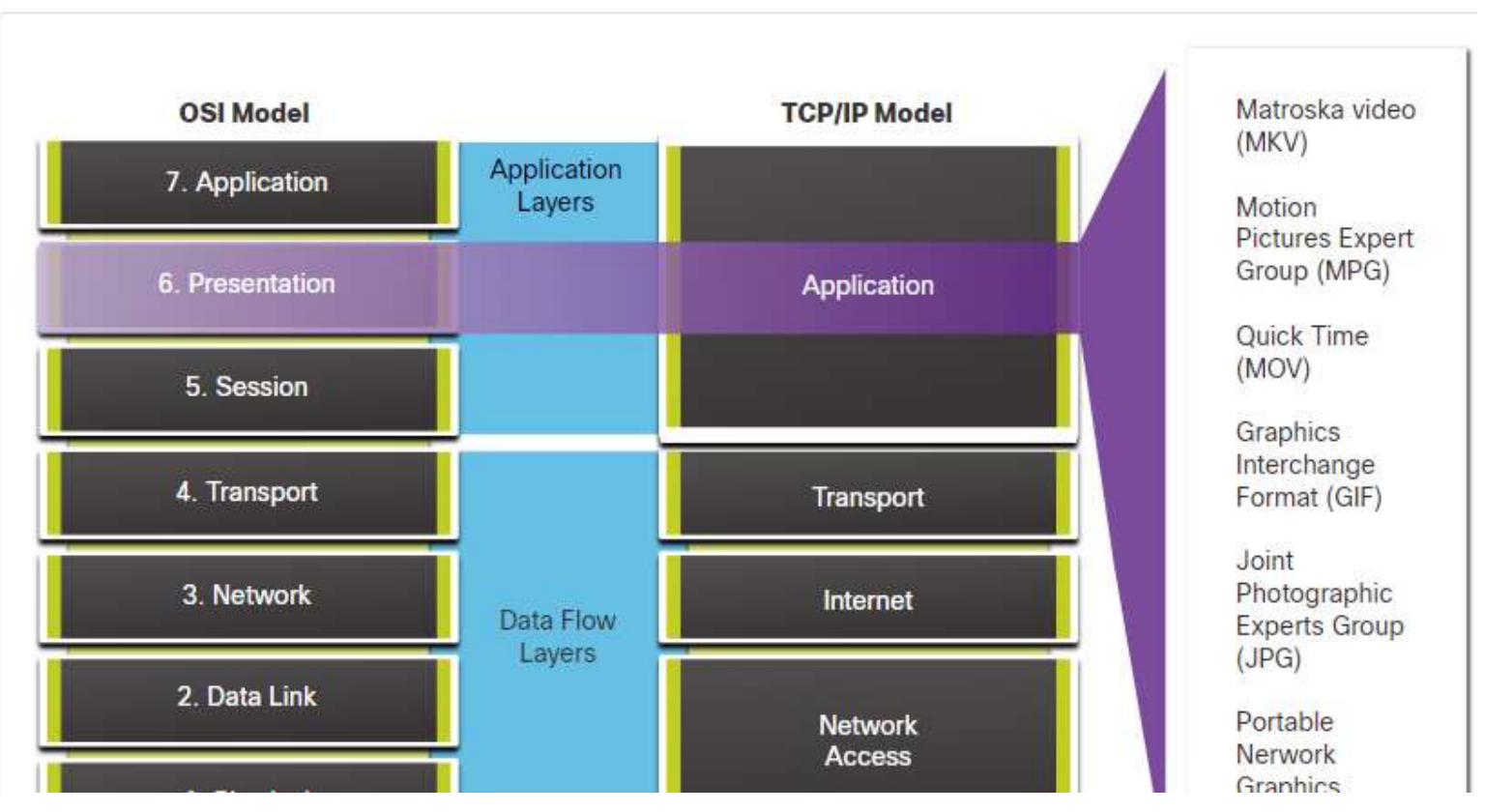

Fig.3. An example of paragraph content

In the sixth semester students are offered the second part of the CCNA course "Switching, Routing, and Wireless Essentials (SRWE) v.7". It provides basic training 
to students as computer network administrators for small and medium-sized businesses.

Finally, preparing students for managing large corporate networks ends with the course "Enterprise Networking, Security, and Automation v7.0 (ENSA) v. 7", presented within the framework of the discipline "Communicating networks building basics based on Cisco technology".

As a rule, the vast majority of students (approximately 90\%) successfully master the materials of our academic disciplines (and, accordingly, the official courses of the Cisco Networking Academy) and receive the opportunity for international certification.

\section{Conclusions}

1. The volumes of the Cisco Networking Academy courses are very large (for example, the basic CCNA course, according to our estimates, reaches 5000 pages of text), so the main task of the teacher is to stimulate the student to study the material by any reasonable means.

2. The value of using official materials of Cisco Networking Academy lies in the possibility of international certification, and such a certificate, when applying for a job, is no less important than a university diploma.

3. We recommend the use of Cisco materials for training not only cyber security bachelors, but also any IT specialists.

\section{References:}

1. netacad.com 


\title{
СИНТЕЗ ТА АНАЛІЗ СКЛАДНИХ СИГНАЛІВ КУТОВОЇ МОДУЛЯЦІї В РЛС
}

\author{
Havaliukh Oleh \\ $\mathrm{PhD}$ military \\ Instructor, Department of Weapons \\ Naval Institute of the National University "Odessa Maritime Academy" \\ Vovk Oleksandr \\ Candidate of technical sciences \\ Associate Professor \\ Naval Institute of the National University "Odessa Maritime Academy"
}

Операція формування складного сигналу 3 набору інших сигналів називається синтезом сигналу. В теоретичній радіотехніці сигнал називають складним, якщо його база значно більше одиниці. Перевагами складних сигналів, які обгрунтовують їх застосування та впровадження в радіолокації є: підвищення дальності дії РЛС, збільшення роздільної здатності локаторів, точності вимірювання дальності до цілі, підвищення завадостійкості радіотехнічних систем, зменшення потужності випромінюваних сигналів без зміни дальності виявлення об'єктів зондування, отримання якісних радіолокаційних портретів цілей.

Складний сигнал можна синтезувати різним шляхом: застосуванням внутрішньоімпульсної частотної лінійної та нелінійної модуляції; створенням фазоманіпульованих імпульсів; генерацією багатоелементного коду у вигляді дискретного частотного сигналу, коли сигнал можна розглядати як сукупність елементів, що мають різні параметри та з'являються у визначені моменти часу [1-3]. Завдяки досягненням в області цифрових технологій зараз з'явилась можливість формування складних сигналів безпосередньо на проміжній носійній частоті або на радіоносійній частоті на одній інтегральній схемі [1].

Аналіз складного сигналу здійснюється радіолокаційним приймачем, який, як правило, містить два тракти аналогового перетворення частоти для перенесення прийнятого сигналу на проміжну частоту, на якій можливо проведення аналогово-цифрового перетворення. Головним елементом радіолокаційних приймачів виступає узгоджений фільтр, сигнал виходу якого 3 фізичної точки зору є результатом стиснення радіоімпульсів, які надходять після зондування цілі, а 3 математичної - автокореляційною функцією вхідного складного сигналу. Для проведення стиснення сигналів в сучасних РЛС застосовують спеціальні цифрові процесори, що реалізують цей процес в часовій або частотній області [1]. 


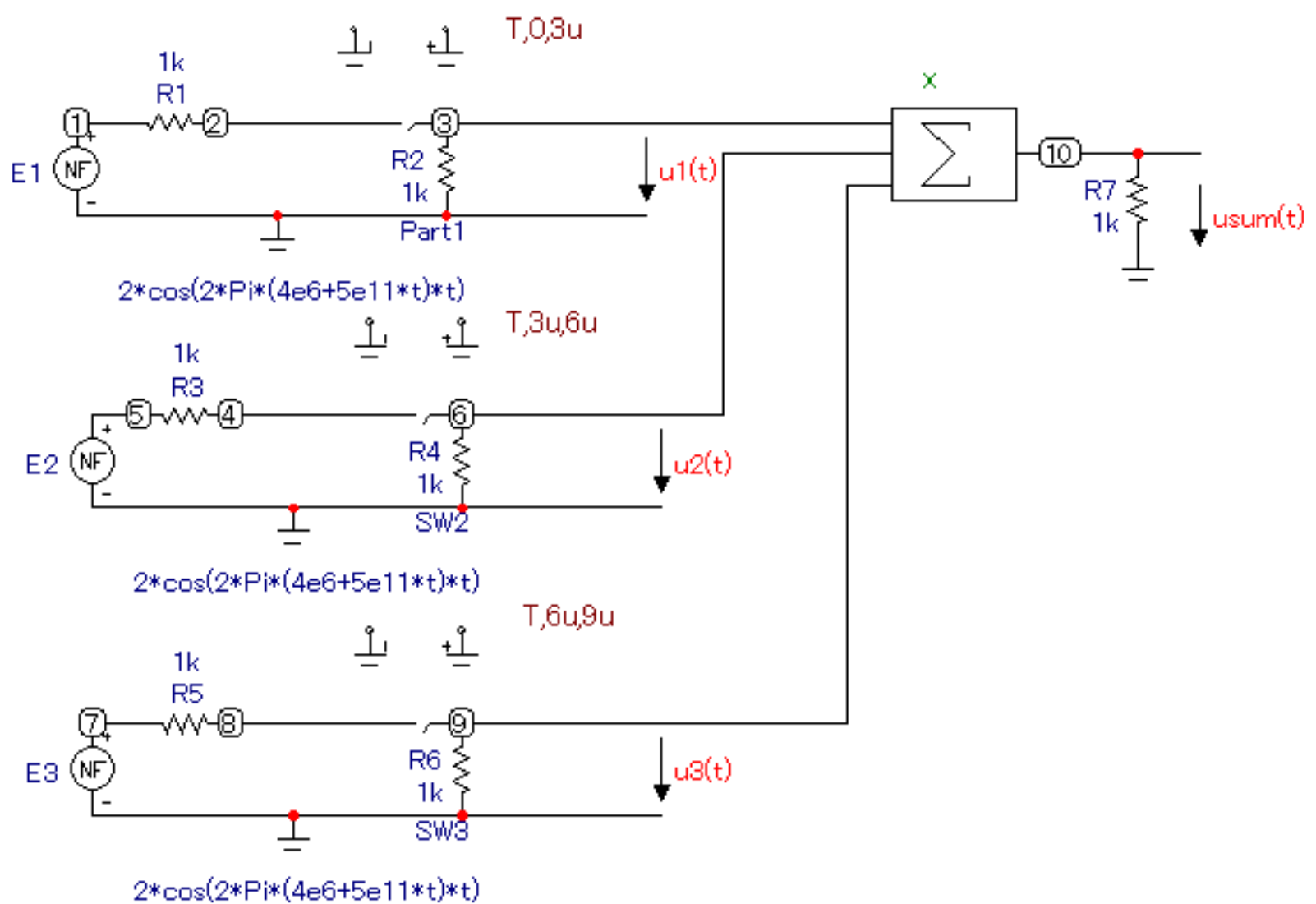

Рис. 1. Генерування дискретних частотних сигналів у програмі схемотехнічного моделювання Micro-Cap: u1(t), u2(t), u3(t) - елементи сигналу; $\operatorname{usum}(\mathrm{t})$ - синтезований дискретний частотний сигнал

Дана робота присвячена дослідженню можливості створення складного сигналу у вигляді дискретних частотних сигналів 3 кутовою модуляцією в РЛС виявлення надводних, повітряних та наземних цілей. Приклад генерування таких сигналів у програмі Micro-Сар зображений на рис. 1. Під сигналом 3 кутовою модуляцією в роботі розуміється сигнал з лінійно-частотною модуляцією (ЛЧМсигнал), який виступав головним елементом синтезованого складного коду. Вибір ЛЧМ-сигналу обгрунтований перевіреною на практиці ефективністю його застосування в багатьох радіолокаторах $[1,4-5]$.

В роботі послідовно досліджені три варіанти синтезу дискретних частотних сигналів з кутовою модуляцією: синтез дискретного сигналу, частотного сигналу та дискретного частотного сигналу (рис. 1).

Синтез та генерування вказаних сигналів проведено у програмі схемотехнічного моделювання Micro-Сар [6] по аналогії до роботи сучасних інтегральних схем. Осцилограми та спектри елементів дискретних частотних сигналів та синтезованих на їх основі дискретних частотних сигналів на відповідних контактах (вузлах) схеми зображені на рис. 2. Для наочності наводиться простий випадок генерації сигналу без стрибка за частотою між елементами коду: між зрізом попереднього та фронтом наступного. Можливим також є синтез кодів з різними стрибками частоти між елементами та генерація кодів 3 часовими інтервалами між елементними. 


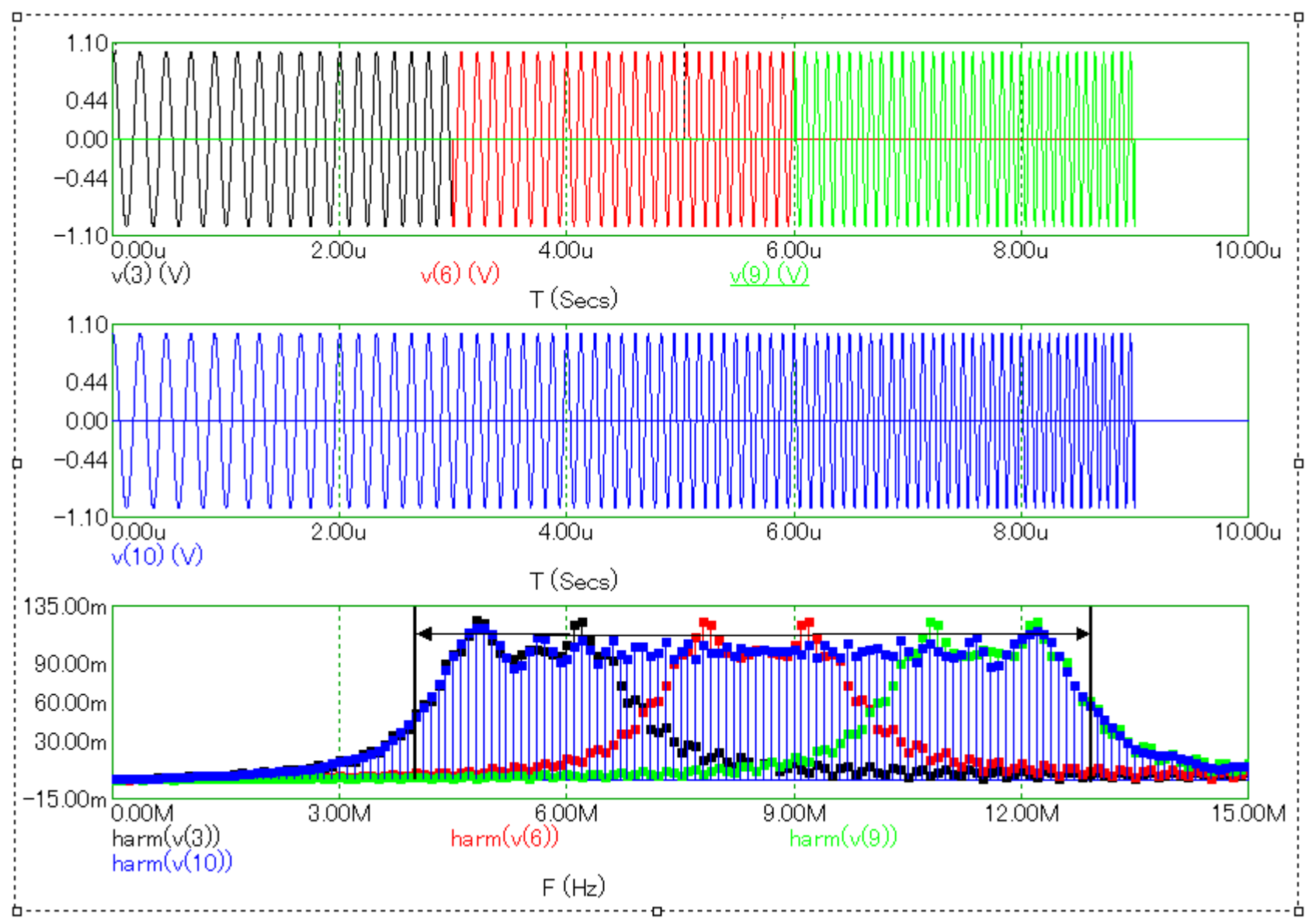

Рис. 2. Осцилограми (v(3), v(6), v(9)) та спектри (harm(v(3)), harm(v(6)), harm(v(9))) елементів дискретних частотних сигналів та синтезованих дискретних частотних сигналів: v(10), harm(v(10)) на відповідних контактах (вузлах) схеми у Micro-Сар

У якості цифрового процесору стиснення імпульсів, що надходять від цілей у роботі застосовувались можливості програми комп'ютерної математики Mathcad [7], за допомогою якої отримувались автокореляційні функції складних сигналів як шляхом чисельного розрахунку на комплексній площині, так і на базі аналітичних співвідношень, реалізація яких показана на рис. 3. Ефективність синтезованих сигналів оцінювалась по рівню бокових пелюстків автокореляційних функцій та їх головного максимуму.

Прикладами РЛС, які використовують одноелементні складні сигнали $є$ мобільні трьохкоординатні локатори AN/TPS-59 Lockheed Martin Corporation, AN/FPS-117 General Electric Company, аеродромний оглядовий радар ASR 12 Northrop Grumman [1], двокоординатні РЛС спостереження за надводною, повітряною та наземною обстановкою тощо.

Синтезовані складні сигнали з кутовою модуляцією в приймальному тракті РЛС можуть піддаватися обробці за допомогою процесорів цифрової обробки сигналів - digital signal processor, DSP [8] на рівні проміжних частот, а при впровадженні швидкодіючих АЦП - на рівні радіочастотних сигналів. Сучасні технології дозволяють оцифровувати аналогові складні сигнали як високих частот (3-30 МГц), так і сигнали, частоти яких відповідають метровим, дециметровим та сантиметровим хвилям [1]. 


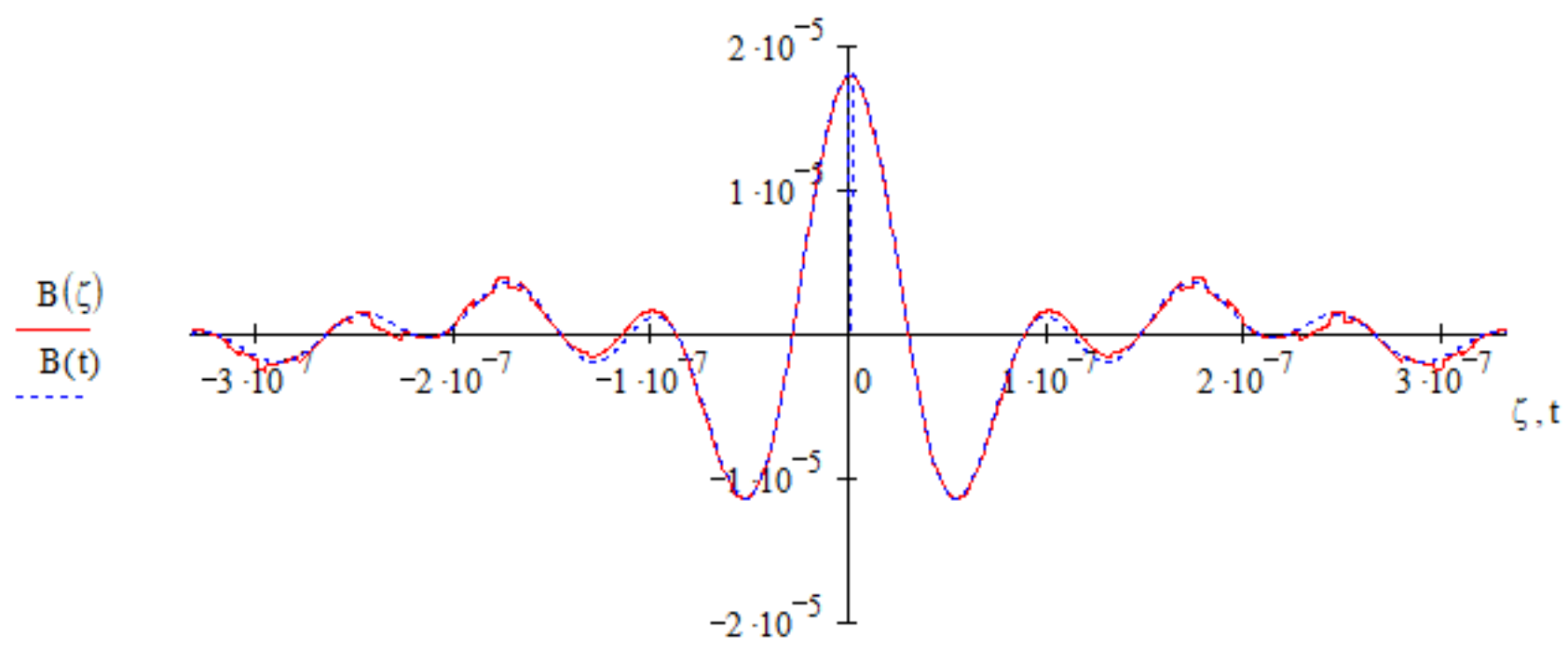

Рис. 3. Автокореляційна функція дискретного частотного сигналу тривалістю $3 \tau$ ( $\tau$ - тривалість одного елементу), розрахована у Mathcad: $\mathrm{B}(\zeta)$ - отримана за допомогою чисельного розрахунку, $\mathrm{B}(\mathrm{t})$ - отримана на базі аналітичного співвідношення

Якість сьогоднішніх АЦП (швидкодія, адекватне відношення сигналу до шуму, високий динамічний діапазон, відсутність паразитних складових) допускає їх застосування в радіолокаційних системах для обробки складних сигналів кутової модуляції. Виробництво таких перетворювачів призводить до створення цифрових радіолокаційних приймачів прямої дискретизації складних сигналів, що є однією з головних перспектив радіотехніки.

\section{Список літератури}

1. Сколник М.И. Справочник по радиолокации / 3-е издание. - Перевод с английского под общей редакцией В.С. Вербы. В 2-х книгах. - М.: Техносфера, 2014. - 672 c. - ISBN 978-5-94836-381-3.

2. Варакин Л.Е. Теория сложных сигналов. - М.: «Сов. радио», 1970. -376 с.

3. Варакин Л.Е. Теория систем сигналов. - М.: «Сов. радио», 1978. -304 с.

4. Радиоэлектронные системы: Основы построения и теория. Справочник. Изд. 2-е, перераб. и доп. / Под ред. Я.Д. Ширмана. - М.: Радиотехника, 2007. $512 \mathrm{c}$.

5. Баскаков С.И. Радиотехнические цепи и сигналы. - М.: Высшая школа, 2000. $-462 \mathrm{c}$.

6. Амелина М.А., Амелин С.А. Программа схемотехнического моделирования Мicro-Сар. Версии 9, 10. - С.: СНИУ МЭИ, 2013. - 618 с.

7. М. Херхагер, Х. Партолль Mathcad 2000: полное руководство: Пер. с нем. - К.: Издательская группа BHV, 2000. - 416 с.

8. Солонина А. И., Улахович Д. А., Яковлев Л. А. Алгоритмы и процессоры цифровой обработки сигналов. - СПб: БХВ-Петербург, 2001. - 464 с. - ISBN 594157-065-1. 


\title{
FEATURES OF THE INFORMATION-MANAGEMENT SYSTEM FOR THE PREPARATION OF BACHELORS IN MARINE EDUCATION
}

\author{
Kisietov Jurii, \\ Associate Professor \\ Candidate of technical sciences \\ Mykolayiv Admiral Makarov National University of Shipbuilding \\ Kuklina Olga, \\ Associate Professor \\ Candidate of technical sciences \\ Mykolayiv Admiral Makarov National University of Shipbuilding
}

\begin{abstract}
The analysis is carried out and recommendations are made on the composition and structure of information support for the process of professional and practical training of specialists at the level of higher education, based on existing components of educational technology, the national training standard and the requirements of regulatory documents of the International Maritime Organization.

A description of the subject area and a process-activity aspect of the specialization "Management of ship technical systems and complexes" in the specialty 271 "River and sea transport" for the first (bachelor's) level of higher education are developed.
\end{abstract}

Keywords: educational technology and its components, information processing, the effectiveness of information support, specialists in maritime professions, analysis of the learning process, competence

Introduction. The informational basis of the modern system of organization of the educational process for training specialists at the level of higher education is the requirements of existing standards and components of educational technology (curricula, work programs of disciplines, comprehensive tests, teaching materials, etc.).

An important feature of education for specialists in maritime professions is the regulation of training standards by the normative documents of the International Maritime Organization (IMO), in particular, the International Convention on the Preparation, Certification of Seafarers and Watchkeeping [1].

The need to constantly increase the level of adaptation of future specialists to life in the conditions of the modern media-information space causes an urgent need for continuous improvement and modification of the set of organizational and technical means of storage and processing of information, which is provided to users of the educational process.

Materials and Methods (Theoretical basis). Problems of increasing the efficiency of information support of program-methodological complexes of educational institutions are considered in many studies, for example [2 - 10, etc.]. In 
the present work, we generalize and develop the available recommendations taking into account the authors' own experience as applied to the features of the educational process of preparing students at the National University of Shipbuilding [11 - 13].

Results. In general, the information management system is an educational training complex, which combines various forms teaching educational material - tutorial; study guide for self-study material; lecture notes; guidelines and manuals for practical exercises and practice in enterprises and vessels, laboratory work, course and diploma design; reference literature.

The system may include two subsystems:

1) a multimedia complex of theoretical material, practical exercises, laboratory work and other components of the above;

2) the information subsystem of the analysis of the learning process and the degree of assimilation of the material.

The professional features of the training processes and subsequent activities of specialists in the maritime industry is also a fairly large amount of the practical component of the training complex. (For example, in the curriculum for training specialists at the bachelor's level, such a form of the educational process as practice occupies up to $25 \%$ of the entire educational load). In addition, the features of the study of some issues require a collective (group) solution through group discussions, roleplaying games, acting out situations, using simulators, etc.

Such rather specific training conditions make it necessary to actually combine fulltime and distance learning forms, in which a student (cadet) independently studies individual courses or sections in electronic format, which does not exclude his direct contacts with the teacher both in full-time and in electronic form.

In this sense, the teacher is increasingly acquiring the functions of a consultant, facilitator, and mentor. In our opinion, the time has come to introduce the so-called hybrid disciplines, which are a combination of full-time and distance learning. (The latter is already used in some foreign educational institutions called hybrid courses $[14,15])$. The need to combine various forms of training requires some changes to the composition and content of the components of the information management system of education - curricula, programs of disciplines, teaching aids, etc.

Discussion. A significant impact on the effectiveness of the functioning of the informational system of the educational process is provided by student feedback with the teacher. The traditional technology of constructing such feedback is based on such well-known forms of training as practical and laboratory studies, seminars, tests, course design, etc. In conditions of intensive development of the media-information component of the learning process, difficulties arise with reliable processing of a large amount of information. Improving the quality of information support of the educational process provides for the mandatory presence in the system of effective diagnostics.

The information subsystem for the analysis of the learning process and the degree of assimilation of the material evaluates the level of assimilation of the material and the preparation of methodological recommendations on the organization of training, subject to preliminary insufficiently deep assimilation of material. The subsystem should include multilevel testing for all types of training. A discipline program may include a set of modular blocks from separate sections that have their own rating and 
affect the final assessment of students' knowledge. Each didactic unit may contain: an information block, that is, a theoretical component developed on the basis of hypertext technologies, static and dynamic graphic material; tasks for independent solution; control questions; test items $[2,7,8]$.

The objectives of training in the International Convention on Standards of Training, Certification and Watchkeeping for Seafarers [1] indicate the acquisition by applicants of the knowledge, understanding, skills and other competencies necessary for the occupation of the posts of command personnel of the vessels. The Ukrainian standard [16] also defines the requirement that at least $70 \%$ of the educational program should be aimed at ensuring general and special (professional) competencies in the specialty. The concept of integral competence is also introduced there - the ability to solve complex specialized problems and practical problems in the field of shipping and marine engineering. Such integral competence is based on the application of theories and methods of sciences about the structure of the ship, navigation, mechanical and electrical engineering, operation and repair of vehicles, resource management and is characterized by the complexity and uncertainty of the conditions.

A fragment of the competency tables for marine engineers from the above documents is shown as an example in Fig. 1 and Table 1.

Table A-III/1

Specification of minimum standard of competence for officers in charge of an engineering watch in a manned engine-room or designated duty engineers in a periodically unmanned engine-room

Function: Marine engineering at the operational level

\begin{tabular}{|c|c|c|c|}
\hline Column 1 & Column 2 & Column 3 & Column 4 \\
\hline Competence & $\begin{array}{l}\text { Knowiedge, understanding } \\
\text { and proficiency }\end{array}$ & $\begin{array}{l}\text { Methods for } \\
\text { demonstrating competence }\end{array}$ & $\begin{array}{l}\text { Criteria for } \\
\text { evaluating competence }\end{array}$ \\
\hline $\begin{array}{l}\text { Use appropeliate } \\
\text { tools for fibrica- } \\
\text { tion and repsir } \\
\text { operatiaus typi- } \\
\text { cally performed } \\
\text { con ships }\end{array}$ & $\begin{array}{l}\text { Characteristics and limitations of ma- } \\
\text { terials uwed in construction and repair } \\
\text { of ships and oquipment } \\
\text { Characteristics and limitations of pro- } \\
\text { cesses used for fabrication and repair } \\
\text { Properties and parameters considered } \\
\text { in the fabricativa and repair of systems } \\
\text { and components } \\
\text { Application of safe working practices } \\
\text { in the workshop enviromment }\end{array}$ & $\begin{array}{l}\text { Assessment of evidence obtainod from } \\
\text { one oc more of the followings } \\
.1 \text { approved workshop stills triming } \\
2 \text { appruved practical experience and } \\
\text { tests }\end{array}$ & $\begin{array}{l}\text { Identification of important parameters } \\
\text { for fabrication of typical ship related } \\
\text { components is appeopriate } \\
\text { Selection of material is appropriate } \\
\text { Fabrication is to designated tolerances } \\
\text { Use of equipment and machine tools } \\
\text { i appropriate and saft }\end{array}$ \\
\hline $\begin{array}{l}\text { Use hand tnols } \\
\text { and messuring } \\
\text { equipment for } \\
\text { dimanting, } \\
\text { mainuenance, } \\
\text { repair and to- } \\
\text { assembly of } \\
\text { shipboard phant } \\
\text { and equipment }\end{array}$ & $\begin{array}{l}\text { Design characteristics and selection of } \\
\text { materiab in construction of equip- } \\
\text { ment } \\
\text { Interpretation of machinery drawings } \\
\text { and handbooks } \\
\text { Operational characterittics of equip- } \\
\text { ment and sysuems }\end{array}$ & $\begin{array}{l}\text { Assesement of evidence obtaincd from } \\
\text { one or mure of the following } \\
1 \text { approved workshop skills training } \\
2 \text { spproved practical experience and } \\
\text { tests }\end{array}$ & $\begin{array}{l}\text { Safety procedures followved are appto- } \\
\text { priate } \\
\text { Selection of tools and spare gear is } \\
\text { appropriate } \\
\text { Dismantling, inspecting, repairing and } \\
\text { reassembling oquipment is in accor- } \\
\text { dance with mannals and good practice } \\
\text { Re-commissioning, and performance } \\
\text { testiag is in accondance with manuals } \\
\text { and good peactice }\end{array}$ \\
\hline
\end{tabular}

Figure 1. Fragment of the competency table for ship mechanics [1] 
Table 1.

Fragment of the competency table for ship mechanics according to requirements special (professional) competencies specialization "Management of ship technicalsystems and complexes" [16]

\begin{tabular}{|c|l|}
\hline SC1 & Ability to carry a safe running machine watch on board \\
\hline SC2 & $\begin{array}{l}\text { Ability to operate, monitor, evaluate operation and safely maintain the } \\
\text { propulsion system without limiting its power and auxiliary mechanisms } \\
\text { and associated control systems and to control the operation of the } \\
\text { propulsion mechanisms }\end{array}$ \\
\hline SC3 & $\begin{array}{l}\text { Ability to provide planning and preparation for the operation of marine } \\
\text { power equipment, taking into account the design parameters of the } \\
\text { power plant and flight requirements }\end{array}$ \\
\hline SC4 & $\begin{array}{l}\text { Ability to identify, cause and troubleshoot marine mechanical } \\
\text { equipment, put it into service, and identify and prevent measures }\end{array}$ \\
\hline SC5 & $\begin{array}{l}\text { Ability to manage operations of fuel, lubricant, ballast and other } \\
\text { pumping systems and associated control systems }\end{array}$ \\
\hline SC6 & Ability to operate electrical, electronic equipment and control systems \\
\hline SC7 & $\begin{array}{l}\text { Ability to perform maintenance and repair of electrical and electronic } \\
\text { equipment, identify, troubleshoot and bring electrical and electronic } \\
\text { control equipment to working condition }\end{array}$ \\
\hline
\end{tabular}

Summary \& Conclusions. We have constructed a description of the subject area, which is necessary for filling the software and information support for the training of marine specialists (Table 2). The results obtained make it possible to formulate the main components of modern educational technology: the processes of activity of objects and subjects, planning, organization, implementation of goals and analysis of results.

Table 2.

The main components of the program-information system of specialization "Management of ship technical systems and complexes"

\begin{tabular}{|l|l|l|l|l|}
\hline \multicolumn{1}{|c|}{ Goals } & \multicolumn{1}{c|}{ Planning } & \multicolumn{1}{c|}{ Organization } & \multicolumn{1}{c|}{$\begin{array}{c}\text { Realization of } \\
\text { goals }\end{array}$} & Results Analysis \\
\hline 1 management & 1 equipment & 1 operation & 1 upgrade & 1 parameter \\
2 analysis & 2 mechanism & 2 diagnostics & 2 job evaluation & 2 indicator \\
3 comparison & 3 system & 3 maintenance & 3 information & 3 characteristic \\
4 development & 4 device & 4 repair & 4 innovation & 4 process \\
5 calculation & 5 process & 5 tests & 5 planning & 5 conditions \\
6 definition & 6 environ & 6 flight, shift & 6 justification & 6 experience \\
7 establishment & & 7 accident & 7 use & 7 security \\
8 identification & & & 8 elimination & 8 influence \\
9 control & & & 9 training & \\
10 supervision & & & & \\
11 faults & & & & \\
\hline
\end{tabular}


The above analysis and the proposed development of software and information support for educational technology on the example of the specialization "Management of ship technical systems and complexes" makes it possible to use the proposed approach in the educational processes of other specialties.

\section{References:}

1. International Convention on Standards of Training, Certification and Watchkeeping for Seafarers 1978, as amended in 1995 and 1997 (STCW Convention) including the Final Act of the 1995 Conference of Parties to the STCW Convention, 1978, and resolutions 1 and 3 to 14 of the Conference and Seafarers' Training, Certification and Watchkeeping Code (STCW Code) including resolution 2 of the 1995 STCW Conference, as amended in 1997, 1998 and 2000.

2. 2. Dubaseniuk O.A. Innovative educational technologies and methods in the system of vocational training // Professional pedagogical education: innovative technologies and techniques: Monograph / Ed. OA Dubaseniuk. - Zhytomyr: View of the ZhDU them. I. Franko, 2009. - P. 14-47, (in Ukranian).

3. Zadnipryanets I.I. Modern Educational Technologies in Physics Teaching / Irina Zadnipryanets / Edited. L. Holvinskaya. - K .: Shk. World, 2011. - 128 p. (in Ukranian).

4. Paliga O.V., Prytula I.A. Innovative training technologies in the training of skilled workers in the system of vocational education, (in Ukranian).http://vpl57.zp.ua/file/IYPNoweV, last accessed 2019/09/13

5. Evseyeva G.P., Babenko V.A. Innovative and traditional technologies of education in the conditions of informatization of education, (in Ukranian), http://eadnurt.diit.edu.ua/bitstream/123456789/3885/1/Yevseeva_Babenko.pdf, last accessed 2019/09/13

6. Soroka O.M. Ways and conditions of formation of psychological readiness of future specialists of sea transport to extreme situations of professional activity / Bulletin of ONU them. I.I. Mechnikov. Psychology. Volume 21. Issue 4 (42). 2016, p. 183 - 194, (in Ukranian).

7. Abilkasimova G., Saduakas A.D. Information support for managing the quality of education of students of higher education institutions // International Journal of Applied and Basic Research. - 2016. - No. 12-5. - S. 902-906, (in Russian).

8. Kaeli Nieves-Whitmore, Hybrid Classes: What are they, how do they work, and are they right for you? - https://www.collegeraptor.com/getting-in/articles/onlinecolleges/hybrid-classes-what-are-they-and-how-do-they-work/, last accessed 2019/09/13

9. McGrath R. Gunther The End of Competitive Advantage: How to Keep Your Strategy Moving as Fast as Your Business / R. Gunther McGrath. - Harvard Business Review Press, 2013. - 240 p.

10. Laszlo C. Embedded Sustainability: The Next Big Competitive Advantage / C. Laszlo, N. Zhexembayeva. - Stanford Business Books: Stanford, CA, 2011. - 288 p.

11. Kuklina O. J., Kisetov J. V. Features of teaching computer graphics for students of specialization "Operation of ship automated systems": Proceedings of the 
VII International Scientific and Technical Conference. - Mykolayiv: NUS, P.418-422 (2017), (in Ukranian).

12. Kisetov J. V., Kuklina O. J. Some questions of organization of independent work of students. Ship Energy: State and Problems: Proceedings of the VII International Scientific and Technical Conference. - Mykolayiv: NUS, P.432-434 (2017), (in Ukranian).

13. Kuklina O. J., Kisetov J. V. 3D Modeling of Ship Power Equipment Parts with Design Elements: Proceedings of the VIII International Scientific and Technical Conference. - Mykolayiv: NUS, P.429-432 (2017), (in Ukranian).

14. Hybrid Classes: What are they, how do they work, and are they right for you? - https://www.collegeraptor.com/getting-in/articles/online-colleges/hybridclasses-what-are-they-and-how-do-they-work/, last accessed 2019/09/13. 


\section{PRACTICE OF DESIGN MODERN NANOCIRCUITS}

Melnyk Olexandr,

Ph.D., Docent

Kyiv National Aviation University

Kozarevych Viktoriia

Senior lecturer

Kyiv National Aviation University

Necessity to create reliable economical and fast arithmetic-logical devices in nanotechnics lades for developing of Quantum-Dot Cellular Automata (QCA) with high compactness of active components arrangement. This nanotechnology has potential application in future computers. In this paper design of full adder built on three dimension five input majority gate is proposed. In terms of structure density, complexity and area proposed design dominates all previous designs.

Adders are one of the basic components in designing of different arithmetic circuits, therefor designing of robust, simple and dense full-adder is in great importance. In this order new five-input three dimension majority gate constructed on ordinary QCA cells[1] is introduced.

Placing cells next to each other in a line and allowing them to interact we can provide flowing of a data down such wire. The basic logic gates in QCA are the majority gate and invertor. Five-input majority gate can be implemented in several ways. The first design is based in 3D QCA cells [2]. A 3D QCA cell is like a cube which has eight quantum dots on its corners where four surplus electrons are trapped (Figure 1a). The schematic presentation of such five-input majority gate is shown on Figure 1b.

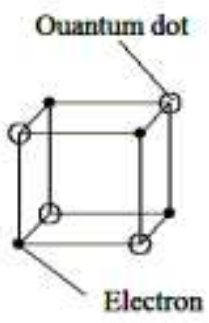

a)

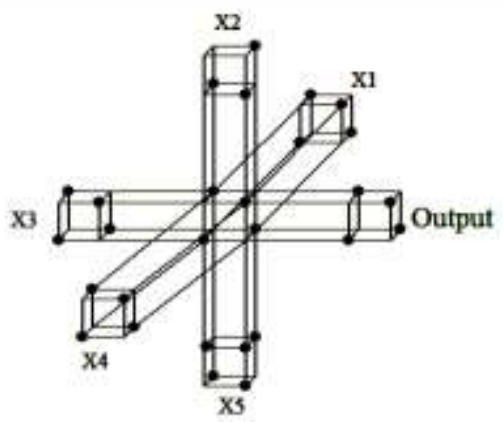

b)

Fig. 1. 3D QCA cell (a) and five-input majority gate (b).

The circuit layout is implemented in 5 cell layers, with one via cell between layers. Inputs $\mathrm{x} 1, \mathrm{x} 3, \mathrm{x} 5$ and output $\mathrm{y}$ are in one cell layer and inputs $\mathrm{x} 2, \mathrm{x} 4$ are in two another layers (Figure 2). 


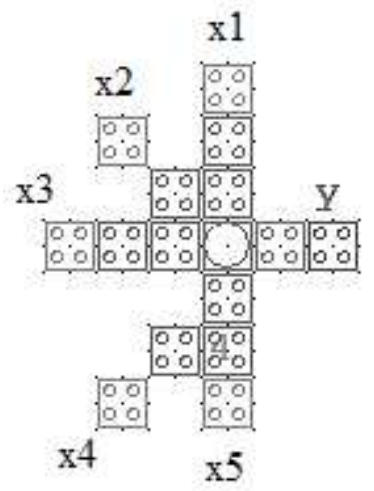

Figure 2. Five-input majority gate built on ordinary QCA cells.

A 1-bit QCA full adder can be assembled from three majority gates and two invertors [3]. The expressions for the sum and carry output for this adder:

$$
\begin{aligned}
& S=\operatorname{maj}\left(\bar{C}_{\text {out }}, x_{0}, \operatorname{maj}\left(x_{1}, \bar{x} 0, C_{\text {in }}\right)\right), \\
& C_{\text {out }}=\operatorname{maj}\left(x_{0}, x_{1}, C_{\text {in }}\right)
\end{aligned}
$$

where $x_{0}, x_{1}, C_{i n}$ are the inputs, and $S$ and $C_{\text {out }}$ are the outputs.

Simulation and designing of QCA full adder and multiplier is done using numerical tools such as the QCADesigner tool.

For construction of input wires 45 degree cell orientation is used. Performing such implementation gives inverter chain where each cell takes on the opposite polarization of its neighbors.

The simulated layout is based on a QCA cell sized $18 \times 18 \mathrm{~nm}$, with 4 quantum dots each having a diameter of $5 \mathrm{~nm}$, and the distance between the center of cells being 20 $\mathrm{nm}$. Design of 2 bit multiplier is rather complicated in comparison with design of full adder, which is connected not only with implementation of bigger amount of operation components but also with necessity to layout multiplier in several layers. For such reason, a multi-layer crossing can be used. The dimensions of the full multiplier design are $1250 \mathrm{~nm} \times 820 \mathrm{~nm}$. There are 6 inputs including conditional carries from previous state, 4 fixed polarized cells and total number of cells is 630 . For simulation of a 2 bit multiplier, first one is applied bistable approximation engine [3]. Using this engine, not all cell effects are considered. Only cell effects within an area defined by the so-called radius of effect $\mathrm{R}$ are considered for each cell.

Another example of device built on QCA is demultiplexor. Figure 3 shows the layout of it. 


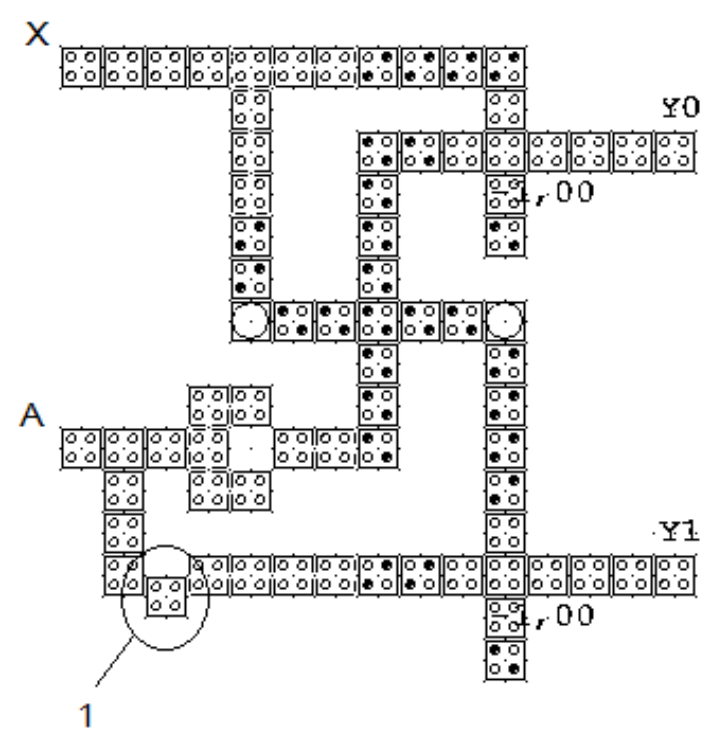

Figure 3. Layout of QCA demultiplexor.

There are 2 inputs (X-information input and $\mathrm{A}$ - address input) and two outputs ( $\mathrm{Y} 0$ and $\mathrm{Y} 1)$; two cells are fixed polarized $(\mathrm{P}=-1)$, therefore two majority gates are working as AND gate. The latency for this demultiplexor is one clock cycle. The cell noted " 1 " is translated down to avoid undesirable influence of upper cell. Results of simulation can be shown in form of input and output signals waveforms (Figure 4).

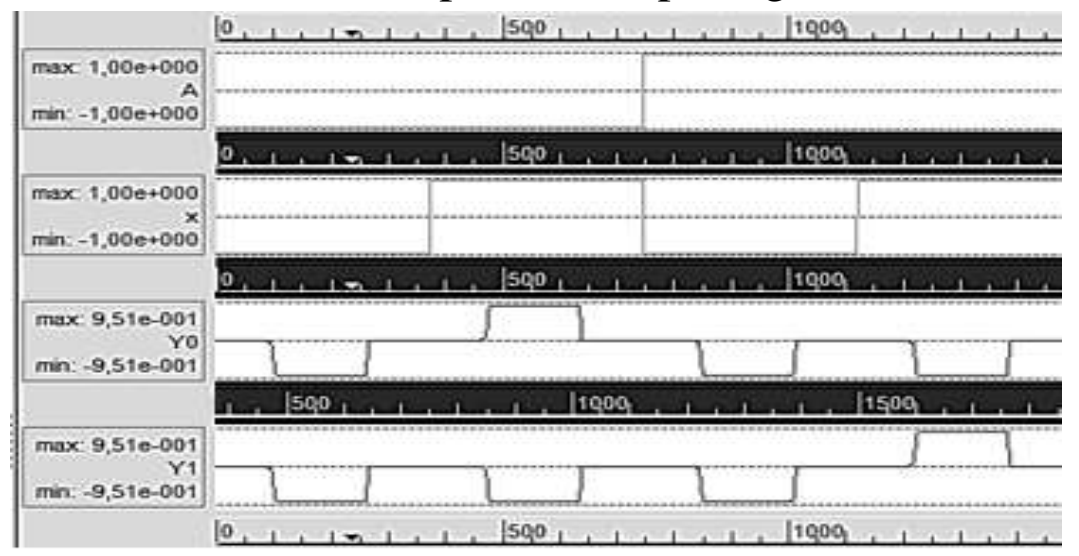

Figure 4. Simulation waveforms of demultiplexor

Total duration of simulation is $1500 \mathrm{~ns}$.

\section{References:}

1. Tougaw, P.D., Lent C.S .Logic devices implemented using quantum cellular automata / Tougaw, P.D., Lent C.S //J. Appl. Phys., American Institute of Physics. 1994, - pp. 49-57.

2. Rahimi Azghadi M., Kavehei O. Novel Design for Quantum-dot Cellular Automata Cells and Full-adders/ Rahimi Azghadi M., Kavehei O.//J. Appl. Sci., - pp. 3460-3468.

3. Пакулов Н.И. Мажоритарный принцип построения надежных узлов и устройств ЦВМ / Пакулов Н.И. - М.: Сов. радио - 1974, - с. 191.

4. Walus, K. QCADesiner: A CAD Tool for an Emerging Nano-Technology / Walus, K. // Micronet Annual Workshop - 2003, - pp. 31-40. 


\title{
INNOVATIVE TECHNOLOGY OF FLOOD ALARM AND FORECASTING
}

\author{
Polishchuk Volodymyr, \\ Ph.D., Associate Professor \\ Uzhhorod National University
}

In the life of modern society, the problems associated with overcoming the consequences of emergencies, which lead to huge material losses and sometimes human losses, play a significant role. A special place among many emergencies belongs to floods of man-made and natural origin, catastrophic flooding and flooding of territories, which are one of the main socio-environmental problems of our time [1].

In the context of crisis management and security of citizens, there is a complex and urgent task of developing a mobile software product that allows, according to the geolocation data of the smartphone, to warn the user about the level of flood risk..

Thus, the aim of the study is to develop an innovative technology that contains a generalized algorithm and software support (mobile application) for flood signaling and forecasting, on the example of the Transcarpathian region. The innovation is that the algorithm is based on a hybrid intelligent model, using the analysis of reasoning and the experience of water experts.

Here is a generalized algorithm for flood signaling and forecasting.

Suppose we have $n$ measuring stations, which each period of time $t$ send data on the actual water level in n. To analyze the measurement data, we use the method of regression analysis, namely the method of pairwise linear regression. We present a general algorithm for flood signaling and forecasting based on a hybrid intelligent model [2] for determining the level of flood risk. The model is able to derive a normalized assessment of water level rise, uses the analysis of reasoning and experience of water management experts, reveals the vagueness of input estimates, increases the degree of validity of further management decisions based on the results. The output of the model is a normalized assessment of the danger of a flood situation and a linguistic interpretation of the level of danger of a flood situation.

1 step. Obtaining data and building a time series

In the first step, we construct a time series where $y$ is the water level, $x$ is the fixation time.

2 step. Determination of regression coefficients

In the second step, the least squares method (LSM) is used to determine the regression parameters. Find the values of the regression coefficients. LSM allows to obtain such estimates of parameters at which the sum of the squares of the deviations of the actual values of the resultant characteristic $y$, from the theoretical values of $y$ at $\mathrm{x}$ is minimal.

\section{3 step. Obtaining predicted values}

In the third step, we construct a pairwise linear regression equation to predict the water level. To do this, we substitute future periods $\mathrm{x}$ into the equation to obtain the predicted values. 
4 step. Fuzzification of input data

In the fourth step, we will phase the input data, based on the predicted data, the

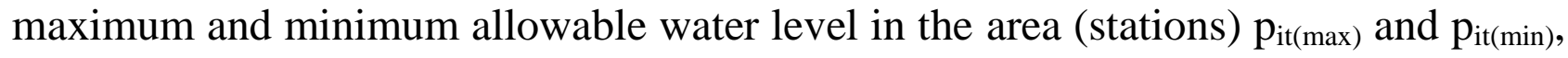
according to the formula:

$$
\mu\left(p_{i t}\right)=\left\{\begin{array}{cc}
0, & p_{i t}<a ; \\
\frac{1}{2}+\frac{1}{2} \cos \left(\frac{p_{i t}-b}{b-a} \cdot \pi\right), & a \leq p_{i t} \leq b ; i=\overline{1, n} \\
1, & p_{i t}>b .
\end{array}\right.
$$

Where to put $a=p_{i t(\min )}$ safe (lowest) level, $b=p_{i t(\max )}$ accordingly dangerous (highest) level. The concept of constructing membership functions assumes the following meaning: the higher the water level, the greater the risk of flooding, and the value of the membership function goes to one [3].

5 step. Estimation of water level projection

In the fifth step, we estimate the water level projection for the relevant area over a period of time:

$$
P_{i t}=\mu\left(p_{i t}\right) \cdot 100 \text {. }
$$

The value obtained $P_{i t}$ characterizes the assessment of the water level projection for the relevant area in a certain period of time [3].

6 step. Obtaining a flood risk assessment

The sixth step requires the water expert to assess the risk of flooding and select one of the proposed options for linguistic variables:

$\mathrm{H}$ \{Low risk of flooding $\}$;

C $\{$ Medium risk of flooding $\}$;

B \{High risk of flooding $\}$.

After that, we calculate the normalized assessment of the risk of flood situation by the formula:

$$
\mu\left(Z_{i t}\right)=\left\{\begin{array}{cc}
0, & P_{i t}<0 \\
\left(\mu\left(p_{i t}\right)\right)^{k}, & 0 \leq P_{i t} \leq 100 \\
1, & P_{i t}>100
\end{array}\right.
$$

Where $\mathrm{k}$ is the degree of risk of flooding. For example, set: for low risk of flooding $\mathrm{k}=1 / 3$, for medium risk $\mathrm{k}=1$, and for high risk of flooding $\mathrm{k}=3 / 5$.

According to the obtained normalized assessment, it is possible to present a linguistic interpretation of the level of danger of a flood situation.

7 step. Decision-making on flood signaling

In the seventh step, based on the linguistic interpretation, the decision maker (water management expert) can signal and / or inform users about the dangerous situation, respectively, through the mobile application.

As a result of the implementation of smart crisis management technologies, the provision of protection against the harmful effects of water on settlements, minimization of damage and creation of safe living conditions for the communities of the region is being strengthened.

Thus, the technology of flood signaling and forecasting has been developed, the output of which is a mobile application that allows to widely disseminate information 
about the danger in the region closest to the user and provide additional information, based on the developed algorithm for risk assessment and modeling.

\section{References:}

1. Kelemen M. (2019). Safety and Knowledge Alliance of Aviation Education: Human factors in Aviation Safety and Air Law. AMELIA Aneta Siewiorek, Poland, 2019.

2. Polishchuk V. (2019). Technology to Improve the Safety of Choosing Alternatives by Groups of Goals. Journal of Automation and Information Sciences, 51 (9), 66-76. DOI: 10.1615/JAutomatInfScien.v51.i9.60

3. Kelemen, M., Polishchuk, V., Gavurová, B., Andoga, R., \& Matisková, D. (2020). The Expert Model for Safety Risks Assessment of Aviation Environmental Projects' Implementation Within the Investment Phase of the Project. IREASE, Vol 13, No 6, 198-207. doi: https://doi.org/10.15866/irease.v13i6.18268 


\section{HYDRODYNAMIC NOISE AND VIBRATIONS OF TOWED MARINE ANTENNA}

\section{Voskoboinick Vladimir}

Dr Sc, Associate Professor

Institute of Hydromechanics of the National Academy of Sciences of the Ukraine

The successful and efficient operation of flexible extended towed antennas is highly dependent on the signal-to-noise ratio. Increasing this ratio is the main goal of the developers of acoustic systems. The main noises that determine the performance of the antenna are hydrodynamic and vibrational noises. The hydrodynamic noise caused by the interaction of the flow with the streamlined surface consists, according to [1], from the acoustic and pseudosonic components. The sound component of hydrodynamic noise is transferred from the source of its radiation into the environment at the speed of sound. Pseudosound is generated by nonlinear interaction of vortex structures of the boundary layer, both with each other and with the streamlined surface. Pseudosonic pressure fluctuations are transported at a velocity close to the flow velocity and do not propagate over long distances and have a characteristic scale of the order of the boundary layer thickness $[1,2]$.

When a pseudosonic field of pressure fluctuations acts on an elastic surface, then it begins to oscillate. This results in the emission of sound, which corresponds to the frequency and intensity of the disturbing hydrodynamic force. Hydrodynamic noise affects the receiving elements of the antenna, since they are located under the soundtransparent streamlined shell and perceive this noise as a useful signal. In addition to hydrodynamic noise, the signal recorded by hydrophones is affected by vibration of the antenna and its elements. Vibration levels increase significantly when the antenna is towed at an angle of attack and in the case of lateral underwater currents [3-5].

The purpose of the experimental study is to study the pseudosonic component of hydrodynamic noise and vibrations of a towed extended antenna and develop recommendations for their reduction.

The research was carried out at the test site of the Institute of Hydromechanics NASU in the bypass channel of the Kanev reservoir of the Dnieper River [6-8]. The length of the rectilinear section of the channel was about $4000 \mathrm{~m}$, width - up to $50 \mathrm{~m}$ and depth - not less than $4 \mathrm{~m}$. The tests were carried out by towing a flexible extended antenna (Fig. 1) with a diameter of $29 \mathrm{~mm}$ and an elongation of about 700 at a depth of $1.2 \mathrm{~m}$ from the water surface. The boat (1) with the help of a long nylon cable (2) with a length of about $160 \mathrm{~m}$ was towing a well-streamlined catamaran (3). A wellstreamlined knife (4) was installed in the aft part of the catamaran, to which a multisection flexible extended antenna was attached. The antenna consisted of a damping (5), measuring (6) and an idle (7) section. The towing velocities varied from $3 \mathrm{~m} / \mathrm{s}$ to $10 \mathrm{~m} / \mathrm{s}$. 

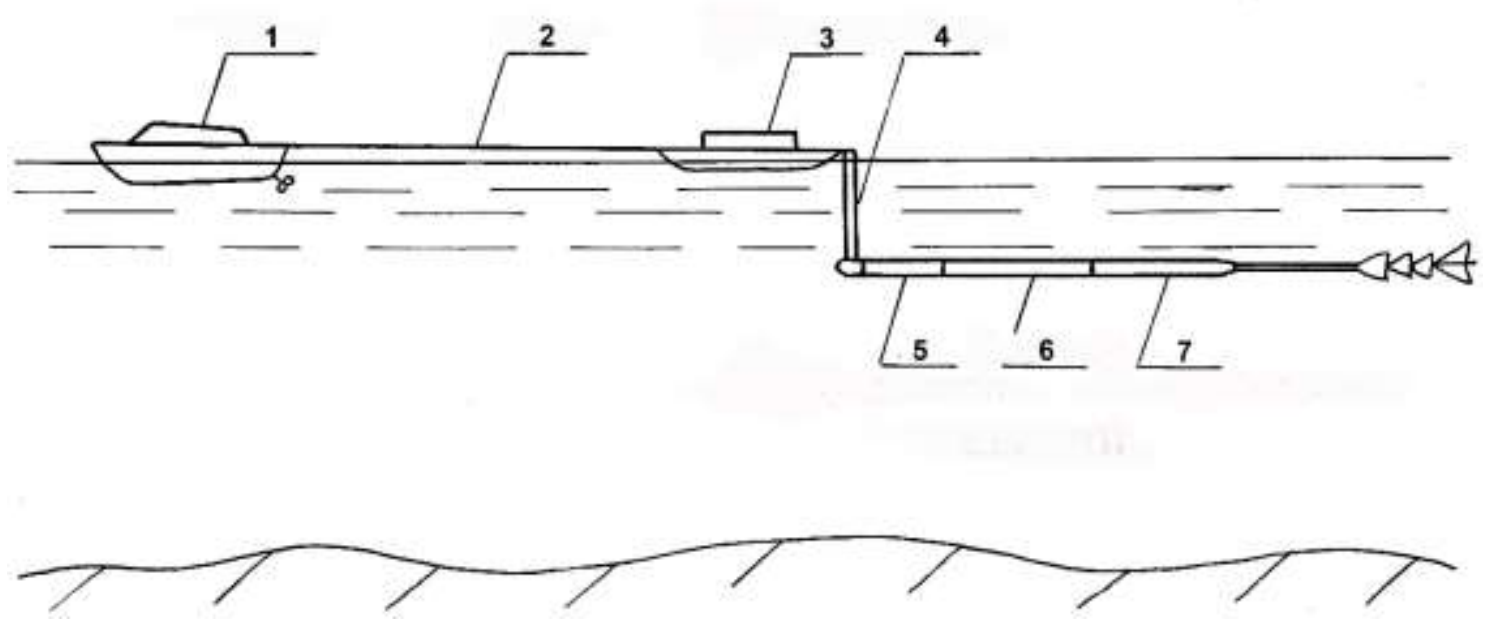

Figure 1. Towing scheme of the flexible extended antenna.

The diagram of the extended antenna and the sensor unit are shown in Fig. 2. The antenna consisted of a damping section (1 in Fig. 2a), an idle section (2), a measuring section (3), and an antenna stabilization and tension system (4). All sections of the antenna were an air-filled shell made of PVC, neutral buoyancy, with a steel cable inside as a power element. In the damping section, a nylon halyard was used as a power element to reduce structural vibrations [2, 8]. Membrane-type pressure fluctuation sensors (PFS in Fig. 2b) were installed flush with the streamlined antenna surface and had an effective diameter of the sensitive surface of $1.6 * 10^{-3} \mathrm{~m}$. Vibration-compensated cylindrical hydrophones (HP in Fig. 2b) were located under a streamlined shell in a sound-transparent compound; their sensitive surface area was $1.6^{*} 10^{-3} \mathrm{~m}^{2}$. Piezoceramic single-component accelerometers (Acc in Fig. 2b) were installed in the antenna in three mutually perpendicular planes. In total, 15 pressure fluctuation sensors, 3 hydrophones, and 7 accelerometers were installed in the measuring section of the antenna. All sensors were calibrated before and during the research [9-11].

Measurements were carried out for Reynolds numbers $\left(\operatorname{Re}_{\mathrm{x}}=\mathrm{Ux} / \mathrm{v}\right)$ from $10^{7}$ to $10^{8}$ (where $\mathrm{x}$ is the longitudinal coordinate where the sensor was located, and $v$ is the kinematic viscosity coefficient), boundary layer thicknesses $(\delta)$ from $40^{*} 10^{-3} \mathrm{~m}$ to $50^{*} 10^{-3} \mathrm{~m}$, displacement thicknesses $\left(\delta^{*}\right)$ from $6.6^{*} 10^{-3} \mathrm{~m}$ up to $7.2^{*} 10^{-3} \mathrm{~m}$ and dynamic velocities $\left(\mathrm{u}_{\tau}\right)$ from $0.11 \mathrm{~m} / \mathrm{s}$ to $0.17 \mathrm{~m} / \mathrm{s}$. Measurement errors did not exceed $10 \%$ for the averaged or integral characteristics of the investigated processes and not more (1$2) \mathrm{dB}$ for spectral dependences in the frequency range $(0.5-1250) \mathrm{Hz}$ with a confidence level of 0.95 .

The signals from the sensors through the corresponding communication lines located inside the antenna and the streamlined knife were fed to the board of the catamaran, where they were recorded on a four-channel measuring tape recorder of type 7005A of the firm "Brüel \& Kjaer". The processing and analysis of experimental data were carried out on a specialized complex of the firm "Brüel \& Kjaer", as well as with the help of personal computers. 

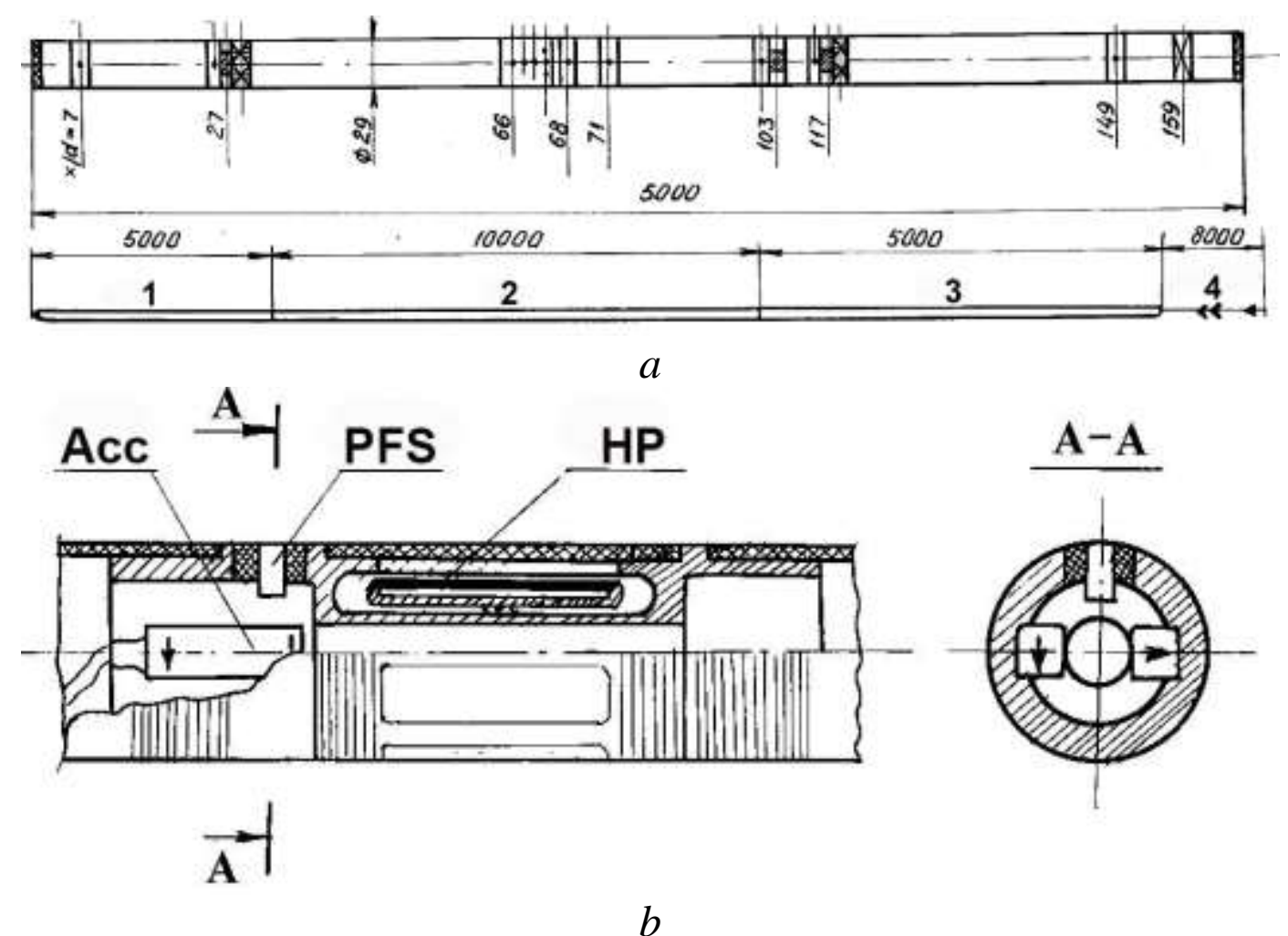

Figure 2. Diagram of the measuring section and the towed part of the extended antenna (a) and the correlation unit of sensors (b).

RMS values of wall pressure fluctuations, dimensioned by the value of dynamic pressure, in the form of the acoustohydrodynamic coefficient $k_{a h}=\left[\overline{\left(p^{\prime}\right)^{2}}\right]^{1 / 2} /\left(\rho U^{2} / 2\right)$

generally showed a fairly good agreement of our results with the measured values on plates and rigid cylinders [12-14]. With an increase in the sensitive surface of the receiver, the values of this coefficient decrease, which is due to the effect of spatial filtering by the surface of the sensor. For pressure fluctuation sensors, they are of the order of $(6.2-6.8) * 10^{-3}$, and for hydrophones - (4.9-5.3)*10-3. According to our estimates, for a point receiver (the sensitive surface is close to zero) the value $\mathrm{k}_{\mathrm{ah}}=9.9^{*} 10^{-3}$, in [12] it is equal to $10.2^{*} 10^{-3}$, and in [14] $-9.7^{*} 10^{-3}$.

The power spectral density levels of the hydrodynamic noise recorded by the hydrophone are shown in Fig. 3a for various flow velocities. Curve 1 was measured for $U=10 \mathrm{~m} / \mathrm{s}$, curve $2-6 \mathrm{~m} / \mathrm{s}$, curve $3-5 \mathrm{~m} / \mathrm{s}$ and curve $4-3 \mathrm{~m} / \mathrm{s}$. With an increase of the velocity, the levels of pressure fluctuations increase and the frequency range expands. This suggests that small-scale high-frequency vortex structures contribute to the energy of the pressure fluctuation field with increasing flow velocity.

The power spectral density of the wall pressure fluctuations on the streamlined surface of the antenna, recorded by miniature pressure fluctuation sensors, whose sensitive surface area is 8000 times smaller than hydrophones, is shown in Fig. 3b. Curve 1 is measured for an antenna towing velocity of $3 \mathrm{~m} / \mathrm{s}$ and curve $2-5 \mathrm{~m} / \mathrm{s}$. Curve 3 is the background noise of the channel when the engine of the towing boat is running. The pseudosonic wall pressure fluctuations caused by the action of the boundary layer on the streamlined surface exceed the background noise by $30 \mathrm{~dB}$ or more in the 
frequency range from 10 to $800 \mathrm{~Hz}$. With an increase in the flow velocity, the spectral levels of the wall pressure fluctuations increase, especially in the high-frequency region. It should be noted that the spectral levels of pressure fluctuations measured by miniature pressure fluctuation sensors are higher than hydrophones, especially in the high-frequency region. This is due to the fact that the sensor, being a kind of wave filter, registers only vortex systems, the scales of which exceed twice the size of its sensitive surface.
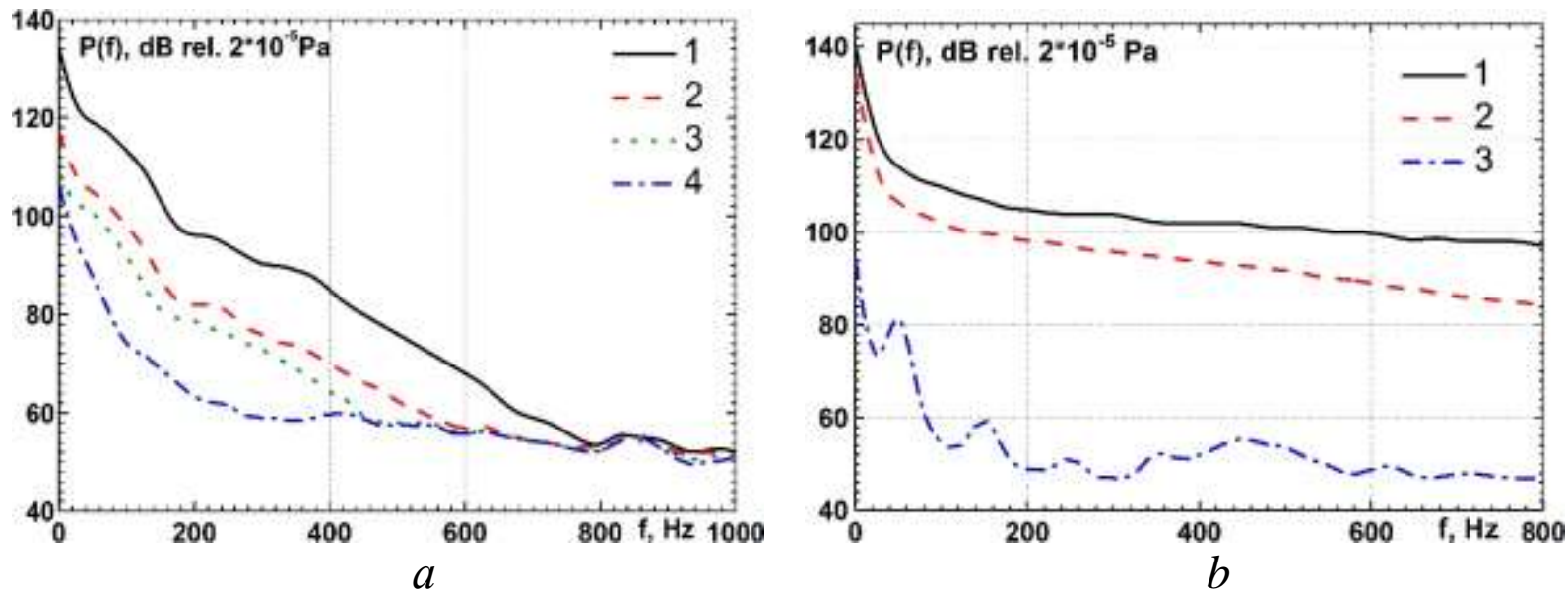

Figure 3. Hydrodynamic noise of the extended flexible antenna (a) and wall pressure fluctuations on the streamlined surface (b).

Fig. 4a shows the spectra of accelerations of an extended towed antenna for flow velocities of $3 \mathrm{~m} / \mathrm{s}$ and $5 \mathrm{~m} / \mathrm{s}$. Curves $1-3$ are measured for $U=5 \mathrm{~m} / \mathrm{s}$ and curves $4-6$ are measured for $U=3 \mathrm{~m} / \mathrm{s}$. Curves 1 and 4 were obtained for the vertical component of the oscillation and the distance from the antenna nose fairing to accelerators $\mathrm{x} / \mathrm{d}=630$, Curves 2 and $5-\mathrm{x} / \mathrm{d}=550$. Curves 3 and 6 are measured for axial vibrations of the antenna. Vertical vibrations of the antenna, as well as horizontal vibrations, but not shown in this figure, decrease when approaching the nose of the antenna and are higher than axial vibrations, especially in the high frequency region. With an increase in the flow velocity, the vibration levels were increased.

As shown in Fig. 3 and Fig 4a, the field of pressure fluctuations and vibrations changes proportionally to the velocity of the incoming flow in the power dependence $\mathrm{U}^{\mathrm{n}}$, and the exponent varies for different frequency ranges, which was noted in [1517]. Fig. $4 b$ shows the dependences of the exponent (n) on the frequency $\left(f^{*}=f / 100 \mathrm{~Hz}\right)$ for the wall pressure fluctuations recorded by pressure fluctuation sensors (curve 1) and hydrophones (curve 2), as well as vibrations (curve 3 ). The indicator of the degree of proportionality of vibrations was determined as the average value for three components of antenna oscillations, with a deviation of no more than $7 \%$ in the lowfrequency region and no more than $12 \%$ in the high-frequency region. From the given data it follows that with an increase in the frequency, pressure fluctuations increase in proportion to the flow velocity with an increasing rate, and vibrations - with a decreasing one. The pressure fluctuations recorded by the hydrophone reach the limiting value of the exponent (close to 3.1) already at frequencies of the order of $200 \mathrm{~Hz}$, while the wall pressure fluctuations registered by the miniature pressure 
fluctuation sensors reach $n=3$ at frequencies close to $800 \mathrm{~Hz}$. Consequently, the wall pressure fluctuations in a developed turbulent boundary layer, excited by lowfrequency large-scale structures, grow in proportion to $\mathrm{U}^{2}$, and excited by highfrequency small-scale eddies, in proportion to $\mathrm{U}^{3}$. Low-frequency antenna vibrations (4-400) $\mathrm{Hz}$ increase in proportion to $\mathrm{U}^{2.5}$, and high-frequency $(400-800) \mathrm{Hz}-\mathrm{U}^{1.6}$.
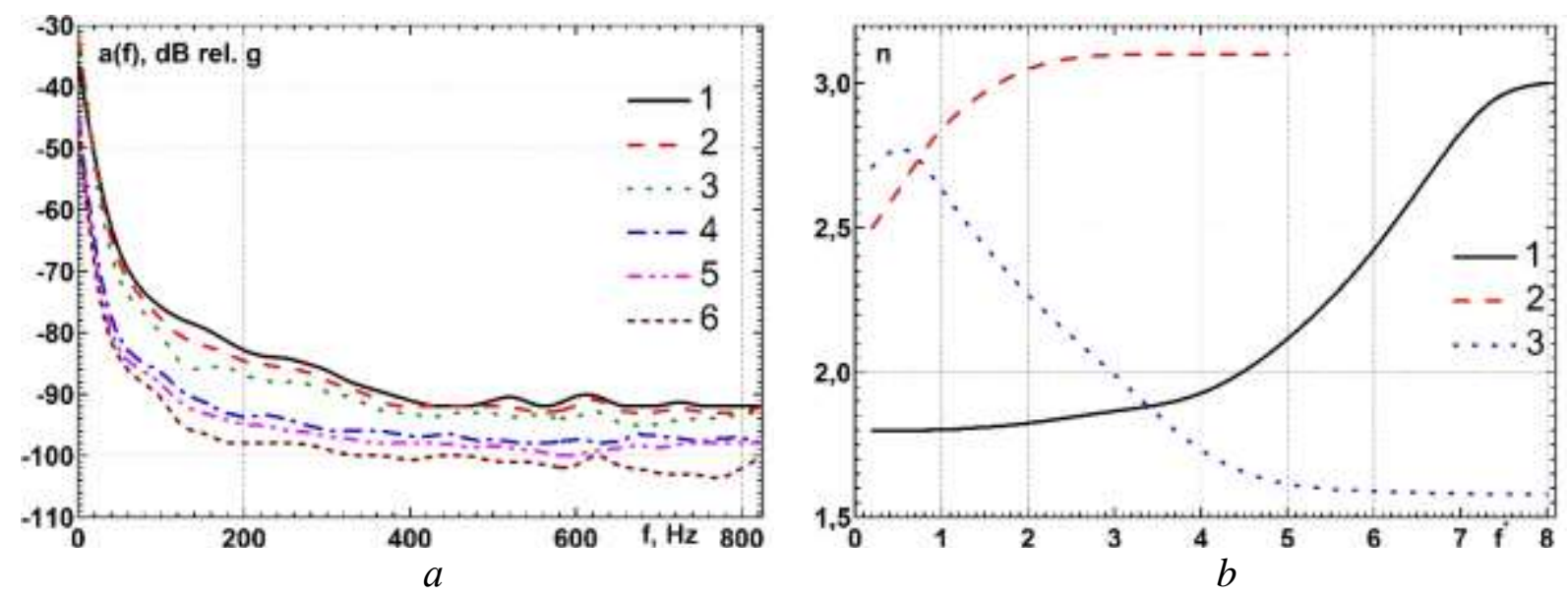

Figure 4. Spectral levels of vibrations of the extended antenna (a) and dependences of the exponent of proportionality of pressure

fluctuations and accelerations (b).

As measures to reduce hydrodynamic noise for the operation of a flexible extended towed antenna, a grouping of acoustic receivers, removal of receivers from the streamlined surface and taking into account the correlation radius, as well as vibration compensation and vibration damping methods were used. It was found that the grouping of receiving elements reduced the level of hydrodynamic noise by the amount of $\sqrt{m} \mathrm{~dB}$, where $\mathrm{m}$ is the number of receivers. Removing the receiving elements from the streamlined surface made it possible to reduce the hydrodynamic noise by an amount proportional to $\Delta \mathrm{h}^{(1.8 \div 2.1)}$. It was found that the hydrodynamic noise was not correlated when the acoustic receivers were removed at a distance greater than 14 boundary layer thicknesses.

The use of vibration-damping and vibration-insulating coatings, as well as specially designed vibration-absorbing structures for the installation of receiving elements, made it possible to reduce vibration noise by almost $20 \mathrm{~dB}$, but in narrow frequency ranges of the effectiveness of such vibration reduction methods. The use of vibrationcompensating techniques for accounting for antenna vibrations in the analysis of acoustic signals made it possible to reduce the vibration noise by (10-15) dB. Vibration compensation covers the entire frequency range where the antenna vibrates, in contrast to vibration damping and vibration isolation methods, which are ineffective in the lowfrequency region.

1. It was found that with an increase in the sensitive surface of the receiver, the levels of pseudosonic pressure fluctuations recorded by it decrease due to the effect of spatial filtering. The power spectral densities of pressure fluctuations for large sensors are narrower and concentrated in the low frequency region. With an increase in the velocity of the flow around the antenna, the levels of pressure fluctuations increase, 
with an increasing rate, in the region of high frequencies, which generate small-scale vortices.

2. It was recorded that horizontal and vertical vibrations grow with distance from the antenna's bow, remaining more than axial ones. With an increase in the flow velocity, the vibration levels increase in the entire frequency range, but to a greater extent in the low frequency range.

3. It was found that the wall pressure fluctuations on the flexible antenna, excited by low-frequency large-scale vortices, increase in proportion to $\mathrm{U}^{2}$, and excited by high-frequency small-scale vortices, increase in proportion to $\mathrm{U}^{3}$. Low-frequency antenna vibrations (up to $400 \mathrm{~Hz}$ ) increase as $\mathrm{U}^{2.5}$, and high-frequency $(400-800) \mathrm{Hz}-$ as $\mathrm{U}^{1.6}$.

4. To reduce hydrodynamic noise and vibrations on a towed extended flexible antenna, it was proposed to use the method of grouping receivers, removing the receiving elements from the streamlined surface of the antenna and separating between receivers at distances exceeding the correlation radius of hydrodynamic noise. The vibration compensation method is more effective, especially in the low-frequency region of the spectrum.

\section{References:}

1. Blokhintsev D.I. Acoustics of an inhomogeneous moving medium. - M.: Nauka, 1981. $-208 \mathrm{p}$.

2. Voskoboinick V.A., Grinchenko V.T., Makarenkov A.P. Pseudo-sound behind an obstacle on a cylinder in axial flow // Intern. J. Fluid Mech. Res. - 2005. - Vol. 32, № 4. - P. 488-510. https://doi.org/10.1615/InterJFluidMechRes.v32.i4.60

3. Aharchaou M., Neumann E. An integrated broadband preprocessing method for towed-streamer seismic data // Geophysics. - 2020. - Vol. 85, № 2. - P. V201-V221. https://doi.org/10.1190/GEO2019-0521.1

4. Smol'yakov A.V. Turbulent boundary layer on the surface of a sea geophysical antenna // Acoustical Physics. - 2010. - Vol. 56, № 6. - P. 1080-1088. https://doi.org/10.1134/S1063771010060345

5. Blake W.K. Mechanics of flow-induced sound and vibration: in 2 Vol. - NY: Academic Press, 1986. - 974 p.

6. Vinogradnyi G.P., Voskoboinick V.A., Grinchenko V.T., Makarenkov A.P. Spectral and correlation characteristics of the turbulent boundary layer on an extended flexible cylinder // J. Fluid Dyn. - 1989. - Vol. 24. - P. 695-700. https://doi.org/10.1007/BF01051721

7. Voskoboinick V.A., Grinchenko V.T., Makarenkov A.P. Correlation characteristics of a wall pressure fluctuation field in a turbulent boundary layer induced by a longitudinal flow along a flexible extended cylinder // Intern. J. Fluid Mech. Res. - 2003. - $\quad$ Vol. 30, № 6. - $\quad$ P. 644-650. https://doi.org/10.1615/InterJFluidMechRes.v30.i6.70

8. Voskoboinick V.A., Makarenkov A.P. Spectral characteristics of the hydrodynamical noise in a longitudinal flow around a flexible cylinder // Intern. J. Fluid Mech. Res. - 2004. - Vol. 31, № 1. - P. 87-100. https://doi.org/10.1615/InterJFluidMechRes.v31.i1.70 
9. Voskoboinick V., Kornev N., Turnow J. Study of near wall coherent flow structures on dimpled surfaces using unsteady pressure measurements. // Flow Turbulence Combust. - 2013. - Vol. 90, № 4. - P. 709-722. https://doi.org/10.1007/s10494-012-9433-9

10. Voskoboinick V.A., Voskoboinick A.A., Turick V.N., Voskoboinick A.V. Space and time characteristics of the velocity and pressure fields of the fluid flow inside a hemispherical dimple generator of vortices // Journal of Engineering Physics and Thermophysics. - 2020. - Vol. 93, № 5. - P. 1205-1220. https://doi.org/10.1007/s10891-020-02223-3

11. Voskoboinick V.A., Voskoboinick A.V., Areshkovych O.O., Voskoboinyk O.A. Pressure fluctuations on the scour surface before prismatic pier // Proc. $8^{\text {th }}$ International Conference on Scour and Erosion (ICSE 2016) 12-15 September 2016. - Oxford, UK, 2016. - P. 905-910. https://doi.org/10.1201/9781315375045-115

12. Schewe G. On the structure and resolution of wall-pressure fluctuations associated with turbulent boundary-layer flow //J. Fluid Mech. - 1983. - Vol. 134. P. 311-328. https://doi.org/10.1017/S0022112083003389

13. Bokde A.L.W., Lueptow R.M., Abraham B. Spanwise structure of wall pressure on a cylinder in axial flow // Phys. Fluids. - 1999. - Vol. 11, № 1. - P. 151161. https://doi.org/10.1063/1.869909

14. Gravante S.P., Naguib A.M., Wark C.E., Nagib H.M. Characterization of the pressure fluctuations under a fully developed turbulent boundary layer // AIAA J. - 1998 - Vol. 36, № 10. - P. 1808-1816. https://doi.org/10.2514/2.296

15. Keith W.L., Abraham B.M. The influence of convection velocity on the turbulent wall pressure wavenumber-frequency spectrum // Hydrodynamics, Naval Undersea Warfare Center Division Newport Technical Digest, August 1996. - 1996. P. 71-81.

16. Hu N., Erbig L. Effect of sensor mounting and flow history on measured wall pressure spectra // AIAA J. - 2020 - Vol. 58, № 7. - P. 2964-2974. https://doi.org/10.2514/1.J057808

17. Bull M.K. Wall-pressure fluctuations beneath turbulent boundary layers: Some reflections on forty years of research // Sound Vibr. - 1996. - Vol. 190, № 3. P. 299-315. https://doi.org/10.1006/jsvi.1996.0066 


\section{МОДЕЛИРОВАНИЕ ТЯГОВОЙ ХАРАКТЕРИСТИКИ ЭЛЕКТРОМАГНИТА КВМ 45 СВЯУ (2D ОСЕСИМЕТРИЧНЫЙ АУДИТ)}

\section{Власов Андрей Вячеславович}

д.т.н, профессор

ООО «Альфа»

\section{Пономарева Марина Вячеславовна}

к.Псх.н, доцент

$\mathrm{OOO} \ll$ Fin ixs»

Якорь с уступами. Прототипом является патент: 2065659. Угаров Г.Г., Кудряш И.А., Польщиков С.А., Нейман В.Ю. Линейный электромагнитный двигатель.

Поставленная цель достигается тем, что линейный электромагнитный двигатель снабжен направляющим корпусом, выполненным из ферромагнитного материала, а его часть, прилегающая к статору, выполнена большего диаметра.

Такое конструктивное исполнение позволяет в 1,5-2 раза увеличить ход якоря в сравнении с аналогичным двигателем, не имеющим указанных отличительных признаков при равенстве тяговых усилий в начале рабочего хода.

На начальном этапе движения якоря, когда необходимо создать большое тяговое усилие двигатель работает как однозазорный. Увеличение начального тягового усилия объясняется уменьшением суммарного воздушного рабочего зазора по основному пути замыкания магнитного потока. На конечном этапе движения якоря, двигатель работает как двухзазорный, чем объясняются большие усилия в конце хода.

Выполнение части направляющего корпуса, прилегающей к статору, большего диаметра позволяет шунтировать основной магнитный поток проходящий через направляющий корпус на конечном интервале движения якоря. Это создает дополнительную силу тяги в рабочем воздушном зазоре, образованном между дисковой частью якоря и торцевой частью статора. 


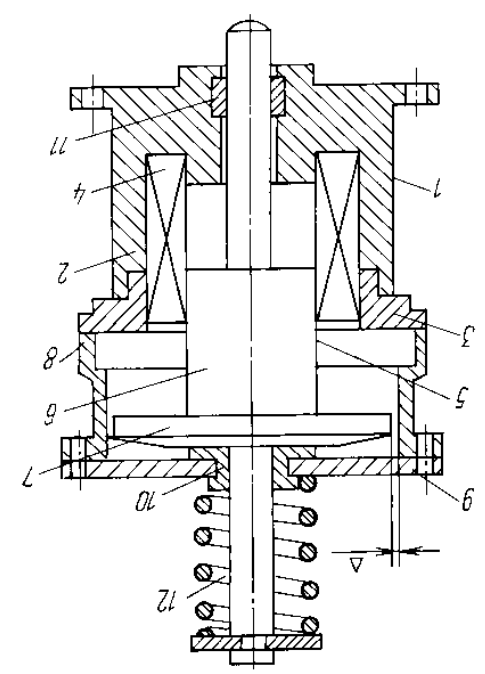

Рис. 1

Резюме: надо зазорами регулировать усилие тяги. Без моделирования авторы на профессиональной интуиции увеличивали тягу. Это будет магнит КВМ 45 СВяу.

0 мм хода якоря (зазоры по 6,2 мм)

Рисунок:

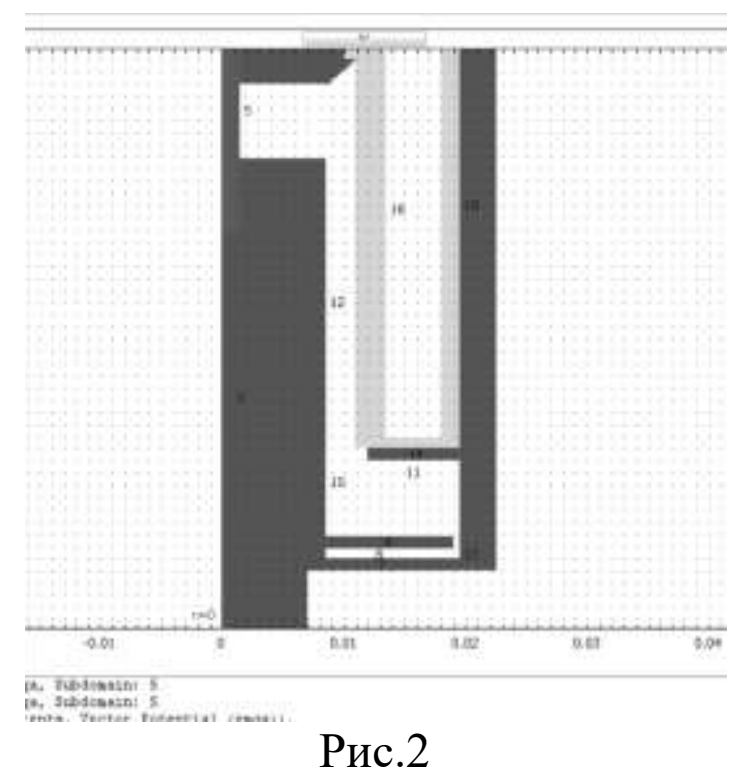

Тяга в верхнем зазоре по формуле Власовых: $F=3,80 \mathrm{H}$

Тяга в нижнем зазоре по формуле Власовых: $F=1,117105 \mathrm{e}-2 \mathrm{H}$

Общая тяга: $F=3,81 \mathrm{H}$

1 мм хода якоря (зазоры по 5,2 мм)

Тяга в верхнем зазоре по формуле Власовых: $F=5,125 \mathrm{H}$

Тяга в нижнем зазоре по формуле Власовых: $F=5,22 \mathrm{e}-2 \mathrm{H}$

Общая тяга: $F=5,1772 \mathrm{H}$

2 мм хода якоря (зазоры по 4,2 мм)

Тяга в верхнем зазоре по формуле Власовых: $F=8,515 \mathrm{H}$

Тяга в нижнем зазоре по формуле Власовых : $F=0,134 \mathrm{H}$

Общая тяга: $F=8,649 \mathrm{H}$

3 мм хода якоря (зазоры по 3,2 мм) 
Тяга верхнего зазора по формуле Власовых: $F=12,33 \mathrm{H}$

Тяга нижнего зазора по формуле Власовых: $F=0,3312 \mathrm{H}$ Общая тяга: $F=12,66 \mathrm{H}$

4 мм хода якоря (зазоры по 2,2 мм)

Тяга в верхнем зазоре по формуле Власовых: $F=23,64 \mathrm{H}$

Тяга в нижнем зазоре по формуле Власовых: $F=0,94454 \mathrm{H}$

Общая тяга: $F=24,58 \mathrm{H}$

5 мм хода якоря (зазоры по 1,2 мм)

Тяга в верхнем зазоре по формуле Власовых: $F=58,00 \mathrm{H}$

Тяга в нижнем зазоре по формуле Власовых: $F=2,79 \mathrm{H}$

Общая тяга: $F=60,79 \mathrm{H}$

6 мм хода якоря (зазоры по 0,2 мм)

Тяга в верхнем зазоре по формуле Власовых: $F=244,11 \mathrm{H}$

Тяга в нижнем зазоре по формуле Власовых: $F=13,165 \mathrm{H}$

Общая тяга: $F=257,27 \mathrm{H}$

Сведем все в таблицу:

Таблица 1

\begin{tabular}{|c|c|c|c|c|}
\hline Нижний & Верхний & \multicolumn{3}{|c|}{ Усилие тяги, Н } \\
\cline { 3 - 5 } $\begin{array}{c}\text { якоря, } \\
\text { мм }\end{array}$ & $\begin{array}{c}\text { зазор } \\
\text { якоря, мм }\end{array}$ & $\begin{array}{c}\text { Теория } \\
\text { (формула } \\
\text { Власовых) }\end{array}$ & $\begin{array}{c}\text { Теория } \\
\text { (формула } \\
\text { Власовых) } \\
\text { КВМ 45 } \\
\text { СВяу }\end{array}$ & $\begin{array}{c}\text { Теория } \\
\text { (формула } \\
\text { Власовых) } \\
\text { КВМ 45 } \\
\text { СВяу } \\
\text { (основной } \\
\text { зазор) }\end{array}$ \\
\hline 0 & 6,2 & 3,96 & 3,80 & 3,81 \\
\hline 1 & 5,2 & 5,57 & 5,12 & 5,17 \\
\hline 2 & 4,2 & 8,62 & 8,51 & 8,64 \\
\hline 3 & 3,2 & 14,52 & 12,33 & 12,66 \\
\hline 4 & 2,2 & 30,34 & 23,64 & 24,58 \\
\hline 5 & 1,2 & 97,86 & 58,00 & 60,79 \\
\hline 6 & 0,2 & 319,74 & 244,11 & 257,27 \\
\hline
\end{tabular}

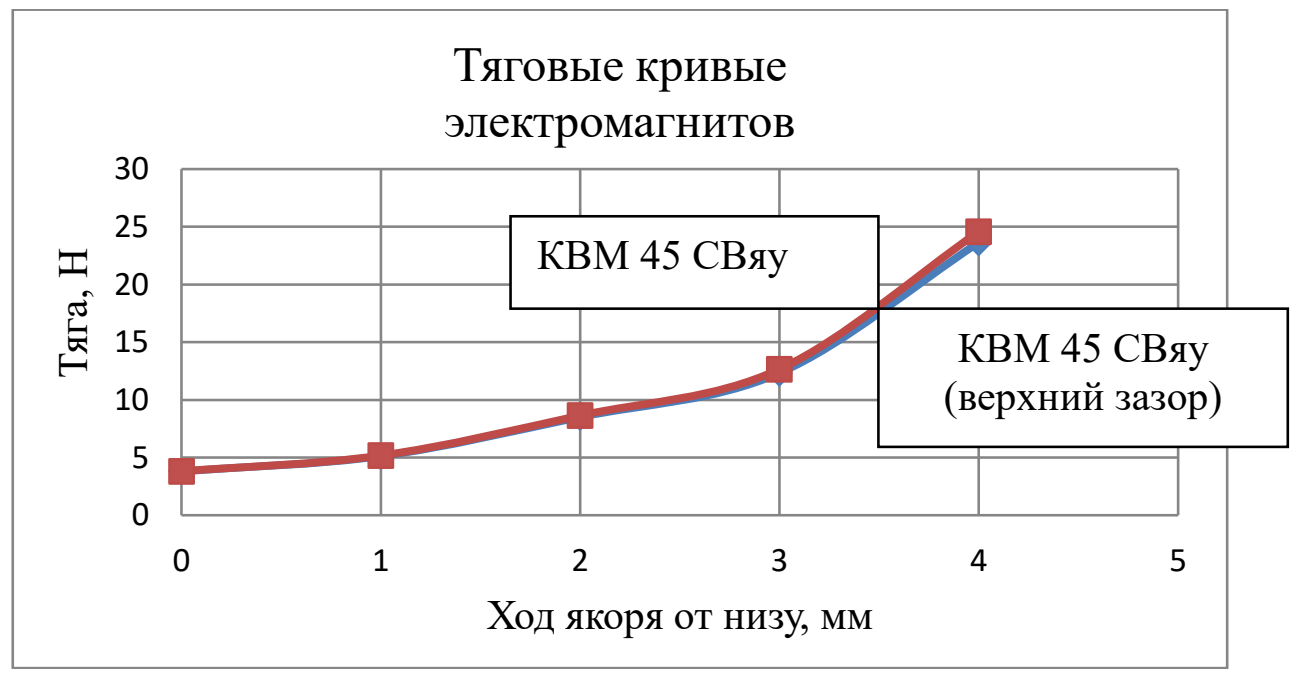

Рис. 2 


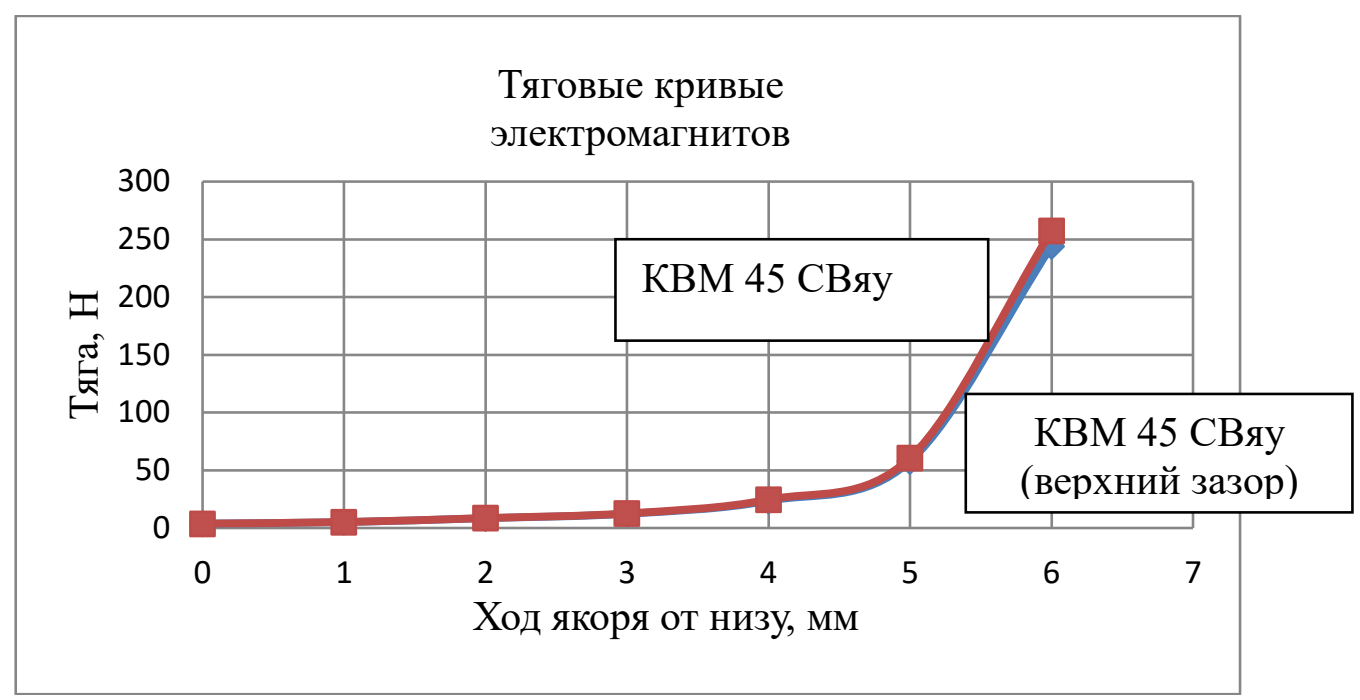

Рис. 3

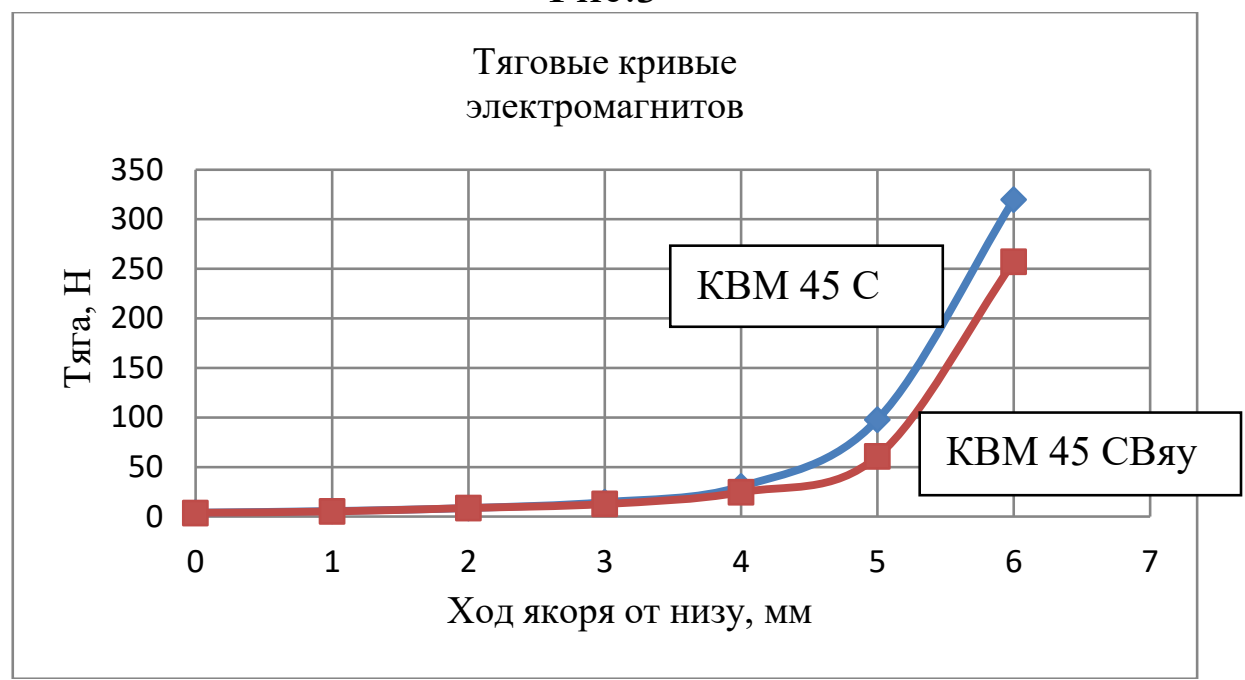

Рис.4

Резюме:

1.Нижний зазор не увеличивает тягу ни в начале, ни в конце

2. Тяга магнита с двумя зазорами более пологая до 5 мм хода якоря и послабее чем у оригинала (КВМ 45 C)

3. 2D осесимметричный аудит показал, что патент RU № 301747 был выдан необоснованно. 


\section{МОДЕЛИРОВАНИЕ ТЯГОВОЙ ХАРАКТЕРИСТИКИ ЭЛЕКТРОМАГНИТА КВМ 45 СВПР (2D ОСЕСИМЕТРИЧНЫЙ АУДИТ)}

\section{Власова Валентина Константиновна}

д.э.н, профессор

Благотворительная общественная организация «Валентина»

Вячеслав Викторович Власов

д.т.н, профессор

Вольский военный институт материального обеспечения

Прототипом является патент RU № 301747. Л.Д. Кисленко.

Электромагнит.

Цель изобретения - получение тяговых характеристик различной формы.

На фиг. 1 показан предлагаемый электромагнит в разомкнутом (обесточенном) состоянии; на фиг. 2 - схема замещения электромагнита в разомкнутом состоянии; на фиг. 3 - электромагнит при притянутом положении якоря; на фиг. 4 - его схема замещения; на фиг. 5 - тяговые и противодействующая характеристики электромагнита.

Электромагнит состоит из ярма 1, выполненного в виде стакана, сердечника 2, стягивающей катушки 3, полюсного наконечника $\mathbf{4}$, конической ферромагнитной спирали 5, установочного кольца 6, немагнитной прокладки 7 и якоря 8. Якорь $8 u$ кольцо 6 могут быть изготовлены как из ферромагнитного, так и немагнитного материала. В этом случае роль якоря играет спираль 5.

В процессе движения якоря коническая спираль изменяет свое положение относительно рабочего воздушного зазора, и происходят следующие физические процессы.

При подаче напряжения на катушку 3 образованный ею магнитный поток создает в рабочем воздушном зазоре магнитодвижущую силу, которая приводит якорь в движение. Величина этой магнитодвижущей силы при заданных параметрах электромагнита зависит от магнитной проводимости рабочего воздушного зазора. Наличие в рабочем воздушном зазоре дополнительного ферроматериала в виде конической спирали 5 увеличивает его магнитную проводимость и, следовательно, повышает начальную силу тяги магнита в разомкнутом состоянии (см. фиг. 2).

Когда якорь 8 находится вблизи ярма 1, часть магнитного потока через витки конической спирали $\mathbf{5}$ ответвляется на ярмо, минуя рабочий воздушный зазор, тем самым уменьшая магнитный поток, проходящий через основной рабочий воздушный зазор. Это приводит к уменьшению силы тяги электромагнита при малых зазорах между якорем и полюсным наконечником (см. фиг. 4). 
Таким образом, коническая спираль 5 повышает начальное тяговое усилие электромагнита и снижает конечное тяговое усилие, а изготовление установочного кольца 6 из ферромагнитного материала практически не влияет на величину начального тягового усилия электромагнита и способствует еще большему снижению величины конечного тягового усилия.

На фиг. 5 показаны тяговая характеристика известных электромагнитов (кривая I), тяговая характеристика предлагаемого электромагнита с якорем и установочным кольцом из ферромагнитного материала (кривая II), тяговая характеристика электромагнита, где функции якоря выполняет коническая спираль совместно с ферромагнитным установочным кольцом (кривая III) и противодействующая механическая характеристика (кривая IV).
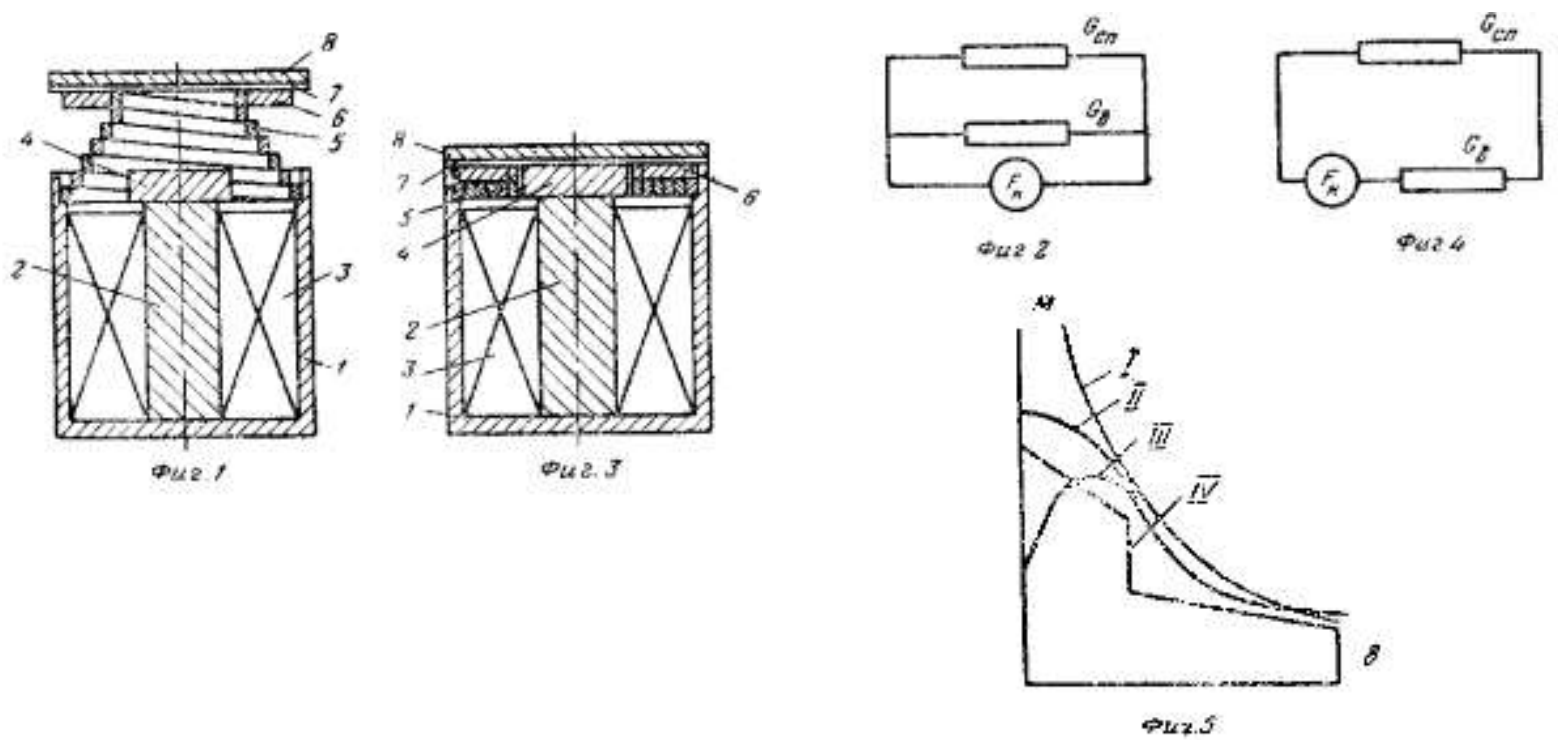

Резюме: идея в том, чтобы снизить тяговую при малых зазорах и выровнять тяговую III приблизив ее к нагрузочной IV. Это достигается ферромагнитной спиралью 5 между якорем 2 с наконечником 4 и подвижным якорем 8. T.e. начальный воздушный зазор также как и последующие зазоры при движении якоря 8 были бы примерно одинаковы. Но мысль главная - уменьшать начальный воздушный зазор для увеличения начальной тяги и уменьшать усилие тяги при конечном воздушном зазоре.

Итак, берем КВМ 45 С и устанавливаем там пружину. Это будет магнит КВМ 45С ВПр.

0 мм хода якоря

Рисунок: 


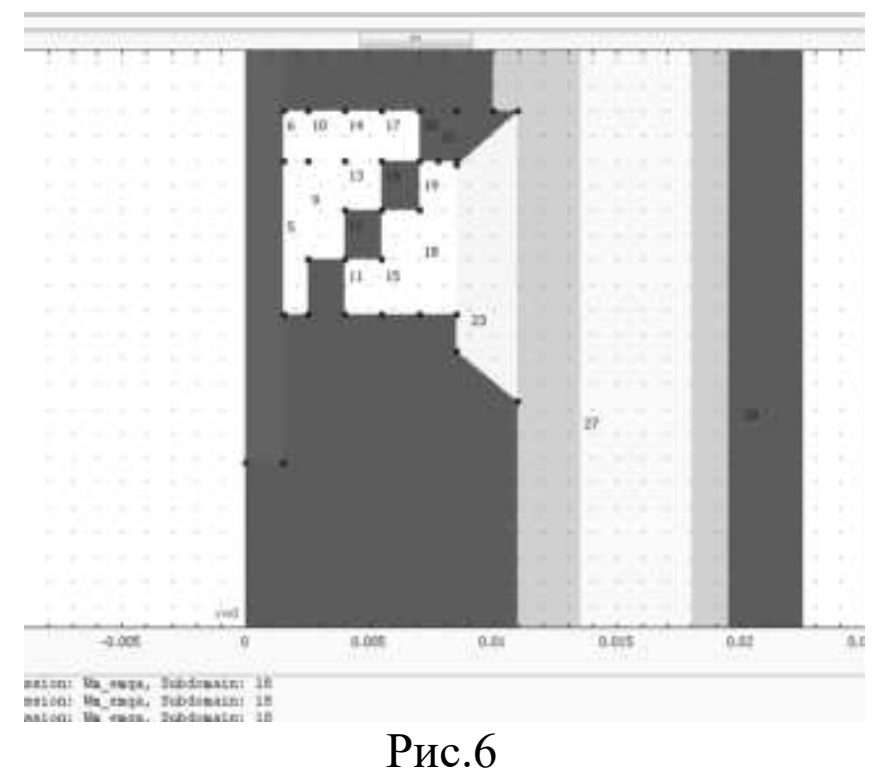

Тяга в области 17 по формуле Власовых: $F=2,04 \mathrm{H}=0,204$ кг.

Тяга в областях 13,14 по формуле Власовых: $F=1,67 \mathrm{H}=0,167$ кг.

Тяга в областях 9,10 по формуле Власовых: $F=1,07 \mathrm{H}=0,107$ кг

Тяга в областях 5,6по формуле Власовых: $F=0,163 \mathrm{H}=0,0163$ кг.

Тяга в областях 18,19по формуле Власовых: $F=1,81 \mathrm{H}=0,181$ кг.

Тяга в области 15по формуле Власовых: $F=2,30 \mathrm{H}=0,230$ кг.

Тяга в области 11по формуле Власовых: $F=4,11 \mathrm{H}=0,411$ кг.

Общая тяга:

$F=2,04+1,67+1,07+0,163+1,81+2,30+4,11=13,163 \mathrm{H}=1,316$ кг.

1 мм хода якоря

Тяга в областях 6,7по формуле Власовых: $F=0,199 \mathrm{H}=0,0199$ кг.

Тяга в областях 10,11по формуле Власовых: $F=1,056 \mathrm{H}=0,1056$ кг.

Тяга в областях 14,15по формуле Власовых: $F=1,25 \mathrm{H}=0,125$ кг.

Тяга в области 19по формуле Власовых: $F=1,66 \mathrm{H}=0,166$ кг.

Тяга в области 12по формуле Власовых: $F=3,13 \mathrm{H}=0,313$ кг.

Тяга в области 16по формуле Власовых: $F=2,43 \mathrm{H}=0,243$ кг.

Тяга в области 20по формуле Власовых: $F=1,65 \mathrm{H}=0,165$ кг.

Общая тяга:

$F=0,199+1,056+1,25+1,66+3,13+2,43+1,65=11,375 \mathrm{H}=1,375$ кг.

2 мм хода якоря

Тяга в областях 6,7по формуле Власовых: $F=0,253 \mathrm{H}=0,0253$ кг.

Тяга в областях 10,11по формуле Власовых: $F=0,8 \mathrm{H}=0,08$ кг.

Тяга в областях 14,15по формуле Власовых: $F=1,33 \mathrm{H}=0,133$ кг.

Тяга в области 19по формуле Власовых: $F=1,47 \mathrm{H}=0,147$ кг.

Тяга в области 12по формуле Власовых: $F=4,20 \mathrm{H}=0,42$ кг.

Тяга в области 16по формуле Власовых: $F=3,70 \mathrm{H}=0,37$ кг.

Тяга в области 20Энергия в области $20: F=3,17 \mathrm{H}=0,317$ кг.

Общая тяга:

$F=0,253+0,8+1,33+1,47+0,42+3,7+3,17=11,143 \mathrm{H}=1,114$ кг.

3 мм хода якоря

Тяга в областях 6,7 по формуле Власовых: $F=0,369 \mathrm{H}=0,0369$ кг. 
Тяга в областях 10,11по формуле Власовых: $F=0,65 \mathrm{H}=0,065$ кг.

Тяга в областях 14,15по формуле Власовых: $F=1,34 \mathrm{H}=0,0134$ кг.

Тяга в области 19по формуле Власовых: $F=1,38 \mathrm{H}=0,138$ кг.

Тяга в области 12по формуле Власовых: $F=7,95 \mathrm{H}=0,795$ кг.

Тяга в области 16по формуле Власовых: $F=6,34 \mathrm{H}=0,634$ кг.

Тяга в области 20по формуле Власовых: $F=5,13 \mathrm{H}=0,513$ кг.

Общая тяга:

$F=0,369+0,65+1,34+1,38+7,95+6,34+5,13=23,159 \mathrm{H}=2,315$ кг.

4 мм хода якоря

Тяга в областях 6,7по формуле Власовых: $F=0,651 \mathrm{H}=0,0651$ кг.

Тяга в области 10по формуле Власовых: $F=1,01 \mathrm{H}=0,101$ кг.

Тяга в области 14по формуле Власовых: $F=1,81 \mathrm{H}=0,181$ кг.

Тяга в области 18по формуле Власовых: $F=1,77 \mathrm{H}=0,77 \kappa г$.

Тяга в области 11по формуле Власовых: $F=17,35 \mathrm{H}=1,735 \kappa г$.

Тяга в области 15по формуле Власовых: $F=12,10 \mathrm{H}=1,210 \kappa г$.

Тяга в области 19по формуле Власовых: $F=10,19 \mathrm{H}=1,019$ кг.

Общая тяга:

$F=0,651+1,01+1,81+1,77+17,35+12,10+10,19=44,81 \mathrm{H}=4,481$ кг.

5 мм хода якоря

Тяга в областях 5,6по формуле Власовых: $F=0,953 \mathrm{H}=0,0953$ кг.

Тяга в области 11по формуле Власовых: $F=3,14 \mathrm{H}=0,314$ кг.

Тяга в области 15по формуле Власовых: $F=4,79 \mathrm{H}=0,479$ кг.

Тяга в области 19по формуле Власовых: $F=5,22 \mathrm{H}=0,522$ кг.

Тяга в области 12по формуле Власовых: $F=43,86 \mathrm{H}=4,386$ кг.

Тяга в области 16по формуле Власовых: $F=28,07 \mathrm{H}=2,807$ кг.

Тяга в области 20по формуле Власовых: $F=28,36 \mathrm{H}=2,836$ кг.

Общая тяга:

$F=0,953+3,14+4,79+5,22+43,86+28,07+28,36=114,393 \mathrm{H}=11,43$ кг.

6 мм хода якоря

Тяга в областях 6,7по формуле Власовых: $F=0,0836 \mathrm{H}=0,00836$ кг.

Тяга в области 11по формуле Власовых: $F=3,36 \mathrm{H}=0,336$ кг.

Тяга в области 15по формуле Власовых: $F=4,03 \mathrm{H}=0,403$ кг.

Тяга в области 19по формуле Власовых: $F=7,22 \mathrm{H}=0,722$ кг.

Тяга в области 12по формуле Власовых: $F=58,4 \mathrm{H}=5,84$ кг.

Тяга в области16по формуле Власовых: $F=34,58 \mathrm{H}=3,458$ кг.

Тяга в области 20по формуле Власовых: $F=30,38 \mathrm{H}=3,038$ кг.

Общая тяга:

$F=0,0836+3,36+4,03+7,22+58,4+34,58+30,38=138,05 \mathrm{H}=13,80$ кг.

Сведем все в таблицу 1 : 
Таблица 1

\begin{tabular}{|c|c|c|c|}
\hline Нижний & Верхний & \multicolumn{2}{|c|}{ Усилие тяги, Н } \\
\cline { 3 - 4 } $\begin{array}{c}\text { зазор } \\
\text { мм }\end{array}$ & $\begin{array}{c}\text { зазор } \\
\text { якоря, мм }\end{array}$ & $\begin{array}{c}\text { Теория } \\
\text { (формула } \\
\text { Власовых) } \\
\text { КВМ 45 С }\end{array}$ & $\begin{array}{c}\text { Теория } \\
\text { (формула } \\
\text { Власовых) } \\
\text { КВМ 45 } \\
\text { СВПр }\end{array}$ \\
\hline 0 & 6,2 & 3,96 & 13,16 \\
\hline 1 & 5,2 & 5,57 & 11,37 \\
\hline 2 & 4,2 & 8,62 & 11,14 \\
\hline 3 & 3,2 & 14,52 & 23,15 \\
\hline 4 & 2,2 & 30,34 & 44,81 \\
\hline 5 & 1,2 & 97,86 & 114,39 \\
\hline 6 & 0,2 & 319,74 & 138,05 \\
\hline
\end{tabular}

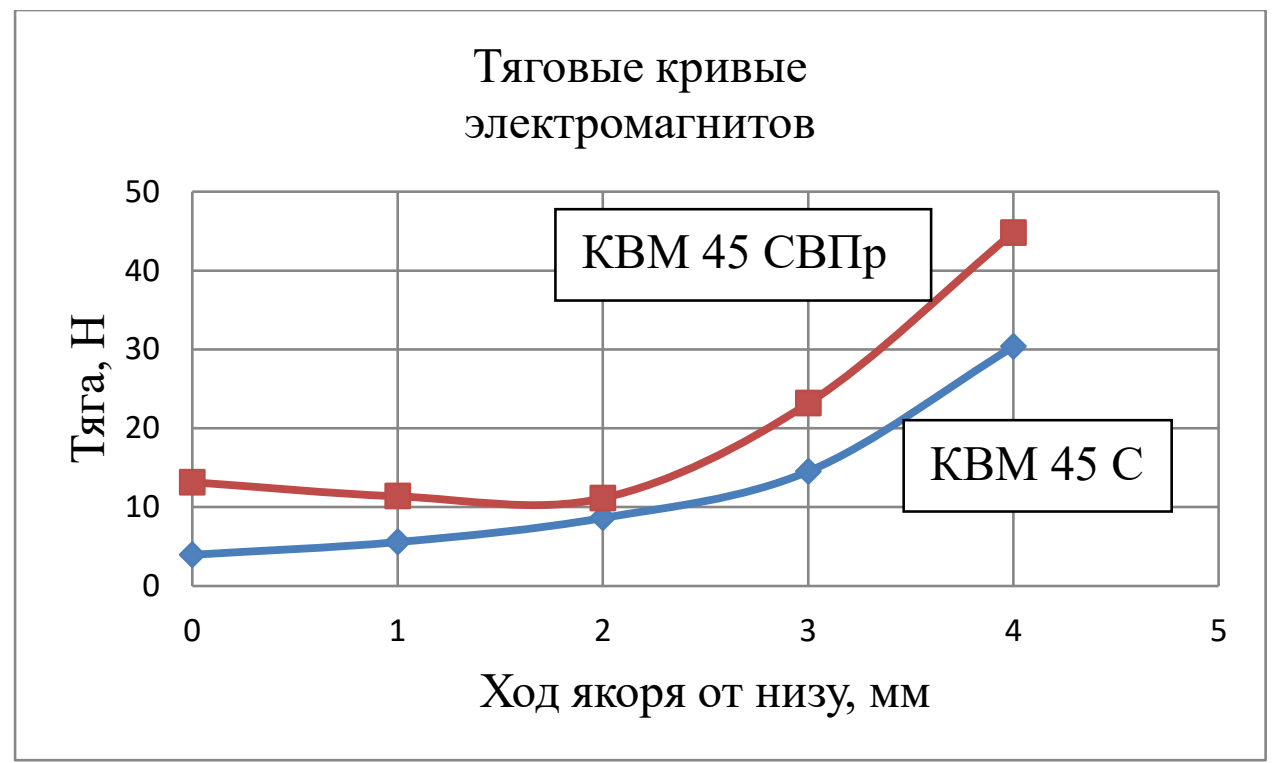

Рис.7

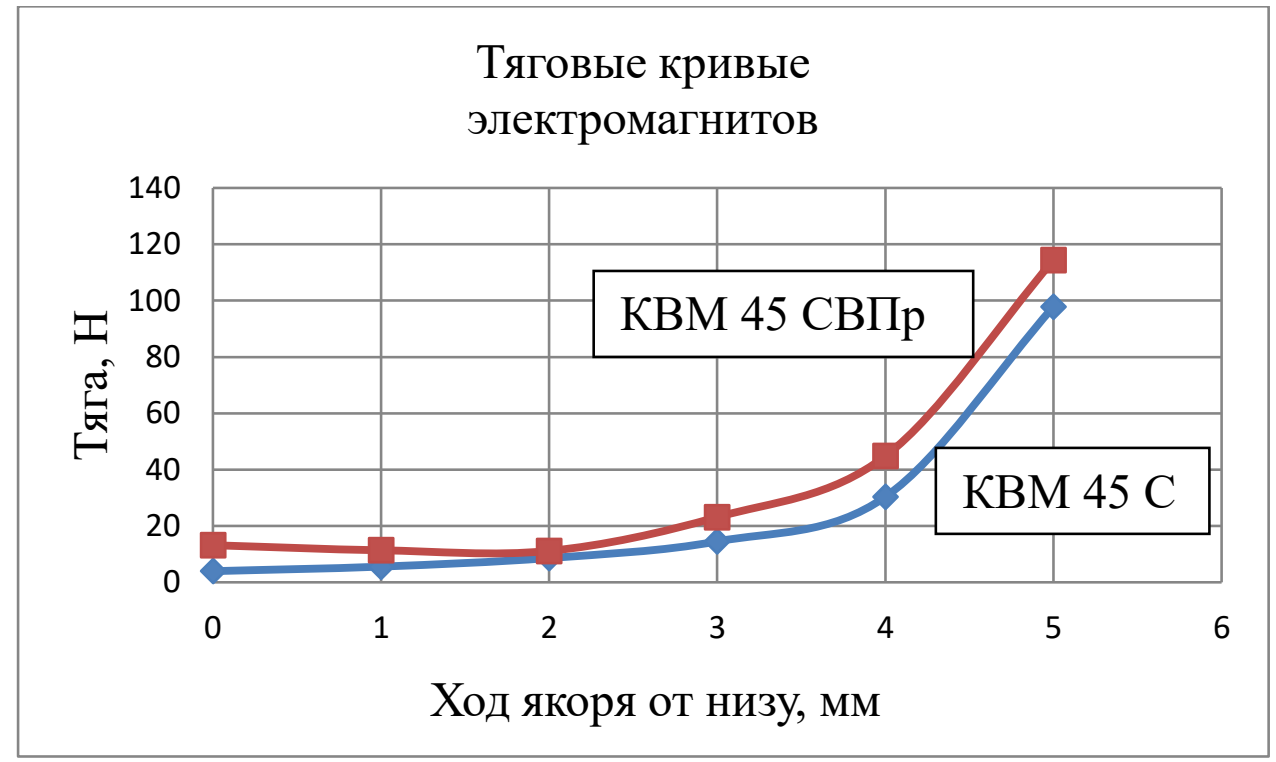

Рис. 8 


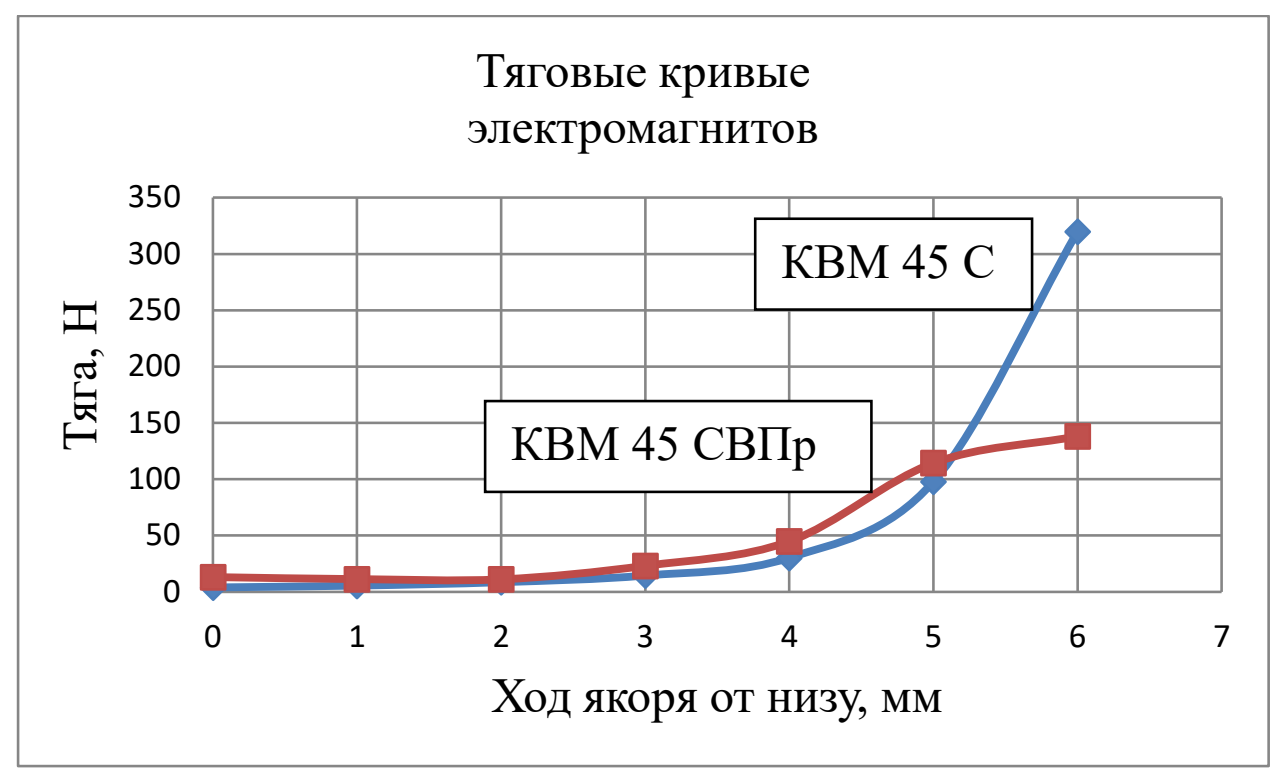

Рис.9

Резюме:

1. Ход кривых идентичен. Между 5 и 6 мм тяга у КВМ 45 СВПр тяга растет умеренно, а у КВМ 45 С лавинно.

2. Чуда от пружины не произошло. Но произошло озарение: если усилие сжатия пружины (прямоугольного сечения как в модели) выбрать $80 \mathrm{H}$, то дойдя на 6 мм хода пружина откинет якорь на 4 мм хода и якорь опять пойдет на 6 мм и получится вибратор с ходом 2 мм. Так что напряжение постоянное и получается пульсатор без коммутационных элементов. Роль коммутационного элемента выполняет сталь пружины как часть подвижного якоря. Это принципиально новые технологии, из которых можно делать и вибраторы, и толкатели и разрушители и долбежные устройства. Это серьезное докторское направление. Способ здесь очевиден.

3. Хлопотный был $2 \mathrm{D}$ осесимметричный аудит, но стоил того. Так что патент RU № 301747 был выдан обоснованно и автор без моделирования на чистой интуиции предложил новое техническое решение. 


\section{НАПІВФАБРИКАТИ ЗАБАГАЧЕНІ ЙОДОМ}

\section{Дьяченко Свгенія Валентинівна,}

магістрантка

Національний Університет Харчових Технологій

Пасічний Василь Миколайович, професор, доктор технічних наук, завідувач кафедри Національний Університет Харчових Технологій

М'ясо та м'ясні продукти є найбільш цінними в харчовому відношенні продуктами, що мають найбільший попит. Завдяки тому, що сировина тваринного походження забезпечує людський організм необхідними для його функціонування ессенціальними амінокислотами і мікронутірєнтами одним 3 шляхів організації повноцінного харчування $\epsilon$ пошук шляхів розширення асортименту м'ясних і м'ясомістких продуктів функціонального призначення та підвищенню їх фізіологічної доступності $[1,2]$.

В останні роки харчування людей стало характеризуватися надмірним споживанням жирів на фоні дефіциту поліненасичених жирних кислот, харчових волокон, вітамінів, макро- i мікроелементів. Істотне зниження енерговитрат людського організму, а також якості споживаної їжі, призводять до постійно зростаючого дефіциту мікронутрієнтів у раціоні харчування людей.

Мікроелементи беруть участь практично у всіх біологічних процесах людського організму. Хронічний же недоотримання 3 раціоном споживання мікроелементів, таких як йод, призводить до зниження імунітету і захисних сил людини [3]. Тому введення йоду в регулярний харчовий раціон стає життєвою необхідністю. В даний час йодну недостатність неможливо невілювати - це стабільний природний феномен, але його можна скорегувати. Для цього людина постійно повинна отримувати йод у доступній формі з продуктами харчування. Основними способами корекції йодної недостатності є застосування лікарських препаратів, що містять йод, харчових добавок і харчових продуктів, збагачених цим мікроелементом [3]. Існують способи профілактики йодної недостатності шляхом споживання в їжу йодованої солі, хлібопекарських дріжджів, плавлених сирів $[4,5]$.

Надходження адекватної кількості йоду в організм, як головного субстрату для синтезу тироїдних гормонів, забезпечує необхідний рівень метаболізму речовий, а на стадії плода — формування та розвиток різних органів і систем.

Зміни, які виникають в організмі людини в результаті дефіциту йоду, прийнято називати йододефіцитними захворюваннями. Найвідомішими 3 них $\epsilon$ зоб (збільшення щитовидної залози) і ендемічний кретинізм (уроджена розумова недостатність).

Захворювання, пов’язані 3 дефіцитом йоду, розвиваються поступово, тривалий час, залишаючись непоміченими. Недарма йодний дефіцит називають прихованим голодом. Тому навіть якщо в даний момент у людини немає 
клінічних проявів йододефіцитних захворювань, але вона мешкає в йододефіцитному регіоні, необхідна профілактика, щоб уникнути негативних наслідків у майбутньому. Слід наголосити, що дефіцит йоду особливо небезпечний для вагітних жінок, жінок дітородного віку, дітей і підлітків.

Одним 3 способів подолання йододефіциту в людських організмах $\epsilon$ збагачення ним продуктів харчування, так як м'ясні продукти є основою харчування людини і містять в значній кількості тирозин, то збагачення м'ясних напівфабрикатів термостійкою формою йоду $\epsilon$ перспективним напрямом досліджень.

Створення м'ясних продуктів лікувально-профілактичного призначення, зокрема напівфабрикатів і ковбасних виробів — це не тільки соціальна, але й наукова задача, оскільки для розробки таких продуктів необхідно змінювати традиційні підходи до технологічного процесу.

Одним з популярних методів збагачення напівфабрикатів є використання в складі рецептур морських водоростей.

Морські водорості - єдине природне джерело йоду та його органічних сполук. Особливо важливе те, що йод міститься у вигляді органічних речовин, що сприяє його більш легкому та безпечному засвоєнню порівняно 3 неорганічним йодом.Водорості відомі як продуценти цілої низки вітамінів. Водорості у значних кількостях містять вітаміни: А, В1, В2, В12, В9, РР, С, Е, Н. При цьому вміст перерахованих вітамінів часом значно перевищує їх вміст у наземних, рослинах.

Харчова цінність водоростей обумовлена вмістом білка, жиру, вуглеводів, вітамінів, мінеральних речовин та клітковини. Біологічною особливістю різних гідробіонтів є виняткова різноманітність, специфічність та неповторність складу комплексів біологічно активних речовин, основну частку яких складають вуглеводи та мінеральні солі (макро- та мікроелементи).

Крім того, харчові продукти з водоростей мають такі цінні якості: здатність поглинати велику кількість води та збільшуватись при цьому в об'ємі; зводою давати в'язкі, клейкі, желюючі розчини; вони містять специфічні для морської рослинності колоїдні полімери (агар, альгінові кислоти), мають значно вищий, ніж у наземних рослин, вміст різноманітних макро- і мікроелементів.

Крім цього в складі продуктів використовується йодована сіль і різного роду інкапсульовані форми йоду $[4,5]$, використання останніх дозволяє забезпечувати наявність в складі м'ясних напівфабрикатів не тільки йоду в фізіологічнодоступній формі, а й можливість вирішення в комплексі питань щодо збалансованості м'ясних напівфабрикатів по основним групам есенціальних речовин, з урахуванням їх рангової оцінки [6, 7].

В усьому світі йодована сіль і інкапсульовані форми йоду використовується як оптимальний засіб масової профілактики йододефіциту завдяки їі ефективності, безпечності та доступності усім верствам населення.

Йодована сіль, як правило, збагачується йодатом калію (KIO3) - це стабільна сполука, що не має ніякого запаху і майже не випаровується з солі під дією температури під час приготування їжі. В Україні йодована сіль містить

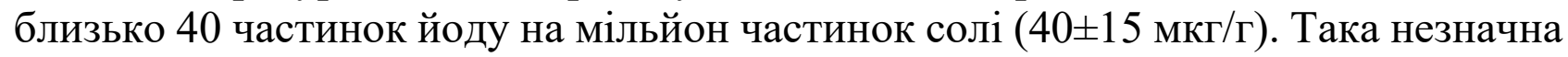


кількість йоду є харчовою, не фармацевтичною, тому вживання збагаченої йодом солі не потребує лікарського припису. Водночас цієї кількості йоду достатньо, щоб компенсувати природний йододефіцит, - за умови присутності йодованої солі у щоденному раціоні.

При використанні збагачених йодом форм напівфабрикатів цільового споживання при йодо дефіциті можливе забезпечення добової потреби в йоді при споживанні від 150 до 200 грам м'ясомістких напівфабрикатів, що потребує більш уважного контролю і може бути реалізована у спеціалізованих курортносанаторних закладах при використанні інтегрованих методів оцінки їх ефективності [8].

\section{Список літератури}

1. Pasichniy, V. M., \& Polumbryk, M. M. (2016). Collagen containing mixtures impact on sensory properties of chicken forcemeat systems. Scientific Messenger of LNU of Veterinary Medicine and Biotechnologies, 18(2 (68)), 150-152.

2. Ukrainets, A., Pasichnyi, V., Shvedyuk, D., \& Matsuk, Y. (2017). Investigation of proteolysis ability of functional destinated minced half-finished meat products. Scientific Messenger of LNU of Veterinary Medicine and Biotechnologies, 19(75), 129-133.

3. Що таке йододефіцит? [Електронный ресурс]: наук. стаття - режим доступа до статті :https://uozter.gov.ua/ua/pages/348

4. Polumbryk, M., Kravchenko, V., Pasichnyi, V., Omelchenko, C., \& Pachitskaya, I. (2019). The effect of intake of sausages fortified with $\beta$-CD-I2 complex on iodine status and thyroid function: A preliminary study. Journal of Trace Elements in Medicine and Biology, 51, 159-163.

5. Йодована сіль [Електронный ресурс]: наук. стаття - режим доступа до статті : https://uk.wikipedia.org/wiki/Йодована_сіль

6. Морські водорості [Електронный ресурс]: наук. стаття - режим доступа до статті :http://kayiles.ru/page/korist-i-vlastivosti-morskih-vodorostej-likuvannjavodorostjami-morski-vodorosti-v-shudnenni-i-proti-celjulitu.

7. Пасічний, В. М. Рангове оцінювання комбінованих м'ясопродуктів / В. М. Пасічний // Наукові праці Національного університету харчових технологій. Київ : УДУХТ, 2002. - Вип. № 11. - С. 77-80.

8. Білецька Я.О., Бадигіна Г.С., Семенюк А.О. Розробка інтегрованого методу впровадження харчових раціонів у лікувально-оздоровчі установи // Technology audit and production reserves. 2020. Vol. 2, No. 4 (52). P. 32-34. 


\title{
МЕТОДИ І ЗАСОБИ ПРОЦЕДУРНОЇ ГЕНЕРАЦЇ̈ КОНТЕНТУ В ІГРОВИХ ДОДАТКАХ
}

\author{
Козуб Юрій Гордійович \\ доктор технічних наук, професор, завідувач кафедри фізико-технічних \\ систем та інформатики \\ Луганського національного університету імені Тараса Шевченка, Україна \\ Климухіна Альона Миколаївна \\ здобувач першого (бакалаврського) рівня вищої освіти \\ Луганського національного університету імені Тараса Шевченка, Україна
}

На сьогоднішній день, одним 3 перспективних і високооплачуваних напрямків в сфері інформаційних технологій, $\epsilon$ розробка програмного забезпечення в індустрії комп'ютерних ігор. За останні кілька років для гравців комп'ютерних ігор стало більш актуальним поняття випадкових подій ігрового процесу. Випадково згенерована місцевість, непередбачуваність сюжетної лінії, надає гравцеві можливість відчути всю різноманітність, яку в гру заклали розробники, тим самим створюючи інтерес і спонукаючи гравця пройти гру більш ніж один раз.

Досить яскравим прикладом такого роду додатків є розроблене застосування для ігор - генератор лабіринтів. Існують різні способи генерації лабіринтів: алгоритм випадкового проходу (рекурсивний метод); генерація лабіринту заснованого на таблиці; з використанням клітинного автомата; алгоритм Еллера.

Для рекурсивного методу генерації лабіринту можна використовувати найпростішу побудову випадкового проходу, 3 використанням додаткових побудов таких же випадкових ходів, що триває до тих пір, поки не буде заповнено весь простір, що виділяється під лабіринт.

Якщо при генерації розмірність лабіринту невелика, то можна використовувати метод рекурсій. Потрібно встановити точку входу та згенерувати основний хід. Рухаючись по клітинам, "пробиваючи ходи", випадково змінюючи вектор руху (по або проти годинникової стрілки). При русі необхідно робити перевірку дотику до краю лабіринту (якщо знайдено дотик, то ставимо вихід). На кожному кроці алгоритму необхідно запам'ятовувати координати "пробитої точки" і збільшувати глибину рекурсії до досягнення краю лабіринту.

Коли край лабіринту досягнутий, необхідно почати зниження глибини рекурсії (повернення до початкової точки) 3 відновленням координат попередньої "пробитої точки", і в залежності від випадковості за тим же алгоритмом генерується бічний хід. При генерації бічних ходів завершенням процесу можна зробити обмеження глибини рекурсії.

Після закінчення генерації бокового ходу, знижується глибина рекурсії основного ходу, відновлюються попередні координати, і розраховується ймовірність створення нового бокового ходу[1]. 
Недоліком будь-якого рекурсивного методу вважається обсяг пам'яті, який буде потрібний для виконання необхідної глибини. Тому використовувати даний метод генерації не рекомендуються для великих лабіринтів.

Генерація лабіринту заснованого на таблиці. Ідея полягає в тому, що поле спочатку розбивається на прямокутні "великі" клітини (тобто не елементарні клітини ігрового поля, а прямокутники, що складаються з декількох клітин), утворюючи таким чином таблицю. Далі в кожній такій клітинці випадковим чином з'являється кімната випадкового розміру, що не перевершує розмірів комірки - тим самим можливість появи пересічних приміщень пропадає. Потім кімнати об'єднуються коридорами, наприклад, тим же способом [2].

Генерація лабіринту 3 використанням клітинного автомата. Суть запропонованого алгоритму полягає в реалізації всього двох кроків: спочатку все поле заповнюється випадковим чином стінами - тобто для кожної клітини випадковим чином визначається, чи буде вона вільною або непрохідною - а потім кілька разів відбувається оновлення стану карти [2].

Використання алгоритму Еллера для генерації лабіринтів. Алгоритм Еллера дозволяє створювати лабіринти, що мають тільки один шлях між двома точками. Сам по собі алгоритм досить швидкий і використовує пам'ять ефективніше, ніж інші популярні алгоритми, вимагаючи об'єм пам'яті пропорційний числу рядків. Це дозволяє створювати лабіринти великого розміру при обмежених розмірах пам'яті [3].

Алгоритм генерації лабіринту полягає у виконанні наступних інструкцій:

- створюється новий рядок з порожніх клітинок. Кожна клітинка не належить жодній множині;

- коміркам, які не входять в множину, присвоюється своя унікальна множина;

- випадково створюються праві межі для комірок рядка (рух відбувається зліва направо);

- якщо межі не створюються, то поточна комірка і комірка справа об'єднуються в одну множину;

- випадково створюються нижні межі для комірок рядка (рух відбувається зліва направо). Необхідно переконатися, що кожна множина має хоча б одну клітинку без нижньої межі (для запобігання ізолювання областей). Якщо комірка в своїй множині одна, то межа знизу не створюється;

- якщо було прийнято рішення, що буде додаватися ще один рядок, то необхідно скопіювати поточний рядок в новий, видалити всі праві межі, видалити комірки з нижньою межею з їх множин, видалити всі нижні межі і почати виконання алгоритму спочатку;

- якщо ж було прийнято рішення закінчити лабіринт, то необхідно додати нижню межу до кожної клітинки. Рухаючись зліва направо: якщо поточна комірка і комірка справа різних множин, то необхідно видалити праву межу i об'єднати множини поточної комірки та комірки праворуч. Вивести завершальний рядок.

Запропонований генератор з обраним алгоритмом можна використовувати 
при побудові комп'ютерних ігор.

\section{Список літератури}

1. Вирт Н. Алгоритмы и структуры данных. СПб .: Невский диалект, 2008. $352 \mathrm{c}$.

2. Голицина О.Л., Попов И.И. Основи алгоритмизации и программирование. 3-е изд., Перераб. и доп. М .: ФОРУМ, 2015. 432с.

3. Рафгарден Т. Совершенный алгоритм. Основы. Санкт-Петербурr: Питер, 2020. $256 \mathrm{c}$. 


\title{
ОХОЛОДЖЕННЯ ПЕРЛІТУ
}

\begin{abstract}
Марчевський Віктор Миколайович
к.т.н., Професор

Київ Національний технічний університет України «Київський політехнічний інститут імені Ігоря Сікорського»
\end{abstract}

\section{Войтюк Вадим Олегович}

студент

Київ Національний технічний університет України «Київський політехнічний інститут імені Ігоря Сікорського»

Перліт - природний мінерал вулканічного походження [1]. В його складі міститься кристалогідратна вода та до 70\% кремнію. При нагріванні перліту до $1000^{\circ} \mathrm{C}$ він стає пластичним, а зв'язана кристалогідратна вода перетворюється на пару, яка роздуває частинки. Вони спучуються збільшується їх пористість i розриваються оболонки. Отриманий таким способом спучений перліт гігроскопічний його не можна використовувати в якості теплоізоляції.

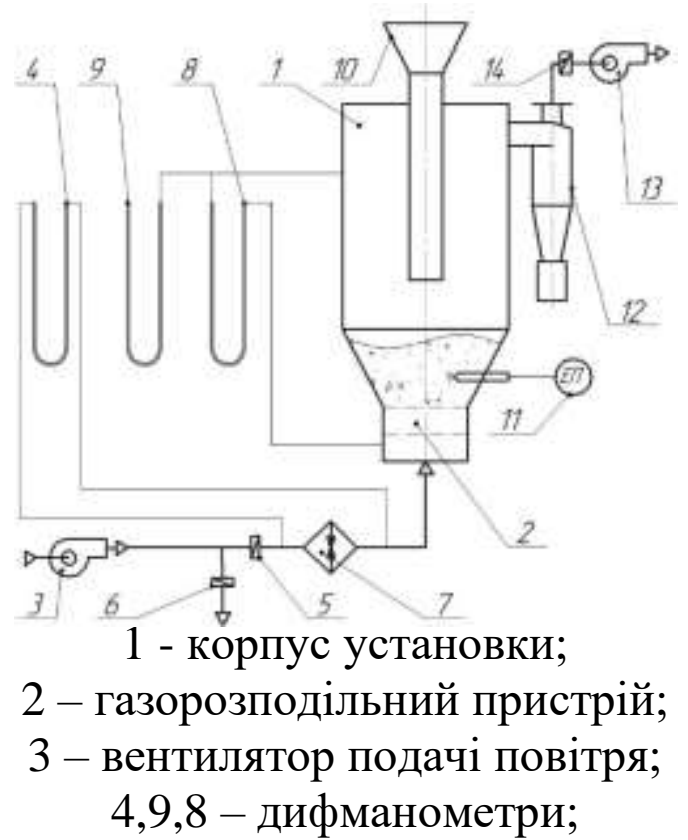

5,6,14 - шибери; 7 - діафрагма;

10 - завантажувальний

пристрій; 11- електронний

потенціометр;

12 - циклон;13 - витяжний вентилятор

Рис. 1

Для уникнення проблеми - розриву оболонок, зменшують вміст зв'язаної води в перліті методом високотемпературного сушіння. Його здійснюють при температурі $180 \div 240^{\circ} \mathrm{C}$, цей процес називають термізацією. Нагрітий до $240^{\circ} \mathrm{C}$ перліт після термізації подають елеватором в розхідний бункер де він довго остигає. При цьому стримується виробництво, не використовується теплота нагрітого до $240^{\circ} \mathrm{C}$ перліту, псуються стрічки елеваторів і пакувальні мішки. Вказана проблема вирішується шляхом охолодження перліту в охолоджувачі безперервної дії.

Ціль даної роботи - визначити основні параметри і кінетичні закономірності процесу охолодження перліту, необхідні для проектування охолоджувача.

Для досягнення поставленої цілі розроблена i виготовлена лабораторна установка [2], що дозволяє виконувати дослідження охолодження перліту в псевдозрідженому шарі, рис. 1.

Проведення дослідів починали з відбирання проб масою 1000 грамів по три проби від кожної із трьох фракцій. Встановлювалася швидкість теплоносія в перетині апарата достатня для псевдозрідження кожної із відібраних фракцій. Відібрані зразки нагрівались до температури $160-240^{\circ} \mathrm{C}$. Нагрітий зразок 
завантажували через завантажувальний пристрій в апарат лабораторної установки, де діючий потік повітря миттєво створював псевдозріджений шар. Одночасно електронний потенціометр починав вимірювати температуру шару. Інтервал вимірювання 1.3 секунди. Кінцева температура охолодження $70^{\circ} \mathrm{C}$, але в процесі експериментів охолодження проводили до більш низьких температур.

В проведенні експериментів підтримували постійними: швидкість теплоносія в псевдозрідженому шарі, $1.3 \mathrm{~m} / \mathrm{c}$; початкову температуру теплоносія $18^{\circ} \mathrm{C}$; масу зразка 1000 г. Оброблені результати експериментів наведено на рис. 2.
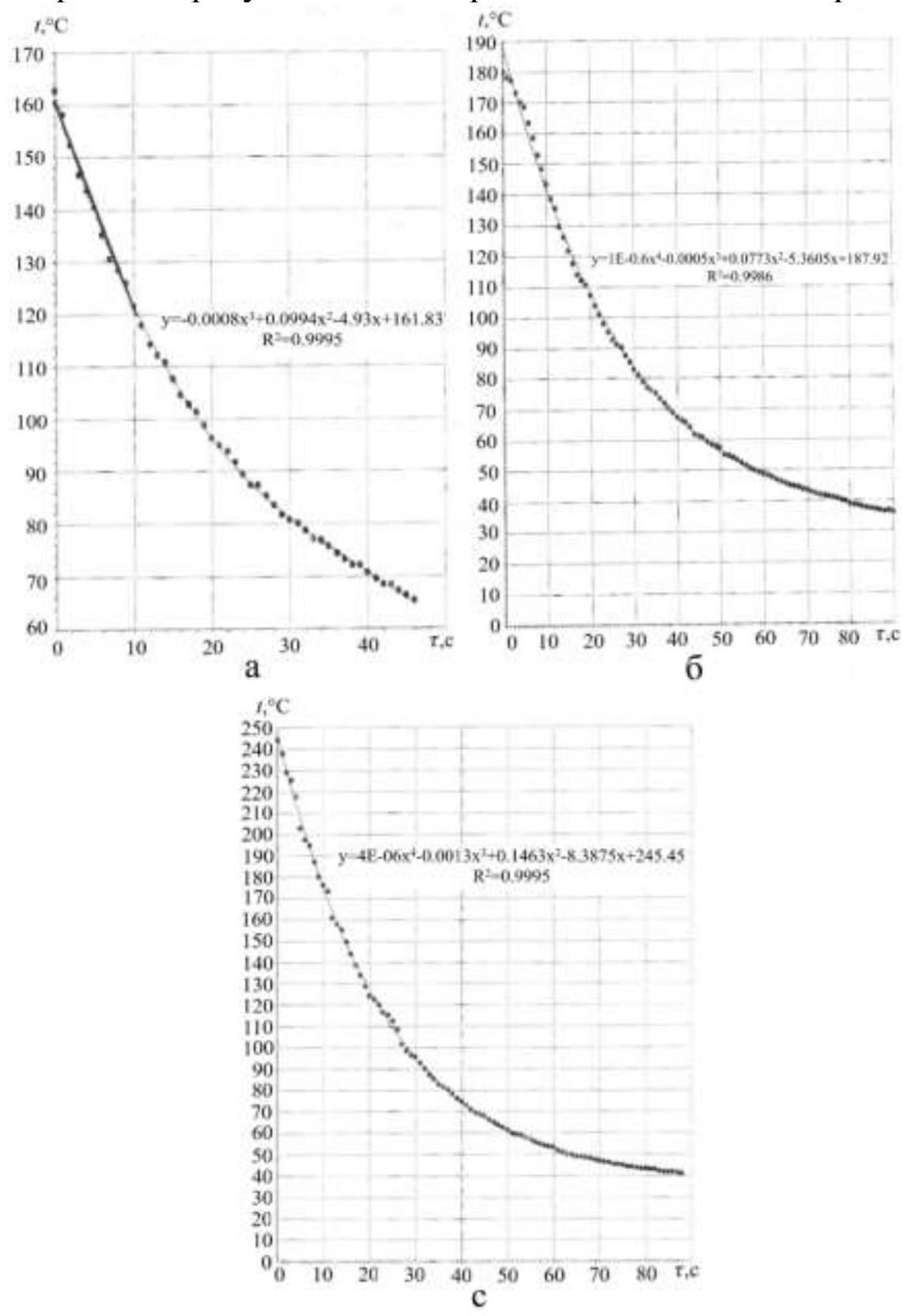

$\mathrm{a}$ - для дрібної фракції $\mathrm{d}_{\mathrm{e}}=0,63$ мм; б - для середньої фракції $\mathrm{d}_{\mathrm{e}}=0,96$ мм; с для крупної фракції $\mathrm{d}_{\mathrm{e}}=2,53$ мм [3]

Рис. 2 - Залежність температури частинок перліту від часу охолодження

Отримані залежності температури перліту від часу охолодження схожі на графічні залежності вологовмісту від часу сушіння [3]. 3 рис. 2, а видно, що процес охолодження починається $3160^{\circ} \mathrm{C}$ і продовжується 3 постійною швидкістю до критичної точки $\left(114^{\circ} \mathrm{C}\right)$. Швидкість охолодження лімітується, 
очевидно, швидкістю тепловіддачі (закон Ньютона-Ріхмана). Після проходження критичної точки швидкість охолодження починає лімітувати теплопровідність (закон Фур'є). В результаті збільшення термічного опору і зменшення градієнту температури. Час охолодження до температури $70^{\circ} \mathrm{C}$ склав 30 секунд. Перепад температури між температурою критичної точки і початковою температурою склав $\Delta t_{1}=46^{\circ} \mathrm{C}$. Зі збільшенням температури нагріву, рис. 2, а зростає перепад температур $\Delta t_{2}=70^{\circ} \mathrm{C}$ і час охолодження, що можна пояснити збільшенням накопиченої енергії та збільшенням еквівалентного діаметра частинок перліту.

Аналогічна крива охолодження значно більших часток, рис. 2,c. Нагріті до $245^{\circ} \mathrm{C}$ частинки діаметром $d_{e}=2.53$ мм охолоджувалися до температури $70^{\circ} \mathrm{C}$ за 43 секунди. Перепад температур між початковою температурою і температурою в критичній точці склав $100^{\circ} \mathrm{C}$.

Висновки. 1. Обгрунтована економічна доцільність охолодження перліту безперервно в потоці його виготовлення, після термізації.

2. Експериментально встановлено час охолодження фракцій перліту різних еквівалентних діаметрів.

3. Отримані рівняння регресії, що з достатньою точністю описують криві охолодження i дають змогу розрахувати час охолодження до заданої температури.

\section{Список літератури:}

1. Петров В.П. Современное состояние и перспективы развития перлитовой промышленности//Перлиты.-М.,1981.-С.5-16.

2. Романков П.Г., Рашковская Н.Б. Сушка во взвешеном состоянии. - изд. 3 е. перераб и доп. - Л.: Химия, $1979-212$ с., ил. - (серия «процессы и апарати химической и нефтехимической технологии).

3. Муштаев В.И. Сушка дисперсных материалов: производственнопрактическое издание / В.И. Муштаев, В. М. Ульянов. - М. : Химия, 1988. - 352с. : ил. 


\section{ОЦІНКА ЯКОСТІ АВІАЦІЙНОЇ ОЛИВИ}

\section{Мікосянчик Оксана Олександрівна,} доктор технічних наук, професор, Національний авіаційний університет

\section{Якобчук Олександр Євгенійович, старший викладач, Національний авіаційний університет}

\section{Мнацаканов Рудольф Георгійович,} доктор технічних наук, професор, Національний авіаційний університет

\section{Хімко Андрій Миколайович}

кандидат технічних наук, доцент, Національний авіаційний університет

Актуальним напрямком при впровадженні нових зразків мастильних матеріалів у виробництво є розробка алгоритму кваліфікаційних випробувань щодо визначення рівня експлуатаційних властивостей олив. При цьому обсяг методів оцінки якісних характеристик олив повинен включати як лабораторні дослідження, так і модельні дослідні стенди або установки [1].

В Україні ведуться розробки нових технічних умов на ряд авіаційних мастильних матеріалів. Одним з перспективних до виробництва і впровадження в експлуатацію є олива «Бора Б» ВО-12 виготовлена за ТУ У 19.2-38474081017:2018 зі зм. 1 «Оливи трансмісійні «Бора Б»» та рекомендована в якості всесезонної оливи для використання в інтервалі температур навколишнього середовища від мінус $50{ }^{\circ} \mathrm{C}$ до $60{ }^{\circ} \mathrm{C}$. [2].

Дослідження оливи «Бора Б» ВО-12 проводяться на програмно-апаратному комплексі (ПАК) для оцінки триботехнічних характеристик трибоелементів [3]. ПАК представляє собою комплекс, до складу якого входить установка тертя (УТ), електронний блок (ЕБ), програмне забезпечення (ПЗ) «Тертя», встановлене на персональному комп'ютері (ПК) типу IBM PC. Програмний блок математичної обробки даних виконує обчислення за заданим алгоритмом розрахунку. В створеній програмі $є$ окремий канал для візуальної оцінки кінетики зміни основних триботехнічних показників трибоконтакту в режимі online.

Методика визначення триботехнічних характеристик вузла тертя при використанні досліджуваного мастильного матеріалу включає оцінку наступних параметрів: 
- змащувальні властивості (гідродинамічна і негідродинамічна складові товщини мастильної плівки) визначаються методом падіння напруги в режимі нормального тліючого розряду;

- антифрикційні властивості контакту визначаються за кінетикою зміни крутного моменту тертя та подальшим розрахунком коефіцієнту тертя в контакті;

- реологічні характеристики мастильного матеріалу (градієнт швидкості зсуву, напруження зсуву змащувальних шарів, ефективна в'язкість в контакті) визначаються за кінетикою зміни товщини мастильного шару, швидкості кочення випереджаючої та відстаючої поверхні, температури мастильного шару;

- визначення питомої роботи тертя в триботехнічному контакті;

- мікротвердість контактних поверхонь металу за ГОСТ 22162-76;

- протизношувальні властивості мастильних матеріалів.

Об'єкти досліджень та умови експерименту. Мастильний матеріал: олива «Бора Б» ВО-12. Матеріал пар тертя: ролики зі сталі 40XН (HRC 38, $\mathrm{R}_{\mathrm{a}}$ 0,34 мкм). Змащування контактних поверхонь здійснювалось шляхом занурення нижнього ролика в ванночку з мастильним матеріалом. Режим тертя: нестаціонарні умови - циклічність проведення в режимі пуск - стаціонарна робота - гальмування зупинка. Максимальна частота обертів: для випереджаючої поверхні - 700 об/хв, для відстаючої поверхні - 500 об/хв. Проковзування - 30\%. Шлях тертя за один цикл: для випереджаючої поверхні - 91,845 м, для відстаючої поверхні - 62,8 м. Загальний шлях тертя: для випереджаючої поверхні - 9184,5 м, для відстаючої поверхні - 6280 м. Максимальне контактне навантаження по Герцу - 200 МПа. Кількість циклів в експерименті: 100 циклів (з 1-го по 45 цикл - температура оливи $20{ }^{\circ} \mathrm{C}$, з 46 по 50 цикл - нагрівання оливи, з 51 по 100 цикл - температура оливи $\left.100{ }^{\circ} \mathrm{C}\right)$. Тривалість циклу $-80 \mathrm{c}$.

Узагальнені результати триботехнічних параметрів за запропонованою методикою оцінки якості олив представлені в таблицях 1 та 2.

Таблиця 1. Антифрикційні, змащувальні та реологічні характеристики оливи «Бора Б» ВО-12

\begin{tabular}{|l|c|c|}
\hline \multirow{2}{*}{\multicolumn{1}{|c|}{ Показник }} & \multicolumn{2}{c|}{ Температура мастильного матеріалу } \\
\cline { 2 - 3 } & 20 & 100 \\
\hline Коефіцієнт тертя & $0,004-0,018$ & $0,005-0,02$ \\
\hline $\begin{array}{l}\text { Товщина граничних } \\
\text { адсорбційних шарів, мкм }\end{array}$ & $0,328-3,321$ & $0,132-2,92$ \\
\hline $\begin{array}{l}\text { Загальна товщина мастиль- } \\
\text { ного шару в контакті, мкм }\end{array}$ & $4,517-10,52$ & $6,11-12,88$ \\
\hline
\end{tabular}


Продовження Таблиці 1

\begin{tabular}{|l|c|c|}
\hline Режим мащення при пуску & $\begin{array}{c}0,39 \text { (напівсухий) - 6,9 } \\
\text { (гідродинамічний) }\end{array}$ & $\begin{array}{c}0,27 \text { (напівсухий) -6,9 } \\
\text { (гідродинамічний) }\end{array}$ \\
\hline $\begin{array}{l}\text { Режим мащення при } \\
\text { максимальних обертах }\end{array}$ & $9,39-22,1$ & $12,7-26,7$ \\
\cline { 2 - 3 } $\begin{array}{l}\text { Напруження зсуву масляного } \\
\text { шару, МПа }\end{array}$ & $3,02-13,1$ & $3,49-13,73$ \\
\hline Ефективна в'язкість, Па·с & $48,17-8206$ & $400-6049$ \\
\hline Питома робота тертя, Дж/мм² & $231-1092$ & $144-3435$ \\
\hline
\end{tabular}

Таблиця 2.

Протизношувальні характеристики оливи «Бора Б» ВО-12

\begin{tabular}{|l|c|c|}
\hline \multicolumn{3}{|c|}{ Знос контактних поверхонь (сталь 40ХН) після 100 циклів напрацювання } \\
\hline $\begin{array}{l}\text { Загальний знос дослідних } \\
\text { зразків, мкм }\end{array}$ & Випереджаюча поверхня & Відстаюча поверхня \\
\hline Знос, мкм & 0,66 & 1,82 \\
\hline $\begin{array}{l}\text { Інтенсивність } \\
\text { зношування }\end{array}$ & $7,186 \cdot 10^{-11}$ & $2,898 \cdot 10^{-10}$ \\
\hline Зносостійкість & $1,39 \cdot 10^{10}$ & $3,45 \cdot 10^{9}$ \\
\hline \multicolumn{2}{|c|}{ Мікротвердість дослідних зразків (сталь 40ХН) } \\
\hline $\begin{array}{l}\text { Мікротвердість поверхні } \\
\text { до експерименту } \\
\text { вихідна), МПа }\end{array}$ & 4729 & 4824 \\
\hline $\begin{array}{l}\text { Мікротвердість поверхні } \\
\text { після 100 циклів } \\
\text { напрацювання, МПа }\end{array}$ & 3027 & 3642 \\
\hline
\end{tabular}

Досліджувана олива «Бора Б» ВО-12 характеризується ефективними припрацьовуючими властивостями, зниження коефіцієнту тертя в 3 рази встановлено на 5-му циклі напрацювання. Встановлені високі антифрикційні властивості оливи в досліджуваному температурному діапазоні мастильного матеріалу.

Олива «Бора Б» ВО-12 характеризується ефективними змащувальними властивостями як в період пуску, так і при максимальних досліджуваних обертах (рис. 2). При підвищенні температури в триботехнічному контакті спостерігається зниження товщини граничних адсорбційних шарів, що обумовлено зміною їх природи - граничні шари переважно фізичної природи змінюються граничними шарами хімічної природи, які характеризуються більш ефективними протизношувальними характеристиками. Зриву мастильного шару при пуску та безпосереднього металевого контакту поверхонь тертя не встановлено, в 2-3 \% циклів встановлено напівсухий режим мащення.

Забезпечення гідродинамічного режиму мащення на максимальних обертах тривалості циклу, в умовах кочення з 30\% проковзуванням відбувається за 
рахунок високої несучої здатності мастильного матеріалу, формування в контакті гідро- та негідродинамічних складових товщини мастильного шару, які характеризуються низькими напруженнями зсуву на рівні, в середньому, 6,2 МПа.

Одержані експериментальні значення питомої роботи тертя в діапазоні $144 \ldots . .3435$ Дж/мм ${ }^{2}$ характеризують умови роботи трибосистеми з незначними енергетичними процесами. 3 підвищенням температури оливи 320 до $100{ }^{\circ} \mathrm{C}$ питома робота тертя зростає, в середньому, в 1,2 рази, що свідчить про перехід трибосистеми в більш складні умови тертя. В початковий період підвищення температури мастильного матеріалу питома робота тертя зростає до 3400 - 9000 Дж/мм ${ }^{2}$. Однак, зриву мастильного шару не встановлено, досліджуваний мастильний матеріал за таких умов забезпечує реалізацію в контакті напівсухого режиму мащення з швидким переходом до гідродинамічного режиму мащення.

Інтенсивність зношування як випереджаючої, так і відстаючої поверхонь характеризується низькими значеннями, що свідчить про високу зносостійкість контактних поверхонь та ефективні протизношувальні характеристики досліджуваної оливи.

Зниження мікротвердості сталі 40ХН після напрацювання 100 циклів встановлено в 1,56 та в 1,33 разів для випереджаючої та відстаючої поверхонь відповідно (рис. 1, 2).

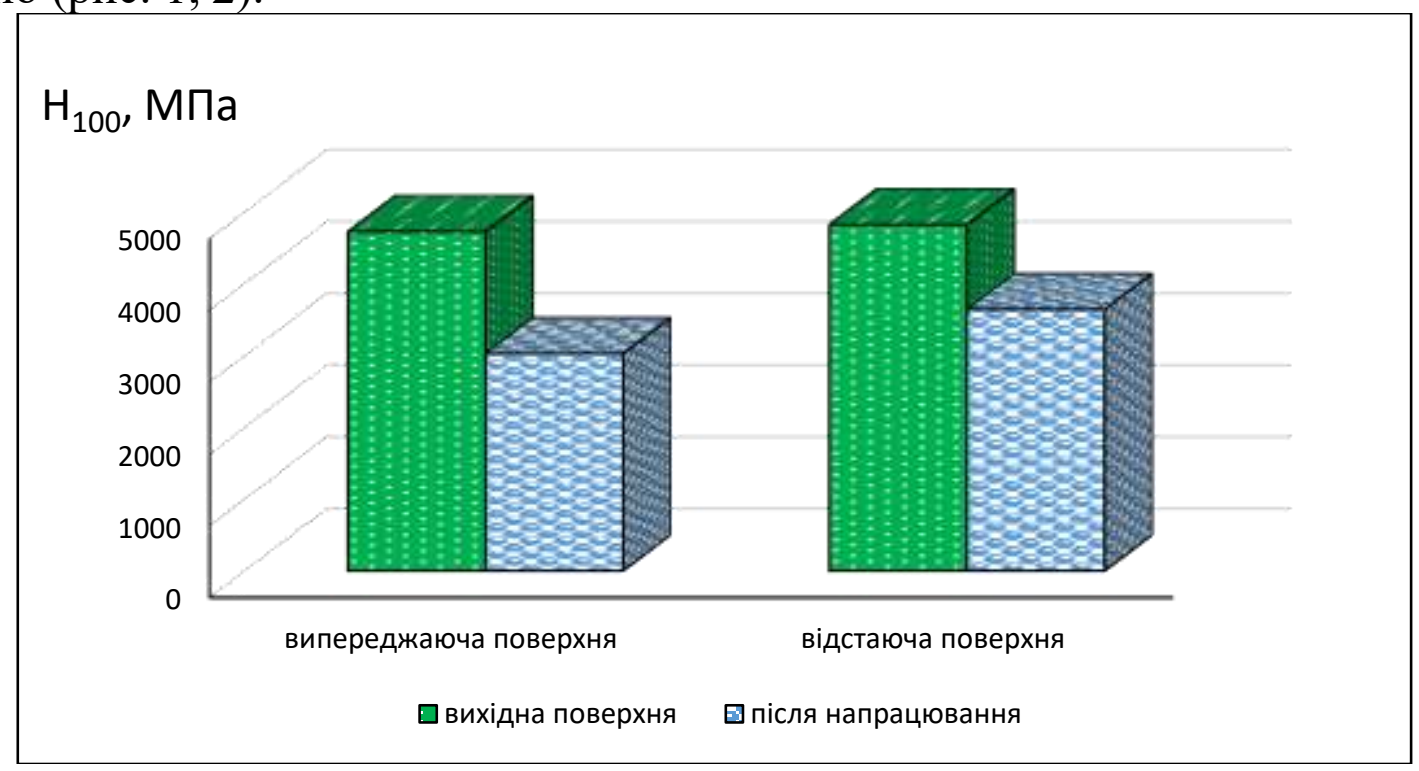

Рисунок 1. Мікротвердість вихідної поверхні та після 100 циклів наробітки дослідних зразків. 


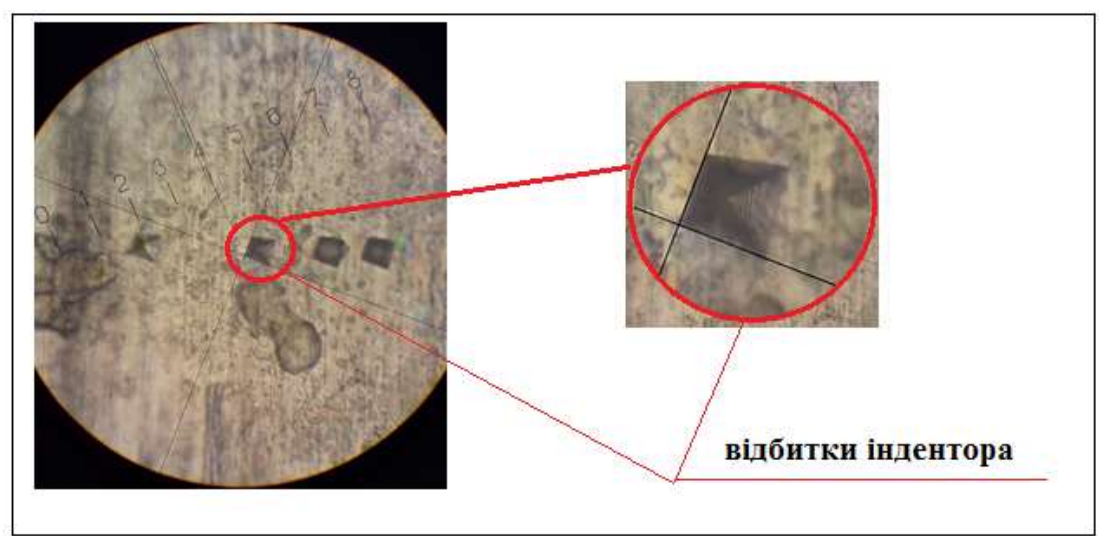

Рисунок 2. Фотографії вимірювання діагоналі відбитку індентора при розрахунку мікротвердості.

Знеміцнення поверхневих шарів металу обумовлено проявом ефекту Ребіндера - адсорбційною пластифікацією твердих тіл під дією поверхнево активних речовин оливи. Товщина пластифікованого шару може складати до 0,1 мкм. Дане явище позитивно впливає на триботехнічні процеси в контакті, оскільки забезпечується зменшення поверхневої енергії контактних поверхонь при адсорбції активних компонентів присадки оливи та формуванні граничних адсорбційних шарів як фізичної, так і хімічної природи. Це призводить до підвищення зносостійкості контактних поверхонь за рахунок зниження опору поверхневого шару твердого тіла пластичному деформуванню, полегшення пластичного зсуву у зернах та виходу дислокацій на поверхню, утворення більш дрібної зернистої структури.

Проведена комплексна оцінка триботехнічних показників оливи дає можливість більш точно оцінити якість оливи та надати рекомендації щодо вибору мастильного матеріалу для конкретних вузлів тертя.

\section{Список літератури:}

1. Mikosianchyk O.O., Yakobchuk O.Ye., Mnatsakanov R. H., Khimko A.M. Evaluation of operational properties of aviation oils by tribological parameters / O.O. Mikosianchyk, O.Ye. Yakobchuk, R. H. Mnatsakanov, A.M. Khimko // Problems of Tribology, 2021. - V. 26, No 1/99. - P43-50. https://doi.org/10.31891/2079-1372-202199-1-43-50

2. Масло

BO-12

[Електронний

pecypc]

https://bora.in.ua/ukraine_import/aviamasla/tsgip.htmı

3. Influence of the nature of boundary lubricating layers on adhesion component of friction coefficient under rolling conditions / O. Mikosyanchyk, R. Mnatsakanov, A. Zaporozhets, R. Kostynik // Eastern-European J. Enterprise Technologies. - 2016. - № 4/1 (82). - P. 24-31. 


\section{ВЫСОКОЭФФЕКТИВНАЯ ТЕХНОЛОГИЯ ФИНИШНОЙ ОБРАБОТКИ ОТВЕРСТИЙ ЦИЛИНДРОВ}

\section{Сергеев Александр}

полковник, начальник кафедры эксплуатации вооружения и военной техники Военного института танковых войск Национального технического университета «Харьковский политехнический институт»

Окончательная обработка внутренней поверхности цилиндров, традиционно, осуществляется на внутришлифовальных станках. Недостатком такого способа является то, что заготовку после выполнения операции растачивания необходимо переустанавливать с токарного станка на шлифовальный станок, а это требует значительного времени на выверку положения обрабатываемого цилиндра, переустанавливаемого с токарного станка на внутришлифовальный. Как правило, это приводит к потере точности взаимного расположения поверхностей и осей. Не менее, а может наиболее важным является то, что в процессе абразивной обработки обработочные риски, т. е. следы, образующиеся от воздействия абразивных зерен, направлены вдоль обработочных рисок, образовавшихся после растачивания, т. е. перпендикулярно по отношению к образующей обрабатываемого отверстия. Поскольку поршни (штоки) в процессе работы пневмо- и гидроцилиндров, компрессоров, двигателей внутреннего сгорания и т. п. перемещаются в осевом направлении, т. е. вдоль образующей, а следовательно, поперек обработочных рисок, последние подвергаются повышенному износу, что отрицательно сказывается на долговечности уплотнений. Частично эти недостатки ликвидируются хонингованием, которое характеризуется низкой производительностью, следовательно, высокой трудоемкостью, т. к. обработка осуществляется за счет возвратно-поступательного движения абразивных брусков вдоль образующей отверстия, при одновременном вращении хонинговальной головки или обрабатываемого цилиндра. Причиной низкой производительности хонингования является возвратно-поступательное движение инструмента, который в каждый возвратный ход снижает скорость до нуля, т. е. проходит через «крайние мертвые точки».

В связи с этим в работе предложены способ и устройство для внутреннего шлифования предварительно расточенного отверстия, которые лишены перечисленных недостатков. Обработка цилиндра производится сначала лезвийным, а затем абразивным инструментом на токарном станке без переустановки детали, т. е. без смены баз. Ось вращения шлифовального круга с индивидуальным приводом устанавливается перпендикулярно оси вращения обрабатываемого отверстия цилиндра (рис. 1). В качестве абразивного инструмента использовался войлочный круг диаметром 175 мм, периферийная поверхность круга была покрыта жидким стеклом, прокатана по абразивному порошку и высушена в течение 1 часа. 


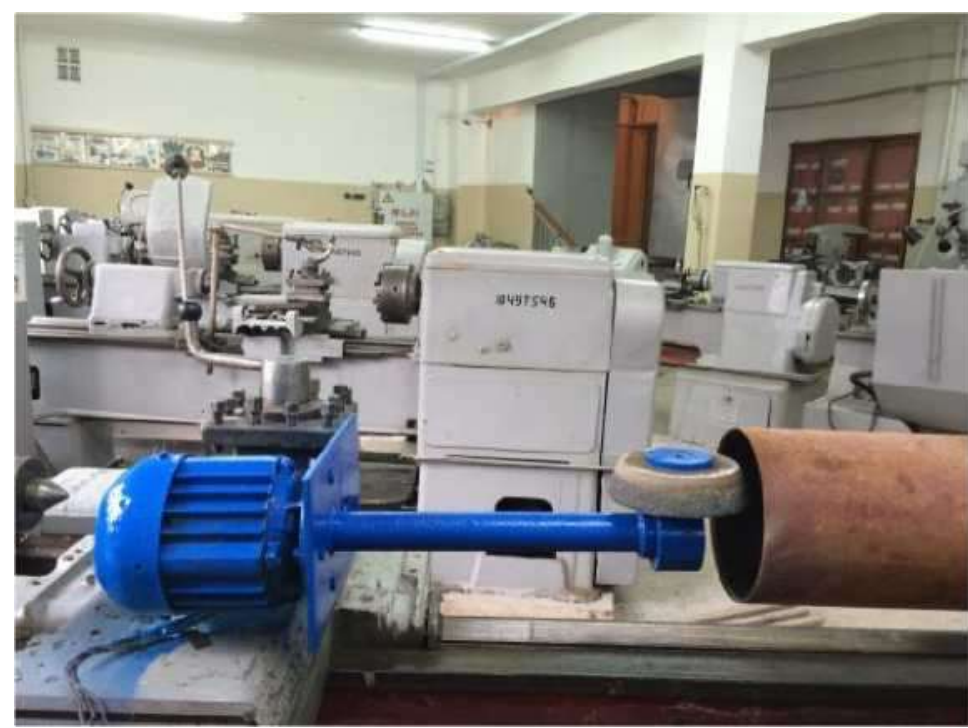

Рис. 1. Устройство для обработки отверстия цилиндра абразивным инструментом

После растачивания отверстия опытный образец устройства устанавливали на токарный станок с высотой центров 300 мм в резцедержатель или на место резцедержателя и подключали электродвигатель привода абразивного круга. Вылет абразивного круга на опытном образце устройства 600 мм. Минимальный диаметр отверстия, к которому применимо изготовленное устройство - 180 мм. Поскольку операции шлифования предшествует лезвийная обработка радиальное и торцевое биение полностью отсутствуют. Это позволяет оставлять минимальный припуск на последующий переход, т. к. исключается необходимость резервировать дополнительный слой межоперационного припуска, компенсирующего радиальное биение после смены баз. Поэтому припуск на окончательную обработку может быть соизмеримым с высотой микронеровностей, полученных после лезвийной обработки, т. е. растачивания. В результате растачивания была получена поверхность с шероховатостью $\mathrm{R}_{\mathrm{a}}=3,2$ мкм.

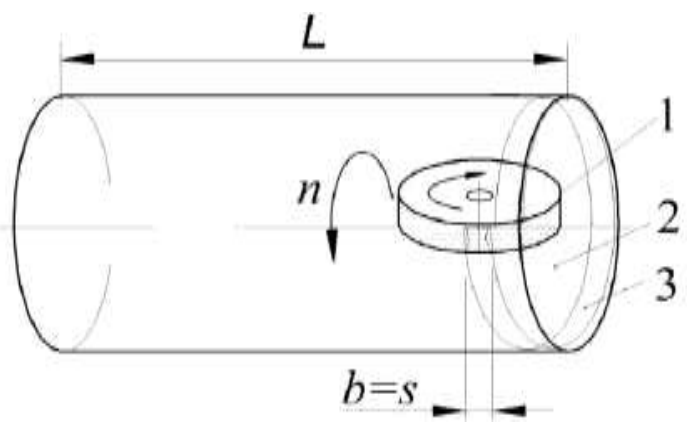

Рис. 2. Схема обработки отверстия цилиндра абразивным инструментом: 1 - войлочный круг с наклеенным абразивным порошком; 2- обрабатываемый цилиндр; 3 - шлифованная полоса; $b$ - ширина пятна контакта; 5 - подача; $n$ частота вращения детали; $L$ - длина детали

Режим абразивной обработки (рис. 2): скорость резания $V=750$ м/мин (12 м/с); продольная подача $S=2$ мм/об; частота вращения заготовки 50 мин $^{-1}$; 
фактическая глубина шлифования Iфракm $=2$ мкм. Следует учитывать, что глубина шлифования устанавливалась в виде прижима абразивного круга с натягом по отношению к обрабатываемой поверхности, равным 2 - 5 мм. Взаимосвязь между величиной натяга и фактической глубиной резания (шлифования) показана на рис. 3.

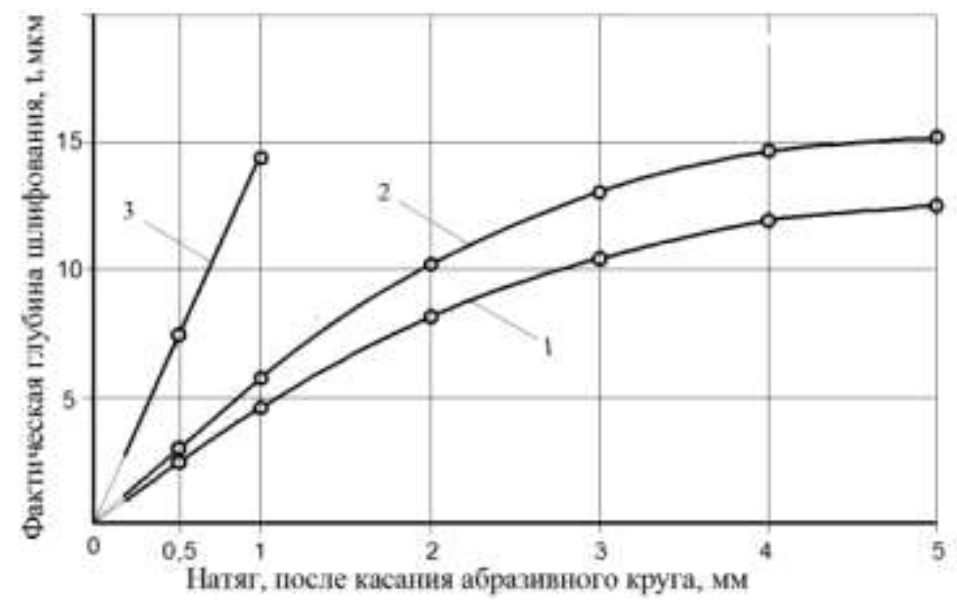

Рис. 3. Зависимость фактической глубины шлифования от установленной величины натяга, после касания абразивного круга: 1 - войлочный круг; 2 - фетровый круг;

3 - круг на вулканитовой связке

В результате абразивной обработки за один рабочий ход диаметр отверстия увеличивался на 2 - 4 мкм, что, в основном, соответствует сглаживанию обработочных рисок, образовавшихся после растачивания.

При предварительном подборе зернистости абразивного материала руководствовались следующими ограничениями: применение зернистости до F100 (по FEPA) сопровождается интенсивным засаливанием рабочей поверхности круга, а крупнозернистый абразив F24 и более в процессе обработки оставляет заметные обработочные риски и относительно быстро выкрашивается с поверхности войлочного круга. Таким образом, выбрана промежуточная фракция, т. е. применена зернистость абразивного материала F40.

Принятая скорость шлифования выбрана максимально возможной с учетом прочности войлочного материала при воздействии центробежной силы, а также с учетом стандартной частоты вращения асинхронного двигателя - 1400 об/мин. Диаметр войлочного круга выбран максимальным, вписывающимся в обрабатываемое отверстие, его диаметр 175 мм.

В результате обработки войлочным кругом с наклеенным порошком карбида кремния зеленого зернистостью F40 за один рабочий ход получена шероховатость $\mathrm{Ra}=1,25$ мкм, а после второго рабочего хода $\mathrm{Ra}=0,63$ мкм. Дальнейшая обработка, т. е. следующий рабочий ход осуществлялся с нанесением на периферию войлочного круга пасты ГОИ, в результате чего получена зеркальная поверхность.

Известно, что шероховатость поверхности измеряют в направлении, перпендикулярном направлению обработочных рисок. Однако в связи с тем, что очередной технологический переход выполняется инструментом, который оставляет обработочные следы, перпендикулярные предыдущему переходу, 
которым является растачивание и их направление совпадает с направлением движения поршня, то в соответствии функциональным назначением поверхности, шероховатость поверхности целесообразно измерять в направлении движения поршня.

Благодаря такому направлению обработочных следов, полностью исчезла необходимость прохождения периода приработки поршня с цилиндром на малых оборотах, например, двигателя внутреннего сгорания, компрессора, насоса и др.

Преимуществом метода является и то, что в процессе обработки не возникают вибрации детали и инструмента, особенно это важно при обработке тонкостенных цилиндров. С учетом этого свойства можно рассчитывать на значительное снижение металлоемкости проектируемых цилиндров, так как толщина их стенок, как правило, устанавливается при конструировании вместо расчетной, конструктивной с целью обеспечения жесткости в процессе обработки.

Перспективным является использование предлагаемой технологии для окончательной обработки внутренней поверхности гильз блока цилиндров двигателей внутреннего сгорания, так как толщина стенок в них должна быть расчетной, т. е. минимальной для скорейшей передачи тепла в охлаждающую жидкость зарубашечного пространства блока цилиндров.

Технология и устройство были применены при изготовлении пневмоцилиндров (диаметром отверстия 195 мм, длиной 400 мм), заготовкой послужила труба прокат 210, сталь 20. Восемь пневмоцилиндров с уплотнениями поршней резиновыми кольцами было установлено на автоматической линии ампулирования лекарственных средств, где они работают без ремонта на протяжении нескольких лет. Следует отметить, что сжатый воздух (0,4 МПа), перед подачей в пневмоцилиндр проходит подготовку в виде подмешивания в него масляного тумана.

Выводы. Предложенная технология внутреннего шлифования с применением мягкого войлочного круга с наклеенным абразивным порошком обладает следующими достоинствами:

позволяет резко снизить высоту микронеровностей поверхности, полученную на предшествующей операции за счет изменения направления главного движения резания путем установления оси вращения шлифовального круга с индивидуальным приводом перпендикулярно оси вращения обрабатываемого отверстия цилиндра. В результате достигается изменение направления обработочных следов и тем самым обеспечивается увеличение срока службы уплотнений поршня;

- обеспечивает увеличение производительности окончательной обработки за счет снижения основного (машинного) времени, например, в сравнении с хонингованием;

- обеспечивает снижение трудоемкости обработки отверстия в целом за счет исключения необходимости переустановки заготовки и выверки на другом станке;

- обеспечивает возможность обработки цилиндров малой жесткости благодаря отсутствию вибраций из-за применения мягких абразивных кругов. 
В дальнейших исследованиях необходимо провести экспериментальные исследования по оцениванию влияния различных характеристик мягких абразивных кругов на шероховатость обработанной поверхности. Это позволит разработать обобщающие практические рекомендации по совершенствованию существующей технологии внутреннего шлифования с точки зрения уменьшения шероховатости обработанной поверхности и повышения производительности обработки. 


\title{
АНАЛИЗ ПРОЦЕССОВ ДЕСТАБИЛИЗАЦИИ КАРБИДНОЙ ФАЗЫ В ЧУГУНЕ ПРИ НАГРЕВЕ И ДЕФОРМАЦИИ
}

\author{
Скобло Тамара Семеновна \\ д.т.н., профессор
}

Харьковский национальный технический университет сельского хозяйства имени Петра Василенко

Нанка Александр Владимирович,

к.т.н., профессор

Харьковский национальный технический университет сельского хозяйства имени Петра Василенко

Клочко Оксана Юрьевна, д.Т.н., доцент Харьковский национальный технический университет сельского хозяйства имени Петра Василенко

\section{Сайчук Александр Васильевич,}

д.т.н., профессор

Харьковский национальный технический университет сельского хозяйства имени Петра Василенко

\section{Рыбалко Иван Николаевич,} К.Т.Н.

Харьковский национальный технический университет сельского хозяйства имени Петра Василенко

Введение. При производстве листового металлопроката широко используют его формовку прокатными валками из высокохромистого и хромоникелевого чугуна. Хромоникелевый чугун отличается более крупными включениями карбидной фазы, которая определяет высокую твердость контактной поверхности с горячим металлопрокатом и обеспечивает износостойкость рабочего инструмента [1-4]. По мере деградации, износа и разрушения кристаллической структуры этой фазы твердость и качество рабочего слоя снижаются и валок подвергают переточке. Количество переточек весьма ограничено из-за того, что легированные чугуны используют чаще всего только для рабочего слоя, который получают методом центробежного литья, а сердцевину, шейки и трефы изготавливают порционной заливкой серого чугуна. Такая технология производства и эксплуатации прокатного инструмента является наиболее эффективной, поскольку исключает выколы буртов и поломку шеек. К числу недостатков может быть отнесено: малая и неравномерная 
толщина рабочего слоя верхней и нижней частей бочки при отливке валков на вертикальной центробежной машине, особенно для станов 3000 и 3600 [1].

В последние годы такой чугун используют и для рабочего слоя при отливке сортопрокатных валков с литыми ручьями центробежным методом и закладными кольцами. Это обеспечивает однородную твердость и износостойкость по периметру всего калибра [5].

В данной работе подробно анализировали зарождение дефектов и их влияние на развитие деградационных процессов при повышенной температуре и локальной деформации в хромоникелевом чугуне. Повреждаемость и деградацию такого чугуна оценивали по развитию диффузионных процессов и изменчивости дислокационной структуры в наиболее крупных включениях карбидной фазы. Анализировали влияние ее упорядочения (формирование субзерен, стенок) на процессы формирования новых фаз и их взаимодействий. Несмотря на то, что дислокационную структуру выявляли и ранее в карбидной фазе [6], оценить экспериментально ее роль в диффузионных процессах удалось только сейчас, благодаря развитию оптико-математического метода описания структурных изменений [7,8].

Целью данной работы было выявление роли изменчивости дислокационной структуры в условиях воздействия температуры и деформации на развитие диффузионных процессов, приводящих к дестабилизации карбидной фазы и связанного с этим формирования новых фаз.

Методика проведения исследований. В литературе практически отсутствует информация об относительной скорости сублимации различных структурных составляющих многофазных и многокомпонентных сплавов при вакуумном травлении. В связи с этим режимы такого травления, для выявления дислокаций по ямкам при различных температурах и деформации, обеспечивающих перенос вещества через газовую среду, выявляли экспериментально [9]. В процессе вакуумного травления происходит поверхностная и объемная диффузия, избирательная сублимация атомов, которые обеспечивают на анализируемой поверхности рельеф [10]. В зависимости от параметров обработки, состояния поверхности образца, типа фазы, один из перечисленных факторов может сыграть основную роль.

Для выявления тонкой структуры карбидной фазы хромоникелевого чугуна в данном случае использовали установленные оптимальные параметры остаточного давления в камере $13.3 \times 10^{-3}$ Па при температурах $200^{\circ} \mathrm{C}-600^{\circ} \mathrm{C}$ (соответствует условиям эксплуатации валков) и локальной деформации. Время обработки зависело от химического состава материала и выявленных структурных изменений.

Для исследований использовали образцы хромоникелевого чугуна $(1.8 \% \mathrm{Cr}$ и $4.2 \% \mathrm{Ni}$ ) размером $30 \times 40 \times 80$ мм, с жестко закрепленными концами. Нагрев осуществляли средней части образца. В этой зоне, за счет возникновения изменений линейного расширения на границе между нагретой и холодной частями, формировались напряжения и была отмечена локальная деформация, которая проявлялась в различные периоды травления увеличением плотности дислокаций, их взаимодействием и скольжением. 
Вопросами, связанными с влиянием дефектов на качество металла, посвящено много исследований. К их числу относятся и те, в которых, при помощи стандартизованных математических подходов, контурно-структурным методом по оттенкам цветовой гаммы, идентифицировали неметаллические включения [11].

В работах [12,13] по выявленным условным цветам определяли долю феррита и карбидов, размер неметаллических включений. Для их выявления путем анализа металлографических изображений предложен подход и компьютерная программа. Разработаны математические модели контроля качества при формировании кривизны решетки в деградационной структуре с оценкой развития усталостных процессов [14].

Рассмотренные подходы направлены на решение конкретных задач, однако они не оценивают причин и явлений, связанных с изменчивостью фазового, химического состава в условиях развития диффузионных процессов при эксплуатации недостаточно стабильных карбидных фаз изделий, работающих в условиях воздействий повышенных температур и деформаций.

Представленные в данной работе исследования предусматривают экспериментальное и теоретическое моделированию для оценки деградационных явлений в карбидной фазе, определяющих эксплуатационную стойкость прокатных валков. Для этого использовали специальный подход с описанием изменчивости дислокационной структуры, определяющей процесс деградации карбидной фазы $[6,15]$.

Описание диффузионных процессов проводили по фотографиям микроструктур, полученных сканирующим электронным микроскопом (SEM) JEOL JSM-6390LV в режиме отраженных электронов (BSE). В качестве математической основы использован метод оптико-структурного машинного анализа, оценивающего изображения, различающиеся по их статистическим характеристикам (по распределению и плотности пикселей на фотографии микроструктуры). Каждой координате пикселя цифрового изображения присваивали значение кода условного цвета (далее просто цвет). Методический подход основан на анализе процессов структурообразования (диссипация энергии, диффузионный перенос, изменение плотности), характеризующих изменчивость фаз, с использованием гидродинамических аналогий [16]. Согласно методике, изложенной в работах $[7,17]$, весь диапазон, получаемых при цифровой обработке от 0 до 255 полутонов серого, был разбит на 16 дискретных интервалов - номеров цвета. При этом интервалы: 0 - отнесен к графиту; от 1 до 9 - к ферриту (по степени возрастания в нем насыщенностью дефектов углеродом); 10 - к бейниту; от 11 до 15 - к карбидам $\mathrm{MeC}, \mathrm{Me}_{\mathrm{x}} \mathrm{Cy} \mathrm{и}$ $\mathrm{Me}_{3} \mathrm{C}$ соответственно. Оценку изменчивости фаз проводили по фотографиям микроструктур в цифровом формате .pgm. Каждое изображение разбивали на фрагменты размером $3 \times 3$ пикселя.

Оценивали появление дислокаций и их изменчивость при определении влияния локальной неоднородности в карбидной фазе. В качестве критериев, описывающих диффузионные процессы, изменение дислокационной структуры 
и ее плотности, были использованы энергетические параметры, такие как функция мощности диссипации энергии (M) и функция напряжений $(\mathrm{S})[7,18]$ :

$$
\begin{aligned}
& M=\operatorname{div} C(x, y) \cdot \Delta C(x, y), \\
& S=\operatorname{div} C(x, y)-\Delta C(x, y),
\end{aligned}
$$

где $\operatorname{div} \mathrm{C}(\mathrm{x}, \mathrm{y})$ - дивергенция; $\triangle \mathrm{C}(\mathrm{x}, \mathrm{y})$ - лапласиан;

$\mathrm{C}(\mathrm{x}, \mathrm{y})$ - функция координат пикселя металлографического изображения; х и $\mathrm{y}$ - его координаты. С $(\mathrm{x}, \mathrm{y})$ в конечно-разностном представлении будет иметь вид матрицы $C_{i, j}$ :

$$
C_{i, j}=\left(\begin{array}{ccc}
c_{i-1, j-1} & c_{i-1, j} & c_{i-1, j+1} \\
c_{i, j-1} & c_{i, j} & c_{i, j+1} \\
c_{i+1, j-1} & c_{i+1, j} & c_{i+1, j+1}
\end{array}\right),
$$

где в качестве координаты принимали пиксель изображения (относительно центрального элемента $c_{i, j}: i$ - номер строки, $j$ - номер столбца); $c_{i, j}$ - цвет.

Обработку такой матрицы проводили путем последовательного сканирования каждого ее пикселя, задавая как средний, находящийся внутри оцениваемого фрагмента. В соответствии с методикой, описанной в работе [15], под изменчивостью состава фаз дислокационной структуры в одной конкретной точке выбранного фрагмента изображения, принимали соотношение числа совпадений цвета среднего пикселя с цветами окружающих ее точек, к количеству всех точек фрагмента.

Результаты исследований. Анализом результатов исследований показано, что дефекты кристаллического строения являются основной причиной развития нестабильности структуры карбидной фазы хромоникелевого чугуна. Диффузия компонентов связана с зарождением, взаимодействием и подвижностью таких дефектов, при которых отмечается и развитие локальной неоднородности в этой фазе при эксплуатации.

При значительном совершенстве структуры процесс деградации ограничивается локальными изменениями в распределении компонентов и фаз. Так, в начальный период зарождения деградационных явлений, отмечается формирование субструктуры в карбидной фазе в виде дислокационных стенок, которые впоследствии являются концентраторами локальных напряжений и вокруг них появляются новые дефекты (рис.1), на которых уже и выделяются различные сочетания фаз: насыщенного углеродом феррита (цвета 8 и 9); до 1.3\% бейнита (цвет 10) и карбидов $\mathrm{MeC}, \mathrm{Me}_{\mathrm{x}} \mathrm{C}_{\mathrm{y}}$ (цвета 11 и 12) - 1.35\%. Движение таких дефектов на этом этапе вокруг дислокационных стенок отсутствует (рис.1).

В случае увеличения их подвижности диффузионные процессы существенно возрастают. Это сопровождается выделением новых фаз в полосах легкого скольжения дефектов, а также отмечается их взаимодействие. В полосах скольжения выявлено более интенсивное выделение фаз, что связано с локальной деформацией «толчками», которые характеризуют продвижение дефектов. О таком характере процесса свидетельствует появление новых точечных дефектов как внутри полос скольжения, так и на их границе (рис.2). 


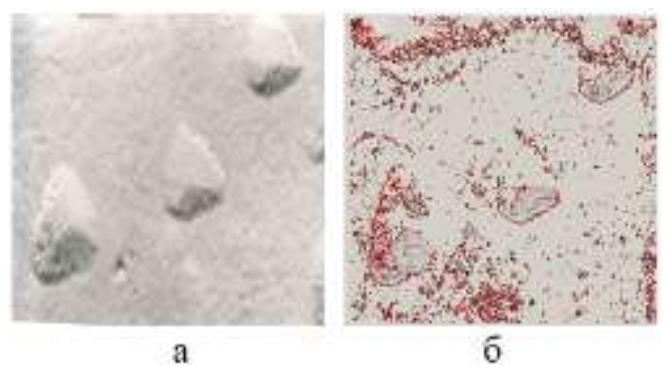

Рисунок 1. Фотография дислокационной стенки (a), ×10000, и плотность новых дефектов вокруг нее (б), рассчитанная через функцию напряжений $\mathrm{S}$ (обозначено красным цветом)

Такую структуру описывали оптико-математическим методом с помощью функций напряжений и мощности диссипации энергии (рис.2).
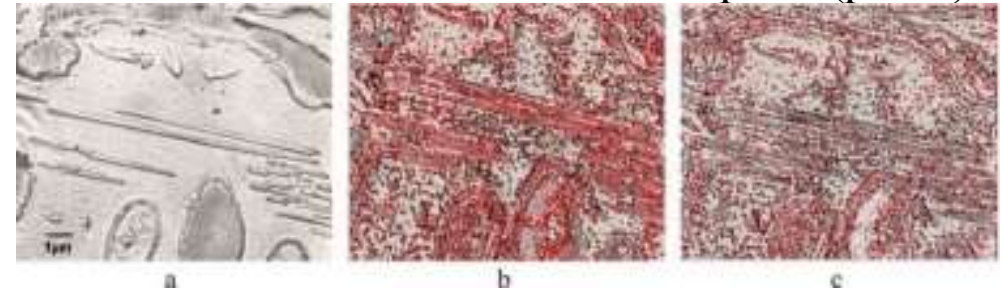

Рисунок 2. Анализ фотографии микроструктуры хромоникелевого чугуна (а), $\times 10000$, структурных изменений при скольжении: оценка по функции напряжений $\mathrm{S}(\mathrm{b})$ и по функции диссипации энергии $\mathrm{M}(\mathrm{c})$

Визуализируя полученные результаты и сопоставляя их, можно заключить, что в процессе скольжения дислокаций напряжения заметно снижаются (на изображении уменьшается количество отличных от нуля значений функций, в том числе, превышающих пороговое значение (255), показано красным цветом).

Для детального анализа формируемых фаз этого же изображения, оценивали количественное соотношение фаз и их взаимодействие (рис.3), согласно изложенной методике. При этом, выявленные ферритные фазы суммарно не превышают 4.63 \% и они выделяются во взаимодействии между собой, те есть такие, которые в разной степени насыщены углеродом (сочетания интервалов цветов 7,$8 ; 8,9 ; 7,8,9)$.

Одновременно выявлены взаимодействия насыщенных углеродом фаз феррита (цвет 9) и бейнита (цвет 10), а также феррита, бейнита и карбидов нестехиометрического состава (цвета 11 и 12). Их суммарная доля составляет $7.85 \%$. В процессе воздействия температуры и напряжений наблюдается особенно сильное изменение состава исходной карбидной фазы. Появилось значительное количество карбидов нестехиометрического состава (до $40.5 \%$ ) с цветами 12, 13 и 14. Их доля по отдельности для карбидов цвета 13 и 14, достигла $5.07 \%$, а при взаимосвязи с $\mathrm{Me}_{3} \mathrm{C}$ - до $23.51 \%$. 


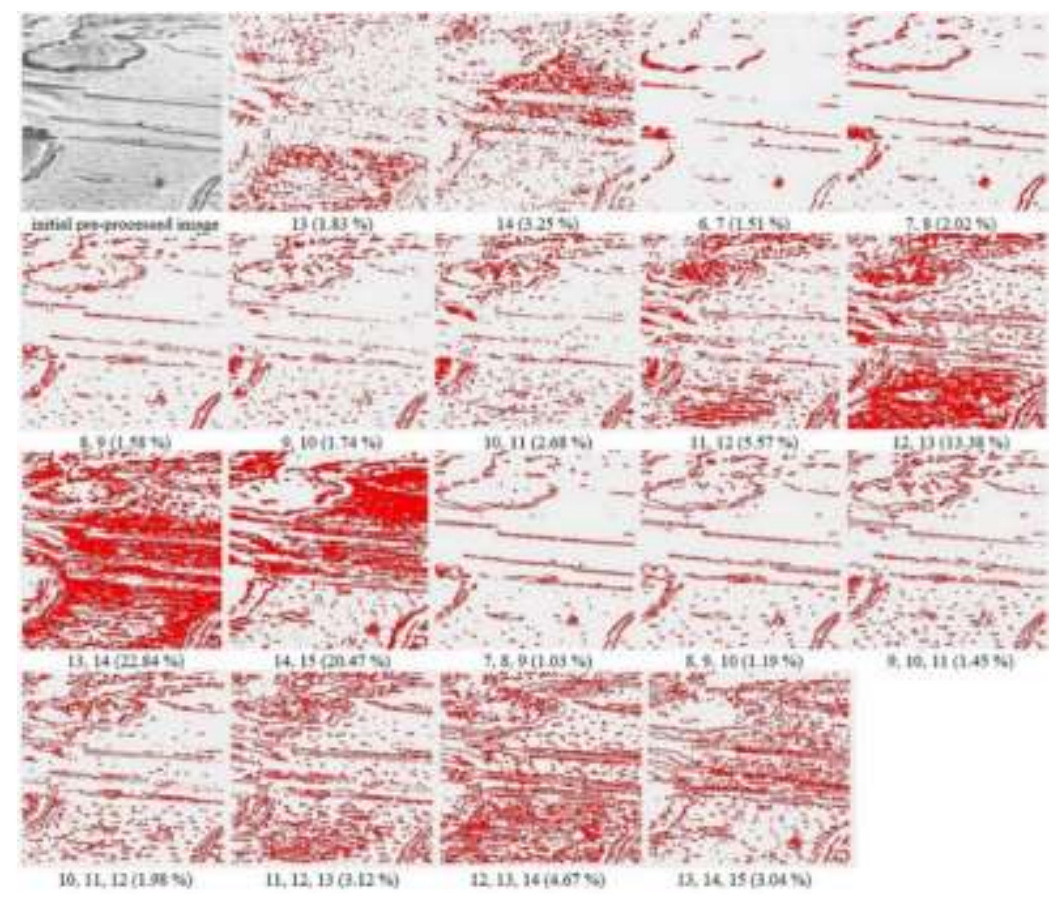

Рисунок 3. Характеристика качественного и количественного соотношения фаз при деградации карбидной фазы, ×10000

Можно предположить, что при скольжении и взаимодействии дислокаций должны происходить процессы снятия напряжений. Для установления этого сопоставили оценки выявленных структурных изменений при описании их оптико-математическим методом (см. рис.2). Показано, что процесс диссипации энергии при скольжении и взаимодействии дислокаций имеет место, однако его роль существенно снижается из-за возникновения новых дефектов и деградации цементита в полосах скольжения и вблизи их границ, что вызывает дополнительные напряжения.

Выводы. Анализируя развитие деградационных процессов при нагреве и локальной деформации, можно сделать заключение о существенной дестабилизации карбидной фазы $\mathrm{Me}_{3} \mathrm{C}$. Такие деградационные явления определяются развитием дефектов кристаллического строения, созданием субструктуры, увеличением плотности дислокаций, их взаимодействием и скольжением. Такие процессы сопровождаются локальной деформацией, диффузией углерода и железа, формированием новых типов фаз, их взаимодействием, а также процессом диссипации энергии. При этом, для управления процессами торможения либо исключения таких деградационных явлений, требуются новые технологические решения производства и упрочнения прокатных валков для стабилизации свойств карбидной фазы. Положительное влияние может оказать дополнительное легирование и модифицирование металла, обеспечивающие дробление карбидной фазы, повышение твердости при достаточной общей доли этой фазы, а также корректировка параметров обжатий и системы охлаждения при эксплуатации на стане. 


\section{Список литературы:}

1. Skoblo, T.S., Vorontsov, N.M., Rudyuk, S.I., Budagyants, N.A., Voronina, V.A. Прокатные валки из высокоуглеродистых сплавов (High carbon alloy rolling rolls), In: Skoblo T.S. (eds.) Publisher: Metallurgy, Moscow, Russia, 1994. (in Russian)

2. Vorob'eva, E.L., Migachev, B.A., Skoblo, T.S. Structure of white cast iron and its conformity with the Charpy rule. Metal Science and Heat Treatment, 17, pp.415416, 1975. https://doi.org/10.1007/BF00663221

3. Nieminen, R., Autio, J., Suomalainen, E., Husu, N., Kauppi, M., Väänänen, E. Wear mechanism of Ni-Hard4 rollers in chromite ore crushing. Wear, 179 (1-2), pp. 95-100, 1994. https://doi.org/10.1016/0043-1648(94)90225-9

4. Skoblo, T.S., Klochko, O.Y., Sidashenko, A.I., Sokolov, R. G. Heat treatment of two-layer alloyed-iron rollers. Steel in Translation, 43, pp.603-606, 2013. https://doi.org/10.3103/S096709121309012X

5. Производство и применение прокатных валков: Справочник: под ред. проф. Скобло Т.С. / Т.С.Скобло, А.И.Сидашенко, Н.М.Александрова, Е.Л.Белкин, В.М.Власовец, О.Ю.Клочко, А.Д.Мартыненко - Х.: ЦД № 1, 2013 $572 \mathrm{c}$.

6. Skoblo, T.S., Rudyuk, S.I., Sandler, N.I., Korobeinik, V.F., Vorobieva, V.L., Kudryavtseva, L.G. Поведение дислокаций в цементите чугуна крупных отливок при нагреве и деформации. Bulletin of the Kharkov Polytechnic Institute: collection of articles. scientific. works: Foundry, 80 (5), Higher school, Kharkiv, Ukraine, pp.125-127, 1973. (in Russian)

7. Теоретические и экспериментальные основы прогнозирования структурообразования, свойств высокоуглеродистых легированных сплавов: монография / Т. С. Скобло, О. Ю. Клочко, А. И. Сидашенко, Е. Л. Белкин. Харків: Діса плюс, 2019. - 278 с.

8. Скобло Т.С., Клочко О.Ю., Белкин Е.Л. Применение компьютерного анализа металлографических изображений при исследовании структуры высокохромистого чугуна. Заводская лаборатория. Диагностика материалов. 2012. 78(6): 35-42.

9. Skoblo, T.S., Sandler, N.I. Методика выявления фигур травления в цементите чугуна. Industrial laboratory, №2, pp.202-203, 1967. (in Russian)

10. Amelinckx, S. The Direct Observations of Dislocations, Publisher: Academic Press, New York, 1964.

11. Skoblo, T.S., Sidashenko, A.I., Saichuk, O.V. Корпусні деталі з чавунів та їх якісні показники: Monograph., In: Skoblo T.S. (eds.) Publisher: Disa plus, Kharkiv, Ukraine, 2019. (in Russian)

12. Skoblo, T.S., Klochko, O.Y., Belkin, E.L., Sidashenko, A.I., Avetisyan, V.K. Structure formation of high-chromium cast irons in the temperature range of the magnetic transformation of carbide phases. Letters on Materials, 10(2), pp.129-134, 2020. https://doi.org/10.22226/2410-3535-2020-2-129-134

13. Skoblo, T.S., Sidashenko, O.I., Saichuk, O.V., Klochko, O.Yu., Levkin, D.A. Influence of Stresses on Structural Changes in Gray Cast Iron. Materials Science, 56, pp.347-358, 2020. https://doi.org/10.1007/s11003-020-00436-8 
14. Panin, V.E., Gromov, V.E., Ivanov, Y.F., Kormyshev, V. E. The Role of Lattice Curvature in Structural Degradation of the Metal Surface Layer of a Rail under Long-term Operation. Doklady Physics, 65, pp.376-378, 2020. https://doi.org/10.1134/S1028335820100043

15. Скобло Т.С., Клочко О.Ю., Белкин Е.Л., Сидашенко А.И. Исследование структуры высокохромистых чугунов. Заводская лаборатория. Диагностика материалов. 2017; 83(5): 27-38.

16. Skoblo, T.S., Belkin, E.L., Klochko, O.Yu. Обоснование применения понятий уравнений гидродинамики Навье-Стокса для анализа металлографических изображений (Application justification of the concepts of fluid dynamics Navier-Stokes equations for the analysis of metallographic images). In: 2011 Materials VII International Scientific and Practical Conference "European Science of the 21st Century - 2011", Przemyśl, Poland, May 7-10, 2011, 21, pp. 94-96. (in Russian) [online] Available at: http://www.rusnauka.com/12_ENXXI_2011/Tecnic/8_85541.doc.htm [Accessed: 11 May 2011]

17. Skoblo, T.S., Klochko, O.Y., Belkin, E.L. Structure of high-chromium cast iron. Steel in Translation, 42, pp.261-268, 2012. https://doi.org/10.3103/S0967091212030151

18. Skoblo, T.S., Klochko, O.Yu., Belkin, E.L., Sidashenko, A.I. Новые подходы в исследовании неоднородности гетерогенных структур" (New Approaches in Study of Inhomogeneity of Heterogeneous Structures). Metallophysics and Advanced Technologies, 40(2), pp. 255-280, https://doi.org/10.15407/mfint.40.02.0255

2018 (in Russian). 


\title{
КВАЗИНЕПРЕРЫВНОЕ ИЗОБРАЖЕНИЕ В ВИДОВЫХ СРЕДСТВАХ С ДИСКРЕТНЫМИ ПРИЕМНИКАМИ: СНИЖЕНИЕ ТРЕБОВАНИЙ К ПИКСЕЛЬНОМУ РАЗМЕРУ СВЕТОЧУВСТВИТЕЛЬНОЙ МАТРИЦЫ
}

\author{
Слонов Михаил Юрьевич \\ Кандидат технических наук, доцент \\ Военно-дипломатическая академия имени Евгения Березняка
}

Вступление. В видовых средствах наблюдения и документирования объекта используют дискретные светочувствительные матрицы. Изображение $X$ картины наблюдения может рассматриваться при этом как множество значений $x_{j}$ [1]:

$$
X=X\left\{x_{j}: x_{j} \in \Omega, j=(\overline{1, N})\right\},
$$

где $N$ - количество значений $x_{j}$, которые участвуют в построении изображения картины наблюдения, $\Omega$ - наблюдаемое пространство.

Разрешение видового средства наблюдения всегда ограничено. Поэтому элементами изображения в (1) являются его наименьшие детали, пикселы [2, 3]. Дискретизация изображения на отдельные пикселы приводит к потере части пространственной информации об объекте. Bo-nервых, в пределах каждого элемента разрешения значение параметра $x_{j}$ усредняется. Если отдельному пикселу соответствует пространство $\Delta \Omega_{j}$, значение параметра $x_{j}$ изображения $X$ усредняется в пределах площади пиксела до значения $\widetilde{x_{j}}$ :

$$
X=X\left\{\tilde{x}_{j}: x_{j} \in \Omega, j=(\overline{1, N}), \widetilde{x}_{j}=\overline{x_{j}\left(\Delta \Omega_{j}\right)} \rightarrow x_{j} \approx \tilde{x}_{j}\right\} .
$$

С увеличением величины $\Delta \Omega_{j}$ количество пространственных градаций информативного параметра объекта в его изображении уменьшается.

Bo-вторых, некоторые детали изображения объекта попадают на промежуток $\Delta$ между двумя соседними пикселами. В светоэлектрическом преобразовании эта часть изображения не участвует.

Уменьшить информационные потери можно при выполнении условий:

$$
\Delta \Omega_{j} \rightarrow 0, \Delta \rightarrow 0, x_{j} \rightarrow \tilde{x}_{j}: j=(\overline{1, N}) .
$$

Пиксельный размер матрицы определяется количеством $m$ строк из элементарных приемников по $n$ приемников в каждой. В данном случае:

$$
\Omega=\left\{\Delta \Omega_{j}\right\}, j=(\overline{1, m \times n}) .
$$

Условия (3) согласно (4) запишутся в следующем виде:

$$
(m \times n) \rightarrow \infty, \Delta \rightarrow 0, x_{j} \rightarrow \tilde{x}_{j}: j=(\overline{1, N}) .
$$

Таким образом, заранее успешное видовое наблюдение предполагает наличие бесструктурного приемника с бесконечно большой светочувствительностью. Физически реализовать такой приёмник невозможно. 
Путей частичного решения проблемы ограниченного пространственного разрешения известно несколько. К ним относятся аппаратные [4-7] и алгоритмические направления [8-10]. Их анализ позволяет утверждать, что проблема увеличения пиксельного размера изображения не решена полностью.

Целью исследования является получение квазинепрерывного изображения в видовых средствах с дискретными приемниками. Указанная цель достигается за счёт разработки способа получения такого изображения. При реализации разработанного способа пиксельный размер изображения существенно (кратно) превышает пиксельный размер чувствительной матрицы.

Изложение основного материала. Способ основан на поэлементном сканировании изображения картины, которая наблюдается. Сканирование осуществляется светочувствительной матрицей с закономерно изменённой (управляемой) плотностью размещения элементарных приемников (УРЭПматрицей), рис. 1. При сканировании после смещения оптического изображения относительно светочувствительной матрицы на один пиксель производится снимок. Количество $K$ смещений, а соответственно и снимков задаётся таким образом, чтобы были просканированы все элементы дискретизации картины наблюдения. Суть реализации способа в следующем.
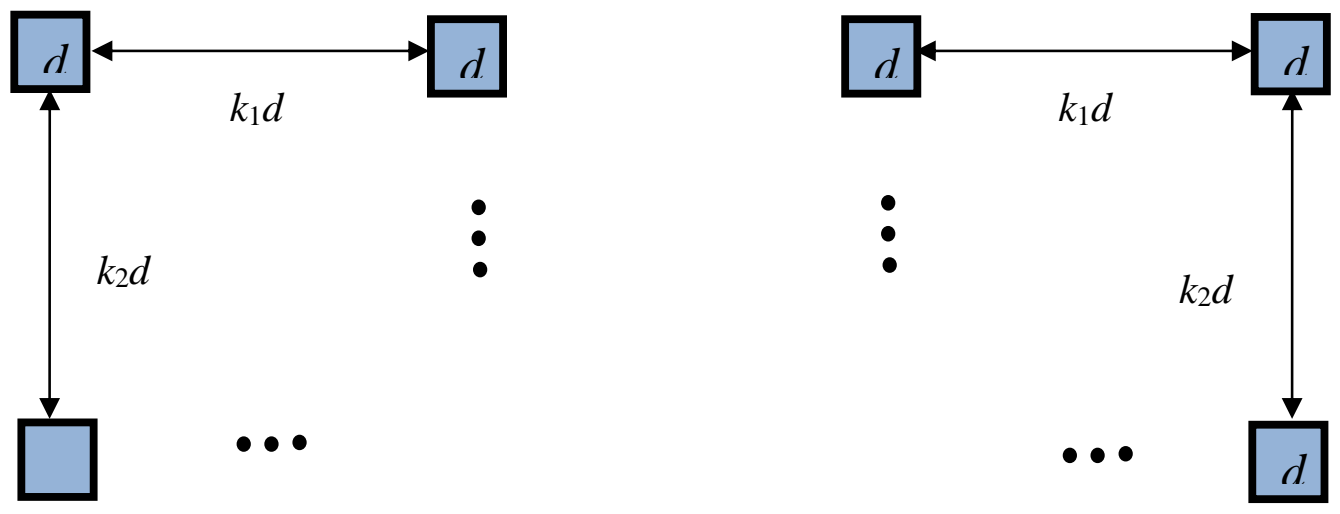

Рис. 1. Структура УРЭП-матрицы

В УРЭП-матрице размещены одинаковые элементарные приемники размером $d$. Они закономерно распределены по поверхности матрицы. Расстояние между соседними приемниками составляет $k d$. Величина $k$ задаёт кратность размещения размера $d$ в расстоянии между двумя соседними элементарными приемниками по вертикали и горизонтали. На рис. 1 приведен участок УРЭП-матрицы с кратностью размещения по горизонтали $k_{1}$ и по вертикали $-k_{2}$. Величины $k_{1}$ и $k_{2}$ выбираются разработчиком УРЭП-матрицы.

Изображение объекта УРЭП-матрицей (отдельный кадр) составляется из серии снимков. Каждый снимок формируется сигналами, поступающими от всех элементарных приемников УРЭП-матрицы.

Смещение делают в направлении вертикального или горизонтального ряда приёмников. Именно смещение обеспечивает документирование в пределах всей наблюдаемой картины. Формализация кадра суммарного цифрового изображения $X$ будет выглядеть следующим образом: 


$$
\begin{gathered}
X=\left\{X_{r}\right\}=\sum_{r=1}^{r=K} X_{r}, \\
X_{r}=X_{r}\left\{\widetilde{x_{r, j}}: x_{r, j} \in \Omega, j \in(\overline{1, m \times n}), r=(\overline{1, K}), K=\max _{0 \leq r \leq K} r, \widetilde{x_{r, j}} \rightarrow x_{r, j}\right\} .
\end{gathered}
$$

В $(5,6)$ под $K$ понимается количество снимков, которое содержится в одном кадре. По сравнению с (2) в уравнении (6) символ «приблизительно равно» $(\approx)$ заменен символом «стремится к» $(\rightarrow)$. Правомочность такой замены объясняется двумя факторами. Отдельно взятый пиксель может иметь сколь угодно малые размеры в пределах физической реализуемости. Кроме того, межпиксельный промежуток $\Delta$ между двумя соседними пикселами сводится к нулю. Изображение становится квазинепрерывным.

Порядок формирования кадра понятен из рис. 2. На нём схематически изображён участок УРЭП-матрицы с $k_{1}=2, k_{2}=1$. Окрашенные пикселы соответствуют размещению элементарных приемников в УРЭП-матрице.

Кадр в данном случае включает в себя 6 снимков. В момент времени $t=0$ экспонируется первый снимок. Изображение на нём содержит сигналы от окрашенных элементарных приемников $d$. Это первая составляющая (снимок 1) $X_{1}$ кадра $X$. Второй снимок $X_{2}$ делается при горизонтальном перемещении изображения или матрицы на величину $d$ вдоль линии элементарных приемников. Элементарные приемники займут положение 2. Снимок $X_{3}$ выполняют, когда элементарные приемники будут в положении 3.

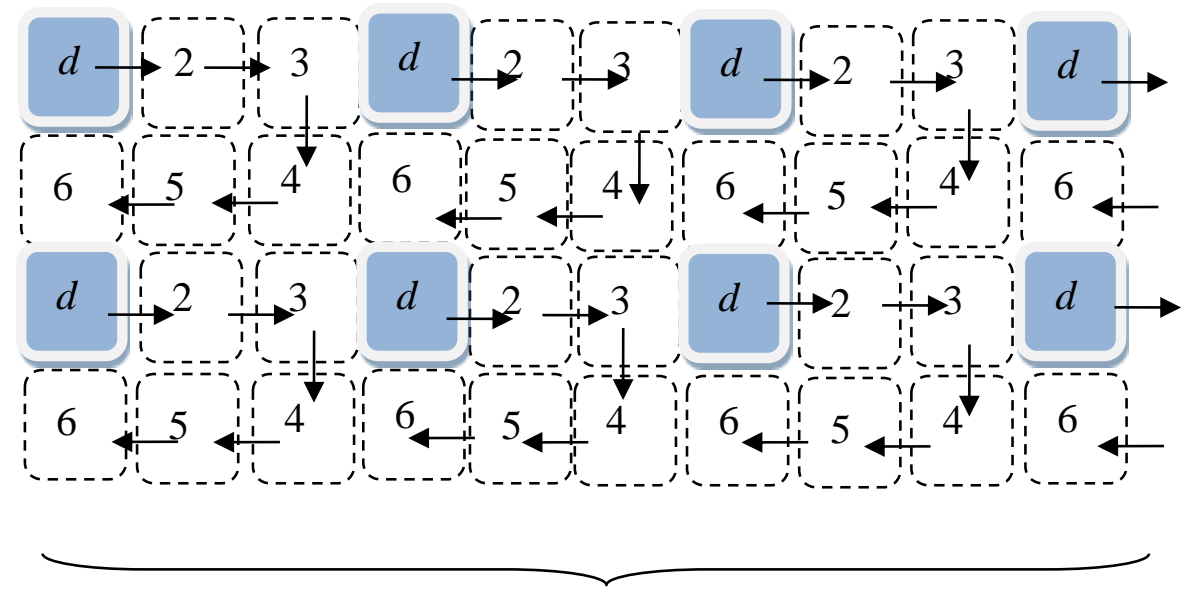

Один кадр, $K=6$

Рис. 2. Формирование кадра УРЭП-матрицей: $k_{1}=2, k_{2}=1, K=6$

Формирование кадра завершается снимками 4, 5, 6. Сканирование проводится по стрелкам после каждого смещения на размер $d$ одного пиксела.

Правило (6) можно формализовать и в таком виде:

$$
X_{r}=X_{r}\left\{\widetilde{x_{r, j}}: j \in(\overline{1, m \times n}), r=(\overline{1, K}), K=\max _{1 \leq r \leq\left(1+k_{1}\right) \times\left(1+k_{2}\right)} r\right\} .
$$

Аппаратная реализация данного способа предполагает решение двух задач. Первой из них является создание светочувствительной УРЭП-матрицы размером 
$(m \times n)$. Степень распределения элементов УРЭП-матрицы может увеличиваться за счёт увеличения площади её поверхности или уменьшения площади элементарного приёмника. $\mathrm{C}$ уменьшением плотности распределения виртуальный пиксельный размер изображения УРЭП-матрицей увеличивается пропорционально величине $K$. Он определится соотношением:

$$
m_{\Sigma} \times n_{\Sigma}=(m \times n) K=(m \times n)\left[\left(k_{1}+1\right)\left(k_{2}+1\right)\right] .
$$

УРЭП-матрица становится эквивалентной по пиксельным размерам светочувствительной матрице размером $\left(m_{\Sigma} \times n_{\Sigma}\right)$. Второй задачей является изменение механизма сохранения кадра с результатами наблюдения.

Обсуждение результатов. В табл. 1 приведены результаты расчётов для УРЭП-матриц с разным пиксельным размером. Данные, которые представлены в табл. 1, визуализированы на рис. 3. Благодаря внутрикадровому сканированию УРЭП-матрица с пиксельным размером видеоформата может работать в режиме светочувствительной матрицы з пиксельным размером 2,5 Мпк. УРЭП-матрица с пиксельным размером 6 Мпк при $K=8$ может работать как 48 Мпк матрица обычной конструкции.

Таблица 1

Физический и виртуальный пиксельный размер УРЭП-матрицы

\begin{tabular}{|c|c|c|c|c|c|c|}
\hline $\begin{array}{c}\text { Пиксельный } \\
\text { размер УРЭП- } \\
\begin{array}{c}\text { матрицы, } \\
m \times n, \text { Мпк }\end{array}\end{array}$ & \multicolumn{7}{|c|}{\begin{tabular}{c} 
Виртуальный пиксельный размер эквивалентной матрицы, $m_{\Sigma} \times n_{\Sigma}$, Мпк, \\
\cline { 2 - 7 }
\end{tabular}} & \multicolumn{7}{|c|}{$K$} \\
\hline 0,31 & 0,31 & 0,62 & 0,93 & 1,24 & 1,86 & 2,48 \\
\hline 1,0 & 1,0 & 2,0 & 3,0 & 4,0 & 6,0 & 8,0 \\
\hline 2,0 & 2,0 & 4,0 & 6,0 & 8,0 & 12,0 & 16,0 \\
\hline 3,0 & 3,0 & 6,0 & 9,0 & 12,0 & 18,0 & 24,0 \\
\hline 4,0 & 4,0 & 8,0 & 12,0 & 16,0 & 24,0 & 36,0 \\
\hline 6,0 & 6,0 & 12,0 & 18,0 & 24,0 & 36,0 & 48,0 \\
\hline
\end{tabular}

При увеличении величины $K$ можно достичь любого пиксельного размера изображения при любом исходном пиксельном размере УРЭП-матрицы. Ограничения обусловлены физической реализуемостью и лимитом времени на формирование кадра.

Важной задачей является изменение механизма сохранения кадра с результатами наблюдения. Согласно условиям распределения элементарных приёмников в УРЭП-матрице уравнение (5) может рассматриваться как матричное:

$$
\mathbf{X}=\sum_{r=1}^{r=K} \mathbf{X}_{r},
$$

В данном случае матрицы $\mathbf{X}$ и $\mathbf{X}_{\mathbf{r}}$ должны иметь одинаковый порядок по горизонтали и вертикали. Он должен соответствовать формату запоминания не снимка, а кадра $\left(m_{\Sigma} \times n_{\Sigma}\right)$. 


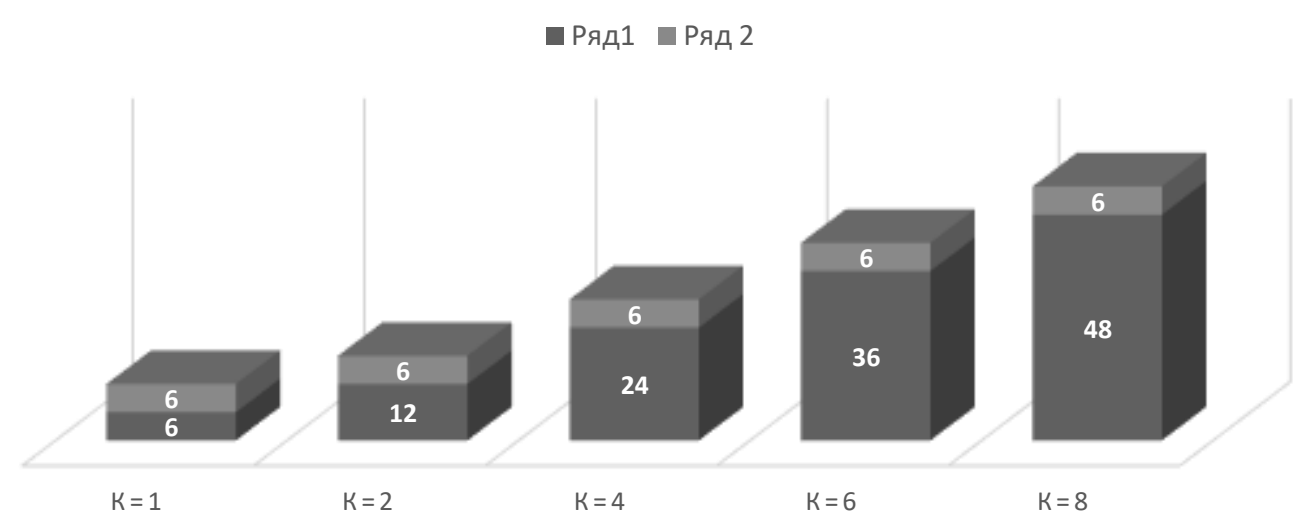

Рис. 3. Пиксельный размер изображения в средстве наблюдения с УРЭПматрицей размером 6 Мпк:

ряд 1 - с изменённым уровнем плотности; ряд 2 - обычная матрица

Последовательность запоминания пикселов в цифровом изображении кадра в соответствии с $(7,8)$ будет следующей:

$$
j=\left(\overline{j_{1}, \ldots, j_{K}}\right), j \in(\overline{1, m \times n}) .
$$

Таким образом, при формировании цифрового изображения кадра в соответствии с (9) сначала запоминаются первые пикселы всех снимков кадра, потом все вторые, третьи и так далее.

Выводы. В статье предложен способ формирования квазинепрерывного изображения в видовых средствах наблюдения с дискретными приемниками. Способ предполагает использование светочувствительной матрицы с закономерно изменённой (управляемой) плотностью размещения элементарных приемников - УРЭП-матрицы. Применение разработанного способа позволит кратно увеличить пиксельный размер изображения относительно пиксельного размера УРЭП-матрицы. К преимуществам предложенного способа относятся:

снижение требований к пиксельному размеру светочувствительной матрицы без ухудшения качества изображения;

отсутствие информационных потерь на промежутках между соседними элементарными приёмниками.

\section{Список литературы}

1. Krasilnikov N.N., Krasilnikova O.I. Study of the efficiency of the human visual system in recognizing static images. Journal of Optical Technology, 2002. Vol. 69, Issue 6. P. 397- 403.

2. Mitchell E.N. Photographic Science. The University of North Carolina at Chapel Hill, John Wiley \& Sons. 1984. P. 56-61.

3. Попов М. А. О технологии создания новых технологий в области дистанционного зондирования Земли. Украӥнський журнал дистанційного зондування Землі. 2018. №17. С. 4-9. https://doi.org/10.36023/ujrs.2018.17.127.

4. LSST: https://tehnobzor.ru/stati/samaja-bolshaja-kamera @TehnObzor. jan 29, 2021. 
5. G. OWC Unleashes 2nd Gen ThunderBlade SSD Drives with a Top Speed of 5000 MBps. DPReview, https://www.dpreview.com/news/ 2707357090, jan 29, 2019.

6. Rehm L.: Samsung Launches 1/3.4" 20 MP Sensor for Use in Smartphone front Cameras and Tele Modules. DPReview, https://www.dpreview.com/news/ 5407916317, jan 22, 2021.

7. Slonov M., Korobchynsky M., Rudenko M., Maryliv O. Assessment of the Effect of Image Shift on the Results of Photo-Video Recording. Proceedings of the IEEE 40th International Conference on Electronics and Nanotechnology, ELNANO 2020. Kyiv, 2020. P. 641-645. ISBN: 978-1-7281-9712-8. https://doi.org/10.1109 / elnano50318.2020.9088766.

8. Ferraris, V., Dobigeon, N., Wei, Q. \& Chabert, M. Detecting Changes Between Optical Images of Different Spatial and Spectral Resolutions: A Fusion-Based Approach. IEEE Transactions on Geoscience and Remote Sensing, 56 (3), 2016. P. 1566-1578. https://doi.org/10.1109/ TGRS.2017.2765348.

9. Станкевич С А., Масленко О.В., Андронов В.В. Адаптація нейромережевих технологій до ідентифікації малорозмірних об'єктів на супутникових зображеннях недостатньої розрізненості в базі графічних еталонів. Український журнал дистаниійного зондування Землі. №27. 2020. С. 13-17. Online ISSN 23132132. https://doi.org/10.36023 /ujrs.2020.27.175.

10.Kwan C. Image Resolution Enhancement for Remote Sensing Applications. Proceedings of the 2nd International Conference on Vision, Image and Signal Processing, ICVISP 2018. No.: 12. 2018. P. 1-5. https://doi.org/10.1145/ 3271553.3271590 . 


\title{
ВИКОРИСТАННЯ СУЧАСНИХ SLA ЗАСОБІВ В АДИТИВНИХ ІТ-ТЕХНОЛОГІЯХ
}

\author{
Тулашвілі Юрій Йосипович,
}

д.пед.н., професор,

Луцький національний технічний університет

\section{Лук'янчук Юрій Анатолійович,}

к.т.н., ст.викладач

Луцький національний технічний університет

Сучасне інформаційне суспільство все більше спирається на використання автоматизованого i роботизованого обладнання, технологій швидкого прототипування (таких як 3D-друк) i програмних засобів конструювання технічних об'єктів. Сьогодні ІТ-індустрія потребує кваліфікованих фахівців, що володіють сучасними технологіями, засобами, обладнанням. Серед таких спеціаліст, що створює на комп'ютері моделі виробів, після чого вони виготовляються на автоматизованому обладнанні. Спеціаліст такого профілю людина креативна, що критично мислить, володіє винахідливістю, спеціальними знаннями та уміннями.

В умовах сучасного ринку і постійного зростання конкуренції якнайшвидше створення інноваційного продукту є життєво важливим для успішного розвитку будь-якого підприємства. Світові виробники розуміють, що в сучасному світі, щоб бути на лідируючих позиціях, потрібно максимально оперативно втілювати нові ідеї в працездатні рішення. Це неможливо без генерації цих ідей і без нових технічних рішень для якнайшвидшого їх втілення в життя [1]. Тому використання технології 3D-друку буде одним 3 кращих технічних рішень для прискорення реалізації різних нових ідей в життя. А процес моделювання технологічних процесів стане корисним при розробці нових продуктів, оскільки віртуально можливо побачити увесь життєвий цикл виготовлення та вносити корективи у роботу обладнання $[2,3]$.

У зв'язку 3 цим актуальним $\epsilon$ питання формування у майбутніх кваліфікованих робітників IT-сфери компетентності в галузі 3D-моделювання та 3D-друку у процесі професійної підготовки за допомогою програмного забезпечення, що моделює технологічний процес. Для забезпечення формування зазначеної компетентності та, як наслідок, підвищення конкурентоспроможності майбутніх кваліфікованих робітників IT-сфери на ринку праці доцільним $\epsilon$ вивчення основ 3D-друку.

Свої професійні навички за допомогою 3D-технології можуть удосконалювати майбутні інженери, дизайнери, архітектори, медики та студенти багатьох інших спеціальностей $[4,5]$.

Адитивне виробництво, або 3D-друк, - процес створення тривимірних об'єктів практично будь-якої геометричної форми на основі їх цифрових 
моделей. Концепція 3D-друку заснована на побудові об'єкта послідовно нанесеними шарами, що відображують контури моделі.

Адитивні технології широко використовуються для прототипування $\mathrm{i}$ розподіленого виробництва в архітектурі, будівництві, промисловому дизайні, автомобільній, аерокосмічній, промисловій, інженерній та медичній галузях, біоінженерії (для створення штучних тканин), виробництві модного одягу та взуття, ювелірних виробів, в освіті, географічних інформаційних системах, харчовій промисловості та багатьох інших сферах людської діяльності.

Технологічні особливості процесу тривимірного друку, що головним чином залежать від технології адитивного виробництва, лежить в основі цього процесу [6]. Класифікація основних методів і технологій, що застосовуються в тривимірному друку на сьогоднішній день, представлено в таблиці 1.1.

Таблиця 1.1.

Класифікація основних методів 3D друку

\begin{tabular}{|c|c|c|}
\hline Метод & Базова технологія & $\begin{array}{c}\text { Матеріали, що } \\
\text { використовуються }\end{array}$ \\
\hline Екструзійний & $\begin{array}{c}\text { Моделювання методом } \\
\text { пошарового наплавлення (FDM, } \\
\text { FFF) }\end{array}$ & $\begin{array}{c}\text { Термопластичні полімери } \\
\text { (поліактид (PLA), } \\
\text { акрилонітрилбутадієнстирол } \\
\text { (ABS)) }\end{array}$ \\
\hline Дротовий & $\begin{array}{c}\text { Виробництво довільних форм } \\
\text { електронно-променевої плавки } \\
\text { (EBF) }\end{array}$ & Майже всі металеві сплави \\
\hline \multirow{5}{*}{ Порошковий } & Пряме лазерне спікання (DMLS) & Майже всі металеві сплави \\
\hline & $\begin{array}{l}\text { Електронно-променева плавка } \\
\text { (ЕВМ) }\end{array}$ & Титанові сплави \\
\hline & $\begin{array}{c}\text { Вибіркове лазерне плавлення } \\
\text { (SLM) }\end{array}$ & $\begin{array}{c}\text { Титанові сплави, кобальт- } \\
\text { хромові сплави, нержавіюча } \\
\text { сталь, алюміній }\end{array}$ \\
\hline & $\begin{array}{c}\text { Вибіркове теплове спікання } \\
\text { (SHS) }\end{array}$ & $\begin{array}{l}\text { Порошкові термопластичні } \\
\text { полімери }\end{array}$ \\
\hline & Вибіркове лазерне спікання (SLS) & $\begin{array}{c}\text { Термопластичні полімери, } \\
\text { металеві порошки, керамічні } \\
\text { порошки } \\
\end{array}$ \\
\hline Струменевий & $\begin{array}{l}\text { Струменевий тривимірний друк } \\
\text { (3DP) }\end{array}$ & $\begin{array}{l}\text { Гіпс, пластики, металеві } \\
\text { порошки, піщані суміші }\end{array}$ \\
\hline Ламінування & $\begin{array}{c}\text { Викготолвення об’єктів методом } \\
\text { ламінування (LOM) }\end{array}$ & $\begin{array}{l}\text { Папір, металева фольга, } \\
\text { пластикова плівка }\end{array}$ \\
\hline \multirow[b]{2}{*}{ Полімеризація } & Стереолітографія (SLA) & Фотополімери \\
\hline & $\begin{array}{l}\text { Цифрова світлодіодна проекція } \\
\text { (DLP) }\end{array}$ & Фотополімери \\
\hline
\end{tabular}

Оскільки представлені в таблиці методи друку суттєво відрізняються по принципам, що лежать в їх основі, умовам застосовності, матеріалами, формою i функціональним призначенням виробів, одержуваних 3 їх допомогою, варто вивчати кожен з методів окремо. 
Одним із найбільш поширених та затребуваних у високоточному виробництві, що спеціалізується на виготовлені виробів із точністю до 0,015мм, $\epsilon$ метод полімеризації, який використовує фотополімери для різних сфер промисловості. Вивчення цього методу є доцільним та актуальним, оскільки на сьогоднійшній день існує велика потреба у фахівцях IT-галузі, що здатні програмувати обладнання для виготовлення високоточних прототипів.

Стереолітографія (SLA) - технологія адитивного виробництва виробів 3 рідких фотополімерних смол. Термін «стереолітографія» був придуманий в 1986 році Чарльзом В. Халлом, який запатентував метод і апарат для виробництва твердих фізичних об'єктів за рахунок послідовного нашарування фотополімерного матеріалу. Патент Халла описував застосування ультрафіолетового лазера, що проектується на поверхню ємності, яка заповнена рідким фотополімером. Опромінення лазером призводить до затвердіння матеріалу в точці дотику з променем, що дозволяє викреслювати контури заданої моделі шар за шаром [7].

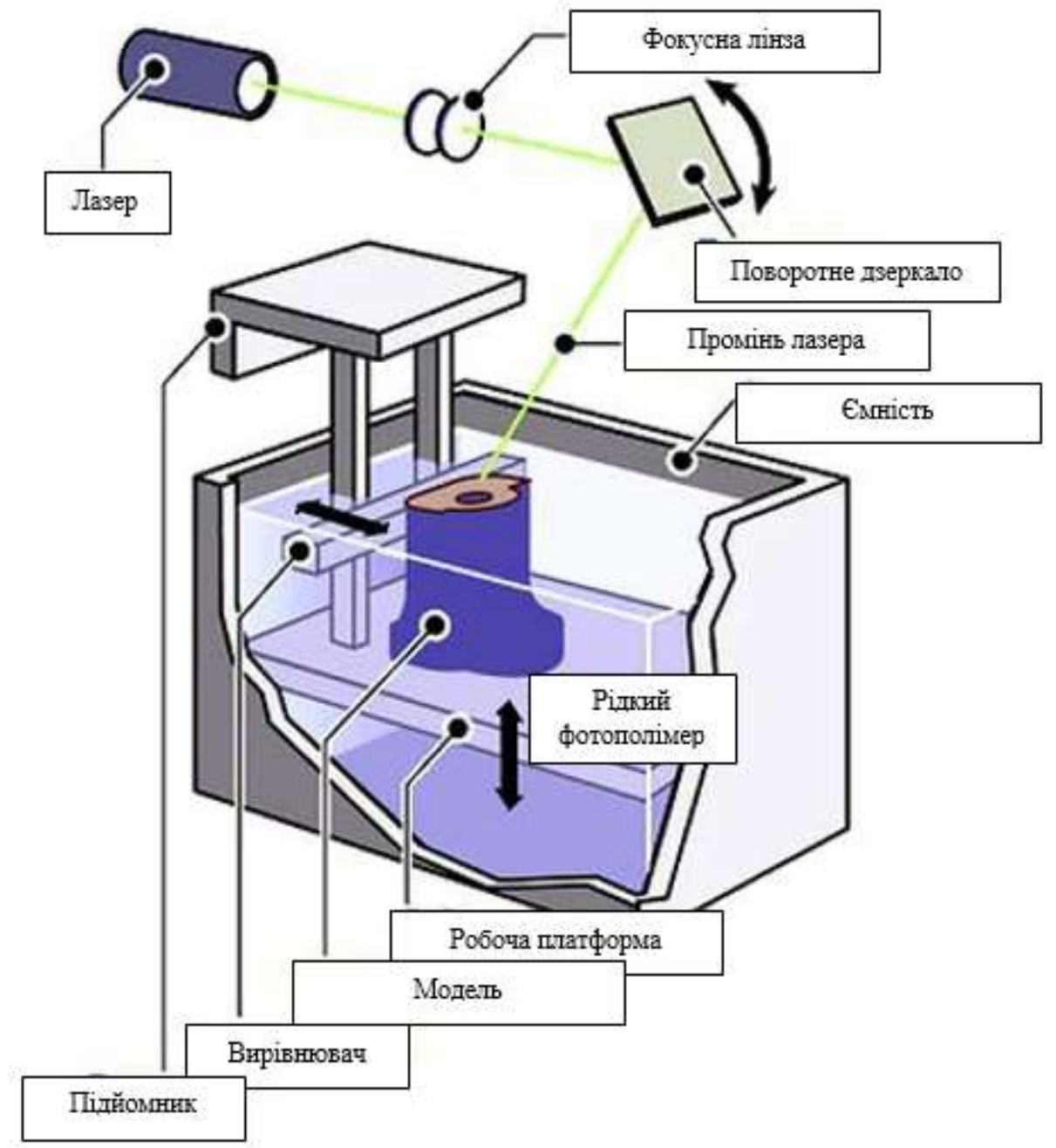

Рис.1. Принцип роботи принтера методом стереолітографії

У 1986 році Халл заснував власну компанію, 3D-Systems, для комерційного просування нової технології. На сьогоднішній день 3D Systems $є$ одним зі світових лідерів серед компаній - розробників і постачальників технологій адитивного виробництва, а технологія стереолітографії $\epsilon$ першою 
запатентованою і отримала комерційне поширення технології тривимірного друку.
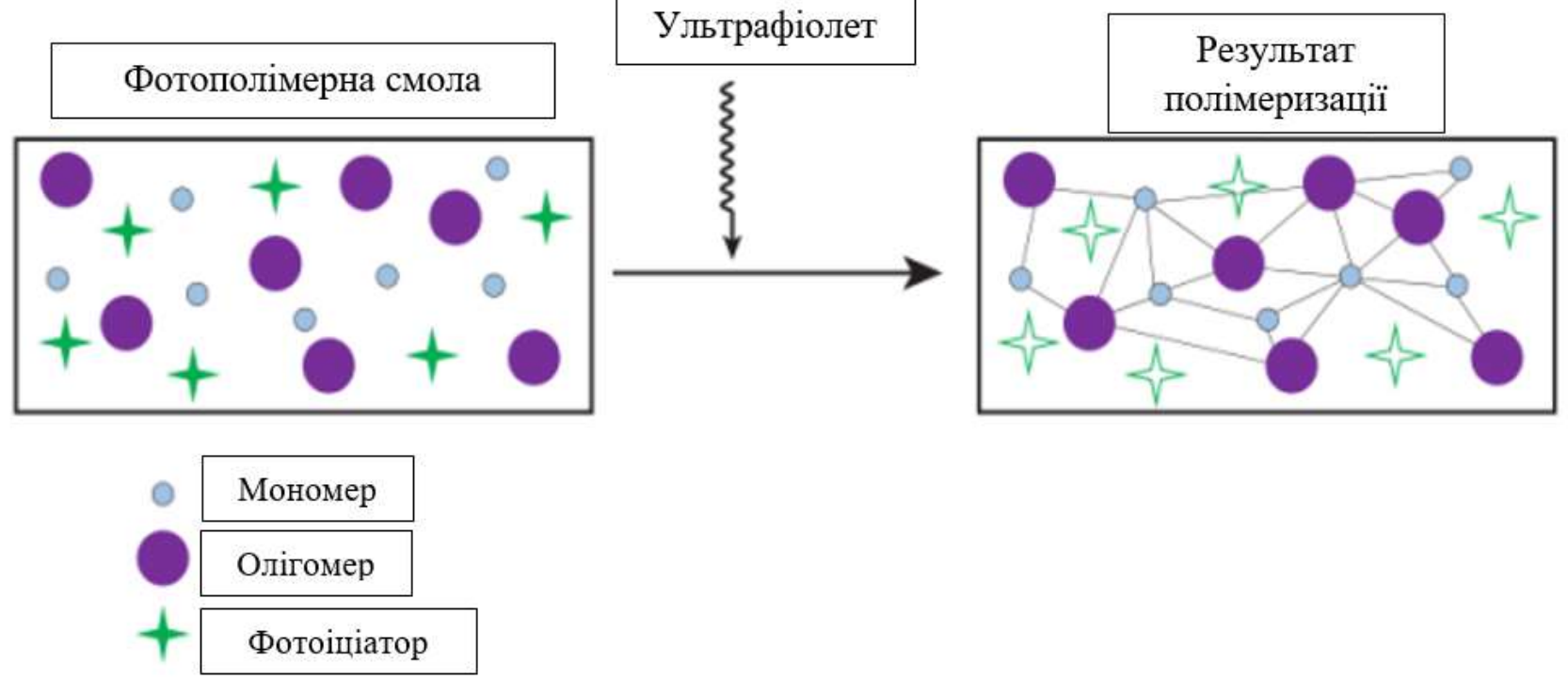

Рис. 2. Схема процесу фотополімеризації

Метод заснований на ефекті фотополімеризації мономерів і олігомерів під дією випромінювання. Розрізняють два основних види фотополімеризації: радикальну і іонну.

Радикальна полімеризація - це процес утворення полімера, коли стадії ініціювання та зростання ланцюга протікають за участю радикалів. Оскільки одним 3 основних способів отримання вільних радикалів є фотоініційована дисоціація, то відповідно фотоініційована полімеризація мономерів і олігомерів, або просто фотополімеризація, $\epsilon$ однією 3 основних різновидів радикальної полімеризації як у виробничих технологіях, так і при проведенні наукових експериментів.

Залежно від типу іона виділяють аніонну і катіонну полімеризації. Катіонна полімеризація є різновидом іонної полімеризації, яка пояснює, що ланцюгова реакція ініціюється взаємодією іона 3 реакційною групою мономерів або олігомерів.

Більш досліджені і більш широко використовуються фотоініціатори, а саме катіонні ініціатори. Оскільки при фотодисоціації відомих іонних ініціаторів утворюється активний катіон i малоактивний аніон, то під іонною фотополімеризацією розуміється катіонна фотоініційована полімеризація. Найбільш широке застосування в $3 \mathrm{D}$-друці знаходить саме катіонна фотополімеризація.

Побудова моделі методом стереолітографії проводиться шар за шаром. Кожен шар викреслюється лазером згідно із заданими параметрами тривимірної цифрової моделі. Опромінення лазером призводить до полімеризації матеріалу в точках дотику з променем.

По завершенні побудови контуру робоча платформа занурюється в бак 3 рідкою смолою на відстань, рівну товщині одного шару. Після вирівнювання поверхні рідкого матеріалу починається процес побудови наступного шару. 
Цикл повторюється до побудови повної моделі. Після завершення друку вироби промиваються для видалення залишкового матеріалу і при необхідності піддаються обробці в ультрафіолетовій печі до повного затвердіння фотополімеру.

Стереолітографія потребує використання підтримок для побудови навісних елементів моделі, аналогічно технології моделювання методом пошарового наплавления (FDM).

Опори передбачаються в файлі, що містить цифрову модель, і виконуються 3 того ж фотополімерного матеріалу. По суті, опори $є$ тимчасовими елементами конструкції, що видаляються вручну після завершення процесу виготовлення.

Головною перевагою стереолітографії можна вважати високу точність друку. Існуюча технологія дозволяє наносити шари товщиною 15 мікрон, що в кілька разів менше товщини людської волосини. Точність виготовлення досить висока для застосування у виробництві прототипів стоматологічних протезів i ювелірних виробів.

Швидкість друку відносно висока, якщо враховувати високу роздільну здатність подібних пристроїв: час побудови однієї моделі може становити лише кілька годин. Готові вироби можуть мати різні механічні властивості в залежності від закладених характеристик фотополімеру.

Стереолітографія дозволяє створювати деталі високої складності, але часто має високу вартість за рахунок високої ціни витратних матеріалів. Висока популярність технології сприяє розробці більш доступних моделей, таких, як FORM 1 від компанії Forml АБС або Pegasus Touch від компанії FSL3D.

У 2011 році у Віденському Технологічному Університеті був представлений компактний i відносно недорогий 3D-принтер, що працює за технологією стереолітографії. Маса представленого принтера склала 1,5 кг, а вартість приблизно 1200 євро.

Одна 3 переваг 3D-друку методом стереолітографії - швидкість. Об'єкти формуються протягом дня, хоча окремі моделі з особливо складною геометрією можуть вирощуватися до декількох днів.

Отже, у майбутніх кваліфікованих робітників IT-сфери компетентності в галузі 3D-моделювання та 3D-друку у процесі професійної підготовки за допомогою програмного забезпечення, що моделює технологічний процес, потрібно постійно вдосконалювати. Для забезпечення формування зазначеної компетентності та, як наслідок, підвищення конкурентоспроможності майбутніх кваліфікованих робітників IT-сфери на ринку праці необхідно постійно розвиватись у сфері основ 3D-друку.

\section{Література}

1. Доступная 3D-печать для науки, образования и устойчивого развития / Э. Канесса, К. Фонда, М. Зеннаро. Международный центр теоретической физики Абдус Салам. 2013. 191 с.

2. Зленко М.А. Нагайцев М.В., Довбыш В.М. Аддитивные технологии в машиностроении // пособие для инженеров. М. ГНЦ РФ ФГУП «НАМИ» 2015. $220 \mathrm{c}$. 
3. История и технологии трехмерной печати / Н.В. Кушнир, А.В. Кушнир, А.М. Геращенко, А.В. Тыртышный // Научные труды КубГТУ. Краснодар: №5. 2015.

4. Применение 3D-принтеров в машиностроении. URL: http:// www.printcad.ru/primeneniya-3d-printerov/mashinostroenie.html.

5. Barnatt C. 3D-Printing: Second Edition / CreateSpace Independent Publishing Platform. 2014. 306 p.

6. Hausman K. 3D-Printing For Dummies / For Dummies. 2014. 384 p.

7. Larson H. Fabricated: The New World of 3D-Printing / H. Larson, M. Kurman - Wiley. 2013. 280 p. 


\title{
РОЛЬ ГЕОМЕТРІЇ ТІЛА, ЩО НАГРІВАЕТЬСЯ, ГРАНИЧНИХ УМОВ ТА ФІЗИЧНИХ ВЛАСТИВОСТЕЙ МАТЕРІАЛУ, ЯКИЙ ПРИЙМАС УЧАСТЬ У ПРОЦЕСАХ ТЕПЛООБМІНУ
}

\author{
Човнюк Ю.В. \\ к.т.н., доц. кафедри конструювання машин і обладнання \\ Національний університет біоресурсів і природокористування України \\ Москвітіна A.C. \\ асистент кафедри теплогазопостачання і вентиляція \\ Київський національний університет будівництва і архітектури \\ Пефтєва I.O. \\ асистент кафедри теплогазопостачання і вентиляція \\ Київський національний університет будівництва і архітектури
}

Щоб виділити й розв'язати задачу теплопередачі у процесі теплообміну матеріалу з теплообмінним апаратом, необхідно визначити геометричні границі тіла, обрати граничні умови й точно охарактеризувати фізичні властивості матеріалу.

1. Найбільш розповсюдженою граничною умовою, котра найчастіше зустрічається, $є$ постійна температура поверхні контакту. Узагальнює цю умову задана температура поверхні, котра може бути подана деякою функцією часу $T(0, t)$. Подібна гранична умова може бути отримана при контакті з поверхнею, температура котрої регулюється, чи при контакті з газоподібним середовищем, котре має великий коефіцієнт тепловіддачі [1,2].

2. Умова «задана тепловіддача на поверхні» математично формулюється так:

$$
h \cdot\left\{T_{a}(t)-T(0, t)\right\}=-k \cdot \frac{\partial}{\partial x} T(0, t),
$$

де, $T_{a}(t)$ - температура оточуючого середовища; $h$ - коефіцієнт тепловіддачі; $k$-коефіцієнт теплопровідності, $T(0, t)$ - температура поверхні $(x=0)$, яка взаємодії з тепловим полем оточуючого середовища.

3. Умова «заданого теплового потоку». Ця умова суттєва при виділенні тепла на контактних поверхнях. До цього ж виду можна віднести радіаційне нагрівання 3 певною інтенсивністю, а також конвективне нагрівання, котрі слабко залежать від температури поверхні. Й, насамкінець, іноді необхідно враховувати труднощі, пов'язані зі значною нелінійністю граничних умов типу «задане поверхневе випромінювання». Поверхня непрозорої речовини радіації (чи поглинання), при температурі $T_{r}$, випромінює/поглинає тепловий потік:

$$
\sigma \cdot F \cdot\left[T_{r}^{4}-T^{4}(0, t)\right] h=-k \cdot \frac{\partial}{\partial x} T(0, t)
$$


де, $\sigma=5,6697 \cdot 10^{-8} \frac{\text { Вт }}{\left(\mathrm{m}^{2}\right) \cdot\left({ }^{\circ} \mathrm{K}\right)^{4}}-$ постійна у рівнянні променевипромінювання Стефана-Больцмана; $F$ - сумарний коефіцієнт променевипромінювання та форми. Якщо $T_{r} \gg T$, гранична умова (2) зводиться до умови заданого теплового потоку.

Перелік відомих розв'язків, що застосовуються при вирішенні конкретних задач теплообміну.

Для тіл різної геометрії дається розподіл температури і вказані початкові та граничні умови [3]. (Фізичні властивості тіла постійні - $h, k, a)$.

1. Напівобмежене тверде тіло. $T=T(x, t)$ - температура.

1a. $\frac{T-T_{1}}{T_{0}-T_{1}}=\operatorname{erf}\left(\frac{x}{\sqrt{4 a t}}\right)$

$x$ - просторова, $t$ - часова координати.

Початкова умова: $T(x, 0)=T_{0}$;

Граничні умови: 1) $\left.T(0, t)=T_{1} ; 2\right) T(\infty, t)=T_{0}$;

Тут функція $\operatorname{erf}(z)=\frac{2}{\pi} \cdot \int_{0}^{z} \exp \left(-s^{2}\right) d s$.

a- коефіціснт температуропровідності.

$$
\text { 16. } T-T_{0}=\frac{q_{0}}{k} \cdot \sqrt{4 a t} \cdot \operatorname{erfc}\left\{\frac{x}{\sqrt{4 \alpha t}}\right\},
$$

Початкова умова: $T(x, 0)=T_{0}$;

Граничні умови: 1) $\left.T(\infty, t)=T_{0} ; 2\right)-\left.k \cdot \frac{\partial T}{\partial x}\right|_{x=0}=q_{0}$,

де $\operatorname{erfc}(z)=1-\operatorname{erf}(z)=1-\frac{2}{\sqrt{\pi}} \int_{0}^{z} \exp \left(-s^{2}\right) d s$;

$q_{0}$ - тепловий потік на поверхні $\mathrm{x}=0 ; k-$ коефіцієнт теплопровідності; $\mathrm{a}-$ коефіцієнт температуропровідності.

2. Плоска пластина товщиною $2 b$.

Розв'язок задачі 2а,б (рис.1): $T=T(x, t)$.

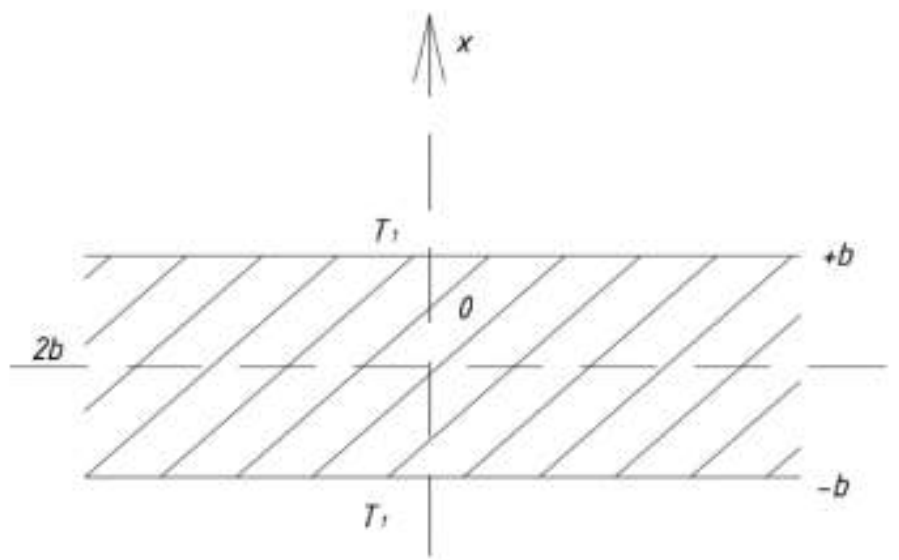

Рис. 1. Плоска площина в розрахунковій системі координат.

2а. Початкова умова: $T(x, 0)=T_{0}$;

Граничні умови: 1) $\left.T(+b, t)=T_{1} ; 2\right) T(-b, t)=T_{1}$.

Розв'язок задачі $2 \mathrm{a}: T=T(x, t)$

$$
\frac{T-T_{1}}{T_{1}-T_{0}}=2 \sum_{n=0}^{\infty} \frac{(-1)^{n}}{\left(n+\frac{1}{2}\right) \cdot \pi} \exp \left\{-\left(n+\frac{1}{2}\right)^{2} \cdot \frac{\pi^{2} \cdot \alpha t}{b^{2}}\right\} \cos \left[\left(n+\frac{1}{2}\right) \cdot \pi \cdot \frac{x}{b}\right]
$$


Розв'язок задачі 2б: $T=T(x, t)$

2б. Початкова умова: $T(x, 0)=T_{0}$;

Граничні умови: $-\left.\frac{\partial T}{\partial x}\right|_{x=-b}=\frac{h}{b} \cdot\left[T_{1}-T(-b)\right] ;-\left.\frac{\partial T}{\partial x}\right|_{x=b}=\frac{h}{b} \cdot\left[T(b)-T_{1}\right]$,

де, $h$ - коефіцієнт тепловіддачі поверхонь пластини $x= \pm b ; k$ - коефіцієнт теплопровідності.

Розв'язок 2б:

$$
\frac{T_{1}-T}{T_{1}-T_{0}}=\sum_{n=1}^{\infty} \frac{2 \cdot\left(\frac{h b}{k}\right) \cdot \cos \left\{\beta_{n}\left(\frac{x}{b}\right)\right\} \cdot \exp \left\{-\frac{\beta_{n}^{2} \cdot \alpha \cdot t}{b^{2}}\right\}}{\left[\beta_{n}^{2}+\frac{h b}{k}+\left(\frac{h b}{k}\right)^{2}\right] \cdot \cos \beta_{n}},
$$

де власні числа $\beta_{n}$ знаходимо з трансцендентного рівняння $\beta_{n} \cdot \operatorname{tg}\left(\beta_{n}\right)=\frac{h b}{k}$.

3. $\quad$ Циліндр радіусу $R$ (нескінченний по довжині) (рис.2).

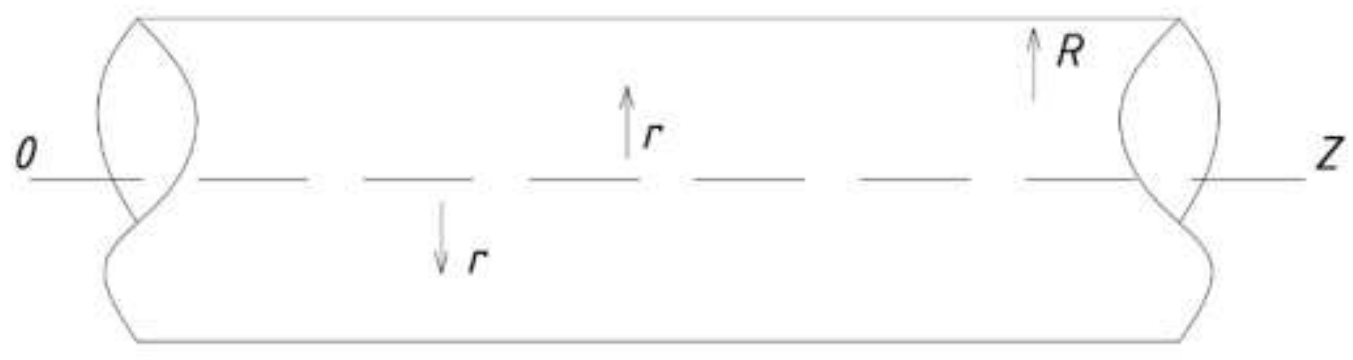

Рис.2. Циліндр радіусу R в розрахунковій системі координат.

$(r$ - поточний радіус у поперечному перерізі; відраховується від осі циліндра $(0 Z))$

3а. Початкова умова: $T(r, 0)=T_{0}$;

Граничні умови: $T(R, t)=T_{1}$.

Розв'язок $T=T(r, t)$ :

$$
\frac{T_{1}-T}{T_{1}-T_{0}}=\frac{2}{R} \cdot \sum_{n=1}^{\infty} \frac{I_{0}\left(r \cdot c_{n}\right)}{c_{n} \cdot I_{1}\left(R \cdot c_{n}\right)} \exp \left(-a \cdot c_{n}^{2} \cdot t\right),
$$

де, $a$ - коефіцієнт температуропровідності; $I_{0}, I_{1}-$ функції Бесселя нульового і першого порядку від дійсного аргументу (табульовані); власні числа $c_{n}$ знаходимо з трансцендентного рівняння:

3б. Початкова умова: $T(r, 0)=T_{0}$;

$$
I_{0}\left(R \cdot c_{n}\right)=0
$$

Граничні умови: $-\left.k \cdot\left(\frac{\partial T}{\partial r}\right)\right|_{r=R}=h \cdot\left[T(R)-T_{1}\right]$;

де, $h$ - коефіцієнт тепловіддачі поверхонь пластини $x= \pm b ; k$ - коефіцієнт теплопровідності.

Розв'язок $T=T(r, t)$ :

$$
\frac{T_{1}-T}{T_{0}-T_{1}}=\frac{2}{R} \cdot \sum_{n=1}^{\infty} \exp \left(-\alpha \cdot \beta_{n}^{2} \cdot t\right) \frac{\left(\frac{h}{k}\right) I_{0}\left(r \cdot \beta_{n}\right)}{\left[\left(\frac{h}{k}\right)^{2}+\beta_{n}^{2}\right] I_{0}\left(R \cdot \beta_{n}\right)} ;
$$


де, $a$ - коефіцієнт температуропровідності; власні числа $\beta_{n}$ знаходимо 3 трансцендентного рівняння:

$$
\beta_{n} \cdot I_{0}\left(R \cdot \beta_{n}\right)+\frac{h}{k} \cdot I_{0}\left(R \cdot \beta_{n}\right)=0
$$

Розв'язок задачі теплообміну для напівобмеженого твердого тіла 3 постійними теплофізичними властивостями й стрибкоподібними змінами температури поверхні (точний розв'язок). (Одновимірна задача нестаціонарної теплопровідності).

Постановка задачі. Нехай деяке напівобмежене тверде тіло 3 постійними теплофізичними властивостями змінює температуру своєї поверхні $(x=0)$ стрибкоподібно (миттєво). Первісна (щодо тіла) температура була $T_{0}$, а у момент часу $t=0$ температура поверхні тіла миттєво зросла до $T_{1}$. У цьому полягає постановка одновимірної нестаціонарної задачі теплопровідності.

Параболічне диференціальне рівняння:

$$
\frac{\partial T}{\partial t}=\alpha \cdot \frac{\partial^{2} T}{\partial x^{2}}
$$

де, $a$ - коефіцієнт температуропровідності; $T(x, t)$ - температура тіла. Рівняння слід розв'язувати при наступних початкових і граничних умовах:

$$
T(x, 0)=T(\infty, t)=T_{0} ; T(0, t)=T_{1}
$$

Введемо нову змінну $\eta$, яка об'єднує дві незалежні змінні $x$ та $t$ :

$$
\eta=C x \cdot t_{m}
$$

де, $C, m$ - константи, які слід у подальшому визначити.

Такий підхід, таке перетворення змінних (4) випливає із загальних методів подібних розв'язків. Термін «подібний» передбачає, що профілі змінної $T=$ $T(x, t)$ (при різних значеннях $x$ ) відрізняються тільки за масштабом. Усі різні профілі можна звести до однісї загальної кривої, змінюючи масштаб впродовж вісі ординат. Задачі, у котрих відсутня «характеристична довжина» зазвичай вдається розв'язати саме цим методом [4].

Тоді рівняння (3) можна звести до виду:

$$
m \cdot \eta \cdot \frac{d T}{d \eta}=\alpha \cdot C^{2} \cdot t^{2 m+1} \cdot \frac{d^{2} T}{d \eta^{2}}
$$

Рівняння (6) не залежить від $t$, якщо $2 m+1=0$, або $m=-1 / 2$. Тому можна отримати рівняння у звичайних похідних:

$$
\frac{d^{2} T}{d \eta^{2}}+\frac{1}{2 \alpha C^{2}} \cdot \eta \cdot \frac{d T}{d \eta}=0
$$

Поклавши $C=\frac{1}{\sqrt{4 \alpha}}$, спростимо рівняння (7):

$$
\frac{d^{2} T}{d \eta^{2}}+2 \eta \cdot \frac{d T}{d \eta}=0
$$

Рівняння (8) легко розв'язати при веденні допоміжної змінної $y=\frac{d T}{d y}$. Результуючий розподіл температури буде мати вид: 


$$
T=C_{1} \cdot \frac{\sqrt{\pi}}{2} \cdot \operatorname{erf}(\eta)+C_{2}
$$

або:

$$
\eta=\frac{x}{(\sqrt{4 \alpha t})} T
$$

та $\operatorname{erf}(z)$ - добре відома функція помилок, яка визначається наступним чином:

$$
\operatorname{erf}(z)=\frac{2}{\sqrt{\pi}} \cdot \int_{0}^{z} \exp \left(-s^{2}\right) d s
$$

Константи $C_{1}$ та $C_{2}$ у (9) визначаються 3 граничних умов. Гранична умова $T(0, t)=T_{1}$ задовольняється, якщо $C_{2}=T_{1}$, тоді як 3 умов $T(x, 0)=T_{0}$ й $T(\infty, t)=T_{0}$ випливає, що $T=T_{0}$ при $\eta \rightarrow \infty$ (це прямий результат комбінації змінних), і це дає:

$$
C_{1}=2 \cdot \frac{\left(T_{0}-T_{1}\right)}{\sqrt{\pi}}
$$

Підставляючи отримані значення у рівняння (9), матимемо:

$$
\frac{T-T_{1}}{T_{0}-T_{1}}=\operatorname{erf}(\eta)
$$

Вираз (13) задовольняє як диференціальному рівнянню, так і граничним умовам, i, відповідно, є розв'язком задачі.

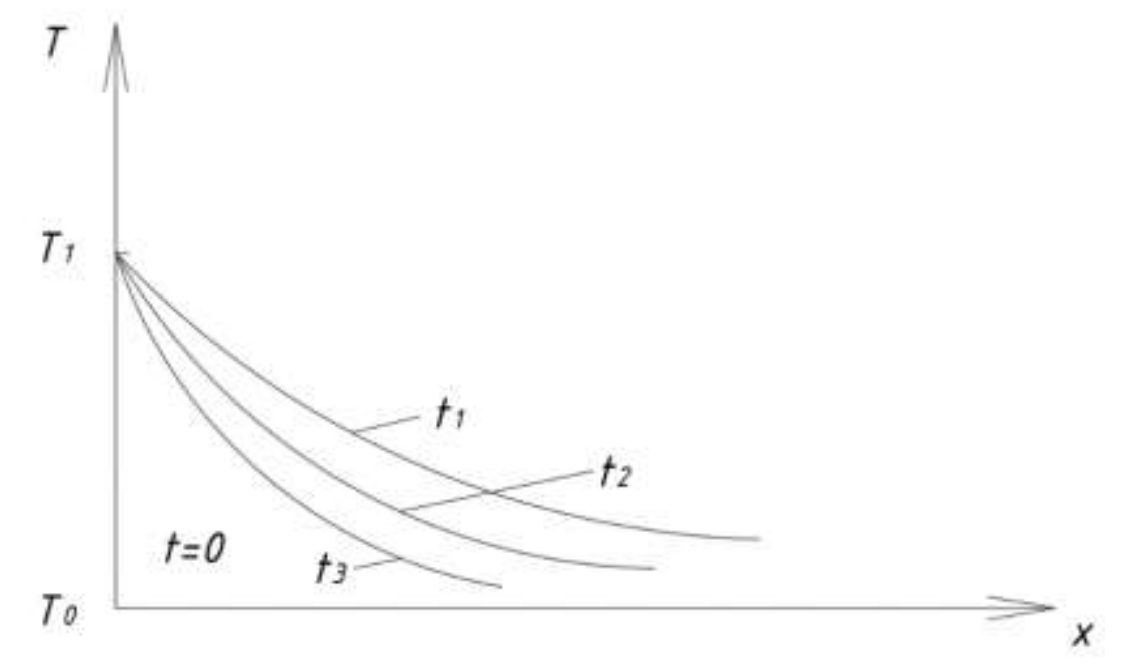

Рис.3. $T(x, t)$ Для напівобмеженого тіла: $t_{3}>t_{2}>t_{1}$.

Потік тепла всередину твердого тіла (наприклад, грунту) можна знайти, диференціюючи по $x$ рівняння (13) й використовуючи потім закон теплопровідності Фур'є:

$$
q_{x}=-\left.k \cdot \frac{\partial T}{\partial x}\right|_{x=0}=-\left.k \cdot\left[\frac{T_{0}-T_{1}}{\sqrt{\pi \alpha t}} \cdot \exp \left(-\eta^{2}\right)\right]\right|_{x=0}=\frac{k}{\sqrt{\pi \alpha t}} \cdot\left(T_{1}-T_{0}\right) .
$$

Отримана особлива безрозмірна комбінація головних змінних: відстані, часу та коефіцієнту температуропровідності у рівнянні (10). У результаті розподіл температри виявляється функцією єдиної безрозмірної $\eta$.

Графік залежності $T(x, t)$ поданий на рис.3. 
Напівобмежене тверде тіло зі змінними теплофізичними властивостями й стрибкоподібною зміною температури поверхні (наближений аналітичний розв'язок).

У попередній задачі було встановлено, що теплофізичні властивості матеріалу $\left(k, \rho, C_{p}\right)$, де $k$ - коефіцієнт теплопровідності, $\rho$ - щільність, $C_{p}$ - питома теплоємність матеріалу за постійного тиску $(p) \in$ постійними величинами, які не залежать від температури [4]. Однак це не так! У дійсності ці коефіцієнти залежать від температури $T$.

Тому диференціальне рівняння, яке описує $T(x, t)$ стає нелінійним. Відомі тільки кілька аналітичних розв'язків нелінійного рівняння теплопровідності, тому необхідно застосовувати чисельні методи розв'язку (метод скінченних різниць й метод скінченних елементів). Проте все ж існує певна кількість наближених аналітичних методів, включаючи інтегральний метод Гудмана [5]

Вихідне диференціальне рівняння, отримане зі звичайною, лінійною для $T(x, t)$, має вид:

$$
\rho \cdot C_{p} \cdot \frac{\partial T}{\partial t}=\frac{\partial}{\partial x}\left\{k \cdot \frac{\partial T}{\partial x}\right\}
$$

яке можна розв'язати для граничних умов: $T(x, 0)=T(\infty, t)=T_{0}$ та $T(0, t)=$ $T_{1}$. Введемо наступну процедуру для перетворення температури до безрозмірної форми:

$$
d \theta(x, t)=\rho \cdot C_{p} \cdot d T
$$

або інтегральної форми:

$$
d \theta(x, t)=\int_{T_{0}}^{T} \rho C_{p} d T .
$$

Змінна $\theta(x, t)$ - це приріст тепловмісту у одиниці об'єму для деяких значень $x$ й $t$. Підстановка (14) у (13) дає:

$$
\frac{\partial \theta}{\partial t}=\frac{\partial}{\partial x}\left\{\alpha(\theta) \cdot \frac{\partial \theta}{\partial x}\right\}
$$

де, $a(\theta)$ - коефіцієнт температуропровідності (його аналог).

Проінтегруємо рівняння (16) по $x$ від зовнішньої поверхні $(x=0)$ до деякої глибини $\delta(t)$, яку будемо вважати глибиною проникнення тепла (вона буде визначена пізніше) [6]. Глибина проникнення відображає часову залежність відстані до поверхні, на якій кількість тепла, що підведене, нескінченно мала величина, якою можна знехтувати:

$$
\int_{0}^{\delta} \frac{\partial \theta}{\partial t} d x=\int_{0}^{\delta}\left[\frac{\partial}{\partial x}\left\{\alpha(\theta) \cdot \frac{\partial \theta}{\partial x}\right\}\right] d x
$$

Застосуємо формулу Лейбніца, тоді для лівої частини рівняння (17):

$$
\frac{d}{d t} \int_{0}^{\delta} \theta d x-\theta(\delta, t) \cdot \frac{d \delta}{d t}=\int_{0}^{\delta} \frac{\partial \theta}{\partial t} d x
$$


Але $\theta(\delta, t)=0$, оскільки $\delta$ визначене як відстань, на яку тепло практично не проникає. Тоді права частина рівняння (17) виявляється рівною:

Звідси рівняння (17) можна переписати як:

$$
\frac{\partial}{\partial x}\left\{\alpha(\theta) \cdot \frac{\partial \theta}{\partial x}\right\}=-\left.\left[\alpha \cdot \frac{\partial \theta}{\partial x}\right]\right|_{x=0},
$$

$$
\frac{d}{d t} \int_{0}^{\delta} \theta d x=-\left.\left[\alpha \cdot \frac{\partial \theta}{\partial x}\right]\right|_{x=0},
$$

Перевага перетворення Гудмана тепер стає очевидною, залежні від температури теплофізичні властивості входять у проінтегроване диференціальне рівняння тільки при постійній температурі поверхні $T_{1}$. Зміна цих властивостей 3 температурою проявляє себе у граничних умовах для $\theta(x, t)$ :

$$
\theta(0, t)=\theta_{1}=\int_{T_{0}}^{T} \rho C_{p} d T .
$$

Обидві граничні умови $T(x, 0)=T_{0} \quad$ та $T(\infty, t)=T_{1} \quad$ враховуються припущенням часової залежності скінченної глибини проникнення тепла. Далі припустимо, що «Температурний профіль», котрий задовольняє граничним умовам:

має вид:

$$
\theta(0, t)=\theta_{1}, \quad \theta(x, \delta)=0,\left.\quad\left(\frac{\partial \theta}{\partial x}\right)\right|_{x=\delta}=0
$$

$$
\theta=\theta_{1}(1-x / \delta)^{3}
$$

Підстановкою виразу (23) у (20) матимемо залежність $\delta$ від часу:

де, $\alpha_{1}-$ значення $\alpha$ при $T_{1}$.

$$
\delta=\sqrt{24 \alpha_{1} t}
$$

3 рівняння (23) маємо:

$$
\theta=\theta_{1}\left(1-\frac{x}{\sqrt{24 \alpha_{1} t}}\right)^{3} .
$$

Температурний профіль для будь-якого заданого моменту часу можна отримати, підраховуючи $\theta$ для різних значень $x(0<x<\delta)$ і користуючись рівнянням (15) для визначення відповідних температур. Останнє, зрозуміло, вимагає значення даних про температурну залежність $\rho \cdot C_{p}$.

Для постійних теплофізичних властивостей рівняння (25) зводиться до виду:

Тепловий потік при $x=0$ дорівнює:

$$
\frac{T-T_{1}}{T_{1}-T_{0}}=\left(1-\frac{x}{\sqrt{24 \alpha t}}\right)^{3} .
$$

$$
q_{x}=\frac{k}{\sqrt{(8 / 3) \alpha t}} \cdot\left(T_{1}-T_{0}\right) .
$$

Порівняння цього результату (15) з точним розв'язком , отриманим для $q_{x} \mathrm{y}$ випадку постійних (не залежних від $T$ ) значень теплофізичних параметрів тіла, показує, що різниця між двома методами розв'язку незначна. Ця різниця 
залежить від вибору пробної функції, і у даному випадку результати відрізняються лише на $8 \%$.

\section{Список літератури:}

1. Лабай В.Й. Тепломасообмін. - Львів: Тріада Плюс, 1998. - 260

2. Константінов С. М. Тепломасообмін: Підручник. - К.:ВП1 ВПК "Політехніка": Інрес, 2005. - 304 с.: іл.

3. Исаченко В.П., Осипова В.А., Сукомел А С. Теплопередача. - М.: Энергия, 1981.- 416c.

4. Лыков А.В. Теория теплопроводности.-М.: Высшая школа. 1967 - 600с.

5. Goodman T.R. Applikation of Integral Methods for Transient Nonlinear "Heat Trausfer. - In: "Advances in Heat Transfer", vol.1. T.F. Irvine, Ir. And J.P. Hartnett, eds. New York Academic Press, 1964. P. 51-122.

6. Джеффрис Г., Свирлс Б. Методы математической физики. М.: Мир, 1969. Вып. 1. 424c.; Вып. 2. 1970. 352с.; Вып. 3. 1970. 344c. 


\section{К ОПРЕДЕЛЕНИЮ АКТИВНОГО ДАСЛЕНИЯ НА ОГРАЖДАЮЩИЕ КОНСТРУКЦИИ УЧЕТОМ ФИЗИЧЕСКОЙ НЕЛИНЕЙНОСТИ ПРОЧНОСТНЫХ СВОЙСТВ ГРУНТА}

Шаповал Владимир Григорьевич, Доктор технических наук, профессор National Technical University Dnipro Polytechnic, Dnipro

Скобенко Александр Васильевич, Кандидат технических наук, доцент National Technical University Dnipro Polytechnic, Dnipro

Пономаренко Иван Александрович, Инженер

Cherkasy State Technological University, Cherkassy, Ukraine

Разрушение удерживающих конструкций (в частности, подпорных стен), к сожалению, обычное явление [1].

Это обусловлено либо нарушением технологии проведения земляных работ, либо несоблюдением правил эксплуатации данных конструкций, либо неправильной оценкой активного давления на конструкцию со стороны грунта.

Одной из причин неправильного определения активного давления (т.е. давления грунта на ограждающую конструкцию) является игнорирование физической нелинейности прочностных свойств грунта.

Так, согласно современным представлениям, зависимость прочности от вертикального давления на глинистый грунт имеет вид нелинейной кривой (ее также называют огибающей Мора).

При этом для определения давления грунта на удерживающие конструкции в настоящее время используют линейный критерий прочности Кулона - Мора [2, $3]$.

Это, в свою очередь, приводит к некорректному учету прочностных свойств грунта и, как следствие, неправильному определению активного давления.

Для иллюстрации сказанного найдем активное давление на ограждающую конструкцию (точнее, вертикальную подпорную стенку) без учета и при учете и без учета нелинейной зависимости прочностных свойств грунта от нормального давления.

В качестве исходных данных примем полученные авторами работы [4] в ходе определения прочности суглинистого грунта результаты:

1. При использовании критерия прочности Кулона-Мора [2, 4]:

$$
\tau_{\kappa}=\sigma \cdot \operatorname{tg}\left(\varphi_{\kappa}\right)+c_{\kappa}=\sigma \cdot 0,4969+0,0576 .
$$

2. При использовании полиномиального критерия прочности грунта [4]: 


$$
\tau_{n}=a_{0}+a_{1} \cdot \sigma+a_{2} \cdot \sigma^{2}=0,023+0,7044 \cdot \sigma-0,2594 \cdot \sigma^{2} .
$$

Здесь: $\tau_{\kappa}$ и $\tau_{n}$ - разрушающее касательное напряжение в рамках критериев прочности Кулона-Мора и полиномиального соответственно; $\sigma$ - то же, нормальное; $\operatorname{tg}\left(\varphi_{\kappa}\right)=0,4969$ - тангенс угла внутреннего трения в рамках критерия прочности Кулона-Мора $\left(\varphi_{\kappa}=26,42^{0}\right) ; c_{\kappa}=0,0576$ МПа - удельное сцепление в рамках критерия прочности Кулона-Мора; $a_{0}=0,023 \mathrm{MПа;} a_{1}=$ 0,$7044 ; a_{2}=-0,2594 \frac{1}{M П a}$ - материальные константы полиномиального критерия прочности.

При проведении численного эксперимента был принят удельный вес грунта $\gamma=20 \frac{\kappa H}{\mu^{3}}=0,02 \frac{M H}{\mu^{3}}$ и представленные в формулах (1) и (2) материальные константы, а для определения активного давления была использована известная формула:

$$
\sigma_{a}=\left\{\begin{array}{c}
0-n p u \quad z \leq h_{k p}=\frac{2 \cdot c \cdot \cos (\varphi)}{\gamma \cdot[1-\sin (\varphi)]} \\
\gamma \cdot z \cdot \operatorname{tg}^{2}\left(\frac{\pi}{4}-\frac{\varphi}{2}\right)-2 \cdot c \cdot \operatorname{tg}\left(\frac{\pi}{4}-\frac{\varphi}{2}\right)-n p u \quad z>h_{k p}
\end{array} .\right.
$$

где $z$ - глубина от верха засыпки; $\sigma_{a}$ - активное давление на удерживающую конструкцию; $h_{k p}$ - критическая высота откоса.

Вначале найдем критическую высоту вертикального откоса и активное давление с использованием критерия прочности Кулона-Мора (1). Имеем:

$$
\sigma_{a, k}=\left\{\begin{array}{l}
0-\text { при } z \leq h_{k p, k}=\frac{2 \cdot c_{k} \cdot \cos \left(\varphi_{k}\right)}{\gamma \cdot\left[1-\sin \left(\varphi_{k}\right)\right]}=\frac{2 \cdot 0,0576 \cdot \cos \left(26,42^{0}\right)}{0,02 \cdot\left[1-\sin \left(26,42^{0}\right)\right]}=9,26 m ; \\
\gamma \cdot z \cdot \operatorname{tg}^{2}\left(\begin{array}{l}
\frac{\pi}{4}- \\
-\frac{\varphi_{k}}{2}
\end{array}\right)-2 \cdot c_{k} \cdot \operatorname{tg}\left(\begin{array}{l}
\frac{\pi}{4}- \\
-\frac{\varphi_{k}}{2}
\end{array}\right)=0,0077 \cdot z-0.0714-n p u \quad z>9,26 m . \text { (4) }
\end{array}\right.
$$

Здесь $\sigma_{a, k}$ - активное давление на удерживающую конструкцию, установленное в рамках критерия прочности Кулона - Мора.

Далее найдем критическую высоту вертикального откоса с использованием полиномиального критерия прочности (2). В этом случае входящие в формулу (3) угол внутреннего трения и удельное сцепление будут являться функциями нормального давления $\sigma$. Имеем: 


$$
\left.\begin{array}{l}
\sigma=\gamma \cdot z ; c_{n}=\tau_{n}-\frac{\partial \tau_{n}}{\partial \sigma} \cdot \sigma=a_{0}-a_{2} \cdot \sigma^{2}=0,23+0,000104 \cdot z^{2} ; \\
\varphi_{n}=\operatorname{arctg}\left(\frac{\partial \tau_{n}}{\partial \sigma}\right)=\operatorname{arctg}\left(a_{1}+2 \cdot a_{2} \cdot \sigma\right)=\operatorname{arctg}(0,7044-0.01038 \cdot z) .
\end{array}\right\}
$$

Для определения критической высоты $h_{k p, n}$ был использован процесс итерации в виде:

$$
\left.\begin{array}{c}
h_{k p n, 0}=0,0 \\
h_{k p n, i}=\frac{2 \cdot c_{k} \cdot \cos \left(\varphi_{n, i-1}\right)}{\gamma \cdot\left[1-\sin \left(\varphi_{n, i-1}\right)\right]} ; \\
\varphi_{n}=\operatorname{arctg}\left(a_{1}+2 \cdot a_{2} \cdot \sigma\right)=\operatorname{arctg}\left(a_{1}+2 \cdot a_{2} \cdot \gamma \cdot h_{k p n, i-1}\right) ; \\
c_{n}=a_{0}-a_{2} \cdot \sigma^{2}=0,023+0,2594 \cdot\left(h_{k p n, i-1}\right)^{2} .
\end{array}\right\}
$$

Здесь $h_{k p n}$ - значение критической высоты вертикального откоса, установленное в рамках полиномиального критерия прочности, а $i$ - номер итерации.

Оказалось, что в этом случае критическая высота вертикального откоса равна: $h_{k p n}=4,68$ метра, что приблизительно в два раза меньше критической высоты $h_{k p, k}=9,29$ метра, рассчитанной в рамках критерия Кулона - Мора.

С учетом формул (3), (5) и (6) активное давление на ограждающую конструкцию с учетом физической нелинейности грунта найдем в виде:

$$
\sigma_{a, n}=\left\{\begin{array}{l}
0-\text { при } z \leq h_{k p, k}=4,62 \mu ; \\
\gamma \cdot z \cdot \operatorname{tg}^{2}\left(\begin{array}{l}
\left.\frac{\pi}{4}-\right) \\
\left.-\frac{\varphi_{n}}{2}\right)
\end{array}\right)-2 \cdot c_{k} \cdot \operatorname{tg}\left(\begin{array}{l}
\frac{\pi}{4}- \\
\left.-\frac{\varphi_{n}}{2}\right)
\end{array}\right)-n p u \quad z>4,62 \mathrm{M} ; \\
\varphi_{n}=\operatorname{arctg}\left(\frac{\partial \tau_{n}}{\partial \sigma}\right)=\operatorname{arctg}\left(a_{1}+2 \cdot a_{2} \cdot \gamma \cdot z\right)=\operatorname{arctg}(0,7044-0,01038 \cdot \mathrm{z}) ; \\
c_{n}=\tau_{n}-\frac{\partial \tau_{n}}{\partial \sigma} \cdot \sigma=a_{0}-a_{2} \cdot \sigma^{2}=0,23+0,000104 \cdot \mathrm{z}^{2} .
\end{array}\right.
$$

В графической форме рассчитанные с использованием формул (4) и (7) эпюры активного давления представлены на рисунке 1. 


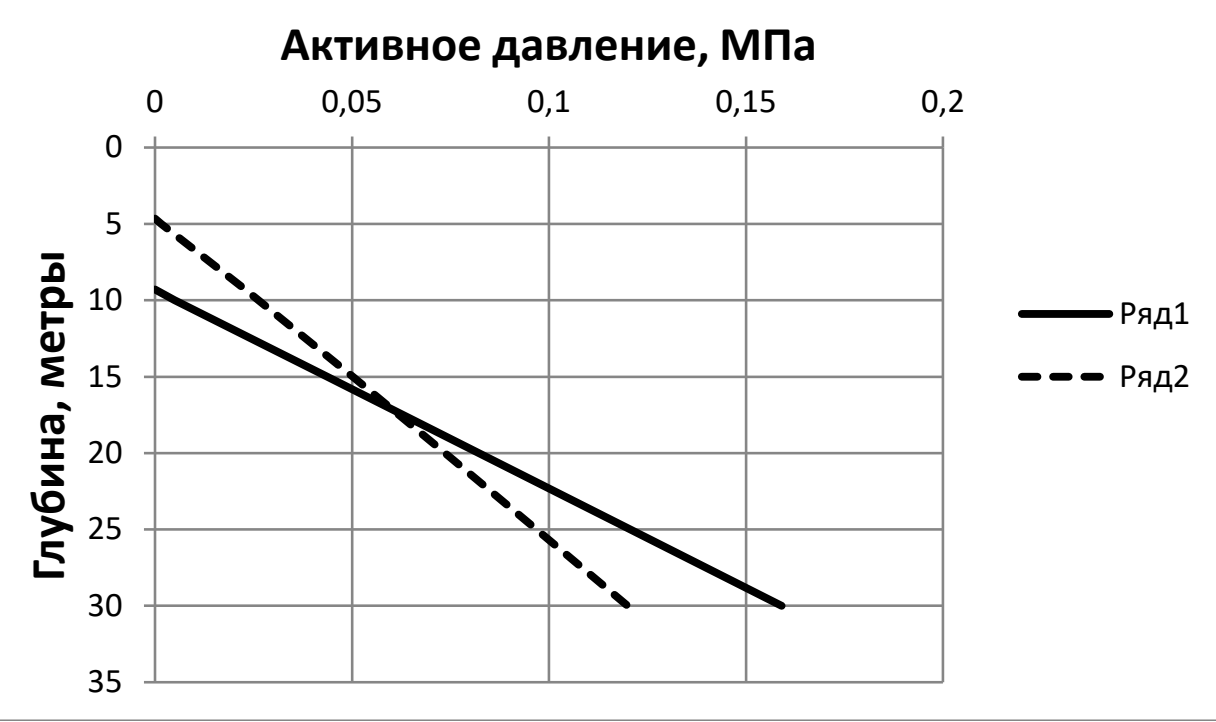

Рис. 1. Зависимости активного давления на ограждающую конструкцию от глубины.

Ряд 1 - активное давление рассчитано с использованием критерия прочности Кулона - Мора; ряд 2 - то же, с использованием полиномиального критерия прочности

Изложенные в настоящей работе материалы исследования позволили сделать такие выводы:

1. Рассчитаны значения активного давления на ограждающую конструкцию в рамках линейного критерия прочности Кулона - Мора и нелинейного полиномиального критерия прочности.

2. Оказалось, что неучет физической нелинейности прочностных свойств грунта на малых глубинах приводит занижению активного давления на удерживающие конструкции, а на больших - к завышению.

Этот факт необходимо учитывать при проектировании удерживающих конструкций.

\section{Список литературы}

1.http://bcrash.ru/?tag=\%D0\%BF\%D0\%BE\%D0\%B4\%D0\%BF\%D0\%BE\%D1\% $80 \% \mathrm{D} 0 \% \mathrm{BD} \% \mathrm{D} 0 \% \mathrm{~B} 0 \% \mathrm{D} 1 \% 8 \mathrm{~F}-$

\section{$\% \mathrm{D} 1 \% 81 \% \mathrm{D} 1 \% 82 \% \mathrm{D} 0 \% \mathrm{~B} 5 \% \mathrm{D} 0 \% \mathrm{BD} \% \mathrm{D} 0 \% \mathrm{BA} \% \mathrm{D} 0 \% \mathrm{~B} 0$}

2. Шаповал В.Г., Седин В.Л., Шаповал А.В., Моркляник Б.В., Андреев В.С. Механика грунтов. Учебник. Днепропетровск: Пороги, 2010- 168 с.

3. Зарецкий Ю.К. Нелинейная механика грунтов и перспективы ее развития // Основания, фундаменты и механика грунтов. - 1982. - N5. - C. 28-31.

4. Shapoval V., Protsenko P., Golovko S., Ponomarenko I. Anent the nonlinear dependence of the strength of loamy soil on normal pressure// Art and Science Multilingual scientific journal. Vol. 1 - 2021 - P. 16-25. 


\title{
ПОРІВНЯЛЬНА ЕФЕКТИВНІСТЬ ПРЕПАРАТІВ ЗА АСКАРОЗНО-ТРИХУРОЗНОÏ ІНВАЗІЇ
}

\author{
Антіпов Анатолій Анатолійович \\ Гончаренко Володимир Петрович, \\ Соловйова Людмила Миколаївна, \\ Авраменко Наталія Володимирівна, \\ Козій Наталія Володимирівна \\ кандидати ветеринарних наук, доценти \\ доценти кафедри паразитології та фармакології \\ Білоцерківський національний аграрний університет
}

Актуальність теми. Світова практика свідчить, що створення м'ясного балансу в країні неможливе без інтенсивного розвитку свинарства. Серед причин, що стримують іiі розвиток - паразитарні хвороби, які завдають значних економічних збитків.

Свиноматки, уражені гельмінтами, народжують ослаблений приплід. Крім того у них зменшується кількість новонароджених поросят. Великі втрати пов'язані із затримкою росту та зниженням маси тіла хворого молодняку. За даними багатьох вчених основними гельмінтозами свиней $\epsilon$ аскароз, езофагостомоз і трихуроз [1,2].

Численні наукові дослідження були присвячені розробці ефективних заходів боротьби з інвазійними хворобами свиней. Проте складна епізоотична ситуація щодо гельмінтозів у свинарських господарствах України свідчить про те, що ці проблеми є актуальними й нині. Становище ускладнюють зміни екологічних умов довкілля, які впливають на систему „паразит-хазяїн”. Тому традиційні способи лікування хворих тварин не приносять бажаного результату [3].

В умовах усіх типів ведення свинарства проблема лікування та профілактики паразитоценозів свиней досі залишається актуальною. За останні роки ефективність багатьох наявних антигельмінтиків різко знизилася внаслідок опірності паразитів до дії лікарських засобів [4].

Вибір того чи іншого препарату повинен бути пов'язаний з тим, чи відповідає він критерію вартість - ефективність.

Тому, вирішення проблем боротьби та профілактики 3 асоціативними інвазіями свиней, дослідження щодо вдосконалення вже існуючих та пошуку нових препаратів дозволить у найближчий час у значній мірі зменшити збитки, які наносяться свинарській галузі й дозволить одержати тваринницьку продукцію, вільну від отрутохімікатів.

Мета роботи полягала у вивченні антигельмінтної ефективності порошків бровадазолу $20 \%$ та фензолу $22 \%$ за аскарозно-трихурозної інвазії у свиней в умовах ФГ „Віктор” Смілянського району Черкаської області. 
Матеріали і методи дослідження. Роботу проводили в умовах ФГ „Віктор” Смілянського району Черкаської області та в лабораторії паразитології кафедри паразитології та фармакології Білоцерківського національного аграрного університету. Досліди по вивченню порівняльної ефективності дегельмінтизації свиней бровадазолом $20 \%$ та фензолом $22 \%$ в дозах згідно настанов провели в вересні-жовтні місяцях 2020 року на підсвинках 4-х місячного віку спонтанно інвазованих аскарисами та трихурисами.

3 метою підбору тварин для дослідів був проведений відбір проб фекалій. Для овоскопічних досліджень фекалії відбирали індивідуально з прямої кишки тварин в ранковий час. Проби фекалій від кожної тварини поміщали у поліетиленові пакети, на які були приклеєні етикетки 3 індивідуальними номерами тварин. Відібрані проби фекалій були досліджені в лабораторії паразитології кафедри паразитології та фармакології Білоцерківського національного аграрного університету комбінованим методом стандартизованим Г.О. Котельниковим та В.М. Хрєновим з використанням насиченого розчину гранульованої аміачної селітри з щільністю 1,3.

Для цього в скляний стаканчик клали 3 г фекалій і при помішуванні скляною паличкою додавали порціями воду до об'єму 50 мл. Суміш фільтрували через металеве сито з ячейками 0,5 х 0,5 мм в інший скляний стаканчик і залишали в спокою 5-6 хвилин. Потім верхній шар рідини зливали і залишали осад 3 надосадовою рідиною в такій кількості, щоб він вмістився у звичайну центрифужну пробірку. Осад добре сколочували, переливали у центрифужну пробірку і центрифугували 2 хвилини 3 швидкістю 1000 об/хв. Потім 3 центрифужної пробірки надосадову рідину зливали, а до осаду додавали розчин гранульованої аміачної селітри і вдруге центрифугували 2 хвилини при 1000 об/хв. Яйця що спливли на поверхню, знімали металічною петлею, струшували 3 краплі на предметне скло і мікроскопували при малому збільшенні мікроскопа.

За принципом аналогів сформували 3 групи свиней (одну контрольну та дві дослідні) по 15 голів у кожній. Підрахунок яєць гельмінтів проводили у середньому в трьох краплинах флотаційного розчину.

Усі групи тварин знаходились в однакових умовах годівлі та утримання. До введення препарату та через 12 діб після останнього застосування антигельмінтиків проводили копроскопічні дослідження. Тестами для обліку ефективності лікування були екстенс- та інтенсефективність (ЕE та IE).

Використання антигельмінтиків наведена у таблиці 1.

Таблиця 1.

\section{Використання антигельмінтиків за аскарозно-трихурозної інвазії свиней}

\begin{tabular}{|c|c|c|c|c|c|c|}
\hline $\begin{array}{c}\text { Групи } \\
\text { тварин }\end{array}$ & $\begin{array}{c}\text { Назва } \\
\text { прпарату }\end{array}$ & $\begin{array}{c}\text { Концент- } \\
\text { рація }\end{array}$ & $\begin{array}{c}\text { Форма } \\
\text { препарату }\end{array}$ & $\begin{array}{c}\text { Спосіб } \\
\text { введення }\end{array}$ & $\begin{array}{c}\text { Крат- } \\
\text { ність }\end{array}$ & $\begin{array}{c}\text { Доза по } \\
\text { лік. формі }\end{array}$ \\
\hline $\begin{array}{c}\text { Дослідна } \\
\text { перша }\end{array}$ & $\begin{array}{c}\text { Брова- } \\
\text { дазол }\end{array}$ & $20 \%$-ний & порошок & $\begin{array}{c}\text { груповим } \\
\text { з кормом }\end{array}$ & $\begin{array}{c}\text { дво- } \\
\text { разово }\end{array}$ & $\begin{array}{c}0,5 \text { г/10 кг } \\
\text { маси тіла }\end{array}$ \\
\hline друга & Фензол & $22 \%$-ний & порошок & $\begin{array}{c}\text { груповим } \\
\text { з кормом }\end{array}$ & $\begin{array}{c}\text { дво- } \\
\text { разово }\end{array}$ & $\begin{array}{c}1,5 \text { г/10 кг } \\
\text { маси тіла }\end{array}$ \\
\hline Контрольна & - & - & - & - & - & - \\
\hline
\end{tabular}


Як видно 3 таблиці 1 тваринам першої дослідної групи застосували мікрогранульований порошок бровадазолу $20 \%$ (рис. 1) у дозі 0,5 г на 10 кг маси тіла (по лікарській формі) або в дозі 0,01 г (по ДР) на кг маси тіла тварини.

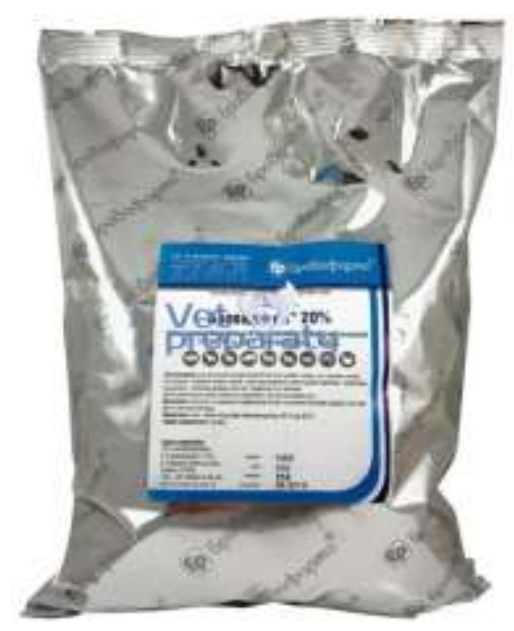

Рисунок 1. Зовнішній вигляд бровадазолу $20 \%$

Бровадазол 20 \% виготовляє ТОВ „Бровафарма” - найбільший в Україні виробник ветеринарних препаратів для лікування і профілактики захворювань тварин. 1 г препарату містить: фенбендазол - 200 мг і представляє собою порошок білого кольору, мікрогранульований, без запаху. Фенбендазол належить до групи бензимідазолів, який руйнує мікроканальці травних клітин i викликає нейротоксичний ефект у гельмінтів. Згубно діє на личинки різних стадій та порушує цілісність оболонок яєць гельмінтів, після чого вони не здатні далі розвиватися.

Тваринам другої дослідної групи використовували фензол 22 \% порошок (рис. 2) в дозі 0,033 г на 1 кг маси тіла по ДР (фенбендазол) або в дозі 1,5 г на 10 кг по лікарській формі.

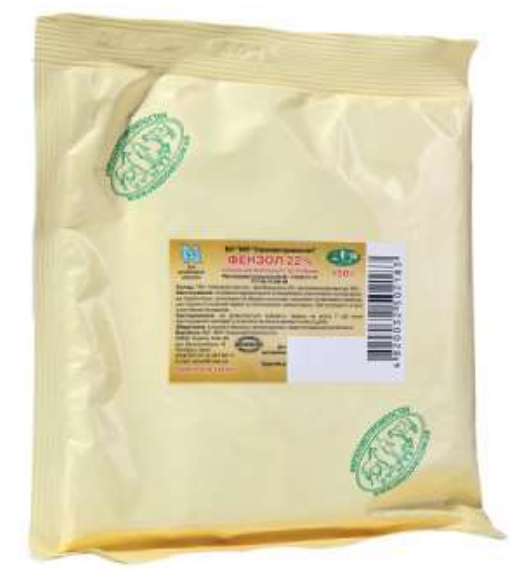

Рисунок 2. Зовнішній вигляд фензолу $22 \%$

Фензол 22 \% (порошок для перорального застосування) випускає ПрАТ «ВНП «Укрзооветпромпостач» і представляє собою порошок білого кольору або кольору барвника без запаху. 100 г препарату містить діючу речовину: фенбендазол - 22 г та допоміжні речовини: цукрова пудра, карбонатний наповнювач, натрію бензоат, сансет жовтий, крохмаль. 
Діюча речовина - фенбендазол (група бензімідазолів) гальмує полімеризацію білків тубулінів у мікротубуліни, знижує активність енергетичних ферментів, що викликає порушення метаболізму у гельмінтів, внаслідок чого обмежується засвоєння глюкози, знижуються мітохондріальні реакції, порушується мітоз клітин - наступає повне виснаження паразитів, викликає параліч м'язів у цестод. Ефективний проти імагінальних та лярвальних стадій паразитів. Фензол $22 \%$ практично нетоксичний для тварин, ембріотоксичні і тератогенні властивості не встановлені.

Бровадазол $20 \%$ та фензол $22 \%$ використовували дворазово на добу груповим методом з вологою мішанкою у ранішню годівлю після 14-годинної голодної дієти. Для приготування суміші антигельмінтика з кормом відважену дозу препарату змішували з сухою дертю розраховану на одноразову годівлю $\mathrm{i}$ зменшену на $1 / 3$. Потім суміш зволожували водою, ретельно перемішували $\mathrm{i}$ розкладали у корита. Після дегельмінтизації тварини задовільно приймали корм.

Свиням контрольної групи антигельмінтик не призначали. Всі дослідні та контрольні тварини протягом періоду досліджень (30 днів) перебували в аналогічних умовах годівлі й утримання. Після дегельмінтизації за тваринами було встановлено клінічне спостереження Антигельмінтну ефективність препаратів визначали на 12-й день після останнього їх застосування.

Власні дослідження. Результати овоскопічних досліджень тварин до дегельмінтизації наведені у таблиці 2.

Таблиця 2.

Результати овоскопічних досліджень тварин до дегельмінтизації.

\begin{tabular}{|c|c|c|c|c|c|c|c|}
\hline \multirow{2}{*}{$\begin{array}{c}\text { Групи } \\
\text { тварин }\end{array}$} & \multirow{2}{*}{\begin{tabular}{c} 
Кількість \\
тварин \\
\cline { 3 - 8 }
\end{tabular}} & \multicolumn{6}{|c|}{ групі, } \\
\cline { 3 - 8 } & гол. & гол. & $\begin{array}{c}\text { Е.I., } \\
\text { у проц. }\end{array}$ & $\begin{array}{c}\text { I.I., } \\
\text { екз. яєць }\end{array}$ & гол. & $\begin{array}{c}\text { Е.I., } \\
\text { проц. }\end{array}$ & $\begin{array}{c}\text { I.I., } \\
\text { екз. яєць }\end{array}$ \\
\hline $\begin{array}{c}\text { Дослідні: } \\
\text { перша }\end{array}$ & 15 & 15 & 100 & 31,6 & 14 & 93,33 & 21,4 \\
\hline друга & 15 & 15 & 100 & 34,8 & 15 & 100 & 23,8 \\
\hline Контрольна & 15 & 15 & 100 & 32,5 & 14 & 93,33 & 22,4 \\
\hline
\end{tabular}

Як видно з даної таблиці усі групи тварин були на 100 \% уражені яйцями аскарисів. Інтенсивність аскарозної інвазії коливалась від 31,6 до 34,8 екземплярів яєць в середньому у трьох краплинах флотаційної рідини. Екстенсивність трихурозної інвазії у тварин коливалась від 93,33 до 100 \% в залежності від групи, а інтенсивність інвазії - від 21,4 до 23,8 екземплярів яєць у середньому в трьох краплинах флотаційної рідини.

На 12-й день після останньої дачі антигельмінтних препаратів ми знову відібрали проби фекалій. Результати цієї роботи наведені у таблиці 3. 
Таблиця 3.

\section{Результати овоскопічних досліджень тварин після дегельмінтизації.}

\begin{tabular}{|c|c|c|c|c|c|c|c|c|c|c|c|}
\hline \multirow[b]{3}{*}{$\begin{array}{c}\text { Групи } \\
\text { тварин }\end{array}$} & \multirow{3}{*}{$\begin{array}{c}\text { Кількість } \\
\text { тварин } \\
\text { у групі, } \\
\text { гол. }\end{array}$} & \multicolumn{10}{|c|}{ уражено } \\
\hline & & \multicolumn{5}{|c|}{ аскарисами } & \multicolumn{5}{|c|}{ трихурисами } \\
\hline & & гол. & $\begin{array}{c}\text { E.I., } \\
\text { у } \\
\text { проц. }\end{array}$ & $\begin{array}{c}\text { Е.Е., } \\
\text { y } \\
\text { проц. }\end{array}$ & $\begin{array}{l}\text { I.I., } \\
\text { екз. } \\
\text { яєць } \\
\end{array}$ & $\begin{array}{c}\text { I.E., } \\
\text { у } \\
\text { проц. }\end{array}$ & гол. & $\begin{array}{c}\text { E.I., } \\
\text { у } \\
\text { проц. }\end{array}$ & $\begin{array}{c}\text { Е.Е., } \\
\text { у } \\
\text { проц. }\end{array}$ & $\begin{array}{l}\text { I.I., } \\
\text { екз. } \\
\text { яєць }\end{array}$ & $\begin{array}{c}\text { I.E., } \\
\text { у } \\
\text { проц }\end{array}$ \\
\hline $\begin{array}{c}\text { Дослідні: } \\
\text { перша }\end{array}$ & 15 & - & - & 100 & - & 100 & 7 & 46,67 & 50,0 & 10,6 & 50,47 \\
\hline друга & 10 & - & - & 100 & - & 100 & - & - & 100 & - & 100 \\
\hline Контрольна & 15 & 15 & 100 & - & 34,8 & - & 14 & 93,33 & - & 27,3 & - \\
\hline
\end{tabular}

3 даної таблиці видно, що всі обидва антигельмінтики, а саме, бровадазол 20 \% у дозі 0,5 г на 10 кг маси тіла (по лікарській формі) або в дозі 0,01 г (по ДР) на кг маси тіла тварини та фензол $22 \%$ в дозі 0,033 г на 1 кг маси тіла по ДР (фенбендазол) або в дозі 1,5 г на 10 кг по лікарській формі дворазово на добу груповим методом 3 вологою мішанкою у ранішню годівлю після 14-годинної голодної дієти показали 100 \% вплив на аскарисів.

Що стосується трихурозної інвазії, то найбільш ефективним виявився препарат фензол 22 \% у дозі 1,5 г на 10 кг маси тіла (лікарська форма) або у дозі 0,033 г на 1 кг маси тіла по ДР (фенбендазол) або в дозі 1,5 г на 10 кг по лікарській формі дворазово на добу груповим методом і він показал $100 \%$ вплив на трихурисів.

Найменшу антигельмінтну ефективність проти трихурисів показал бровадазол $20 \%$ у дозі 0,5 г на 10 кг маси тіла (по лікарській формі) або в дозі 0,01 г (по ДР) на кг маси тіла тварини дворазово груповим методом і він становив $50,0 \%$ при інтенсефективності 50,47\%.

Таким чином можна зробити висновок, що фензол $22 \%$ в дозі 0,033 г на 1 кг маси тіла по ДР (фенбендазол) або в дозі 1,5 г на 10 кг по лікарській формі дворазово на добу груповим методом з вологою мішанкою у ранішню годівлю після 14-годинної голодної дієти показал 100 \% вплив на аскарисів та трихурисів. Щодо бровадазолу $20 \%$ у дозі 0,5 г на 10 кг маси тіла (по лікарській формі) або в дозі 0,01 г (по ДР) на кг маси тіла тварини дворазово на добу груповим методом то він був ефективним тільки за аскарозу свиней і його ЕЕ та IE склала $100 \%$. За трихурозної інвазії цей препарат був менш ефективним і EЕ та IE відповідно склали 50,0 та $50,47 \%$

\section{Список літератури}

1. Пономар C.I. Епізоотологія нематодозів свиней в Україні / С.I. Пономар, А.А. Антіпов // Ветеринарна медицина України - 1998. - № 5. - С.30-31.

2. Шмаюн С.С. Ефективність застосування Аверсекту-2 при кишкових нематодозів свиней / С.С. Шмаюн, А.А. Антіпов // ВМУ. - 2003. - №6. - С.27-28.

3. Ефективність промектину $1 \%$-ного ін'єкційного розчину за кишкових нематодозів свиней / А.А. Антіпов, В.П. Гончаренко, В.С. Шаганенко та ін. // Науковий вісник Національного університету біоресурсів і 
природокористування України. Серія „Ветеринарна медицина, якість і безпека продукції тваринництва”. - Київ, 2013. - Том 3. - № 188. - С.191-194.

4. Антіпов А.А. Ефективність Верміку $1 \%$-ного ін'єкційного розчину за кишкових нематодозів свиней / А.А. Антіпов, В.П. Гончаренко, О.М. Джуринський // Наук. вісник вет. медицини: зб-к наук. праць. - Біла Церква: БНАУ, 2013. - Вип. 11 (101). - С.11-14. 


\title{
ВПЛИВ ВІТАМІНУ Е ТА ЦИТРАТІВ МІКРОЕЛЕМЕНТІВ НА ПЕРОКСИДНЕ ОКИСНЕННЯ ЛІПДІВ У КРОВІ ПОРОСЯТ
}

\author{
Токарчук Тетяна Сергї̈вна
} канд. с.-г. наук, асистент кафедри гігієни тварин та ветеринарного забезпечення кінологічної служби Національної поліції України Подільський ДАТУ

\section{Антонецька Любов Василівна} викладач вищої категорії фахового Коледжу Подільського ДАТУ

\section{Колащук Любов Григорівна} викладач вищої категорії фахового Коледжу Подільського ДАТУ

Вільнорадикальне окиснення органічних сполук $є$ фізіологічним явищем та протікає в усіх тканинах організму. Зміни показників вільнорадикального окиснення виявлені у різних видів тварин, а також у разі дії низки фізикохімічних чинників [1-12]. Одними із найрозповсюджених вільнорадикальних реакцій у клітинах $\mathrm{i}$ тканинах сільськогосподарських тварин та птиці $\epsilon$ пероксидне окиснення ліпідів (ПОЛ), що, переважно, вражає структуру ліпідів мембран [3-6, 8, 9]. Вільнорадикальне окиснення відіграє одну з ключових ролей у проходженні різних фізіологічних та патологічних реакції в організмі $[4,5]$. На процеси ПОЛ здатні впливати різні солі, хелатні сполуки та наночастинки металів і неметалів $[1,2,8,10]$.

У результаті пероксидного окиснення ліпідів утворюються проміжні та кінцеві продукти. Дієнові кон'югати (ДК) є проміжними продуктами ПОЛ. При вільнорадикальному окисненні арахідонової кислоти відбувається відрив водню в $\alpha$-положенні, що призводить до переміщення цього подвійного зв'язку. Дієнові кон'югати, відносяться до токсичних метаболітів, які пошкоджують ліпопротеїди, білки, ензими і нуклеїнові кислоти. Гідропероксиди ліпідів (ГПЛ) - це хімічно змінені ліпіди або жирні кислоти, які виникають в результаті клітинного стресу. У високій концентрації вони можуть викликати смерть клітин. Малоновий діальдегід (МДА) - це ендогенний альдегід, що утворюється в результаті метаболізму арахідонової та інших поліненасичених жирних кислот. Внаслідок подальших біохімічних перетворень він окислюється до діоксиду вуглецю або вступає у взаємодію з фосфоліпідами, амінокислотами і нуклеїновими кислотами. В даний час малоновий діальдегід розглядається в якості маркера оксидативного стресу. Рівень МДА важливий для діагностики широкого спектру захворювань.

Метою досліджень було вивчити вміст продуктів пероксидного окиснення ліпідів в сироватці крові поросят у період відлучення за випоювання вітаміну Е i внутрішньом'язового введення комплексу цитратів Феруму, Цинку та 
Германію, встановити оптимальну дозу введення тваринам комплексу цитратів цих мікроелементів.

Контрольна група поросят утримувалась за умов згодовування основного раціону без додаткового введення вітаміну Е та мікроелементів. Поросятам I дослідної групи за три доби до відлучення і на четверту добу після відлучення, випоювали вітамін Е в дозі 4,5 мг на 1 кг маси тіла за добу. II дослідна група отримувала дворазово вітамін Е та двічі внутрішньом'язове введення комплексу цитрату мікроелементів $\mathrm{Zn}, \mathrm{Fe}$ та $\mathrm{Ge}$ у кількості 2,0 $\mathrm{cm}^{3}$ на 10 кг маси тіла. Тваринам III дослідної групи, на фоні додаткового випоювання вітаміну E,

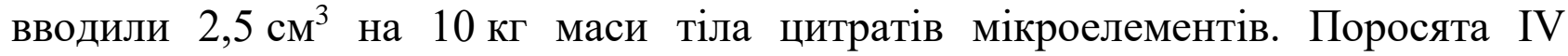
дослідної групи отримували вітамін Е у кількості 4,5 мг на 1 кг маси тіла та по 3,0 cм³ цитратів мікроелементів. Цитрати мікроелементів вводили за три доби до відлучення поросят і на четверту добу після відлучення у внутрішню поверхню стегна. Вітамін Е випоювали продовж однієї доби (за три доби до відлучення поросят і на четверту добу після відлучення). Вага поросят на початок досліду (24-а доба життя) становила $6,31 \pm 0,33$ кг. Відлучення поросят від свиноматок проводили у 28-добовому віці.

Вміст дієнових кон'югантів у сироватці крові поросят контрольної i дослідних груп на 24-у добу життя був у межах фізіологічної норми. Найвищий вміст ДК зафіксовано у поросят IV дослідної групи.

Дослідження сироватки крові поросят отриманої на другу добу після формування груп показало, що у тварин контрольної та дослідних груп вміст ГПЛ коливався в межах 10,1 ум. Од./см³ (табл. 1). Не встановлено суттєвого підвищення або зниження вмісту ГПЛ у сироватці крові поросят, яким мали випоювати вітамін Е та комплекс цитратів мікроелементів.

Відхилення у дослідних групах було в межах від 0,9% (IV дослідна група) до 2,9 \% (II дослідна група). Ці показники були в межах похибки середнього арифметичного.

Вміст ТБК-активних продуктів у поросят контрольної і дослідних груп до введення вітаміну Е та цитратів мікроелементів був на рівні 10,2 нмоль/см³. На 24-у добу також не встановлено суттєвих відхилень у вмісті ТБК-активних продуктів у сироватці крові тварин із дослідних груп. Зниження вмісту досліджуваних сполук у сироватці крові поросят I дослідної групи на 2,9 \% не мало вірогідного характеру. Таким чином, до проведення дослідження вміст ТБК-активних продуктів у сироватці крові тварин був майже ідентичним.

При відлученні поросят від свиноматок у контрольній групі спостерігається підвищення вмісту ГПЛ. Цей показник у сироватці крові на 28-у добу становив 12,8 ум. Од./см³. Застосування додаткового випоювання вітаміну E ( $\alpha$-токоферол) супроводжувалось зменшенням вмісту ГПЛ у сироватці крові поросят I дослідної групи на вірогідну величину відносно контролю.

Встановлено вірогідне зниження вмісту ГПЛ у сироватці крові від поросят II дослідної групи на 14,0 \% стосовно контролю. За умови введення комплексу цитратів мікроелементів у дозі 2,5 $\mathrm{cm}^{3}$ на голову на 28-у добу вміст ГПЛ у сироватці крові поросят III дослідної групи знижується на $15,6 \%$ (p $\leq 0,05)$. Підвищення дози мікроелементів до $3,0 \mathrm{~cm}^{3}$ призводило до вірогідного 
зменшення вмісту ГПЛ у сироватці крові поросят IV дослідної групи стосовно контролю.

Встановлено, що у поросят контрольної групи на 35-у добу вміст ГПЛ у сироватці крові зріс на 4,7 \% відносно показника на 28-у добу життя. Рівень ГПЛ у тварин контрольної групи на 35-у добу життя був вищим щодо 50 доби. У сироватці крові поросят I дослідної групи вміст цих метаболітів ПОЛ був вірогідно нижчим, ніж у тварин контрольної групи на 7,5 \%.

Таблиця 1

Вміст продуктів пероксидного окиснення ліпідів в сироватці крові поросят $(\mathrm{M} \pm \mathrm{m}, \mathrm{n}=5)$

\begin{tabular}{|c|c|c|c|c|}
\hline \multirow{2}{*}{ Групи тварин } & \multicolumn{4}{|c|}{ Вік тварин, доба } \\
\hline & 24 & 28 & 35 & 50 \\
\hline & \multicolumn{4}{|c|}{ ДК, ум. Од. $/ \mathrm{cm}^{3}$} \\
\hline Контрольна & $1,8 \pm 0,16$ & $3,1 \pm 0,28$ & $2,8 \pm 0,37$ & $2,0 \pm 0,12$ \\
\hline І дослідна & $1,7 \pm 0,09$ & $2,8 \pm 0,17$ & $2,5 \pm 0,14$ & $1,9 \pm 0,11$ \\
\hline II дослідна & $1,9 \pm 0,13$ & $2,6 \pm 0,25$ & $2,4 \pm 0,23$ & $1,8 \pm 0,07$ \\
\hline III дослідна & $1,9 \pm 0,08$ & $2,5 \pm 0,31$ & $2,2 \pm 0,29$ & $1,7 \pm 0,18$ \\
\hline \multirow[t]{2}{*}{ IV дослідна } & $2,0 \pm 0,17$ & $2,6 \pm 0,32$ & $2,3 \pm 0,19$ & $1,8 \pm 0,09$ \\
\hline & \multicolumn{4}{|c|}{ ГПЛ, ум. Од. $/ \mathrm{cm}^{3}$} \\
\hline Контрольна & $10,1 \pm 0,45$ & $12,8 \pm 0,37$ & $13,4 \pm 0,28$ & $10,4 \pm 0,65$ \\
\hline I дослідна & $9,9 \pm 0,38$ & $11,2 \pm 0,47 *$ & $12,4 \pm 0,23^{*}$ & $10,5 \pm 1,02$ \\
\hline II дослідна & $9,8 \pm 0,34$ & $11,0 \pm 0,51 *$ & $12,0 \pm 0,39 *$ & $9,8 \pm 0,67$ \\
\hline III дослідна & $10,3 \pm 0,53$ & $10,8 \pm 0,52 *$ & $11,7 \pm 0,51 *$ & $9,6 \pm 0,86$ \\
\hline \multirow[t]{2}{*}{ IV дослідна } & $10,2 \pm 0,41$ & $10,9 \pm 0,49 *$ & $11,8 \pm 0,49 *$ & $10,0 \pm 0,98$ \\
\hline & \multicolumn{4}{|c|}{ ТБК-активні продукти, нмоль/см ${ }^{3}$} \\
\hline Контрольна & $10,2 \pm 0,38$ & $12,3 \pm 0,45$ & $12,7 \pm 0,54$ & $10,6 \pm 0,35$ \\
\hline I дослідна & $9,9 \pm 0,24$ & $11,9 \pm 0,38$ & $12,2 \pm 0,27$ & $10,7 \pm 0,18$ \\
\hline II дослідна & $10,3 \pm 0,55$ & $11,6 \pm 0,43$ & $11,8 \pm 0,37$ & $10,6 \pm 0,27$ \\
\hline III дослідна & $10,6 \pm 0,37$ & $11,7 \pm 0,44$ & $11,6 \pm 0,53$ & $10,5 \pm 0,17$ \\
\hline IV дослідна & $10,4 \pm 0,45$ & $11,5 \pm 0,43$ & $11,8 \pm 0,38$ & $10,4 \pm 0,23$ \\
\hline
\end{tabular}

За внутрішньом'язового введення 2,0 $\mathrm{cm}^{3}$ комплексу цитратів мікроелементів у 35-добових поросят II дослідної групи знижується вміст ГПЛ на $10,4 \%(\mathrm{p} \leq 0,05)$ у порівняні із контролем.

У сироватці крові поросят III дослідної групи добавки сприяють зниженню утворення вільних радикалів, що підтверджується вірогідним зменшенням вмісту ГПЛ на 12,7 \% відносно контролю.

У 35-добових поросят IV дослідної групи вірогідно знижувався вміст ГПЛ відносно тварин контрольної групи на 11,9\%.

До 50 доби у сироватці крові поросят дослідних і контрольної групи вміст ГПЛ знизився до рівня від 9,6 до 10,5 ум.од./ $\mathrm{cm}^{3}$. Показники вмісту ГПЛ у сироватці крові тварин із контрольної і I дослідної групи були майже на одному рівні. Введення комплексу цитратів мікроелементів та випоювання вітаміну Е 
тваринам I- IV дослідних груп суттєво не впливало на вміст ГПЛ у сироватці 50добових поросят.

За відлучення поросят вміст ГПЛ у сироватці крові підвищується. Це може пояснюватись дією комплексу стресів на тварин. Рівень ГПЛ у сироватці поросят знижувався за дії вітаміну Е та комплексу цитратів Феруму, Цинку та Германію.

Вивчаючи вміст ДК у сироватці крові поросят виявили, що у тварин контрольної групи на 28-у добу життя цей показник становив 3,1 ум. од./см ${ }^{3}$ і був найвищим стосовно інших періодів. Випоювання вітаміну $\mathrm{E}$ ( $\alpha$-токоферол) сприяло зниженню вмісту ДК у сироватці крові поросят I дослідної групи на 9,7 \% відносно контролю. Різниця була в межах тенденції.

На 28-у добу виявлено тенденцію щодо зниження вмісту ДК у поросят II дослідної групи у порівнянні з даними у контролі. Розбіжність між групами була в межах 16,2 \%. На 35-у добу у поросят контрольної групи вміст ДК був меншим у порівняні із 28 добою життя на 9,7\%. Це обумовлюється поступовою адаптацією тварин до їх відлучення від свиноматок. У поросят I дослідної групи вітамін Е сприяв зниженню вмісту ДК на 10,7 \%.

Введення комплексу цитратів мікроелементів та випоювання вітаміну Е поросятам I-IV дослідних груп сприяло тенденції до зниження вмісту ДК у сироватці крові порівнюючи із контролем в усі досліджуванні вікові періоди.

Таким чином, виявлено ряд закономірностей. По-перше встановлено, що вміст ДК у сироватці крові поросят у період відлучення підвищується у порівняні із даними на 28-у добу (стосовно 24-добового віку) та зменшується 50 добу (період повної адаптації організму).

По-друге випоювання вітаміну Е та комплексу цитратів мікроелементів знижує вміст ДК у сироватці крові дослідних тварин. На 28-у добу у сироватці крові поросят контрольної групи вміст ТБК-активних продуктів становив 12,3 нмоль $/ \mathrm{cm}^{3}$, що на 20,5 \% вище, ніж на 24-у добу життя. У поросят I дослідної групи вміст ТБК-активних продуктів був нижчим на 3,2\% відносно даних контролю і на 20,2 \% вищим, ніж на 24-у добу життя. Виявлено підвищення на 28-у добу життя вмісту ТБК-активних продуктів у сироватці крові поросят II- IV дослідних груп у порівняні із 24-ю добою.

У сироватці крові поросят III дослідної групи концентрація ТБК-активних продуктів була меншою, ніж у контролі на 4,8 \%. Різниця не мала вірогідного характеру. На 28-у добу у тварин IV дослідної групи виявлено тенденцію щодо зниження вмісту ТБК-активних продуктів. Показник був нижчим, ніж у контролі на $6,5 \%$.

Встановлено незначне зростання вмісту ТБК-активних продуктів у сироватці крові поросят контрольної групи на 35-у добу у порівняні із даними на 28 -у добу життя. Підвищення було в межах $3,2 \%$. У тварин I дослідної групи вміст ТБК-активних продуктів був нижчим у порівняні із контролем на $3,9 \%$. Зниження у межах тенденції вмісту ТБК-активних продуктів виявлено у сироватці крові поросят, яким вводили $2,0 \mathrm{~cm}^{3}$ комплексу цитратів мікроелементів. Різниця із контролем становила 7,1 \%. Найнижчий вміст ТБКактивних продуктів у сироватці крові було встановлено у тварин III дослідної групи. Показник поступався даним контролю на 8,7 \%. На 35-у добу також 
виявлено тенденцію щодо зниження вмісту ТБК-активних продуктів у тварин IV дослідної групи.

Вміст ТБК-активних продуктів у сироватці крові поросят контрольної групи на 50-у добу суттєво знизився порівнюючи із даними на 35-у добу життя. Встановлено аналогічне зниження досліджуваних сполук і у сироватці крові тварин із дослідних груп.

За випоювання вітаміну $\mathrm{E}$ ( $\alpha$-токоферол) та введення цитратів поросятам дослідних груп суттєво не впливало на вміст ТБК-активних продуктів в межах одного вікового періоду і був майже на одному рівні, що і у контролі. Різниця становила лише $0,9 \%$. Не встановлено суттєвих відхилень щодо вмісту ТБКактивних продуктів у сироватці крові тварин дослідних і контрольної групи. Відхилення не переважало 1,8\%.

Отже, встановлено, що під час відлучення поросят від свиноматок вміст ТБК-активних продуктів у їх сироватці підвищується. Застосування комплексу цитратів мікроелементів на фоні додаткової вітамінізації вітаміном Е $(\alpha-$ токоферол) викликає тенденцію до зниження вмісту ТБК-активних продуктів у дослідних тварин, а відповідно частково зменшує концентрацію вільних радикалів.

\section{ЛІТЕРАТУРА}

1. Харчишин В.М., Бітюцький В.С., Мельниченко О.М., Цехмістренко О.С., Цехмістренко С.I., Тимошок Н.О., Співак М.Я. (2021). Ефективність застосування комплексних розробок сучасної біотехнології. Проблеми та досягнення сучасної біотехнології: матеріали I міжнародної наук.-практ. інтернет-конф. Харків, 329-330.

2. Цехмістренко О.С., Бітюцький В.C., Цехмістренко C.I. (2020). Нанотехнологіï i навколишнє середовище. Аграрна освіта та наука: досягнення, роль, фактори росту. Екологія, охорона навколишнього середовища та збалансоване природокористування: освіта - наука виробництво, 26-29.

3. Цехмістренко C.I., Поліщук В.М. (2010). Вікові особливості функціонування системи антиоксидантного захисту крові страусів. Укр. біохім. журн., 82(5), 92-97.

4. Цехмістренко C.I., Поліщук С.А., Поліщук В.М. (2012). Особливості вільнорадикальних процесів у спермі кнурів-плідників. Технологія виробництва і переробки продукції тваринництва: 3б. наук. праць, 8(98), 128-131.

5. Цехмістренко С.I., Пономаренко Н.В. (2013). Склад ліпідів та їх пероксидне окислення у підшлунковій залозі перепелів за дії нітратів і у разі згодовування насіння амаранту. Укр. біохім. журн., 85(2), 84-92.

6. Bityutsky, V. S., Tsekhmistrenko, S. I., Tsekhmistrenko, O. S., Tymoshok, N. O., \& Spivak, M. Y. (2020). Regulation of redox processes in biological systems with the participation of the Keap1/Nrf2/ARE signaling pathway, biogenic selenium nanoparticles as Nrf2 activators. Regulatory Mechanisms in Biosystems, 11(4), 483-493. 
7. Rol N., Tsekhmistrenko S., Tsekhmistrenko O., Polishchuk V., Polishchuk S., Ponomarenko N., Seleznyova O. (2019). Lipid peroxidation in the body of different species of animals and birds. $3^{\mathrm{RD}}$ International Conference „Smart Bio“ 02-04 May Kaunas Lithuania. Abstract Book, 159.

8. Tsekhmistrenko O. S., Bityutskyy V. S., Tsekhmistrenko S. I., Spivak M. Y. (2020). Influence of cerium dioxide nanoparticles on biochemical indicators in the organism of broiler chicken. Veterinary science,technologies of animal husbandryand nature management, 6, 112-117.

9. Tsekhmistrenko O., Tsekhmistrenko S., Bityutskyy V. (2019). Nanoscale cerium dioxide as a mimetic of antioxidant protection enzymes. Multidisciplinary conference For young researchers 22 November, 68-71.

10. Tsekhmistrenko O.S., Bityutsky V.S., Tsekhmistrenko S.I., Kharchyshyn V.M., Tymoshok N.O., Spivak M.Ya. (2020). Efficiency of application of inorganic and nanopreparations of selenium and probiotics for growing young quails //Theoretical and Applied Veterinary Medicine, 8(3), 206-212.

11. Tsekhmistrenko O.S., Bityutskyy V.S., Tsekhmistrenko S.I., Kharchishin V.M., Melnichenko O.M., Rozputnyy O.I., Malina V.V., Prysiazhniuk N.M., Melnichenko Y.O., Vered P.I., Shulko O.P., L.S. Onyshchenko L.S. (2020). Nanotechnologies and environment: A review of pros and cons. Ukrainian Journal of Ecology, 10(3), 162-172.

12. Tymoshok N.O., Kharchuk M.S., Kaplunenko V.G., Bityutskyy V.S., Tsekhmistrenko S.I., Tsekhmistrenko O.S., Spivak M.Y., Melnichenko O.M. (2019). Evaluation of effects of selenium nanoparticles on Bacillus subtilis. // Regulatory Mechanisms in Biosystems, 10(4), 544-552. 
The authors of the XXIII International Scientific and Practical Conference «Theory, practice and science» were representatives of the following educational institutions:

Vinnytsia National Technical University; Institute of Water Problems and Land Reclamation; Bila Tserkva National Agrarian University; Lviv Polytechnic National University; Kyiv National University of Building and Architecture; Ternopil National Pedagogical; Volodymyr Hnatyuk University; National Academy Of Fine Arts And Architecture; Institute of Radiation Problems; Baku State University; Uman National University of Horticulture; Uman educational complex "General school of I-III degrees №10 - medical gymnasium"; Zaporizhzhya National University; Tavria State Agrotechnological University; Hryhorii Skovoroda University in Pereiaslav; M. Kh. Dulati Taraz State University; Borys Hrinchenko Kyiv University; Kyiv National University of Culture and Arts; Taras Shevchenko National University of Kyiv; Vasyl Stefanyk Precarpathian National University; Lviv State University of Internal Affairs; Kharkiv National Agrarian University named after V.V. Dokuchaiev; Khmelnytsky National University; Dniprodzerzhyns'kyi state technical University; Kyiv National University of Technologies and Design; Odesa National Polytechnic University; Institute of Industrial Economics; Institute of Socio - Economic and Energy Problems; Kharkiv University or Karazin University; National University of Civil Defence of Ukraine; Odesa State Ecological University; Kharkiv National University of Internal Affairs; Odesa Mechnikov National University; Donbass State Pedagogical University; Kharkiv National Medical University; Poltava Institute of Business; Lesia Ukrainka Volyn National University; National Aviation University; Vasyl' Stus Donetsk National University; Yaroslav Mudryi National Law University; National Academy of Internal Affairs; Western Ukrainian National University; Dniprovsk State Technical University; Mykolayiv State Agrarian University; Odesa Law Academy; Lviv National Academy of Arts; Bukovinian State Medical University; Bogomolets National Medical University; Shupyk National Healthcare University of Ukraine; Volgograd State Physical Education Academy; Bukovinian State Medical University; Danylo Halytsky Lviv National Medical University; The Communal institution «Semenivska children's music school»; Lviv State University of Internal Affairs; The National Pedagogical University named after Abai; H.S. Skovoroda Kharkiv National Pedagogical University; Volodymyr Vynnychenko Central Ukrainian State Pedagogical University; Dnipro Academy Of Continuous Education; Kryvyi Rih State Pedagogical University; University Of Educational Management; Teacher Training Institute; Rivne State Humanitarian University; International Economics and Humanities University; Donbass Institute of Technology and Management; Y.Bugay International Scientific Technical University; National University Of Pharmacy; Petro Mohyla Black Sea National University; Poltava Institute of Economics and Law; National University of Life and Environmental Sciences of Ukraine; Ivan Franko National University of L'viv; Egyptian University Of Islamic Culture Nur-Mubarak; Saryagash Madrasah College; Fergana State University; Kokand State Pedagogical Institute; Kyiv National University Of Trade And Economics; National Pedagogical Dragomanov University; Interregional Academy of Personnel Management; Oles Honchar Dnipro National University; Kiev National Aviation University; Odessa Maritime Academy; Mykolayiv Admiral Makarov National University of Shipbuilding; Uzhhorod National University; Institute of Hydromechanics; Volsk Military Institute of Material Support; Ukrainian State University of Food Technologies; Luhansk Taras Shevchenko State Pedagogical University; National Technical University of Ukraine "Igor Sikorsky Kyiv Polytechnic Institute"; National Technical University "Kharkiv Polytechnic Institute"; Kharkiv Petro Vasylenko National Technical University of Agriculture; Volsk Military Institute of Material Support, Military Diplomatic Academy named after Yevgeny Bereznyak; Lutsk National Technical University; National Technical University Dnipro Polytechnic; Cherkasy State Technological University; College of Podolsk State Agrarian Technical University. 


\title{
THEORY, PRACTICE AND SCIENCE
}

\author{
Scientific publications
}

Materials of the XXIII - the International Science Conference «Theory, practice and science», Tokyo, Japan. 493 p.

(April 27-30, 2021)

UDC 01.1

ISBN - 978-1-63848-669-5

DOI - 10.46299/ISG.2021.I.XXIII

Text Copyright (C) 2021 by the International Science Group(isg-konf.com).

Illustrations (C) 2021 by the International Science Group.

Cover design: International Science Group(isg-konf.com) ${ }^{\odot}$

Cover art: International Science Group(isg-konf.com) ${ }^{\odot}$

All rights reserved. Printed in the United States of America.

No part of this publication may be reproduced, distributed, or transmitted, in any form or by any means, or stored in a data base or retrieval system, without the prior written permission of the publisher.

The content and reliability of the articles are the responsibility of the authors. When using and borrowing materials reference to the publication is required. Collection of scientific articles published is the scientific and practical publication, which contains scientific articles of students, graduate students, Candidates and Doctors of Sciences, research workers and practitioners from Europe, Ukraine, Russia and from neighboring countries and beyond. The articles contain the study, reflecting the processes and changes in the structure of modern science. The collection of scientific articles is for students, postgraduate students, doctoral candidates, teachers, researchers, practitioners and people interested in the trends of modern science development.

The recommended citation for this publication is: Vozniuk L., Rymar Y., Lisnykh L. Review of methods for researching lightweight covering plates // Theory, practice and science. Abstracts of XXIII International Scientific and Practical Conference. Tokyo, Japan. 2021. Pp. 32-34.

URL: https://isg-konf.com. 